DEPARTAMENTO DE COMPOSICIÓN ARQUITECTÓNICA

ESCUELA TÉCNICA SUPERIOR DE ARQUITECTURA

\title{
MÉXICO EXPORTA \\ La arquitectura moderna en las revistas europeas y norteamericanas (1950-1970) \\ Tesis Doctoral
}

Autora:

VANESSA NAGEL VEGA, arquitecta

Directora:

Dra. ANA ESTEBAN MALUENDA (ETSA-UPM)

2016 

Tribunal nombrado por el Mgfco. y Excmo. Sr. Rector de la Universidad Politécnica de Madrid, el día

\section{Presidente D.}

Vocal D.

Vocal D.

Vocal D.

Secretario D.

Realizado el acto de defensa y lectura de Tesis el día

en la Escuela Técnica Superior de Arquitectura

Calificación:

EL PRESIDENTE

LOS VOCALES

EL SECRETARIO 

Dedicatoria... 

Agradecimientos... 



\section{Índice}

Introducción .............................................................. 15

\section{Parte I}

Los orígenes del descubrimiento: medios impresos y modernidad arquitectónica mexicana

1. El peso de la historia. Los antecedentes de la nueva arquitectura en México ..........43

2. Modernidad impresa. El punto de vista de los títulos extranjeros . . . . . . . . . . . . . 57

2.1 El papel canónico. La arquitectura mexicana en los libros entre 1937 y $1969 . \ldots \ldots . . .59$

2.2 La presencia constante. Dos décadas de revistas de arquitectura .............. 101

\section{Parte II}

A vista de página: las publicaciones periódicas de arquitectura

3. Edición impresa. La difusión internacional de México en las revistas especializadas . . . . . . 155

3.1 Cinco miradas extranjeras. Las publicaciones periódicas de Estados Unidos, España,

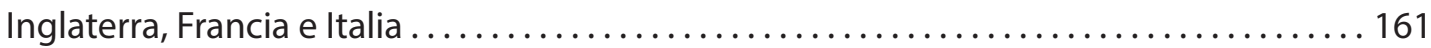

3.2 Recuento de contenidos. De la reseña al artículo . . . . . . . . . . . . . . . . . . . . . . . . 207

3.3 Diversidad edificada. Desde vivienda hasta infraestructura urbana . . . . . . . . . . . 217

4. Territorio descubierto. La geografía nacional en el papel impreso . . . . . . . . . . . . . . 243

4.1 Más allá de la capital. Otra visión a la modernidad mexicana . . . . . . . . . . . . . . . 245

4.2 De norte a sur en la región más transparente. La zonificación urbana del valle de México .................................................. 291

\section{Parte III}

\section{Cruzando fronteras: los grandes temas en el extranjero}

5. Teorías y prácticas. La discusión académica y la especificación técnica .............. 327

5.1 La historia interminable. Los debates teóricos modernos . . . . . . . . . . . . . . . . 331

5.2 Modernos y no tanto. Materiales en la modernidad mexicana . . . . . . . . . . . . . . 351

6. De Augusto H. Álvarez a Alejandro Zohn. Presencia de arquitectos mexicanos en las revistas

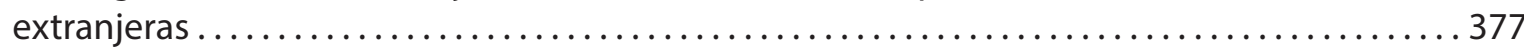

6.1 La representación constante. Los arquitectos en los medios foráneos . . . . . . . . . . . 379

6.2 Entre la vida y la obra. El arquitecto como protagonista . . . . . . . . . . . . . . . . 387

6.3 La construcción como noticia. El edificio y su autor . . . . . . . . . . . . . . . . . . . . 429

7. Materialidad tangible. El edificio como protagonista de las páginas impresas . . . . . . . . 471

7.1 Reto e innovación. La Ciudad Universitaria de México . . . . . . . . . . . . . . . . . . 475

7.2 De los mínimos al exceso. La vivienda de interés social y el lujo habitacional . . . . . . . 499

7.3 Camino a la escuela. El aula-casa rural y la educación básica, media y superior . . . . . . 543

7.4 La presencia discreta. Los pabellones de México en las ferias internacionales ....... 561

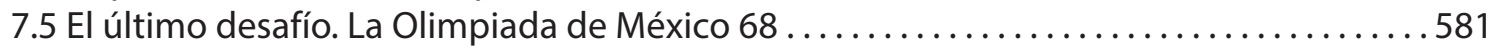

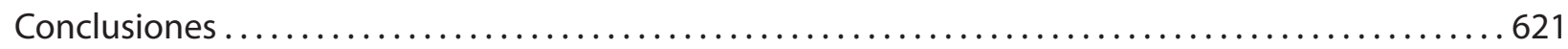

Apéndices

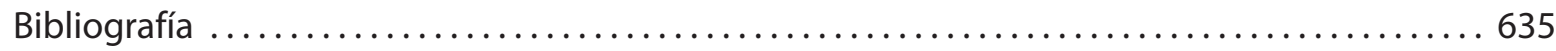

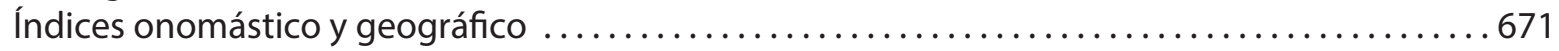

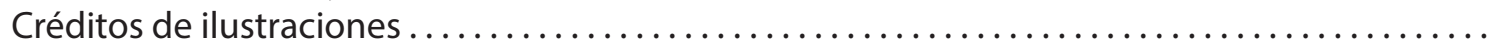





\section{Resumen}

Esta tesis aborda la difusión internacional de la arquitectura moderna mexicana a través de las publicaciones periódicas europeas y norteamericanas en torno a la mitad del siglo xx. La producción arquitectónica mexicana de las décadas de 1950 y 1960 activó el interés internacional, que se mantuvo constante mediante la publicación frecuente de noticias en los medios especializados foráneos. El crecimiento económico sostenido de esos años y el bienestar de una parte importante de la sociedad dio paso a una cantidad significativa de edificaciones surgidas de la iniciativa privada. Asimismo, las demandas sociales que dejaba en evidencia la Revolución de 1910 recibieron una notable respuesta institucional que se reflejó en nueva infraestructura para la educación, la salud y la vivienda. La cantidad y calidad de las obras construidas entonces apoyaron un considerable flujo de noticias en las revistas de arquitectura extranjeras.

Así, esta tesis revisa los principales nodos de difusión de la cultura arquitectónica moderna de la segunda mitad del siglo xx: Estados Unidos, Francia, Inglaterra e Italia. También incluye las publicaciones especializadas de España, por su papel fundamental en la divulgación de la arquitectura moderna mexicana, potenciado por los vínculos históricos entre ambos países.

La revisión de estas fuentes de primera mano se considera, a estas alturas, ineludible, pues se reconoce el papel imprescindible que desempeñaron las revistas de arquitectura a lo largo del siglo $\mathrm{xx}$ y su indudable protagonismo en el auge de la modernidad. Por lo tanto, se estudia la realidad del momento desde una perspectiva poco frecuente: el debate sobre los intercambios de información que se produjeron entre los diversos medios de difusión especializados, lo que propició la consolidación de una arquitectura que mantuvo su identidad tradicional sin negar su actualidad y su pertenencia a la modernidad universal. 
Esta investigación partió de la evidencia de una amplia difusión fuera de las fronteras nacionales y de la certeza de una modernidad arquitectónica construida más allá de un limitado número de personajes, por lo que se intentó evaluar las circunstancias particulares de los medios impresos que favorecieron la pluralidad y valorar su impacto global en las fuentes consultadas. La narración sobre la arquitectura moderna mexicana que se conoce hoy en día, mucho más heterogénea y enriquecedora, ya se dibujaba en las publicaciones periódicas de la época, lo que sustenta su papel fundamental en la aceptación de la diversidad arquitectónica, un signo de su espíritu vanguardista.

De esta manera, esta tesis expone la visión de la modernidad mexicana que se dio a conocer en las publicaciones periódicas durante las dos décadas de estudio, y demuestra, con datos objetivos, que su divulgación fue por completo inclusiva. Todo ello se muestra al analizar la simultaneidad de lo publicado sobre obras tan disímiles como la Biblioteca Central universitaria y el Museo Experimental El Eco. Así, aunque se mencionen en la tesis casos particulares, también se ofrece un amplio panorama de los temas que se conocieron fuera de las fronteras nacionales. 


\section{Abstract}

This thesis deals with the international diffusion of Mexican's modern architecture carried out by European and American architectural magazines during the half of the twentieth century. The Mexican architectonical production in the decades of fifties and sixties stimulated the international attention, which it remained constant trough the prevalent news in the media. The wellness of an important part of the society and the sustained economic growth, led to a significant number of buildings that arose from private initiative. Likewise, the social demands that 1910's Revolution made evident received a substantial institutional response which were guided especially to social housing, public education and health services. The quantity and quality of the constructed works in those years supported the considerable flow of news in foreign architecture magazines.

Thus, this work studies the main spread nodes of modern architectural culture from the second half of the twentieth century: The Unites States, France, England and Italy. Also are included the periodicals from Spain, due its fundamental role in diffusing Mexican modern architecture, powered by historical ties between the two countries.

The review of these primary sources is considered, at this time, unavoidable, due the main role that architectural magazines played throughout the twentieth century and its undoubted leadership in the rise of modernity. Therefore, this thesis looks at the reality of the moment since a different point of view: the debate over the information exchanges that occurred between the various specialized media. This led to the consolidation of an architecture that maintained its traditional identity without denying its relevance and its membership in the universal modernity. 
This research derives from the evidence of a widely diffusion outside national borders and the certainty of a modern architecture built beyond a limited number of characters, so it was intended to evaluate the particular circumstances of the print media that favored the plurality and assessed their overall impact on the sources. The narrative of Mexican modern architecture that is known today, much more heterogeneous and enriching, as was already outlined in the journals of the time, sustains its fundamental role in the acceptance of architectural diversity, a sign of his spirit avant-garde.

Thus, this thesis expounds the view of Mexican modernity that was unveiled in periodicals during the two decades of study, and demonstrate with objective data, that its diffusion was fully inclusive. This is evident when analyzing the simultaneity of the published about the works of the Biblioteca Central Universitaria and the Museo Experimental El Eco, as different as they could be. Therefore, although the thesis mentioned particular cases, also it offered a broad overview of the issues that were known outside national borders. 


\section{Introducción}

Esta tesis estudia la difusión internacional de la arquitectura mexicana en uno de sus periodos más prolíficos, el de mediados del siglo xx, para lo que utiliza como material principal de consulta las publicaciones periódicas de arquitectura de la época, sin duda una potente herramienta de análisis.

La actualidad e importancia de las revistas especializadas como fuente primaria de investigación es un tema presente no sólo en recientes congresos internacionales ${ }^{1}$ - de los que han derivado numerosas e interesantes comunicaciones-, sino también en las revisiones y actualizaciones museísticas de algunos centros de difusión artística de vanguardia ${ }^{2}$. De hecho, la revisión de estas fuentes como parte fundamental de la propia historiografía de la arquitectura del Movimiento Moderno se considera obligatoria a estas alturas. Desde hace ya tiempo se reconoce el papel imprescindible que desempeñaron las revistas de arquitectura a lo largo del siglo xx y su indudable protagonismo en el auge de la modernidad. Cabe destacar ya desde este punto que un entendimiento cabal de la evolución de la arquitectura del siglo xx no es factible si se prescinde de la consulta de estas fuentes, de las que se obtiene documentación básica sobre las obras construidas ${ }^{3}$.

1. El Seminario Internacional "La cultura arquitectónica y las publicaciones periódicas", coordinado por el doctor Horacio Torrent en la Pontificia Universidad Católica de Chile, se realizó anualmente de 2009 a 2013; sus reuniones han dado pie a publicaciones como Revistas, arquitectura y ciudad. Representaciones en la ciudad moderna, coord. por Horacio Torrent (Santiago de Chile, Escuela de Arquitectura/Pontificia Universidad Católica de Chile, 2013). En 2012, en el Congreso Internacional de 'Docomomo International', realizado en México, la doctora Patricia Méndez del
Cedodal (Centro de Documentación de Arquitectura Latinoamericana) coordinó una mesa redonda con la misma temática, http://www. docomomo2010.unam.mx/ roundtables.html\#Table2, consultada 2 mayo, 2016. En 2013, en su décima primera reunión en Aguascalientes, México, el Foro de Historia y Crítica de la Arquitectura, coordinado por el doctor Enrique X. de Anda Alanís, se centró en el tema en "Información escrita e imaginarios de la arquitectura del siglo XX, en revistas, secciones especializadas de periódicos, boletines, hojas volantes y otros medios de circulación impresa periódica y masiva: periodo 1930-1970," http://www.enriquedeanda. $\mathrm{mx} /$ foro-de-historia-y-critica-de-la-arquitectura-moderna /\#mctmp, consultada 2 mayo, 2016. Desde España, la Universidad de Navarra también se enfocó en el tema en su VIII Congreso Internacional de Arquitectura: "Las revistas de arquitectura (1900-1975), crónicas, manifiestos, propaganda”, realizado en 2012 .

2. Más adelante se comentará el caso de la reciente museografía (2013) del Centro Pompidou de París.

3. Ramón Gutiérrez, coord., Arquitectura Latinoamericana en el siglo XX (España: Lunwerg, 1998), 168. 
Para el caso latinoamericano, en general, y el mexicano, en particular, su consulta enriqueció enormemente los alcances de la arquitectura moderna. Esto se debió principalmente a que, en sus años de formación, la arquitectura moderna no fue un fenómeno mundial, por lo que los diversos medios no sólo facilitaron su difusión en las diferentes geografías, sino también la reinterpretación de los postulados teóricos de la modernidad bajo prismas locales en las distintas latitudes.

Esta tesis, más que realizar una revisión historiográfica de la arquitectura moderna latinoamericana, aborda un estudio de la realidad del momento desde un punto de vista poco frecuente: el debate sobre los intercambios de información que se produjeron entre los diversos medios de difusión especializados, lo que, sin duda, propició la consolidación de una arquitectura que buscó mantener su identidad tradicional sin negar la actualidad o su pertenencia a la modernidad universal.

De esta manera, las publicaciones periódicas de arquitectura consideradas en este estudio no se han tomado como objetos aislados susceptibles de un análisis individual, sino como un grupo que, en conjunto, resulta un medio eficaz para valorar el impacto de la propagación de la arquitectura moderna mexicana fuera de sus fronteras.

Para ello se han examinado los que se consideran focos de difusión más importantes de la cultura arquitectónica moderna de la segunda mitad del siglo xx: por una parte, los Estados Unidos, y por otra, los tres nodos fundamentales europeos, Francia, Inglaterra e Italia. Además, se han incluido las publicaciones especializadas de España, un país que si bien manejó estándares inferiores a los anteriores en cuanto a difusión

4. Los títulos consultados son, de Estados Unidos: Arts \& Architecture (A\&A), Architectural Forum (AF), Architectural Record $(A R)$ y Progressive Architecture (PA); de Francia: L'Architecture d'Aujourd'hui $(A A)$ y Techniques et Architecture (T\&A); de Inglaterra: $A r-$ chitectural Design $(A D)$, Journal of the RIBA (RIBA) y The Architectural Review (AR); de Italia: Domus (D), Casabella (C) y Zodiac ( $Z$ ) y de España: Revista Nacional de Arquitectura (RNA) / Arquitectura (A), Boletín de la Dirección General de Arquitectura (BDGA), Hogar y Arquitectura (HyA) e Informes de la Construcción (IC). internacional se refiere, en este caso particular adquiere un destacado papel en la propagación de la información sobre la arquitectura moderna mexicana, dada la estrecha relación histórica entre ambas culturas ${ }^{4}$.

\section{Importancia del tema}

Que la difusión internacional de la arquitectura de Luis Barragán se disparó a partir de la exposición del MoMA de 1976 o que la presencia de México en las revistas de arquitectura durante la década de 1950 se produjo sólo gracias a la obra de Félix Candela son dos ideas que - sin fundamentos suficientes- manejábamos los estudiantes de arquitectura de mi generación. Esa historia mexicana contada a partir de un limitado 


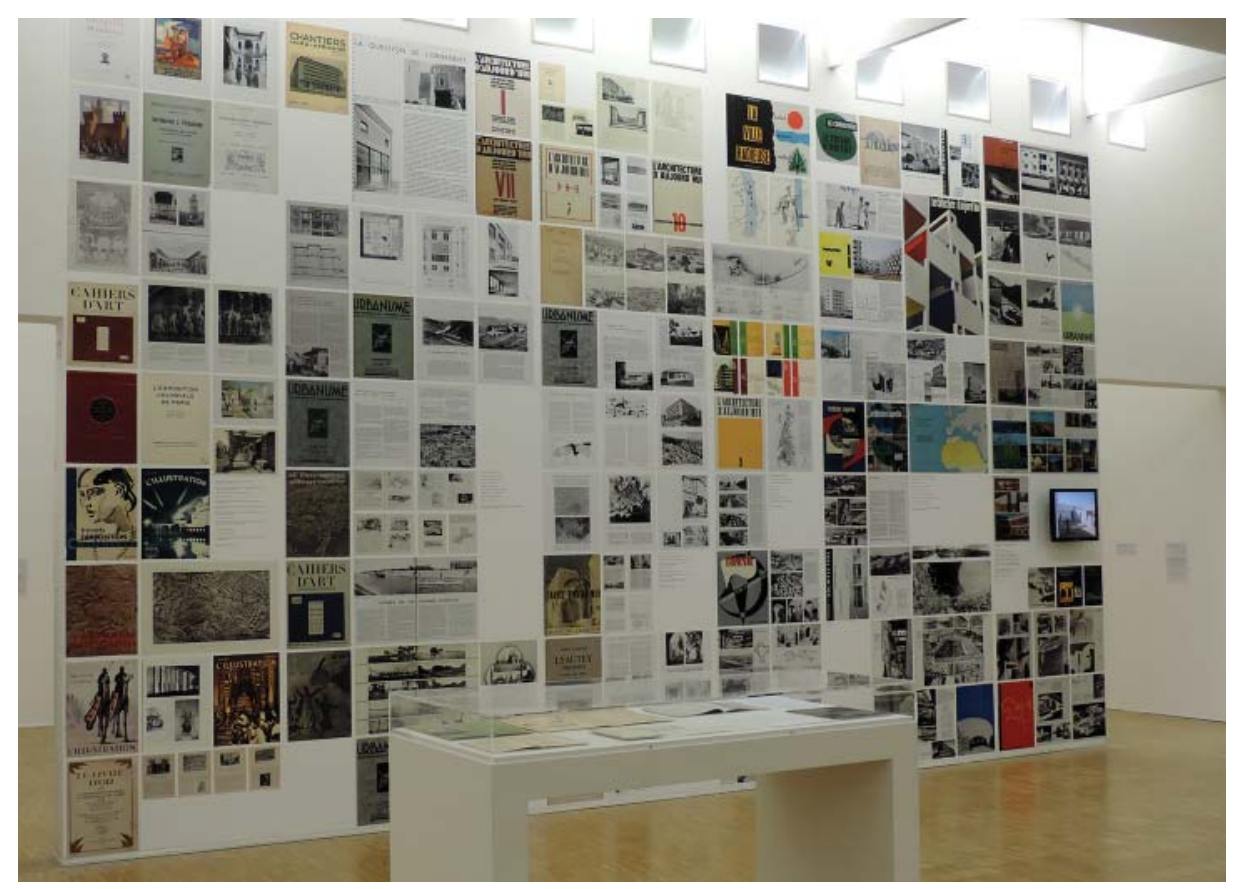

número de personajes, provocó la disolución de otra narración que hoy en día ofrece un panorama mucho más plural y enriquecedor. Antes de que la historiografía tradicional apostara por una restringida cifra de arquitectos como los protagonistas indiscutibles de la realidad construida, las publicaciones periódicas de arquitectura, dibujaron un paisaje heterogéneo y mucho más global de la modernidad mexicana.

$\mathrm{Al}$ abordar el estudio de la arquitectura moderna mexicana a través de las revistas especializadas surgieron diversas contradicciones. La primera, la convivencia de historias canónicas sobre algunos personajes y edificios clave de la modernidad junto con las narraciones múltiples que poblaron las páginas impresas durante nuestro periodo de estudio. La denominada "arquitectura moderna mexicana" se consolidaba a través de ejemplos muy puntuales, mientras que los medios de difusión foránea tanto libros como publicaciones periódicas - desafiaban esa visión unitaria de la modernidad y ampliaban considerablemente su rango de acción.

De la incorporación de todos estos nodos surge otra de las preguntas clave de la investigación: ¿la difusión internacional de la arquitectura moderna mexicana fue más importante para México o para los otros países? Si como sugiere Fernando Lara, la nacionalidad se afirma al ser consumidos por el resto del mundo a través de las revistas ${ }^{5}$, - un punto necesariamente favorable para el país - y dada la paulatina aceptación de la existencia de diferentes modernidades — hoy definidas como "otros modernismos"6-, el papel de las publicaciones periódicas
Publicaciones periódicas del siglo $x x$ en el Centro Pompidou, París, 2013.
5. Fernando Luiz Lara, "Espelho de fora: arquitetura brasileira vista do exterior," $A r$ quitextos, (septiembre 2000). Consultado 4 junio, 2013. http://www.vitruvius.com. $\mathrm{br} / \mathrm{revistas} / \mathrm{read} /$ arquitextos/01.004/986. El autor asevera que «Reflejar en la distancia lo que ocurre en el país es un juego de legitimación».

6. El IX Congreso Internacional Docomomo 2006, en la Universidad de Ankara, Turquía, definió el término de "otros modernismos" para ampliar el conocimiento de la arquitectura y el urbanismo modernos, más allá de los casos europeo y norteamericano. Así, se ensanchó la geografía de estudio, dando pie a interpretaciones referidas a culturas no occidentales, a ejemplos nacionales, regionales o locales, a la heterogeneidad de lo anónimo y lo vernáculo, de lo híbrido y de lo subdesarrollado, contra el concepto todavía muy arraigado de la modernidad entendida como algo homogéneo, canónico, puro y altamente tecnificado. Cfr. "IX International Docomomo Conference, 'Other Modernisms,' consultada 30 abril, 2016, http:// www.docomomo.com/pdfs/ events/docomomo_conferences/082548_9thDICIstanbulandAnkara2006.pdf. 
7. Cfr. Ana Fernanda Canales González, "La modernidad arquitectónica en México: una mirada a través del arte y los medios impresos" (Tesis de Doctorado, Universidad Politécnica de Madrid, 2013).

8. Esther Born, The new architecture in Mexico (New York: Architectural Record, 1937).

9. Irving E. Myers, Mexico's modern architecture (New York: Cornwall Press, 1952).

10. Clive B. Smith, Builders in the sun: Five Mexican Architects (New York: Architectural Book Publishing, 1967). adquiere un rol fundamental en la aceptación de la diversidad, algo que, en cierto modo, es un signo de su espíritu innovador.

Esta aproximación a las visiones heterogéneas -contra el enfoque unitario centrado en figuras clave- ha cobrado fuerza en los últimos años. La reciente exposición (2013) del Centro Pompidou parisino, cuya presentación de la colección permanente bajo el título de “Modernidades múltiples: 1905-1970”, no sólo amplió considerablemente los parámetros de valoración del periodo moderno, sino que situó en un lugar protagónico a las publicaciones periódicas de la época. Esta mirada, mucho más abierta e inclusiva, equilibra la representación en varias regiones del planeta y evita —en lo posible - la reincidencia en los nombres canónicos, compensando la omisión a los países en desarrollo que prevaleció durante décadas.

En este contexto, - como ya lo hizo el Centro Pompidou con las artistas-, cabe destacar aquí la importante presencia de algunas mujeres que, con sus textos críticos, sus fotografías y sus obras, escribieron parte de la historia de la modernidad mexicana durante las décadas de 1950 y 1960. Sería el caso de Esther Born, Sibyl Moholy-Nagy, Esther McCoy o Irene Nicholson, con sus acertadas críticas a la modernidad mexicana, y de las fotógrafas Marilyn Silverstone, Marianne Goeritz, Elizabeth Timberman, Lola Álvarez Bravo, Tania Stanham, Christina Smith o Rosalie Thorne McKenna. Por supuesto hay que mencionar a la arquitecta Ruth Rivera y a la diseñadora industrial Clara Porset, ambas con presencia en las publicaciones periódicas durante el periodo de estudio.

Lo sustancial para esta investigación no era, por principio, certificar la existencia de la difusión fuera de las fronteras nacionales ni comprobar que la modernidad arquitectónica en México no es una historia homogénea construida a partir de determinados personajes ${ }^{7}$, sino evaluar las circunstancias particulares de los medios impresos que favorecieron dicha pluralidad y valorar su impacto global en las fuentes consultadas.

Si algunos de los libros clásicos de la difusión de la arquitectura moderna mexicana, como The new architecture in Mexico de Esther Born $^{8}$ o Mexico's modern architecture de Irving E. Myers ${ }^{9}$ mostraron un panorama heterogéneo, otros fueron por completo excluyentes, como Builders in the Sun. Five Mexican Architects de Clive B. Smith ${ }^{10}$. 


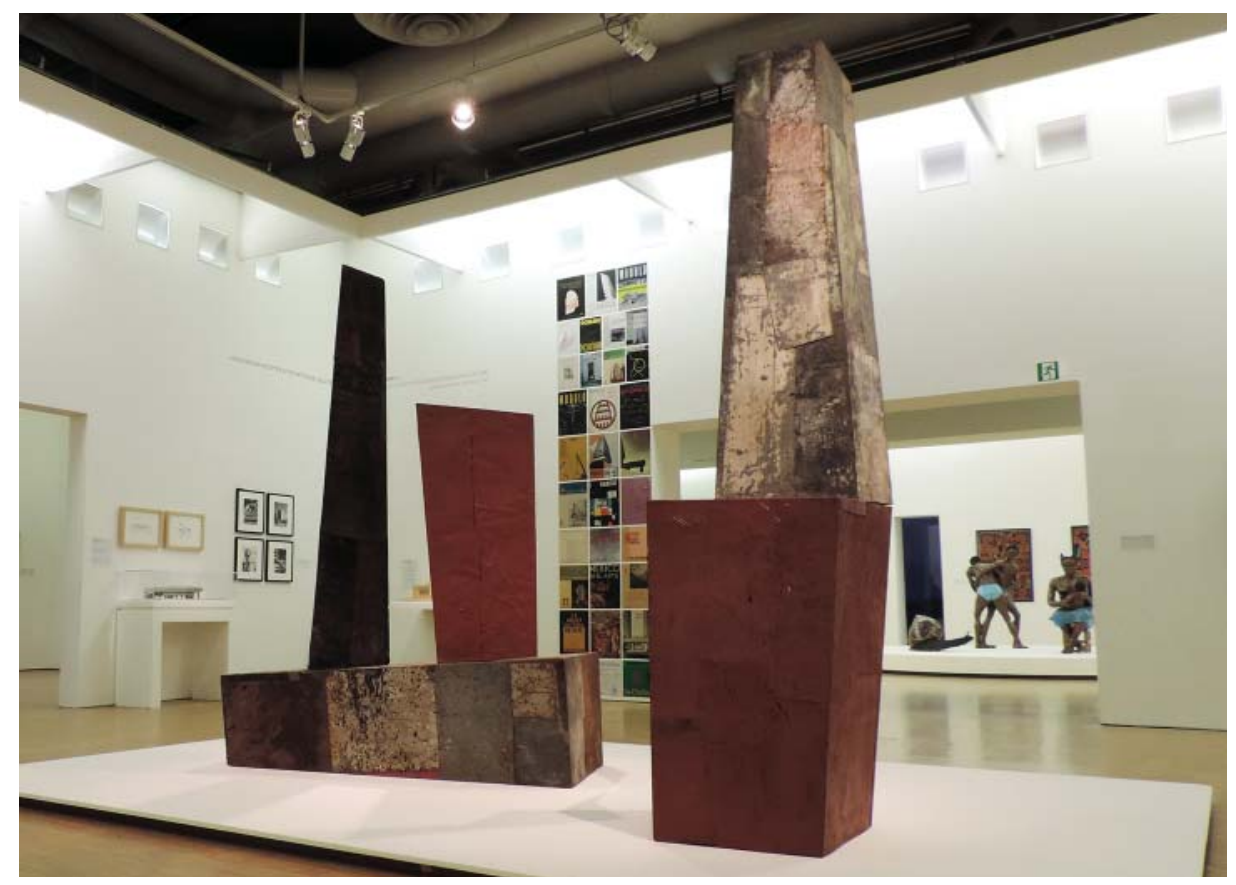

¿Respondía esto a una tendencia generalizada del momento? ¿Ambos acercamientos a la modernidad compartían vigencia? Al tiempo que se verificaba esta contradicción se fue evidenciando que la única manera de comprobar qué visión tuvo más peso durante los años de estudio fue a través de las consultas exhaustivas de los medios, para así poder brindar un panorama más completo sobre el tema que nos ocupa. ¿En qué medida las publicaciones periódicas seguían el patrón de los libros impresos? ¿Se notaba un cambio entre los números monográficos ${ }^{11}$ respecto a las noticias que iban apareciendo en los números regulares?

Si en una primera aproximación a la divulgación de la arquitectura moderna mexicana parecía que todo se centraba en protagonismos - pensemos en la Ciudad Universitaria - las consultas sucesivas a los medios impresos fueron alimentando una base de datos que ponía en duda este acercamiento protagónico y daba paso a una interpretación plural de la modernidad.

Aunque los libros y los números monográficos de revistas dedicados a México en el periodo que nos ocupa siguen siendo fuente casi inagotable de consulta y publicaciones académicas y divulgativas, esta tesis pretende algo más que recopilar su aparición puntual y los contenidos más conocidos hasta el momento ${ }^{12}$. Por ello, se ha procedido a comparar esos artículos ya canónicos para la historia de la arquitectura moderna mexicana con las menciones que quedaban fuera de los monográficos y los libros.
Latinoamérica, sus revistas de arte y arquitectura, sus arquitectos y sus artistas. Al centro "Pirámides mexicanas" (1959) de Mathias Goeritz. Centro Pompidou, París, 2013.

11. Durante el periodo de estudio y en las revistas que comprende esta investigación, aparecieron cuatro números monográficos dedicados a México. Dos en la francesa $A A$, en abril de 1955 y septiembre de 1963. Uno en la española $A r-$ quitectura en agosto de 1962 y otro en la inglesa $A D$, en septiembre de 1963. Los números que tanto Arquitectura como IC destinaron a la arquitectura olímpica mexicana del año 1968 se consideran aparte debido a que sus ejemplos se limitaron a las infraestructuras deportivas, sin llegar a ser, como los otros casos citados, una muestra más amplia de la producción nacional.

12. A 50 años del monográfico que L'Architecture d'Aujourd'hui dedicó a México en septiembre de 1963, Arquine recordó su publicación con una breve mención a sus contenidos. Véase Pilar Echezarreta, "Architecture d'aujourd'hui No. 109/México hace 50 años," Arquine (2014). Consultado 7 enero, 2015. http://www.arquine.com/architecture-daujourdhui-no-109-mexico-hace-50-anos/. 
Visto globalmente, el panorama que se ofreció de México en las revistas foráneas distó mucho de ser único. A lo largo de esta tesis podrá comprobarse la simultaneidad en los medios de obras tan dispares como la Biblioteca Central universitaria y el Museo Experimental El Eco, de concepciones y fines totalmente opuestos. La visión de la modernidad mexicana que se dio a conocer en las publicaciones periódicas durante las dos décadas de estudio fue por completo inclusiva. Con todo, aunque se mencionen casos particulares, esta tesis también pretende ofrecer un panorama amplio de los temas que se conocieron fuera de las fronteras nacionales.

De hecho, en este documento se recogen tanto las visiones de los propios mexicanos como las de los críticos externos, al igual que queda explícita la trama de intereses - entre directores de las revistas, editores y autores de las obras - que en su momento suscitó la publicación de las noticias, un aspecto que no puede desvincularse del conocimiento actual de la arquitectura moderna con fines a su preservación.

Antes de pasar a explicar la metodología cabría subrayar un aspecto sustancial de la arquitectura que nos ocupa y que nos enfrenta, necesariamente, a nuestro momento presente. Si bien gran parte de la producción arquitectónica mexicana que se publicó durante las décadas de 1950 y 1960 surgió de la iniciativa privada, un porcentaje considerable respondió a los diversos planes de seguridad social del Estado, potenciados por el interés - vigente entonces - en resolver las demandas públicas que hizo patente la Revolución. Esta investigación también podría plantearse como una llamada de atención sobre cuestiones propias de ese momento y que van perdiéndose sucesivamente: seguridad social —en vías de privatización-, museos públicos — cada vez menos accesibles al grueso de la población - mercados populares — sustituidos por hipermercados de capital internacional — unidades habitacionales — sujetas más a la especulación urbana del territorio que a las necesidades reales de la población. Por lo tanto, este documento destaca los mejores ejemplos de las obras sociales que produjo el México moderno, un país que - en muchos sentidos - ya no existe. 


\section{Metodología y estado de la cuestión}

La metodología de análisis cuantitativo destinada a las publicaciones periódicas de arquitectura es un método riguroso, sistemático y completo para el estudio de la arquitectura moderna. Como veremos un poco más adelante, diversos estudiosos trabajan actualmente en esta original línea de investigación, aplicando la técnica de consulta y análisis de las fuentes primarias del periodo considerado, para obtener como resultado la comprensión íntegra de los componentes sociales, políticos, económicos y culturales que caracterizaron el periodo de la arquitectura moderna.

Con este método de comparación de fuentes y de repetición de casos, se han conseguido detectar los ejemplos de la arquitectura moderna mexicana que avivaron en mayor medida el interés internacional; un interés que se mantuvo constante durante los años de estudio mediante la publicación frecuente de noticias en los medios especializados extranjeros. Por el mismo procedimiento se ha logrado un acercamiento a los temas generales que fueron motivo de debate constante en la época. En esta tesis, se analizan, además de algunas propuestas surgidas de la iniciativa privada -en especial la vivienda unifamiliar - los problemas de la solución urgente a la vivienda social y, en general, los nuevos edificios que respondieron a las demandas sociales, educacionales y culturales del momento.

Para comparar la trayectoria de la difusión de la arquitectura moderna mexicana en las diferentes revistas especializadas, se consideró la fecha de publicación del artículo con respecto al tiempo de conclusión o inauguración de las obras, así como el tipo de noticia — distinguiendo entre si se trataba de un número monográfico, un artículo principal, una mención breve o la inserción de una imagen que acompaña a un texto ${ }^{13}$. Esta información obtenida de primera mano de las revistas se analizó tanto cuantitativa como cualitativamente.

Cabe comentar que la consulta de las publicaciones periódicas foráneas como herramienta historiográfica se entiende como una revisión absolutamente actual. Sin embargo, se reconocerán algunos de los elementos ideológicos, narrativos y formales que, en el papel impreso, dieron al mundo la imagen de determinada obra.

También, hay que insistir en que el rigor del método aplicado se refiere a la revisión directa de los ejemplares, no a una búsqueda superficial de artículos relacionados con un tema o arquitecto específico
13. Las definiciones para cada tipo de noticia se exponen en el Apartado 3.1. Recuento de contenidos. De la reseña al artículo. 
14. Cabe aclarar que la consulta física exhaustiva de todos los ejemplares de las revistas contempladas en esta investigación, considerando los años de estudio, se realizó en las bibliotecas de la ETSAM y del COAM entre octubre de 2011 y junio de 2014. La revisión de los números impresos originales alcanza los siguientes porcentajes por países: España $100 \%$, Estados Unidos 80\%, Francia 99\%, Inglaterra 97\% e Italia $82 \%$. Se constata que un porcentaje mínimo no pudo ser consultado físicamente por falta de fondos en las bibliotecas, por lo que, de aquellos números no revisados se consultaron sus contenidos en bases de datos digitales, con el fin de no obviar artículos en estrecha relación con el tema de estudio.

15. Marina Waisman, El interior de la historia. Historiografía arquitectónica para uso de latinoamericanos (Bogotá: Escala, 1990): 30. 65.

16. Waisman, El interior, en catálogos. Al tratarse de una consulta exhaustiva se encontró que la difusión alcanzó un rango mucho más amplio de lo esperado al incluirse menciones y fotografías en diversos artículos cuyo tema principal no sería la arquitectura moderna mexicana. Una riqueza a la que habría sido imposible acceder si se hubiese obviado el trabajo de la consulta física de las revistas extranjeras ${ }^{14}$.

Una última aclaración metodológica — antes de pasar al estado de la cuestión - se refiere a que la propia estructura del trabajo permite la lectura independiente de cada capítulo, por lo que la repetición de ciertos artículos sustanciales - tanto en el texto como en notas al pie de páginano significa un error de planteamiento de la tesis, sino que la información da lugar a diferentes lecturas y a distintas profundidades de análisis de una misma comunicación.

Ahora bien, para confirmar no sólo la metodología, sino la línea de investigación aquí propuesta, se hace necesario repasar a los autores fundamentales que ayudaron a determinar el camino que ha seguido el desarrollo de esta tesis. Así, se exponen enseguida algunas lecturas imprescindibles para abordar el tema latinoamericano, y a continuación se comentan algunos de los estudios más actuales sobre publicaciones periódicas en relación tanto con la arquitectura moderna como con el panorama latinoamericano y, en especial, el mexicano.

Marina Waisman fue pionera en formular instrumentos historiográficos adecuados para la comprensión y el análisis de la realidad latinoamericana, al rechazar los moldes de la historia europea y establecer un sistema de ordenamiento que respete sus cualidades y características propias ${ }^{15}$. En El interior de la historia, la autora asume los valores propios de la posmodernidad y los aplica a la historiografía arquitectónica latinoamericana, sugiriendo que el desarrollo tecnológico ya no es una finalidad en sí misma, que ha desaparecido el concepto de la historia única y que ya no hay centros que dicten líneas ideológicas. Para Waisman, la condición de pérdida del valor del centro como fundamento y el deslizamiento de éste hacia los márgenes dan lugar al pluralismo, acabando con el monopolio cultural occidental, lo que deriva en la legitimación de proyectos locales ${ }^{16}$. Donde los mestizajes o sincretismos no son excluyentes sino incluyentes, la diversidad es vista como riqueza y no como obstáculo. Esta apreciación dictará la pauta de los estudios 
historiográficos que desde la década de 1990 empezaron a florecer en los países latinoamericanos.

Asimismo, los textos teóricos de Cristián Fernández Cox son sustanciales para comprender que la modernidad no es algo que se impone, sino que también se produce en Latinoamérica. En Arquitectura $y$ modernidad apropiada, el autor sugiere que las tecnologías particulares produjeron un orden moderno y local ${ }^{17}$. Así, el término de "modernidad apropiada" se define por la actitud que aborda los desafíos planteados por los hechos históricos modernos - como la respuesta a los problemas urbanos y a la vivienda social- cuando se adecúa a la realidad latinoamericana y la hace propia ${ }^{18}$.

En el ámbito latinoamericano del siglo xx se hace imprescindible la consulta de los trabajos de Ramón Gutiérrez. Una de sus obras fundamentales, Arquitectura Latinoamericana en el siglo $\mathrm{Xx}^{19}$, es una guía básica para cualquier estudio actual porque supera las revisiones historiográficas generales, en las que venía prevaleciendo el punto de vista eurocéntrico. Para este trabajo ha sido fundamental adoptar la visión de Gutiérrez sobre que las diversas arquitecturas nacionales primero existieron y después fueron 'descubiertas' por los medios especializados, pero no fueron creadas a priori para ser exportadas al extranjero a través de las páginas impresas.

Otro aspecto a recalcar del libro coordinado por Gutiérrez es su aproximación a obras o arquitectos que manifiestan un interés especial en la cultura de su tiempo y un compromiso social con su país. Los distintos textos hacen un énfasis en aspectos que caracterizaron la circunstancia latinoamericana, como la vivienda popular, los asuntos ambientales, la gestión y la participación comunitarias, la preservación del patrimonio o las tecnologías alternativas. Todos estos temas, de una u otra manera, se reflejaron en las publicaciones periódicas foráneas.

De publicación reciente, una amplia revisión a la modernidad latinoamericana se efectuó por Luis E. Carranza y Fernando Luiz Lara ${ }^{20}$. En Modern Architecture in Latin America, los autores exponen la diversidad latinoamericana a través de fragmentos vinculados únicamente por la cronología. Lo que separa este estudio de volúmenes anteriores es el hecho que América Latina se presenta como un soporte geográfico, no como un
17. Cristián Fernández Cox, Arquitectura y modernidad apropiada: tres aproximaciones y un intento (Santiago de Chile: Taller América, 1990).

18. Cristián Fernández Cox, "Modernidad apropiada," Arquitecturas del Sur, no. 14 (1989): 5.

19. Ramón Gutiérrez, coord., Arquitectura Latinoamericana en el siglo XX (España: Lunwerg, 1998).

20. Luis E. Carranza y Fernando Luiz Lara, Modern Architecture in Latin America. Art, Technology, and Utopia (Corea, University of Texas Press, 2014). 
21. Barry Bergdoll et al., Latin America in Construction. Architecture 1955-1980 (Nueva York: The Museum of Modern Art, 2015).

22. La exposición de 1955 se trata con amplitud en el Capítulo 1. El papel canónico. La arquitectura mexicana en los libros entre 1937 y 1969.

23. Bergdoll et al., Latin America, 20

24. Beatriz Colomina, Clip, Stamp, Fold: The radical architecture of little magazines, 196x to 197x (Barcelona: Actar 2010). atributo; no hay categorías que identifiquen a las obras publicadas y la lectura no es lineal. Esto responde a que las construcciones culturales no son unidireccionales - no hay un centro y un solo destino- sino una construcción de múltiples agentes y de señales cruzadas. La metodología actual remite a lecturas fraccionadas marcadas por una consciente discontinuidad histórica.

Cabe mencionar también el catálogo firmado por Bergdoll, Comas, Liernur y Del Real, editado en 2015 con motivo de la exposición que el Museo de Arte Moderno de Nueva York dedicó a la arquitectura en América Latina en dicho año ${ }^{21}$. Así, Latin America in Construction toma como inicio de su revisión el año 1955, fecha de la exposición dedicada al mismo tema, organizada por Henry-Russell Hitchcock para el museo neoyorquino ${ }^{22}$. Para el equipo curatorial actual, a partir de ese momento comenzaría un periodo de reevaluación de la arquitectura moderna, después de la euforia de los años cuarenta, tanto desde fuera como desde dentro de Latinoamérica. 1955 es el punto de partida con el objeto de reabrir la consideración a un complejo cuerpo de diseños innovadores que lucharon, en nombre del papel de la arquitectura, contra la rápida urbanización y el crecimiento de las ciudades ${ }^{23}$. De forma similar al volumen de Carranza y Lara, este volumen no muestra una visión unitaria de Latinoamérica, sino que ofrece las distintas especificidades de la amplia región, como las diferentes culturas urbanas y la pluralidad de posiciones. Si bien los ejemplos mexicanos seleccionados de la mitad del siglo xx ya se destacaban en las publicaciones periódicas de la época, lo más novedoso que aporta este estudio es el material gráfico expuesto. Un exhaustivo trabajo de archivo y algunas fotografías actuales refrescan la visión más conocida de la modernidad latinoamericana, no obstante la repetición de nombres conocidos.

Por otro lado, el protagonismo de las publicaciones periódicas como objeto de estudio cuenta con la aportación fundamental de Beatriz Colomina, quien a través de compilaciones y análisis críticos pondera los medios de difusión periódica. Si bien su libro Clip, Stamp, Fold ${ }^{24}$ se centra en el papel de las Little Magazines en las décadas de mayor revisión y debate de los fundamentos ideológicos del Movimiento Moderno, no puede dejar de mencionarse este estudio en el que se han inspirado muchas de las investigaciones actuales sobre el tema. 
Un aspecto sustancial de las discusiones de Colomina se centra en el vínculo indisoluble de las vanguardias en el arte, la arquitectura o la literatura y su relación con los medios. Es decir, no se trata sólo de que las vanguardias usaron los medios para difundir su información, sino que su trabajo — siguiendo a la autora- simplemente no existe antes de ser publicado. Durante el Movimiento Moderno, las publicaciones especializadas como propulsoras de las vanguardias arquitectónicas y de sus avances teóricos y formales se cargaron de una importancia más que justificada ${ }^{25}$.

De esta manera, en la ponencia "Little magazines: small utopia", Colomina reconoce el papel imprescindible que las publicaciones periódicas tuvieron para formar una red global de comunicación e intercambio entre estudiantes y arquitectos, pero también entre la arquitectura y otras disciplinas, ya que por primera vez se pusieron a prueba los límites propios de la profesión ${ }^{26}$. Para el caso de México al igual que en otros países- la irrupción de los movimientos sociales de finales de la década de 1960 fue paralela a la publicación de críticas hacia la arquitectura y el objeto arquitectónico, que se devaluó a favor de cuestiones como la autogestión, la sociología urbana y la participación ciudadana. En algunos casos, se contó con números especiales dedicados a los movimientos de protesta y a la respuesta implacable empleada contra los manifestantes por parte de las autoridades ${ }^{27}$.

Y ya de lleno en el tema principal de esta tesis, pero todavía en el ámbito latinoamericano, las revistas de arquitectura han sido tema frecuente de revisiones historiográficas, como lo demuestra Ramón Gutiérrez junto con Patricia Méndez. La edición en el año 2001 del libro Revistas de Arquitectura de América Latina 1900-2000²8 recopila cientos de títulos que durante una centuria circularon en el territorio latinoamericano. Así, se revela la importancia de las publicaciones periódicas especializadas para los países hispano y luso parlantes. Paulatinamente, numerosos investigadores han abordado los contenidos de tan vasto panorama editorial, ofreciendo interesantes análisis que siguen alimentando las páginas de revistas internacionales. Es el caso de "Las revistas de arquitectura en Latinoamérica", de Gutiérrez y Méndez ${ }^{29}$, en que se subraya el valor de las lecturas transversales de la información, -algo que queda patente en el desarrollo cualitativo de este documento ${ }^{30}$ y que se expone como un reto que permitiría comprender la arquitectura
25. Beatriz Colomina, "Little magazines: small utopia," en Actas del Congreso Internacional: Las revistas de arquitectura (1900-1975), crónicas, manifiestos, propaganda (Pamplona: Universidad de Navarra, 2012), 13-21.

26. Colomina, "Little magazines," 18.

27. Colomina, "Little magazines," 19. De México la autora cita la revista Arquitectos de México, su número de septiembre-octubre de 1969.

28. Ramón Gutiérrez, Patricia Méndez y Florencia Barcina, Revistas de Arquitectura de América Latina 1900-2000 (San Juan de Puerto Rico: Universidad Politécnica de Puerto Rico, 2001).

29. Ramón Gutiérrez y Patricia Méndez, "Las revistas de arquitectura en Latinoamérica: perfiles de su historia y apuntes para su futuro," Bitácora, no. 19 (2009): 6-11.

30. Si bien la acotación de esta investigación no ha dado lugar a lo publicado en los países latinoamericanos, aquí se hace hincapié en la metodología que sugiere el cruce de información de los medios analizados. 
31. Candelaria Alarcón Reyero, "La arquitectura en España a través de las revistas especializadas 1950-1970. El caso de Hogar y Arquitectura" (Tesis de Doctorado, Universidad Politécnica de Madrid, 2000).

32. Eva Hurtado Torán, "Desde otra voluntad de permanencia: Las publicaciones periódicas de arquitectura. España 1897-1937” (Tesis de Doctorado, Universidad Politécnica de Madrid, 2001).

33. Carlos Velasco Barral, "La modernidad paradigmática de la arquitectura popular. Orígenes y evolución de su descubrimiento en las publicaciones periódicas de arquitectura en España 1897-1958" (Tesis de Doctorado, Universidad Politécnica de Madrid, 2014). del siglo xx a través de esta fuente inagotable e insustituible. Los autores presentan las revistas como documentos excepcionales, ya que nos permiten cotejar, por medio de lecturas cronológicas, el momento histórico y cultural del cual debemos dar cuenta como historiadores de la arquitectura.

De forma mucho más específica, diversos estudiosos han abordado el tema de las publicaciones periódicas - tanto nacionales como extranjeras, según se vea en cada situación - tomando como punto de partida de los análisis un país en particular. De esta manera, España, Brasil, Chile, Colombia o México se perfilan como las geografías particulares de la difusión arquitectónica del siglo xx.

Para comenzar, cabe la mención de algunas tesis doctorales que tratan directamente el tema de esta investigación: las publicaciones periódicas y la modernidad mexicana en los medios impresos. Candelaria Alarcón abordó el panorama arquitectónico español en "La arquitectura en España a través de las revistas especializadas 1950-1970"31, además, se centró en un caso de estudio particular, la revista que dirigió Carlos Flores en Madrid: Hogar y Arquitectura, editada entre 1955 y 1978. Eva Hurtado revisó el desarrollo de las primeras publicaciones españolas dedicadas al arte, la arquitectura y la técnica en "Las publicaciones periódicas de arquitectura. España 1897-1937”32. Su análisis corrió paralelo al de las revistas europeas de arquitectura, desde sus orígenes en el siglo XIX y su auge en los primeros años de la modernidad marcada por la producción arquitectónica de las vanguardias históricas. Así, se ofrece un panorama general importante sobre el medio de difusión que ocupa a esta investigación y que antecede a su periodo de estudio.

En fecha más cercana, Carlos Velasco rescató de las publicaciones periódicas españolas la arquitectura popular con el fin de analizar cómo ésta aparece en la escena de la cultura arquitectónica. En la tesis "La modernidad paradigmática de la arquitectura popular"33, Velasco asume que las revistas especializadas no son sólo transmisoras de acontecimientos de actualidad, sino una importante plataforma de difusión, debate y reflexión, que facilitó a la arquitectura popular ibérica ser 'descubierta', reconocida y valorada, lo que ha dado pie, en muchos casos, a su conservación. De forma paralela se puede hablar del proceso de afirmación que la arquitectura moderna mexicana experimentó en las páginas impresas internacionales. 
Y sobre el caso particular que propone esta investigación, el antecedente más próximo es "La modernidad arquitectónica en México", de Fernanda Canales ${ }^{34}$, quien acometió el estudio de la arquitectura mexicana desde el punto de vista de los medios impresos. En dicha tesis se ofrece una nueva mirada sobre la arquitectura del siglo $\mathrm{xx}$ a partir de su relación con la fotografía, el dibujo, las ideas y los medios. Canales se basa en la hipótesis de que la modernidad arquitectónica en México no es una historia homogénea sino todo lo contrario, ya que se brinda una multiplicidad de narrativas complejas en las cuales el arte y los medios juegan un papel esencial. Con todas las posibilidades que la investigación de Canales tiene para convertirse en un referente fundamental de la historiografía mexicana, el amplio periodo de estudio que abarca no permite la profundidad de un análisis de cronología más limitada, como es el caso de la presente tesis.

Todavía queda por comentarse el caso de la tesis doctoral de Ana Esteban Maluenda, quien por su amplia producción académica en estrecha relación con el tema de este documento, merece un seguimiento especial. Así, "La modernidad importada. Madrid 1949-1968: Cauces de difusión de la arquitectura extranjera" 35 aborda el estudio de una parte de la historia de la arquitectura española del siglo xx: el periodo del reencuentro con las ideas arquitectónicas del Movimiento Moderno y con la actualidad internacional tras el paréntesis provocado por el proceso de la Guerra Civil y sus consecuencias. La autora plantea una revisión de los distintos 'cauces' que sirvieron a los arquitectos españoles para alcanzar la modernidad. A través de un recorrido por la labor de instituciones como la Escuela de Arquitectura y el Colegio de Arquitectos, así como de actividades culturales en las que pudieron participar los protagonistas y la consulta de contenidos de las publicaciones más accesibles para los arquitectos madrileños, la tesis expone las posibilidades reales con las que contaron éstos para seguir la evolución de la arquitectura internacional. El documento demuestra, con datos objetivos, la existencia de los flujos de entrada de información extranjera en esos años, pero más importante, el exhaustivo estudio profundizó en los medios que hicieron posible que esos flujos informativos dieran nacimiento a una nueva arquitectura española.

La aproximación al análisis cuantitativo y cualitativo de la autora con relación a las publicaciones periódicas de arquitectura resulta
34. Ana Fernanda Canales González, "La modernidad arquitectónica en México: una mirada a través del arte y los medios impresos" (Tesis de Doctorado, Universidad Politécnica de Madrid, 2013).

35. Ana Esteban Maluenda, "La modernidad importada. Madrid 1949-1968: Cauces de difusión de la arquitectura extranjera" (Tesis de Doctorado, Universidad Politécnica de Madrid, 2007). 
36. Ana Esteban Maluenda, "Transmisión Bipolar: La difusión de la arquitectura moderna latinoamericana en España (1949-1968)," Revista 180, no. 29 (2012): 24-29. Reeditado en DANA (Documentos de Arquitectura Nacional y Americana), no. 43 (2013): 22-35.

37. Ana Esteban Maluenda, "Brasil exporta. La arquitectura moderna brasileña y la latinoamericana en las publicaciones periódicas europeas después de la II Guerra Mundial," en Anais do III ENAN$P A R Q$, cidade e projeto: una construçao coletiva (São Paulo, 2014): 1-18. de incuestionable valor para la tesis aquí presentada. La novedosa metodología llevada a cabo nos confirma los innumerables caminos de análisis crítico que se pueden lograr a través de la consulta exhaustiva y rigurosa del material publicado durante el siglo xx.

Siguiendo la línea de investigación que arrancó en su tesis doctoral, Esteban Maluenda continúa aportando nuevos datos al entendimiento de la arquitectura moderna internacional, tomando como material de primera mano las publicaciones periódicas de arquitectura. Es el caso de "Transmisión Bipolar", artículo en el que se enfrenta de manera directa el estudio de la difusión de la arquitectura latinoamericana en España $^{36}$. Aquí, los datos concretos derrumban la idea de que, debido a las aparentes dificultades de comunicación con el exterior, el país mediterráneo vivió a puertas cerradas en ese periodo. La fuerza de la arquitectura latinoamericana habría sido el principal motivo para que ésta disfrutase de una enorme difusión en los medios madrileños más importantes durante las décadas de 1950 y 1960. La autora atribuye este auge, también, a la estrecha relación cultural que se sigue manteniendo entre la Península Ibérica y Latinoamérica.

Esteban Maluenda destaca la calidad de contenidos y análisis de los medios españoles, quizá menos valorados en el contexto contemporáneo de estudio que sus equivalentes europeos o norteamericanos. El análisis expuesto en el artículo comprende las distintas geografías, la fecha de publicación, temas específicos por edificio o arquitecto, o por contenidos generales de las revistas. Un consistente contexto histórico de fondo sitúa al lector en las diversas condiciones que propiciaron las decisiones editoriales expresadas en los innumerables artículos a que se hace referencia. Otra vez, esta aproximación al estudio y análisis crítico de las fuentes primarias del Movimiento Moderno, brinda muestras casi inagotables de interpretación actual. Dicho artículo, por su cercanía con nuestra propia investigación, se ha convertido en una guía fundamental para acometer cualitativamente la información vaciada en nuestra base de datos.

La misma autora amplía el alcance de la investigación anterior al incluir en otro estudio no sólo a España, sino a otros países europeos, como difusores de la modernidad latinoamericana. En "Brasil exporta. La arquitectura moderna brasileña y la latinoamericana en las publicaciones periódicas europeas después de la II Guerra Mundial”37, Esteban Maluenda 
expone un panorama global de los contenidos latinoamericanos incluidos en revistas de Francia, Inglaterra, Italia y España. Aquí, la investigadora comprueba que la difusión de la arquitectura latinoamericana en Europa fue mucho más allá de los conocidos monográficos, ya que su presencia fue constante en los medios. Los resultados cuantitativos arrojan datos sorprendentes sobre la cantidad de información accesible en números regulares, no obstante, los monográficos son importantes porque su publicación suele ir de la mano de acontecimientos o intereses muy particulares de un determinado momento. Cabe destacar que este tipo de análisis ha guiado en gran medida el desarrollo metodológico de la presente tesis.

Del otro lado del Atlántico, Fernando Lara ha trabajado una metodología emparentada con la de Esteban Maluenda por sus aportaciones al análisis de las revistas de arquitectura y los distintos modos de interpretación que brindan sus trabajos. Por ejemplo, en "Espelho de fora" ${ }^{38}$ el autor introduce al lector en los mecanismos ideológicos sobre la necesidad de reconocimiento externo a través de la 'legitimación' que brindan las revistas internacionales, que alimentó, en cierto sentido, a las identidades nacionales latinoamericanas. Lara ha hecho una búsqueda general sobre lo publicado de arquitectura brasileña fuera de su país, durante prácticamente todo el siglo $\mathrm{xx}$, destacando diferentes periodos de la producción arquitectónica, que pasó de ser un consumidor pasivo de una modernidad incipiente a los productores de una modernidad elegante, misma que después entró en crisis, para ser, algunas décadas más tarde, redescubierta y revalorada.

El principal valor de las investigaciones no consiste en la confirmación de lo que todo el mundo ya sabía: la enorme difusión que tuvo la arquitectura brasileña durante el siglo xx. En palabras de su autor, gracias a este tipo de estudios pueden elaborarse gráficas comparativas que despejan aspectos fundamentales como por qué la curva de publicaciones no encuentra paralelo con el cambio de crecimiento económico, pero sí coincide con los periodos democráticos del país. La posibilidad de descubrir y exponer este tipo de relaciones se alzaría como la aportación primordial de este método de análisis.

Se va viendo que las publicaciones periódicas se mantienen como protagonistas de investigaciones de actualidad. Otra vertiente en 
39. Nelci Tinem, $O$ Alvo do olhar estrangeiro: o Brasil na historiografia da arquitetura moderna (João Pessoa: Manufatura, 2002). Este libro es la traducción al portugués de su tesis de doctorado "El caso de Brasil en la historiografía de la arquitectura moderna 1936-1955", (Tesis de Doctorado, Universidad Politécnica de Cataluña, 2000).

40. Nelci Tinem, "As revistas de arquitetura como documentos pré-canônicos" (ponencia presentada en el $I$ Encontro Nacional da Associação Nacional de Pesquisa e Pós-graduação em Arquitetura e Urbanismo, Rio de Janeiro, 29 de noviembre al 3 de diciembre, 2010).

41. María Beatriz Camargo Capello, "Arquitectura moderna en Brasil y su recepción en los números especiales de las revistas europeas de arquitectura (1940-1960)," Revista de Arquitectura 23, (2011): 4151.

42. Camargo Capello, "Arquitectura moderna en Brasil," 42. su estudio se basa en los arquitectos más conocidos de la modernidad latinoamericana, con lo que se comprueba el papel fundamental de estos medios impresos en la consolidación de visiones canónicas. Así, Nelci Tinem analiza el proceso de formación de la versión historiográfica clásica de la arquitectura moderna brasileña en $O$ Alvo do olhar estrangeiro: $o$ Brasil na historiografia da arquitetura moderna ${ }^{39}$. Este estudio muestra cómo la figura de Oscar Niemeyer se traduce —en los medios impresos de la época - en una sola versión de la historia, pero que permite diferentes lecturas que dependen del medio impreso: volúmenes monográficos, los libros canónicos de historia de la arquitectura moderna y las publicaciones periódicas internacionales de más impacto en la época.

En otra oportunidad, Tinem asevera que las revistas internacionales comprometidas con la divulgación de la arquitectura moderna encontraron en la producción de países como Brasil, Finlandia o Japón, la posibilidad de supervivencia del Movimiento Moderno ${ }^{40}$, afirmación que podría extenderse también a México, país que se apropió de la modernidad que llegó de ultramar.

También en relación con arquitectura brasileña, Maria Beatriz Camargo Capello ha registrado tanto la producción extranjera que apareció en publicaciones brasileñas como la arquitectura de su país que se mostró en numerosas publicaciones periódicas internacionales. En diversos artículos académicos y de divulgación, la investigadora pondera estas fuentes de primera mano como una base documental imprescindible para la evaluación de la arquitectura moderna, recobrando este material bibliográfico y verificando su importancia en la constitución de una historiografía del Movimiento Moderno y su preservación ${ }^{41}$.

Capello insiste en distintos aspectos que determinaron la difusión internacional de la arquitectura brasileña. Uno de ellos fue el detonante de la exposición "Brazil Builds" en el MoMA, en 1943, momento a partir del cual empezaron a surgir los números monográficos en diversos países europeos. Pero también, al igual que se registró para el caso mexicano, desde muy temprano las publicaciones extranjeras ya destacaban que la aportación de Brasil a la arquitectura moderna sería «su creatividad al resolver cada problema, explotando al máximo las ventajas de los materiales y de las condiciones naturales, una arquitectura adaptada al país, utilizando las técnicas de los materiales disponibles» ${ }^{42}$. Se comprueba 
así no sólo la similitud de los métodos de análisis empleados sino los paralelismos entre la difusión europea y norteamericana de los países latinoamericanos.

Desde Chile, Horacio Torrent pondera las revistas de arquitectura por su papel fundamental en la constitución del mundo de las ideas de la arquitectura y el urbanismo modernos. Para el investigador, durante el siglo $\mathrm{xx}$ «las publicaciones periódicas asumieron en parte el papel que los tratados habían tenido para la arquitectura clásica, ser difusores de conceptos, imágenes y formas; pero al mismo tiempo fueron elementos constituyentes del campo disciplinar, por sus anhelos iniciales y sus impactos posteriores» ${ }^{43}$. En "Ciudades en papel. Teorías arquitectónicas y urbanas en Chile 1930-1940"44, Torrent evidencia que las publicaciones otorgaron existencia pública a las ideas y desafiaron los límites de lo pensable en el campo urbano. Una aportación metodológica importante que se sugiere aquí es la confrontación de ideas referidas a la ciudad publicadas tanto en revistas de arquitectura y urbanismo, como en revistas institucionales y más aún, en ediciones de amplio alcance y divulgación, como revistas no disciplinares y periódicos. El autor insiste que «el instrumental moderno para pensar la ciudad yla arquitectura se constituyó por representaciones, - conceptos e imágenes- cuya circulación tuvo a las publicaciones periódicas como medio preponderante» ${ }^{45}$.

Las revistas de arquitectura como uno de los medios principales a través de los cuales los arquitectos enfrentaron los procesos de modernización cuenta con el estudio fundamental de Max Aguirre. En La arquitectura moderna en Chile (1907-1942): revistas de arquitectura y estrategia gremial ${ }^{46}$ se argumenta que ciertas estrategias para afrontar los cambios producidos por la modernidad se apoyaron en las publicaciones periódicas. Así, la creación del Colegio de Arquitectos, la formación de Facultades de Arquitectura, la integración social de la profesión a través de la participación en congresos de la especialidad y la promoción de la reglamentación de la práctica de la arquitectura fueron maniobras gremiales promovidas desde las revistas especializadas. Entonces, la investigación de Max Aguirre es fundamental para comprender los alcances de los medios impresos de la modernidad latinoamericana.

Otro estudio representativo que alcanza dos naciones del Cono Sur es el de Hugo Mondragón, quien propuso un análisis comparativo
43. Horacio Torrent, "Presentación," en Revistas, Arquitectura y Ciudad. Representaciones en la cultura moderna, coord. por Horacio Torrent (Santiago de Chile: Pontificia Universidad Católica de Chile, 2013): 7.

44. Horacio Torrent, "Ciudades en papel. Teorías arquitectónicas y urbanas en Chile 1930-1940," en Revistas, Arquitectura y Ciudad. Representaciones en la cultura moderna, coord. por Horacio Torrent (Santiago de Chile: Pontificia Universidad Católica de Chile, 2013): 127-155.

45. Torrent, "Ciudades", 127.

46. Max Aguirre, La arquitectura moderna en Chile (1907-1942): revistas de arquitectura y estrategia gremial (Santiago de Chile: Editorial Universitaria, 2012). Este libro tomó como base su tesis de doctorado "La arquitectura moderna en Chile: el cambio de la arquitectura en la primera mitad del siglo xx: el rol de la organización gremial de los arquitectos (1907-1942) y el papel de las revistas de arquitectura (1913-1941)" (Tesis de Doctorado, Universidad Politécnica de Madrid, 2004). 
47. Hugo Mondragón, "Arquitectura, modernización económica y nacionalismo. Una visión a partir de dos revistas de arquitectura latinoamericanas de posguerra: Arquitectura y construcción (Chile) y Proa (Colombia)," Bitácora urbano/territorial, no. 18 (2011): 55-74.

48. Hugo Mondragón, "Experiencias metropolitanas $y$ publicaciones periódicas no disciplinares. El objeto de investigación y las fuentes," en Revistas, Arquitectura y Ciudad. Representaciones en la cultura moderna, coord. por Horacio Torrent (Santiago de Chile: Pontificia Universidad Católica de Chile, 2013): 221-237.

49. Mondragón, "Experiencias", 231. de dos revistas publicadas en la misma época - las décadas de 1940 y 1950 - pero con fines claramente diferenciados ${ }^{47}$. Proa, de Colombia y Arquitectura y construcción, de Chile, representan los dos extremos entre los cuales osciló la cultura arquitectónica moderna de la región después de la Segunda Guerra Mundial. Los límites fueron, por un lado, la visión de nación concebida como proyecto cultural, de pasado y permanencia y, por el otro, como proyecto civilizatorio de futuro y de cambio. Al inicio ambas revistas estuvieron determinadas por el intento de lograr articular una síntesis entre modernización económica y nacionalismo, en esa época, un debate común a la mayoría de los países latinoamericanos. Lo que más interesa de este análisis comparativo es que ambas situaciones representan las dos líneas entre las cuales osciló ideológicamente toda la cultura arquitectónica de la región. Un caso análogo a lo que ocurrió en México, ya que, como podrá comprobarse a lo largo de este documento, el país produjo una y otra vertiente en su propio territorio.

Pero los alcances metodológicos de Mondragón en estudios posteriores superan la consulta de una sola fuente impresa -las revistas de arquitectura- como material principal de primera mano. En "Experiencias metropolitanas y publicaciones periódicas no disciplinares. El objeto de investigación y las fuentes" ${ }^{48}$, el autor habla de las revistas no disciplinares como la fuente más pertinente cuando el fin es encontrar registros de los tipos de reacciones que las transformaciones de la ciudad y de lo urbano causaban en los individuos. El artículo argumenta que «si las publicaciones disciplinares contienen una colección de ideas sobre el deber-ser de la ciudad, las publicaciones nodisciplinares son un escaparate de sensaciones y emociones producidas por el encuentro de los habitantes con su ciudad ${ }^{49}$. Se prueba así la vigencia de los estudios que parten de la consulta de documentos de difusión de primera mano.

Finalmente, cabe considerar la situación particular de México y cómo se ha abordado el análisis de las publicaciones periódicas de arquitectura dentro de las fronteras nacionales. Sin duda, la digitalización y puesta en línea de un importante repertorio de revistas mexicanas de arquitectura publicadas a lo largo del siglo $\mathrm{xx}$ ha detonado el interés de los estudios nacionales en los medios impresos de la modernidad. La colección "Raíces Digital: Fuentes para la Historia de la Arquitectura 
Mexicana" es un proyecto editorial de la Facultad de Arquitectura de la UNAM, encabezado por el doctor Carlos Ríos Garza. La primera edición digital vio la luz el año 2004 y a la fecha ya cuenta con dieciséis colecciones $\operatorname{completas}^{50}$. Cabe señalarse no sólo el valor de la digitalización en sí, sino los estudios introductorios que acompañan las páginas digitales, que dan soporte y contexto a la cuantiosa información disponible.

De los numerosos estudios y artículos que en los últimos años han ido apareciendo en el ámbito editorial mexicano, cabe destacar a varios autores que han abordado de manera puntual el tema que ocupa a esta investigación. Georg Leidenberger ha expuesto un acercamiento muy apropiado al periodo inmediato anterior a los años de este estudio en "Tres revistas mexicanas de arquitectura" ${ }^{2}$. En dicho artículo examina tres publicaciones que circularon durante las décadas de 1920, 1930 y 1940 en México. La primera, El Arquitecto (1923-1933), asociada al gremio profesional a través de la Sociedad de Arquitectos Mexicanos (SAM), de la que por su estrecha relación con el proyecto editorial de la revista, el autor también comentó "La Sección de Arquitectura", publicada semanalmente en el diario Excélsior. La segunda publicación es Cemento (1925-1930), que después cambió su título por Tolteca (1929-1932), vocera de la industria privada. La última revista presentada aquí es Arquitectura México (19381978). Cada una representó una plataforma de análisis para revisar cómo los profesionales mexicanos tomaban posición frente al Movimiento Moderno. Al enfrentar lo que llegaba de Europa, cada editorial tuvo su manera de 'abrirse al mundo', en su compromiso con el proyecto cultural y político seguido después de la Revolución.

50. La colección Raíces Digital cuenta con los siguientes títulos: (1) Anuario SAM 19221923. Primera publicación en forma de volumen editada por la Sociedad de Arquitectos Mexicanos. (2) Revista Arquitectura y lo Demás; 14 números publicados entre 1945 y 1950. (3) Revista El Arquitecto; 19 números publicados entre 1923 y 1927. (4) Publicaciones del Autogobierno; 25 revistas de cinco órganos de difusión y los planes de estudio originales de la licenciatura y el posgrado, publicadas entre 1976 y 1986. (5) Traza, Temas de Arquitectura y Urbanismo; 12 números publicados entre 1983-1986 como separata del periódico Uno más Uno, en formato tabloide y con el mismo papel que el periódico. (6) Arquitectura México; 119 números publicados de 1938 a 1978. (7) Planificación; 30 números publicados entre 1927 y 1936. (8) Entorno; 8 números publicados entre 1982 y 1984. (9) Diseño UAM; 7 números publicados entre 1983 y 1997. (10) Revista El Arte y la Ciencia; 145 números publicados entre 1899 y 1911 . (11) Calli. Revista Analítica de Arquitectura Contemporánea; 68 números publicados entre 1960 y 1983. (12) Arquitectura y Decoración; 22 números publicados entre 1937 y 1943. (13) Espacios. Revista Integral de Arquitectura y Artes Plásticas; 41 números publicados entre 1948 y 1957. (14) Arquitectos de México; 33 números publicados entre 1956 y 1969. (15) Cuadernos de Arquitectura del INBA; 20 números publicados entre 1961 y 1967. (16) Cemento; 32 números publicados entre 1925 y 1929. Véase "Raíces Digital," consultada 6 octubre, 2015, http:// arquitectura.unam.mx/biblioteca-digital.html.

51. Georg Leidenberger, "Tres revistas mexicanas de arquitectura. Portavoces de la modernidad, 1923-1950", Anales del Instituto de Investigaciones Estéticas, no. 101 (2012): 109138. 
52. Louise Noelle, "Arquitectura/México y la arquitectura internacional," en Imaginarios de modernidad y tradición. Arquitectura del siglo $X X$ en América Latina, coord. por Catherine R. Ettinger (México: Miguel Ángel Porrúa, 2015), 33-44.

53. Louise Noelle, "Los Textos de la Segunda Modernidad," en Segunda Modernidad Urbano Arquitectónica. Construcción Teórica y Caracterización del Periodo, coord. por Enrique Ayala Alonso (México: Universidad Autónoma Metropolitana, 2013), 141-52. El volumen citado define una «Primera Modernidad iniciada a partir del triunfo de la Revolución Mexicana, extendida hasta finales de los años treinta, al concluir el gobierno del general Lázaro Cárdenas, quien consolidó las instituciones emanadas de ésta. A partir de entonces se hizo evidente un estado diferente de cosas, que demuestra la existencia de una época decididamente más moderna; en ella se crearon instituciones con un sentido notoriamente social, enfocadas a resolver problemas sobre todo en las ciudades. La sociedad aceptó la modernidad de la mejor manera y se asumió moderna, contrariamente a lo que sucedió unos cuantos años antes, cuando aún era evidente la resistencia a lo nuevo». Esta segunda época es la que se denomina en este estudio Segunda Modernidad. Enrique Ayala Alonso, "Introducción," 19.
Leidenberger exponelalógica propia ylas características intrínsecas de una revista en cuanto medio de comunicación: circula con facilidad, aparece periódicamente, puede llegar a abarcar espacios geográficos amplios y es una herramienta apta para hacer circular conceptos, ideas, o imágenes incluso más allá de las fronteras nacionales. Esto último porque - como se sabe - era práctica común de las casas editoriales intercambiar textos e ilustraciones con revistas internacionales o publicar los reportajes de los corresponsales que radicaban fuera del país.

También resulta fundamental para este análisis subrayar cómo las revistas obedecen, por su naturaleza, a un mercado local conformado por sus lectores, suscriptores, anunciantes y patrocinadores. De esta manera, el principal vínculo de estas publicaciones a su lugar es su dependencia de los ingresos de las ventas y de los anuncios publicitarios y, en su caso, de la disposición de las instituciones patrocinadoras. Las tres publicaciones analizadas destacaron por el ímpetu con que defendían sus posturas a favor de cierto lenguaje de construcción y su afán proselitista que involucró intereses institucionales o incluso personales.

Este último aspecto es asimismo destacado por Louise Noelle en "Arquitectura/México y la arquitectura internacional"52. En este texto se revisa no sólo la trayectoria de Mario Pani y la fundación de la conocida publicación periódica, sino también los factores ideológicos de la misma, como su primera intención de ser una revista internacional que muestre lo mejor de la arquitectura del momento, pero que paulatinamente se transforma en una plataforma que prioriza y difunde la arquitectura nacional. Un aspecto que interesa en especial es el análisis a los contenidos extranjeros en dicha publicación, ya que la presencia extranjera en Arquitectura/México no es escasa, abordándose de manera puntual la reseña de obras internacionales. El texto comprueba que mientras los ejemplos europeos y norteamericanos aparecieron con frecuencia, los casos de arquitectura latinoamericana quedaron restringidos a los proyectos más conocidos de los años cincuenta. Noelle puntualiza que esta situación se debió al interés natural de su director por lo que acontecía en la escena europea, lo que desvela la tendencia de la publicación.

La misma autora revisa las ideas de los arquitectos mexicanos de mediados del siglo xx expresadas en ensayos y libros en "Los textos de la Segunda Modernidad"53. Lo más destacado del análisis es el acercamiento 
al periodo que considera las expresiones regionales que buscaron soluciones locales específicas, en varios casos, vinculadas a determinados compromisos sociales. Así, no se habla ya de una modernidad sino de "otros modernismos" ${ }^{2}$. Para Noelle, las diversas tendencias arquitectónicas de la mitad del siglo xx que dominaron el panorama mexicano, como la integración plástica, la arquitectura emocional, el formalismo o el estilo internacional, destacan la heterogeneidad de las propuestas modernas. La autora demuestra cómo la orientación teórica de ciertos arquitectos mexicanos y sus textos publicados se reflejaron en la arquitectura que produjeron, lo que los convierte en fuente de consulta imprescindible para ampliar el conocimiento de la arquitectura mexicana de mediados del siglo $\mathrm{xx}$.

Otra publicación fundamental de Noelle Gras es "La arquitectura mexicana en las publicaciones periódicas del siglo $\mathrm{xx}^{\prime 55}$, donde la autora revisa las revistas mexicanas más significativas durante el siglo xx. El análisis destacó el papel de las publicaciones como un mero receptáculo de información gráfica, pero también subrayó el proselitismo involucrado en cada una de ellas. Así, Noelle recala en un punto que se viene repitiendo en los estudios analíticos de este tipo: no podemos soslayar los compromisos ideológicos de editores, críticos y arquitectos al aproximarnos a estas fuentes sustanciales.

De esta manera, se acentúa que presentar las obras de los arquitectos es un hecho relevante, pero que no por ello se deja de lado la labor de información y de análisis de los hechos mismos, sus cambios y sus novedades. Por lo tanto, la historiografía de la arquitectura mexicana debería considerar las revistas de arquitectura como uno de los pilares para su conocimiento y análisis. En cualquier caso, esta revisión consideró únicamente el ámbito editorial mexicano, por lo que aún resta por ejecutar el estudio de la presencia mexicana en los medios extranjeros, cuestión que se aborda en profundidad en esta tesis.

Por último, y en estrecha relación con el tema que nos ocupa, el artículo "Estados Unidos y la Arquitectura Mexicana en el siglo xx. El punto de vista de las publicaciones"56, expone la interacción en las propuestas impresas de ambos países, con relación a la arquitectura moderna, enfatizando una mayor importancia en la influencia de Estados Unidos en la arquitectura mexicana desde el periodo moderno y hasta el presente.
54. Término definido, como ya se ha visto, en el IX Congreso Internacional Docomomo 2006, en Ankara, Turquía.

55. Louise Noelle, "La arquitectura mexicana en las publicaciones periódicas del siglo xx" Bitácora, núm. 19 (2009): 12-17.

56. Louise Noelle, "Estados Unidos y la Arquitectura Mexicana en el siglo xx. El punto de vista de las publicaciones," Anales del Instituto de Investigaciones Estéticas, no. 85 (2004): 49-60. 
57. Catherine R. Ettinger, "De modernidades y regionalismos. El editor de Architectural Forum visita México," en Imaginarios de modernidad y tradición. Arquitectura del siglo $X X$ en América Latina, coord. por Catherine R. Ettinger (México: Miguel Ángel Porrúa, 2015): 65-81.

58. Ettinger, "Modernidades," 66. Véase también Catherine Ettinger, "La segunda modernidad vista desde afuera. Arquitectura mexicana en las revistas estadounidenses" en Segunda Modernidad Urbano Arquitectónica. Lecciones significativas de la Segunda Modernidad en México, coord. por Catherine Ettinger, Louise Noelle y Alejandro Ochoa (México: Universidad Autónoma Metropolitana-Conacyt, 2014): 395-412.
Noelle cita los casos más conocidos y tempranos de la difusión de la arquitectura moderna mexicana en el país norteamericano, pero también subraya que fueron contadas las apariciones de construcciones mexicanas en las páginas de medios especializados en Estados Unidos. Por el contrario, un análisis cuantitativo que compare la cantidad de información que se publicó en el otro sentido - la arquitectura americana en medios mexicanos- podría parecer apabullante; sin embargo, el texto no brinda datos precisos sobre esta relación que se intuye por demás desequilibrada.

La autora, a lo largo del texto, enfatizó especialmente la falta de influencia de la arquitectura mexicana en Estados Unidos, aunque también en Europa o Asia, debido a que las publicaciones mexicanas o latinoamericanas no llegaban a esos países en ediciones bilingües o en el idioma local.

Cabe insistir que la principal aportación de dicho artículo para esta investigación ha sido el acertado manejo de las fuentes primarias de estudio y cómo éstas facilitan diversas interpretaciones de actualidad sobre la arquitectura moderna mexicana. Con estas herramientas metodológicas se acometió el análisis global de las publicaciones periódicas que - tanto en resultados cuantitativos como cualitativos- se exponen a lo largo de esta tesis.

Otra autora mexicana que incursiona con análisis actuales sobre las relaciones entre las publicaciones periódicas estadounidenses y la arquitectura moderna mexicana es Catherine R. Ettinger. En “De modernidades y regionalismos. El editor de Architectural Forum visita México" ${ }^{57}$, la autora destaca cómo la visión extranjera se enfrentó con otra forma de construir la modernidad - apoyada en la historia y la tradición - en un momento en que ya se dudaba de la pertinencia de continuar con los modelos canónicos. A través de este estudio, Ettinger evidencia que los ejemplos seleccionados y «la manera de presentar el trabajo de arquitectos latinoamericanos están cargadas de intenciones, vinculadas a las inquietudes propias de los editores y producto, en muchas ocasiones, de amistades forjadas a través de las fronteras» ${ }^{58}$.

Para terminar esta breve exposición sobre el estado de la cuestión entre los estudiosos mexicanos, cabe decir que han comenzado a fluir los análisis comparativos que involucran las publicaciones latinoamericanas, 
a diferencia de los casos ya comentados sobre el mundo editorial mexicano con alguna puntualización en los Estados Unidos. Un caso es el artículo "El pensamiento sobre la arquitectura moderna a través de revistas latinoamericanas. 1925-1945"59, de Lourdes Cruz González Franco, que toma como material de consulta algunas revistas de Uruguay, México, Argentina, Brasil, Chile y Cuba. El texto destaca cómo se vivía la modernidad en Latinoamérica durante las primeras décadas del siglo $\mathrm{xx}$, momento de cambio en el sentido del tiempo y del espacio. Así, la autora se sitúa en la época de transformación en las comunicaciones y la tecnología, y encuentra en las publicaciones los puntos en común en todo el mundo latinoamericano. González Franco trata el tema de la falta de consenso hacia un concepto de qué es moderno, pero sobre todo habla de la conformación de un imaginario de modernidad ligado a la casa habitación a través de la noción de confort, y el papel de las mujeres en la publicidad y en el diseño de la época.

Con todo lo anterior, queda de manifiesto no sólo la vigencia de la metodología empleada sino también la riqueza interpretativa que deriva de la consulta rigurosa a las publicaciones periódicas de arquitectura del siglo xx. Cabría señalar que un punto común entre los autores considerados es la ponderación de diversos análisis comparativos para sacar partido a los cruces de información que facilita la consulta de estos documentos periódicos. Lo anterior no solo confirma la difusión internacional de la arquitectura, sino que aporta interpretaciones de actualidad.

Los párrafos anteriores no han hecho más que esbozar el extenso horizonte que ofrece la profundización en el estudio de los diversos flujos informativos en su relación con la historia de la arquitectura moderna. Como se ha visto, la comprensión cabal de los diferentes aspectos que dieron forma a la materialización de propuestas gráficas, primero, y teóricas o edilicias, después, exponen diferentes lecturas y análisis de la actualidad. Hay que insistir que en todos los estudios comentados no se trata la arquitectura como un hecho aislado, sino como un componente indisoluble de su momento social, político, económico y cultural.
59. Lourdes Cruz González Franco, "El pensamiento sobre la arquitectura moderna a través de revistas latinoamericanas. 1925-1945," en Imaginarios de modernidad $y$ tradición. Arquitectura del siglo XX en América Latina, coord. por Catherine R. Ettinger (México: Miguel Ángel Porrúa, 2015): 45-64. 


\section{Descripción de contenidos}

La presente tesis se estructura en tres partes principales: los medios impresos y la modernidad arquitectónica mexicana, las publicaciones periódicas de arquitectura y los grandes temas en el extranjero. La PARTE I introduce al lector a los principales medios impresos de difusión de la arquitectura moderna mexicana fuera de sus fronteras: los libros y las publicaciones periódicas. El CAPÍtulo 1 ofrece los antecedentes de la arquitectura en México en las primeras décadas del siglo xx. Por su parte, el CAPítulo 2 revisa la modernidad desde la perspectiva de los títulos extranjeros. Un primer apartado revela parte de la historia de la arquitectura moderna mexicana que se ha construido esencialmente a través de libros que por su consulta obligada se han vuelto canónicos. Esta sección ofrece una confrontación entre las fuentes clásicas y las reseñas que se publicaron - en su momento- en las revistas que forman el corpus principal de esta investigación. Así, se comentan no sólo algunos de los libros clave de la difusión internacional de la arquitectura mexicana, sino también los debates que su propia publicación generó en los medios especializados. Un segundo apartado revisa la pluralidad arquitectónica mexicana que se conoció en el extranjero y el impacto que supuso la repetición de noticias en los medios especializados para consolidar la imagen de modernidad del país. Se exploran las décadas de 1950 y 1960, en las que México estuvo siempre bien representado en el panorama editorial periódico del extranjero.

La PARTe II aborda directamente uno de los medios de difusión más vigorosos durante el periodo de estudio de esta tesis: las publicaciones periódicas de arquitectura. Esta parte se sustenta en la consulta rigurosa y en el análisis cuantitativo de una selección de títulos que, por su impacto en la época y por su accesibilidad actual en los fondos públicos de las bibliotecas madrileñas, han conformado el corpus principal de esta investigación. Esta aproximación detectó los diferentes temas publicados por los medios extranjeros, lo que hizo posible el posterior análisis cualitativo que considera el impacto de la información en cada revista, la velocidad de difusión, las semejanzas y diferencias con respecto a un mismo tema en las publicaciones de distintos países, así como la verificación de los detonantes del interés internacional que alimentaron la publicación de noticias en los medios especializados extranjeros. 
De esta manera, el CAPítulo 3 hace un recuento de contenidos de las publicaciones estadounidenses, españolas, francesas, inglesas e italianas, que van de las reseñas a los artículos pasando por las noticias de actualidad o las cartas de y para los editores. También, se cuantifica la diversidad edificada desde la vivienda unifamiliar hasta la infraestructura urbana. Una vez enterados de qué revista publicó qué temas y cuándo, se procedió a analizar en qué lugares del territorio nacional se construyeron dichos ejemplos. Por lo tanto, el CApítulo 4 sitúa geográficamente al lector en los lugares donde el auge constructivo moderno llegó a las páginas internacionales. Se intenta así superar el mito de que todo lo que se publicó sobre México a mediados del siglo xx se edificó en la capital mexicana. Dentro de una visión panorámica que va de lo general a lo particular, también se analiza la propia geografía del Distrito Federal para situar igualmente las zonas urbanas con mayor impacto de construcciones modernas que se difundieron en las revistas foráneas.

La PARTe III agrupa los temas que, por su repetición en las revistas o por su decidido impacto, dibujaron el panorama de la difusión internacional de la arquitectura mexicana. Desde luego no son todos los contenidos presentes en las publicaciones periódicas, pero sí los que, después de la consulta estricta a las fuentes primarias de información, se han perfilado como susceptibles de un análisis cualitativo y a profundidad. Así, el CAPÍTULO 5 presenta a la discusión teórica como parte indisoluble de las publicaciones periódicas modernas. El análisis de la selección de artículos se divide aquí en dos grandes apartados: el primero, los debates en torno a conceptos generales, y el segundo, los estudios de materiales, su aplicación y algunos temas técnicos y de ingeniería. Se examinan ideas que engloban tanto las condiciones particulares de emplazamiento, el urbanismo, o ejemplos específicos de arquitectura moderna mexicana que se vieron involucrados - de forma directa o indirecta - en las discusiones que, en torno a la actualidad de la arquitectura moderna y su futuro, ocuparon las páginas de los medios internacionales.

El CAPÍtulo 6 aborda el análisis de los arquitectos que llegaron a las páginas de los medios foráneos especializados. Un primer acercamiento cuantitativo brinda el complejo panorama de los más de cien arquitectos mexicanos que, con al menos una obra como autores principales, se dieron a conocer en las revistas internacionales. El desarrollo del capítulo 
continúa con la discusión sobre los contados casos en que los arquitectos mexicanos alcanzaron un trato protagónico, es decir, su presencia en las publicaciones no estuvo relacionada únicamente con la construcción puntual de un edificio sino con aspectos de su vida y obra en general. La última parte trata los casos de los arquitectos que, ya sea por la cantidad de edificios publicados o por la reincidencia de determinadas construcciones en las revistas extranjeras, destacaron notablemente sobre la totalidad de los nombres consignados.

Para terminar, el CApítulo 7, el de mayor desarrollo en esta tesis, concentra uno de los grandes temas mexicanos en las revistas de arquitectura: los edificios como protagonistas de las páginas impresas. Los casos analizados no son los únicos posibles, pero sí los que, desde este estudio, abarcaron un amplio panorama de disertación. También, se revisan algunos hitos fundamentales de la historia arquitectónica del país en su condición de límites del periodo de estudio. 


\section{Parte I}

\section{Los orígenes del descubrimiento}

Medios impresos y modernidad arquitectónica mexicana 



\section{El peso de la historia \\ Los antecedentes de la nueva arquitectura en México}

México sigue siendo un país de contrastes y desigualdades, donde su pasado cultural heterogéneo y la pluralidad de sus circunstancias sociales, económicas y políticas - propias de una nación en construccióndibujaron el escenario arquitectónico de las primeras décadas del siglo $\mathrm{xx}$. Estas condicionantes favorecieron la multiplicidad material que hoy forma el patrimonio de la arquitectura moderna mexicana y que, en forma de debates teóricos y auto explicativos de nuestra diversidad, acompañaron la divulgación de la obra edificada dentro y fuera de las fronteras territoriales. La afirmación de la divergencia y la pertenencia -al mismo tiempo - al movimiento internacional de la arquitectura moderna se expresó en diversas ocasiones desde los círculos oficiales del ejercicio profesional ya en la década de $1950^{1}$. Era evidente que, entendiendo la disparidad de la que se partía como realidad, no se esperaba alcanzar una síntesis y una unidad arquitectónica².

Aproximarse a la modernidad ${ }^{3}$ mexicana del siglo xx requiere deshilvanar un poco el tejido de determinantes que caracterizó el contexto ideológico y físico de las obras de arquitectura que se divulgaron en las

1. En el libro 4000 años de arquitectura mexicana, editado por la Sociedad de Arquitectos Mexicanos (SAM) y el Colegio Nacional de Arquitectos de México (CNAM) en 1956, se subraya que «El movimiento arquitectónico moderno [en México] no es un todo homogéneo y uniforme, por el contrario, es variado en tendencias e ideas directrices; como algo surgido en una forma orgánica, sin restricciones intelectuales o estatales, se manifiesta en formas diversas, en enfoques bajo puntos de vista diferentes, dentro de la gran corriente de la arquitectura moderna». 4000 años de arquitectura mexicana (México:
Libreros mexicanos unidos, 1956), 139.

2. En 1963, Ricardo de Robina aclaró que «el supuesto de una base teórica 'única' para nuestra arquitectura se halla[ba] sustituido por una base múltiple, como reflejo sin duda de una situación compleja y múltiple a su vez, de la realidad nacional». Ricardo de Robina, "25 años de arquitectura mexicana: Diálogo en torno a sus supuestos, sus logros y directivas 1938 1963," Arquitectura México, no. 83 (septiembre 1963): 141 Esta interpretación se puede vincular al concepto vigente de "modernidades múltiples", que presupone una nueva forma de entender el mundo contemporáneo y de explicar la historia de la modernidad viéndolo como una historia de continuas constituciones y reconstituciones de una multiplicidad de programas culturales. Cfr. Josetxo Beriain, "Modernidades múltiples y encuentro de civilizaciones," Papers, no. 68 (2002): 33. Consultado 12 mayo, 2015. http://papers.uab.cat/article/ view/v68-beriain.

3. La modernidad como la puesta en entredicho de una línea continua de actuación se relaciona aquí con el Movimiento Moderno en la arquitectura, entendido éste como el conjunto de tendencias 
publicaciones periódicas foráneas durante el periodo de estudio. Hablar de modernidad en México es considerar las reivindicaciones sociales de la Revolución al mismo tiempo que suponer la generalización de las estructuras de hormigón armado; es entablar un diálogo entre las obras surgidas de los programas estatales y las nacidas de los presupuestos económicos de la iniciativa privada. Es imposible entender cabalmente la modernidad en México si no visualizamos tanto sus vínculos formales con la arquitectura extranjera como sus interpretaciones locales o los revolucionarios cambios que se dieron en la enseñanza de la arquitectura. Tampoco podemos soslayar el papel del gremio de profesionales tanto en la administración pública como su posición desde la iniciativa privada. Asimismo, debe reflexionarse en que el peso de la tradición y de una historia viva convivió con los cambios fundamentales sobre cómo se transporta el ciudadano en la urbe moderna, cómo se adapta a las nuevas viviendas o cómo se apropia de los nuevos servicios públicos de salud y educación. Los anteriores no son conceptos contrapuestos sino complementarios entre sí; estos rasgos distintivos, analizados en conjunto, dieron paso a los innumerables ensayos estilísticos ${ }^{4}$ de las primeras décadas del siglo pasado, pruebas que no podían devenir en un estilo nacional único sino en diferentes vertientes - todas válidas- que desde lo internacional hasta lo regional conformaron la diversidad de la arquitectura moderna mexicana.

Se comentan a continuación algunas de las piezas clave de interpretación de la modernidad mexicana. Es apropiado iniciar con la inevitable mención de la relación del presente moderno con el pasado y la oposición que su fuerte presencia ejercía al mismo tiempo que la avidez de cambio y renovación ${ }^{5}$. En este contexto, fue fundamental la invariable

surgidas en las primeras décadas del siglo xx que marcaron una ruptura con la tradicional configuración de espacios, formas compositivas y estéticas que aprovechó las posibilidades de los nuevos materiales industriales como el hormigón armado, el acero laminado y el vidrio plano en grandes dimensiones. Si bien es común caracterizarlo por sus plantas y secciones ortogonales, generalmente asimétricas, ausencia de decoración en las fachadas y grandes ventanales horizontales conforma- dos por perfiles de acero, es imprescindible subrayar que esta modernidad «reordenó los principios fundamentales de la disciplina e instauró nuevas libertades para el futuro; luchó para conciliar el idealismo con el progreso material, la ciencia con la historia, y la ciudad con la naturaleza», además de servir como un "prisma de refracción a través del cual podían volver a examinarse las tradiciones locales». William J. R. Curtis, La arquitectura moderna desde 1900, $3^{a}$ ed. (Londres: Phaidon Press
Limited, 2006), 685.

4. Se entiende el estilo como el conjunto de características formales que individualizan la tendencia artística de una época y que permite su clasificación.

5. A diferencia de otros países latinoamericanos, en México «la historia se vive [vivía] con una vehemencia de actualidad y presencia, que no puede menos que traducirse en un sentido o en otro en operatividad determinante. La presencia histórica en la actualidad [1963] ... inunda el 
histórica cultural de la lucha interna entre dos mundos bien diferenciados -el prehispánico y el occidental- de cuyo «antagonismo constante, obrando como catalizador, surge la creación de elementos nuevos» ${ }^{6}$. Estos determinantes de la cultura mexicana fueron en gran medida responsables de la falta de unidad en su producción arquitectónica, pero, de igual manera, han «constituido su riqueza y variedad, sus diferentes corrientes y su diversidad ${ }^{7}$.

No menos importante que la recuperación de la historia para enfrentar los cambios que implicó la modernidad, fueron las consecuencias del movimiento armado de la Revolución, acontecimiento de gran significación en el proceso de evolución social y política del país, ya que estableció nuevas determinantes para la arquitectura. El paso de una economía establecida en la producción agropecuaria y de minería e industria extractiva de materias primas a un capitalismo incipiente, aunado al régimen de propiedad privada de los medios de producción que reconoció la Constitución de 1917, determinaron de forma paralela tanto la existencia de clases obreras como los derechos de los trabajadores, que se tradujeron en nuevos programas sociales dirigidos a la educación, la salud y la vivienda ${ }^{8}$.

De esta manera, la reivindicación social de la Revolución Mexicana y el anhelo de modernidad fueron importantes expresiones de la arquitectura desde la tercera década del siglo xx y hasta ya superada la primera mitad de la centuria, cuando los preceptos revolucionarios «aún tenían un peso muy importante dentro del proyecto ideológico del Estado» ${ }^{9}$. Si bien ha sido común identificar el periodo posrevolucionario con el funcionalismo ${ }^{10}$, hay que insistir en el papel de la arquitectura como «uno de los muchos dispositivos al alcance del gobierno para transmitir

campo de la política, el social y el económico, formando uno de los supuestos de toda actividad cultural y plástica. La arquitectura ha sentido su acción en forma constante y aun cuando se haga arquitectura que ignore los valores tradicionales, aun entonces, no tiene un carácter de desconocimiento de los mismos, sino de lucha consciente de ellos». De Robina, “25 años," 145.

6. De Robina, "25 años," 149.

7. De Robina, "25 años," 149 .
8. Enrique Yáñez, Del Funcionalismo al Post-racionalismo: Ensayo sobre la Arquitectura Contemporánea en México (México: Universidad Autónoma Metropolitana, 1990), 37.

9. Enrique $X$. de Anda, "1920-1970: cincuenta años de arquitectura en la ciudad de México," en Ciudad de México. Arquitectura: 19211970, coord. por Enrique X. de Anda (Ciudad de México: Gobierno del Distrito Federal, 2001), 30.

10. Entendemos el funcionalismo como el movimien- to arquitectónico donde la función constituye el objetivo primordial de la composición y, por ello, todos los elementos derivarán de la misma. Para el caso mexicano, nos aproximamos a la definición de Enrique Yáñez para quien «el funcionalismo mexicano es la modalidad del racionalismo aplicado a obras de utilidad social, tendencia que con extraordinario vigor se manifestó en el periodo post-revolucionario de la historia contemporánea de nuestro país». Yáñez, Funcionalismo, 39. 
Yuriria, Guanajuato y Chiapa de Corzo, Chiapas. La síntesis del encuentro: arquitectura del siglo xvı, en 4000 años de arquitectura mexicana.
11. Antonio E. Méndez-Vigatá, "Política y lenguaje arquitectónico: Los regímenes posrevolucionarios en México y su influencia en la arquitectura pública, 1920-1952” en Modernidad y arquitectura en México, ed. por Edward R. Burian (España: Gustavo Gili, 1998), 62.

12. Gustavo López Padilla, "Aportaciones mexicanas al movimiento moderno de la arquitectura entre $1920 \mathrm{y}$ 1970," en Ciudad de México. Arquitectura: 1921-1970, coord. por Enrique X. de Anda (Ciudad de México: Gobierno del Distrito Federal, 2001), 110.

13. Israel Katzman, $L a$ arquitectura contemporánea mexicana: Precedentes $y$ desarrollo (México: Instituto Nacional de Antropología e Historia, 1964), 14.
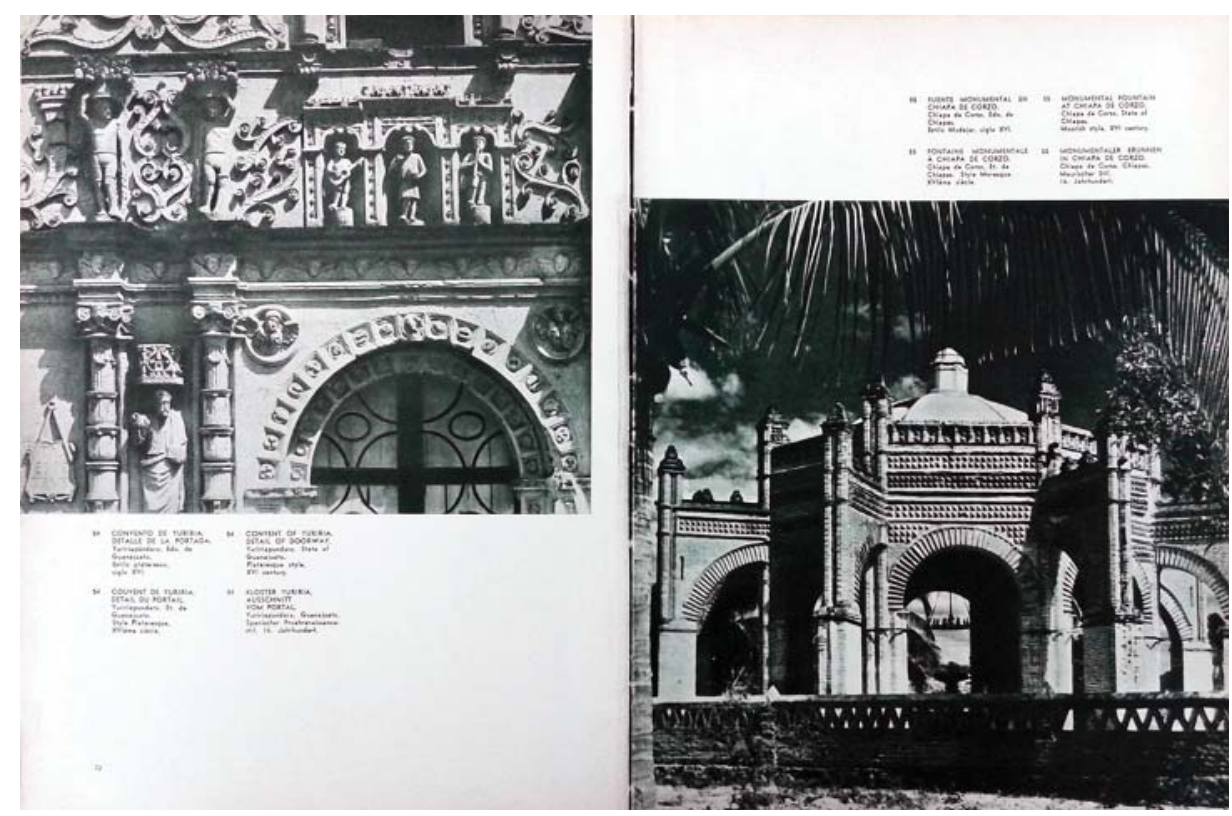

ideas» ${ }^{11}$. Esto se refiere a la manera de proyectar una imagen moderna y progresista del país a nivel internacional, aspecto que claramente se reflejó en las publicaciones periódicas que forman el corpus de esta investigación. Ante la demanda de grandes volúmenes de hospitales, escuelas y habitación popular, el gremio de arquitectos entró al escenario al adoptar gran parte de la tecnología y los materiales de reciente aparición en el mercado.

El vínculo entre estas primeras décadas del siglo xx y la arquitectura funcionalista se entiende como una alternativa conceptual a partir de la cual se resolvieron algunos de los problemas planteados al gobierno posrevolucionario, en materia de edificios para la salud, la vivienda, la educación y los servicios públicos. El reto consistió en «edificar obras económicas, en tiempos razonablemente rápidos y satisfacer en cantidad a los grandes grupos sociales que las demandaban ${ }^{12}$. Para esto, la organización espacial funcional y los volúmenes sencillos — de la mano de los nuevos materiales y técnicas constructivas- fueron fundamentales, aspectos que necesariamente distanciaron las referencias históricas y sus costosos sistemas edificatorios.

La intensa actividad del arquitecto en los planes nacionales y en la creación de infraestructura y equipamientos urbanos, dibujó una figura profesional que muy pronto se interpretó como «más democrática» y - supuestamente- con «mayor interés por los problemas sociales y urbanísticos» ${ }^{13}$, pero tampoco podemos desvincular la participación de un significativo número de arquitectos en importantes puestos de la 


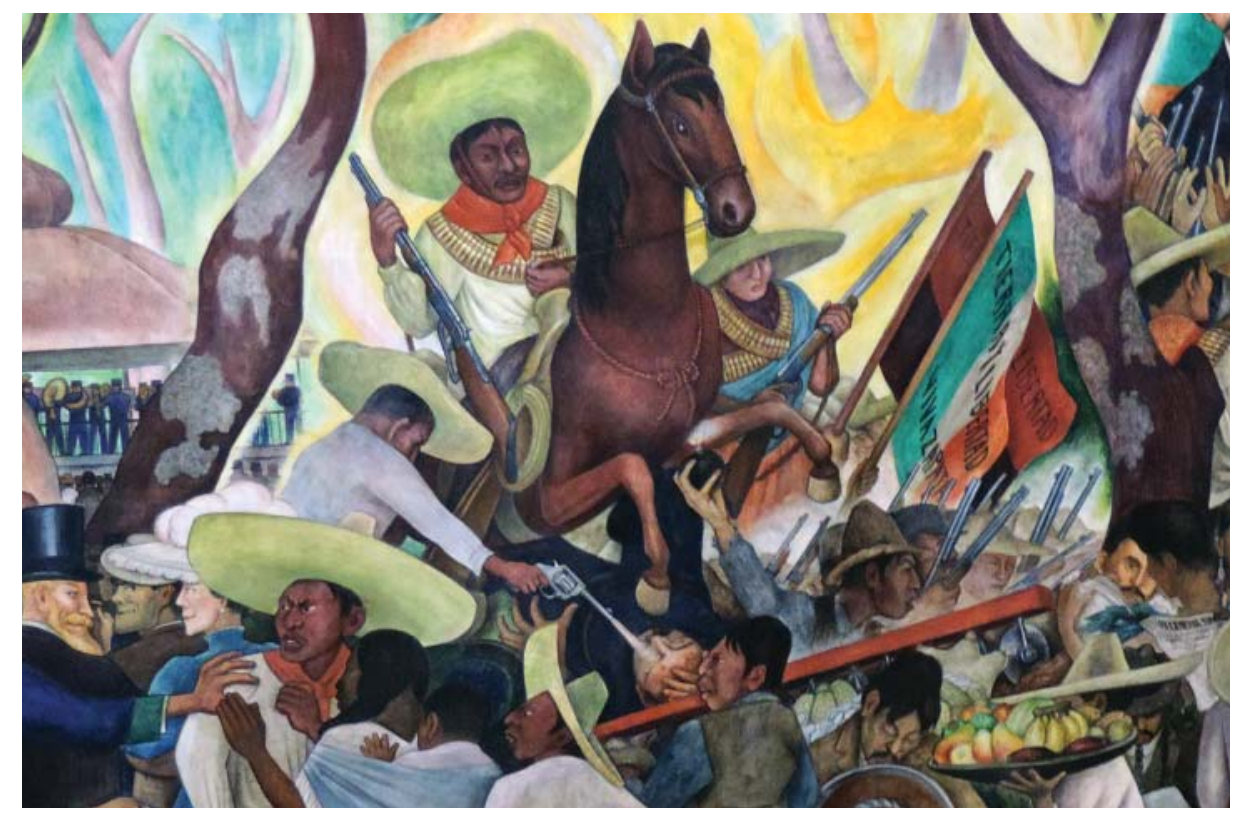

administración pública durante las primeras décadas de la modernidad en México. Si bien en un principio se pensaron resueltos los problemas arquitectónicos colectivos con financiamiento estatal, muy pronto se hizo evidente que, no obstante la acción del Estado había sido importante cualitativa y cuantitativamente, se terminó beneficiando a la incipiente clase media y dejando sin resolver cabalmente las carencias de las capas más pobres de la población ${ }^{14}$.

La transformación que experimentó el país se reflejó tanto en la obra pública como en la financiada por inversionistas particulares, si bien los cambios se registraron primero en la ciudad de México por concentrar los poderes políticos y económicos de la nación. En términos generales, se puede hablar de un predominio de la obra pública sobre la privada entre 1920 y 1970, donde la vivienda colectiva de interés social, la arquitectura hospitalaria, las escuelas y los mercados - cuantitativamentesobrepasaron a los edificios de oficinas y las industrias ${ }^{15}$. Sin embargo, lo que se reflejó en las publicaciones periódicas - como se comprobará a lo largo de esta tesis - tomará otra vertiente a la que trazó la realidad construida.

Si bien el poder estatal propulsó la arquitectura racionalista ${ }^{16}$ por motivos principalmente económicos e ideológicos, no podemos soslayar el papel fundamental de la iniciativa privada para difundir el uso del cemento Portland y el hormigón armado en México desde 1925. Con Federico Sánchez Fogarty a la cabeza de la revista Cemento - publicación de la recién instalada planta de cemento La Tolteca (Compañía de Cemento
El impacto de la Revolución mexicana en el arte: mural "Sueño de una tarde dominical en la Alameda Central" (1947) de Diego Rivera, Museo Mural Diego Rivera, ciudad de México.

14. Yáñez, Funcionalismo, 28.

15. De Anda, "1920-1970", 32.

16. Siguiendo a Yáñez, la arquitectura racionalista sería aquella en que «el razonamiento lógico preside todos los pasos y las decisiones que se toman en el proceso creativo de las obras: en la determinación de los propósitos que las originan, en el análisis de los requerimientos y estructuración de los espacios habitables, en la adopción de sistemas constructivos y materiales para su realización, etc., advirtiendo que la actitud racionalista enfatiza de manera diferente, según los medios culturales de los países y la personalidad de los arquitectos, diversos aspectos, en unos casos la sencillez formal, en otros la eficiencia técnica o bien la economía». Yáñez, Funcionalismo, 34. 


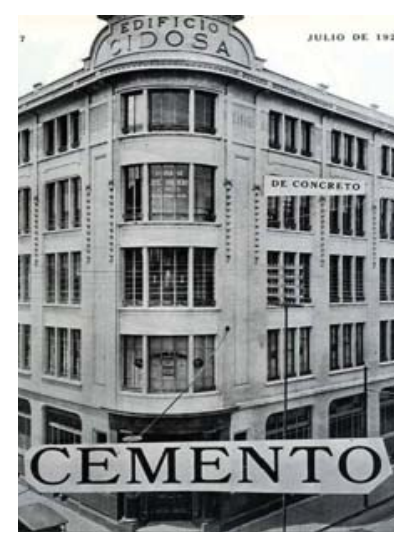

En esta página, portadas de la revista Cemento entre 1925 y 1929; en la siguiente página, vista del Paseo de la Reforma de la ciudad de México, ca. 1950.
17. Rafael López Rangel, La modernidad arquitectónica mexicana: Antecedentes y vanguardias 1900-1940 (México: Universidad Autónoma Metropolitana, 1989), 59.

18. López Rangel, Modernidad, 61.

19. «Cemento tenía un tiraje de treinta mil ejemplares y se enviaba gratuitamente hasta al cura de cada pueblo, de manera que es innegable que fue no sólo un importante vehículo de difusión de los nuevos materiales, sino el primer medio por el que la gente no especializada, empezó a familiarizarse con la arquitectura contemporánea europea y los primeros intentos mexicanos». Katzman, Arquitectura, 108.

20. Enrique Del Moral, "Villagrán García y la evolución de nuestra arquitectura," Arquitectura México, no. 55 (septiembre 1956): 131.

21. Del Moral, "Villagrán García," 132.

\section{E M E N T O}
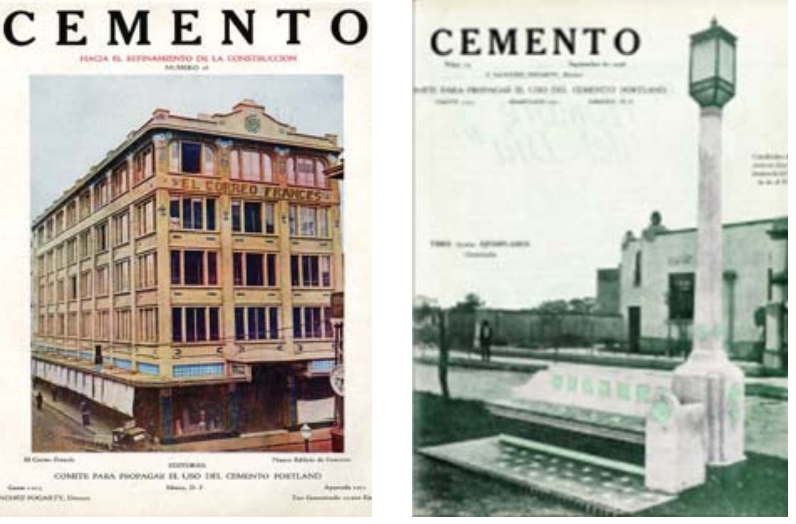

C E M E N T O

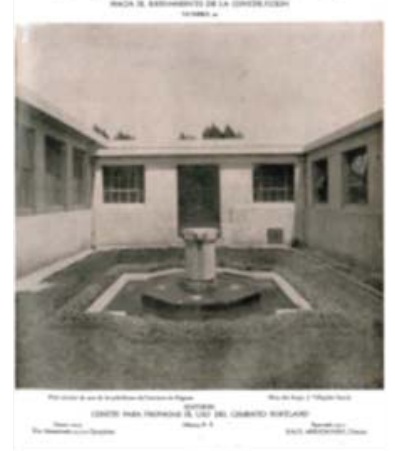

Portland, S.A.), de capital mayoritariamente norteamericano- el uso del nuevo material en el país se implantó y consolidó rápidamente ${ }^{17}$. Si bien Cemento fue de enorme influencia para la adopción del art déco, «lenguaje que era presentado como el estilo propio del concreto armado» ${ }^{18}$, hay que recordar que al mismo tiempo que se generalizaba el empleo del hormigón armado, convivían varios estilos arquitectónicos, como el citado decó, el neocolonial o las primeras simplificaciones racionalistas. Así, la divulgación del nuevo material durante la tercera década del siglo xx en México, de la mano de la exitosa campaña comercial de la compañía cementera ${ }^{19}$, tampoco puede considerarse un factor aislado de análisis para entender las transformaciones en la arquitectura mexicana del siglo $\mathrm{xx}$.

El mismo año que Cemento comenzó a circular, inició también la labor docente de José Villagrán García en la Escuela Nacional de Arquitectura de la antigua Academia de San Carlos. Su labor fundamental radicó en ser el primero que «orientó a las nuevas generaciones ... hacia la urgencia de un análisis meticuloso de la función para conocer íntimamente las necesidades y llegar así en forma lógica a una solución arquitectónica adecuada y armoniosa $»^{20}$. Para Enrique del Moral - uno de sus primeros discípulos- el maestro Villagrán tuvo «las dotes necesarias para iniciar y guiar el movimiento de renovación de la arquitectura que nuestro país necesitaba: una disciplina técnica rigorista y lógica, gobernada por una mente analítica poderosa y con amplio sentido de autocrítica» ${ }^{21}$. Contemporáneo a Del Moral, Alberto T. Arai explicó también la acción innovadora llevada a cabo por Villagrán en México en los términos de una completa asimilación de la nueva técnica de construir en la que «no creyó necesario abatir todo lo legado por la tradición, sino que, aprovechando las ventajas de la vida y la industria modernas, interpretó los elementos 
arquitectónicos tradicionales a través de los nuevos materiales, los nuevos métodos y la nueva sensibilidad simplificadora característica del nuevo arte» ${ }^{22}$. De esta manera - especialmente notable en sus primeras obras-Villagrán respetó la existencia de paramentos macizos, vanos o techumbres, que se veían transformados en su constitución, su función y su forma; o conservó elementos inmemoriales - por ejemplo las cornisas - por su inminente utilidad.

Para Enrique Yáñez, la importancia de Villagrán García fue que elaboró una teoría que sustentó el movimiento racionalista de la arquitectura en México, de igual forma, estableció las bases de una metodología a seguir en el proceso de diseño. En una época de confusión e inconsistencia, la enseñanza teórica y práctica del maestro «fueron una sólida base para acceder al movimiento racionalista del cual conocíamos resultados pero no las ideas de los autores ni el planteamiento del proceso seguido hasta llegar a sus modernas realizaciones» ${ }^{23}$.

Así, a la transformación de la enseñanza de la arquitectura que impulsó a las nuevas generaciones por un camino diferente, se sumaron las nuevas técnicas de construcción, la mejor resolución de los aspectos utilitarios, las diferentes condiciones económicas y la simplicidad formal de la arquitectura de transición ${ }^{24}$, que terminó por pavimentar el camino de la arquitectura moderna mexicana. A todo lo anotado es indispensable

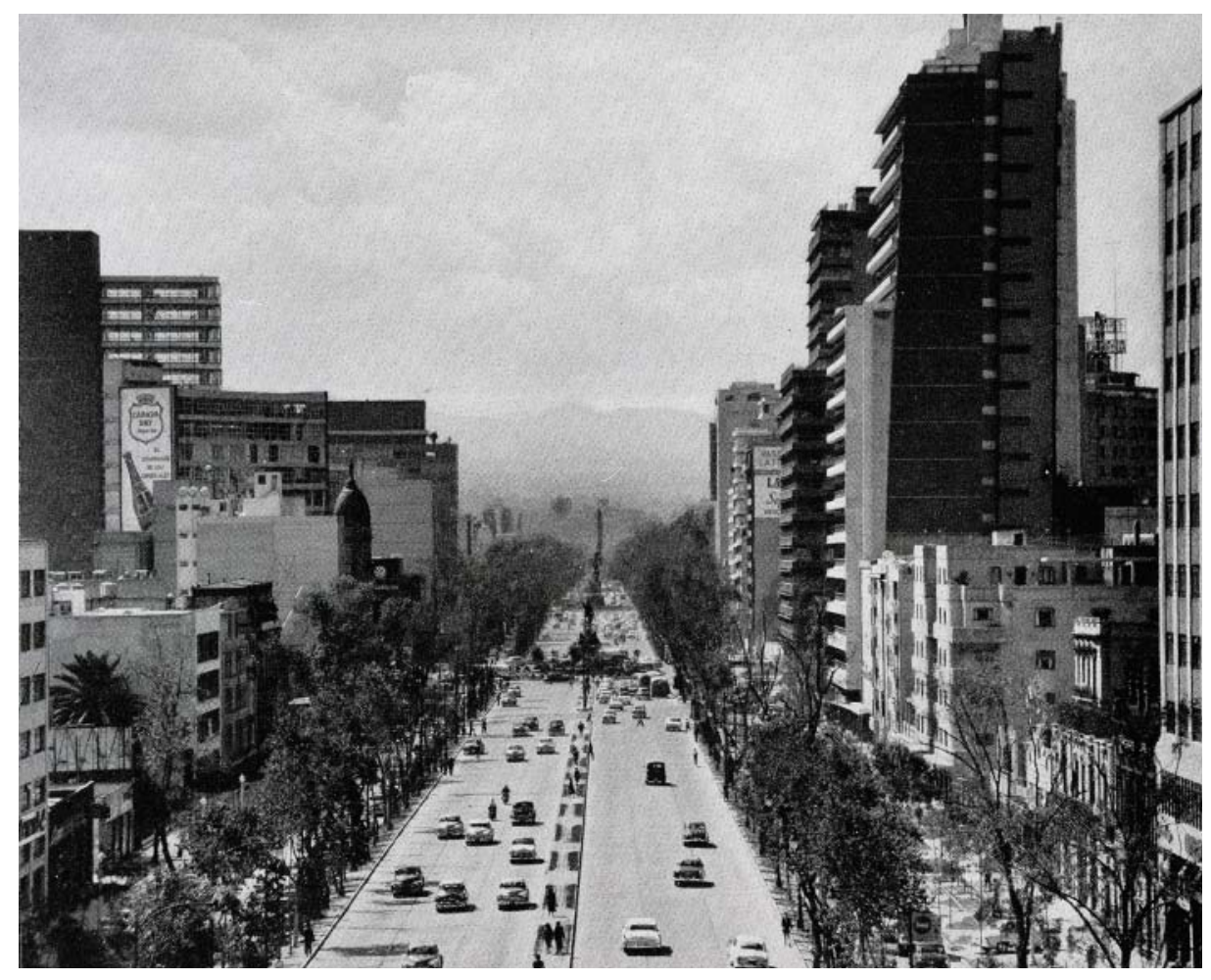

Los antecedentes de la nueva arquitectura en México
22. Alberto T. Arai, "José Villagrán García: Pilar de la arquitectura contemporánea de México," Arquitectura México, no. 55 (septiembre 1956): 142.

23. Yáñez, Funcionalismo, 35-36.

24. Katzman, Arquitectura, 129. 
25. Yáñez, Funcionalismo, 35 , menciona que en revistas como L'Architecte o Bauformen, que llegaron a México, se dieron a conocer obras tempranas de la arquitectura moderna como la Villa Savoye de Le Corbusier, la fábrica de tabaco Van Nelle en Holanda, la exposición de arquitectura moderna en Stuttgart -la Weissenhof Siedlunglos nuevos fraccionamientos alemanes en Frankfurt o las obras de Gropius en la Bauhaus.

26. Yáñez, Funcionalismo, 35.

27. López Rangel, Modernidad, 111.

28. Del Moral, "Villagrán García," 132.

29. Del Moral, "Villagrán García," 132.

30. Del Moral, "Villagrán García," 132. agregar el papel fundamental de las publicaciones periódicas que llegaban a México desde Francia y Alemania ${ }^{25}$. Ante la sorprendente novedad de las imágenes, los estudiantes de arquitectura de San Carlos confrontaron que «el propósito de alcanzar la belleza había provocado el olvido de la utilidad y de la lógica». Los postulados que sustentaban las obras nuevas parecían contrarias a las reglas de composición que inculcaban los maestros. El racionalismo que llegó como producto de importación reveló volumetrías simples y ligeras, escasos elementos figurativos y masas sustentadas en grandes claros o en voladizos al aire ${ }^{26}$.

En México, se puede decir que la primera obra que asumió el funcionalismo arquitectónico fue el Instituto de Higiene del Departamento de Salubridad - Granja Sanitaria de Popotla— de $1925^{27}$. Desde la década de 1950 ya se reconocía la importancia de esta realización de Villagrán García, por su proyección de pabellones sencillos con un mínimo de elementos, por la distribución y proporción de los diferentes locales, así como por su sistema constructivo y solución de las fachadas. La estructura se concibió como una «consecuencia lógica del análisis rigorista del programa y las necesidades por satisfacer ${ }^{28}$. En esta obra se eliminaron los pretiles de las azoteas, la losa plana de la techumbre se prolongó como alero para proteger las fachadas, las bajadas pluviales aparentes se integraron a la composición y «la nueva estética se logró mediante el juego de sombras producidas por el alero, el estudio justo de las proporciones de volúmenes y de las relaciones entre macizos y vanos de los muros» ${ }^{29}$. Para Enrique del Moral, en 1956, «esta manera de enfocar el problema arquitectónico, replanteándolo en sus bases lógicas y naturales, es el paso definitivo que determina la iniciación de la arquitectura moderna en México» ${ }^{30}$.

Sin dejar de considerar la Granja Sanitaria de Villagrán García como una de las piezas fundamentales hacia la instauración de la arquitectura moderna en el país, no es posible descontextualizar la obra de su momento histórico, cuando ésta representó un caso aislado en la producción arquitectónica nacional. Lo que dio inicio entonces, y que se mantendría por décadas, fue el debate sobre el camino que debería tomar la arquitectura mexicana. Es sorprendente que, tan temprano como 1927 ya se discutía la vigencia del neocolonial desde las revistas que, irónicamente, validaban los criterios oficiales sobre las artes plásticas 


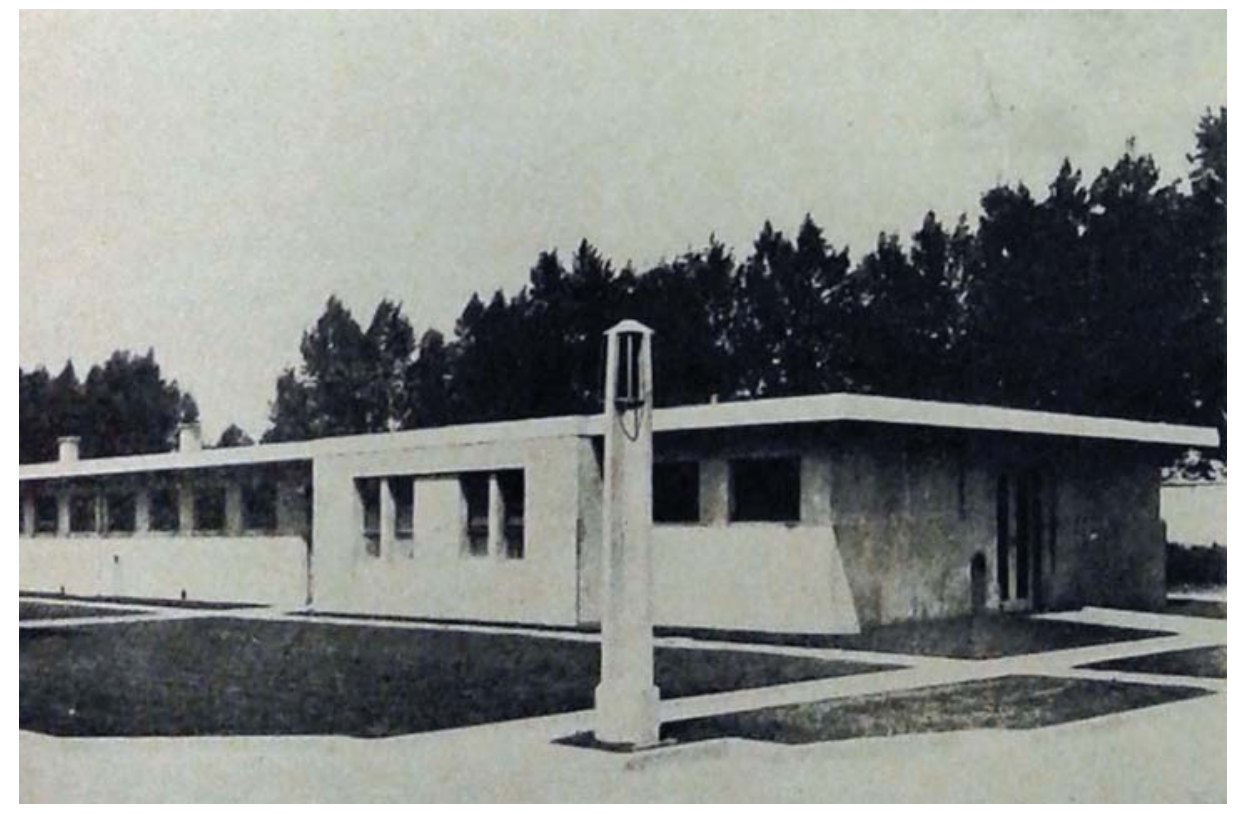

en el periodo inmediato a la Revolución. La revista Forma ${ }^{31}$ publicó una encuesta que respondía a las candentes preguntas: ¿Qué orientación debe darse a la arquitectura actual en México? y ¿Debe trabajar el arquitecto mexicano dentro de relaciones de tradición o debe unirse al movimiento de arquitectura mundial? Para Rafael López Rangel, las preguntas revelaban las preocupaciones por definir el rumbo de la arquitectura en esa etapa de intenciones nacionalistas, pero también de incertidumbre ante los avances técnicos y los nuevos requerimientos. Una idea común surgió de todos los encuestados, «que la arquitectura mexicana debería tener carácter moderno, incluso mundial, sin descartar el respeto a la tradición» ${ }^{32}$. La dualidad tradición-modernidad como característica de la identidad se hacía presente desde entonces en el discurso formativo y explicativo de la singular manera de afrontar los cambios del siglo $\mathrm{xx}$.

Estas cuestiones, sacadas del debate teórico y llevadas al campo práctico de la arquitectura, no podían menos que dibujar un panorama heterogéneo en el que todas sus expresiones eran válidas y contrapuestas entre sí al mismo tiempo. Por mucho que se quisiera hablar de una arquitectura moderna y nacional, la realidad fue que se construyó en varias direcciones - todas ellas presentes en las publicaciones periódicas foráneas- inclinándose, en algunos casos, «hacia un localismo tradicionalista, en otros variando de rumbo hacia un racionalismo e intelectualismo universal y en otros tomando el campo del valor social $\mathrm{y}$ funcional de sus producciones» ${ }^{33}$. Todavía hacia la mitad del siglo $\mathrm{xx}$,

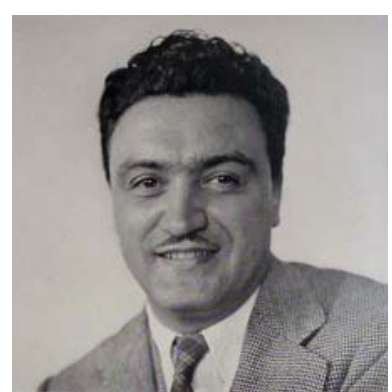

José Villagrán García (n. 1901). Pionero de la arquitectura moderna mexicana. A la izquierda su obra fundamental, el Instituto de Higiene - Granja Sanitaria- en Popotla (1925): el primer edificio funcionalista mexicano.

31. Editada por la Secretaría de Educación Pública y la Universidad Nacional de México entre 1926 y 1928. Su director fue el pintor Gabriel Fernández Ledesma y su codirector Salvador Novo. Hay que destacar que si bien sus estudios hispanoamericanos sobre arte y arquitectura virreinal seguían la línea trazada por Vasconcelos -de Manuel Toussaint su conocido estudio sobre Teposcolula- por otro lado, su espacio editorial se abrió al debate para refutar el estilo arquitectónico neocolonial, en ese momento todavía con mucho empuje. López Rangel, Modernidad, 77-78.

32. López Rangel, Modernidad, 77-78.

33. De Robina, "25 años," 141. 
la visión de la historia y el progreso como una línea ascendente infinita permeaba la interpretación de la obra arquitectónica, alertando contra el periodo de un nuevo academicismo que impedía el avance lineal y puro de la arquitectura. Para Carlos Obregón Santacilia, en 1952, se había caído ya en la repetición de elementos y formas «tan censurable como el que criticamos del 1910». Esta retórica formal inaceptable y sin razón de ser enturbiaba la «línea limpia de progreso ascendente» ${ }^{34}$. El arquitecto arremetió contra la copia sin sentido de las formas modernas tan solo para pasar como "modernos", criticando el uso de edificios levantados sobre columnas - siguiendo a Le Corbusier - cuando no se necesitan, o los muros cortina - siguiendo a Mies van der Rohe- cuando son prescindibles; lo mismo se podía decir de los parteluces brasileños de Niemeyer, Reidy o Moreira.

Ya en la década de 1960, Israel Katzman interpretaba la realidad arquitectónica nacional desde los postulados teóricos de la historia del arte en boga por entonces, calificando de «voluntad estética actual» a la falta de ornamentos y la simplicidad. En ese momento, los determinantes económicos ya no se entendían como prioritarios, pues muchas obras contemporáneas que seguían la estética moderna, debían su alto costo a «sus dimensiones, al precio de los materiales empleados, a su fina obra manual, pero no a la ornamentación ${ }^{35}$. Esta paráfrasis sitúa un aspecto notable sobre la época que se trata, la mención a la «fina obra manual» se aleja de una arquitectura industrializada y estandarizada y retorna a la mano de obra tradicional característica — en muchos sentidos- de la modernidad mexicana.

Si bien en un principio se aceptaba una evolución natural del gusto estético que desde un repertorio austero y monótono había conquistado la «nueva forma» sobre la base del cuadrado y el rectángulo, el ángulo recto y las duras intersecciones de la línea, muy pronto se agregó al repertorio la libertad formal de la curva y la casi ilimitada respuesta de las superficies regladas en paraboloides hiperbólicos de hormigón armado. Para Ricardo

34. Carlos Obregón Santacilia, 50 años de arquitectura mexicana: 1900-1950 (México: Patria, 1952), 114-15.

35. Katzman, Arquitectura, 19. 151. de Robina era natural la continuidad - una vez superadas las formas rectas - de una búsqueda geométrica de los cuerpos en movimiento a través de formas más complejas ${ }^{36}$. Se hablaba así de una secuencia lógica, no de la simultaneidad de las expresiones formales y de las vertientes compositivas modernas. 
El funcionalismo radical aplicado a la arquitectura escolar. Escuela técnica industrial de Juan O'Gorman.

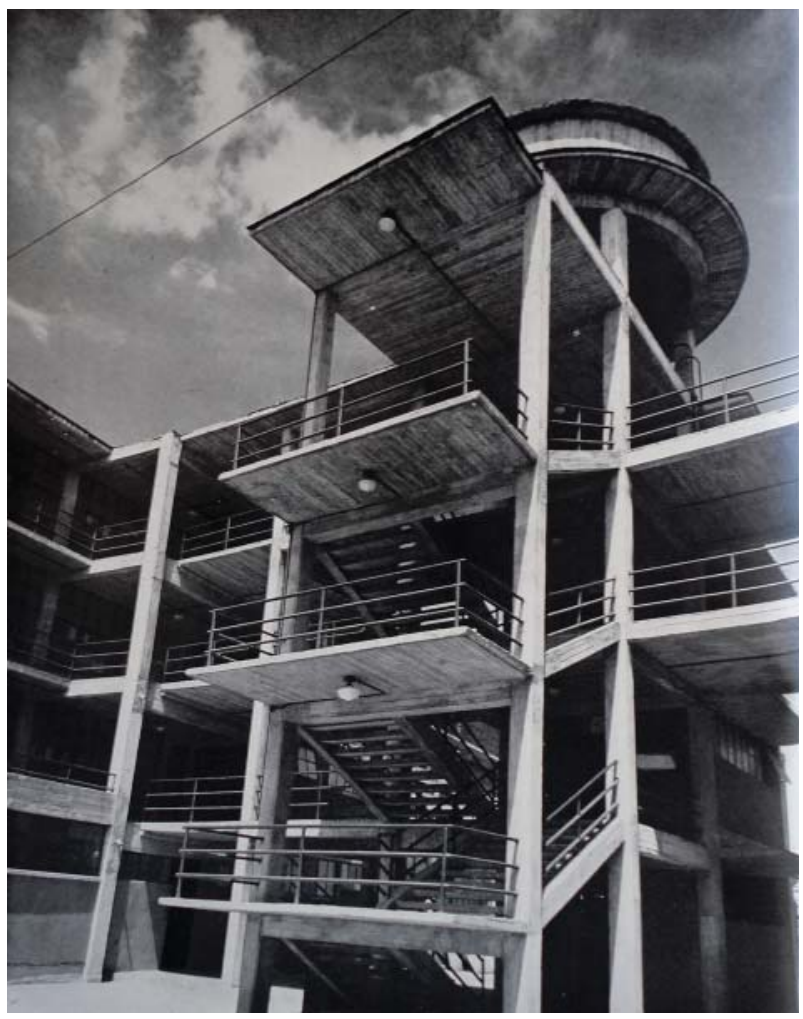

Pero además de la forma y el volumen, también entraron en escena el color y la luz. Se puede decir que en México nunca hubo una transición entre una arquitectura monocroma y una colorida, sino más bien una constante experimentación en el uso del color —en ningún caso privativa de Luis Barragán - tanto en interiores como en exteriores y desde una escala doméstica hasta la monumental. De forma más discreta, pero también el tratamiento de la luz, su gradación y tonalidad, cobraron poco a poco un papel más importante como creador de ambientes y como modelador de formas ${ }^{37}$.

Con base en todo lo anterior, no era tarea fácil interpretar en su momento las características de la arquitectura moderna mexicana, no obstante, el entendimiento del presente siempre se ha contado como una constante en la difusión de la arquitectura contemporánea. José Villagrán García lo explicaba en 1954 cuando hablaba de dos vertientes que «sin ser antagónicas ni del todo opuestas, tampoco son paralelas, sino que más bien interfieren entre sí sinuosamente: una tiende, de hecho, a cierta internacionalización de soluciones formales, y la otra, a la búsqueda de lo propio y local dentro de lo actual $»^{38}$. Para el teórico, el formalismo -otros autores lo llamaron academicismo- sería siempre utópico pues no resolvía los programas arquitectónicos específicos de las distintas localidades. Una solución internacional supondría la «identidad completa de problemas,
37. De Robina, "25 años," 155.

38. José Villagrán García, "Ideas regentes en la arquitectura actual," Arquitectura México, no. 48 (diciembre 1954): 198. Conferencia sustentada en la sala "Manuel M. Ponce" del Palacio de Bellas Artes el 30 de julio de 1954. 
Programas nacionales de salud y vivienda que reivindicaron las demandas sociales de la Revolución. En esta página un hospital de zona del Imss, de Enrique Yáñez; en la página siguiente el Centro Urbano Presidente Juárez, de Mario Pani.
39. Villagrán García, "Ideas regentes," 199.

40. Villagrán García, "Ideas regentes," 200.

41. 4000 años, 139. Como se mencionó al principio de este capítulo, la edición de este libro se debió a la Sociedad de Arquitectos Mexicanos (SAM) y al Colegio Nacional de Arquitectos de México (CNAM). Si bien Pedro Ramírez Vázquez, como presidente de ambas agrupaciones, firmó la presentación de este volumen, sería erróneo atribuirle su autoría.

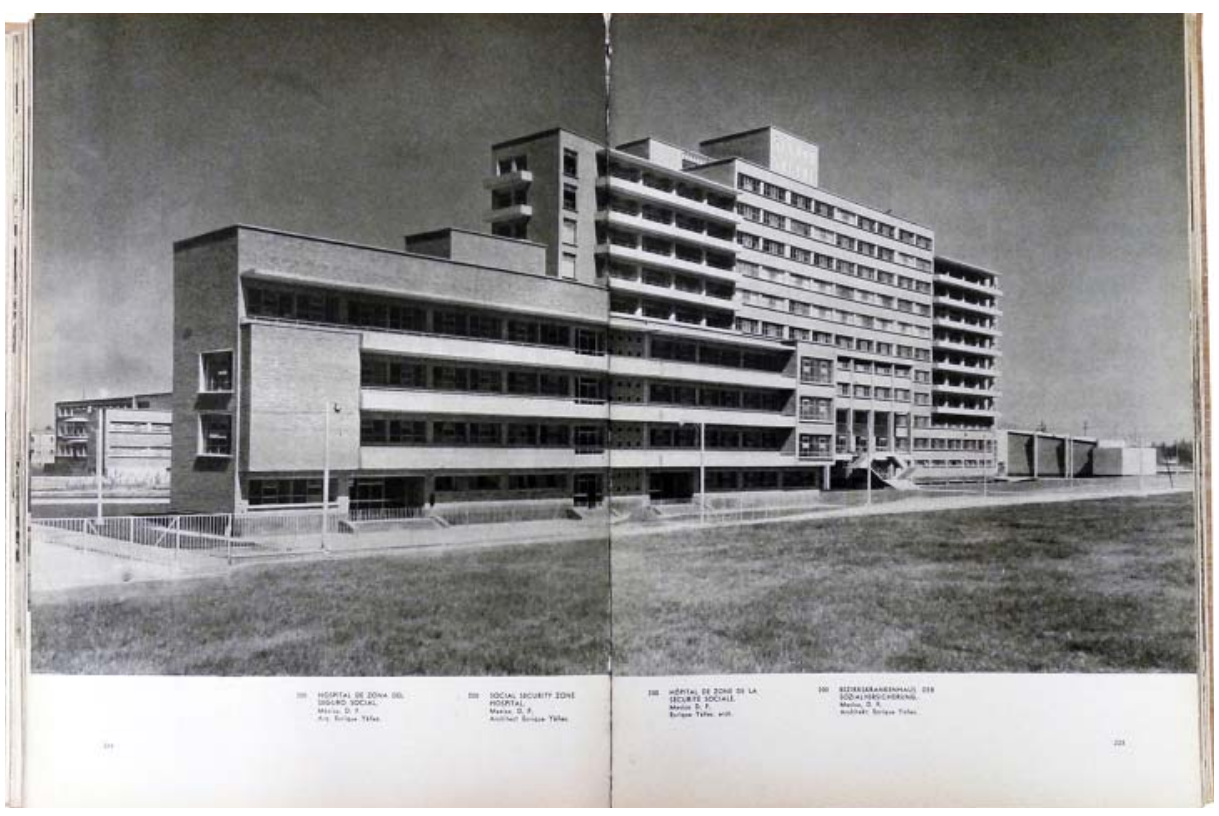

no sólo en cuanto a lo físico-geográfico o lo climático sino en cuanto a la cultura que encierra las múltiples reacciones vitales humanas ante el mundo y ante la misma vida ${ }^{39}$. Lo más interesante de la conferencia de Villagrán no es sólo la propuesta para la arquitectura mexicana de seguir un camino «moderno y regional», es decir, «solucionar los problemas locales, regionales o nacionales con apego a las condiciones y limitaciones propias» ${ }^{40}$, sino en subrayar el carácter «local» de la llamada arquitectura internacional pues ésta surgió, precisamente, de resolver sus propios problemas de acuerdo a sus recursos.

La pluralidad de las propuestas arquitectónicas quedaría así entretejida entre las soluciones situadas entre los extremos de la inclinación a las formas internacionales y los recursos que ofrecía la tradición. En 4000 años de arquitectura se enfatizó la diversidad de tendencias, personales o de grupo, y los «múltiples caminos seguidos por el arquitecto mexicano» que iban desde un «apego más o menos estricto a la arquitectura moderna en general, hasta ensayos de enraizarla con la tradición plástica mexicana en el pasado, preocupándose especialmente por su integración con la pintura y escultura actuales» ${ }^{41}$.

La propuesta de Villagrán para el desarrollo de la arquitectura moderna mexicana sería confirmada por Raúl Henríquez en 1963 cuando reconsideró los peligros de seguir a ciegas un camino impersonal que llevaría a la pérdida de la identidad de continuar bebiendo de la estética formal de la arquitectura internacional. En cambio, lo mejor sería seguir la tendencia que asimila las formas y principios modernos pero en 


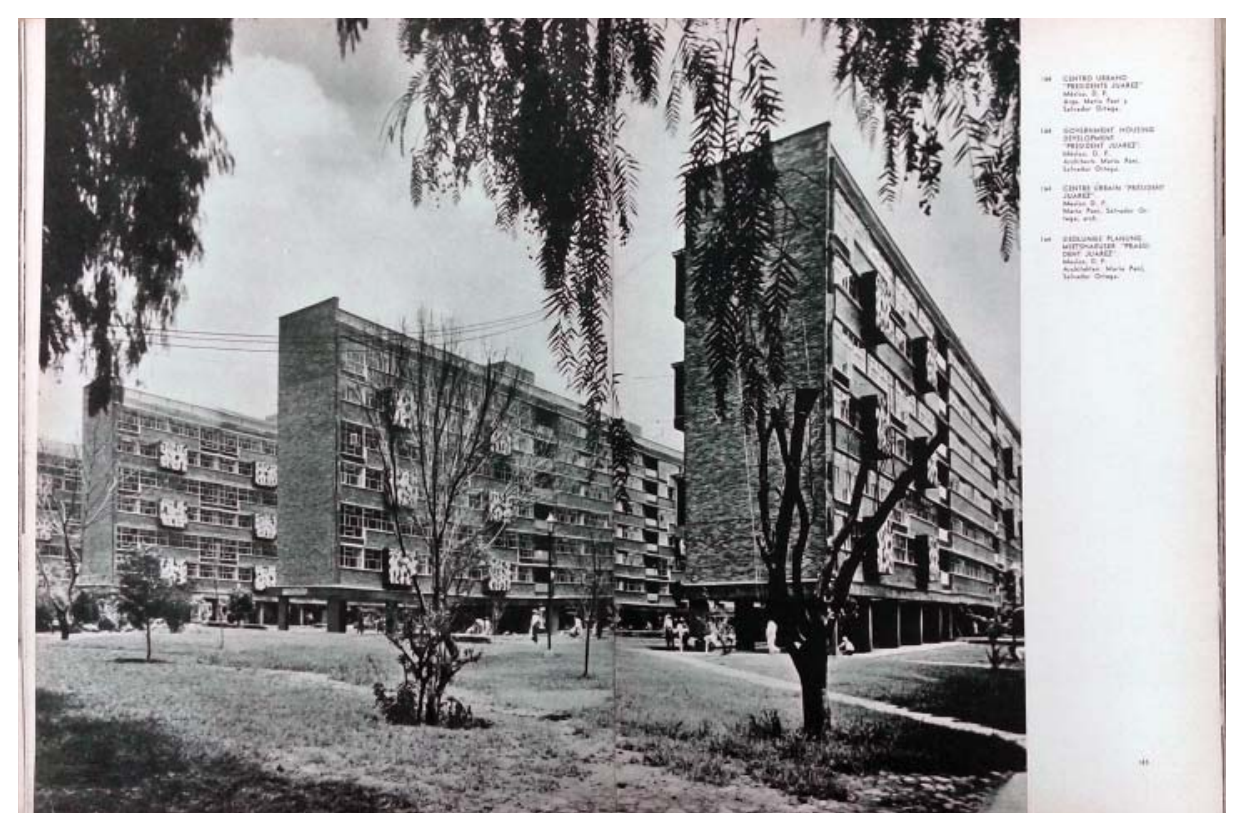

relación a la vida actual mexicana y a su tradición ${ }^{42}$. Para el autor, parte del camino ya se había trazado con algunas obras de Barragán y Del Moral, en las que su carácter no se debía a la «introducción arbitraria de formas tradicionales mexicanas, sino a un proceso de síntesis profunda de los principios de la arquitectura moderna con los del pasado» ${ }^{43}$.

Después de varias décadas de experimentación arquitectónica, se llegaba a la conclusión de que «el verdadero respeto de la tradición es el no repetir los estilos jamás, sino el llevarla siempre adelante en constante creación de formas que encarnen y expresen lo invariable del ser del país y la raza pero a través de las siempre variables circunstancias de lo individual y lo contemporáneo ${ }^{44}$. Este entendimiento de las particularidades del país dio lugar a algunos de los ejemplos señeros de la arquitectura moderna que hoy son patrimonio de la humanidad. Ciertamente, como se intuía desde el principio, las respuestas formales no llegarían a integrar un solo estilo nacional situado idealmente en el punto medio entre la apropiación de la tecnología y los materiales modernos y, en el otro extremo, el pasado vivo a través de la tradición. Si por un lado se mantuvo una fuerte tendencia internacional durante toda la década de 1960, por otro, el camino de la tradición se volvería indisoluble del entendimiento de dicho periodo. En 1952, Obregón Santacilia afirmaba que, sin olvidarnos de los factores universales, es decir, los adelantos técnicos en cuanto a materiales y sistemas constructivos, «una verdadera arquitectura contemporánea mexicana sólo puede surgir del conocimiento de nuestro pueblo y de nuestro país» ${ }^{45}$.
42. Raúl Henríquez, "Arquitectura moderna en México," Arquitectura México, no. 82 (junio 1963): 74. El autor define esta tendencia como «sintética de lo propio con lo universal moderno».

43. Henríquez, "Arquitectura moderna," 75 .

44. Henríquez, "Arquitectura moderna," 74 .

45. Obregón Santacilia, 50 años, 118. Continúa el autor: «Se necesita desconocer a México, a su más viejo pasado, a su pasado inmediato, a su provincia, su paisaje, sus materiales naturales para suponer que todos estos factores no darán un sello, un colorido, un sabor inconfundible aun a la arquitectura más avanzada que se haga en México». 
En este contexto nacional $-\mathrm{y}$ ante la ya evidente crisis que atravesaba la arquitectura moderna en la década de 1960 a nivel internacional ${ }^{46}$ - se construyeron los edificios - que se cuentan por cientos- que ganaron difusión en los medios impresos entre 1950 y 1970. Evidenciar un país complejo como fuente de la diversidad arquitectónica moderna establece los parámetros de interpretación que se construyeron desde el inicio de su transmisión en el extranjero. Esta breve aproximación a los orígenes de la modernidad en México abre las puertas al análisis del descubrimiento ${ }^{47}$ de su arquitectura moderna por parte del mundo editorial foráneo, revelación que, como se comprobará a lo largo de esta tesis, quedó plasmada en numerosos libros y cuantiosas publicaciones periódicas especializadas.

46. Esta crisis puede ser entendida como el «choque entre las posibilidades teóricas de la arquitectura, emanadas de sus principios y las limitaciones y resultantes que los hechos y la realidad misma le han impuesto». De Robina, "25 años," 165.

47. Se habla de un descubrimiento por la intención explícita de subrayar la cualidad de centralidad europea y norteamericana desde la que se difundió la arquitectura mexicana de las décadas de estudio. Se toma la definición de "descubrimiento" de Leopoldo Zea, quien advierte de las connotaciones euro-centristas del término, en el sentido de que «los europeos se encontraron con algo que les era desconocido, otro mundo, otra cultura». Leopoldo Zea, Descubrimiento e Identidad Latinoamericana (México: Universidad Nacional Autónoma de México, 1990), 14. 


\section{Modernidad impresa \\ El punto de vista de los títulos extranjeros}

La historia de la arquitectura moderna mexicana se ha construido esencialmente a través de libros que por su consulta obligada se han vuelto canónicos; libros que, como paradigmas de características perfectas, han ido trazando el conocimiento y valoración de las obras señeras de la mitad del siglo xx en México ${ }^{1}$. Sin desvirtuar una aproximación historiográfica tradicional, lo que se ofrece en la primera parte de este segundo capítulo es una confrontación entre las fuentes clásicas y las reseñas que se publicaron -en su momento- en las revistas que forman el corpus principal de la presente investigación. Así, se comentarán no sólo algunos de los libros clave de la difusión internacional de la arquitectura mexicana sino también los debates que su propia publicación generó en los medios especializados. Este acercamiento refresca las revisiones habituales a los medios impresos a la vez que introduce al lector a las fuentes de consulta prioritarias de este estudio.

Las ediciones extranjeras no sólo fueron sustanciales por su difusión foránea sino, en gran medida, por su papel en la consolidación de la imagen moderna de México. Siguiendo a Fernando Luiz Lara, el reconocimiento externo, el verse a sí mismo en el espejo de los medios internacionales es un medio eficaz de afirmar la nacionalidad. Ser consumidos por el resto del mundo - a través de los filtros que suponen las culturas particulares- y reflejar en la distancia lo que ocurre en nuestro país es un juego de legitimación².

Así, con la referencia ineludible al primer libro que trató la arquitectura moderna mexicana: The new architecture in Mexico, de Esther Born, publicado en $1937^{3}$, revisaremos más de dos décadas en que salieron a la luz en el extranjero diversos catálogos y monografías. En éstos, ya fuesen volúmenes dedicados exclusivamente a México o formando parte de un análisis más amplio, innumerables ejemplos de arquitectura moderna
1. La reciente investigación de Fernanda Canales compiló tanto los libros realizados en México como los publicados en el extranjero y las revistas que dieron a conocer la arquitectura mexicana del siglo $\mathrm{xx}$, dentro y fuera de sus fronteras. Ana Fernanda Canales González, "La modernidad arquitectónica en México: una mirada a través del arte y los medios impresos" (Tesis de Doctorado, Universidad Politécnica de Madrid, 2013), 217-72.

2. Si bien el autor trató el caso brasileño, su análisis bien se puede aplicar al ejemplo mexicano. Cfr. Fernando Luiz Lara, "Espelho de fora: arquitetura brasileira vista do exterior," Arquitextos, (septiembre 2000), consultado 4 junio, 2013, http://www.vitruvius.com.br/revistas/read/ arquitextos/01.004/986.

3. Esther Born, The new architecture in Mexico (New York: Architectural Record, 1937). Se sitúa el límite inferior de la cronología de los libros en el año 1937 por la importancia fundamental que tuvo este volumen como el primer monográfico extranjero que dio a conocer la nueva arquitectura mexicana. 
mexicana se discutieron en torno a temas históricos, técnicos o urbanos. Los libros en sí, aunados a la crítica especializada en las publicaciones periódicas, jugaron un papel fundamental al aumentar el impacto de la difusión sobre la arquitectura moderna de México que ya estaba presente en las revistas. De ahí surgió el interés por preparar este capítulo y en comparar los contenidos originales de los libros seleccionados con los comentarios de actualidad que aportaron puntualmente los medios periódicos.

Entonces, se tratan los librosque presentaron a la nueva arquitectura moderna mexicana en la totalidad de sus contenidos y también aquellos que expusieron un panorama mundial de la arquitectura o el urbanismo, dentro del cual fue importante la presencia de ejemplos mexicanos. Se analizan asimismo las publicaciones monográficas dedicadas a varios de los arquitectos mexicanos más reconocidos en esos años y el lugar de México dentro del amplio panorama latinoamericano.

De esta manera, se introduce al lector en la revisión necesaria de las fuentes impresas clásicas que dieron a conocer en el extranjero la arquitectura moderna mexicana al mismo tiempo que se brinda un panorama general sobre cómo fue entendida, difundida y valorada la nueva arquitectura desde el momento de su aparición y cómo diferentes apreciaciones foráneas aportaron sus muy particulares puntos de vista sobre el tema que se desarrolla a lo largo de esta tesis.

Por su parte, el capítulo que expone el preámbulo a la difusión de la arquitectura moderna mexicana a través de las publicaciones periódicas foráneas comprende un desarrollo igual o incluso más importante que el dedicado a los libros. La pluralidad de ejemplos mexicanos que se dieron a conocer en el extranjero y el impacto que supuso la repetición de noticias en los medios especializados fue todavía más sustancial que en otros medios de comunicación como los libros impresos. Esto se debió a la amplia circulación de las revistas de arquitectura entre los profesionales y académicos. De esta manera, la presencia mexicana en las publicaciones periódicas europeas y estadounidenses se convirtió en el corpus principal de este análisis. Así, se revisarán las décadas de 1950 y 1960, en las que México estuvo siempre bien representado en el panorama editorial periódico del extranjero. 


\subsection{El papel canónico \\ La arquitectura mexicana en los libros entre 1937 y 1969}

\section{La nueva arquitectura moderna mexicana}

Para los países involucrados en la contienda, el final de la Segunda Guerra Mundial en 1945 supuso la reactivación de la industria constructiva gracias a la canalización de los recursos económicos antes destinados a la industria bélica1. En septiembre de 1945, Kenneth K. Stowell, editor de Architectural Record, hacía un llamado a los arquitectos, ingenieros y constructores del mundo para consagrar sus energías creativas en la reconstrucción y edificación de nuevos y mejores inmuebles para todas las actividades del hombre ${ }^{2}$. La América angloparlante estaba ansiosa de redirigir sus finanzas hacia el área de la construcción y, como se verá enseguida, el aspecto comercial — fuertemente ligado a la idiosincrasia norteamericana - pronto se dejó ver en la difusión de la nueva arquitectura latinoamericana.

Desde 1937, año de edición del libro de Esther Born que se citó antes, había pasado casi una década cuando, en enero de 1946, la revista norteamericana Architectural Record recordó a sus lectores que al sur del Río Grande, una arquitectura de líneas rectas, superficies planas sin ornatos, en contraste dramático con los viejos y excesivamente ornamentados edificios coloniales, se había aclimatado perfectamente al paisaje. Hospitales, casas en el campo y en la ciudad, edificios comerciales, fábricas, escuelas, apartamentos y casas para trabajadores conformaban un volumen de referencia para los diseñadores, ya que éste contenía una muestra completa de las ideas progresistas de arquitectos e ingenieros americanos «aztecas y españoles» ${ }^{3}$. Así se anunciaba la nueva arquitectura de México por los medios especializados de publicación periódica en los Estados Unidos, al poco tiempo de finalizar la Segunda Guerra Mundial.

The New Architecture in Mexico se coeditó en Nueva York por Architectural Record y William Morrow and Company ${ }^{4}$. Los editores
1. Desde enero de 1945, cuando resultó evidente para Estados Unidos el fin de la guerra, los editoriales de las publicaciones especializadas en la arquitectura y la construcción, se mostraron favorables ante la inminente reactivación económica del área. Véase Kenneth K. Stowell, "Demands of War come first," Architectural Record 97, no. 1 (enero 1945): 57 y "Beyond Architecture," Architectural Record 97, no. 3 (marzo 1945): 69.

2. Kenneth K. Stowell, "From Destruction to Construction," Architectural Record 98, no. 3 (septiembre 1945): 69.

3. Architectural Record 99, no. 1 (enero 1946): 160. Anuncio publicitario del libro New Architecture in Mexico de Esther Born, publicado en 1937. El mismo anuncio aparecería en el siguiente número en febrero de 1946 en la página 144. Nótese cómo se diferencia culturalmente al mexicano, quien también, geográficamente, es norteamericano, con los calificativos de 'azteca' y 'español'. Ciertamente hacía décadas que en el país latinoamericano se había aceptado el mestizaje como definitorio de la cultura y la identidad nacionales.

4. Esta publicación nació como revista en el número especial de Architectural Record de abril de 1937; poco tiempo después sería editado como libro. 
Libros publicados en el extranjero entre 1937 y 1969 y reseñados en las revistas contempladas durante el periodo de estudio. La columna indica la cantidad de noticias sobre cada libro en las publicaciones periódicas consultadas.
5. Born, New architecture, 3. 6. Born, New architecture, 3. 7. Carlos Contreras, "Plan Development of Mexico City," en The new architecture in Mexico, comp. Esther Born (New York: Architectural Record, 1937), 4-7.

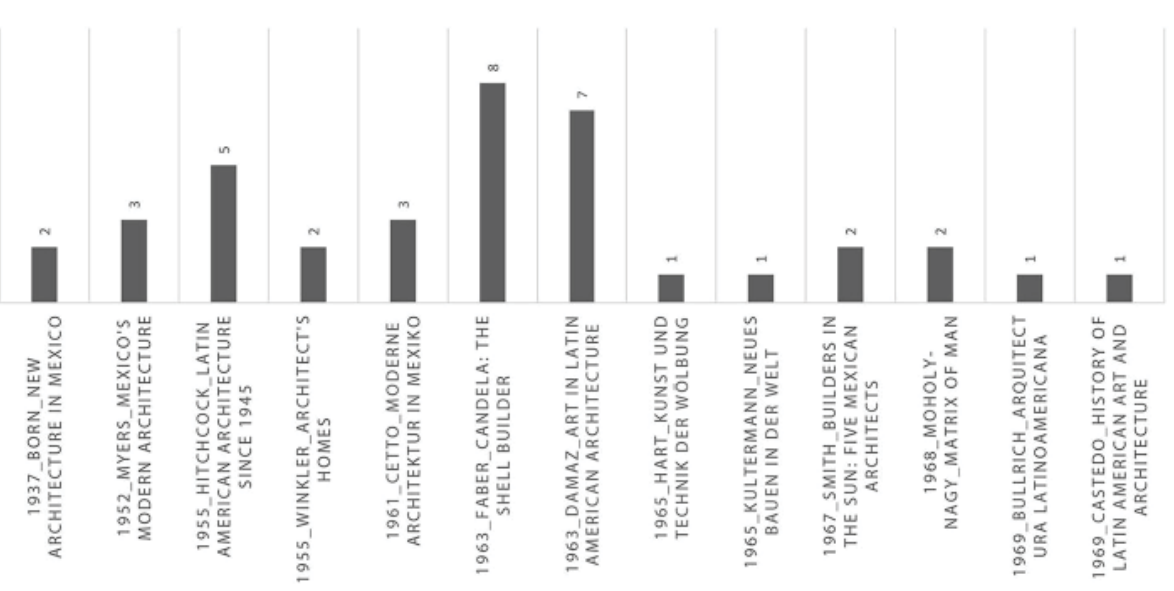

se sorprendieron por varios aspectos del tema propuesto por la autora, quien era fotógrafa y arquitecta; uno de ellos, la cantidad de arquitectura moderna en México, y también, la calidad y la vanguardia de la misma. En ese entonces, en Estados Unidos se tenía asumido que «sus vecinos» iban encaminados por rumbos muy distintos a los suyos, de hecho disímiles, precisamente por considerarse a los mexicanos como «sus opuestos» ${ }^{5}$. Acaso lo que más sorprendía a los editores era que a pesar de las diferencias culturales, históricas, raciales y geográficas, los mexicanos estaban siguiendo y buscando los mismos objetivos que ellos: «El punto de vista es similar pero el acento es diferente» ${ }^{6}$.

Para situar al lector estadounidense ante el panorama urbano, geográfico, arquitectónico y social del país - seguramente poco conocido-, el volumen se estructuró con una serie de breves ensayos y entrevistas que antecedían a la presentación de los edificios. Así, el Plan de Desarrollo Urbano para la ciudad de México, ejecutado por Carlos Contreras en 1935, se expuso concisamente por su autor ${ }^{7}$. Desde el siglo XXI, nos resulta sorprendente que se estimó un crecimiento poblacional siguiendo la tendencia del siglo anterior; en el estudio realizado en 1935 se planeó la expansión de la ciudad para el año 1985 con tan sólo 2 millones de habitantes, cuando la realidad multiplicó por ocho veces el número calculado entonces.

Recordemos que lo que hoy es la ciudad de México empezó a crecer desde el siglo xIv sobre un lago y que durante el siglo xx las nuevas tecnologías se enfrentaron a las condiciones de cimentar edificios en altura sobre suelos arcillosos de baja resistencia. En junio de 1936, en la Universidad de Harvard se escuchó la conferencia internacional "El suelo y los medios de cimentación en la ciudad de México" del ingeniero José A. 
Cuevas, como parte de un congreso sobre mecánica de suelos e ingeniería de cimentaciones; la misma se reprodujo en la compilación de Born sobre la nueva arquitectura mexicana ${ }^{8}$. No sería ésta la única vez que el suelo de la capital mexicana alcanzara protagonismo como tema de estudio o como noticia internacional de actualidad ${ }^{9}$.

Los ensayos introductorios que presentó Born no sólo enfatizaron las condiciones del suelo y cómo los expertos, durante varias décadas, fueron resolviendo acertadamente las cimentaciones de los edificios citadinos, ya que también fue fundamental comentar el papel del arquitecto como contratista de su propia obra. En la introducción al texto de Federico Sánchez Fogarty - gerente comercial de la cementera La Tolteca $^{10}$ - la autora destacó las condiciones favorables en México para que los propios arquitectos edificasen sus obras - en especial a pequeña escala - lo que propiciaba un incremento en la calidad del diseño y de la construcción. Born comparó la situación mexicana con la de Estados Unidos, en donde las grandes firmas tendían a construir todo, lo que podía incurrir en diseños de menor calidad. Para el caso de México, se facilitaba que un arquitecto diera inicio a su carrera profesional con una obra de escala menor, obtuviese un pequeño capital, lo invirtiese en especulación de terrenos y viviendas, ganase más dinero y experiencia con la práctica de los métodos constructivos, promoviendo la reinversión y el crecimiento del negocio, lo que se traduce en mayores ganancias ${ }^{11}$. Si no se está acostumbrado al pragmatismo financiero, la crudeza de la visión norteamericana puede resultar un poco apabullante.

En el libro se distingue también una clara colaboración entre la autora, sus editores y los arquitectos, ingenieros, urbanistas, empresarios y estudiosos mexicanos que tomaron parte activa en la difusión de la nueva arquitectura del país. Dentro de éste último grupo de profesionales, el crítico de arte Justino Fernández contó con el ensayo más extenso de la publicación. Dividido en dos secciones, se presentó primero un resumen que trató los antecedentes recientes de la nueva arquitectura en México - esto es, sin ir más lejos que el siglo XIX - y, para cerrar el volumen, se dedicó una parte a la pintura y la escultura contemporáneas ${ }^{12}$. Para el estudioso actual, acostumbrado ya a las constantes referencias a la arquitectura prehispánica mexicana, que solían anteceder a los estudios de arquitectura del siglo xx publicados durante las décadas de estudio,

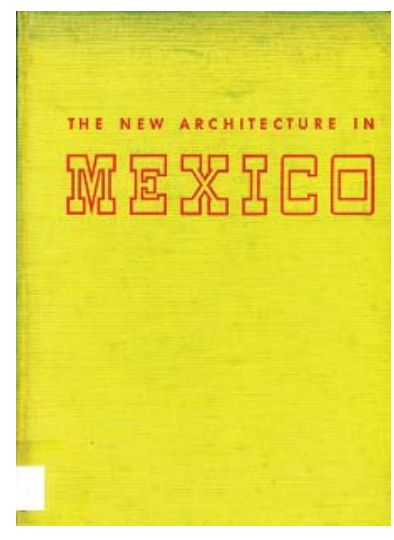

Portada de The New Architecture in Mexico de Esther Born (1937).

8. José A. Cuevas, "Soil and foundation conditions in Mexico City," en The new architecture in Mexico, comp. Esther Born (New York: Architectural Record, 1937), 8-9. El resumen de la conferencia también se publicó en Engineering-News Record el 9 de julio de 1936.

9. Durante el periodo de estudio, las consecuencias del sismo del 28 de julio de 1957 que cimbró a la ciudad de México se reseñaron en algunas revistas foráneas, subrayando las condiciones particulares del suelo capitalino y el tipo de cimentaciones empleadas. Véase "Quake hits Mexico City; architect hangs self," Architectural Forum 107, no. 3 (septiembre 1957): 9 y 12 y Robert E. Fischer, "Mexico City's Earthquake," Architectural Record 122, no. 4 (octubre 1957): 243-47.

10. Cabe recordar el papel fundamental de la revista Cemento encabezada por Sánchez Fogarty y la consolidación en el uso del hormigón armado en México en la tercera década del siglo xx.

11. Born, New architecture, 10.

12. Justino Fernández, "The new architecture in Mexico: An outline of its development," en The new architecture in Mexico, comp. Esther Born (New York: Architectural Record, 1937), 14-15 y "Contemporary painting and sculpture in Mexico," en The new architecture in Mexico, comp. Esther Born (New York: Architectural Record, 1937), 123-59. 
13. Born, New architecture, 2.

14. Fernández, "New architecture", 14.

15. Fernández, "Contemporary painting", 143.

16. Justino Fernández, El arte moderno en México: Breve historia siglos XIX $y \mathrm{XX}$ (México: Instituto de Investigaciones Estéticas de la Universidad Nacional de México, 1937).

17. Beach Riley, "Social progress and the new architecture," en The new architecture in Mexico, comp. Esther Born (New York: Architectural Record, 1937), 18-20. sorprende un poco que la única mención a una estructura prehispánica sea a la pirámide de Cuicuilco, «probablemente la estructura más antigua del continente norteamericano» ${ }^{13}$, pero en este caso, los editores plantearon una relación formal con Le Corbusier.

Entonces, el texto de Fernández omitió cualquier referencia arquitectónica más allá del establecimiento de la Academia de San Carlos en la Nueva España hacia finales del siglo XvinI, casi coincidente con el inicio de la vida independiente del país. A través de una breve revisión de nombres y estilos, se abrió paso el término "funcionalismo", «cuyo sentido moderno - afirmó el autor - fue seriamente considerado en México por primera vez por el arquitecto José Villagrán García» ${ }^{14}$. La influencia del maestro ya se notaba en los arquitectos más jóvenes, quienes llevaban a la práctica sus teorías, enarbolando la bandera funcionalista contra la atmósfera conservadora todavía imperante.

Justino Fernández cerró el libro con un apartado dedicado a la pintura y escultura contemporáneas en México. Por su importancia e influencia a nivel internacional, la pintura mural tuvo un lugar destacado del estudio. Lo más sobresaliente del ensayo, si es posible obviar el lugar predominante que se dedicó a los grandes maestros, fue la enumeración de muralistas - algunos de ellos extranjeros_ con participación activa en ese momento en edificios públicos de diversas escalas. El autor afirmó que, «el movimiento existe, es importante [y sus obras] pueden ser comparadas de forma favorable con la producción extranjera más relevante del mundo civilizado» ${ }^{15}$.

Acaso algo más que se debe comentar sobre esta participación es que, si bien se trató de la traducción al inglés de algunos capítulos de $E l$ arte moderno en México ${ }^{16}$ y que ambos libros - tanto el de Born como el de Fernández - se publicaron en 1937, se reconoce una colaboración recíproca en el intercambio de material gráfico. El crítico de arte mexicano tomó algunas de las fotografías de Born para su libro, y no haría falta decir que las imágenes que ilustran el texto de Fernández en la publicación neoyorquina son las mismas que en el volumen mexicano.

Ahora bien, del hecho que la arquitectura mexicana durante las décadas de 1920 y 1930 fue producto de importantes cambios sociales dejó constancia el último ensayo publicado por Born y firmado por Beach Riley ${ }^{17}$. Crecimiento, cambio social y progreso fueron las constantes 


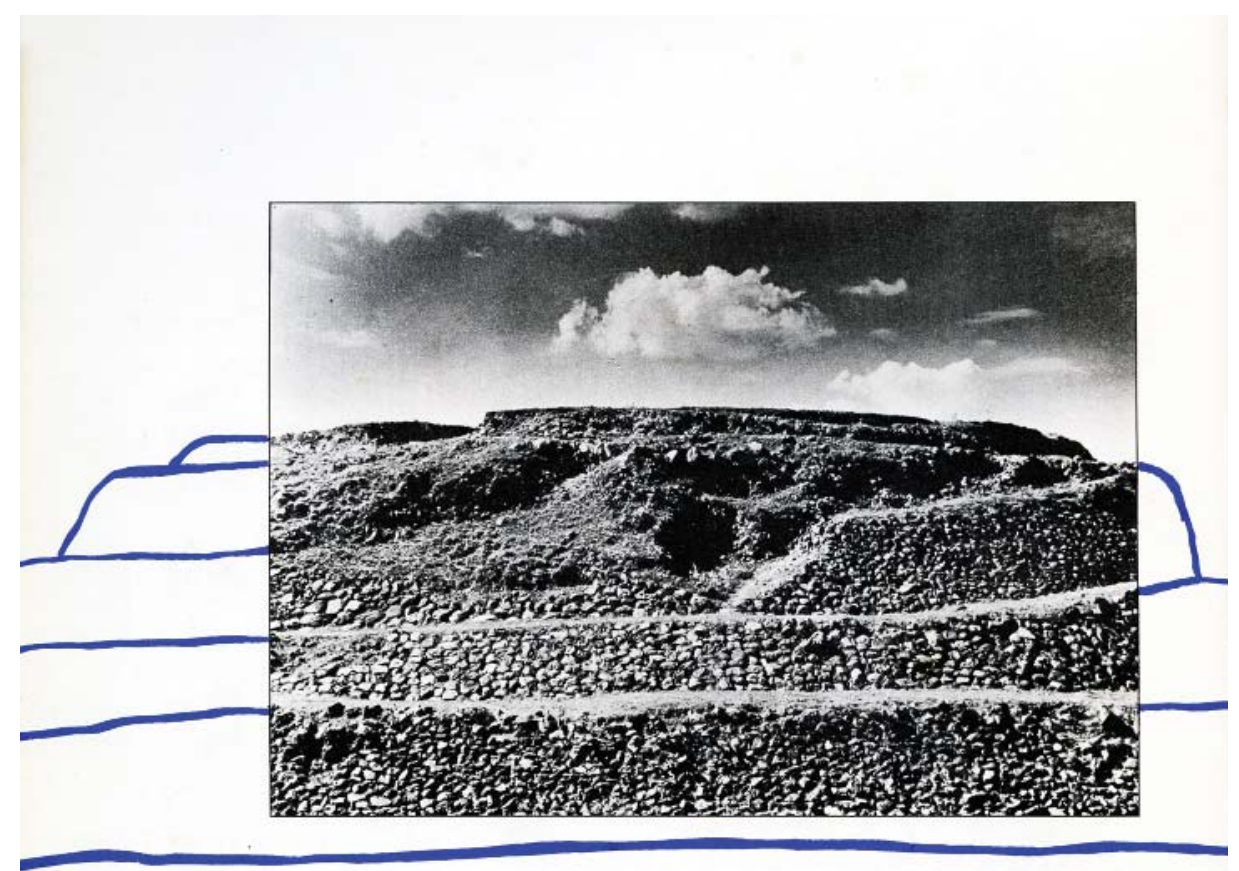

THE PYRAMID OF CUICUILCO NEAR TLALPAM, D. F.

PROBABLY THE OLDEST STRUCTURE ON THE NORTH AMERICAN CONTINENT

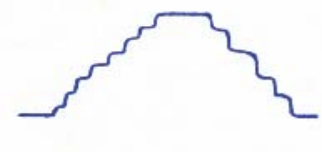

CUICUILCO

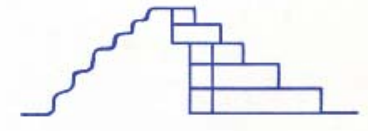

AFTER LE CORBUSIER

utilizadas por el autor para señalar el reciente movimiento arquitectónico, producto de la Revolución Mexicana. Ésta propició la respuesta del gobierno a las demandas sociales como la creación de escuelas, hospitales y vivienda para los trabajadores.

Riley también reseñó el debate de la época entre los arquitectos mexicanos con respecto a la búsqueda de identidad en la arquitectura. Una facción quería encontrar las raíces de la arquitectura en el pasado, por lo que resurgieron los neos indigenismo y colonialismo. Por otro lado, los arquitectos de vanguardia estaban convencidos que ese pasado tenía menos que ver con lo que en realidad era México en ese momento - un país en camino hacia el progreso-, por lo que afirmaban que esa búsqueda era estéril y había que hallar la identidad en lo moderno. El autor norteamericano se inclinó hacia el segundo grupo, pues estaba convencido «que el progreso y la línea constructiva que ya se ha iniciado, continuará en el futuro próximo» ${ }^{18}$.

Confrontación de la

tradición con la modernidad.

Pirámide de Cuicuilco en

relación con Le Corbusier, en el libro de Esther Born. 

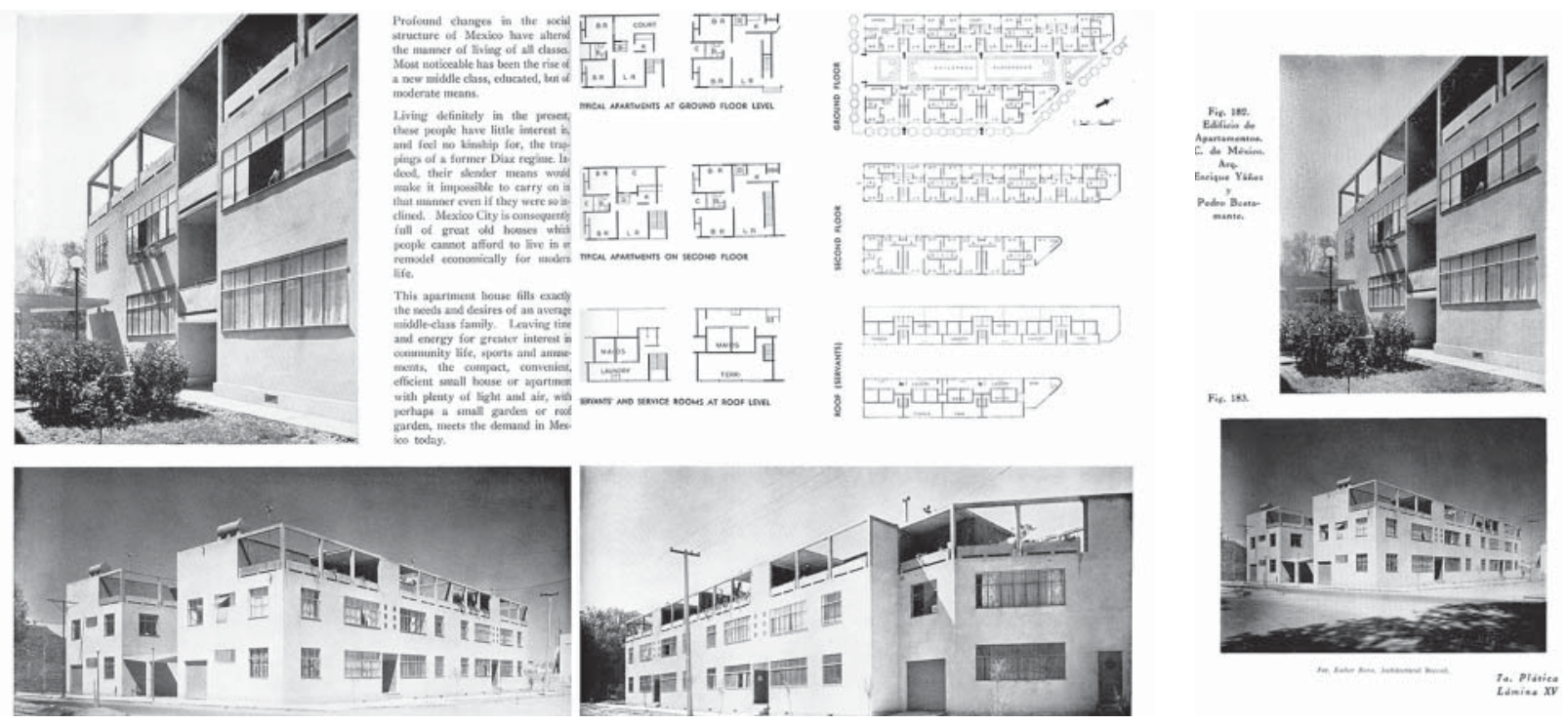

Apartamentos para la nueva clase media, de Enrique Yáñez. A la izquierda las páginas en The New Architecture in Mexico y a la derecha las mismas fotografías en el libro de Justino Fernández.
19. Born, New architecture, educacional público. proyectos arquitectónicos, profusamente ilustrados y analizados en sus intenciones generales de diseño. Se contó con ejemplos de industria, educación, instituciones, hospitales, parques, monumentos, oficinas, centros comerciales, mercados, apartamentos, vivienda unifamiliar residencial y casas para los trabajadores.

En especial, interesa llamar la atención hacia dos obras, ya que se trata de las primeras respuestas institucionales a las demandas sociales de las primeras décadas del siglo. La primera es el Centro Escolar Revolución, en la ciudad de México, diseñado por el arquitecto Antonio Muñoz García en 1934. Si bien en una primera impresión esta obra parece todavía muy académica por su monumentalidad y simetría, así como por algunos elementos de estilo déco en la fachada principal, sorprenden las enormes crujías de aulas absolutamente funcionales. México — se insistesigue siendo un país de contrastes, como se comprueba ante la siguiente afirmación de la autora: «los visitantes, invariablemente, se sorprenden con la actitud estudiosa de los niños mexicanos, muchos de los cuales todavía acuden a la escuela sin zapatos, cargando montañas de libros, obviamente encantados con la idea de aprender» ${ }^{19}$. Esta escuela primaria, proyectada para cinco mil estudiantes, educó principalmente a los hijos de obreros y trabajadores. Hay que decir que la mitad de los estudiantes eran niñas, quienes tuvieron el mismo derecho que los niños al uso de la piscina, la pista deportiva y el teatro al aire libre. Los deportes y la expresión artística, desde entonces, fueron considerados como parte fundamental del programa 

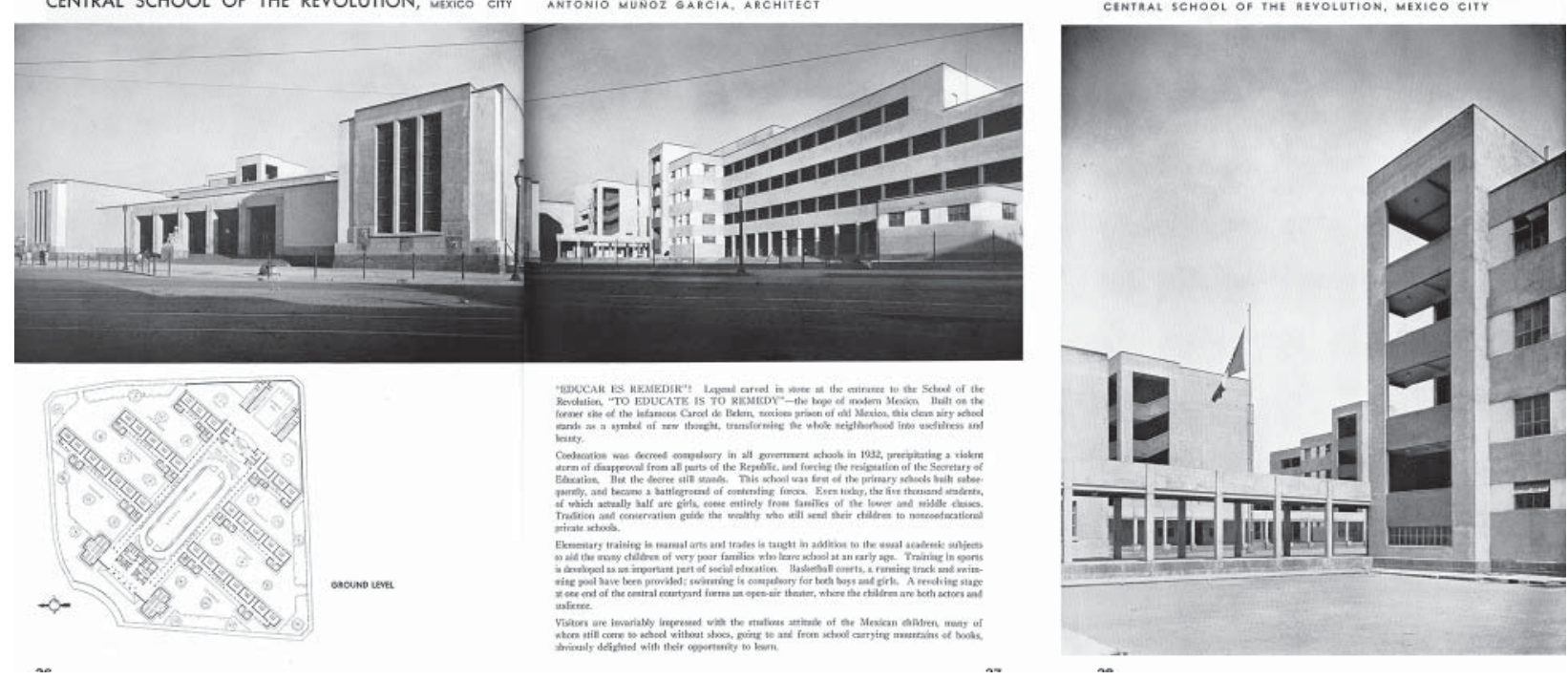

Otra obra fundamental de los años iniciales de la modernidad mexicana es el grupo de casas para trabajadores de la primera mitad de la década de 1930. En 1932 el gobierno de la ciudad de México convocó un concurso en busca de la mejor solución para el problema de la vivienda obrera. El arquitecto Juan Legarreta ganó el primer premio y fue comisionado para construir una primera serie de viviendas en la colonia Balbuena. Dos años más tarde, dos nuevos desarrollos fueron realizados en San Jacinto y La Vaquita siguiendo sus planos. Los tres conjuntos compartían las siguientes características: parques y amplias áreas libres, guarderías para niños de madres trabajadoras y escuelas primarias ${ }^{20}$. La diversidad formal se alcanzaba con el meticuloso estudio y combinación de las áreas mínimas de la vivienda social²1.

El periodo posrevolucionario cobijó la ideología de un grupo de jóvenes arquitectos funcionalistas quienes adoptaron los cambios formales y tecnológicos de las construcciones para obras de utilidad social. Se proyectó y construyó «una arquitectura de beneficio social, estrictamente económica a la vez que técnicamente moderna $»^{22}$. Si bien, al término de la década de 1930 no se paralizó la respuesta gubernamental hacia las demandas sociales más inmediatas, la tendencia cambió en 1940, al término del periodo presidencial progresista de Lázaro Cárdenas. Al iniciar la quinta década del siglo se propició otra política de desarrollo debido a la demanda de productos por parte de los países aliados - principalmente de Estados Unidos- durante la Segunda Guerra Mundial, orientación que se mantendría al término de ésta.

Esto significó el establecimiento de industrias, el auge del comercio y de la banca, la creación de riqueza y la consecuente

Centro Escolar Revolución, de Antonio Muñoz García en The New Architecture in Mexico.
20. Born, New architecture, 80-83.

21. Si bien en el desarrollo de esta tesis se aborda tanto el caso de la arquitectura educativa como el de la vivienda colectiva de interés social, se deja constancia de estos importantes antecedentes que quedan fuera del periodo de análisis.

22. Yáñez, Funcionalismo, 36-37. 

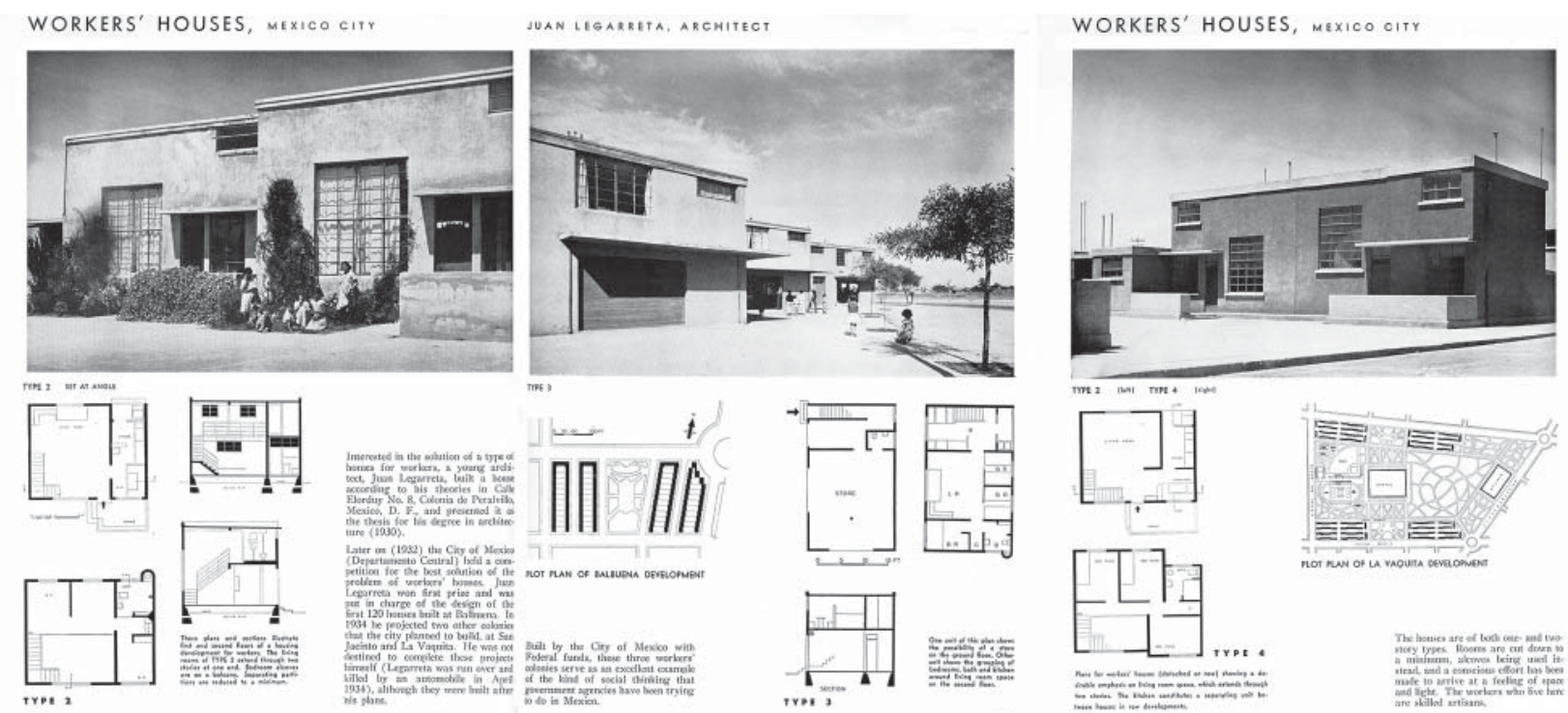

Casas para trabajadores en Balbuena y La Vaquita, de Juan Legarreta. 43.

23. Yáñez, Funcionalismo,

24. I. E. Myers, Mexico's modern architecture (New York: Cornwall Press, 1952). El libro fue editado con el apoyo del Instituto Nacional de Bellas Artes de México en una edición bilingüe inglés/ español.

25. "Mexico's Modern Architecture," Architectural Forum 97, no. 5 (noviembre 1952): 158. distribución inequitativa de los recursos económicos, lo que polarizó los estratos sociales con una mayoría empobrecida y una oligarquía poderosa, trascendiendo a la edificación en general. No sólo hubo una demanda de la alta burguesía de construcciones acordes con la riqueza acumulada, también el Gobierno Federal y las instituciones paraestatales, al ver incrementados sus recursos, pusieron en marcha importantes obras de beneficio social, programas que, a pesar de su empuje, no llegarían a cubrir el total de las necesidades colectivas ${ }^{23}$. En este entorno económico y político se edificaba en México durante la década de 1940.

Si bien se construyeron varias obras icónicas durante estos años -Escuela Nacional de Maestros (1947) o el Centro Urbano Presidente Alemán (1949) — no cabe duda que el proyecto y realización de la Ciudad Universitaria (1947-1952) fue la imagen emblemática de la consolidación de una arquitectura moderna con personalidad propia. En este contexto el libro Mexico's modern architecture, de Irving E. Myers ${ }^{24}$ fortaleció en los medios impresos extranjeros los alcances de la obra universitaria y de una importante selección de obras de menor escala. Extensas reseñas desde Nueva York, París y Londres comentaron los contenidos de este volumen, uno de los más importantes de la arquitectura moderna mexicana publicados en el extranjero.

En noviembre de 1952, Architectural Forum legitimó el libro de Myers al citar en la primera frase de su reseña la introducción de Richard Neutra, quien calificó a México como «el país más vital de América» ${ }^{25}$. Los editores compararon el libro de Myers con el de Born, de quien enfatizaron haber logrado en 1937 una exploración emocionante de los alcances de 
la arquitectura moderna mexicana hasta ese momento. En detrimento de Myers, se comentó el haber brindado la misma importancia visual a los esfuerzos de los talentos menores que a los trabajos más sobresalientes. Asimismo, se dijo que el concienzudo ensayo sobre la gente, los lugares y la historia no era indispensable. Ahora bien, a favor de la arquitectura se recalcó que ésta se mantenía —incluso después del periodo virreinal— «enérgica, terrenal, monumental y dramática, ya se trate de levantar un edificio sobre el lago desecado de la ciudad de México o de construir sobre camas de lava» ${ }^{26}$.

Pocos meses después, las reseñas del libro de Myers cruzaron el Atlántico; en febrero de 1953, L’Architecture d’Aujourd'hui hizo públicos algunos comentarios sobre el volumen ${ }^{27}$. En Francia se comentó la importancia de la aportación del México moderno al desarrollo de la arquitectura contemporánea. También se insistió en la herencia cultural expresada en el conjunto monumental de la Ciudad Universitaria, trabajo de un amplio equipo, en donde se constató la calidad e independencia de los arquitectos mexicanos con respecto a otros países americanos. La cultura y la economía se reflejaron en los ejemplos de habitación, oficinas, industria o educación y los comentarios más generales de la reseña apuntaron hacia la calidad de las fotografías, el glosario o la bibliografía.

No sería sino hasta el año siguiente, en febrero de 1954 - casi dos años después de publicado el libro- que The Architectural Review dedicó una extensa reseña al volumen de Myers $^{28}$. En principio, dos aspectos sorprendieron a los ingleses: que un país hubiese producido tal cantidad de ejemplos meritorios de arquitectura moderna y que ese país fuese latinoamericano. Advirtieron los londinenses su falta de visión hacia Latinoamérica - ya les había pasado algo parecido la década anterior con el caso de Brasil. Anotaron como el mérito principal del libro que mostraba todo tipo de edificios. Destacaron, asimismo, la contemporaneidad de las obras, todas — salvo contadas excepciones- del año 1947 en adelante. La reseña ahondó en la comparación de obras de un mismo autor -como Mario Pani o Juan O’Gorman- en las que se reconocía una evolución técnica y formal.

A juicio de E. J. Carter, quien firmase la reseña, la primera parte del libro, dedicada a las viviendas unifamiliares, incluía buenos ejemplos, pero quizá menos interesantes en conjunto que las secciones dedicadas

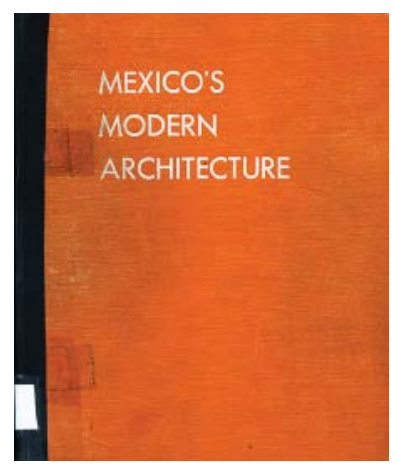

Portada del libro Mexico's Modern Architecture, de Irving E. Myers (1952).
26. "Mexico's Modern," Architectural Forum, 158.

27. "Mexico's Modern Architecture," L'Architecture d'Aujourd'hui, no. 46 (febrero 1953): XXIII.

28. E. J. Carter, "Mexican modern," The Architectural Review 115, no. 686 (febrero 1954): 135. 
29.

30. Yáñez, Funcionalismo, 18-19. Irving E. Myers fue un arquitecto estadounidense que se había establecido en México desde 1950. Su interés en el desarrollo moderno del país lo llevó a buscar el apoyo del INBA para publicar un libro sobre el tema. En 1952, la institución estaba a cargo de Carlos Chávez, y contaba con el arquitecto Enrique Yáñez como jefe del Departamento de Arquitectura.

31. Myers, Mexico's Modern, 16. a la educación, la vivienda social o los edificios de oficinas. Si por un lado las viviendas privadas se leían como fachadas acristaladas que abren hacia pórticos o patios, en juegos que difuminan los límites entre los espacios interiores y exteriores, para el caso de la vivienda social, lo que se confrontaba era la inmediatez de una buena solución a las demandas más apremiantes de las clases trabajadoras. La reseña enfatizó los ejemplos del Centro Urbano Presidente Alemán y la urbanización Jardín Balbuena.

Por supuesto, la Ciudad Universitaria tuvo un lugar destacado en los comentarios. Del conjunto se destacaron el edificio de ciencias y el pabellón de rayos cósmicos. Al contrario de la reseña publicada en Architectural Forum, el autor dejó al final y casi como un comentario al margen la aportación al libro de Richard Neutra ${ }^{29}$.

Mexico's Modern Architecture fue el resultado del esfuerzo realizado en México por el Instituto Nacional de Bellas Artes (INBA), quien emprendió la búsqueda de material con el fin de realizar una exposición y editar un libro sobre la situación actual de la arquitectura. Al no conseguirse los recursos económicos para la edición del libro, se brindó el material a Myers para que se publicase el texto bilingüe en Estados Unidos ${ }^{30}$. Una ventaja de esta colaboración fue la claridad con la que el autor definió la arquitectura nacional como aquella «arquitectura moderna transformada de sus orígenes europeos en una vital expresión americana. Nacida de la técnica moderna, su crecimiento ha recibido nuevo ímpetu en la última década a través del genio de los arquitectos de México» ${ }^{31}$.

Después del prólogo del arquitecto Enrique Yáñez, del prefacio del autor y de la introducción firmada por Richard Neutra, el libro inicia un recorrido un tanto forzado por los capítulos dedicados a la herencia cultural, el pueblo, la tierra, la economía y la ciudad. Tres lustros después de la publicación de Esther Born, sorprende encontrar de nuevo el mismo debate sobre el camino que debería seguir la arquitectura, comentado ya en el libro de 1937. El argumento que sostenían los arquitectos conservadores al tachar las innovaciones tecnológicas y formales de importación imperialista aparecía un tanto trasnochado, sin embargo, la insistencia con que este grupo buscó una arquitectura que pudiese expresar el espíritu nacional mexicano con ecos del pasado, fue lo suficientemente fuerte como para mantener largos y acalorados debates. Tanto que 


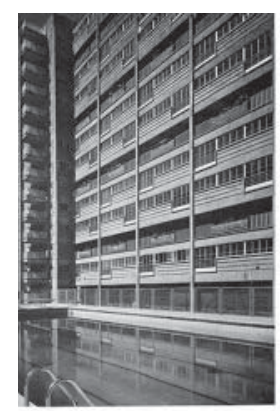

PRES. MIGUEL ALEMAN MULTTPLE OWELUNGS

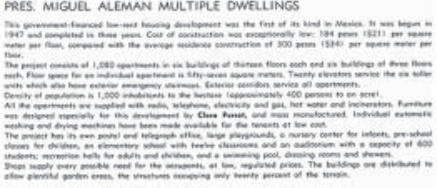

140

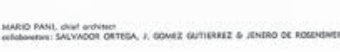

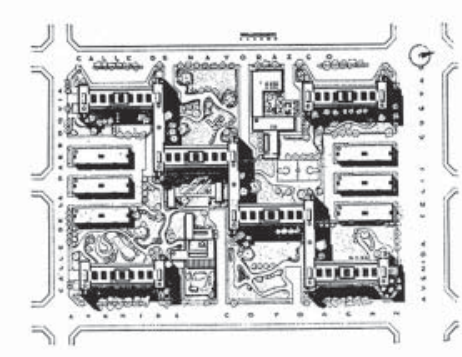

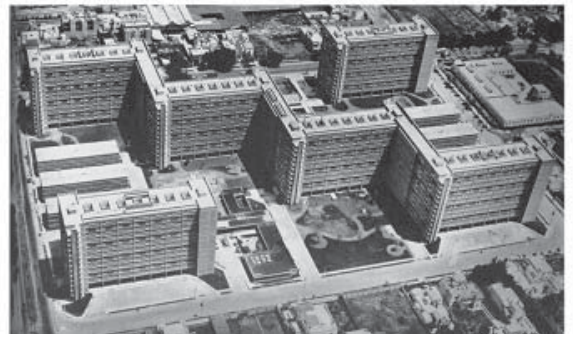

todavía en 1952 «el tema de un estilo nacional de arquitectura estaba siendo discutido ${ }^{32}$, no obstante el grupo de vanguardia no olvidaba que la utilización íntegra de los últimos progresos de la técnica serviría para aliviar los males sociales de la nación. Estos arquitectos sostenían que «la construcción de unidades de habitación, escuelas y hospitales modernos expresaría mucho mejor el espíritu nacional que la resurrección del pasado muerto, o la falsa utilización de los materiales indígenas» ${ }^{33}$.

El volumen de Irving Myers se estructura por tipologías, siendo la primera y más extensa la que se dedica a la vivienda, tanto unifamiliar como colectiva de interés social y de lujo. Otros géneros como las oficinas, las tiendas y comercios, la industria, la recreación y religión, los hospitales y clínicas o las escuelas cubrieron el amplio panorama de lo edificado en los años previos inmediatos a la publicación del libro en 1952. El penúltimo capítulo se dedica a la Ciudad Universitaria, magno conjunto que destacó por su escala monumental y el generoso tratamiento de los espacios abiertos. Por último, los Jardines del Pedregal de San Ángel y su diseño del paisaje completa el abanico de propuestas originales que desde México se daban a conocer al lector internacional.

Lo más destacado de la compilación de Myers fue que no se limitó a traducir la información brindada por los estudiosos mexicanos, ya que su papel de autor se amplió con el de fotógrafo. Sus vistas de algunos de los edificios de la Ciudad Universitaria prueban que visitó la obra unos meses antes de ser finalizada. Los recorridos por las explanadas universitarias y el puntual desarrollo de todos sus edificios debieron motivar al autor para escribir sobre el conjunto educativo como
32. Myers, Mexico's Modern, 46.

33. Myers, Mexico's Modern, 46.
Conjunto Urbano Presidente Alemán (1949) de Mario Pani, en Mexico's Modern Architecture. 
una obra de magnitud e importancia no sólo para México sino para el mundo. Se ha inspirado en la visión realista de una gran necesidad y ha sido acometida con un espíritu de cooperación tan magnífico que su plena realización será un testimonio del invencible deseo creador del hombre, aun en un mundo propenso a la destrucción como el nuestro ${ }^{34}$.

Habría de pasar casi una década desde la publicación de Myers en 1952 hasta que, en 1961, saliera a la luz el libro de Max Cetto: Moderne Architektur in Mexiko ${ }^{35}$. El libro recopila más de ochenta proyectos de los últimos años, así como el análisis puntual de la arquitectura mexicana a lo largo de la historia. El libro se divide en doce capítulos: iglesias; hospitales; escuelas; ciudades universitarias e institutos politécnicos; restaurantes, teatros, clubes; pabellones de exposiciones; aeropuertos y talleres vehiculares; comercios y mercados; cascarones de Candela; oficinas; edificios de departamentos y hoteles y casas con jardín.

Para el año de la publicación, el arquitecto Max Cetto - de origen alemán- ya se había nacionalizado mexicano, por lo que su aproximación al tema dista mucho de ser una visión superficial. Al contrario de un acercamiento frío, el autor consideró que poner los logros de la arquitectura mexicana al nivel del desarrollo de la arquitectura en general y verificar su validez más allá de sus fronteras, era la manera de corresponder al país que siempre consideró su segundo hogar. Sin embargo, después de esta declaratoria de intenciones, uno no encontrará un análisis trivial sino todas las herramientas históricas y críticas para que el propio lector determine sus parámetros de valoración.

La introducción subrayó algunas características de las arquitecturas históricas - en especial de la prehispánica y la barroca- que, a juicio del autor, se integraron en el siglo xx en la arquitectura moderna; por ejemplo,

34. Myers, Mexico's Modern, 227.

35. Max L. Cetto, Moderne Architektur in Mexiko (Stuttgart: Verlag Gerd Hatje, 1961). Edición bilingüe alemán/ inglés; el mismo libro sería publicado también en 1961 en Nueva York por Frederick A. Praeger en edición bilingüe inglés/español.

36. Cetto, Moderne Architektur, 12.

37. Cetto, Moderne Architektur, 26. el interés centrado en los acabados y no en la estructura ${ }^{36}$. Esta constante, siguiendo a Cetto, se olvidó cuando se construyeron los primeros ejemplos de arquitectura puramente funcional, totalmente libres de ornamento. Estas obras tempranas, que impulsaron un primer funcionalismo radical, produjeron las primeras escuelas económicas y viviendas para obreros construidas en poco tiempo. Sin embargo, no correspondían a un signo de madurez espiritual — como habría sugerido Adolf Loos- sino a un síntoma de pobreza mental, esto es, se diseñarían en contra del espíritu mexicano ${ }^{37}$. 


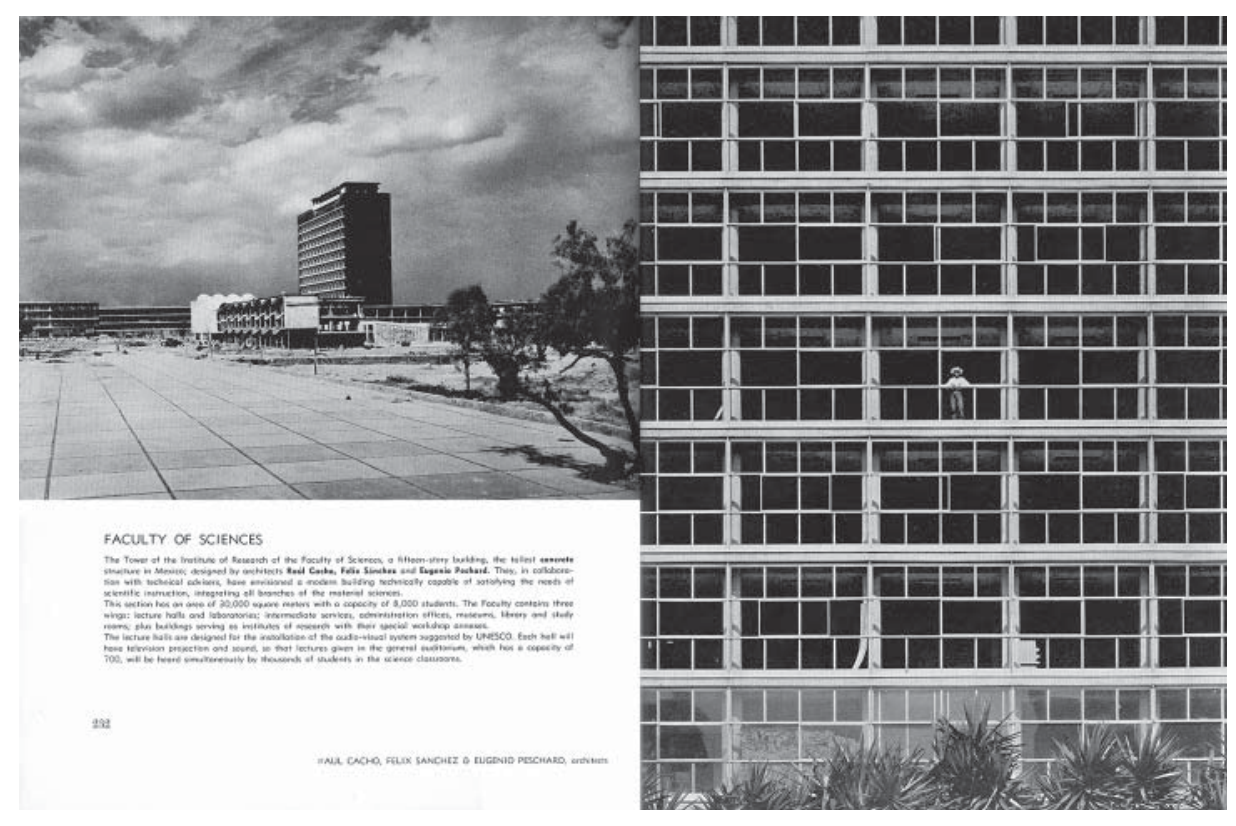

El autor insistió en que

si la arquitectura no surge del vacío, entonces no puede ser satisfecha con la fórmula del estilo internacional. La cultura arquitectónica de un país es una fiel expresión de constantes como el tipo de vida de sus habitantes, y un espejo de la etnia, la geografía y las condiciones sociales. Incluso si hubo un frente común de la arquitectura moderna considerando estos aspectos, hay diferencias en el significado y en el modo de hacer, y es este punto, no el ideológico, el que nos interesa destacar aquíi ${ }^{38}$.

Por otra parte, un aspecto del análisis que llamó especialmente la atención y que fue reseñado en las publicaciones periódicas, fue la enorme influencia en México de Mies van der Rohe, lo que dio como resultado una especie de manierismo arquitectónico. La libre interpretación de las formas miesianas, esto es, la copia sin fundamento de lo que se veía en las revistas, había degenerado en una arquitectura ajena a su contexto histórico ${ }^{39}$. Como contraparte, también se habló del rasgo distintivo de México: su rica tradición histórica, en que cada civilización fue dejando su huella en el arte y la arquitectura. Fue fundamental que hasta el siglo $\mathrm{xx}$ los arquitectos mexicanos hicieran consciente la intención de producir obras de su tiempo ${ }^{40}$. Esto es, la arquitectura mexicana se inscribía en dos tendencias contradictorias, por un lado, dentro de la arquitectura occidental, como la producida en Estados Unidos, por el otro, volvía a conectar con las tradiciones nacionales y las arquitecturas locales.
Facultad de Ciencias en construcción. Foto de Irving Myers publicada en Mexico's Modern Architecture.
38. Cetto, Moderne Architektur, 29.

39. "Modern Architecture in Mexico," Architectural Forum 114, no. 6 (junio 1961): 176.

40. "Modern Architecture in Mexico," Architectural Design 31, no. 6 (junio 1961): 7. 



Las constantes referencias al pasado prehispánico. Arquitectura maya confrontada con la Biblioteca Central en el libro de Max Cetto, Moderne Architektur in Mexiko (1961).
41. "Moderne Architektur in Mexiko," L'Architecture d'Aujourd'hui, no. 101 (abrilmayo 1962): p. LVII.

42. The New Architecture in Mexico, de Esther Born (1937); Mexico's Modern Architecture, de I. E. Myers (1952) y Moderne Architektur in Mexiko, de Max Cetto (1961).
Un último aspecto que se destacó en las reseñas publicadas fue el del papel fundamental de José Villagrán García como impulsor de la arquitectura moderna en México. Como resultado de sus investigaciones, Villagrán propuso un equilibrio entre los componentes sociológicos, técnicos, funcionales y formales de la arquitectura. Sin embargo, ya en los inicios de la década de 1960, era notable entre los jóvenes arquitectos mexicanos, un divorcio entre la doctrina y la práctica, haciéndose cada vez más comunes los formalismos decorativos sin fundamento teórico ${ }^{41}$.

Si bien los tres libros revisados ${ }^{42}$ pueden considerarse los estudios más completos publicados en el extranjero sobre arquitectura moderna mexicana de mediado el siglo $\mathrm{xx}$, numerosos volúmenes que trataron la arquitectura internacional, incluyeron ejemplos mexicanos entre sus páginas. Ediciones de Zúrich, Múnich, Tubinga o Nueva York, reseñadas en las revistas de arquitectura, tomaron también como ejemplo la arquitectura contemporánea de México durante las décadas de 1950 y 1960.

Así, a continuación se revisan algunas de las ediciones -y sus correspondientes reseñas - que van de las menciones de una obra en particular, en el contexto general de una selección más amplia, hasta las publicaciones dirigidas a los aspectos técnicos de la construcción, o incluso los libros de historia del urbanismo y sus debates contemporáneos. 
Uno de los edificios más difundidos durante las décadas de 1950-60. Iglesia de la Virgen Milagrosa de Félix Candela (1954-55).

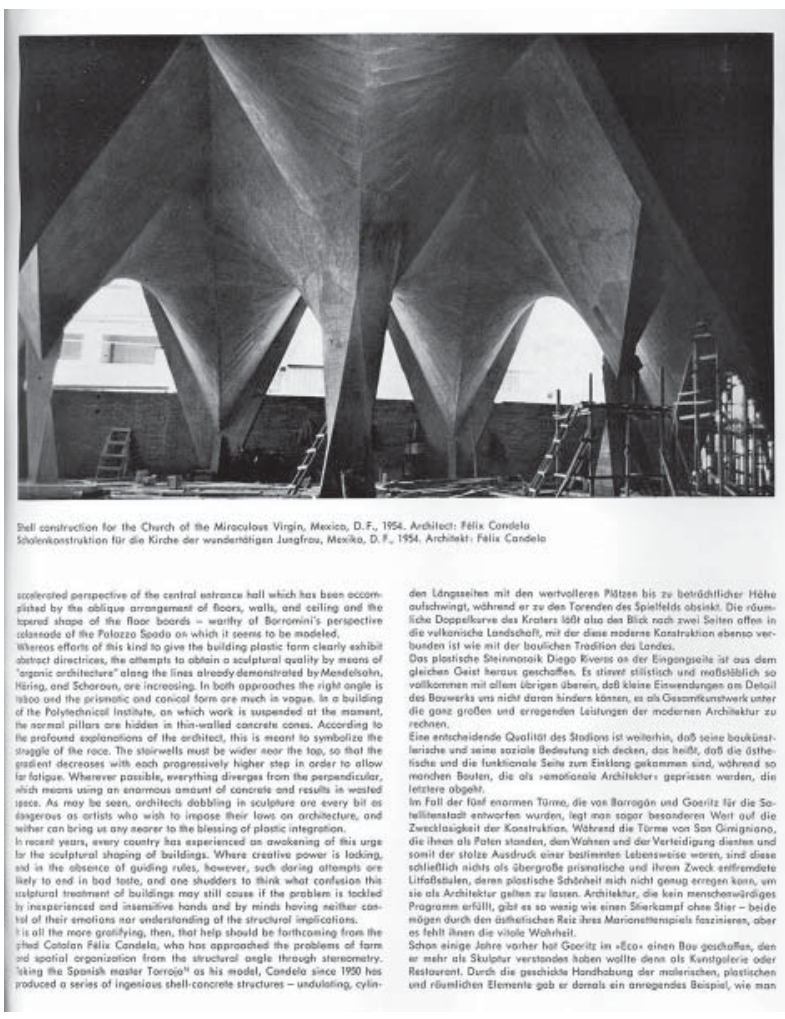

\section{El caso particular en la historia general}

Hacia la mitad del siglo xx, la vivienda del hombre moderno había sufrido cambios sustanciales de lo que había sido a principios del siglo. Esas transformaciones se hacían más evidentes cuando se comparaban las casas de los propios arquitectos, donde las innovaciones con respecto al nivel de vida alcanzado entonces se reflejaron en instalaciones sanitarias y eléctricas de lo más nuevo, calefacción automática, refrigeradores, lavadoras o lavavajillas. Es claro que también la concepción general de la vivienda se transformó. En el transcurso de unas décadas, fue común que los espacios se fusionaran y compartieran - cocina, comedor y estancia juntos- y sobre todo, que se abrieran al exterior en franca comunicación con la naturaleza.

Publicado en Zúrich en 1955, salió a la luz el libro Architects' Homes, de Robert Winkler ${ }^{43}$, con cuarenta y cuatro ejemplos de viviendas contemporáneas ${ }^{44}$ diseñadas para ser habitadas por los propios arquitectos. Winkler reveló las ideas básicas de la casa, generalmente aceptadas como guías principales en todo el mundo: asimetría, diseño condicionado por el soleamiento y comunicación de espacios interiores con exteriores, ya fuese a través de salidas al jardín o de vistas al paisaje ${ }^{45}$.

Si bien estructurado por geografía, el autor notó algunas invariantes en el diseño habitacional: el esfuerzo por conseguir volúmenes
43. Robert Winkler, Architects' Homes (Zürich: Verlag Girsberger, 1955). Cabe recordar como antecedente al tema el libro 18 residencias de arquitectos mexicanos, publicado por Ediciones Mexicanas en 1951, con introducción del arquitecto Enrique Yáñez.

44. Los ejemplos se distribuyen en los siguientes capítulos: Suiza (15); Alemania, Holanda, Escandinavia (11); Inglaterra, Francia, Italia, Portugal (7); Estados Unidos, Brasil, México y Japón (11). Se hace notar que de este último capítulo, sólo dos casos son brasileños, y solamente hay un ejemplo mexicano $y$ uno japonés.

45. Winkler, Architects' Homes, 10. 
46. Winkler, Architects' Homes, 10.

47. Winkler, Architects' Homes, 210-215. Las fotografías son de Guillermo Zamora, uno de los más importantes fotógrafos de arquitectura mexicana y activo colaborador de la revista $A r$ quitectura México, editada por Mario Pani.

48. Winkler, Architects Homes, 212.

49. "La maison de l'Architecte," L'Architecture d'Aujourd'hui, no. 67-68 (octubre 1956): xxxvir. Otra reseña de este libro se publicó en Progressive Architecture 37, no. 9 (septiembre 1956): 193, firmada por Lawrence E. Mawn, quien describió someramente el volumen, sin hacer ningún tipo de crítica.

50. "La maison de l'Architecte," xxxvir. Las casas ilustradas son ejemplos de Francia, Estados Unidos, Portugal, Finlandia, Gran Bretaña, Suiza, Holanda, Brasil y México. Al revisar la publicación, sorprende - aunque no debería pues la edición es suiza- que el mayor porcentaje de ejemplos son de este país centroeuropeo. independientes que generasen tensiones ópticas y el uso cuidadoso de las diferentes texturas y colores, por ejemplo, en la combinación de materiales modernos como el hormigón, el acero o el vidrio con otros materiales tradicionales como la piedra, la madera o el tabique, creando efectos nuevos que brindaran a las construcciones cierta espontaneidad. Pero el autor no sólo llamó la atención en las reglas generales, sino también en los «factores regionales que siguen haciéndose sentir y son una influencia decisiva en la arquitectura ${ }^{46}$ como las variantes climáticas o los diferentes modos de vida en los diversos países, así como las influencias derivadas de la herencia cultural o de la falta de ella.

El criterio del autor para la selección de las casas fue: evitar imitaciones estilísticas y elegir casas con una clara presencia moderna. Así, el ejemplo mexicano en este volumen es la casa del arquitecto Víctor de la Lama en la ciudad de México ${ }^{47}$. Se publicaron las plantas, la descripción de los espacios y los materiales utilizados, así como numerosas fotografías interiores y exteriores. Sorprende la total transparencia de los muros de cristal de piso a techo, en juego limpio con los muros sólidos que dividen algunos de los espacios interiores. Las cubiertas descansan en delgadas columnas de acero de sección cuadrangular, las intersecciones entre planos verticales y horizontales son perfectas.

El autor destacó dos aspectos de la vivienda, el primero, más general si se compara con los demás ejemplos mostrados fue que «la frontera entre los espacios interiores y exteriores es expresamente abolida ${ }^{48}$, concepto que se corrobora al mirar las fotografías de Guillermo Zamora. También, y más característico de la vivienda unifamiliar mexicana por entonces, fue que las dimensiones superaban con mucho cualquier concepción del espacio que se acostumbraba en Europa.

Esta apreciación fue subrayada por la reseña que, en octubre de 1956, publicó L'Architecture d'Aujourd'hui ${ }^{49}$. Los editores valoraron el trabajo comparativo del autor, que facilitaba a los lectores el estudio de las diferentes concepciones espaciales y su resultado formal. Se destacó la diferencia de escala entre las casas europeas con las sudamericanas. La reseña se ilustró con ejemplos de nueve diferentes países, con la clara intención de mostrar el amplio abanico geográfico de la publicación ${ }^{50}$.

El año de 1965, nueve años después de la publicación de Robert Winkler, se divulgaron dos títulos que también mostraron un amplio 

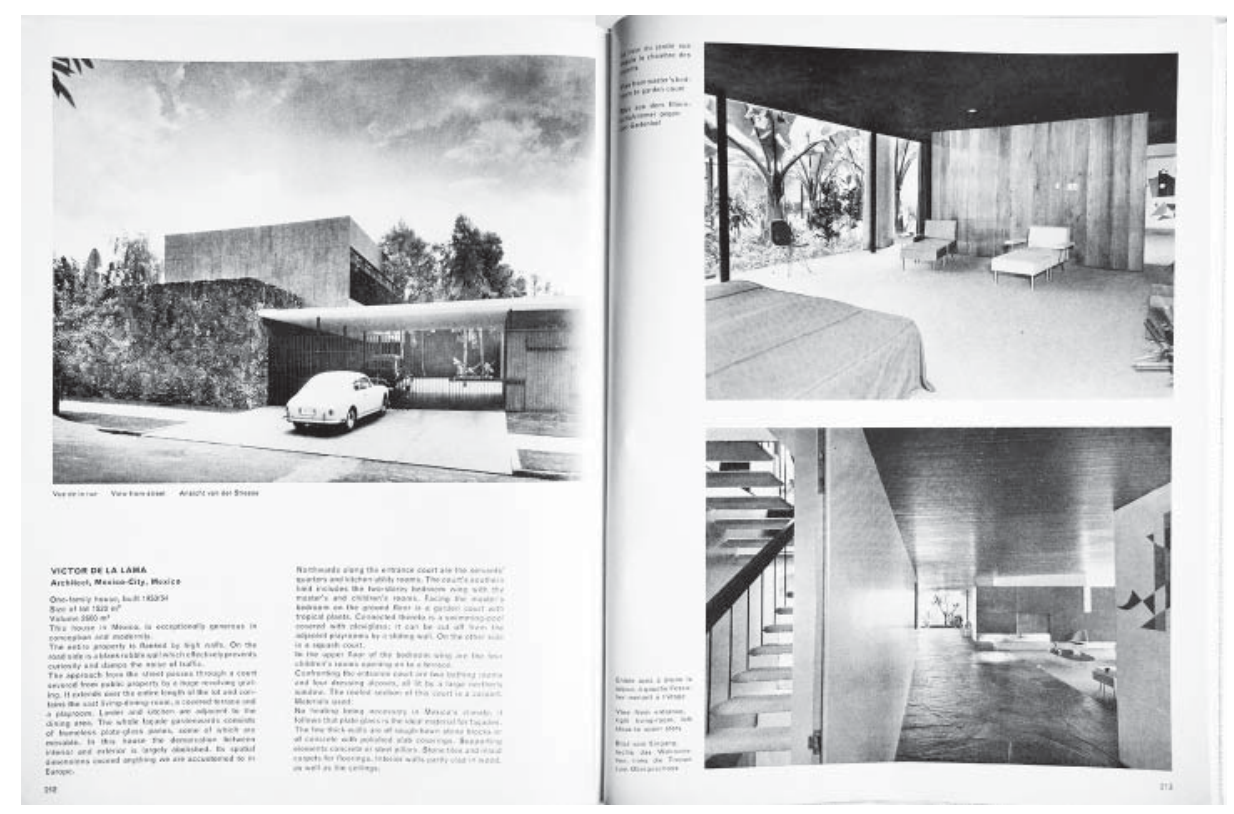

Casa de Víctor de la Lama en Architect's Home (1955) de Robert Winkler.

abanico de arquitectura internacional. Los enfoques particulares fueron, el primero, el de la historia de la bóveda desde la antigüedad hasta sus aplicaciones últimas en cascarones de hormigón armado y, el segundo, el repertorio de las tendencias más novedosas del diseño arquitectónico en todos sus géneros edilicios. Destacamos aquí estos títulos pues ambos contaron con importantes ejemplos de arquitectura moderna mexicana.

El primero de ellos fue un estudio completo de la bóveda, desde sus orígenes hasta los tiempos modernos, publicado en Múnich por Franz Hart con el título: Kunst und Technik der Wölbung ${ }^{51}$. El autor ilustró la evolución técnica de la bóveda en una obra dividida en dos partes, la primera dedicada a la historia y la segunda a su uso contemporáneo. Desde los análisis de los casos históricos, el autor explicó con intuición y agudeza inusual los cambios formales de este sistema constructivo. Para Hart, la bóveda representaba uno de los logros tecnológicos más importantes del ser humano, sin contar con las posibilidades formales que las curvaturas brindaban al desarrollo de la arquitectura ${ }^{52}$.

Para ese año de 1965, las superficies regladas de Félix Candela ya eran parte de la historia de la arquitectura. Así, una fábrica en Vallejo y el restaurante Los Manantiales, en Xochimilco, ambos en la ciudad de México, fueron analizados con dibujos que acompañaron la información técnica como las dimensiones de alturas, claros que cubren o anchos de las láminas de hormigón ${ }^{53}$. La segunda parte del libro, dedicada a los usos modernos de la bóveda, incluyó — también de Candela - una fotografía de la nave de embotellamiento de la compañía Bacardí, así como dos

51. Franz Hart, Kunst und Technik der Wölbung (München: Verlag Georg D. W. Callwey, 1965).

52. Hart, Kunst, 10.

53. Hart, Kunst, 114-15. Nave industrial El León, Vallejo, México, 1956-57, arquitectos F. y J. Álvarez Ordoñez, construcción F. Candela y Restaurante Los Manantiales, Xochimilco, México, 1958, construcción F. Candela, arquitecto J. Álvarez Ordoñez. 
54. Hart, Kunst, láminas 60 61, s/p.

55. Udo Kultermann, Neues Bauen in der Welt (Tübingen: Verlag Ernst Wasmuth, 1965).

56. Se incluyeron ejemplos de los siguientes países: de América: Canadá, Estados Unidos, México, Cuba, El Salvador, Venezuela, Brasil, Argentina. De África: Marruecos, Ghana y Mozambique. De Europa: Noruega, Suecia, Finlandia, Dinamarca, Inglaterra, España, Italia, Bélgica, Francia, Suiza, Alemania, Austria Checoslovaquia, Polonia, Yugoslavia y Rumanía. De Asia: Israel, Jordania, Rusia, Irak, Irán, Pakistán, India, China, Hong Kong, Birmania, Camboya y Japón y de Oceanía: Australia. proyectos: una perspectiva para la catedral de Villahermosa en Tabasco y un mercado de escala gigantesca en forma de cruz latina ${ }^{54}$.

Una revisión de las últimas tendencias del diseño arquitectónico internacional ya mediada la década de 1960 se debió a Udo Kultermann en Neues Bauen in der Welt ${ }^{55}$. Por primera vez, un extenso abanico geográfico se abría con las páginas del libro. Ordenado de acuerdo a diversos temas, cuarenta países de los cinco continentes mostraron sus construcciones más vanguardistas ${ }^{56}$. Así, se incluyeron distintos géneros como: edificios estatales, museos, teatros, iglesias, clubes, hospitales, centros deportivos, oficinas, hoteles, restaurantes, salas de exposiciones, industria, vivienda individual y colectiva. Lo más interesante de esta publicación fue su intención de muestrario, ya que, después de una breve introducción en la que se puntualizaban los tipos de edificios, la segunda parte del libro contó con las fotografías a página completa y con un mínimo de información, apenas el nombre del edificio, el lugar y el nombre del arquitecto, sin incluir un texto descriptivo ni el año de construcción, acentuando aún más el carácter contemporáneo de la publicación. Si bien se reconocían la mayoría de los nombres de los arquitectos más famosos por entonces, con sus obras más recientes, fue significativa la intención de ampliar el espectro geográfico e incluir ejemplos poco accesibles en otros medios.

Dos obras completamente opuestas - ampliamente difundidas en otros medios impresos - fueron los ejemplos mexicanos. Se trató de la capilla de San Vicente de Paul, proyecto arquitectónico de Enrique de la Mora y Fernando López Carmona y cálculo estructural de Félix Candela, y las oficinas para la compañía Bacardí, en las afueras de la capital, de Mies van der Rohe. Las dos obras expuestas ilustraron - a juicio del autor- las dos tendencias de diseño del panorama mexicano. Por un lado, las formas libres, curvas y expresivas de los paraboloides hiperbólicos y, en clara oposición, los volúmenes puros y estrictos de la arquitectura miesiana. Pero no sólo las diferencias formales son abismales, sino también los sistemas constructivos: el primero casi artesanal y el segundo totalmente industrializado.

Por otro lado, la cercanía geográfica entre Milán —el principal foco italiano de difusión de la arquitectura moderna- y ciudades del sur de Alemania, como Múnich y Stuttgart, desvelan intercambios de información entre los medios impresos. Es notorio que de las 


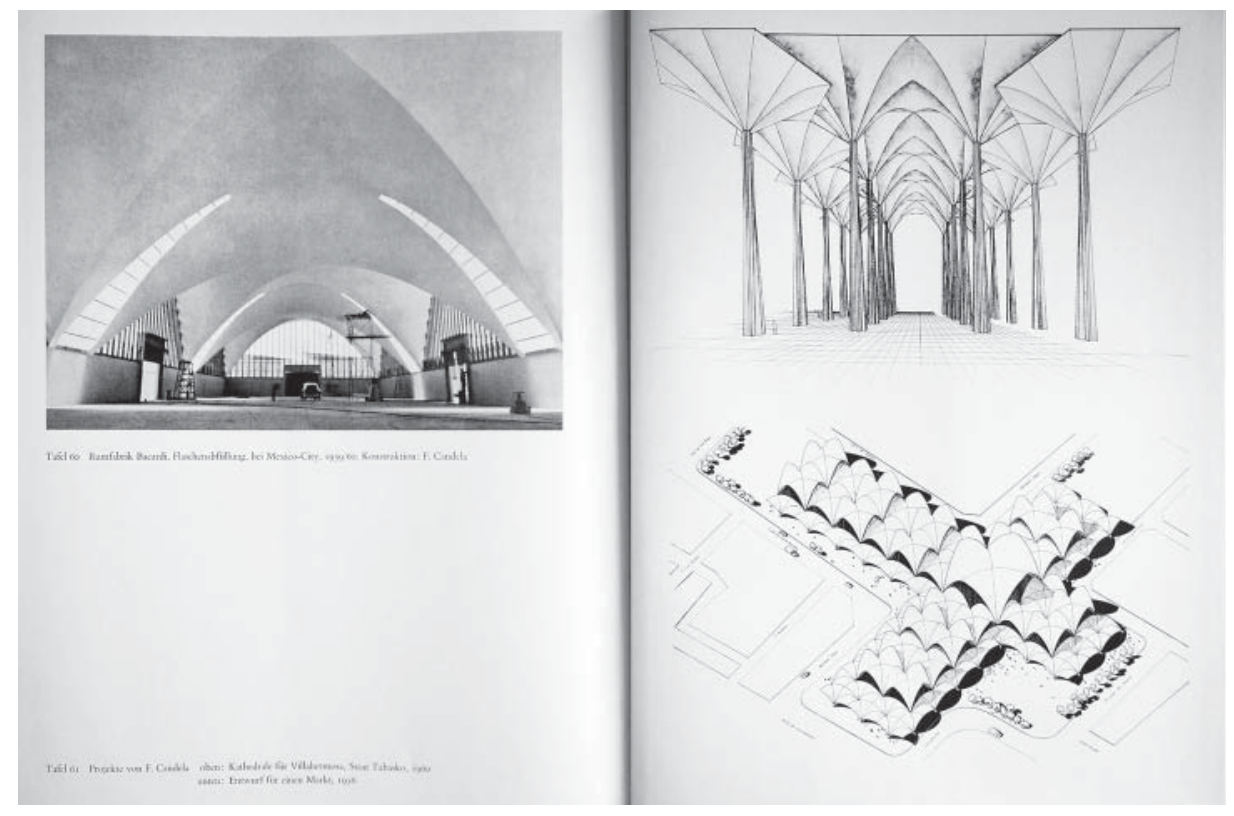

dos publicaciones alemanas citadas antes, se encuentren las reseñas correspondientes solamente en revistas italianas.

Así, en Domus se publicó la reseña sobre el libro de Franz Hart, del cual se destacaron algunos ejemplos sobresalientes del uso del hormigón armado en superficies regladas construidas en el siglo $\mathrm{xx}$, como el hipódromo de la Zarzuela de Eduardo Torroja (1935), el palacio de los deportes de Roma, de Pier Luigi Nervi, el restaurante Los Manantiales en Xochimilco, de Félix Candela (1958) o el mercado de Hamburgo de Bernhard Hermkes (1959-62). Agnoldomenico Pica, autor de la reseña, también señalaba las cualidades del material del siglo y las innovaciones técnicas que habían propiciado una nueva libertad expresiva, complejidades espaciales y riqueza plástica, lo que se comprobaba en las bóvedas post-racionalistas ${ }^{57}$.

En Casabella, lo que se destacó sobre el libro de Udo Kultermann fue la extensa documentación sobre la arquitectura contemporánea que abría la cuestión de cuáles obras, dentro de una corriente internacional, indicaban una evolución visiblemente nueva. Como se mencionó antes, sorprende la vastedad geográfica de los ejemplos mostrados, en donde el notable número de obras de oriente y occidente y su contraposición, permitía un extenso análisis comparativo. Kultermann abordaba directamente el problema de la crisis que la arquitectura sobrellevaba a mediados de los sesenta y sugería a los arquitectos del mundo, más que nunca, «mirar más allá de las fronteras de su propio país, no sólo para recibir incentivos, sino también para una mejor comprensión y trabajar
Proyectos y realizaciones de Candela publicados en Kunst und Technik der Wölbung (1965) de Franz Hart.
57. Agnoldomenico Pica, "Kunst und Technik der Wölbung," Domus, no. 445 (diciembre 1966): 14. Cabe aclarar que la reseña omite el crédito arquitectónico de Los Manantiales: Joaquín Álvarez Ordoñez, no así el libro de Hart, quien sí reconoce al autor del proyecto, no sólo al famoso calculista. 
58. "Neues Bauen in der Welt," Casabella Continuitá, no. 306 (junio 1966): 77.

59. Eric Hobsbawm, "Cities and insurrections," Architectural Design 38, no. 12 (diciembre 1968): 579-88.

60. Peter M. Green y Ruth H. Cheney, "Urban planning and urban revolt: a case study," Progressive Architecture 49, no. 1 (enero 1968): 134-57. El caso de estudio fue New Haven, Connecticut, Estados Unidos.

61. Sibyl Moholy-Nagy, Matrix of Man: An illustrated history of urban environment (New York: Frederick A. Praeger Publishers, 1968).

62. Moholy-Nagy, Matrix, 16.

63. Moholy-Nagy, Matrix, 11.

64. Los cinco "arquetipos" son: geomorfológico, concéntrico, ortogonal conectivo, ortogonal modular y agrupado.

65. Ervin Galantay, "Capricious mingling of archetypes," Progressive Architecture 50, no. 3 (marzo 1969): 158. Véase otra reseña del mismo libro en: John Carter, "Images of man," RIBA Journal 77, no. 7 (julio 1970): 331. en una tarea común, ya que la interdependencia universal es hoy una realidad y una necesidad $»^{58}$.

Hacia el final de la década de 1960 se intensificaría el tema de la ciudad en libros y publicaciones periódicas. Quedando al margen el interés en las nuevas tendencias de diseño arquitectónico, en ese momento se cuestionaban las políticas urbanas consolidadas después de la Segunda Guerra Mundial. Así, algunos artículos estudiaron si la estructura de la ciudad propiciaba o limitaba las insurrecciones urbanas ${ }^{59}$. Y, también, determinados casos de estudio debatieron la problemática de la violencia en las calles y la cuestión de qué tanto los nuevos planes de desarrollo urbano habrían propiciado diversas revueltas ${ }^{60}$.

En este contexto de crisis urbanas y búsqueda de alternativas para las ciudades del último tercio del siglo $\mathrm{xx}$, se publicó en Nueva York Matrix of Man: An illustrated history of urban environment, de Sibyl Moholy-Nagy ${ }^{61}$. En un momento en que los especialistas legitimaban la búsqueda de una metodología científica para tratar los problemas de la ciudad causados por cambios cuantitativos como el crecimiento urbano, la autora rechazaba la aproximación numérica en boga y clamaba por un análisis cualitativo que reiterara el sentido de la ciudad histórica. Para Moholy-Nagy, el problema del supuesto acercamiento científico era que no se podían tratar los problemas urbanos con soluciones únicas ${ }^{62}$, ya que el aspecto cualitativo de la ciudad sería la descripción de su entorno, no científico, porque su denominador común sería la auto-conservación social y espiritual al máximo bienestar.

Desde la perspectiva de que «la ciudad no descansa en el progreso material sino en las opciones históricas a las que se enfrenta cada sitio en particular» ${ }^{63}$, la autora clasificaba las ciudades en cinco categorías ${ }^{64}$. Sin embargo, las reseñas en los medios especializados debatieron esta afirmación. Esto es, que las formas de ordenar el territorio no se limitan a sólo cinco tipos urbanos y que estos patrones no son reinventados espontáneamente por civilizaciones distantes. El principal problema era que los arquetipos propuestos por Moholy-Nagy no eran funcionales sino formales y sólo se definían por el modelo de calles y bloques. Faltaba el entendimiento de la ciudad como un sistema que contiene grupos de actividades interrelacionadas, a pesar de que la naturaleza de esta relación es un determinante principal de la forma urbana ${ }^{65}$. 


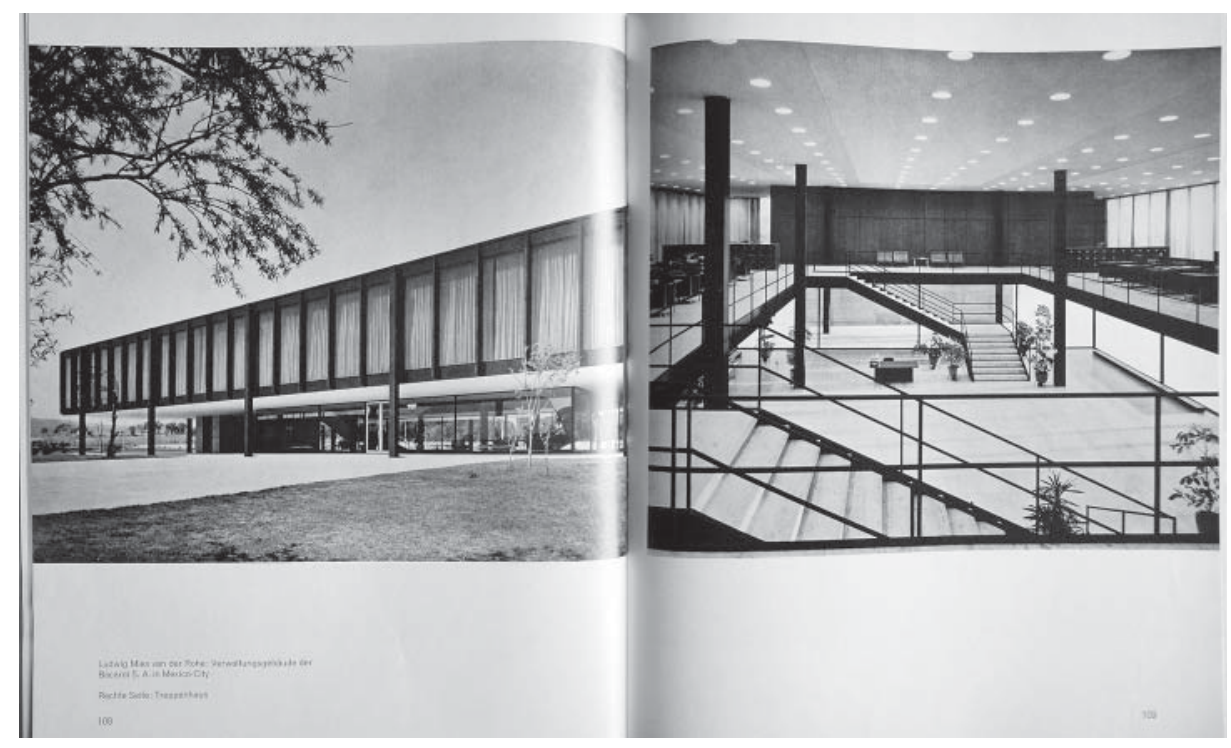

De Matrix of Man sobresalela mención a dos delos más importantes desarrollos urbanos mexicanos del siglo xx: Nonoalco-Tlatelolco y Ciudad Satélite. Así, la Plaza de las Tres Culturas de Tlatelolco se destacaba por el respeto que los urbanistas modernos tuvieron con el significado histórico del sitio, vestigio de la importante ciudad prehispánica y escenario, durante la conquista española, de la batalla decisiva en contra de los aztecas. En una clara vinculación de la herencia indígena americana y el movimiento moderno latinoamericano, las amplias explanadas de la Plaza de las Tres Culturas se comparaban —salvando mil años y más de mil setecientos kilómetros de distancia - con las terrazas de la ciudad maya de Copán, en Honduras. En el ejemplo contemporáneo también se hablaba de una "reminiscencia" de foro clásico para la asamblea pública, que había sido la herencia común de las ciudades concéntricas o nucleares ${ }^{66}$. La imagen publicada apenas dejaba ver los vestigios prehispánicos. La explanada casi vacía se delimitaba con los edificios de vivienda de vanos cuadrados; lo único que desafía la monotonía son algunas de las ventanas que abren oscilantes.

La mención a Ciudad Satélite formaba parte de las alternativas de diseño urbano que la autora proponía para los últimos años del siglo xx. El diseño de Mario Pani se subrayaba como un curioso esquema híbrido síntesis de todos los conceptos ancestrales de desarrollo urbano históricos. Se describían sus vecindarios aislados en forma de racimos auto contenidos, sus modelos de calles rectas y la estrecha alineación de casas, reminiscencia de la "casa muro" de tradición colonial. También, se señalaban los caminos que seguían el contorno de las colinas, ajustando
Oficinas de la compañía Bacardí en Cuautitlán Izcalli, diseño de Mies van der Rohe. en Neues Bauen in der Welt (1965) de Udo Kultermann.
66. Moholy-Nagy, Matrix, 56. 


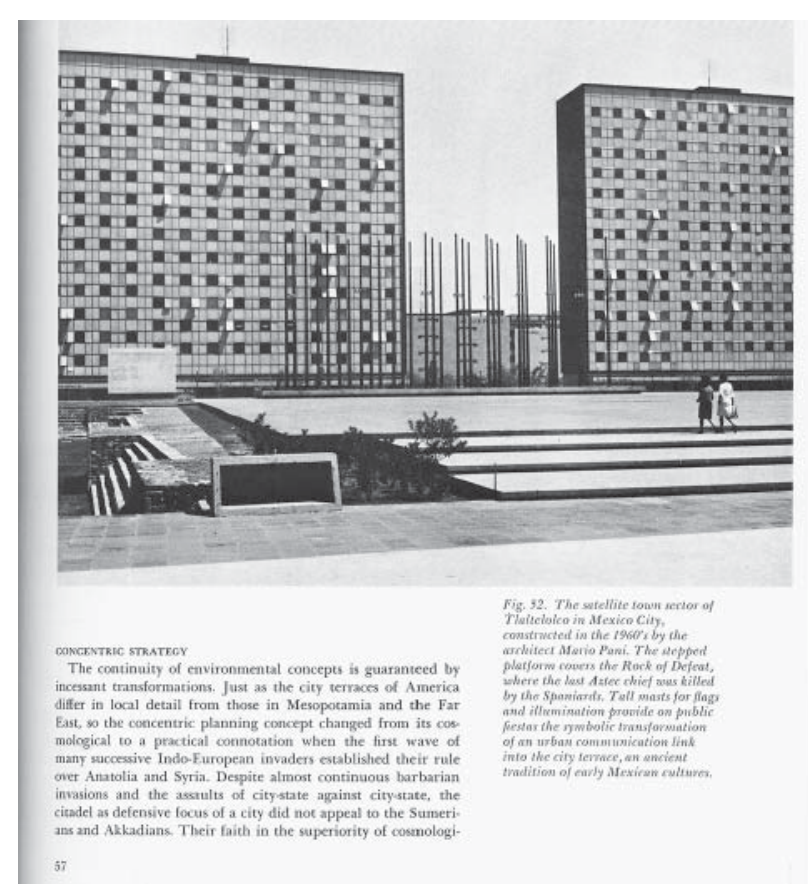

La Plaza de las Tres Culturas de Tlatelolco en Matrix of Man (1968) de Sibyl MoholyNagy.

la vinculación de los edificios a las pendientes naturales. Este elemento geomorfológico sería decisivo para la ubicación del "centro de la ciudad", el cual se levantaba en sucesivas terrazas al igual que una acrópolis precolombina ${ }^{67}$.

Pero la aportación urbana más importante - a juicio de la autora- eran las Torres de Satélite, de Mathias Goeritz y Luis Barragán, símbolos perdurables de la ambición humana para afirmar el sentido de la ciudad histórica como un lugar permanente en la tierra proyectado hacia el futuro. Para Moholy-Nagy, las enormes torres de hormigón eran los descendientes contemporáneos de los zigurates mesopotámicos, y con ellas la visión cíclica de la historia se cerraba volviendo a los orígenes del desarrollo urbano ${ }^{68}$.

\section{El arquitecto como actor}

Si se habla de la modernidad mexicana, se habla de la contradicción de ser moderna y a la vez ser realizada prácticamente de forma artesanal. Resulta significativo que el primer libro monográfico, dedicado por completo a la obra de un arquitecto mexicano, fuese el que mejor ilustró esta contradicción. La rara combinación de innovar en el uso de materiales como el hormigón armado, cuestionar la teoría de la

67. Moholy-Nagy, Matrix, 302. 303.

68. Moholy-Nagy, Matrix, 


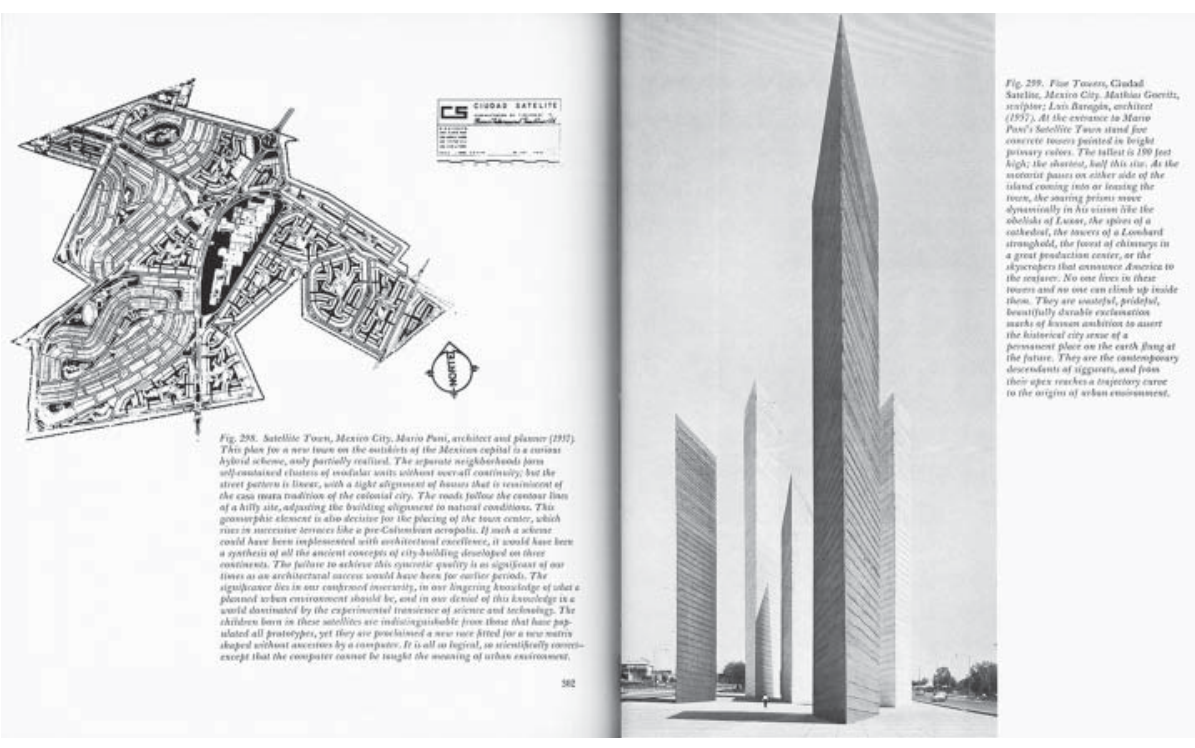

En 1963, Colin Faber, después de varios años de trabajo en la oficina de Félix Candela en la ciudad de México, publicó en Nueva York el libro Candela: The Shell Builder dedicado al arquitecto español nacionalizado mexicano ${ }^{69}$. En el prefacio de la obra, Ove Arup recordaba que Candela no había inventado los cascarones de hormigón ni fue el primero que utilizó paraboloides hiperbólicos, pero sí destacaba la variedad de formas que, para ese momento, Candela había diseñado, calculado y edificado. Ciertamente, sin el conocimiento moderno del cálculo del hormigón armado no hubiese sido posible esa evolución en las formas estructurales, pero no deja de ser notorio en el caso de México, que uno de los arquitectos más difundidos internacionalmente trabajase con mano de obra casi sin especializar y usando métodos artesanales de encofrados. En cierto sentido sus obras son "únicas", como las obras de arte, porque cada una es distinta ${ }^{70}$.

En un texto que inicia de manera informal, el autor va adentrando al lector en el universo Candela, a través de una clara descripción constructiva y evolutiva de decenas de proyectos. Desde su primera aproximación e impresión en la oficina del calculista, pasando por el aprendizaje y el trabajo cotidiano, Faber desmiente la idea - recurrente en las publicaciones periódicas de arquitectura- de que Candela saltase de un diseño a otro en busca de formas cada vez más atrevidas. Al contrario, como persona práctica, nunca buscó cambiar de modelo a menos que él mismo hubiese probado que era más fácil de calcular y construir. Este criterio hacía más difícil generar nuevos diseños, sin embargo, como se sabe, esos son los que llenaron los medios impresos. La prueba está en la
El plan de desarrollo urbano de Ciudad Satélite, de Mario Pani y las Torres, de Mathias Goeritz y Luis Barragán en Matrix of Man.
69. Colin Faber, Candela: The Shell Builder (New York: Reinhold Publishing Corporation, 1963).

70. Ove Arup, prefacio a Candela: The Shell Builder, por Colin Faber (New York: Reinhold Publishing Corporation, 1963), 7-8. 
exorbitante cantidad de estructuras construidas por la empresa en diez años: alrededor de $300^{71}$.

Dentro del periodo de estudio, Candela: The Shell Builder, alcanzó la mayor cantidad de reseñas publicadas en las revistas extranjeras. Si antes se habían revisado comentarios desde Nueva York, París y Londres, este volumen amplió el rango de influencia de Los Ángeles hasta Madrid y Milán, contando además con las otras ciudades antes mencionadas.

Las reseñas analizaron básicamente cuatro aspectos del libro. El primero, el relativo a la innovación tecnológica derivada de los cálculos de estructuras ligeras y del entendimiento del comportamiento de los materiales, la comprensión de las fuerzas y tensiones que se originan en el hormigón $\operatorname{armado}^{72}$. El segundo aspecto, su contribución al desarrollo de la arquitectura moderna por las cualidades estéticas de sus formas estructurales ${ }^{73}$. Un tercer aspecto destacó la oposición entre la estructura "en estado puro", esto es, antes de la intervención de los arquitectos o diseñadores de interiores, quienes, en la mayor parte de los casos, cerraban las estructuras con carpinterías metálicas inadecuadas o mal adaptadas a las formas curvas de las cubiertas, o peor, llenaban los espacios con asientos e imágenes religiosas, que alteraban el concepto puro de la estructura en estado natural ${ }^{74}$. Se hace notar que la mayor parte de las imágenes de este volumen corresponden a fotos de obra con las estructuras recién terminadas, y casi nunca se ven los edificios en pleno uso. El cuarto aspecto fue el de hacer una simple descripción del volumen y hablar de sus características más obvias y de su estructuración por capítulos ${ }^{75}$.

Mención aparte merece la crítica de Esther McCoy publicada por Arts \& Architecture en febrero de $1964^{76}$. La autora destacaba, antes

71. Faber, Candela, 9-10. La cifra refiere las cubiertas realizadas al momento de publicación del libro; la producción de Cubiertas Ala entre 1950 y 1970 ascendería a 850 obras. Dato proporcionado por Louise Noelle.

72. "Candela: The Shell Builder," Arquitectura, no. 59 (noviembre 1963): s/p.

73. "Candela: The Shell Builder," L'Architecture d'Aujourd'hui, no. 111 (diciembre 1963-enero 1964): LII. La reseña comentaba el premio "Auguste Perret" de la UIA otorgado a Candela en 1961. Se justificaba así la publicación del libro.
74. "Candela," Architectural Record 134, no. 6 (diciembre 1963): 42 y 50: «a veces la magia de las estructuras desaparece cuando entra la arquitectura ... las fotografías más sorprendentes son de las estructuras en construcción». Véase también Edward D. Mills, "Candela: The Shell Builder," RIBA Journal 71, no. 7 (julio 1964): 331-32: «El edificio más bello de todo el libro es el restaurante Los Manantiales, el cual, con sus bóvedas de arista flota delicadamente a la orilla de los canales, revelando verdadera elegancia en la construcción de cascarones ...
Otros ejemplos ... son degradados cuando entra en escena la arquitectura y sus poco sensibles diseñadores, que no aprecian la belleza natural y elegancia de estas estructuras».

75. Véase: "Candela: The Shell Builder," Casabella Continuitá, no. 285 (marzo 1964): 57; "Candela: The Shell Builder," Architectural Design 34, no. 8 (agosto 1964): 416 y "Candela: The Shell Builder," Arts \& Architecture 80, no. 12 (diciembre 1963): 4.

76. Esther Mc Coy, "Candela: The Shell Builder," Arts \& Architecture 81, no. 2 (febrero 1964): 11 y 40 . 


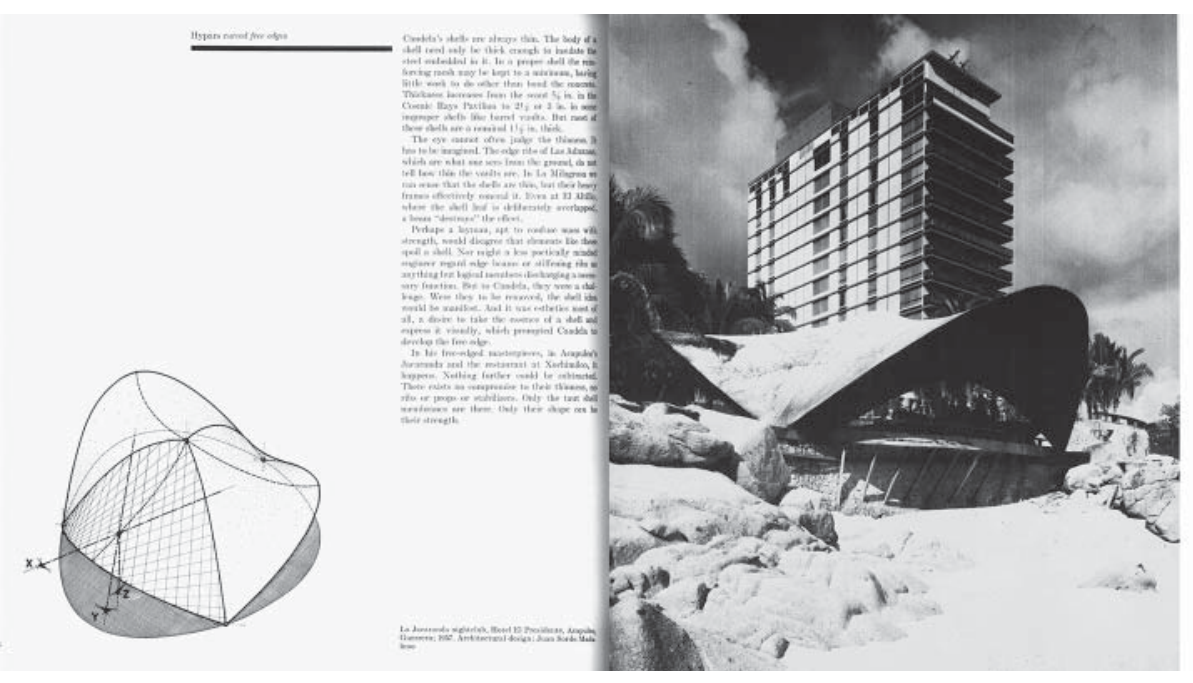

que el trabajo de Candela per se, el trabajo de Faber, a quien calificaba de autor adecuado para acometer la esperada biografía, alguien que conocía de primera mano el trabajo del arquitecto, los edificios, el método de cálculo y el proceso de diseño, a la vez que fuese capaz de sintetizar toda la información de forma clara y concisa.

Sobre Candela, McCoy destacaba su triunfo como constructor de cascarones: el triunfo de la curva sobre la línea recta, de la ligereza sobre la masa, de la intuición sobre la fórmula matemática. Candela no inventó los cascarones pero estuvo en el momento preciso en el lugar adecuado para hacer uso de todo el conocimiento existente sobre el comportamiento del hormigón en tensión.

Un punto por demás interesante, dirigido en especial al lector norteamericano, fue la postura de Candela como detractor de los cascarones, ya que en muchos casos, una estructura de columnas y vigas horizontales, sirve mejor al propósito funcional, donde el acero es abundante y la mano de obra es bien cualificada. También, la autora destacaba cómo la experiencia de Candela lo llevó a separar las cubiertas en inadecuadas y adecuadas: en el primer caso se encuentran las cubiertas de una sola curvatura, como las bóvedas de cañón o las losas plegadas, que son menos resistentes y requieren más cantidad de material. La segunda opción son las superficies de doble curvatura, más ligeras y a la vez más resistentes, y también más bellas. La autora concluía que Candela, basándose en la observación del entorno, había creado superficies que inevitablemente recordaban las formas de la naturaleza ${ }^{77}$.

Cuatro años después de la publicación del monográfico sobre Félix Candela, otro libro neoyorkino saldría a la luz para exponer el
La cubierta del centro nocturno Jacaranda del Hotel Presidente en Acapulco, en Candela: The Shell Builder (1963) de Colin Faber.
77. Mc Coy, "Candela," 11 y 40 . 
78. Clive B. Smith, Builders in the sun: Five Mexican Architects (New York: Architectural Book Publishing, 1967).

79. José Villagrán García, prólogo a Builders in the sun: Five Mexican Architects, por Clive B. Smith (New York: Architectural Book Publishing, 1967), 11. Se refiere al manejo del espacio abierto, a la utilización de patios, pórticos, terrazas, atrios, así como al empleo de materiales como la piedra, las diferentes texturas o la aplicación de color en los acabados.

80. Villagrán García, prólogo, 12. universo personal de cinco arquitectos mexicanos, cuyas obras ya eran ampliamente conocidas internacionalmente. El periodista inglés Clive B. Smith, entonces residente en la ciudad de México, haría un acercamiento a la arquitectura mexicana, no ya a través de las condiciones históricas, sociales o económicas del país, sino a través de los personajes y sus obras. Esta aproximación era ya un uso común alrededor del mundo: la historia de la arquitectura escrita a través del actor.

De esta manera, Builders in the sun. Five Mexican Architects, de 1967, tuvo como único cohesionador la obra —por lo demás diversade cinco arquitectos trabajando en la misma geografía, con la misma luz y compartiendo la misma cultura ${ }^{78}$. Las obras de Juan O'Gorman, Luis Barragán, Félix Candela, Mathias Goeritz y Mario Pani no sólo certificaban las últimas tendencias del diseño mexicano, sino que acercaban al lector a la personalidad de cada uno de sus creadores. Este modo de aproximación se enfatizaba en la manera que fueron presentados los personajes: cada capítulo se abrió con un retrato - o autorretrato en el caso de O’Gormanque no soslayaba la intención de proyectar la imagen construida de cada arquitecto.

En el prólogo a este importante volumen de difusión internacional, José Villagrán García expuso la existencia de constantes en la arquitectura mexicana. El teórico explicaba que México era un país complejo, donde las antiguas culturas mantenían un fuerte peso simbólico. Villagrán se preguntaba cuál era en realidad "nuestro propio acento", afirmando que el común denominador era el definido por el clima y la economía distintos y que podía ser identificado en los ejemplos más sobresalientes de arquitectura de la historia nacional ${ }^{79}$.

Villagrán tocó otro tema fundamental, mismo que sería omitido por completo en el desarrollo del libro, centrado en los autores, su personalidad y sus obras más sobresalientes. Esto es, para el teórico, «lo más importante es que el arquitecto pueda resolver algunos de los problemas sociales que aquejan al país» ${ }^{80}$. Si esto se resolvía poniendo o no un acento local era casi irrelevante, pues el arquitecto debiera regirse por la economía y el clima. Para Villagrán, la prioridad era resolver las demandas sociales y no la mirada extranjera.

Sin embargo, la intención de la publicación fue precisamente construir esa visión foránea, que a su vez fue comentada y cuestionada 
en los medios periódicos de difusión de la arquitectura. Dos revistas neoyorkinas, Progressive Architecture y Architectural Record, confrontaron la realidad mexicana con la propuesta editorial de Clive Smith. Wilson Forrest ${ }^{81}$ y Sandra Kocher ${ }^{82}$ arremetieron contra la selección arbitraria de los cinco arquitectos y la falta de cohesión del libro, pero reconocieron el estímulo producido por sus páginas y el entusiasmo general hacia la riqueza de la arquitectura mexicana contemporánea. El libro resultaba fascinante simplemente por su tema.

El prólogo de Villagrán hacía eco en los revisores, quienes discutían de O'Gorman no tanto su propio rechazo, en la madurez, hacia sus obras tempranas -interpretaciones corbuserianas de la máquina para habitar - y su posterior arquitectura fantástica ejemplificada en su propia casa. Se cuestionaba que, a pesar de su profunda conciencia social, O’Gorman no había trabajado en crear una solución arquitectónica para aliviar la abismal condición de pobreza de los indios que se hacinaban en miserables casas de cartón en los extrarradios de la ciudad de México. A ellos, O’Gorman les había dado mosaicos simbólicos ${ }^{83}$. Estos murales coloridos se entendían como una transición entre los motivos indígenas mexicanos y las pinturas narrativas de los muralistas. Las incrustaciones de O'Gorman parecían burlarse de sus primeras traducciones del funcionalismo de Le Corbusier, al mostrar un retorno consciente a uno de los idiomas característico de México ${ }^{84}$.

Es curioso que, aunque la urbanización de los Jardines del Pedregal, en el sur de la ciudad de México, nació para ser poblada con vivienda unifamiliar accesible únicamente a la clase alta mexicana, no despertó ningún tipo de crítica social. En los medios se exaltaba su conformación rocosa y áspera transformada en asiento de las mejores casas modernas. La roca se entendió como el corazón de la arquitectura mexicana, como su materia prima original y única y a Barragán, como el mago creador del oasis en el desierto de lava volcánica ahora intervenido con jardines $\mathrm{y}$ fuentes.

«Candela es Candela y es internacional ${ }^{85}$. Del maestro de los cascarones de hormigón no había nada nuevo que decir para la crítica, acaso subrayar que sus estructuras ya alcanzaban geografías distintas a la mexicana, como Cuba, Puerto Rico, Venezuela, Perú e incluso los Estados Unidos. Y tampoco estaba de más recordar a los lectores la interesante

81. Wilson Forrest, "Hot Sun, Burning Walls," Progressive Architecture 48, no. 8 (agosto 1967): 196 y 206.

82. Sandra Kocher, "Mexico," Architectural Record 143, no. 4 (abril 1968): 274, 282 y 290.

83. Forrest, "Hot Sun," 196. 84. Kocher, "Mexico," 282. 85. Forrest, "Hot Sun," 206. 
Construcción emocional de Mathias Goeritz exhibida en un barrio popular de la ciudad de México. Páginas de Builders in the Sun.
86. Kocher, "Mexico," 282. 87. Kocher, "Mexico," 282. 88. Forrest, "Hot Sun," 206 $\mathrm{El}$ autor se refiere a la serie de imágenes de las páginas 15761 del libro, que mostraron los juegos escultóricos de Goeritz en medio de una calle sin pavimentar, en una zona proletaria de los extrarradios de la ciudad, con unos niños desconcertados ante la "obra de arte".

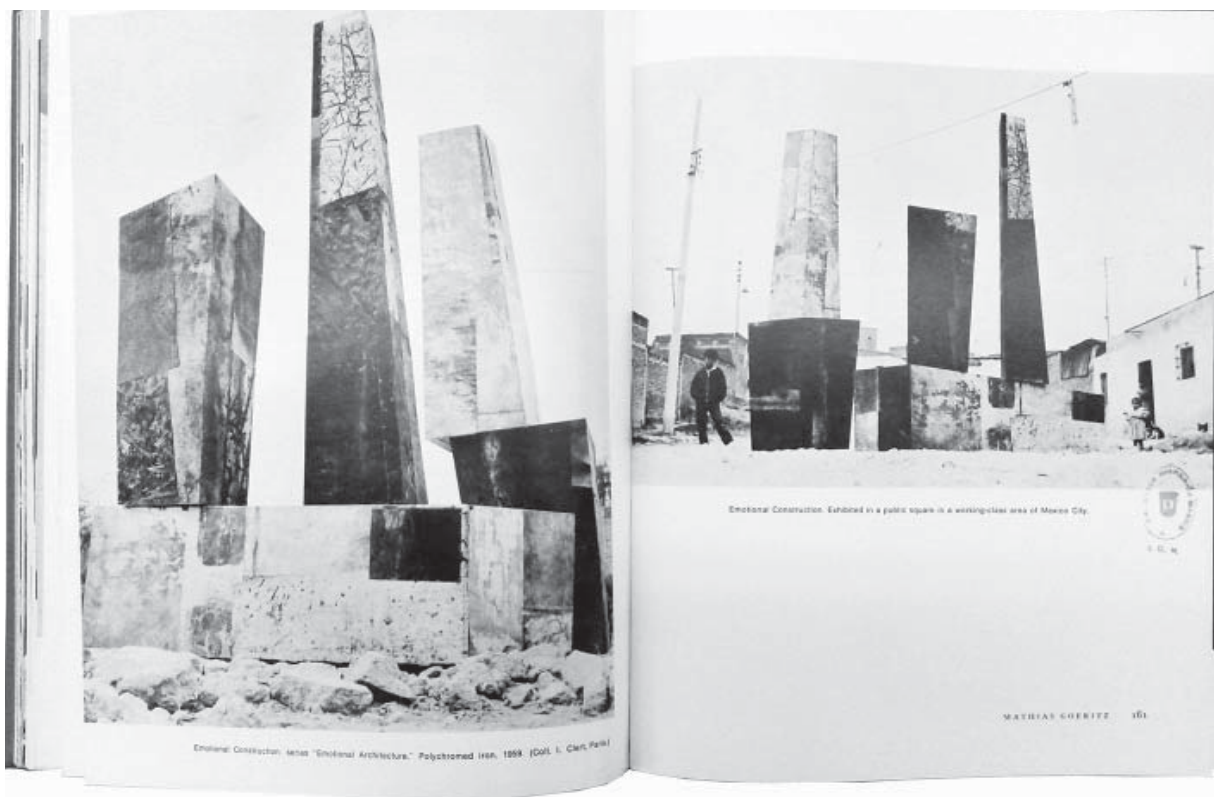

postura del autor, para quien la principal tarea era «simplificar, convencer a la gente que el éxito no depende de las formas extravagantes de los edificios, sino, por el contrario, hacerlos sencillos y estudiar los detalles con amor y cuidado» ${ }^{86}$.

La inclusión de Mathias Goeritz en este volumen se justificaba por su amplia producción de iconos urbanos e intervenciones artísticas en varios edificios, a pesar de su casi nula producción arquitectónica, salvada por el museo experimental El Eco. Sus esculturas "arquitectónicas" inhabitables se mostraron como prácticos iconos urbanos que, como en el caso de la ciudad Satélite de México, se elevaban como simbólicos manifiestos. También se destacó su postura ante la arquitectura que «debe ser una fuerza física que despierte emociones latentes en el hombre ${ }^{87} \mathrm{y}$ su sensibilidad a la luz, creadora de nuevas formas a través de reflejos y sombras. No obstante, se pusieron en duda sus intervenciones artísticas de "construcciones emocionales", exhibidas en barrios proletarios de la ciudad de México, calificándolas de declaraciones intelectuales sin sentido en un ámbito en el que lo necesario era proveer cobijo adecuado o, por lo menos, proporcionar un lugar de juego para los niños pobres ${ }^{88}$.

Cierra el volumen y las reseñas el trabajo emblemático de Mario Pani, destacando el conjunto urbano Nonoalco-Tlatelolco al norte de la ciudad de México. Si en ocasiones la arquitectura se daba las licencias de caer en lo personal, emocional o escultórico, siempre llegaría el momento de que se expresase franca y racionalmente para alcanzar las necesidades de la población urbana siempre en expansión. Si a primera vista los 
vastos desarrollos urbanos de Pani aparecían como repeticiones frías de elevados edificios, ecos en la década de 1960 de la ciudad jardín de Le Corbusier, bajo una mirada más cercana, los edificios compensaban al observador con sus finas texturas de piedra mexicana o con patrones de ventanas rítmicas, hábilmente colocadas contra la masa de cada edificio ${ }^{89}$. Para la crítica internacional, las obras de Pani se justifican más por lo económico que por lo estético. Una nota sobresaliente la daba la fotografía de las unidades de vivienda experimental en las afueras de la ciudad para remplazar las viviendas de cartón de los campesinos emigrados del campo a la ciudad. La solución se mostraba sorpresivamente sensible: «Este es el tipo de diseño que uno hubiera esperado de O’Gorman ${ }^{90}$ concluía la reseña.

\section{Los estudios latinoamericanos}

El año de 1955 fue fundamental para la difusión de la arquitectura moderna latinoamericana en los medios impresos. Gracias a la exposición que dedicó al tema el Museo de Arte Moderno de Nueva York (MoMA) se editó el catálogo Latin American Architecture Since 1945, de HenryRussell Hitchcock ${ }^{91}$, con amplia difusión en las publicaciones periódicas especializadas. La primera de ellas, Architectural Record en enero de 1956, dedicó un extenso resumen del compendio a lo largo de varias páginas intercaladas entre publicidad ${ }^{92}$. En la primera página de la amplia reseña se incluían pequeñas imágenes que daban idea de la diversidad de las soluciones latinoamericanas. Para el caso de México, se hacía una clara referencia a la arquitectura prehispánica y su influencia —en este caso directa - en la arquitectura moderna; se aprecia cómo los frontones deportivos de la Ciudad Universitaria reproducen a pequeña escala la forma piramidal teotihuacana.

En general, la reseña es una cita textual del libro, los únicos comentarios de los editores se refieren a que en la exposición del MoMA, por primera vez, fueron evidentes las características definitorias de este auge constructivo latinoamericano. Esto sobresalió tanto en las formas como en la escala monumental, así como en los vivos colores, a veces chillones ${ }^{93}$. La única crítica al estudio señalaba que a pesar de que el autor describió los mejores trabajos de cada país de forma individual, no discutió el mérito de los arquitectos de forma individual con mucho
89. Kocher, "Mexico," 290. 90. Forrest, "Hot Sun," 206.

91. Henry-Russell Hitchcock, Latin American Architecture since 1945 (New York: The Museum of Modern Art, 1955). Esta publicación es el catálogo de la exposición del mismo nombre, presentada en el museo neoyorkino en 1955.

92. "A Survey of Architecture in Latin America," Architectural Record 119, no. 1 (enero 1956): 56, 60, 330 y 334.

93. Lo que más llama la atención de esta afirmación es la insistencia en los colores vibrantes y chillones. El catálogo, sobra decirlo, se editó con fotografías en blanco y negro, las mismas que, en gran formato, debieron ocupar las salas del MoMA. No se cuenta con información que confirme si en la exposición se mostraron también imágenes a color o si simplemente las reseñas repetían las sentencias de Hitchcock en relación al uso del color en Latinoamérica. 
94. Sibyl Moholy-Nagy, "Dispassionate appraisal: Latin American Architecture since 1945," Progressive Architecture 37, no. 4 (abril 1956): $178,180,184,188$ y 192.

95. Al decir extranjeros se refiere a extranjeros no afincados o nacionalizados en los países latinoamericanos. Se trata de la Embajada de Estados Unidos en La Habana, de Harrison \& Abramovitz y la casa para el Dr. Curuchet en La Plata, de Le Corbusier.

96. "Latin American Architecture Since 1945," Architectural Design 26, no. 4 (abril 1956): 7 y 9. detalle. Sin embargo, sí realzó el trabajo de Oscar Niemeyer y la profunda influencia que tuvo en todo el continente. Hitchcock, reconocido autor —el año anterior a esta publicación había sido premiado por la Society of Architectural Historians- presentó la imagen de la arquitectura latinoamericana con claridad, erudición e interés.

Tres meses después de la primera reseña, Progressive Architecture publicó la de Sibyl Moholy-Nagy, en abril del mismo año ${ }^{94}$. En un texto mucho más crítico, la autora primero destacaba las ventajas de una exposición sobre arquitectura, como sería ver los problemas básicos y las premisas de la profesión desde fuera de su esfera de influencia inmediata. Se crea así — según la autora- una especie de laboratorio que permite una valoración desapasionada y objetiva del tema de estudio.

También, la autora acentuaba lo que ya había hecho notar Hitchcock: la homogeneidad de las construcciones si se consideran las vastas distancias que separan las ciudades latinoamericanas. Un punto que se podía considerar en común —-todavía a mediados del siglo xxera el "espacio libre" que rodeaba los edificios, con lo que se daba un aire de monumentalidad a las construcciones. Pero la nota fundamental la ponía la riqueza decorativa y el uso del color, mezcla de tradiciones tanto ibéricas como nativas. Las estructuras se escondían debajo de murales, mosaicos, cerámicas coloridas o esculturas, en efectos a veces cercanos al barroco.

Lo que Moholy-Nagy criticó fue la escasez de datos históricos o un contexto más amplio que permitiese entender estos edificios no sólo como se mostraban en las fotos, por completo aislados de la ciudad, sino que echaba en falta imágenes que ilustrasen la riqueza cultural de los países latinoamericanos. Para la autora parecía no haber relación entre los edificios y la tierra que los recibía. Por último, era desconcertante para Moholy-Nagy que los dos ejemplos más inadecuados de arquitectura moderna se tratasen de los realizados por arquitectos extranjeros ${ }^{95}$.

Si la crítica desde Nueva York fue bastante más argumentada, la publicada el mismo mes de abril de 1956 en Londres, fue meramente descriptiva de los contenidos generales ${ }^{96}$. Los editores de Architectural Design, tomando como referencia la anterior muestra del museo dedicada a Brasil, esperaban ya esta nueva exposición, que ampliaba a todo el continente los ejemplos más destacados de arquitectura contemporánea. 
Hitchcock brindaba una visión de conjunto, ejemplificada con ciudades universitarias, estadios, piscinas, edificios industriales y comerciales, hospitales, vivienda social y privada.

Asimismo, se subrayó que para el caso delos paíseslatinoamericanos las filiaciones formales y conceptuales de la arquitectura moderna llegaron directamente de Estados Unidos o de Europa, pero también se acentuó que las condiciones locales como el clima y los materiales habían dado la característica propia a la arquitectura al sur del río Bravo. En este contexto, se destacó que sólo en México hubo conciencia de las culturas antiguas. Por otra parte, los editores llamaron la atención hacia el material estructural por excelencia utilizado en Latinoamérica: el hormigón armado, así como a los aspectos característicos de esta arquitectura, los recubrimientos de mosaico, murales o estucados pintados, la forma curva tanto en planta como en alzados y especialmente el color.

Otra vez desde Nueva York, tan sólo un mes después de publicada la reseña anterior, otra revista comentaría también la obra de Hitchcock. En mayo de 1956, Architectural Forum ${ }^{97}$, en breve texto, hizo hincapié en las magníficas fotografías y el importante logro arquitectónico que en los once países latinoamericanos se estaba llevando a cabo. Los editores atribuyeron este desarrollo en la arquitectura a los medios físicos, económicos e históricos propios de cada país.

La última reseña que se revisa sobre Latin American Architecture es la publicada por The Architectural Review en abril de $1957^{98}$, quince meses después de la primera aquí citada. Michel Santiago aportaría la segunda reseña más aguda —después de la de Moholy-Nagy— publicada en las revistas de arquitectura. Para Santiago, el libro de Hitchcock no sería un estudio completo ni un ensayo definitivo sobre el tema, sino más bien el producto de lujo de las exposiciones del MoMA. Por supuesto siguiendo al autor- la publicación es cuidada y las fotos magníficas, y tiene la aportación de redirigir las miradas a otros países latinoamericanos, no sólo a Brasil y México. Lo que para unos puede ser una ventaja, para otros es desventaja, en este caso, que el propio Hitchcock seleccionó los ejemplos que más le parecieron adecuados para brindar el panorama general de la arquitectura contemporánea en Latinoamérica.

Ahora bien, a pesar de la casi contemporaneidad de los libros de Myers (1952) y Hitchcock (1955), sorprende la originalidad del material

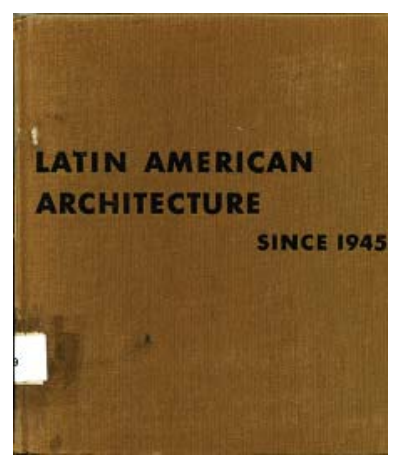

Portada de Latin American Architecture since 1945 (1955)de Henry-Russell Hitchcock.
97. "Latin American Architecture since 1945," Architectural Forum 104, no. 5 (mayo 1956): 206.

98. Michel Santiago, "South America Builds," The Architectural Review 121, no. 723 (abril 1957): 268. 


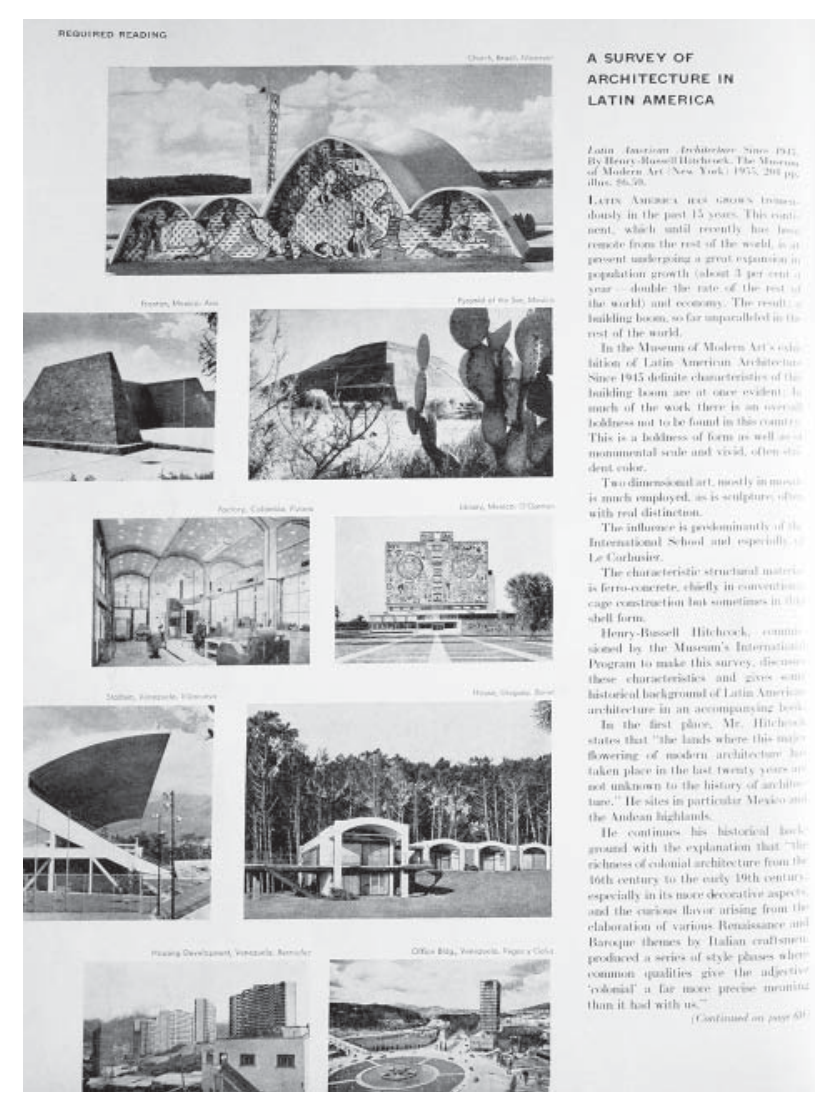

Página de presentación de la reseña a Latin American Architecture since 1945 (1955) de Henry-Russell Hitchcock en Architectural Record (enero 1956).

presentado en ambos. Se ha visto cómo el proyecto de Mexico's Modern Architecture fue resultado de la colaboración directa del Departamento de Arquitectura del INBA en México con el autor norteamericano para realizar la edición bilingüe. En el caso de Latin American Architecture el criterio de selección de material procedió exclusivamente de Hitchcock. Tampoco se debe obviar que se está considerando dicho título como difusor fundamental de la arquitectura moderna mexicana, si bien el volumen ofrece un panorama general de once países latinoamericanos ${ }^{99}$.

Latin American Architecture había surgido de la comisión que el MoMA encargó al historiador de arquitectura Henry-Russell Hitchcock, quien también se había encargado de la exposición previa del museo: Built in USA. Post-war Architecture en 1953. El autor visitó los once países latinoamericanos, acompañado de la fotógrafa Rosalie Thorne McKenna, muchas de cuyas fotografías se publicaron en el libro.

Hitchcock introduce al lector con los países latinoamericanos mencionando el crecimiento poblacional constante y el auge económico,

99. Los once países presentados fueron Argentina, Brasil, Chile, Colombia, Cuba, México, Perú, Puerto Rico, República de Panamá, Uruguay y Venezuela. que había provocado una producción arquitectónica sin comparación con cualquier otro lugar del mundo occidental. Pero acaso más importante y quizá todavía más difícil de aprehender, era el hecho de la extensión del territorio que implica el término "Latinoamérica". Hitchcock había 
viajado por las diversas naciones para documentar la exposición, por lo que se entiende su aseveración sobre la pertenencia de esta nueva arquitectura a la «era del aeroplano, ya que hasta bien entrado el siglo xx América Latina se caracterizó por ser muy remota, no sólo para el mundo occidental sino para sí misma» ${ }^{100}$. Si bien esta condición de aislamiento se ha ido transformando en las últimas décadas, también es verdad que, en general, los latinoamericanos solemos considerar únicamente lo que acontece dentro de nuestras fronteras ${ }^{101}$.

El autor puntualizaba sobre la generalización que se había hecho del término "América Latina", ya que los países y culturas que lo conforman son muy distintos. Por ejemplo, la actitud hacia la herencia indígena puede ir del entusiasmo a la denigración. Para el caso que aquí se trata, Hitchcock aseveraba que «solo en México hay una preocupación consciente por mantener la continuidad de la cultura nacional moderna tanto con lo indígena como con el pasado español» ${ }^{\mathbf{1 0 2}}$.

Hitchcock enfatizaba que no sólo el clima fue determinante para potenciar la nueva arquitectura latinoamericana, pues también la influencia directa de algunos arquitectos europeos que migraron a los países latinoamericanos o el nacimiento de escuelas de arquitectura renovadas desde dentro en pos de la vanguardia fueron fundamentales para el desarrollo de la arquitectura moderna. Otra condición sería la propia formación profesional de algunos arquitectos latinoamericanos en algunas universidades estadounidenses ${ }^{103}$.

$\mathrm{Al}$ referirse a México, el crítico detallaba cuatro grandes temas, los mismos que fueron ejemplificados en la exposición con casos particulares. El primero, la arquitectura industrial, con la mención a los cascarones de hormigón de Félix Candela, el segundo, la educación a nivel superior, con los ejemplos de la Ciudad Universitaria de México, la Escuela de Ingeniería y Arquitectura del Instituto Politécnico Nacional (IPN), así como el nuevo campus del mismo instituto, al norte de la ciudad de México, que se esperaba sería menos típicamente "mexicano" pero más consistente en escala y diseño. El tercer tema general correspondía a la vivienda colectiva de interés social, expuesto con el Centro Urbano Presidente Juárez ${ }^{104}$.

Por último, el cuarto tema que se destacaba para el caso mexicano era el de la vivienda unifamiliar de lujo. La pervivencia del patio interior
100. Hitchcock, Latin American, 11.

101. Aquí se coincide con el crítico Hugo Segawa, quien «Cree, como Guimarães Rosa, que Brasil y el resto de Suramérica son como hermanos siameses: "Cosidos por la espalda pero incapaces de verse el rostro": "Miramos para lados distintos. Pero tenemos problemas y contradicciones comunes». Anatxu Zabalbeascoa, "Más allá de Niemeyer", entrevista a Hugo Segawa publicada en El País el 9 de febrero de 2008, consultada 13 mayo, 2016, http://elpais. com/diario/2008/02/09/babelia/1202515570_850215.html. 102. Hitchcock, Latin American, 27.

103. Hitchcock, Latin American, 20-21. Para el caso mexicano cabe destacar la formación en la Universidad de Columbia, Nueva York, del arquitecto y urbanista Carlos Contreras, primer impulsor del Programa Planificador para el Distrito Federal, así como de Jorge González Reyna, egresado de la Universidad de Harvard y director de la Escuela Nacional de Arquitectura de la UNAM entre 1961 y 1964.

104. Hitchcock, Latin American, 45. Este conjunto contaría con la colaboración del pintor Carlos Mérida, quien proveyó menos policromía estridente, en comparación con otros casos mexicanos de integración plástica, y más ornamentación arquitectónica figurativa. 
Laboratorios CIBA de Alejandro Prieto en Latin American Architecture since 1945.
105. Paul Damaz, Art in Latin American Architecture (New York: Reinhold Publishing Corporation, 1963).
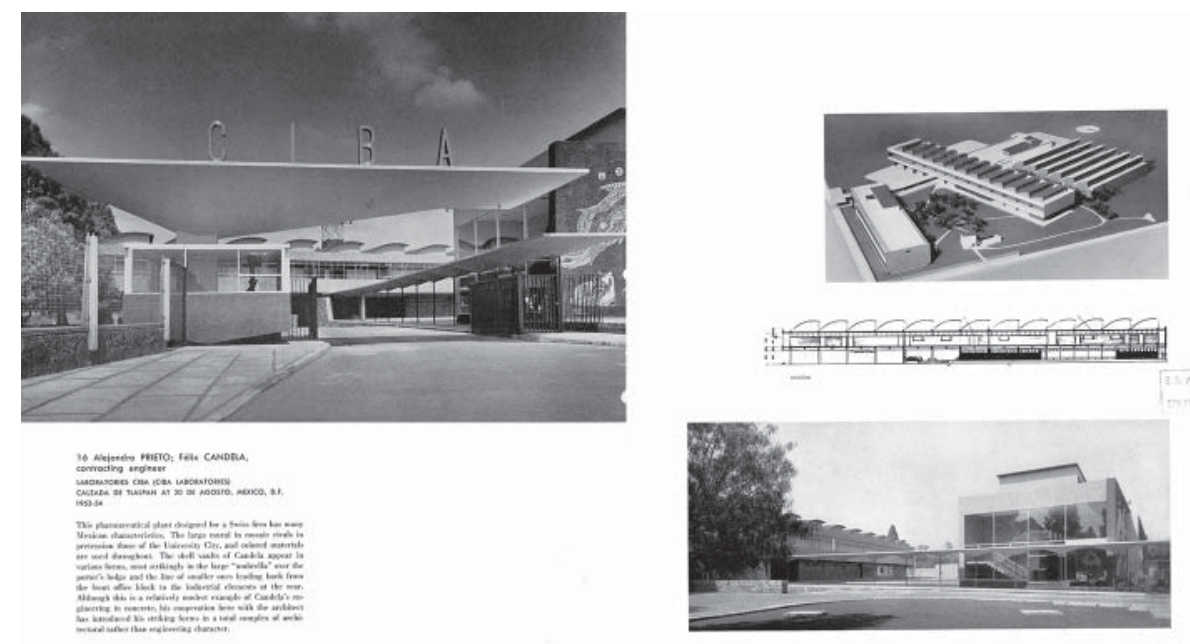

como reminiscencia de la tradición hispanomusulmana se perfilaba como característica general. La variedad en el diseño pasaba por las estructuras tradicionales de sólidos barraganescos, siguiendo el modelo de la casa del arquitecto en Tacubaya, a las transparencias miesianas del arquitecto Francisco Artigas.

Una conclusión fundamental del autor es que la arquitectura de América Latina debería ser entendida como un conjunto que, con sus propios recursos, utilizó el lenguaje común de fuera. En esta afirmación se pueden establecer los parámetros de valoración contemporáneos apropiados para el análisis del presente tema.

Pasarían ocho años desde la publicación del libro de Hitchcock para que saliera a la luz otro volumen dedicado por completo a la arquitectura latinoamericana. Esta vez el cohesionador de las diversas obras sería la aplicación del arte a la arquitectura. Así, en 1963, Paul Damaz publicaba en Nueva York Art in Latin American Architecture ${ }^{105}$, de enorme difusión internacional.

El autor, corresponsal en Estados Unidos de L'Architecture d'Aujourd'hui gracias a una beca de la Architectural League of New York, viajó por los países latinoamericanos para documentar sus estudios sobre el tema de la integración plástica, cuestión por él conocida pues unos años antes había publicado Art in European Architecture. En ambas publicaciones el autor discutía ampliamente el tema de la integración de las artes en la arquitectura, sus principios y posibilidades, así como las dificultades inherentes de aplicar el arte a la arquitectura moderna.

Damaz rechazaba la integración basada en la fusión y beneficiaba la confrontación, ya que, teóricamente, la arquitectura nunca se integraría 
con el arte ${ }^{106}$. Esto es, la obra de arte siempre quedaría como un agregado a la arquitectura y lo que más se esperaría de ella es que tomase en cuenta "el espacio" en el que se inserta: la luz, los colores, el ambiente, etc. De esta forma los mejores ejemplos de integración de los últimos años serían aquellos en los que arte y arquitectura eran confrontados, así, el arte podría incluso oponerse a la arquitectura pero como un complemento ${ }^{107}$.

El argumento que mantiene la aseveración anterior es simple: las formas de la arquitectura y de la pintura abstracta tienen sus mismos orígenes, sus mismas corrientes de pensamiento. Pasa todo lo contrario cuando se trata de "fusionar" arte figurativo o de realismo social a los volúmenes racionales. Para el autor, quedaba claro que «el arte abstracto es el más apropiado para la integración de las artes en la arquitectura que cualquier tipo de arte figurativo» ${ }^{108}$.

El carácter de esta publicación fue construir una mirada de conjunto de todo Latinoamérica, por lo que se destacaron las similitudes de origen, economía, geografía, clima y política que engloban a los países bajo el concepto general latinoamericano ${ }^{109}$. Lo que seguía sorprendiendo a los autores extranjeros - como ya había pasado con Hitchcock- era confrontar la vastedad del territorio y comprobar sus puntos en común. Este panorama contemplaba los factores económicos que determinaron su crecimiento, la migración del campo a la ciudad, los cambios sociales y los materiales generalizados en todo el continente: hormigón reforzado, lo que propició el desarrollo de la forma curva.

Escuela de Ingeniería y Arquitectura del IPN de Raúl Izquierdo y Marcelo Aguilar, en Latin American Architecture.

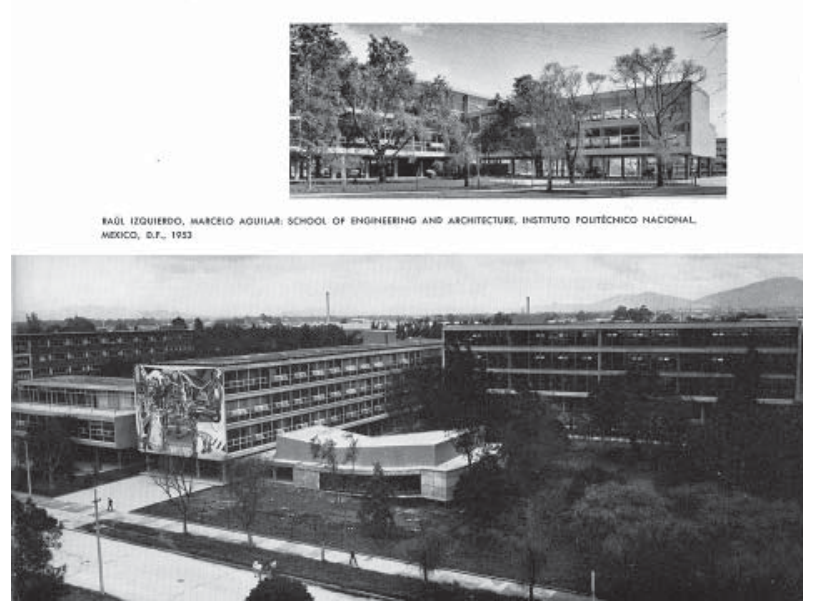

106. Damaz, Art, 14.

107. Damaz, Art, 14. Más adelante el autor dirá que el mejor ejemplo de esta confrontación es la Ciudad Universitaria de Caracas. Por el contrario, la de México, por intentarse la fusión, sería el más grandioso fracaso.

108. Damaz, Art, 14.

109. Los ejemplos de arquitectura moderna en la primera parte del libro corresponden a México, Brasil, Venezuela, Colombia, Perú, Chile, Argentina, Uruguay, Cuba y Puerto Rico. 

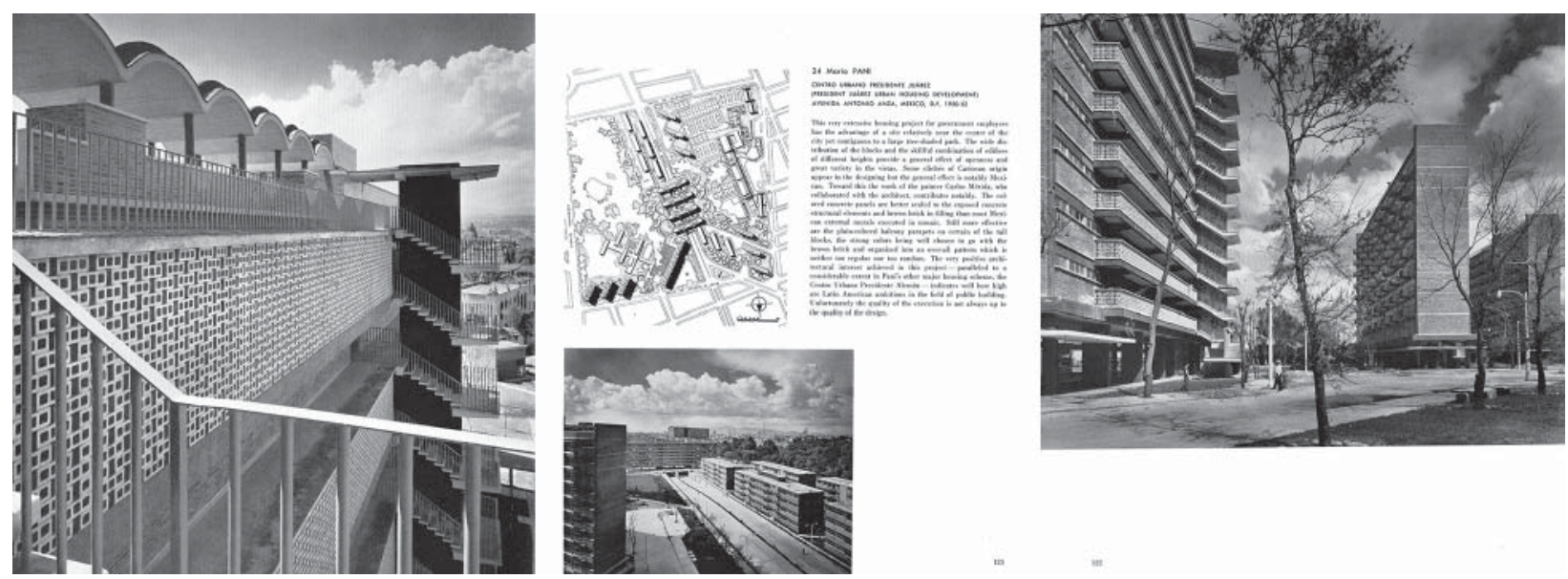

Centro Urbano Presidente Juárez (CUPJ) de Mario Pani.
110. Damaz, Art, 69.

11. Damaz, Art, 214-215.

112. Véase "Art in Latin American Architecture," L'Architecture d'Aujourd'hui, no. 109 (septiembre 1963): 123; "Art in Latin American Architecture," Casabella Continuitá, no. 280 (octubre 1963): 56 y "Latin America," Architectural Record 134, no. 6 (diciembre 1963): 50

113. "Art in Latin American Architecture," Architectural Forum 119, no. 3 (septiembre 1963): 140-141.
Para ahondar en el análisis, Damaz insistía en dos aspectos: el económico y el técnico. A diferencia de los países industrializados, en América Latina la mano de obra todavía era muy barata y especializada, pero en general, los materiales industrializados de construcción eran de costo elevado, por lo que cubrir un muro con un diseño de artista no representaba un gasto extra mayor ${ }^{110}$.

El caso de México se destacaba por las decoraciones complejas $\mathrm{y}$ los colores fuertes, el gusto por la riqueza de forma y la existencia del grupo de muralistas. Esta combinación propició en los arquitectos el experimento de reunificación de las artes que se daría a conocer en todo el mundo. Fue muy activa la participación de muralistas de la talla de Diego Rivera en las obras públicas. Menos conocida que el estadio universitario es la fuente de Tláloc y la estación de control del agua del río Lerma en el bosque de Chapultepec, de 1952. La gigantesca figura - monstruo aterrador o dios- dio muestra de la imaginación de Rivera. Realizada en hormigón y cubierta de piedra de colores, empleó una técnica similar a la utilizada en el estadio universitario y es de una escala abrumadora; la violencia del diseño se calificó de típicamente mexicana ${ }^{111}$.

Art in Latin American Architecture gozó de enorme difusión internacional en las publicaciones periódicas. Si bien se cuenta con reseñas que solamente hicieron una descripción del libro y sus contenidos generales ${ }^{112}$, hubo otras que mantuvieron el debate sobre la pertinencia de la aplicación de las artes a la arquitectura moderna; sobre éstas se ofrece una revisión.

Architectural Forum destacaba el valor de la experimentación en los países latinoamericanos, aun con el riesgo de un fracaso monumental ${ }^{113}$. También, enfatizaba que en los ejemplos de colaboración artística del 
continente se podían seguir las coloridas herencias de incas, mayas y aztecas, que culminaron en los casos más famosos: Brasilia y las ciudades universitarias de Caracas y México. Aunque la reseña sí subrayaba que para el autor el mejor caso de integración había sido la ciudad universitaria de Caracas, no ahondaba en la polémica sobre la utilización de arte abstracto o figurativo en las construcciones.

En septiembre de 1963, Arts \& Architecture reproducía el prefacio de Niemeyer en su sección "Notes in Passing", y en su reseña subrayaba que en América Latina la separación entre arte y arquitectura nunca había sido concebida ni en las mentes del público ni en las intenciones de los arquitectos ${ }^{114}$. Los arquitectos y los artistas no formarían dos clases separadas, como en Estados Unidos. También se destacaban los colores audaces y las formas extremas y potentes tanto del arte como de la arquitectura latinoamericana. Es interesante en la publicación angelina la comparación que expone la manera de abordar la profesión entre arquitectos estadounidenses y latinoamericanos.

Para cerrar el año, Architectural Design recalcaba la postura tanto de Niemeyer en el prólogo, como de Damaz en el desarrollo del libro, quienes no asumían la posibilidad de una total integración de las artes ${ }^{115}$. Asimismo, insistían en que los arquitectos contemporáneos deberían esforzarse por evitar una integración fallida, como había sido el caso de la Ciudad Universitaria de México, y sí, por el contrario, seguir el ejemplo de Caracas. Con amplio sentido crítico, la reseña cuestionaba la omisión de un trabajo de jóvenes arquitectos y artistas en Chile, y sí la inclusión de los ejemplos ya por todos conocidos.

La reseña más aguda de todas, firmada por J. A. Wells-Thorpe y publicada por RIBA Journal, debatía la tesis de Damaz y calificaba el volumen de «libro de imágenes con comentarios de apoyo» ${ }^{116}$. Sin embargo, sí valoraba la revisión del trabajo de los arquitectos latinoamericanos, para quienes la "economía de medios" nunca había sido aceptada como un canon arquitectónico prioritario. Este comentario cabía bien en el contexto de los primeros años de la década de 1960, cuando la arquitectura occidental se daba cuenta de que su camino se dirigía hacia la pura expresión escultórica.

Wells-Thorpe aseveraba que cualquier cosa podía ser dicha de América Latina, pero que nadie negaría su vigor, que seguía latente desde

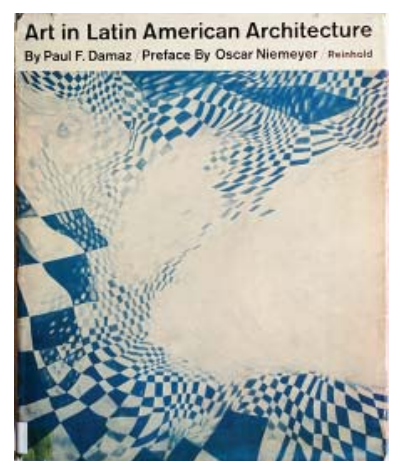

Portada de Art in Latin American Architecture de Paul Damaz.

114. "Art in Latin American Architecture," Arts \& Architecture 80, no. 9 (septiembre 1963): 8 y 11.

115. "Art in Latin American Architecture," Architectural Design 33, no. 12 (diciembre 1963): 606.

116. J. A. Wells-Thorpe, "Art in Latin American Architecture," RIBA Journal 71, no. 1 (enero 1964): 35. 

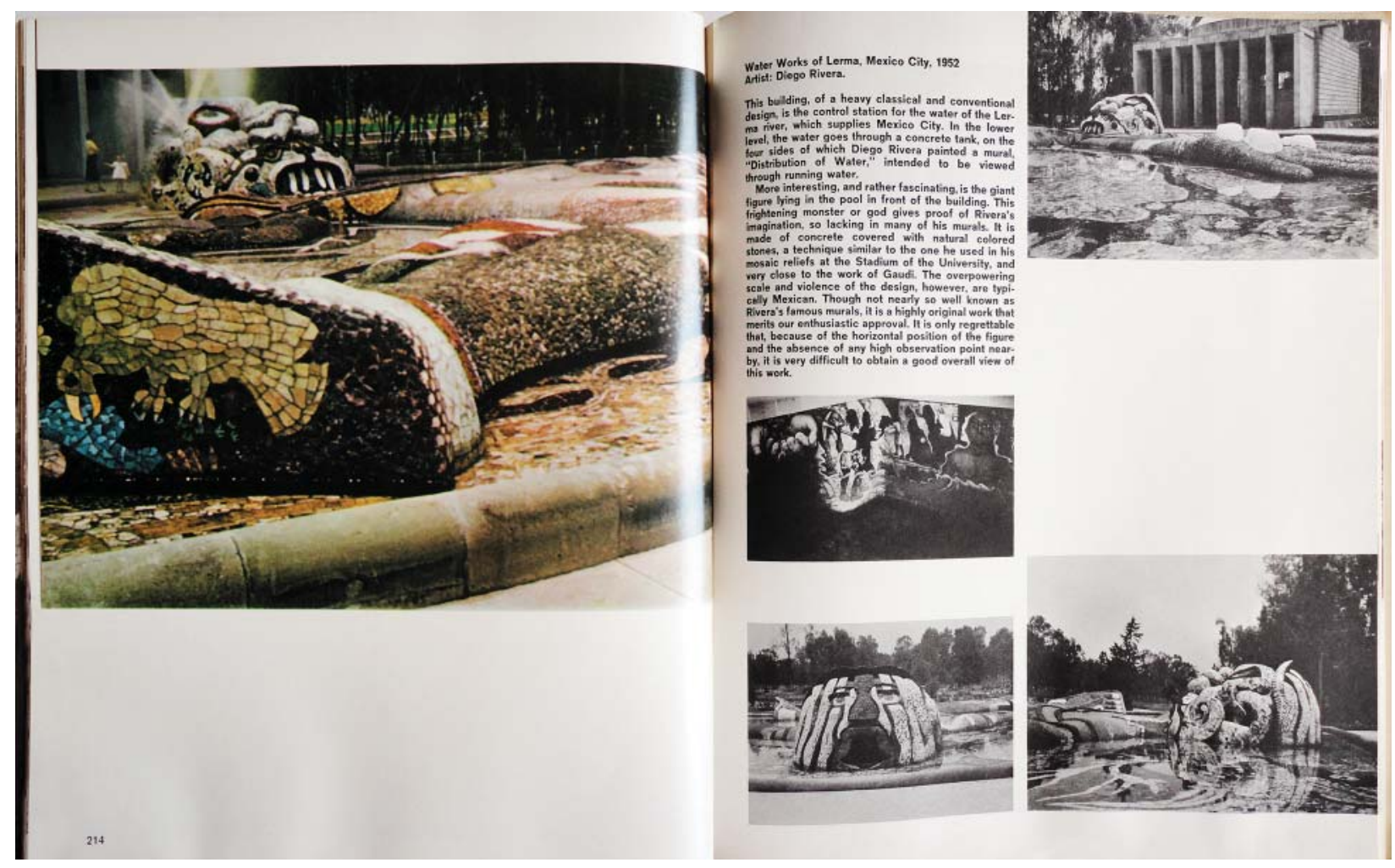

Fuente de Tláloc en Chapultepec, de Diego Rivera (1952) en Art in Latin American Architecture de Paul Damaz (1963).
117. Leopoldo Castedo, $A$ History of Latin American Art and Architecture from pre-Columbian times to the present (London: Pall Mall Press, 1969).

118. Francisco Bullrich, Arquitectura Latinoamericana 1930-1970 (Buenos Aires: Gustavo Gili, 1969).

119. "A History of Latin American Art and Architecture from pre-Columbian times to the present," RIBA Journal 77, no. 6 (junio 1970): 277. los tiempos de mayas y aztecas. Incluso en las siguientes centurias, bajo dominio ibérico, no se había alterado la noción de que la arquitectura es esencialmente un arte, y era significativo que, entre los arquitectos latinoamericanos, la integración de las artes permanecía sin debatirse, quizá porque se consideraba como la forma natural de hacer las cosas. Este acercamiento afectaría especialmente a México, en donde el tema de la integración no terminaría siempre bien, como se probaba ante los ejemplos que combinaban el arte figurativo o de realismo social con la arquitectura moderna.

De los estudios latinoamericanos que abordaron la arquitectura contemporánea al finalizar la década de 1960, fueron importantes dos títulos. El libro de Leopoldo Castedo sobre la historia del arte y la arquitectura latinoamericanos, traducido al inglés y publicado en Londres en $1969^{117}$ y la Arquitectura Latinoamericana de Francisco Bullrich ${ }^{118}$, publicado el mismo año de forma simultánea en Buenos Aires y Barcelona.

En junio de 1970, la linterna de la iglesia de Santa Mónica en la ciudad de México, obra de Félix Candela de 1966, ocupó la página de reseñas de RIBA Journal. La fotografía de Leopoldo Castedo ilustró así más de tres mil años de historia de la arquitectura latinoamericana ${ }^{119}$. El recurso del autor para abordar la historia del arte y la arquitectura se basaba en comentar, en términos generales, las constantes y variables de los 
periodos más representativos de producción artística de todo el continente. Para Castedo, existía una expresión estética distintiva que daba unidad al concepto de "América Latina". Entre los diversos factores - ya destacados por todos los autores que habían tratado el tema latinoamericano- el que más había condicionado la evolución latinoamericana en el pasado y la había determinado en el presente era a la vez la más obvia y la más profunda: el mestizaje ${ }^{120}$.

A History of Latin American Art and Architecture presentaba lo más distintivo de cada lugar y periodo en línea cronológica y al final concluía con el siglo xx y la arquitectura moderna, como si fuese una evolución natural. El autor afirmaba así que la principal aportación latinoamericana del siglo había sido precisamente la arquitectura y no alguna de las otras artes.

Por otro lado, con motivo del X Congreso de la Unión Internacional de Arquitectos en Buenos Aires en 1969, el arquitecto argentino Francisco Bullrich presentó un balance equilibrado de la nueva arquitectura de Latinoamérica. La ocasión permitiría a los arquitectos de otros continentes cotejar directamente la contribución latinoamericana a la arquitectura del momento ${ }^{121}$. Al año siguiente, en julio de 1970, Miguel Ángel Baldellou comentaría dicho estudio en la revista madrileña Hogar y Arquitectura ${ }^{122}$.

Para Baldellou,

la condición que se espera de Latinoamérica es que se libre de prejuicios internacionalistas que la mediatizan, con lo que se esperaría que sus próximos logros marquen un nuevo camino libre de compromisos con el pasado, capaz de la originalidad, el realismo y la fuerza necesarios para su auténtica configuración de su entorno con características propias ${ }^{123}$.

Para el arquitecto español, el problema latinoamericano se traducía en querer trasplantar formas arquitectónicas de otras culturas, reflejo de otros esquemas sociales. A finales de los sesenta, esta situación se hacía cada vez más consciente en los arquitectos latinoamericanos y, por lo tanto, las soluciones propias adquirían valor añadido a los ojos de los extranjeros.

Si bien la visión de Bullrich se generó dentro de América Latina, en cierto sentido, no deja de parecerse a la de Hitchcock en 1955;

120. Castedo, History, 11. 121. Bullrich, Arquitectura. Los países analizados fueron Brasil, Argentina, Uruguay, Chile, Cuba, Venezuela y México.

122. Miguel Ángel Baldellou, "Arquitectura Latinoamericana," Hogar y Arquitectura, no. 89 (julio-agosto 1970): 118-122.

123. Baldellou, "Arquitectura," 122 . 
seguramente se consideró que la difusión de la publicación iría más allá de los países tratados en el análisis. Así, el autor introdujo al lector con el inconveniente de englobar la inmensa región geográfica y la diversidad cultural latinoamericana en una sola entidad. Tanto sus pueblos como sus construcciones serían, necesariamente, parecidos pero diferentes. Otro punto que ya se había destacado en 1955 era que el pasado iberoamericano se enfrentaba de forma distinta en cada país.

Se destacan aquí dos temas analizados por el autor, primero, el nacionalismo y su expresión en las edificaciones - que se mantuvo como constante en muchas de las publicaciones hasta ahora revisadas- y segundo, el sustento teórico que potenciaba la integración plástica. De este último tema se comentaba su posterior declive y la opción de muchos arquitectos mexicanos de seguir el camino probado de la arquitectura internacional de los muros-cortina.

Es común a los latinoamericanos decir que la identidad es la búsqueda de identidad. Los debates sobre la arquitectura nacional probarían que los arquitectos «son conscientes de su dependencia respecto de los modelos europeos y norteamericanos [pero] esta conciencia es parte del esfuerzo de Latinoamérica por encontrar una nueva y definida personalidad cultural» ${ }^{124}$. Para Bullrich, la expresión nacional sería sólo el resultado de un genuino proceso creador, no de ideas artísticas preconcebidas por los nacionalismos políticos. Sin embargo, la contradicción latinoamericana parecería girar en torno al círculo que va de la adopción de influencias extranjeras, a su posterior rechazo argumentando su falta de autenticidad, a la creación de una tendencia original como contraejemplo, a la puesta en duda de esta última opción, y la adopción, de nueva cuenta, de la influencia extranjera.

En México, durante las décadas de 1920 y 1930, fue vital el movimiento muralista. Los artistas cubrieron una enorme cantidad de metros cuadrados, apoyados en la ideología posrevolucionaria del progreso social. Sin embargo, los edificios que sirvieron de soporte a este arte de vanguardia no fueron, prácticamente en ningún caso, arquitectura nueva. A raíz de esta contradicción, arquitectos mexicanos como Enrique Yáñez y Juan O’Gorman buscaron - y encontraron- lo

124. Francisco Bullrich, Nuevos caminos de la arquitectura latinoamericana (Barcelona: Blume, 1969): 17. que sería en determinado momento la expresión arquitectónica nacional. Para Bullrich, esta búsqueda terminaría en obsesión, sorprendiéndose 


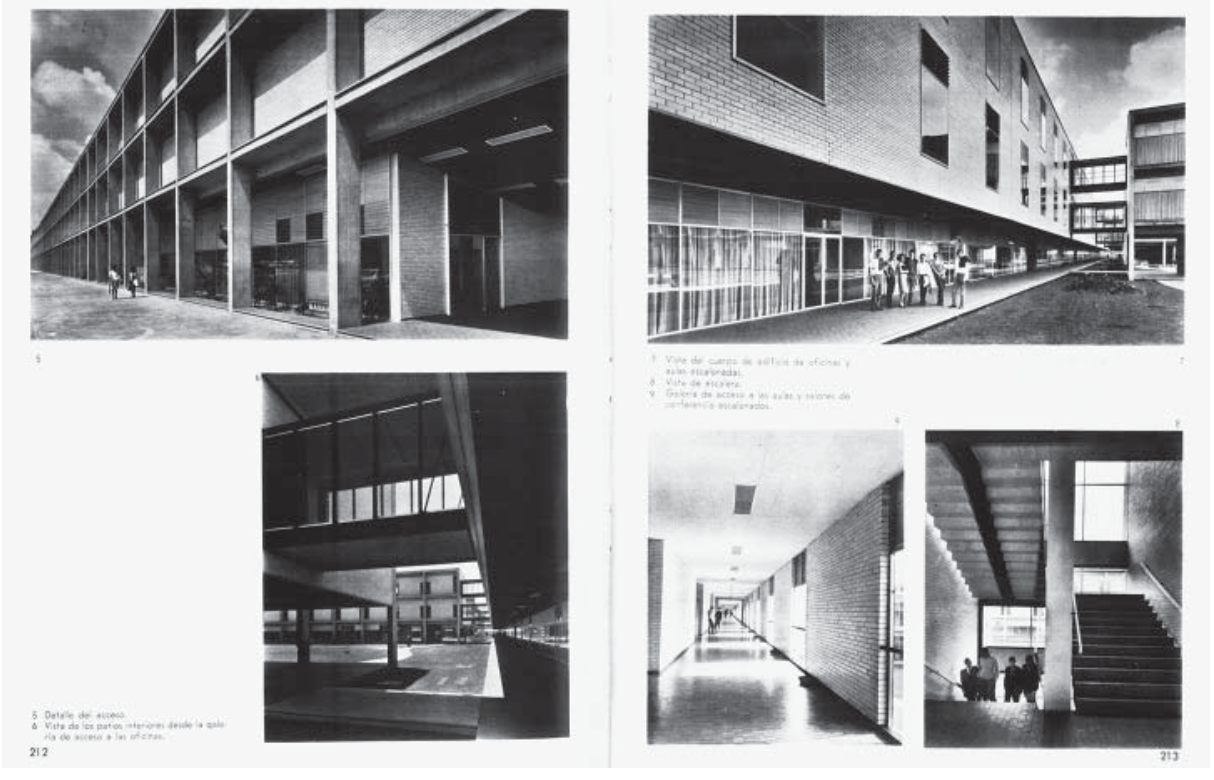

al comprobar «cómo sus aspiraciones se confundían con un anhelo de integración de las artes» ${ }^{125}$. Diversos experimentos formales, a partir de la década de 1940, llevarían a la definición y uso extendido de la integración plástica ${ }^{126}$; no está de más insistir en que, desde México, la mayor aportación de este movimiento fue que «rompió el tabú de la ornamentación en la arquitectura racionalista, abriendo cauce a la significación de nuestra identidad» ${ }^{127}$.

Ahora bien, para Bullrich, el sustento teórico que potenció el movimiento de integración plástica fue la influencia del historiador de arte Wilhelm Worringer, quien opinaba que una actitud integradora caracterizaba al arte alemán. Sus teorías habrían sido adaptadas en México para concluir que la misma integración era característica de las arquitecturas prehispánica y virreinal y, con toda seguridad, lo sería también de la arquitectura moderna.

Uno de los ejemplos latinoamericanos más difundidos de integración plástica fue la Biblioteca Central universitaria. En 1955, Hitchcock calificó sus muros como el soporte de un gigantesco códice narrando la historia del país, pero sin ahondar en la oposición de la estructura como sustento de los murales. En 1969, Bullrich insistía en la contradicción del volumen puro cargado de la «violencia rítmica, cromática, de las cándidas anécdotas que estallan abiertamente» ${ }^{28}$. Es evidente que durante la década de 1960 la integración plástica había perdido fuerza para ceder ante la arquitectura internacional, caracterizada por el uso extensivo de grandes superficies acristaladas.
Universidad Iberoamericana de Augusto H. Álvarez en las páginas de Arquitectura Latinoamericana (1969).
125. Bullrich, Nuevos caminos, 28.

126. El término se refiere al trabajo conjunto de arquitectos con otros artistas como escultores o pintores, con el fin último de enriquecer la expresión de las obras arquitectónicas.

127. Yáñez, Funcionalismo, 67. Véase también del mismo autor: "El movimiento de integración plástica en la arquitectura contemporánea de México." Cuadernos de Arquitectura Mesoamericana, no. 9 (enero 1987): 80-89.

128. Bullrich, Nuevos caminos, 29. 
Más allá del nacionalismo y como postura crítica ante el internacionalismo, Bullrich destacaba la nueva generación de arquitectos mexicanos con la figura de Augusto H. Álvarez, quien en 1969 tenía una prolífica carrera y una postura contundente ${ }^{129}$. Para Álvarez,

el lenguaje arquitectónico ha de adquirir, por su sola autenticidad, un carácter propio. Sólo en la búsqueda de soluciones concretas a funciones vitales contemporáneas, a requisitos climáticos característicos, y en la indagación de procedimientos constructivos adecuados, ha de encontrarse un lenguaje viviente ${ }^{130}$.

Para Bullrich, en obras como la Universidad Iberoamericana se reconocía una progresiva depuración y se percibía el comienzo de un nuevo camino emancipado del estilo internacional ${ }^{131}$.

Ese año de 1969 no podía saberse aún que el camino que tomaría la arquitectura mexicana a partir de la siguiente década no sería el de la depuración y correcta adecuación del estilo internacional sugerido por Bullrich y ejemplificado con Augusto H. Álvarez, sino dos vertientes opuestas. Una, la de la monumentalidad derivada de Pedro Ramírez Vázquez y reinterpretada por figuras como Teodoro González de León y Abraham Zabludowsky, y, por otro lado, el regionalismo mexicano, nacido

129. Para una revisión de los edificios de Augusto $\mathrm{H}$. Álvarez publicados en las revistas foráneas véase en esta tesis el capítulo: "De Álvarez a Zohn. Presencia de arquitectos mexicanos en las revistas extranjeras".

130. Bullrich, Nuevos caminos, 94 .

131. Sin embargo, para una facción de la crítica contemporánea, la antigua sede de la Universidad Iberoamericana en la ciudad de México «emanaba un rigor funcionalista apto para ejercer la represión militar y no el aura de la libertad de pensamiento que conviene a la educación superior». Cfr. Peter Krieger, "Augusto H. Álvarez. Arquitecto de la modernidad," reseña de $\mathrm{Au}$ gusto H. Álvarez. Arquitecto de la modernidad, por Lourdes Cruz González Franco, Anales del Instituto de Investigaciones Estéticas 33, no. 98, 2011, 311. de la interpretación de la obra de Luis Barragán, cuya principal figura a partir de la década de 1970 sería Ricardo Legorreta. Ninguna de estas dos vías fue sugerida en su momento por el crítico argentino. Sin embargo, permanece como la principal aportación de Bullrich la síntesis realizada al final de la década de 1960, con los ejemplos más sobresalientes de arquitectura de la vasta y diversa región que nombramos América Latina. 


\subsection{La presencia constante Dos décadas de revistas de arquitectura}

\section{Realidad revelada. La explosión informativa de los años 1950-59}

Durante los años de estudio dos hitos arquitectónicos indicaron, primero, un aumento considerable en la producción noticiosa y, después, su descenso paulatino. Se trató de la construcción de la nueva Ciudad Universitaria en la capital mexicana, inaugurada en 1952, y, en 1968, la XIx Olimpiada con sus construcciones deportivas y sus eventos culturales y artísticos. Entonces, el límite cronológico de esta revisión de noticias internacionales se sitúa dos años antes y después de la materialización de estos dos hitos fundamentales en la difusión de la arquitectura moderna mexicana.

En febrero de 1950, la madrileña Revista Nacional de Arquitectura (RNA) —años después simplemente Arquitectura- ${ }^{1}$ iniciaría la difusión europea de las grandes obras arquitectónicas mexicanas finalizadas en los últimos años de la década de 1940. Y después de la Olimpiada, al principio de la década de 1970, desde la neoyorquina Progressive Architecture, se cierra uno de los periodos más prolíficos de transmisión de la arquitectura nacional.

No obstante, antes de abordar este análisis, es imprescindible comentar algunos antecedentes de la difusión de la arquitectura moderna mexicana en los medios impresos periódicos. En el apartado anterior ya se revisó el libro de Esther Born, The New Architecture in Mexico, de 1937, donde quedó anotado que su origen fue la revista neoyorquina Architectural Record, en su número de abril de ese mismo año. El interés sobre México no fue espontáneo, ya que previamente habían salido a la luz varios artículos, unos tan tempranos como los dedicados a las primeras obras residenciales en Jalisco de Luis Barragán, publicados en 1931 y 1935², o el artículo sobre el Centro Materno Infantil no. 9, de José Villagrán García y Enrique de la Mora, en $1936^{3}$. Es claro que en esta revista hubo antecedentes importantes que fueron centrando el interés en el país vecino.

1. Los primeros años del régimen franquista la Revista Nacional de Arquitectura dependió de la Dirección General de Arquitectura, parte del Ministerio de Gobernación; fue hasta enero de 1959 que la publicación volvió a manos del Colegio Oficial de Arquitectos de Madrid, renombrada como Arquitectura. En esta tesis se considera la misma publicación debido a que su director por más de veinte años fue el arquitecto Carlos de Miguel.

2. Architectural Record 70, no. 3 (septiembre 1931): 16264 y Architectural Record 77, no. 1 (enero 1935): 33-46. Citado por Ana Fernanda Canales González, "La modernidad arquitectónica en México. Una mirada a través del arte y los medios impresos" (Tesis de Doctorado, Universidad Politécnica de Madrid, 2013), 232.

3. Architectural Record, (junio 1936): 422, 445-450. 


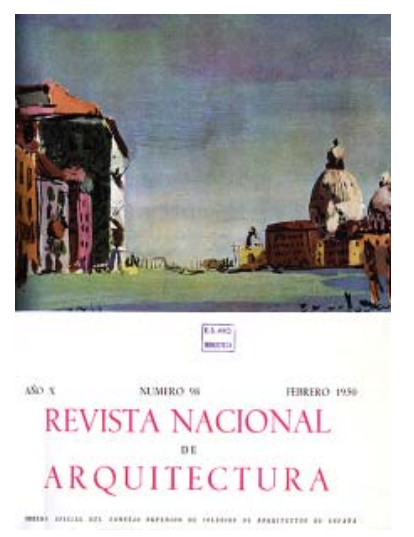

Revista Nacional de Arquitectura isil $x$ teaneno 1950 ำ

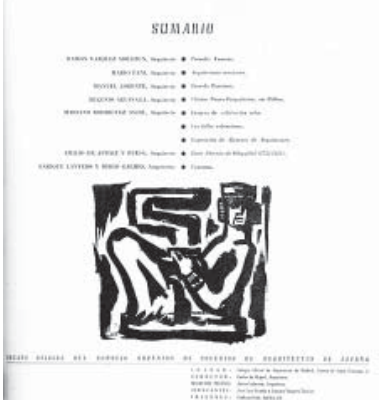

Portada y página de contenido de la Revista Nacional de Arquitectura (febrero 1950). El inicio de la difusión durante los años comprendidos en este análisis. Nótese la referencia al mundo prehispánico como antecedente a la arquitectura moderna mexicana.

Después de abril de 1937, momento cumbre dela publicación, en un medio extranjero, de los edificios modernos más importantes construidos hasta ese momento en México, Architectural Record mantuvo su interés por el país durante la siguiente década, lo que se expresó con notables ejemplos de actualidad. Dio a conocer, en 1947, la recién terminada Escuela Nacional de Maestros de Mario Pani ${ }^{4}$ y el Centro Materno Infantil Maximino Ávila Camacho, de Enrique de la Mora, construido en $1946^{5}$. Un último ejemplo, también publicado a la vanguardia en Architectural Record, fue la gasolinera - Servicio Lomas-, de Vladimir Kaspé, en julio de $1949^{6}$. Sin embargo, para la década de 1950, la revista, que había sido casi el único medio extranjero en publicar algo del país, pierde enorme fuerza y, como se verá enseguida, serán otras revistas las que mantengan vigente la presencia del país en los medios impresos internacionales.

De esta manera, en febrero de 1950, el sumario de la madrileña Revista Nacional de Arquitectura debió sorprender a sus lectores con la imagen de un chac-mool como referencia a las páginas dedicadas en dicho número a la arquitectura contemporánea mexicana ${ }^{7}$. Se trataba del primer artículo publicado en España ${ }^{8}$ con las obras más importantes construidas en México al finalizar la primera mitad del siglo xx, todas ellas autoría del arquitecto Mario Pani. Así, el Conservatorio Nacional de Música, la Escuela Nacional de Maestros y el Centro Urbano Presidente Alemán (CUPA) - el primer gran conjunto de vivienda de interés social del paísabrirían uno de los periodos más fructíferos, tanto de la producción arquitectónica nacional como de su difusión internacional ${ }^{9}$.

4. "National Teachers' Schools," Architectural Record 102, no. 1 (julio 1947): 76-77.

5. "A center for mothers and infants." Architectural Record 102, no. 2 (agosto 1947): 79-84.

6. "Well designed commercial building in Mexico" Architectural Record 106, no. 1 (julio 1949): 110-115.

7. Además de la imagen prehispánica del chac-mool, la primera página del artículo abrió con la reproducción de un mapa virreinal de la capital mexicana. Estas imágenes sin duda relacionaron al lector español con el imaginario del país "azteca” y su pasado colonial con las obras contemporáneas de arquitectura. Véase Vanessa Nagel, "Emblemas de identidad en la ar- quitectura moderna mexicana: los edificios prehispánicos y virreinales en las publicaciones periódicas extranjeras 19491968" (ponencia presentada en el IV Simposio Becarios Conacyt en Europa, Estrasburgo, 6 noviembre, 2014).

8. Algunas muestras de lo más reciente construido en México y dado a conocer en España se encuentran desde 1946. Véase Revista Nacional de Arquitectura, no. 52-53 (abril-mayo 1946): 104. En este número se publicaron algunas fotografías que formaron parte de la Exposición Iberoamericana de Arquitectura, una de ellas la "casa de viviendas en México" de Mario Pani. Pocos años después, en julio de 1949, la misma
RNA publicó una crítica a la reciente arquitectura mexicana, aparecida originalmente en México en la revista Hoy y firmada por Antonio Rodríguez; la aportación española al artículo fueron los dibujos del arquitecto Joaquín Vaquero Turcios. Véase Revista $\mathrm{Na}$ cional de Arquitectura, no. 91 (julio 1949): 311-14. También, el mismo año de 1949, en un número especial dedicado a las plazas de toros, se contó con el ejemplo mexicano recién terminado en la Ciudad de los Deportes de la capital. Véase Revista Nacional de Arquitectura, no. 93 (septiembre-octubre 1949): 434-37.

9. "Arquitectura Mexicana," Revista Nacional de Arquitectura, no. 98 (febrero 1950): 47-58. 

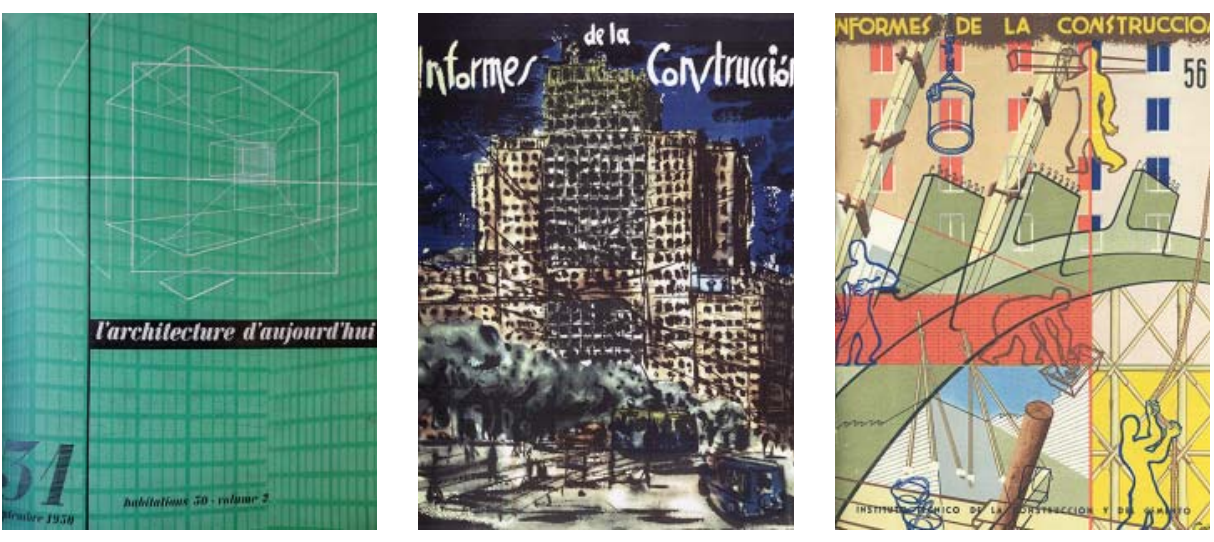

A diferencia de los contenidos de la revista madrileña, que incluyó temas diversos en ese número de febrero de 1950, en septiembre del mismo año, L'Architecture d'Aujourd'hui publicó su número 31 dedicado exclusivamente a la habitación colectiva, en el que mostraba no sólo el antes citado Centro Urbano Presidente Alemán ${ }^{10}$ sino gran variedad de ejemplos europeos, estadounidenses y latinoamericanos ${ }^{11}$. La información preparada desde las editoriales mexicanas había comenzado a moverse y alcanzaba ya dos capitales europeas ${ }^{12}$.

Mario Pani gozó de enorme difusión internacional, especialmente en España y Francia, ya que, a poco de ser finalizado el segundo gran conjunto habitacional de interés social de la capital mexicana, el Centro Urbano Presidente Juárez, fue publicado por la revista madrileña Informes de la Construcción en diciembre de $1953^{13}$. Las veintidós páginas — sin duda el artículo más extenso dedicado a la vivienda social mexicana en el extranjero- volcaron descripciones de los diferentes tipos de edificios y apartamentos, mostraron plantas de conjunto, cortes, plantas tipo, perspectivas de los interiores así como gran cantidad de las excelentes fotografías de Guillermo Zamora, uno de los fotógrafos de planta de Arquitectura México. Informes tampoco se olvidó de exponer los dibujos con la fantástica aportación del artista Carlos Mérida para los murales exteriores, inspirados en la iconografía prehispánica, recurso habitual de integración plástica de esos años.

Pero la vivienda social no fue el único tema que interesó especialmente a los medios españoles, la misma Informes, en un número especial dedicado a nuevos hoteles en el mundo, publicaba, en agosto-septiembre de 1951, el mexicano Hotel del Prado, autoría de Carlos Obregón Santacilia, obra finalizada en $1946^{14}$. La actualidad de su programa se debía al uso mixto del inmueble, ya que además de las

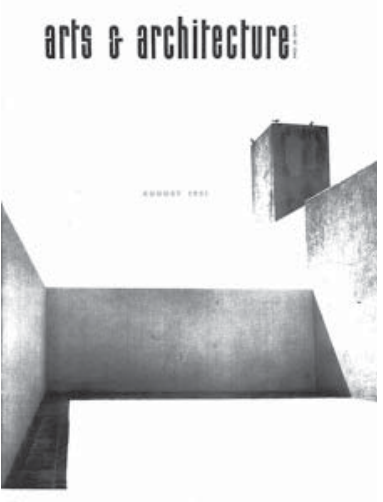

Portadas de L'Architecture d'Aujourd'hui (septiembre 1950), Informes de la Construcción (agosto 1951 y diciembre 1953) y Arts \& Architecture (agosto 1951).

10. "Centre Urbain 'President Aleman' Mexico," L'Architecture d'Aujourd'hui, no. 31 (septiembre 1950): 2-7.

11. Además de México, publicó conjuntos habitacionales de Venezuela, Argentina, Brasil y Cuba.

12. En México, el CUPA también vio la luz en febrero de 1950 en Arquitectura México, la revista fundada y dirigida por Mario Pani en 1938. Hay que destacar que, aunque los textos son los mismos, el envío de suficiente material gráfico a las editoriales extranjeras propició que no todas las fotografías se repitiesen, gracias a la selección personalizada de cada editorial.

13. "Centro urbano 'Presidente Juárez"' Informes de la Construcción, no. 56 (diciembre 1953): s/p. Los contenidos arquitectónicos de este número se dedicaron en su mayoría a la vivienda social, mostrando casos, además del mexicano, de París, Milán, Madrid y un plan nacional de edificación de Venezuela. La editorial madrileña dio los créditos del material proporcionado para el artículo del Presidente Juárez a la mexicana Arquitectura.

14. "Hotel del Prado," Informes de la Construcción, no. 33 (agosto-septiembre 1951): $\mathrm{s} / \mathrm{p}$. 
Centro Urbano Presidente Juárez en las páginas de Informes de la Construcción (diciembre 1953).
15. Alberto T. Arai, "La arquitectura mexicana contemporánea," Boletín de Información de la Dirección General de Arquitectura v, (cuarto trimestre 1951): 27-30. 29.

16. Arai, "La arquitectura,"
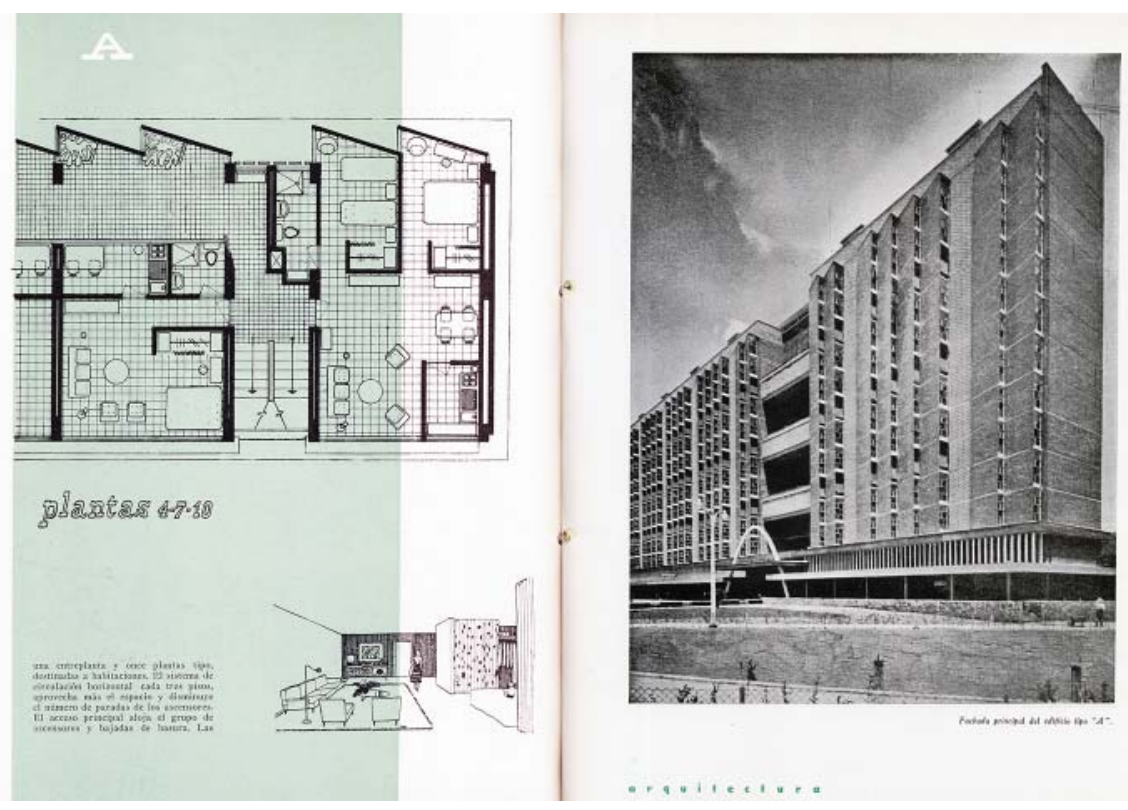

funciones propias de un hotel, albergaba locales comerciales, sala de fiestas, teatro, estacionamiento y apartamentos.

Acaso cabe comentar otro tema presente en los medios españoles este primer lustro de difusión: el debate sobre la orientación que debía darse a la arquitectura nacional. El tema de la modernidad versus la tradición, y el medio que tenía la arquitectura para no romper ni con uno ni con otro aspecto, fue un discurso permanente en México - así como en otros países latinoamericanos- que estuvo siempre indagando en sus raíces para afrontar la modernidad. Así, el último trimestre de 1951, en Madrid, el Boletín de Información de la Dirección General de Arquitectura (BDGA) difundía un ensayo sobre la arquitectura mexicana contemporánea, escrito por Alberto T. Arai y publicado primero en México en "Urbe", suplemento del diario Excélsior ${ }^{15}$. En él, se expresaba la inquietud de un nutrido grupo de arquitectos mexicanos que habían empezado a ocuparse intensamente de los programas de necesidades nacionales, a la vez que urgía encontrar una expresión propia capaz de diferenciar a los edificios nacionales de los del resto del mundo ${ }^{16}$.

No obstante los interminables debates teóricos de la época, no cabía duda que la singularidad de la producción arquitectónica mexicana daba sus frutos y que éstos superaban las fronteras nacionales a través de las publicaciones periódicas extranjeras. Un caso notable y muy difundido fue el de la vivienda unifamiliar, pues tan temprano como 1951 ya aparecía en Los Ángeles el primer número especial de la revista Arts 
$\&$ Architecture dedicado a los casos mexicanos ${ }^{17}$. Así, en agosto de dicho año, la portada de la angelina lucía una fotografía en blanco y negro de la azotea de la casa de Luis Barragán, construida en el barrio de Tacubaya de la ciudad de México. El número contaba con un texto introductorio de Esther McCoy, para entonces ya bien establecida en California.

Los Jardines del Pedregal, emblema de la nueva urbanización para la clase alta mexicana, ocupaban las primeras páginas, en las que se destacaban los paisajes todavía naturales del sur de la ciudad de México, con sus enormes formaciones rocosas de lava volcánica petrificada y un horizonte interrumpido por las siluetas de los dos volcanes que al oriente delimitan el valle en que se asienta la capital. Las fuentes, rejas y esculturas domesticaban así un entorno que hasta hacía muy poco había sido valorado y que, a partir de la intervención de Luis Barragán, se convertiría en una imagen de identidad nacional ${ }^{18}$.

Para este número de $A \mho A$ se seleccionaron viviendas de Luis Barragán, Juan O’Gorman, Max Cetto, Enrique del Moral, Luis Rivadeneyra, Jaime López Bermúdez, Víctor de la Lama y Ramón Torres Martínez. Gran parte del material había sido recopilado poco antes por Enrique Yáñez, entonces jefe del Departamento de Arquitectura del INBA, con motivo de una exposición en el Palacio de Bellas Artes en la primavera de $1951^{19}$. No obstante, la edición angelina contó con algunas imágenes exclusivas de la fotógrafa estadounidense Elizabeth Timberman, como la serie de Barragán en su estudio o las de un siempre dubitativo Juan O'Gorman en su casi finalizada casa del Pedregal, con el remate de la escalera que subía de la sala y que ostentaba la popular cruz de madera que -tradicionalmente- los trabajadores de la construcción colocan en sus obras el 3 de mayo, día de la Santa Cruz.

El mismo año 1951, otro medio estadounidense, éste de Nueva York, dedicaría también unas páginas a la vivienda unifamiliar en México, pero con un caso muy distinto a los anteriores. Se trataba de la casa Silverstone, ubicada en la población de Taxco, Guerrero, obra de los arquitectos Anshen \& Allen, firma fundada en San Francisco, California, en 1940. Aquí hay que subrayar como aportación mexicana al clima cálido, que determinó el adecuado empleo de materiales tradicionales al lado del hormigón armado, aspecto que - naturalmente - se destacaba en Architectural Forum ${ }^{20}$.
17. Arts \& Architecture 68, no. 8 (agosto 1951).

18. Los Jardines del Pedregal de San Ángel, así como el caso de la vivienda unifamiliar de lujo se tratan in extenso en el subcapítulo 7.2 De los mínimos al exceso. La vivienda de interés social y el lujo habitacional.

19. Las imágenes de la vivienda unifamiliar mexicana iniciaban así su reimpresión en diversos medios. Irving Myers las retomaría al año siguiente en Mexico's Modern Architecture.

20. "Textured mansion: On a Mexican hillside, a colorful paradise," Architectural Forum 94, no. 1 (enero 1951): 136-41. 


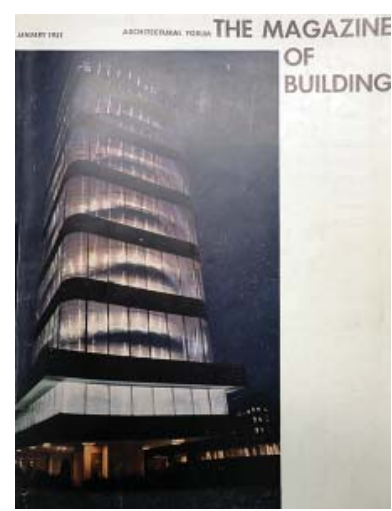

Portada y páginas interiores de Architectural Forum (enero 1951). Casa Silverstone en Taxco, Guerrero.

21. Gio Ponti, "Il Pedregal di Città del Messico," Domus, no. 280 (marzo 1953): 15-22. Ponti era entonces editor de la publicación.

22. Esta primera parte de la tesis ofrece un acercamiento a las noticias más importantes sobre la obra universitaria en los medios internacionales. El criterio de selección se basa en el impacto de los artículos en cada revista y en la amplia difusión de las revistas seleccionadas. El tema en profundidad se desarrolla en el capítulo: "Reto e innovación. La Ciudad Universitaria de México".

23. "Cité Universitaire de Mexico," L'Architecture d'Aujourd'hui, no. 34 (febrero-marzo 1951): 82-87. En este número también se publicó el Liceo Franco Mexicano diseñado por Vladimir Kaspé, corresponsal de la revista francesa en México.

24. Además de México, se publicaron ejemplos de Francia, Suiza, Holanda, Gran Bretaña, Suecia, Estados Unidos, Brasil Panamá y Venezuela.
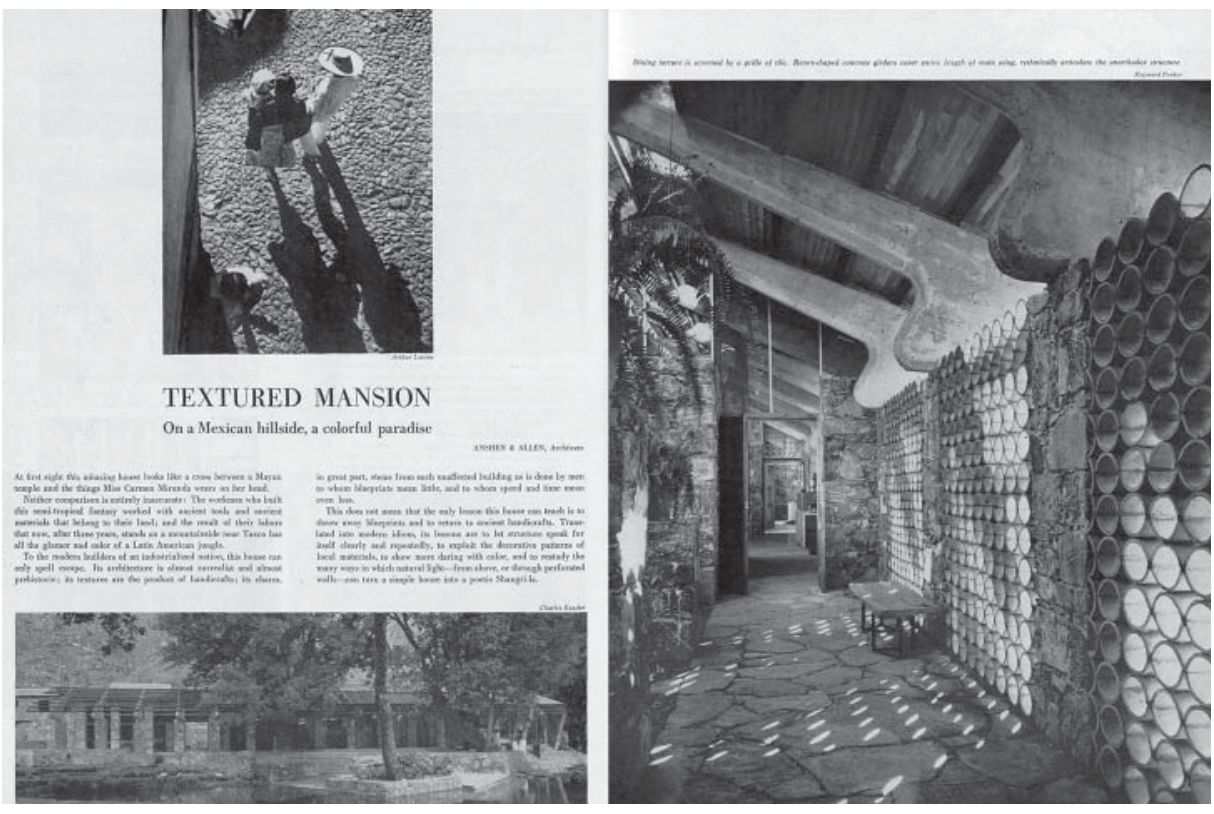

Esta primera oleada de noticias sobre la vivienda unifamiliar la cierra Domus, desde Milán, en marzo de 1953. La revista italiana brindó un protagonismo absoluto a Luis Barragán y su intervención paisajística en el Pedregal de San Ángel y su casa de Tacubaya ${ }^{21}$. En las imágenes del Pedregal seleccionadas por Gio Ponti, son notables los contrastes creados entre la lava derramada y petrificada y los cortes precisos y geométricos de terrazas, escalones y muros que aprovecharon el mismo material. No casualmente, esta piedra oscura de textura rugosa y porosa se volvió el sello distintivo de esa modernidad mexicana de la mitad del siglo $\mathrm{xx}$.

Ahora bien, si antes hablamos de una oleada de noticias, lo que se movía de forma paralela a las reseñas anteriores fue más bien una avalancha, que merece un acercamiento independiente de los temas antes comentados. Hito fundamental de la arquitectura moderna mexicana es la Ciudad Universitaria, magna obra que generó numerosos artículos y críticas en los medios especializados internacionales. A continuación se muestra una selección de los principales textos que aparecieron en algunas publicaciones europeas y norteamericanas ${ }^{22}$.

Los avances en las obras de la Ciudad Universitaria de México tuvieron una primera aparición en la revista francesa L'Architecture d'Aujourd'hui en su número 34 de principios de $1951^{23}$, dedicado a las construcciones escolares europeas y americanas ${ }^{24}$. El texto destacaba que la dispersión de los edificios universitarios en el centro de la ciudad justificaba, por sí misma, el planeamiento de la nueva ciudad que agruparía el ámbito universitario. También, se enfatizaba que la falta de comunicación entre las 

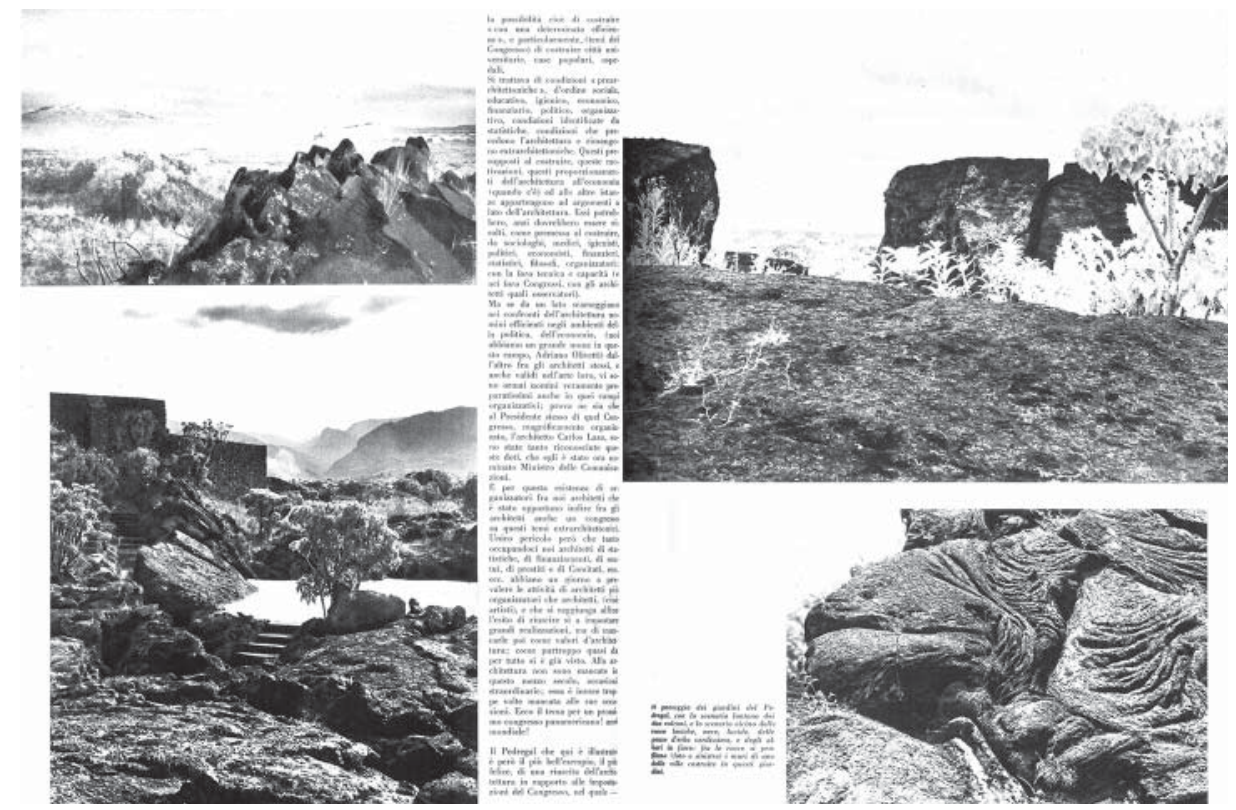

facultades de humanidades y ciencias impedía el verdadero desarrollo de una cultura humanista que sería la base de la educación latinoamericana. A dieciocho meses de la inauguración oficial de los edificios, las páginas mostraban fotos de maquetas, planos, perspectivas y algunas imágenes del desarrollo de la obra de la Facultad de Ciencias.

Durante 1952, el viII Congreso Panamericano de Arquitectos tuvo lugar en México, y se aprovechó el evento para dar por terminada la obra universitaria. Es notoria y justificada la concentración de noticias y números especiales tanto en México como en el extranjero ${ }^{25}$. Así, en Francia, Techniques et Architecture publicaba la obra en julio ${ }^{26} \mathrm{y}$, en Estados Unidos, Arts \& Architecture en agosto ${ }^{27}$ y Architectural Forum en septiembre ${ }^{28}$. De las estadounidenses, cabe mencionar que la angelina dedicó su portada con una fotografía de la cubierta de los laboratorios de Ingeniería y la neoyorkina, que también ofreció su portada a México, optó por una foto de detalle del Pedregal, importante por su intención en mostrar los materiales tradicionales como la piedra volcánica y el muro de mampostería aplanado y pintado de rosa intenso.

Para el número de Arts \& Architecture se contó de nueva cuenta con Esther McCoy para preparar el material, quien entonces ya figuraba en el consejo editorial de la revista. La vanguardia de este medio radicaba en que no sólo echaron mano del material gráfico proporcionado por los autores de las obras, sino que enviaban fotógrafos y corresponsales para producir su propio material ${ }^{29}$. Los artículos dedicados a la Ciudad Universitaria se podrían agrupar en dos conjuntos, por un lado, los que

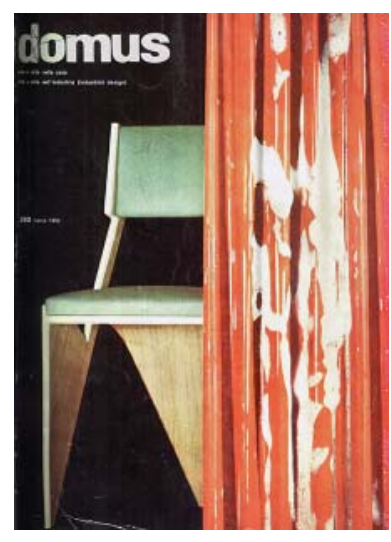

Pedregal de San Ángel en Domus (marzo 1953). La piedra volcánica se volvería icono de modernidad en México.
25. $\mathrm{Si}$ bien Arquitectura México ya había adelantado mucho del conjunto desde sus números 32 (octubre 1950), 35 (septiembre 1951) y 36 (diciembre 1951), fue hasta septiembre de 1952, en su número 39 , que condensó la mayor cantidad de información publicada sobre la Ciudad Universitaria, ejemplar que además estuvo listo para ser distribuido a los asistentes internacionales del congreso.

26. "Mexique: cité universitaire de Mexico," Techniques et Architecture 11, (julio 1952): 13-18.

27. "The new University City of Mexico," Arts \& Architecture 69, no. 8 (agosto 1952): 20-37 y 41-42.

28. "Mexico's University City," Architectural Forum 97, no. 3 (septiembre 1952): 99119.

29. Además de las visitas de Esther McCoy a México, el fotógrafo californiano Erwin Lang documentó la mayoría de las vistas en construcción de la Ciudad Universitaria publicadas en $A \& A$. El mismo Lang viajaría en varias ocasiones a México para registrar también el florecimiento de los cascarones de hormigón armado de Candela. Véase Colin Faber, Candela: The Shell Builder (New York: Reinhold Publishing Corporation, 1963), 9. 
publicaban las noticias conociendo de antemano los avances de la obra in situ y, por otro lado, los que "descubrieron" la aportación mexicana a la arquitectura mundial gracias al congreso internacional y la visita al país de numerosos editores y corresponsales, lo que resultó en la posterior publicación de impresiones. El artículo de Arts \& Architecture de agosto de 1952 forma parte, sin duda, del primer grupo.

En septiembre de 1952, Architectural Forum dedicaba veintiuna páginas a la obra recién terminada de la Ciudad Universitaria, las mismas que brindaron un panorama muy completo del conjunto. Sin embargo, el acercamiento a la obra moderna enfatizando la tradición mexicana, resultaría un exceso. Esto se comprueba a la vista de su página de apertura, donde sobre la fotografía de un paisaje rural se superponían las imágenes de detalle de una pirámide prehispánica, de un edificio virreinal y de dos albañiles recubriendo un muro de mampostería con lajas de piedra volcánica como acabado aparente.

Así, en octubre de 1952 el viII Congreso Panamericano de Arquitectos invitó al país a un gran número de profesionales de todo el mundo, sobrepasando los mil quinientos congresistas inscritos. La capacidad de organización del director del encuentro, Carlos Lazo, no se remitió a los siete días de actividades oficiales, sino que lo llevó, meses antes del encuentro, a cruzar el Atlántico y recorrer las principales ciudades europeas para invitar personalmente a arquitectos destacados y editores de revistas de arquitectura. Esta actividad propició la pronta aparición de noticias y reseñas en diversos medios, tanto del evento como de la propia sede. En Madrid, el Boletín de Información de la DGA en el primer trimestre de 1953 ya publicaba un artículo completo con las aportaciones más destacadas de los participantes del encuentro, así como sus propias apreciaciones sobre la nueva arquitectura mexicana y sus logros en temas de interés social ${ }^{30}$.

30. "El VIII Congreso Panamericano de Arquitectos," Boletín de Información de la Dirección General de Arquitectura viI (primer trimestre 1953): 28-32. Véase también: "Congrés Mexico," L'Architecture d'Aujourd'hui, no. 46 (febrero-marzo 1953): xxv.

31. Gio Ponti, "Antologia della Città Universitaria di Città del Messico," Domus, no. 285 (agosto 1953): 1-6.
Como resultado de la visita a México de editores y corresponsales, el año 1953 recogió varios artículos sobre la Ciudad Universitaria. En Milán, Gio Ponti, editor de Domus, firmaba el texto del mes de agosto ${ }^{31}$. Después de visitar las obras, Ponti comentó los edificios que a su juicio eran los más sobresalientes del conjunto. Aunque las fotografías en blanco y negro - tomadas por el equipo italiano durante las visitasdestacaron mucho más los volúmenes prismáticos, las líneas ortogonales 

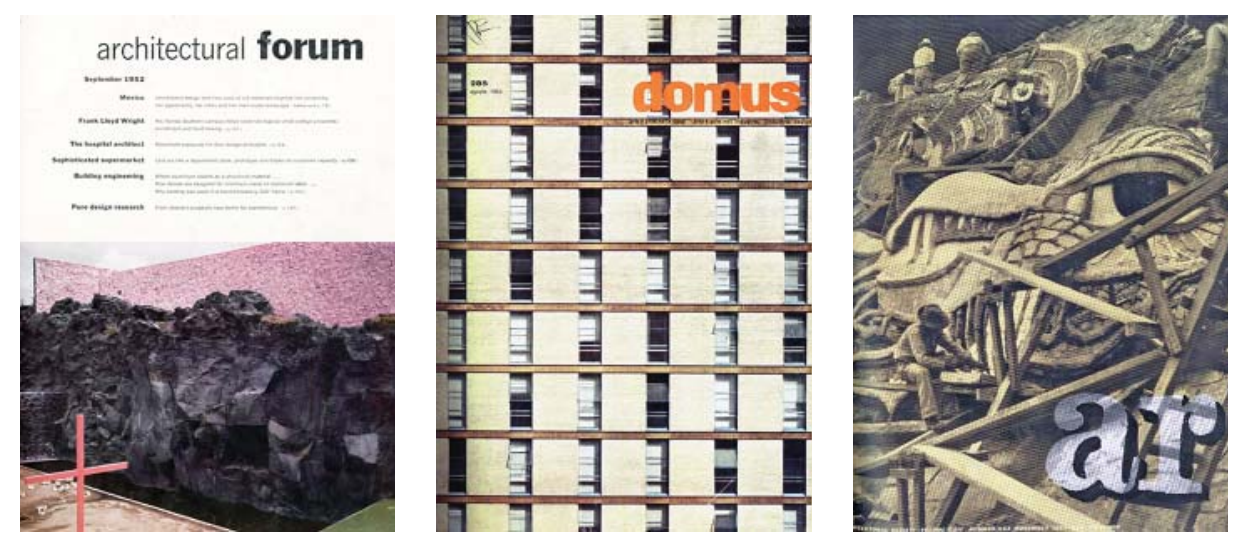

y la geometría pura, el texto se centraba en la descripción de varias de las aportaciones artísticas del conjunto, que alcanzaría fama mundial precisamente por su integración plástica.

En noviembre del mismo año The Architectural Review y Progressive Architecture dieron a conocer los edificios universitarios. Para el caso londinense el corresponsal fue Thomas Sharp, quien destacaba que el proyecto de la Ciudad Universitaria para treinta mil estudiantes no era notable solo por su tamaño sino, en buena medida, por la manera en que los diseñadores, usando métodos constructivos tradicionales y nuevos, unían las concepciones de las arquitecturas mexicana e internacional ${ }^{32}$. Para la revista neoyorquina, Sibyl MoholyNagy firmaba la crítica sustentada, principalmente, en dos aspectos: que el paisaje del valle de México, de clara tendencia horizontal, se invadía con volúmenes altos que desafiaban la geografía conocida y aprehendida hasta entonces por los mexicanos y que en la diversidad de respuestas formales no se leía claramente una unidad compositiva ${ }^{33}$. También cabe destacar que, ambos números, dedicaron su portada —o parte de ellaal tema mexicano. The Architectural Review seleccionaba un detalle del recubrimiento escultórico del estadio universitario - obra del artista Diego Rivera- mientras que Progressive utilizaba como referencia visual las pirámides truncas de piedra volcánica de los frontones. Es evidente cómo se echaba mano de los aspectos más relacionados con los materiales tradicionales y la herencia cultural.

En España, Informes de la Construcción editó un amplio artículo sobre la Ciudad Universitaria tomando como material de base Arquitectura México y el análisis de Thomas Sharp de The Architectural Review. Éste apareció en febrero de $1954^{34}$ en veintitrés páginas que exhibían vistas de conjunto y detalles, planos y una descripción detallada

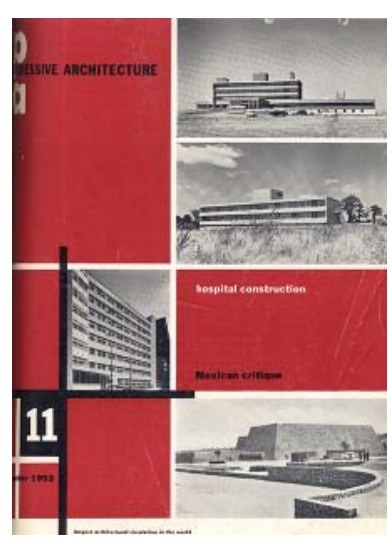

Portadas de Architectural Forum (septiembre 1952),

Domus (agosto 1953), The Architectural Review (noviembre 1953) y Progressive Architecture (noviembre 1953). La Ciudad Universitaria de México: protagonista de las publicaciones foráneas.

32. Thomas Sharp, "Mexico University," The Architectural Review 114, no. 683 (noviembre 1953): 306-18.

33. Sibyl Moholy-Nagy, "Mexican critique," Progressive Architecture 34, no. 11 (noviembre 1953): 109, 170, 172, 175-176.

34. "La Ciudad Universitaria de México," Informes de la Construcción, no. 58 (febrero 1954): s/p. Aunque los créditos son claros al respecto de las dos fuentes citadas, el artículo también utilizó gran parte de las imágenes de Domus de agosto de 1953. 


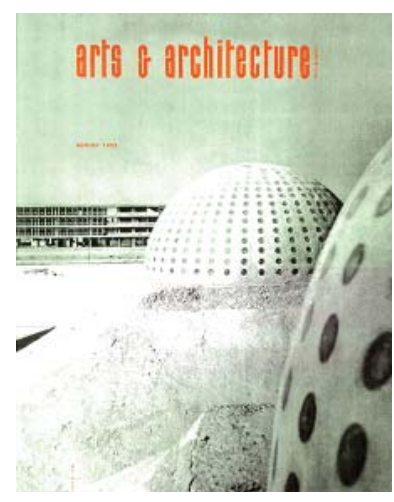

Protagonismo de la Ciudad Universitaria de México en la portada y páginas interiores de Arts \& Architecture en agosto de 1952.

35. "La Cité Universitaire de Mexico," L'Architecture d'Aujourd'hui, no. 59 (abril 1955): 14-39.

36. "Mexico's mammoth campus. Does its size go beyond the bounds of human scale?," Architectural Forum 108, no. 3 (marzo 1958): 10813.
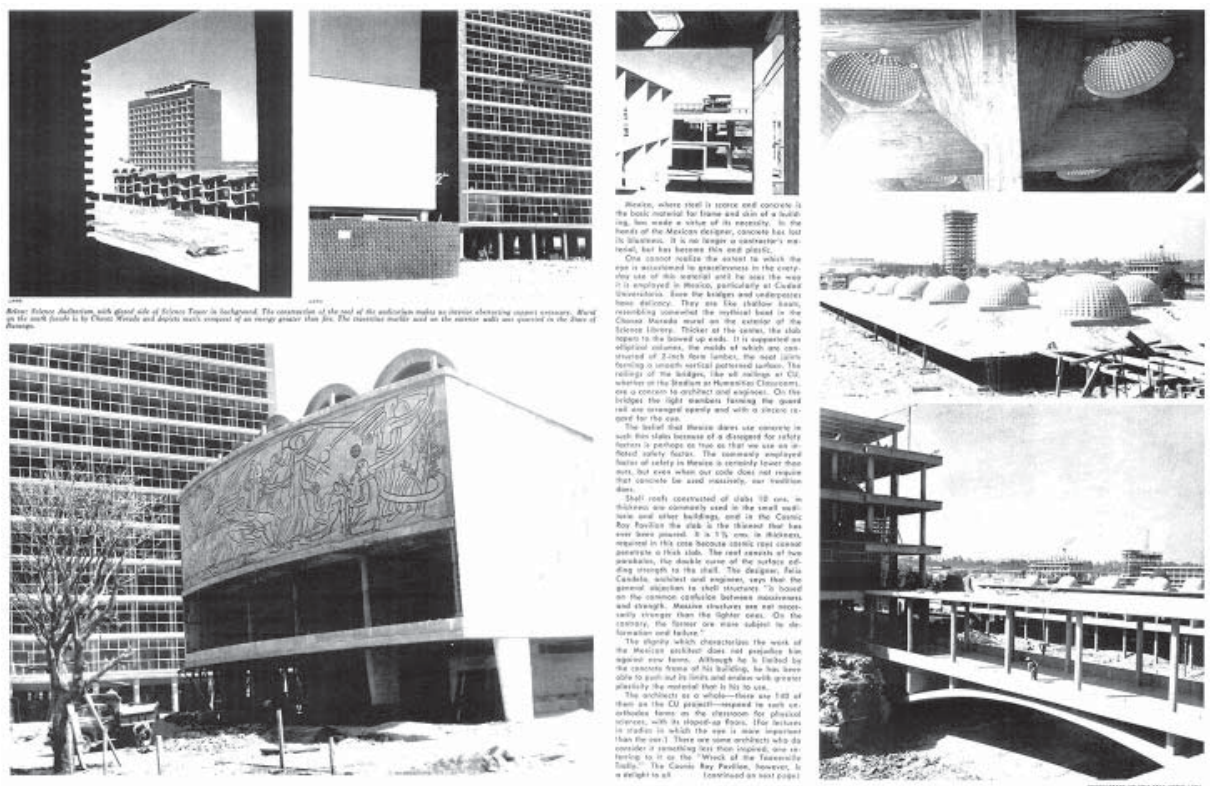

de la obra. Hasta ese momento, Informes había publicado el artículo más extenso sobre el conjunto universitario, superando los casos de Forum y Arts \& Architecture, que, sin embargo, se caracterizaron por su delantera al publicar también artículos generosos desde 1952.

Todavía cabe comentar aquí dos artículos más sobre la Ciudad Universitaria: el que formó parte del monográfico que L’Architecture d'Aujourd'hui dedicó a México en abril de $1955^{35}$ y otro en Architectural Forum $^{36}$ en 1958. Ambos artículos se caracterizaron por el uso del color en algunas de las fotografías, aspecto que, por esos años, todavía no era habitual en las revistas de arquitectura. La publicación parisina comentaba la nueva ubicación del conjunto universitario con respecto al centro histórico de la ciudad y anotó como características esenciales de la obra la solución de las circulaciones, los materiales y la integración plástica; asimismo, incluía la revisión a los edificios más representativos. Por su parte, la neoyorquina revisitaba la obra a pocos años de iniciadas las labores docentes y a través de una galería de imágenes corroboraba cómo los estudiantes se adaptaban a la gigantesca escala del campus. Las fotografías de Wallace Litwin dejaban la impresión de espacios abiertos muy extensos en los que apenas destacaban algunos grupos de estudiantes. Actualmente, a pesar de haberse superado con creces el número planeado de alumnos para las instalaciones educativas, las grandes explanadas de la Ciudad Universitaria se mantienen como lugar de descanso visual y físico con respecto al caos urbano que caracteriza a la actual megalópolis. 


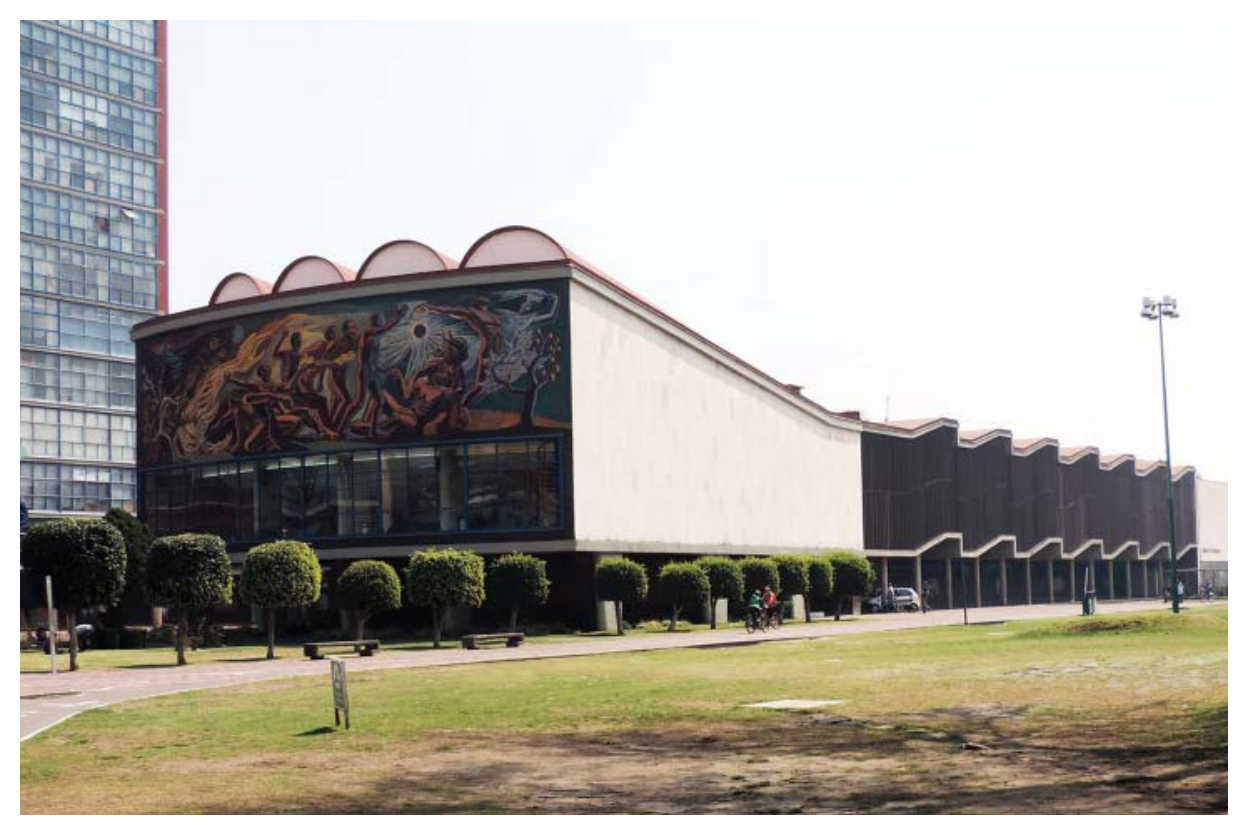

La segunda mitad de la década de 1950 contó con dos protagonistas absolutos en cuanto a la difusión de la arquitectura mexicana en los medios internacionales. Por un lado, el número monográfico que editó L'Architecture d'Aujourd'hui en $1955 \mathrm{y}$, por el otro, las estructuras regladas en hormigón armado de Félix Candela. Aquí, a pesar de la cantidad apabullante de artículos dedicados al arquitecto de origen español, y sin omitir las menciones esenciales a los cascarones, se dedican también varias líneas a otros edificios y estructuras urbanas que se han vuelto emblema de modernidad tanto o más que las ondulantes superficies.

Ahora bien, como antecedente directo de la importante difusión francesa que fructificó en el número monográfico de abril de 1955, de debe citar el viII Congreso Panamericano de Arquitectos de 1952 que actuó como detonante del interés internacional en la arquitectura nacional. También, es importante destacar el trabajo realizado durante 1953 desde el Departamento de Arquitectura de Bellas Artes de México, entonces a cargo de Alberto T. Arai, con el apoyo de la Sociedad de Arquitectos Mexicanos (SAM) - dirigida por Pedro Ramírez Vázquezquienes organizaron la sección de arquitectura de la Exposición de Arte Mexicano ${ }^{37}$. Este material se convirtió en una exposición itinerante individual que tomó el papel de carta de presentación de la arquitectura mexicana contemporánea en varias ciudades europeas y norteamericanas. En 1955 se mostró en Londres en la sede del RIBA ${ }^{38}$, en el pabellón mexicano de la Ciudad Universitaria de París, y con motivo del IV Congreso de la UIA, las fotografías montadas en láminas de aluminio y
Auditorio "Alfonso Caso" en la Ciudad Universitaria de la UNAM, 2016.
37. La Exposición de Arte Mexicano fue inaugurada en el Palacio de Bellas Artes en noviembre de 1953 y clausurada a finales de 1954 . La sección de arquitectura se presentó en la sala 20 con el título: "La arquitectura contemporánea y sus antecedentes históricos". Véase Arquitectura México, no. 47 (septiembre 1954): $182-83$.

38. "Mexican architecture: exhibition at the RIBA," RIBA Journal 62, no. 5 (mayo 1955): 282-85. 
39. "Una exposición de arquitectura mexicana en Londres," Arquitectura México, no. 50 (junio 1955): 115-16. El año 1956, después de la itinerancia europea, el material alcanzó la costa oeste americana con motivo de la 88 $8^{a}$ Convención Nacional del Instituto Americano de $\mathrm{Ar}$ quitectos en Los Ángeles en mayo. Véase "Exposición de arquitectura mexicana en Los Ángeles," Arquitectura México, no. 56 (diciembre 1956): 25153.

40. "El Gran Premio de honor a la arquitectura mexicana," Arquitectura México, no. 57 (marzo 1957): 51-52.

41. Pierre Vago era el presidente del comité de redacción de L'Architecture d'Aujourd'hui, E. Beaudouin y R. Lebret fueron los delegados por Francia al viII Congreso Panamericano de Arquitectos.

42. Se trató del muro de acceso a la Biblioteca Central de la Ciudad Universitaria, donde destaca la piedra volcánica, característica inconfundible de esta obra en su conjunto.

43. Los editores advierten que sin el antecedente en mente del trabajo de los muralistas mexicanos, podría ser contradictorio encontrar las extensas superficies de los edificios recubiertas de murales. Véase "Editorial," L'Architecture d'Aujourd'hui, no. 59 (abril 1955): LXXX. planchas de plástico, visitaron también La Haya, Holanda ${ }^{39}$. El catálogo de esta exposición nació después como libro bajo el título 4000 años de arquitectura mexicana, editado en 1956 por la Sociedad de Arquitectos Mexicanos. Su material se mantuvo en circulación por varios años, ya que sus imágenes circularon en diversas publicaciones periódicas. El impacto que se alcanzó en Francia por la difusión de los logros más notables del país latinoamericano, se reflejó en la obtención del Gran Premio de Honor a la arquitectura mexicana, otorgado por la Sociedad de Artistas Franceses a la exposición "4000 años de arquitectura mexicana”

Resulta evidente que Francia estaba bien familiarizada con el desarrollo de la arquitectura mexicana, debido no sólo a la labor de promoción nacional, sino también gracias al importante trabajo editorial que mantenía L'Architecture d'Aujourd'hui alrededor del mundo con un cuantioso número de corresponsales. Para el caso de México, durante todo el periodo de estudio, el nombre del arquitecto Vladimir Kaspé se encuentra indisolublemente ligado a la revista parisina.

La idea del primer número monográfico de L'Architecture d'Aujourd'hui surgiría después de la visita al país de Pierre Vago, E. Beaudouin y R. Lebret ${ }^{41}$ en 1952 . Un conocimiento más amplio del país latinoamericano y de su nueva arquitectura sin duda promovió el interés en el tema en la editorial francesa.

Así, en abril de 1955, la revista francesa lanzó una portada en la que combinaba un detalle de arquitectura contemporánea mexicana —inspirado en diseños de la iconografía prehispánica ${ }^{42}$ - con unos glifos de la escritura maya tomados de una estela. De esta manera, junto con los colores patrios, el mayor impacto de la portada fueron las referencias a una tradición que para entonces encontraba su legitimación en diversos medios extranjeros.

Las referencias a la herencia cultural - por supuesto- no se limitaron a una imagen de portada sino que fueron tratadas en artículos introductorios que ayudarían al lector francés a acercarlo al mundo de las culturas mesoamericanas, a comprender la psicología de la arquitectura mexicana en relación a la integración plástica ${ }^{43}$ y a valorar la importancia de lo social derivado de la relativamente reciente Revolución.

Es interesante constatar cómo, en los breves textos introductorios, se subrayaba tanto la postura oficial en relación a la cultura, fundamentada en la integración de las raíces indígenas con las aportaciones europeas 

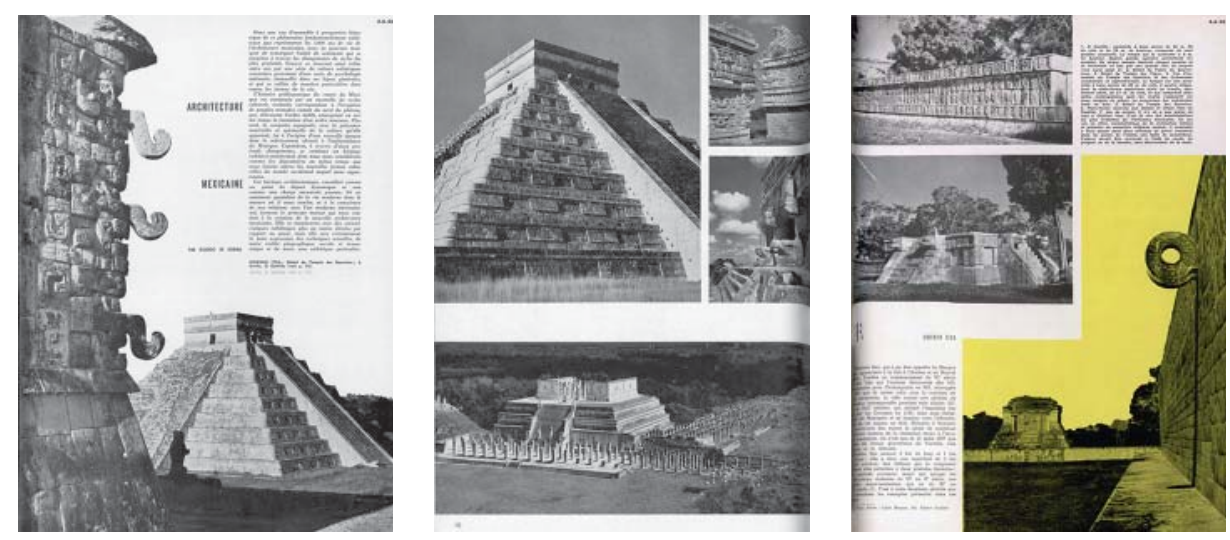

que llegaron a América a partir del siglo xvi, como el empleo de tecnologías modernas aunado a las ideas sociales de la Revolución como determinantes de la arquitectura moderna mexicana ${ }^{44}$. José Villagrán García insistía en que había que buscar la originalidad de la arquitectura mexicana no bajo la visión eurocéntrica que había llevado a apreciar nuestro arte bajo los criterios europeos, provocando incomprensión, sino ver las particularidades en vez de guiarse por los cánones occidentales.

El texto que se dedicó a la arquitectura histórica se debía a Ricardo de Robina, quien recorría el periodo prehispánico, virreinal e independiente, enfatizando lo mesoamericano $-\mathrm{y}$ dentro de éste mundo aparte, lo maya - sobre lo barroco o lo neoclásico, sección en que las fotos son menos y más pequeñas ${ }^{45}$. Además de la cuidadosa selección de ejemplos con lo más reciente de la arquitectura moderna, se incluyeron dos temas de análisis teórico-arquitectónico: el problema de la vivienda popular y el de la enseñanza de la arquitectura en México ${ }^{46}$.

Sobre los contenidos de este número especial, destacaron, en primer lugar, las veintiséis páginas dedicadas a la Ciudad Universitaria, seguidas por ejemplos de prácticamente todos los géneros arquitectónicos: vivienda unifamiliar, vivienda colectiva de interés social, vivienda colectiva de lujo, educación, oficinas de gobierno, oficinas privadas, salud, servicios, industrias, infraestructura y urbanismo. Más de setenta edificios mexicanos ocuparon estas páginas, y casi medio centenar de arquitectos tuvieron créditos como autores principales de las obras.

La publicación destacaba por su diseño gráfico y por el uso de las imágenes. Se mencionó antes que se utilizó el color para foto de arquitectura en época temprana, pero también sobresalió la edición de imagen; la misma perspectiva publicada en Arquitectura México podía no ser tan notoria como la que ofrecía L'Architecture d'Aujourd'hui después

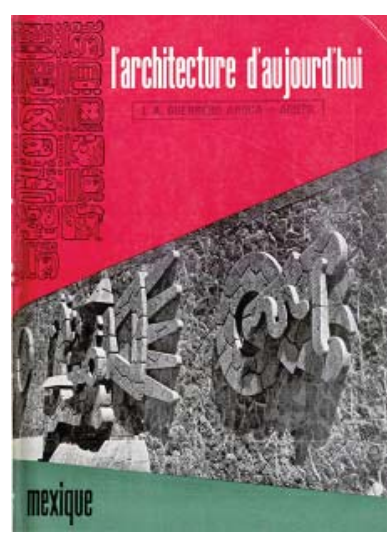

Portada del monográfico de $A A$ dedicado a México en abril de 1955. A la izquierda, páginas interiores con profusión de ejemplos de arquitectura maya.

44. Pedro Ramírez Vázquez y José Villagrán García, "Préface," L'Architecture d'Aujourd'hui, no. 59 (abril 1955): 2 y E. Beaudouin, "Impressions d'un voyage au Mexique," L'Architecture d'Aujourd'hui, no. 59 (abril 1955): 3. Éste último confirmó en su texto la continuidad cultural desde los tiempos prehispánicos hasta el presente, lo que a la sazón era el discurso oficial del arte y de la historia.

45. Ricardo De Robina, "Architecture mexicaine," L'Architecture d'Aujourd'hui, no. 59 (abril 1955): 5-13. En la página 74 de este monográfico, entre un edificio de apartamentos y el Pedregal de San Ángel, se incluyó una página de texto para completar el estudio sobre la arquitectura mexicana. Los textos intercalados entre los ejemplos de arquitectura son: "Évolution de l'Architecture" de Alberto T. Arai y "Évolution de l'Architecte" de Jorge L. Medellín. El primero destacó el siglo xix y el eclecticismo y el segundo explicó los primeros pasos hacia el funcionalismo.

46. Félix Sánchez, "Le problème de l'habitat populaire a Mexico," L'Architecture d'Aujourd'hui, no. 59 (abril 1955): 59 y Alonso Mariscal, "L'Enseignement de l'architecture au Mexique," L'Architecture d'Aujourd'hui, no. 59 (abril 1955): 97. 
Estadio Universitario en el especial de arquitectura mexicana de L'Architecture d'Aujourd'hui (abril 1955).

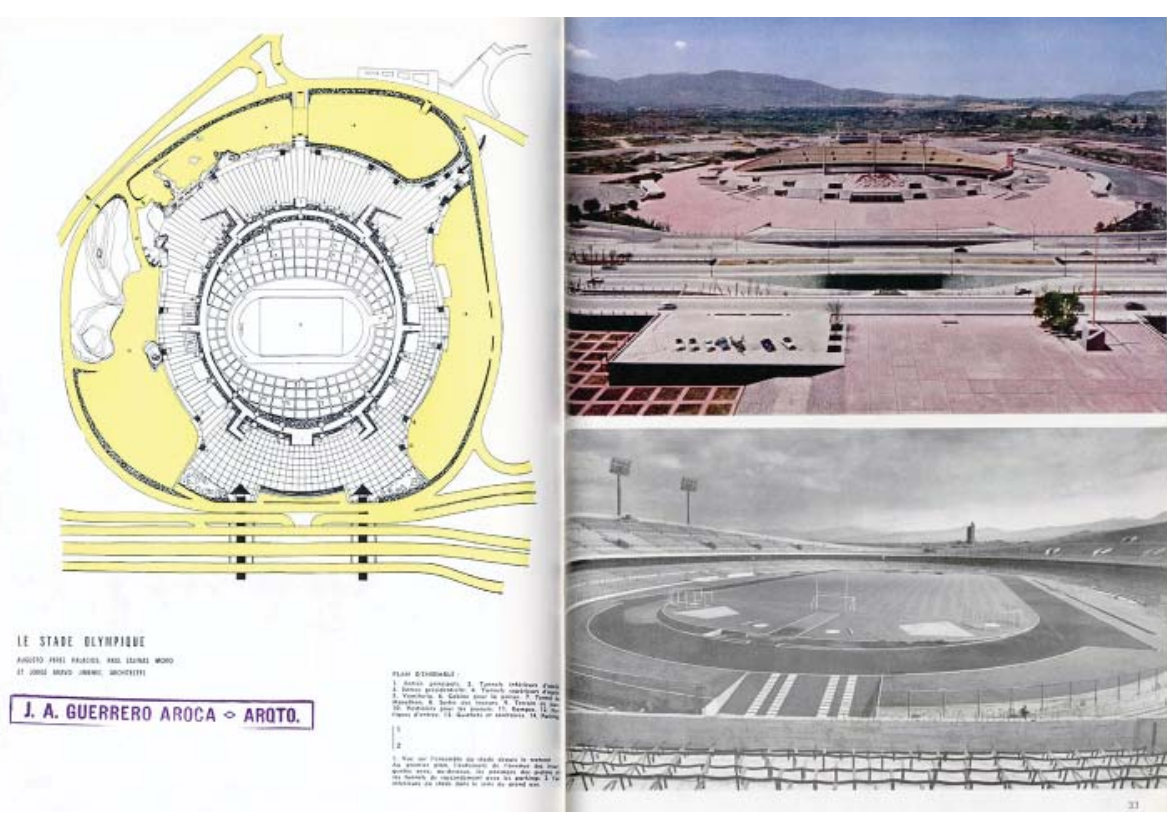

de recortar y limpiar el material enviado desde México. Con todo, las más de cien páginas dedicadas a la nueva arquitectura mexicana no representaron un aumento en la cantidad promedio de impresiones que la revista solía dedicar a todos sus números, que siempre se caracterizó por la gran cantidad de material publicado.

Hay intención de un orden de lectura que empieza con la obra más grande y representativa del momento - la Ciudad Universitariay que continúa con una presentación de los edificios por género y dentro de éstos, también se enseñó primero, o la obra más grande - en el caso, por ejemplo, de los edificios de gobierno- o la que se consideró más representativa, como se nota al revisar la sección dedicada a la vivienda unifamiliar, en la que difícilmente se podría hablar de una casa más grande que otra ${ }^{47}$. El único aspecto editorial que rompe con la unidad de lectura señalada es la inserción de páginas extras intercaladas entre la extensa publicidad. Se encuentra ahí un ejemplo de oficinas privadas y otro de vivienda colectiva de interés social, que, definitivamente, al situarse aisladas del contenido general del número, pierden importancia.

Más allá del primer monográfico de L'Architecture d'Aujourd'hui,

47. La Secretaría de Comunicaciones y Transportes de Carlos Lazo, Raúl Cacho y Augusto Pérez Palacios abrió la sección de edificios gubernamentales y la casa de Luis Barragán en Tacubaya, la correspondiente a la vivienda unifamiliar. las noticias sobre una gran cantidad de arquitectos mexicanos y sus obras, recorrían el mundo. Entre 1955 y 1959 el flujo informativo se mantuvo constante después del detonante de la Ciudad Universitaria en 1952. En España, Italia, Estados Unidos, Francia e Inglaterra se publicaron desde viviendas unifamiliares hasta aeropuertos, pasando por museos 
experimentales, iglesias, edificios industriales, oficinas, teatros y conjuntos de vivienda colectiva de interés social.

En Madrid, Informes de la Construcción dedicó un número especial a entrevistas de arquitectos de seis países ${ }^{48}$ titulado: "Los arquitectos opinan de arquitectura", de quienes se mostraba, también, su obra más reciente. Los ejemplos publicados se presentaron como manifestaciones aisladas de gran calidad, que adaptaban las funciones a las nuevas técnicas y a los materiales empleados. Las preguntas que se enviaron a los arquitectos solicitaban definir las características de su producción y comentar los problemas actuales de la arquitectura, cómo se valoraban los materiales, si la función debía anteponerse a la estética o qué orientación debía tomar la arquitectura del momento ${ }^{49}$.

DeMéxico se incluyeron las respuestas de tres arquitectos, Lorenzo Carrasco, Guillermo Rossell y Enrique de la Mora. Los dos primeros eran por esos años los editores de la revista Espacios, publicación que compaginaba «expresiones plásticas y arquitectónicas que se enlazaban con la corriente nacionalista del momento ${ }^{50}$. Como características de su arquitectura anotaron «el resultado de un correcto enlace entre las necesidades y la técnica propia de los materiales empleados» ${ }^{51}$, lo que se comprobaba al ver con detalle el edificio seleccionado para mostrar al lector español su obra reciente: el nuevo edificio de oficinas Auto-Mex, en la ciudad de México. En la fachada principal se veía el mural "Velocidad", de David Alfaro Siqueiros, de líneas curvas en alto relieve y una losa de cubierta ondulante sobre volúmenes prismáticos horizontales. La fachada posterior acristalada rompía su monotonía con pequeños cubos ciegos que recorrían a intervalos regulares toda la franja horizontal del primer nivel de oficinas. Acompañaba a las fotografías la descripción detallada de los espacios y funciones del edificio.

Por su parte, Enrique de la Mora definió el problema de la arquitectura actual como el mismo para todas las épocas: «construir para el hombre ${ }^{52}$, aunque puntualizaba que se debía encontrar una nueva expresión estética de acuerdo con la producción industrial. La obra que presentó fue el diseño arquitectónico de la iglesia de Nuestra Señora de la Soledad, obra original que debía su forma al programa requerido, esto es, una capilla con coro para los Misioneros del Espíritu Santo, donde la planta romboidal permitía adaptar una cubierta laminar de doble
48. En las entrevistas participaron arquitectos de Brasil, España, Estados Unidos, Francia, Italia y México.

49. F. Cassinello, "Los arquitectos opinan de arquitectura," Informes de la Construcción, no. 76 (diciembre 1955): $\mathrm{s} / \mathrm{p}$.

50. Louise Noelle, "La arquitectura mexicana en las publicaciones periódicas del siglo xx," Bitácora, no. 19 (2009): 13

51. "Lorenzo Carrasco y Guillermo Rossell," Informes de la Construcción, no. 76 (diciembre 1955): s/p.

52. "Enrique de la Mora y Palomar." Informes de la Construcción, no. 76 (diciembre 1955): $\mathrm{s} / \mathrm{p}$. 

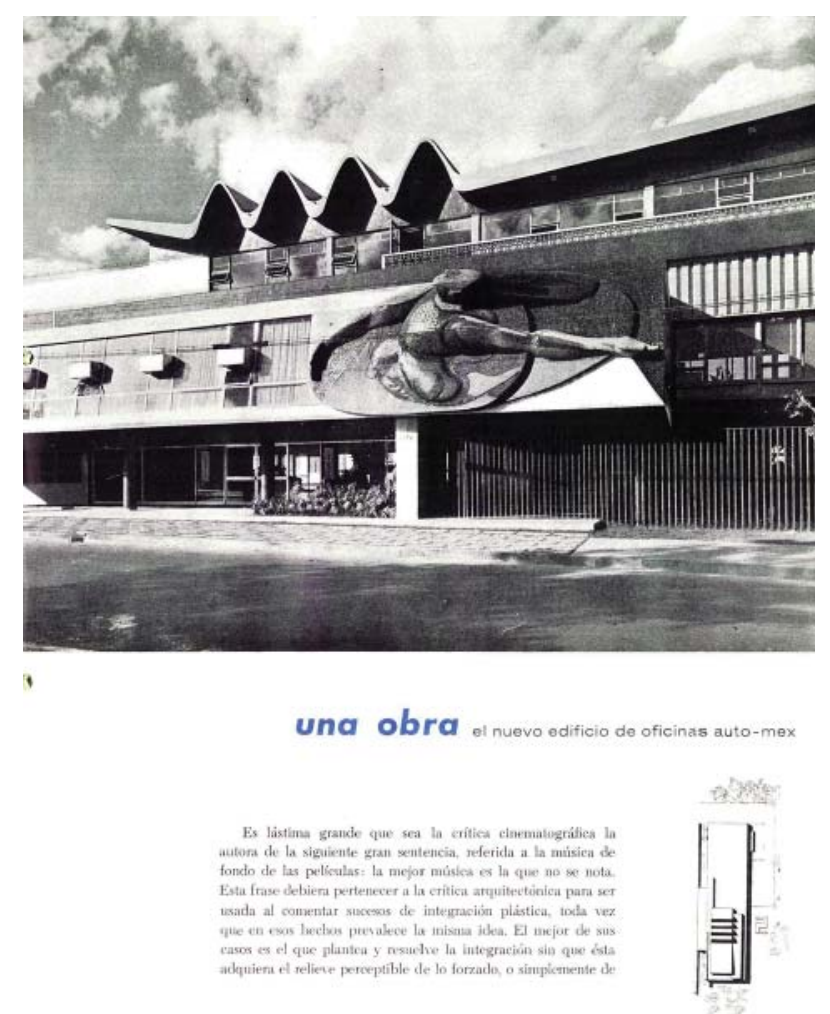

Oficinas Auto-Mex en la ciudad de México, de Lorenzo Carrasco y Guillermo Rossell. Página de Informes de la Construcción (diciembre 1955).
53. Hay que decir que sólo se publicaron aquí las plantas, fachadas, cortes y perspectivas, sin una sola fotografía. Esta obra, como veremos más adelante, será ampliamente difundida con los créditos a Félix Candela como calculista y constructor. De este último se publicó en este número de Informes el artículo técnico "Estructuras laminares parabólico-hiperbólicas", tomado del Journal of the American Concrete Institute.

54. "Barragán a Città del Messico," Domus, no. 321 (agosto 1956): 1-7. Sorprende bastante que las quince fotografías del artículo sean todas a color, algo por completo inusual en esa época para las revistas de arquitectura.

55. Este tema también llamó la atención de otra fotógrafa, Marianne Goeritz, de quien Progressive Architecture publicó un artículo con sus fotos en septiembre de 1957.

56. G. Nesbit, "The Towers of Satellite City," Arts \& Architecture 75 , no. 5 (mayo 1958): $22-23$. curvatura cuyos únicos puntos de apoyo se encuentran en los ángulos mayores de la planta, liberando totalmente el espacio interior ${ }^{53}$.

En Italia, en esos años, uno de los protagonistas indiscutibles fue Luis Barragán, de quien Domus publicó a todo color la casa Prieto ${ }^{54}$. Una de las exclusivas de la revista italiana fueron las fotografías de Marilyn Silverstone, de quien incluyeron en la página de contenido su única foto en blanco y negro: un horno para cocer tabiques de barro en las afueras de la ciudad de México ${ }^{55}$. El artículo introduce al lector con la referencia a los Jardines del Pedregal, publicados con anterioridad por la misma revista, lugar del que reavivan el imaginario poético del paisaje bañado por la lava volcánica petrificada. La sensibilidad de Barragán hacia el muro se reforzaba con el acercamiento visual a la residencia Prieto que deja verse primero desde la calle, para ir penetrando poco a poco en la calidez de sus espacios interiores - eso sí- se mantiene siempre al espectador en los espacios públicos de la casa: el patio interior, la piscina, el recibidor, el comedor y la biblioteca.

También de Barragán, pero en estrecha colaboración con el artista Mathias Goeritz, se publicó en Arts \& Architecture la exclusiva sobre el avance constructivo de las Torres de Satélite, hito urbano de escala monumental que indicaba la entonces nueva urbanización de Ciudad Satélite al norponiente de la ciudad de $\mathrm{México}^{56}$. El material fue preparado por G. Nesbit, quien mostraba en fotografías tanto algunos de 

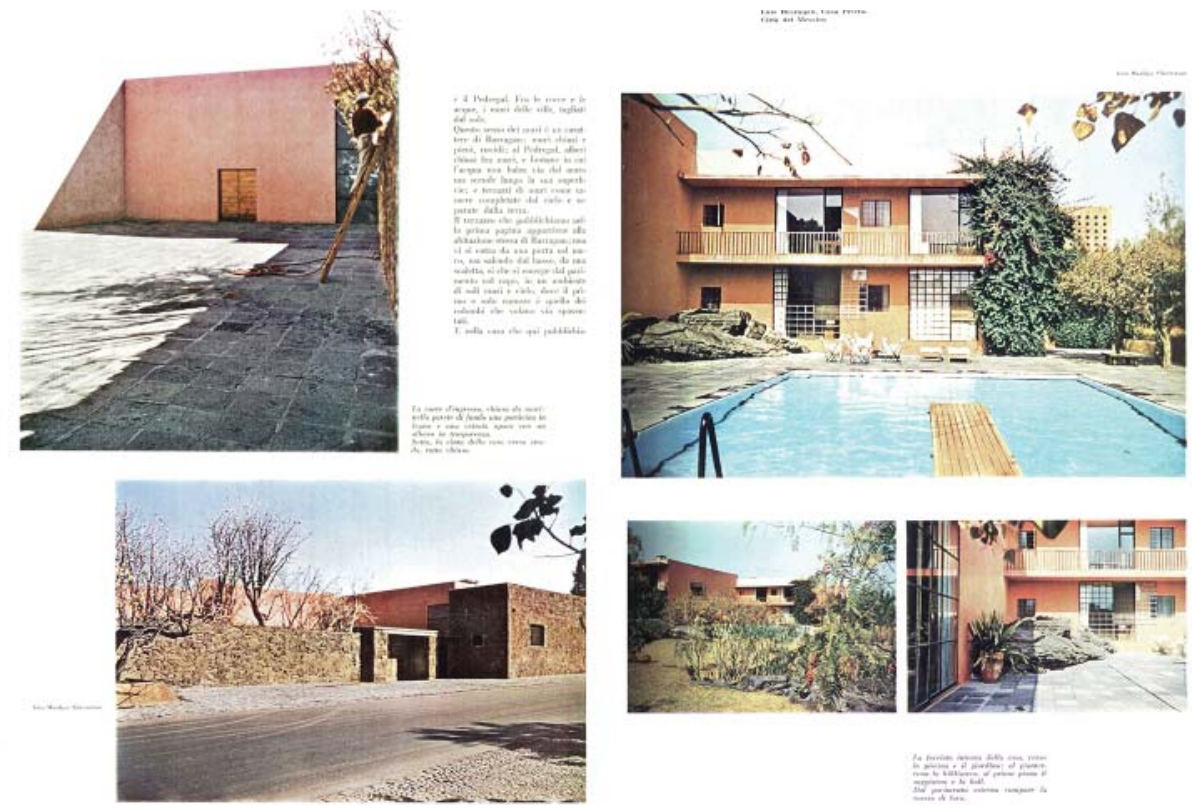

los conceptos escultóricos previos como las cinco torres todavía coronadas con la cimbra para colar el hormigón. A diferencia del trabajo previo de Barragán en el Pedregal, el reto aquí consistía en el cambio de escala y en la función icónica de estas torres sin función; la solución fue la vertical. A pesar de ser un elemento estático del paisaje, la forma triangular de sus plantas, las diferentes alturas - que van de los 34 a los 54 metros- el emplazamiento en pendiente y el movimiento propio de los vehículos que transitan por la carretera que los circunda, hacen que el punto de vista sea siempre dinámico, cualidad que se destacaba en la revista angelina.

Colaborador de Barragán en las Torres de Satélite, pero artista único, de creatividad inagotable y extensa producción, Mathias Goeritz aportó a la arquitectura mexicana moderna un edificio memorable: el museo experimental El Eco, de corta vida en un inicio ${ }^{57}$ pero de enorme difusión a nivel internacional. A finales de 1956 la neoyorquina Progressive Architecture dedicaba su portada y un artículo al museo ${ }^{58}$, y en septiembre de 1957, la londinense Architectural Design también se dejó cautivar por el experimento artístico ${ }^{59}$. El ensayo consistía, en palabras del propio Goeritz, en alcanzar una verdadera "arquitectura emocional", en integrar la plástica abstracta para producir en el hombre moderno el máximo de emoción ${ }^{60}$. Sin duda, las fotografías tomadas durante las performances del ballet experimental de Walter Nicks, en las que la serpiente - la escultura geométrica que ocupaba el patio- formaba parte indisoluble de las coreografías, fue algo que no tenía referente en lo conocido hasta ese momento dentro de la arquitectura moderna mexicana.
Casa Prieto de Luis Barragán en Domus (agosto 1956). El color desborda las páginas de la revista milanesa.
57. Después de su paulatina transformación de museo hasta restaurante, club nocturno, teatro y lugar de encuentro para actividades políticas, la suerte quiso que la Universidad Nacional Autónoma de México comprase el edificio en 2004, restaurándolo hasta dejarlo en su estado original. Así, el Museo Experimental El Eco reabrió sus puertas el 7 de septiembre de 2005. "Museo Experimental El Eco," UNAM, consultada 18 mayo, 2015, http://eleco.unam.mx/eleco/ inicio/el-eco/.

58. "Experimental Museum: Mexico City", Progressive Architecture 37, no. 12 (diciembre 1956): 89-91.

59. Peter Carter, "Mathias Goeritz," Architectural Design 27, no. 9 (septiembre 1957): 327-29.

60. Si bien El Eco, al igual que muchos otros edificios de la época, integró obras artísticas en sus espacios, no se debe confundir lo que por entonces se llamó integración plástica con este verdadero experimento que, si bien con aportaciones no por completo abstractas, sí lo suficientemente geométricas como para separarlas de cualquier antecedente en el país. 
Lo que sí tuvo punto de comparación fueron los edificios de oficinas, que llegaron a ser confrontados con sus semejantes de los países de tecnología más avanzada. Así, en junio de 1957 apareció en Architectural Record una obra de Juan Sordo Madaleno en la ciudad de México compartiendo espacio editorial con otro edificio de similar forma y función en Atlanta, Georgia ${ }^{61}$. Siguiendo la línea de esta revista, abocada principalmente a la arquitectura comercial, el mismo año publicó el edificio más alto construido hasta entonces en el país: la Torre Latinoamericana ${ }^{62}$, junto a un reportaje gráfico dedicado a los daños que afectaron diversas estructuras de la capital después del fuerte terremoto del 28 de julio de $1957^{63}$.

Sin importar el riesgo sísmico de la ciudad, ésta siguió creciendo a un ritmo imparable, proveyendo de todo tipo de edificios públicos, incluyendo - por supuesto- los dedicados al entretenimiento. Con un proyecto que modernizó en México la arquitectura para espectáculos, Alejandro Prieto diseñó el Teatro de los Insurgentes, que incorporaba la tecnología más novedosa, como una plataforma giratoria que permitía la movilidad de la escenografía. Los volúmenes del conjunto, soportados por una estructura de hormigón armado, respondían a la distribución interna: el vestíbulo, la sala y el escenario. La fachada ostenta la última gran obra pública de Diego Rivera, un gigantesco mural sobre una superficie convexa, que entre las alegorías al arte dramático no olvidó las alusiones a los tiempos prehispánicos y a la lucha revolucionaria. The Architectural Review publicó la obra en febrero de $1958^{64}$ dedicando plantas, un corte esquemático, fotografías de interiores y exteriores, así

61. "Two Office Buildings," Architectural Record 121, no. 6 (junio 1957): 207-14.

62. Adolfo Zeevaert, "Tower Latino Americana: Mexico City's 'Quake-Proof Skyscraper," Architectural Record 122, no. 4 (octubre 1957): 249-52.

63. Robert E. Fischer, "Mexico City's Earthquake," Architectural Record 122, no. 4 (octubre 1957): 243-47.

64. "Theatre in Mexico City," The Architectural Review 123, no. 733 (febrero 1958): 110-13.

65. Con la colaboración de Enrique Carral Icaza, Manuel Martínez Páez, Ricardo Flores Villasana y Guillermo Pérez Olagaray. como una descripción detallada de sus espacios principales y de los servicios complementarios del teatro.

Asimismo, grandes obras de infraestructura se realizaron en México durante el segundo lustro de 1950. Los nuevos aeropuertos de México y Acapulco no sólo fueron un indicador del crecimiento de ambas ciudades, sino que respondieron al aumento generalizado a nivel mundial del movimiento de pasajeros que anualmente viajaban por aire. En diciembre de 1957, Progressive Architecture dedicó un número especial a las recientes terminales aéreas en distintas partes del mundo, que contó con el aeropuerto capitalino, de Augusto H. Álvarez ${ }^{65}$ y con el de Acapulco, de Mario Pani y Enrique del Moral. Del primero, se destacaba un esquema 
frontal que permitiría futuras ampliaciones y que dividía el edificio en dos alas, separando a los viajeros nacionales de los internacionales ${ }^{66}$. En Acapulco, el clima tropical definía las formas y materiales empleados en la terminal aérea ${ }^{67}$. La cubierta - una bóveda ligera de hormigón- es soportada por dos arcos elípticos de concreto ubicados de forma paralela a todo lo largo del edificio, lo que favorecía que los muros laterales no tuviesen ninguna función estructural y fueran cerrados por celosías que permiten una ventilación natural cruzada. El funcionamiento que distingue a los pasajeros nacionales de los internacionales se ordenó bajo la enorme cubierta curva.

La doble celosía de bloques huecos prefabricados del aeropuerto de Acapulco fue utilizada como foto de fondo de la portada del número de octubre de 1956 de L'Architecture d'Aujourd'hui, dedicado a la construcción en los países cálidos. En este número, además de la reseña a dicho aeropuerto, se publicó también el club náutico y una casa de descanso en el puerto, del mismo Mario Pani con diversos colaboradores. De la ciudad de Cuernavaca una vivienda unifamiliar de Vladimir Kaspé y del estado de Veracruz un conjunto de vivienda de interés social de Felipe Salido Torres. También, una propuesta muy interesante para una vivienda tipo inspirada en la arquitectura vernácula y destinada a los habitantes originarios de la región del río Papaloapan ${ }^{68}$. Todos los proyectos se caracterizaban por su adaptación al clima tropical a través de la utilización de materiales — tanto naturales como industrializadosque concilian la habitabilidad con las altas temperaturas y el sol intenso.

Más allá del clima, otro tema que interesaba a L'Architecture d’Aujourd'hui era la producción de la generación más joven de arquitectos en todo el mundo. Así, en septiembre de 1957 veía la luz un número dedicado a los jóvenes arquitectos de veintidós países, que contó no sólo con las geografías más habituales para el medio parisino como era Europa o América, sino que también se incluyó a Israel, Turquía, Irak, Japón y Australia.

Mario Pani introdujo el caso mexicano, destacando que en ese momento la matrícula de la Escuela de Arquitectura de México ya contaba con mil quinientos estudiantes, situación que favorecía un ambiente escolar competitivo que propiciaba el surgimiento de los jóvenes talentos. Por esos años, la ciudad de México era todavía un lugar de oportunidad
66. "One-Level Finger System: Mexico City." Progressive Architecture 38, no. 12 (diciembre 1957): 96-99. 67. "One-Level frontal system: Acapulco, Mexico." Progressive Architecture 38, no. 12 (diciembre 1957): 100-101.

68. Véase L'Architecture d'Aujourd'hui, no. 67-68 (octubre 1956): 140-147 y xxxI. 
69. Mario Pani, "Les Jeunes architectes dans lambiance du Mexique," L'Architecture d'Aujourd'hui, no. 73 (septiembre 1957): 61-67.

70. De vivienda colectiva de interés social el Centro Urbano Presidente Alemán y el Centro Urbano Presidente Juárez; la Rectoría de la UNAM y en Acapulco el club náutico y el condominio Los Cocos.

71. "Unité d'Habitation et de Services Sociaux No. 1 a Santa Fe, Mexico," L'Architecture d'Aujourd'hui, no. 87 (diciembre 1959): 62-67. En este número también se publicaron algunos edificios de vivienda de lujo de Vladimir Kaspé, Manuel Rosen, Augusto $\mathrm{H}$. Álvarez y Enrique Carral.

72. En el apartado 6.2 Entre la vida y la obra. El arquitecto como protagonista, se revisan otros ejemplos de Candela, así como una aproximación cuantitativa a sus obras en las publicaciones periódicas foráneas.

73. Félix Candela, "StereoStructures," Progressive Architecture 35 , no. 6 (junio 1954): 84-93. No es ésta la primera noticia de Candela en los medios internacionales, pues desde 1952 el pabellón de rayos cósmicos, diseñado por Jorge González Reyna y calculado y construido por Candela, ya aparecía regularmente en las revistas de arquitectura. para los recién egresados arquitectos. Destaca que de todas las obras presentadas sólo dos no sean viviendas unifamiliares: una escuela de Ignacio Medina Roiz y un edificio de oficinas de Héctor Velázquez Moreno y Ramón Torres Martínez. Así, Enrique Castañeda Tamborrell, Manuel Teja y Juan Becerra, Manuel Rosen, Carlos B. Zetina, Salvador Ortega Flores y Felipe Salido Torres se conocieron en Francia a través de la arquitectura de vivienda unifamiliar ${ }^{69}$.

Uno de estos jóvenes talentos ya aparecía regularmente y desde hacía varios años en la revista francesa, pues, como estrecho colaborador de Mario Pani, Salvador Ortega Flores compartía los créditos de varias de las más importantes realizaciones mexicanas ${ }^{70}$. En diciembre de 1959 aparecía de nuevo como colaborador de la unidad habitacional Santa $\mathrm{Fe}$, en un número dedicado a la vivienda ${ }^{71}$. De este centro urbano al poniente de la ciudad de México se destacaban, sobre todo, los edificios complementarios a la habitación colectiva que son los que prestan los servicios sociales, como la clínica, la guardería, las escuelas, los centros comerciales o el club central. La habitación se resolvió con un esquema mixto de edificios de departamentos y casas individuales, con mayor cantidad de estas últimas. Si bien la disposición de las casas en banda continua respondía a los requerimientos económicos y de infraestructura propios de esta organización, la consecuencia final sería más bien monótona. La mayor crítica de L'Architecture d'Aujourd'hui fue hacer notar que, aunque los bloques de vivienda se adaptan ligeramente a la pendiente natural del terreno, el conjunto resultaba en un trazo urbano tradicional y rígido.

Estos mismos años, en el extremo opuesto a la rigidez, acaparaban la atención de los medios internacionales las cada vez más sorprendentes formas estructurales de Félix Candela. Se cita aquí una selección de artículos dedicados a los cascarones de hormigón armado del arquitecto español nacionalizado mexicano, capítulo indispensable de la difusión de la arquitectura moderna mexicana fuera de sus fronteras ${ }^{72}$.

Sin duda, el artículo que llamó la atención de forma definitiva hacia la obra de Candela fue el que él mismo envió a Progressive Architecture, publicado en junio de $1954^{73}$. "Stereo-Structures" tuvo su origen en una conferencia dirigida a la Sociedad de Arquitectos Mexicanos, texto que después el mismo arquitecto tradujo y remitió a la revista 
Portada de Progressive Architecture (junio 1954). Candela arremete contra la Teoría de la Elasticidad.

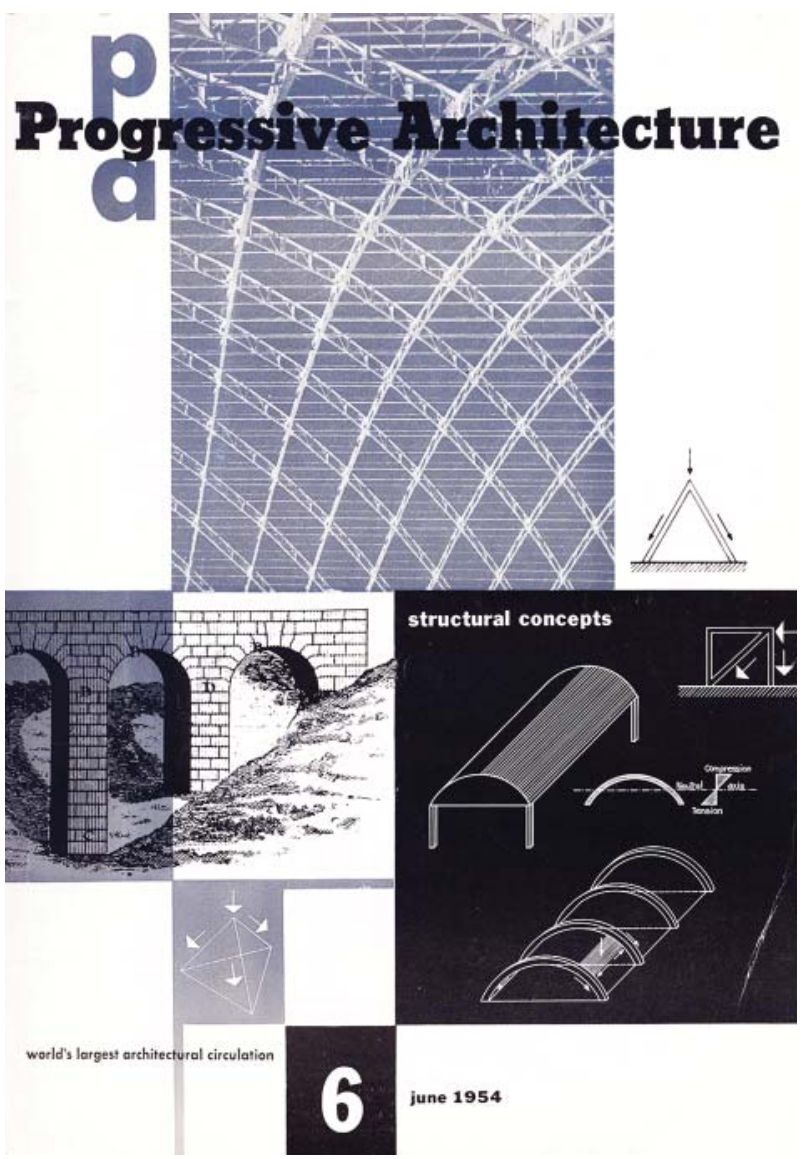

norteamericana, prediciendo que sería la última vez que tendría que solicitar que le publicaran un artículo ${ }^{74}$. El ensayo fue tan bien recibido en Nueva York que incluso el editor, Thomas Creighton, seleccionó algunos de los diagramas de Candela para la portada de ese mes. Ese número de Progressive contó con varios textos de análisis dentro del tema general "Hacia nuevos conceptos estructurales" y la aportación de Candela no consistió solamente en las nuevas estructuras sino en cómo arremetió contra la Teoría de la Elasticidad aplicada indiscriminadamente por los ingenieros al hormigón armado cuando su comportamiento es contrario ${ }^{75}$. Pocos meses después, la misma revista publicaría una selección de sus obras, de las que destacó la iglesia de la virgen de la Medalla Milagrosa ${ }^{76}$.

El año que Candela gozó de protagonismo absoluto en las publicaciones periódicas frente a otros arquitectos mexicanos fue indiscutiblemente 1956. En enero, marzo, mayo, junio, octubre y diciembre, seis diferentes medios internacionales emitieron considerables artículos sobre las realizaciones emblemáticas del genio de las estructuras. Así, Techniques et Architecture, en un número dedicado al hormigón armado, incluyó ocho ejemplos que iban de las bóvedas cilíndricas, las superficies conoidales a los paraboloides hiperbólicos ${ }^{77}$. En portada
74. Colin Faber, Candela: The Shell Builder (New York: Reinhold Publishing Corporation, 1963), 13.

75. Faber, Candela, 14.

76. "Work of Felix Candela," Progressive Architecture 36, no. 7 (julio 1955): 10615.

77. "Constructions en voiles minces, au Mexique," Techniques et Architecture 15, no. 4 (enero 1956): 117 19. 
destacó una sección de las bodegas aduanales, fotografía de Antonio Candela, hermano de Félix y fotógrafo habitual de Cubiertas Ala.

En su número de marzo, L'Architecture d'Aujourd'hui publicó un texto de análisis teórico sobre la espacialidad de las bóvedas delgadas de hormigón armado y la capilla de Nuestra Señora de la Soledad ${ }^{78}$. En mayo, Arts \& Architecture dedicó su portada a la famosa fotografía de Erwin Lang79; en esa ocasión, la revista angelina publicó, al igual que la parisina, El Altillo, además de la destilería Bacardí en Puebla y la Casa de Bolsa de la ciudad de México, acompañados de un interesante análisis de Colin Faber ${ }^{80}$.

Hacia la mitad del año, las cubiertas ligeras de Candela llegaron a Milán, calificando al autor como «uno de los mayores hombres de nuestro tiempo ... dotado de enorme inventiva plástica ${ }^{81}$. La intuición estructural que en Candela siempre fructificó, se subrayó en Domus con varias vistas interiores de la iglesia de la virgen de la Medalla Milagrosa recién terminada, poniendo el broche final a las páginas previas dedicadas a otros ejemplos de sus estructuras.

En octubre de 1956, Progressive Architecture dedicó un número a la arquitectura religiosa, en el cual se publicó la capilla de Nuestra Señora de la Soledad en el Altillo, Coyoacán ${ }^{82}$. Del mismo modo que L'Architecture d'Aujourd'hui y Arts \& Architecture en los meses previos, la neoyorquina mostraba los avances constructivos de la obra. La excepcional solución arquitectónica de la planta — de Enrique de la Mora- capaz de congregar en coro a la comunidad completa de misioneros durante los servicios religiosos es cobijada por una única superficie laminar de doble curvatura. Las fotos de Antonio Candela muestran la cimbra de madera que siempre se realizaba in situ y el sorprendente entramado de acero dispuesto a

78. Félix Candela, "Les voutes minces et l'espacé Architectural," L'Architecture d'Aujourd'hui, no. 64 (marzo 1956): 22-24 y "Eglise a Coyoacan, Mexique," L'Architecture d'Aujourd'hui, no. 64 (marzo 1956): 25-27.

79. Se trata de la fábrica textil High Life, en Coyoacán. Los paraboloides hiperbólicos en paraguas, perforados por vitro-blocks hicieron al fotógrafo ganador de una mención de honor en la primera exposición anual de fotografía de arquitectura del Instituto de Arquitec- tos Americanos en 1955. Véase también "The Photographers Win," Architectural Record 118, no. 1 (julio 1955): 15.

80. Colin Faber, "Felix Candela as a contemporary," Arts \& Architecture 73, no. 5 (mayo 1956): 20-24 y 40-41.

81. "Breve documentario di Felix Candela," Domus, no. 319 (junio 1956): 3-5. Si bien Domus ya había publicado el pabellón de rayos cósmicos de la Ciudad Universitaria (no. 299) y la iglesia de la virgen de la Medalla Milagrosa (no. 308), se trató, en el primer caso, de una mención a esta obra en el tema general de las nuevas estructuras y el color y en el segundo, de una noticia de actualidad de una página tomada de Arts \& Architecture.

82. "Doubly-curved, thin shell concrete slab for chapel," Progressive Architecture 37, no. 10 (octubre 1956): 13945. El mismo medio publicó otras obras de Candela en septiembre de 1957, febrero de 1959, julio de 1962 y noviembre de 1968 , por mencionar los artículos más importantes. 


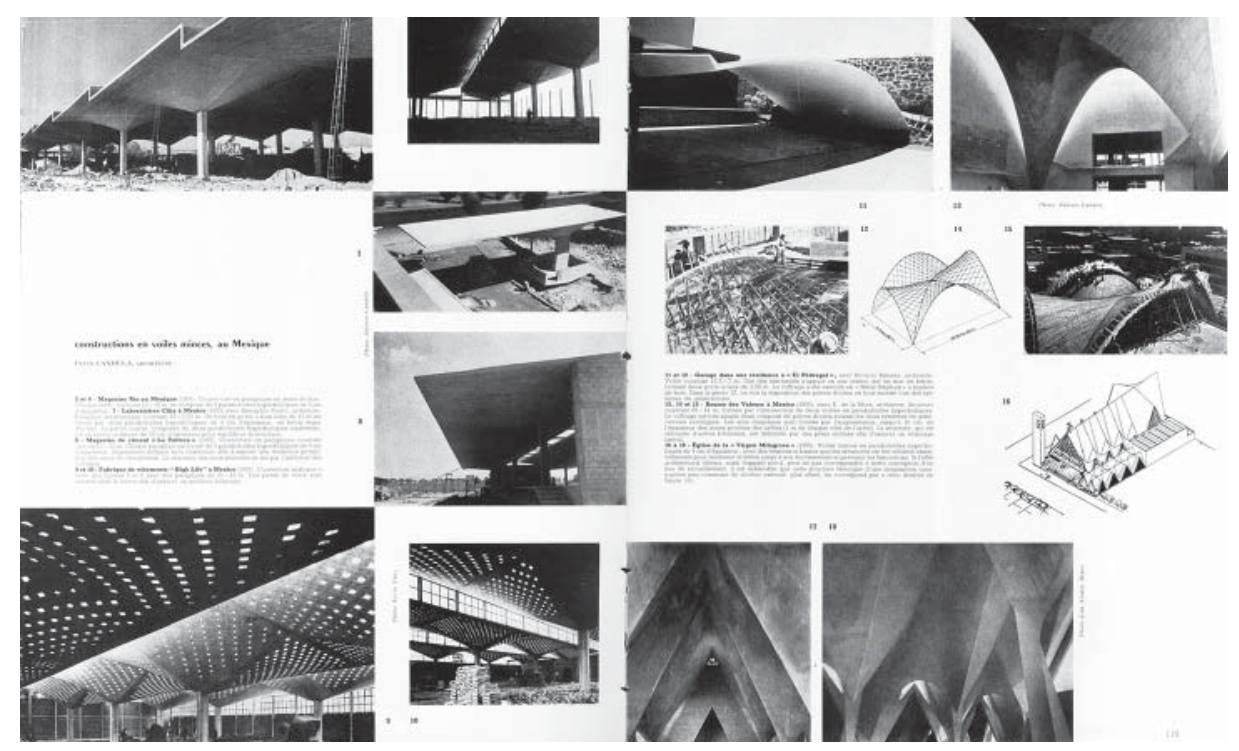

recibir el colado de hormigón que ya indicaba la forma final que tomaría la superficie reglada.

Ahora bien, la revista técnica del instituto dedicado a la investigación del cemento en Madrid, no podía dejar de publicar la obra reciente de Candela, salvando el riesgo de posibles censuras ${ }^{83}$. Así, al finalizar 1956, Informes de la Construcción abría su número con un artículo dedicado al hormigón como el «material noble de hoy» ${ }^{84}$. Entre varios ejemplos internacionales, la multicitada foto de Erwin Lang de los paraguas perforados por vitro-blocks, se medía al lado de la capilla de Ronchamp o el estadio del Real Madrid. Pero el edificio de Candela mejor documentado aquí fue la iglesia de la virgen de la Medalla Milagrosa, de la que se incluyeron vistas exteriores, plantas, alzados y secciones, detalles constructivos de los soportes - mostrando la distribución de las varillas de acero- una interesante vista superior del armado de algunos de los paraboloides hiperbólicos y - por supuesto- las conocidas fotografías del interior. El propio Candela hablaba de su proceso de diseño, de dentro hacia afuera con la intención de conseguir un espacio interior interesante, buscando que la expresión interna dependiera de la forma estructural ${ }^{85}$.

También en Madrid, Arquitectura -hasta 1958 la Revista Nacional de Arquitectura- ${ }^{86}$ quiso recuperar el espacio editorial que no había podido dedicar a su connacional y en octubre de 1959 dedicó un extenso artículo de treinta y dos páginas a la obra más reciente de Candela $^{87}$. Para la portada se eligió una vista desde el interior de la cubierta de Los Manantiales, a través de la cual se intuyen los perfiles arbóreos característicos de Xochimilco. La selección de obras se debió

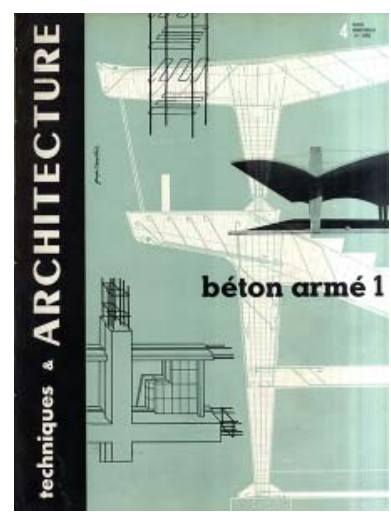

Portada y páginas interiores de Techniques et Architecture (enero 1956). Cascarones de hormigón armado de Félix Candela.

83. Félix Candela dejó España al finalizar la guerra civil, como uno de los miles de republicanos para los que el único camino posible fue la inmigración masiva. Esta condición política pudo causar que no se publicara la obra reciente de Candela en otras publicaciones españolas como la $R e-$ vista Nacional de Arquitectura.

84. "Hormigón: material noble de hoy," Informes de la Construcción, no. 86 (diciembre 1956): s/p.

85. "Iglesia de la Virgen Milagrosa," Informes de la Construcción, no. 86 (diciembre 1956): s/p.

86. Se insiste que el cambio administrativo de la revista en enero de 1959, desde la Dirección General de Arquitectura al Colegio Oficial de Arquitectos de Madrid, necesariamente significó una mayor libertad de expresión para el medio periódico, lo que se reflejó de inmediato en sus contenidos.

87. "Láminas de hormigón armado," Arquitectura, no. 10 (octubre 1959): 2-33. Los edificios más importantes mostrados aquí fueron la capilla de San Vicente de Paul, el centro nocturno La Jacaranda en el Hotel Presidente de Acapulco, la entrada a una urbanización en el lago de Tequesquitengo, la cubierta para banda de música en el conjunto habitacional Santa Fe, el restaurante Los Manantiales y, en Cuernavaca, la plaza de los abanicos y la capilla abierta. 
88. Se encuentran textos de Luis Moya, Fernando Chueca Goitia, Rafael Fernández Huidobro, Antonio Vallejo, Fernando R. Dampierre, Javier Lahuerta, Francisco A. Cabrero, Fernando Higueras y Francisco de Inza.

89. "Strutture e Strutturalismo: Una lettera di Felix Candela," Casabella Continuitá, no. 232 (octubre 1959): 48-53. Si bien fue petición explícita de Candela en esta carta que no se omitieran los créditos de los arquitectos responsables del diseño.

90. Además de la Plaza de los Abanicos en Cuernavaca y el acceso a un fraccionamiento en Tequesquitengo, también se publicó el restaurante Los Manantiales y la capilla de San Vicente de Paul, los mismos ejemplos que aparecían también en Arquitectura el mismo mes.

91. "Wizard of the shells," Architectural Forum 111, no. 5 (noviembre 1959): 154-59. Los ejemplos fueron la iglesia de San Antonio de las Huertas y las capillas de San Vicente de Paul y la abierta de Cuernavaca. al propio autor, quien envió el material para ser publicado a petición del editor español. La aportación madrileña al artículo fue la recopilación de comentarios de varios arquitectos españoles que también se habían formado en la Escuela Superior de Arquitectura de Madrid, en relación a su colega afincado en México y su prolífica producción de cascarones ${ }^{88}$.

El mismo mes de octubre de 1959, salía a la luz en Milán la protesta pública de Candela hacia los excesos a que habían llegado las estructuras. Tres meses antes, Ernesto N. Rogers y Pier Luigi Nervi habían firmado el editorial de Casabella advirtiendo los peligros del exhibicionismo pseudoestructural que se agudizaba cada día más. Candela se sumó a esta crítica, pues, a su juicio, los arquitectos se perdían fácilmente en la superficialidad buscando la expresividad de la estructura como fin sin importar la función, que siempre podría ser resuelta con medios más modestos.

Candela fue claro en deslindarse de los autores de los proyectos arquitectónicos y afirmó su papel como calculista y constructor; ni él ni Nervi podían ser los responsables de la situación del momento. Así, el trabajo editorial de este artículo separaba las obras integrales de Candela - como las naves industriales de forma sencilla adecuada a la funciónde las fantasías que desbordaban de las mentes de los arquitectos y que Candela simplemente calculaba y edificaba ${ }^{89}$. Así, se presentaban por un lado los interiores regulares y amplios correspondientes a una arquitectura industrial de calidad, y por el otro, las extravagantes fuentes y accesos de nuevas urbanizaciones ${ }^{90}$.

Un mes después, en noviembre de 1959, Architectural Forum se distanció radicalmente de la aproximación que el mes anterior había tomado la revista milanesa. Forum presentó a Candela desde la singularidad del personaje, que pasó por su descripción física, su edad, el comentar sus logros de juventud como haber sido campeón de ski o su lealtad como soldado en tiempos de guerra. Este hombre era el que probablemente había ejercido más influencia directa para la realización de cascarones de concreto en todo el mundo. No nos sorprende que, de los cientos de cascarones que Candela había realizado en México por entonces, se publicaran aquí los de formas más extraordinarias. Tres ejemplos de arquitectura religiosa ocupaban fotografías a toda página y una escasa descripción de sus características estructurales. El regalo estaba dado a la vista ${ }^{91}$. 


\section{Cúmulo noticioso. La pluralidad arquitectónica de la séptima década}

La séptima década del siglo xx abrió con el número extraordinario de L'Architecture d'Aujourd'hui, Panorama 1960, con motivo de los treinta años de la revista. En su contenido destacaron las nuevas construcciones estadounidenses, italianas o alemanas, no obstante, la presencia latinoamericana también estuvo presente con ejemplos de Brasil, Venezuela y México. La portada se compuso de un mosaico de edificios entre los que se encontraba la pequeña capilla de San Vicente de Paul, de Enrique de la Mora y Félix Candela.

La pequeña foto de portada se reprodujo en el interior a una escala mayor, pero no era nueva en los medios pues Architectural Forum ya la había publicado. La novedad que se podía ver en $A A$ con relación al mismo edificio publicado antes fue la foto del interior que ya presentaba los vitrales que convergen al centro del espacio. Éstos delimitan las tres láminas de doble curvatura que forman la cubierta de la planta triangular de la capilla. Junto a este ejemplo, se publicó también la obra en construcción de la iglesia de San José Obrero en Monterrey, de similar aspecto visual y sistema constructivo, si bien en este caso hay solamente dos paraboloides hiperbólicos que cierran una planta romboidal ${ }^{92}$.

Se puede decir que este artículo sobre la obra reciente de Enrique de la Mora y Félix Candela fue el único que formalmente representó a México en el panorama francés de 1960, si bien se podrían hacer dos salvedades. La primera, la breve noticia sobre el plan de regeneración urbana de Tlatelolco, de Mario Pani, que mostró una foto aérea de la zona en que se desarrollaría el conjunto. En la planta de la urbanización ya se dejaba ver la magnitud de la empresa: 15 mil apartamentos y una población estimada de 90 mil habitantes distribuidos en edificios de cuatro, ocho y doce niveles. Entre las ventajas se contaba con un 75 por ciento de áreas libres y la integración de vestigios prehispánicos y virreinales de la población histórica al nuevo centro urbano ${ }^{93}$.

$\mathrm{Y}$, sin entrar en debates, también se podría mencionar el proyecto y los avances de obra del edificio de oficinas para la compañía Bacardí, en Tultitlán, Estado de México, de Mies van der Rohe. Ante las fotos descontextualizadas de la maqueta y de las recién levantadas armaduras desnudas de acero, no quedaba duda que este edificio en México era por completo circunstancial y que su ubicación podía leerse como nota al pie ${ }^{94}$.
92. "Deux Églises au Mexique," L'Architecture d'Aujourd'hui, no. 91-92 (septiembre-noviembre 1960): 166-67.

93. "Ensemble urbain de Nonoalco-Tlatelolco a Mexico," L'Architecture d'Aujourd'hui, no. 91-92 (septiembre-noviembre 1960): LXxx.

94. "Immeuble de Bureaux a Mexico," L'Architecture d'Aujourd'hui, no. 91-92 (septiembre-noviembre 1960): 106107. 


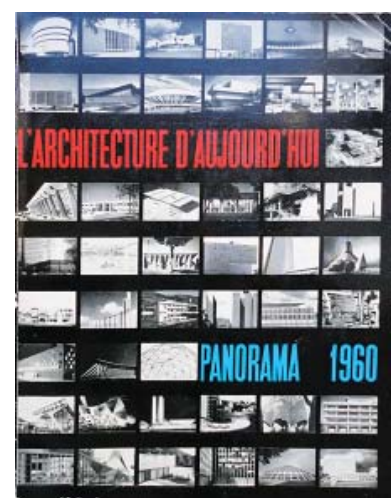

Iglesias de San José Obrero en Monterrey y San Vicente de Paul en DF. Panorama 1960 de L'Architecture d'Aujourd'hui (septiembre 1960).
95. Para los detalles sobre este extenso programa nacional y su impacto en las revistas foráneas véase el apartado 7.3 Camino a la escuela. El aulacasa rural y la educación básica media y superior.

96. "Alla XII Triennale: la scuola rurale messicana," Domus, no. 373 (diciembre 1960): 13-16.

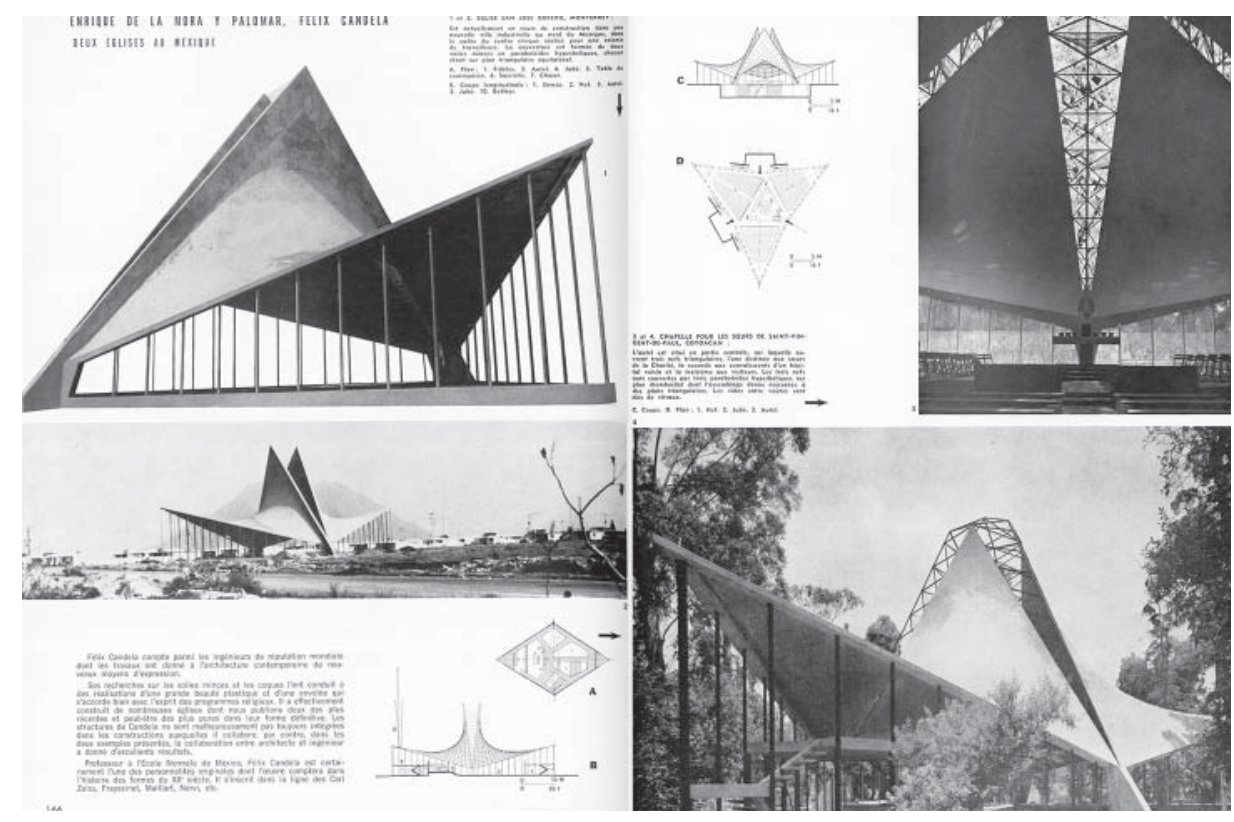

Sin embargo, el mismo año de 1960, en el polo opuesto de esta muestra aislada de arquitectura internacional, comenzó a circular la noticia sobre los procesos de prefabricación que desarrollaba México por entonces. La solución arquitectónica del Comité Administrador del Programa Federal de Construcción de Escuelas (CAPFCE), dirigida especialmente al medio rural y a la educación básica, fue una empresa cien por ciento nacional que obtuvo un enorme éxito debido al adecuado manejo de tecnología y recursos propios ${ }^{95}$.

Así, los modestos ejemplos de escuelas rurales saltaron a los medios internacionales, gracias - en gran medida- a su exitosa participación en la XII Trienal de Milán. El prototipo levantado en la ciudad italiana para ser mostrado al público internacional fue premiado en la muestra por su acertada solución a un problema social urgente que demandaba un procedimiento eficaz. En diciembre de 1960, Domus enfatizó cómo la estructura llegaba a los puntos más alejados del país en piezas prefabricadas y cómo los mismos habitantes participaban en la construcción en las partes del edificio que no requerían técnicos calificados, como los muros de cerramiento sin función estructural ${ }^{96}$. Éstos variaban en cada localidad dependiendo de los materiales accesibles y de los diferentes climas del país. Este programa nacional de construcción de escuelas fue tan completo que incluyó no sólo la casa para el maestro rural, sino también los libros de texto gratuitos y todo el material didáctico para iniciar el curso escolar.

Hay que destacar que no sólo las escuelas captaron la atención de los programas nacionales por esos años, también la habitación rural, 
desde el Instituto Nacional de la Vivienda —bajo la dirección de Félix Sánchez- incursionó con un programa que enseñó a los campesinos cómo construir adobes prefabricados para edificar ellos mismos sus propias viviendas con un conocimiento técnico básico. Estos aspectos fueron comentados en la actualización del acontecer arquitectónico mexicano que publicó The Architectural Review en agosto de $1961^{97}$.

En dicho artículo, el excelente análisis de Irene Nicholson brindó un panorama completo del país con ejemplos que iban de la vivienda unifamiliar de las clases altas a los grandes conjuntos habitacionales de interés social o de edificios aislados que iban a la vanguardia en tecnología al lado de otros que con recursos constructivos probados resolvían las demandas sociales más urgentes. Un tema de debate no demasiado discutido todavía por esos años era cómo integrar la arquitectura contemporánea en un entorno rico en inmuebles de épocas históricas. La autora comentó el diseño de Mario Pani para la regeneración de Nonoalco-Tlatelolco, proyecto que integró vestigios ancestrales con los edificios modernos, o el caso de Ricardo de Robina, por esos años limpiando de retablos neoclásicos la catedral de Cuernavaca y ajustándola al nuevo gusto de la época con retablos contemporáneos. Con este resumen puntual, The Architectural Review se puso al frente de los medios que, al iniciar la década de 1960, miraron globalmente cómo se desarrollaba la arquitectura mexicana.

Pero Tlatelolco no fue sólo un ejemplo que buscó la convivencia de arquitecturas históricas con modernos edificios, sino la mayor empresa realizada en México con interés en resolver el problema de la vivienda social. Ningún antecedente en escala podía compararse a la intervención urbana que regeneraba la zona norte de la ciudad. L'Architecture d'Aujourd'hui siguió de cerca el desarrollo de esta magna obra con noticias puntuales sobre el proyecto y sus avances constructivos, así, en un número dedicado a las nuevas ciudades y centros urbanos, la revista parisina publicó un resumen del estudio urbano y el aspecto formal de los primeros edificios que ya se levantaban sobre el último bastión de los mexicas ${ }^{98}$.

No obstante la magnitud de dicha empresa — diecisiete mil obreros trabajando diariamente- Tlatelolco no era lo único que se construía en el país en los primeros años de la década de 1960. Así, entre 1962 y 1963 se contó con suficientes ejemplos como para editar tres importantes
97. Irene Nicholson, "Mexican Newsletter," The Architectural Review 130, no. 774 (agosto 1961): 101-103.

98. Manuel Chacón, "Restructuration de Mexico: Aménagement d'un secteur," L'Architecture d'Aujourd'hui, no. 101 (abril-mayo 1962): 76-83. 


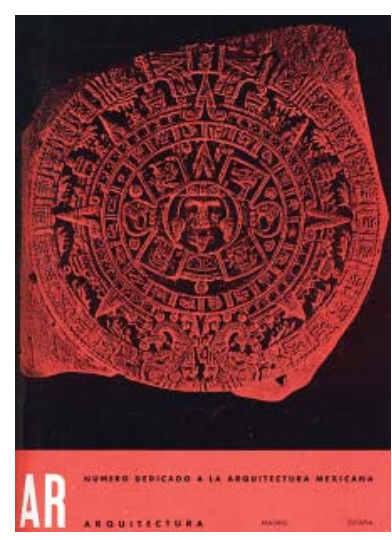

Portada y páginas interiores del monográfico de Arquitectura (agosto 1962).

99. Estados Unidos, por cuestiones políticas, anunció que no asistiría a la reunión internacional en la isla caribeña, por lo que México promovió su participación como organizador de un Simposio Internacional de Arquitectura, a la par que las reuniones de la Asamblea y del Comité Ejecutivo de la UIA. Éste se realizó en suelo nacional entre el 8 y el 12 de octubre de 1963, después del encuentro en La Habana. Se contó con la asistencia de un gran número de arquitectos norteamericanos. El total de asistentes de todos los países sumaron más de dos mil participantes. Véase Mario Pani, "Comentarios," Arquitectura México, no. 84 (diciembre 1963): 344.

100. Ana Esteban Maluenda, "Transmisión bipolar: la difusión de la arquitectura moderna latinoamericana en España (1949-1968)," Revista 180, no. 29 (2012): 28.

101. Arquitectura México, con Mario Pani al frente, tuvo siempre como colaborador a Vladimir Kaspé, corresponsal de la revista francesa en nuestro país.
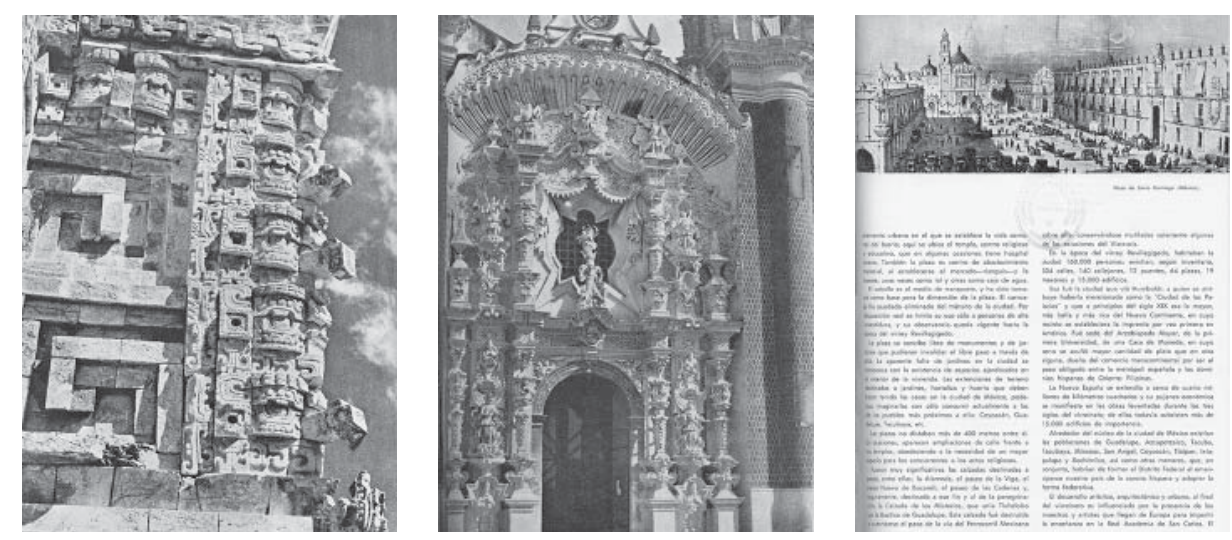

monográficos dedicados al país: Madrid, Londres y París ofrecieron una nueva visión global de México.

Este interés en el acontecer arquitectónico mexicano estuvo ligado - una vez más - a la organización de un evento internacional que activó la red de transmisión fuera de las fronteras nacionales. Así como en la década anterior la organización del Congreso Panamericano de Arquitectos ya había movido los contactos internacionales, en esta ocasión se preparaba el terreno para recibir a la Asamblea y al Comité Ejecutivo de la Unión Internacional de Arquitectos (UIA), después de las sesiones plenarias de su vir Congreso, cuya sede oficial sería La Habana, Cuba ${ }^{99}$.

Así, un año antes de estos encuentros y como resultado de un viaje a México que realizaría el arquitecto español Carlos de Miguel ${ }^{100}$, la revista madrileña Arquitectura, con su monográfico de 1962, se adelantó a otros medios al publicar varios edificios que repetirían al año siguiente Architectural Design y L'Architecture d'Aujourd'hui. Si bien en la década anterior el interés de España en México estuvo siempre presente, no fue sino hasta agosto de 1962 cuando se mostró un compendio realmente significativo de la nueva arquitectura mexicana dirigido al lector español.

La redacción de Arquitectura contó con la colaboración del arquitecto mexicano Enrique Cervantes para la preparación del material, lo que dirige nuestra mirada hacia la Sociedad de Arquitectos Mexicanos y refresca las mancuernas de colaboración ya bien definidas entre otras publicaciones, por ejemplo, Arquitectura México y L’Architecture d’Aujourd'hui ${ }^{101}$. Así, la revista española se nutrió de casos que no serían publicados en otros medios internacionales, pero también, dio a conocer autores y edificios un año antes que la capital francesa e inglesa. 




Aunque a primera vista el monográfico de 1962 parecería un tanto anacrónico $^{102}$, casos como la Escuela Agropecuaria en Dolores Hidalgo de Jorge Campuzano, la Escuela Normal Regional en Ciudad Guzmán de Salvador de Alba o el Instituto Politécnico Nacional de Reynaldo Pérez Rayón, cruzaron las fronteras nacionales trece meses antes de ser publicados en los principales focos de difusión de la arquitectura moderna. Pero también hay que destacar que el Conjunto Aristos, de José Luis Benlliure, las unidades habitacionales Tlalpan y Tacubaya de Jorge Cuevas o la iglesia en el asilo de Zoquiapán de Israel Katzman -entre otros ejemplos- alcanzaron al público internacional sólo a través de Arquitectura ${ }^{103}$.

Si bien la actualidad de la mayoría de los edificios seleccionados es incuestionable para la época —el Hotel María Isabel recién se terminaba el año que era publicado por Arquitectura - también encontramos el caso aislado de los frontones de la Ciudad Universitaria que para ese año ya cumplían una década de haberse construido ${ }^{104}$. Por otro lado, la única omisión importante en este número fue Tlatelolco. No por falta de interés del medio en el urbanismo y la vivienda social, pues dos textos de análisis trataron ampliamente el tema del crecimiento de la ciudad ${ }^{105}$ sino a la exclusividad que ejercía Mario Pani con sus proyectos y los medios —nacionales e internacionales - en los que decidía publicar.

Hay que destacar que el monográfico de Arquitectura de 1962 ofreció una visión del país bastante acertada, pues descubría la
Conjunto Aristos de José Luis Benlliure en las páginas del especial de Arquitectura consagrado a México.

102. La foto de portada y el texto introductorio sobre la arquitectura histórica fueron tomados del catálogo 4000 años de arquitectura mexicana publicado en 1956, cuyo antecedente fue la exposición itinerante que se ha comentado antes.

103. Debido a que los alcances de este estudio se centran en comparar la velocidad de difusión entre medios internacionales, se está obviando que los ejemplos citados se publicaron en medios nacionales y que la propia difusión que alcanzaron las revistas mexicanas al ser distribuidas fuera de las fronteras nacionales es, en cierta forma, también difusión internacional.

104. También llama la atención que se haya integrado en esa página el plano del conjunto universitario, ya tantas veces publicado. Lo cierto es que en la Revista Nacional de Arquitectura esta obra solo tuvo cabida en una fotografía aérea que invitaba al viII Congreso Panamericano de Arquitectos. Véase RNA, no. 127 (julio 1952): 38. Esta mención en el monográfico de 1962 pudo ser una compensación por la omisión del medio hacia la universidad mexicana.

105. Seminario de Urbanismo de la Escuela Nacional de Arquitectura, "Historia del urbanismo en México y en su ciudad capital," Arquitectura, no. 44 (agosto 1962): 7-12 y Enrique Cervantes, "Panorama del urbanismo contemporáneo en México," Arquitectura, no. 44 (agosto 1962): 16-18. 
106. Hay que recordar que también el monográfico de L'Architecture d'Aujourd'hui de abril de 1955 utilizó el recurso en la portada del pasado prehispánico como carta de presentación del país extranjero.

107. "1963 Congress and Assembly of the International Union of Architects," RIBA Journal 70, no. 3 (marzo 1963): 92. Además del interés que el propio simposio podía despertar en los participantes, se enfatizó la organización de visitas turísticas a Mérida y las ruinas mayas, Oaxaca, Mitla, Monte-Albán y Acapulco.

108. "VII $I^{\text {th }}$ Congress Havana Cuba," RIBA Journal 70, no. 11 (noviembre 1963): 433 $34 \mathrm{y}$ "The Seventh Congress of the IUA," RIBA Journal 70, no. 12 (diciembre 1963): 478-80. arquitectura contemporánea mexicana de la misma forma en que se llega a conocer realmente el país: visitando sus extremos. De viviendas de lujo en zonas residenciales exclusivas hasta pequeñas casas de interés social apiñadas en barrios populares; de edificios gubernamentales que todavía recurrían a un cierto monumentalismo hasta edificios comerciales de formas internacionales; de escuelas rurales hasta centros universitarios tecnológicos utilizando una rigurosa modulación y elementos constructivos estandarizados y prefabricados. Todo esto - y más- pobló las páginas del número especial de la revista madrileña.

Todavía cabe puntualizar dos aspectos más, el primero, que si bien la revista se adelantó a medios de mayor influencia en mostrar algunos edificios, su diseño gráfico fue demasiado convencional, aunque se reconoce que en casi todas las páginas las fotografías se acompañaron con una breve descripción, alguna planta, un corte o un alzado. Un segundo aspecto es la clara intención en remitir al pasado prehispánico mexicano con la foto del calendario azteca en la portada ${ }^{106}$, que no tenía relación alguna con la arquitectura contemporánea que se revelaba en sus páginas. Se confirmaba así que, pese a la actualidad de su arquitectura, México seguiría habitando en el imaginario de la tradición que alimentó la modernidad.

Sin embargo, será hasta 1963 cuando se alcance el punto más alto de la difusión de la arquitectura moderna mexicana en las revistas europeas. Desde principios de ese año la mirada internacional giró hacia Latinoamérica con la invitación a participar en el viI Congreso de la UIA en Cuba y México ${ }^{107}$. No por casualidad, la revista del Royal Institute of British Architects (RIBA) dio especial difusión al encuentro, pues su director - Sir Robert Matthew- lo era también en esos años de la UIA. El discurso inaugural de la sesión plenaria en La Habana, así como un resumen de ambos encuentros llegaron también a las páginas del citado medio inglés ${ }^{108}$.

La cita internacional en México — organizada desde la Sociedad de Arquitectos Mexicanos- ofreció reuniones para las ocho comisiones de trabajo de la UIA, conferencias magistrales y exposiciones de arquitectura. Es notable que el interés internacional por ver de cerca el trabajo mexicano estuviese dirigido al programa de construcción de escuelas rurales que, desde iniciada la década, ya ganaba sitio en las publicaciones periódicas. 
Edificio Cremi de Ricardo de Robina y Jaime Ortiz Monasterio en el monográfico de Architectura Design (septiembre 1963). A la derecha la portada de dicho número.

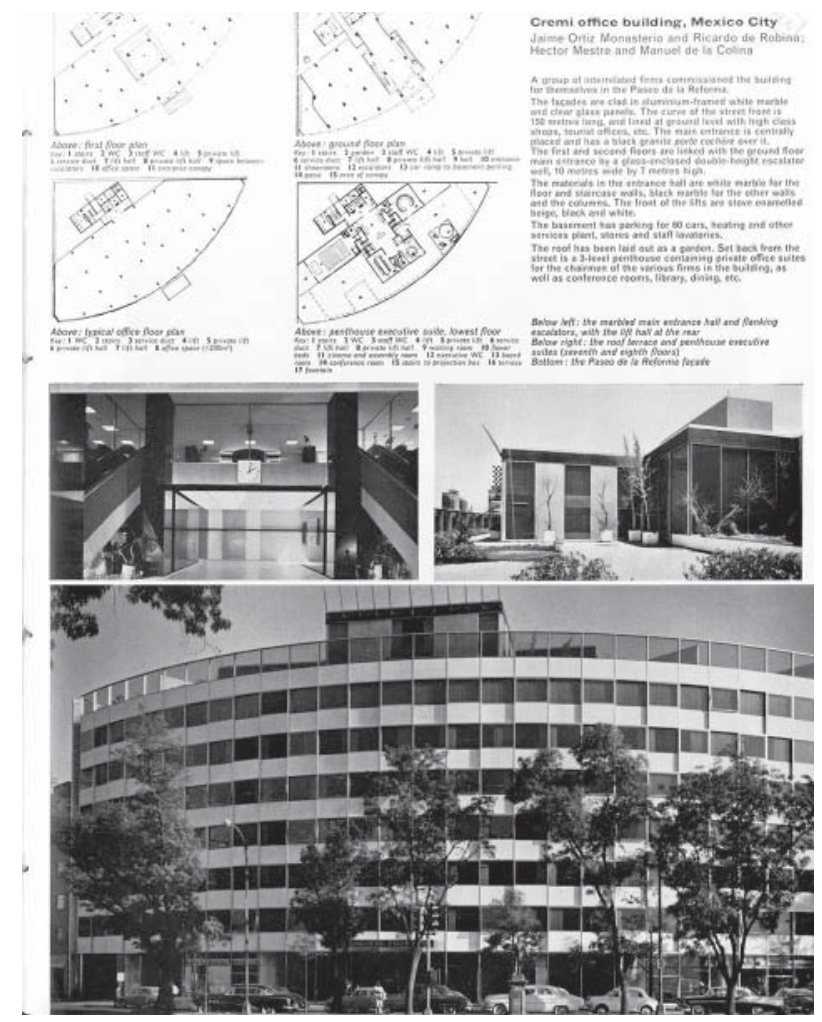

Es de lamentar que, por falta de organización, tan sólo una mínima parte de los interesados en conocer los procesos mexicanos de prefabricación, asistiesen a la visita guiada ${ }^{109}$.

Sin contar las fallas inherentes a todo evento multitudinario, el panorama editorial se mostró de lo más saludable y al día. En septiembre de 1963 - un mes antes de las Jornadas Internacionales en Méxicotres importantes medios de difusión sacaron a la luz números especiales dedicados a la producción arquitectónica más reciente. Arquitectura México aprovechó la conmemoración de los 25 años de su revista y publicó su número 83 - con capacidad triple de lo normal - brindando una panorámica de lo que en el país se había realizado en los últimos años ${ }^{110}$. Y en el extranjero, Architectural Design y L'Architecture d'Aujourd'hui hacían lo propio con importantes ejemplares monográficos.

Para la preparación del material, Architectural Design contó con la colaboración de su corresponsal Jorge Gleason, quien entonces era el editor - junto con Manuel González Rul- de Arquitectos de México. Y L'Architecture d'Aujourd'hui, además de su corresponsal de siempre - Vladimir Kaspé- contó también con la ayuda del joven arquitecto mexicano Irving Nerubay. Es sintomático que ambas publicaciones ofrecieran en portada imágenes del mundo prehispánico que - una vez más- vinculaban la tradición con la modernidad. Así, un mapa de

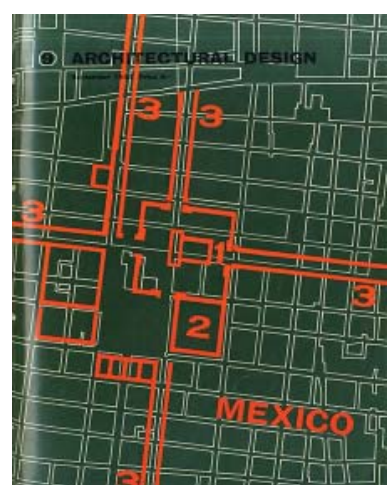

109. No obstante la prodigiosa hospitalidad mexicana, el simposio falló en logística básica, como la falta de coordinación de los medios de transporte que movilizarían a los visitantes del centro de la ciudad a las sedes oficiales, lo que devino en impuntualidad de los eventos o cancelaciones de última hora. Con respecto a la escuela rural, el resultado fue que sólo 35 de unos 800 interesados, asistieron a la demostración pues las invitaciones no llegaron a tiempo a la mayoría de los asistentes al simposio. "The Seventh Congress of the IUA," RIBA Journal 70, no. 12 (diciembre 1963): 480.

110. Arquitectura México, no. 83 (septiembre 1963). Se menciona aquí este número nacional por su relevancia dentro de la propia publicación y como coincidencia con los otros dos números monográficos, éstos sí extranjeros, que en el mismo mes y año se dedicaron a México. 
Tenochtitlan — capital del imperio mexica - que se sobreponía al trazado virreinal y moderno de la actual ciudad de México fue el recurso de la revista londinense para presentar al país latinoamericano, mientras que una cabeza monumental olmeca fue el medio de la publicación parisina ${ }^{111}$.

No obstante esta coincidencia, se encuentran diferencias sustanciales entre ambos monográficos. La aproximación a la arquitectura mexicana por parte de ambas publicaciones se realizó desde perspectivas diferentes, aunque - como se verá—algunos de los edificios publicados necesariamente se repitieron. Así, el texto introductorio de Architectural Design - firmado por el mexicano Carlos Mijaresdebatió por qué sí o por qué no habría una arquitectura contemporánea mexicana ${ }^{112}$. Mientras tanto en L'Architecture d'Aujourd'hui, textos de diferentes autores revisaron la evolución de la arquitectura mexicana desde tiempos prehispánicos pasando por el periodo virreinal y el independiente hasta alcanzar el siglo $\mathrm{xx}^{113}$. Solo después de varias páginas ilustradas profusamente con arquitectura histórica llegamos a una breve actualización de la arquitectura mexicana de la última década ${ }^{114}$.

Pero - obviamente- también se encuentran temas teóricos de debate que coincidieron en intereses, como la singularidad de la arquitectura mexicana contemporánea, la orientación que debía seguir en ese momento la arquitectura, su enseñanza en el país o los problemas del urbanismo y la vivienda social ${ }^{115}$. El gran ausente del monográfico de Arquitectura de 1962 - Tlatelolco - tuvo presencia - si bien mínimaen Design y una gran acogida - como era de esperarse- en $A A$, con un extenso artículo que actualizó la información ya dedicada al proyecto y

111. La portada se ilustró también con una tumba olmeca. Como indica la revista, las fotos se tomaron de la Historia General del Arte Mexicano, época prehispánica, de Raúl Flores Guerrero. Las piezas monumentales pueden verse en la actualidad en el Parque-Museo La Venta en Villahermosa, Tabasco, México.

112. Carlos Mijares B., "Mexican contemporary architecture, or contemporary architecture in Mexico?", Architectural Design 33, no. 9 (septiembre 1963): 410-11.

113. César Novoa Magallanes, "Architecture
Préhispanique," L'Architecture d'Aujourd'hui, no. 109 (septiembre 1963): 2-5; Roberto Álvarez Espinosa, "L'Architecture Hispanique," L'Architecture d'Aujourd'hui, no. 109 (septiembre 1963): 6; Luis Mc Gregor Cevallos, "L'Architecture de la Nouvelle Espagne," L'Architecture d'Aujourd'hui, no. 109 (septiembre 1963): 7 y Enrique del Moral, "Le Baroque et le Néo-classique," L'Architecture d'Aujourd'hui, no. 109 (septiembre 1963): 8-9.

114. Pedro Ramírez Vázquez, "LAArchitecture Mexicaine de 1955 a 1963,"
L'Architecture d'Aujourd'hui, no. 109 (septiembre 1963): 10-11.

115. Alberto González Pozo, "The basis of Mexican economy and the remedy for the housing problems," Architectural Design 33, no. 9 (septiembre 1963): 412-14; Vladimir Kaspé, "Orientation actuelle de larchitecture mexicaine," L'Architecture d'Aujourd'hui, no. 109 (septiembre 1963): 10-11 y Jorge González Reina, "Évolution de l'enseignement de l'architecture au Mexique. Nécessité d'une réforme," L'Architecture d'Aujourd'hui, no. 109 (septiembre 1963): 10-11. 
Mercado Alcalde en

Guadalajara de Horst

Hartung en el monográfico

de L'Architecture

d'Aujourd'hui (septiembre de

1963). A la derecha portada

de dicho número.

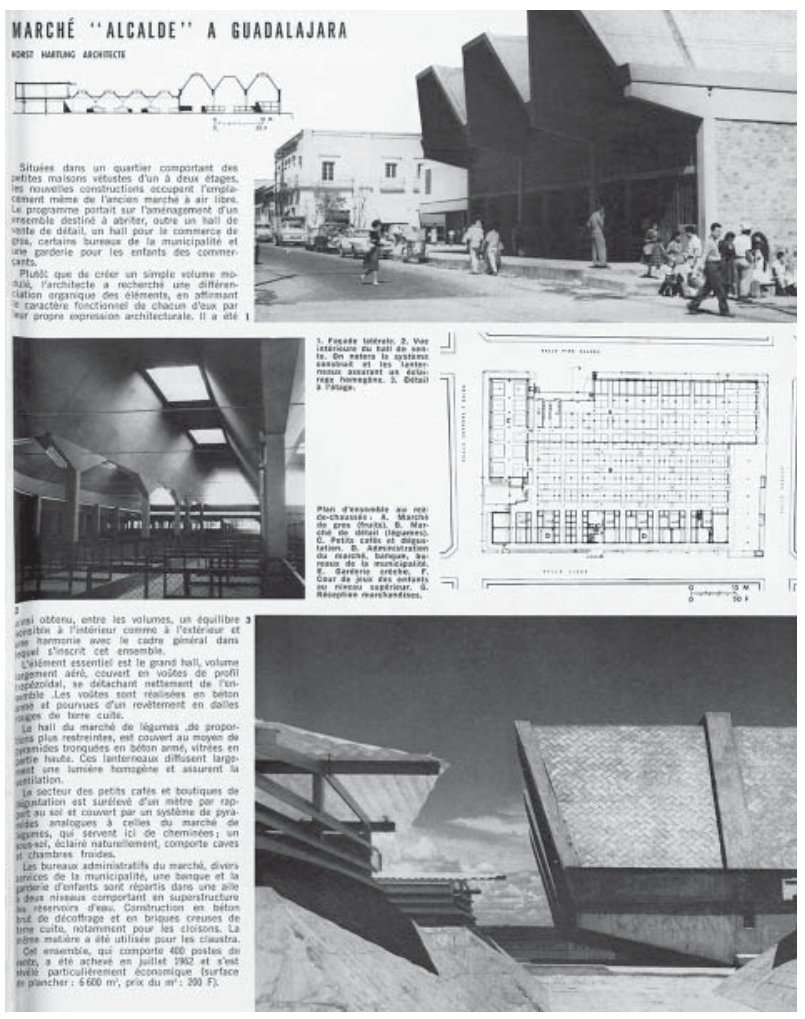

publicada desde abril de $1962^{116}$. La torre de apuntada forma triangular —símbolo del conjunto- mostraba los veinticuatro niveles de su todavía desnuda estructura de hormigón armado antes de ser recubierta por la cancelería de aluminio y cristal.

Entre los edificios coincidentes entre estos dos monográficos se encuentran algunas escuelas, como la ya mencionada Escuela Normal Regional en Ciudad Guzmán de Salvador de Alba o la escuela rural del CAPFCE, pero también ejemplos de vivienda de interés social, como la Unidad Independencia de Alejandro Prieto o una casa particular, obra de Francisco Artigas. Dentro de la arquitectura comercial y de servicios, destacó el Centro Comercial Jacaranda de Ramón Torres Martínez y Héctor Velázquez y la capilla de San Vicente de Paul, de Enrique de la Mora y Félix Candela, que ya se sabe publicada varios años antes también en otras revistas.

Architectural Design publicó en exclusiva algunos edificios de oficinas como el de Seguros Monterrey de Enrique de la Mora o el edificio Cremi de Ricardo de Robina y Jaime Ortiz Monasterio. El primero con un diseño estructural absolutamente vanguardista y el segundo, de diseño más bien convencional, pero adaptado a la esquina curva del importante Paseo de la Reforma. L'Architecture d'Aujourd'hui, a diferencia de la londinense, prestó especial atención a otras latitudes mexicanas y

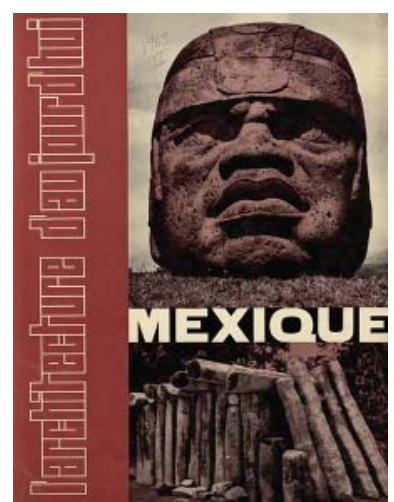

116. Mario Pani, "Urban renewal programme for Mexico City, and the Nonoalco-Tlaltelolco housing scheme," Architectural Design 33, no. 9 (septiembre 1963): 415 y "Restructuration d'un secteur de Mexico Nonoalco-Tlaltelolco," L'Architecture d'Aujourd'hui, no. 109 (septiembre 1963): 14-17. 
fijó la mirada en Guadalajara, publicando importantes obras de Julio de la Peña, Horst Hartung y Alejandro Zohn ${ }^{117}$. También, con el programa nacional de construcción de hospitales — dirigido por Alejandro Prietoconsiguió que nombres de ciudades nunca antes mencionadas en las revistas especializadas de arquitectura -como Manzanillo, Culiacán o Los Mochis - ampliaran una geografía que por primera vez superaba la exclusividad de la ciudad de México. Aunque también —es ciertoeste monográfico de $A A$ se caracterizó por la gran cantidad de ejemplos capitalinos - muchos de ellos de vivienda unifamiliar- que sólo se conocerían fuera de México por su inclusión en este número especial.

También, cabe comentar que, a diferencia del anterior monográfico de $A A$ de 1955, que destacó por el uso de la fotografía a color, estos dos especiales de 1963 siguieron un diseño gráfico sin innovaciones, pero, eso sí, muy cuidadoso y limpio. En algún caso, en que fue publicada la misma fotografía - como en la Escuela Secundaria Tierra y Libertad de Alfonso Garduño- $A A$ borró el fondo de la calle aledaña, para beneficiar una panorámica pura de los amplios descansos con barandales que salen del volumen de las escaleras.

Otra diferencia fundamental que se reconoce entre estos especiales de 1963 y su equivalente de 1955 es que no sólo se aumentó considerablemente la cantidad de edificios distintos publicados, sino que no hubo una obra representativa del país que en conjunto antecediera a todo lo construido en México hasta ese momento. Ninguna obra con la unidad e importancia de la Ciudad Universitaria se llevaría a cabo de nuevo, y, a pesar de la intención de presentar a Tlatelolco en lugar protagónico de las publicaciones, no se consiguió la contundencia alcanzada al abrir el monográfico de 1955.

Hay que hacer notar que, a pesar del intento de agrupar por

117. Del primero, la Biblioteca y Casa de la Cultura; del segundo el Mercado Alcalde y del tercero -entre otras obras- el Mercado Libertad, el Parque Agua Azul o el Internado Cervantes.

118. Sorprende que, a diferencia del monográfico de 1955 en que éste fue el caso de sólo dos edificios, en este número de 1963 se aumentó a quince los ejemplos intercalados entre los anuncios comerciales. géneros arquitectónicos, no se reconoce un orden de lectura y el recorrido termina siendo disperso y sin unidad. La confusión aumenta en $A A$ al encontrar ejemplos aislados de edificios intercalados entre las páginas de publicidad que quedaron fuera del contenido general monográfico ${ }^{118}$. De esta manera, los números dedicados al país en 1963 simbolizaron el estado del momento: ausencia de grandes obras institucionales como las que caracterizaron la década anterior y abundancia en ejemplos de menor escala. 
Pero, sin duda, lo más importante a destacar de ambos monográficos es la calidad de sus textos de análisis — aunque la aproximación al tema arquitectónico vaya de lo más académico y oficial hasta las posturas más novedosas de análisis - y la actualidad de la mayoría de los edificios presentados al lector internacional. Por ejemplo, Architectural Design publicó el edificio de Seguros Monterrey finalizado el mismo año que la publicación salía a la luz y L’Architecture d’Aujourd'hui comentó el Instituto Nacional Indigenista - de Alejandro Caso- con un diseño que ya prescindía del formalismo funcionalista utilizando arcos en la fachada y ventanas rectangulares asimétricas, terminado también en 1963. Para $A A$ también hay que destacar la apertura hacia la difusión en conjunto de la otra gran escuela de arquitectura del país, la de Guadalajara.

En los siguientes años todavía encontraremos algunas actualizaciones que ofrecieron una panorámica general de la arquitectura mexicana. Sin embargo, estos dos monográficos de 1963, en conjunto, ofrecieron la última visión completa de los alcances de la arquitectura moderna mexicana. Con ellos, México se mostró por última vez como un país que se seguía construyendo incansablemente abarcando los géneros edificatorios más importantes que vio nacer la modernidad: la educación, la salud y la vivienda social. Lo que se descubrirá después, aunque sus ejemplos sean notables, no podrán igualarse al intento de cubrir la extensa gama de necesidades sociales básicas que, a principios de la década de 1960, materializaban con los modestos - pero sobresalientes- prototipos de escuelas rurales y hospitales diseminados en la vasta geografía nacional.

No sólo Francia e Inglaterra prestaron atención a México en 1963, ya que un mes después de la aparición de los monográficos de L'Architecture d'Aujourd'hui y Architectural Design, la italiana Zodiac publicó una visión parcial sobre México ${ }^{119}$. La autora, Esther McCoy — miembro del consejo editorial de la angelina Arts \& Architecture y colaboradora de la revista milanesa - presentó su aproximación personal al país. En dos artículos, McCoy narró una reciente visita a su vecino del sur, en los que destacó algunos aspectos de la arquitectura y el urbanismo contemporáneos. En el primero, al regresar a México después de seis años, la autora reconoció el crecimiento de una clase media que se adaptaba a las nuevas urbanizaciones de los extrarradios de la ciudad diseñadas para el automóvil, pero también descubrió cómo los estudiantes —después
119. Esther McCoy, "Mexico Revisited (I)," y "Mexico Revisited (II): The Presence of Candela," Zodiac, no. 12 (octubre 1963): $106-17$ y 118-131 respectivamente. 


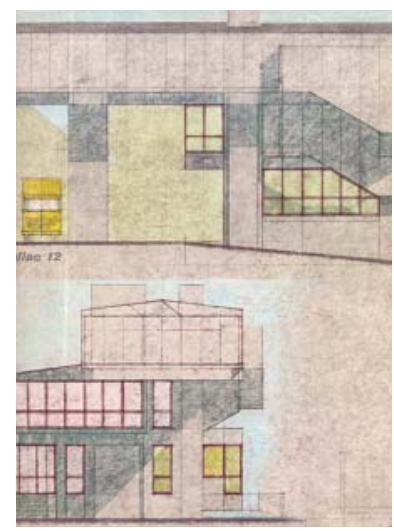

Revisión a la arquitectura mexicana en Zodiac (octubre 1963).

120. Véase por ejemplo "Concrete structure - Félix Candela," Arts \& Architecture 75, no. 10 (octubre 1958): 1819.

121. Proyecto para la catedral de Villahermosa, Tabasco, de 1960, con el arquitecto Jorge Creel o la iglesia en los Jardines de San Mateo, de finales de 1961, entre otros.
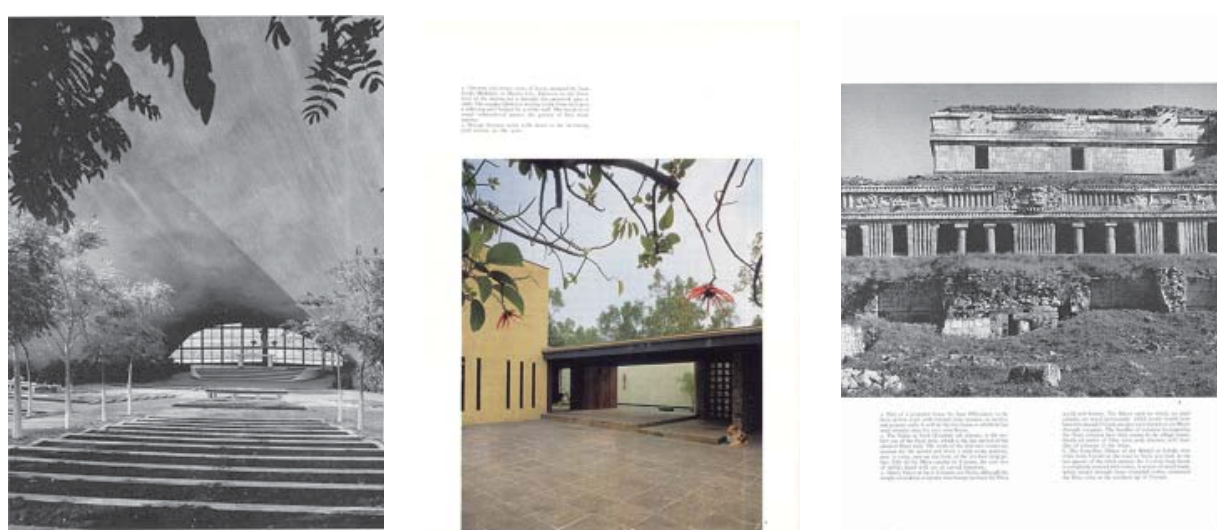

de una década en funciones- se apropiaban del amplio espacio central del campus universitario. La vivienda de la clase alta había encontrado la forma, escala y color adecuados, y su máximo exponente - siguiendo a McCoy - no era Luis Barragán sino Juan Sordo Madaleno. Y, al margen de las tendencias, Juan O'Gorman y sus mosaicos - tema que sería el gran interés de la autora - fueron recordados en el texto antes de dejar la ciudad de México para trasladarse a la península de Yucatán y admirar el desarrollo arquitectónico y urbano de los mayas del periodo clásico.

Un segundo artículo revisó la obra reciente de Félix Candela. McCoy no era ajena al tema de los cascarones del español radicado en México, pues desde 1955 Arts \& Architecture mantenía al corriente a sus lectores con las realizaciones más recientes del famoso arquitecto. Así, su análisis para Zodiac fue un resumen de lo que el medio angelino manejaba con soltura. Un aspecto fundamental que destacó la autora sobre estas cubiertas delgadas de hormigón armado fue que los cascarones tenían validez sólo cuando reflejaban el desarrollo tecnológico del país para el que son diseñados. De esta manera, las superficies de Candela se percibían como puramente mexicanas, ya que reproducirlas en países como los Estados Unidos, en donde la mano de obra resultaba prohibitiva, implicaba una labor casi imposible de imitar. El artículo también mostraba no sólo las realizaciones más recientes - aunque ya publicadas en otros medios como el restaurante Los Manantiales- ${ }^{120}$ sino algunos de los proyectos en curso de Cubiertas Ala ${ }^{121}$.

Al pasar las páginas de Zodiac, queda la impresión de que México no es sólo esto, por tanto se subrayó antes el valor de los monográficos, que mostraron un panorama mucho más amplio del que podía ofrecer un repaso a la arquitectura prehispánica y a las sorprendentes formas - si bien ya para entonces demasiado vistas- de Candela. 
En 1964 L'Architecture d'Aujourd'hui dedicó un número doble a un siglo de arquitectura, mismo que revisó el desarrollo de la arquitectura moderna desde mediados del siglo xix hasta la década de 1960. Diversos análisis se estructuraron por temas generales, escuelas, arquitectos o países, y, si bien de estos últimos se reconocían los nombres de siempre -Francia, Estados Unidos, Inglaterra - hay grandes ausencias - Brasil— y nuevas presencias -España - en el panorama internacional. Puede sorprender que el único país latinoamericano que gozó de una revisión en este número fue México, que contó con el análisis puntual de Irving Nerubay $^{122}$.

A diferencia de lo publicado por Zodiac meses antes, el artículo sobre México fue una visión mucho más general del panorama arquitectónico nacional. Un breve repaso contextualizó al lector con la tradición constructiva ancestral -monumentalidad, espacios abiertos, uso del color- y explicó así la presencia de las extensas explanadas universitarias y de los auditorios musicales al aire libre en el siglo xx. Aunque el texto identificó a la arquitectura mexicana con la idiosincrasia propia del país, esto es, exuberancia y gran sensibilidad, la racionalidad de algunos de los ejemplos mostrados - como los volúmenes prismáticos del Hotel María Isabel- contradecían la percepción unitaria de un solo espíritu mexicano, lo que al final favoreció la aproximación del autor al país, cuna de inmensas contradicciones. Hay que hacer notar que, después de las referencias obligadas a los maestros mexicanos - Villagrán, Pani y Del Moral—o a las mancuernas definitivas como Candela-De la Mora para el diseño y construcción de iglesias, Nerubay subrayó también la importancia de la joven escuela de arquitectura de Guadalajara, que había tenido considerable presencia en el número monográfico del año anterior.

Así, las obras representativas de la arquitectura moderna mexicana -a través de las fotografías que ya habían circulado extensamente en los medios internacionales - cerraron una serie de revisiones y actualizaciones que construyeron la visión panorámica del país durantelos primeros años de la década de $1960^{123}$. Entonces, México era considerado todavía un país joven en continuo crecimiento económico, resolviendo sus problemas sociales; sin duda, parecía seguir siendo el paraíso de las nuevas generaciones de jóvenes arquitectos que por miles llenaban las aulas de las cada vez más numerosas escuelas de arquitectura del país.
122. Irving Nerubay, "Mexique," L'Architecture d'Aujourd'hui, no. 113-114 (abrilmayo 1964): 174-77. El autor colaboró en la realización del número monográfico de septiembre de 1963.

123. En el citado artículo se incluyeron imágenes del Conservatorio Nacional de Música, del Centro Urbano Presidente Alemán, de las Torres de Satélite, del Pedregal de San Ángel, de la casa-estudio de Luis Barragán, de la Ciudad Universitaria, del aeropuerto de Acapulco, del Hotel María Isabel y del Conjunto Habitacional Nonoalco-Tlatelolco. Nótese el predominio de ejemplos de Mario Pani en la selección. 
Hacia la mitad de la década de 1960 surgió un nuevo protagonista en la difusión de la arquitectura moderna mexicana. Como resultado de un extenso programa gubernamental, el Museo Nacional de Antropología e Historia (MNAH) se erigió como la obra más importante del país dada a conocer en los medios internacionales. Desde la construcción de la Ciudad Universitaria en 1952, ningún otro edificio había alcanzado la notoriedad del vasto museo, $\mathrm{y}$ - al igual que en el proyecto universitario- se reconoce un trabajo de equipo, a pesar de que el nombre de esta obra se encuentre indisolublemente ligado al de un solo arquitecto.

Este fue el proyecto más significativo que resolvió magistralmente el déficit de espacios dedicados a la exhibición del inmenso patrimonio arqueológico y artístico nacional ${ }^{124}$. Bajo la dirección de Pedro Ramírez Vázquez asociado con Rafael Mijares y Jorge Campuzano, al menos cuarenta especialistas diseñaron el programa arquitectónico y los recorridos de las diversas salas. A la par del diseño y la construcción del edificio, se realizó importante trabajo de campo que incrementó el acervo, ya que se trasladaron miles de piezas de todo el país a la capital, desde cerámica hasta monolitos de toneladas de peso. Asimismo, se realizaron numerosos viajes al interior de la República para documentar la parte etnográfica de la museografía ${ }^{125}$. Los logros alcanzados fueron inmediatamente destacados en una oleada de noticias que fueron llenando las páginas de importantes revistas europeas y norteamericanas.

124. En 1962, con Adolfo López Mateos como presidente de la República y Jaime Torres Bodet como secretario de Educación Pública, se creó el sistema de museos nacionales. $\mathrm{Al}$ arquitecto $\mathrm{Pe}$ dro Ramírez Vázquez se le encomendaron -de nueva factura- el Museo de Ciudad Juárez, la Galería de Historia, el Museo de Arte Moderno y el Museo Nacional de Antropología e Historia, además de la restauración del Museo de la Ciudad de México y la instalación del Museo del Virreinato en Tepotzotlán. Todos fueron inaugurados en 1964 antes de finalizar el mandato presidencial.

125. Pedro Ramírez Vázquez, "Museo Nacional de Antropología," Arquitectura México, no. 88 (diciembre 1964): 193-212.

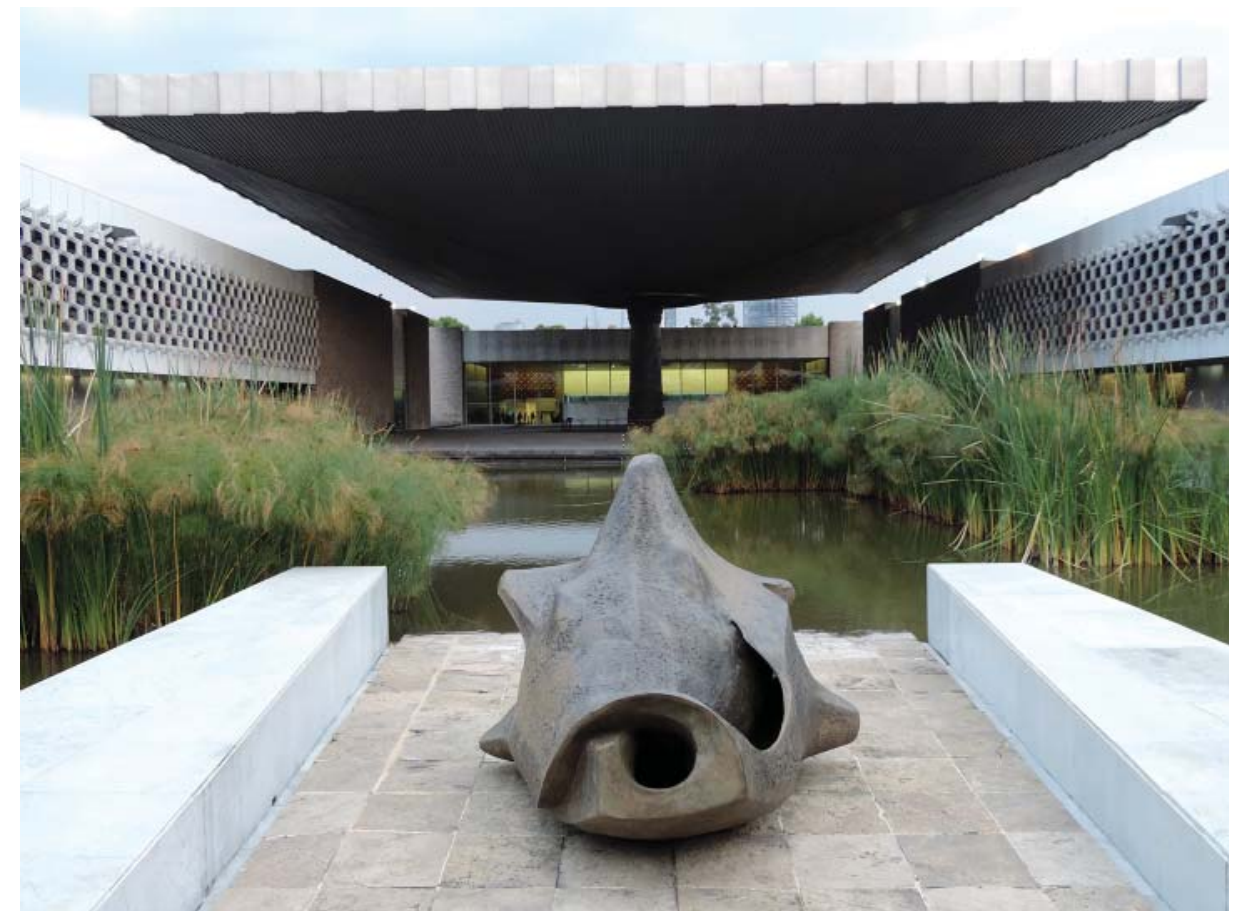


Paraguas de $82 \times 54$ metros en el patio del Museo Nacional de Antropología e Historia de la ciudad de el relieve del artista José Chávez Morado (1964). En la página anterior, el paraguas visto desde el fondo del patio, 2014 México. El soporte ostenta

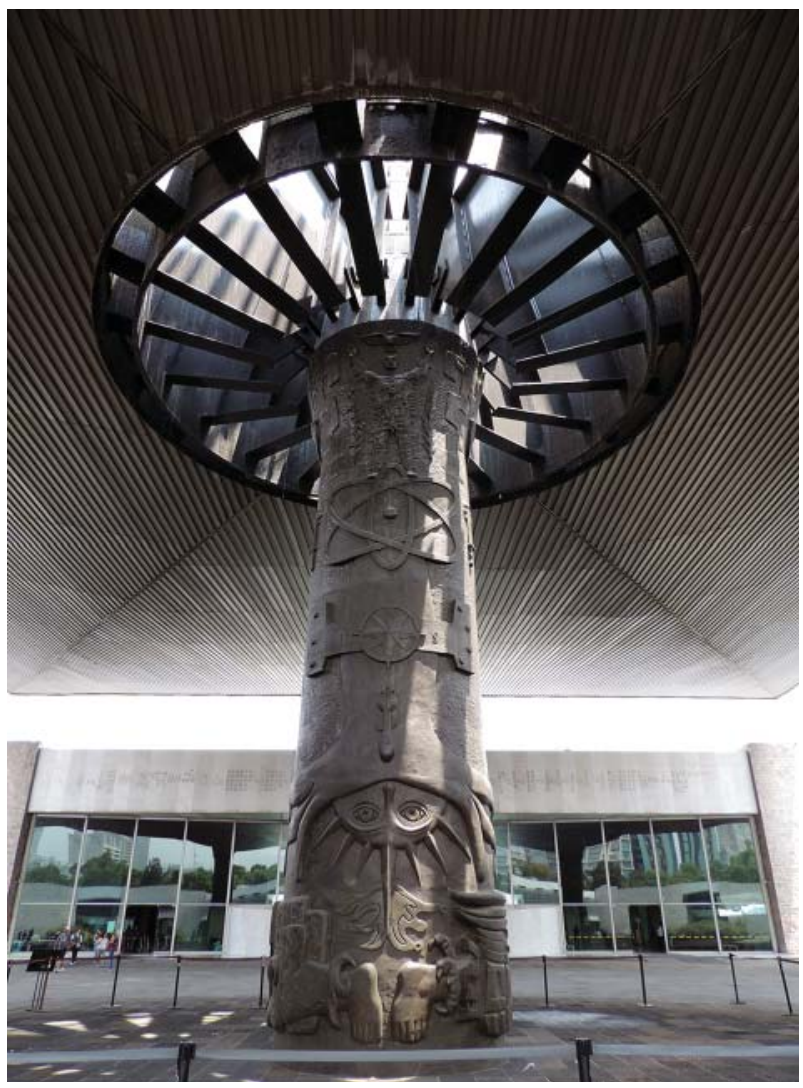

El museo abrió sus puertas el 17 de septiembre de 1964 y, al año siguiente, las noticias empezaron a circular en los medios especializados internacionales. En mayo, Arquitectura ${ }^{\mathbf{1 2 6}}$, de Madrid y Techniques et Architecture $^{127}$ de París, publicaron artículos que destacaron la libertad de recorrido, el amplio patio central que distribuye al visitante a todas las salas y el enorme paraguas que cubre un área importante de la zona descubierta, elemento que permite mantenerse a resguardo aún en tiempo de lluvias. T\&A concentró su interés en la cubierta de 82 x 54 metros - resuelta con un solo apoyo central— pues publicó no sólo la fotografía del anillo estructural del que en forma radial salen las vigas de acero, sino también el corte longitudinal del museo donde se nota la estructura de tirantes y los pilotes de cimentación. También subrayó la tecnología utilizada como el aire acondicionado y las guías electrónicas, de vanguardia en esa época en la arquitectura de museos.

Por otro lado, la madrileña rescató los textos del discurso inaugural de Ramírez Vázquez y repitió la postura oficial de la época que enfatizaba los valores de la arquitectura prehispánica y virreinal en la arquitectura moderna, esto es, la generosidad en la concepción de los espacios abiertos, las proporciones volumétricas o el uso de los materiales con su color y textura natural. La aportación española a esta noticia fue el texto de Juan
126. "Museo nacional de antropología México," Arquitectura, no. 77 (mayo 1965): 23-28.

127. "Museé d'Anthropologie et d'Histoire," Techniques et Architecture 25, no. 4 (mayo-junio 1965): 14-15. 
128. Juan Ramírez de Lucas, "Notas de arte. Los nuevos museos de la ciudad de México, un alarde de instalaciones modélicas," Arquitectura, no. 77 (mayo 1965): 29-32.

129. "Dos museos en México," Informes de la Construcción, no. 182 (julio 1966): 33 43. Menos de un año después, en marzo de 1967, la misma revista publicó otros dos museos del mismo programa nacional, también bajo la dirección de Pedro Ramírez Vázquez: el Museo de Arte Moderno y el Museo de Ciudad Juárez.

130. Irene Nicholson, "Anthropological Museum, Mexico City," The Architectural Review 140, no. 834 (agosto 1966): 118-25.
Ramírez de Lucas, que describió la museografía y sus logros modernos, uno de ellos, la creación de un museo como un organismo dinámico y vivo, autónomo, y no un museo muerto como almacén de antigüedades valiosas ${ }^{128}$. Esto se logró gracias a que el museo no se limitó a las salas de exposiciones sino que contó desde un principio con biblioteca, servicios escolares, talleres, bodegas de estudio, laboratorios, un auditorio y la sede de la propia Escuela Nacional de Antropología e Historia.

Durante 1966 se mantuvo el interés del nuevo museo en España y Francia - aunque desde otros medios- y se sumaron a la difusión Inglaterra e Italia. De esta manera, la madrileña Informes de la Construcción publicó en julio un artículo que también incluyó a la Galería de Historia, en el mismo Bosque de Chapultepec ${ }^{129}$. Si bien los textos seguían de cerca el discurso inaugural de Ramírez Vázquez, Informes también destacó otros aspectos más de acuerdo a los intereses de la revista técnica, como la combinación de materiales industrializados al lado de otros de manufactura artesanal. Así, en los recubrimientos de muros podía verse tanto mármol blanco laminado industrialmente como mármoles de Santo Tomás de Puebla de calidad artesanal. Claro que la tecnología de punta no se reflejó exclusivamente en los acabados, si se considera el paraguas del patio, cuyo apoyo fue tratado escultóricamente en bronce con una composición de José Chávez Morado que muestra tanto el mestizaje como la proyección de la cultura mexicana hacia todos los rumbos cardinales.

El mismo año 1966, un mes después que IC, The Architectural Review aportó un análisis del edificio basado en la visita a éste por parte de la crítica Irene Nicholson ${ }^{130}$. La autora destacó como uno de los logros más sobresalientes del museo el ser un soporte moderno contra el cual mostrar los objetos antiguos de forma magnífica. Su recorrido habló de los detalles que mantenían al mismo tiempo la tradición mexicana y los requerimientos técnicos modernos, pero también, de la adecuada proporción de los volúmenes y el tratamiento de las sombras - así como de las explanadas y las escalinatas que descienden al restauranteentendido todo esto como un aprendizaje de la arquitectura monumental prehispánica.

La museografía contó con la ventaja de ser precisa para el estudioso, pero suficientemente atractiva para el público en general. Para la parte etnográfica, si bien se podía pensar que el museo presentaba 


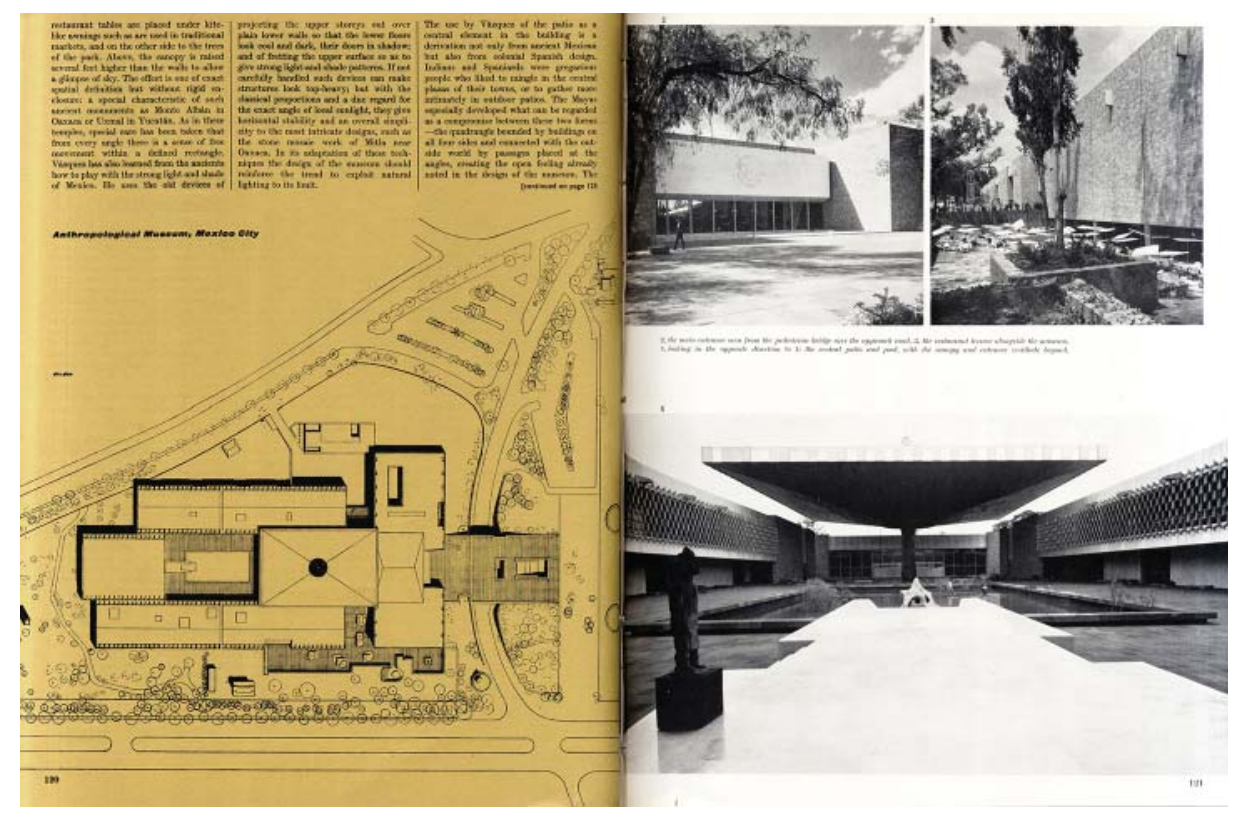

una visión paradisíaca de México al mostrar lo mejor del arte antiguo y de las artesanías modernas - sin las desventajas del calor y el polvo del exterior - también notó que el papel del museo era precisamente mostrar lo mejor de su arte y preservar su artesanía que - desde entonces se sabía - se estaba transformando - al disminuir su calidad — debido a la demanda turística de su consumo.

Por otro lado, la difusión en Italia del MNAH estuvo acompañada por otros ejemplos mexicanos igual de destacados. Así, en octubre de 1966 las páginas de Casabella dieron a conocer no sólo el museo de antropología sino, también, el Museo de Arte Moderno, la Galería de Historia -los tres en Chapultepec- el Palacio de Justicia y el recién finalizado conjunto habitacional Nonoalco-Tlatelolco ${ }^{131}$. El artículo contó con el acercamiento al país de Mario Brunatti y Giulia Carnevale, quienes destacaban la búsqueda de una expresión propia en un territorio con la tradición cultural de México y, también, las soluciones a las demandas sociales — vivienda, salud, educación - que por primera vez incluían la posibilidad de brindar al pueblo con las herramientas para valorar su patrimonio a través del amplio programa cultural de museos que resguardarían el arte nacional.

Si hubo una constante en los artículos que reseñaron el Museo Nacional de Antropología e Historia ésta fue destacar la proeza técnica del paraguas soportado en un único apoyo a través de tensores de los que radialmente cuelga la cubierta. Este elemento reflejó especialmente la arquitectura moderna mexicana: técnicas constructivas de vanguardia combinadas con aportaciones artísticas, como se comprueba al ver

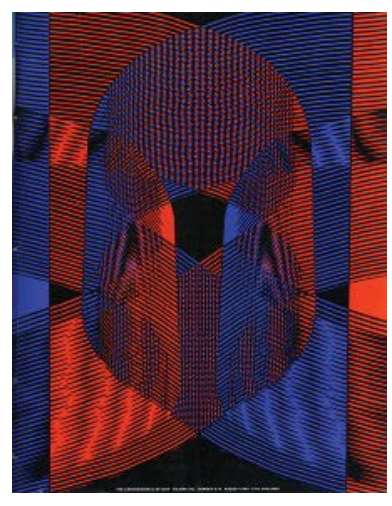

Portada y páginas interiores de The Architectural Review (agosto 1966). EI MNAH como nuevo protagonista de las publicaciones periódicas.
131. M. Brunatti y G. Carnevale Cantoni, "Nuova architettura in Messico," Casabella, no. 310 (octubre 1966): 32-55. Carnevale Cantoni era la corresponsal de la revista italiana en México. 


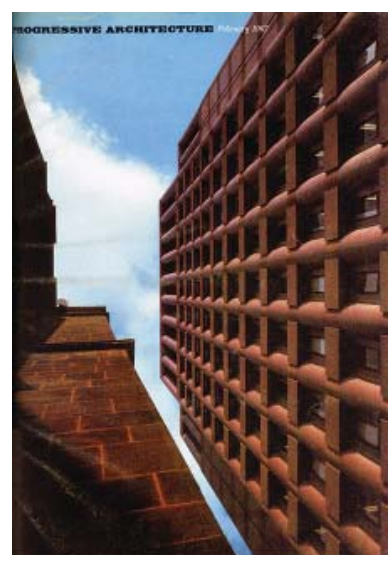

Portada y páginas centrales de Progressive Architecture (febrero 1967). A la derecha la vista del jardín que recrea la arquitectura maya.
132. Esta no fue la única aportación artística al conjunto, pues también se contó con la participación de otros artistas, entre los que cabe destacar a Leonora Carrington, Rufino Tamayo, Rafael Coronel, Carlos Mérida, Mathias Goeritz o Raúl Anguiano.

133. "Musée National d'Anthropologie à Mexico," L'Architecture d'Aujourd'hui, no. 129 (diciembre 1966): 12-15. En el mismo número también se publicó el Museo de Ciudad Juárez.

134. "What makes 'the best museum in the world'?" Progressive Architecture 48, no. 2 (febrero 1967): 98-105.
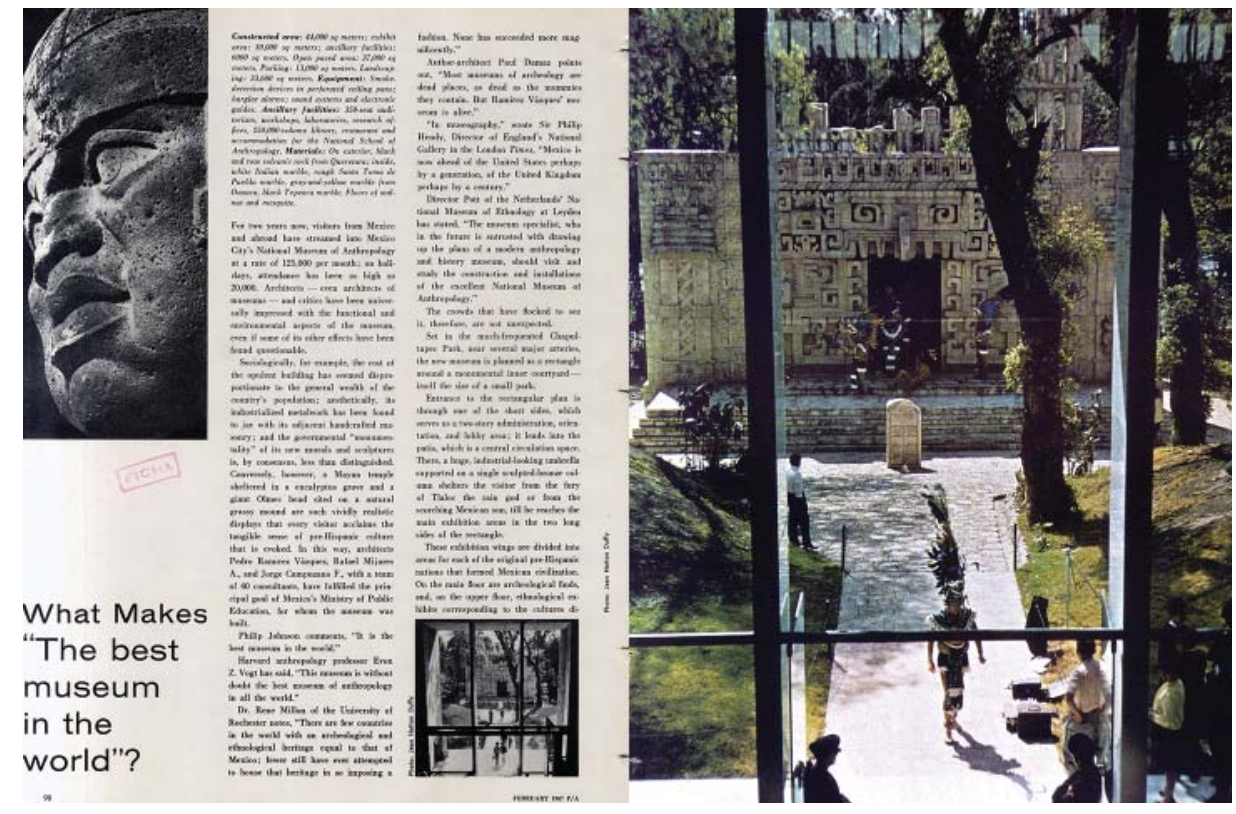

el relieve escultórico en bronce que cubre el pilar central, obra de José Chávez Morado ${ }^{132}$. Cabe hacer notar que al pasar las páginas, las aportaciones artísticas que completan el programa del museo dejaron de tener presencia en las imágenes seleccionadas y publicadas en la revista italiana. La notoriedad que en la década anterior alcanzó la integración plástica en la Ciudad Universitaria, en una década, había pasado a segundo plano. Y sin embargo, al seguir el tema de la integración presente en el discurso oficial, los medios internacionales siguieron repitiendo en sus traducciones la singularidad y el gusto por la plástica del mexicano, aunque sin mostrarlo.

Al finalizar el año de 1966 encontramos que la única aportación que hace L'Architecture d'Aujourd'hui a la difusión del MNAH fue contextualizarlo en un número especial dedicado a edificios culturales como museos, bibliotecas, teatros o centros culturales ${ }^{133}$. Así, el museo mexicano podía compararse con los de otras partes del mundo como el Museo Whitney en Nueva York - de Marcel Breuer- o el proyecto para la Nueva Galería Nacional en Berlín, de Mies van der Rohe. Por lo demás, no hubo novedad en tomar extractos del multicitado discurso inaugural de Ramírez Vázquez y en repetir las mismas fotografías que desde hacía más de un año circulaban en los medios internacionales.

La difusión del MNAH finalizó en el año de 1967 con el refrescante artículo que Progressive Architecture publicó en febrero ${ }^{134}$. Fotos a color a toda página y un recuento de críticas de arquitectos y personalidades del mundo de la cultura habían comprobado in situ los aspectos más 
Transición de espacios interiores y exteriores en el recorrido del Museo Nacional de Antropología e Historia. Ciudad de México, 2014.

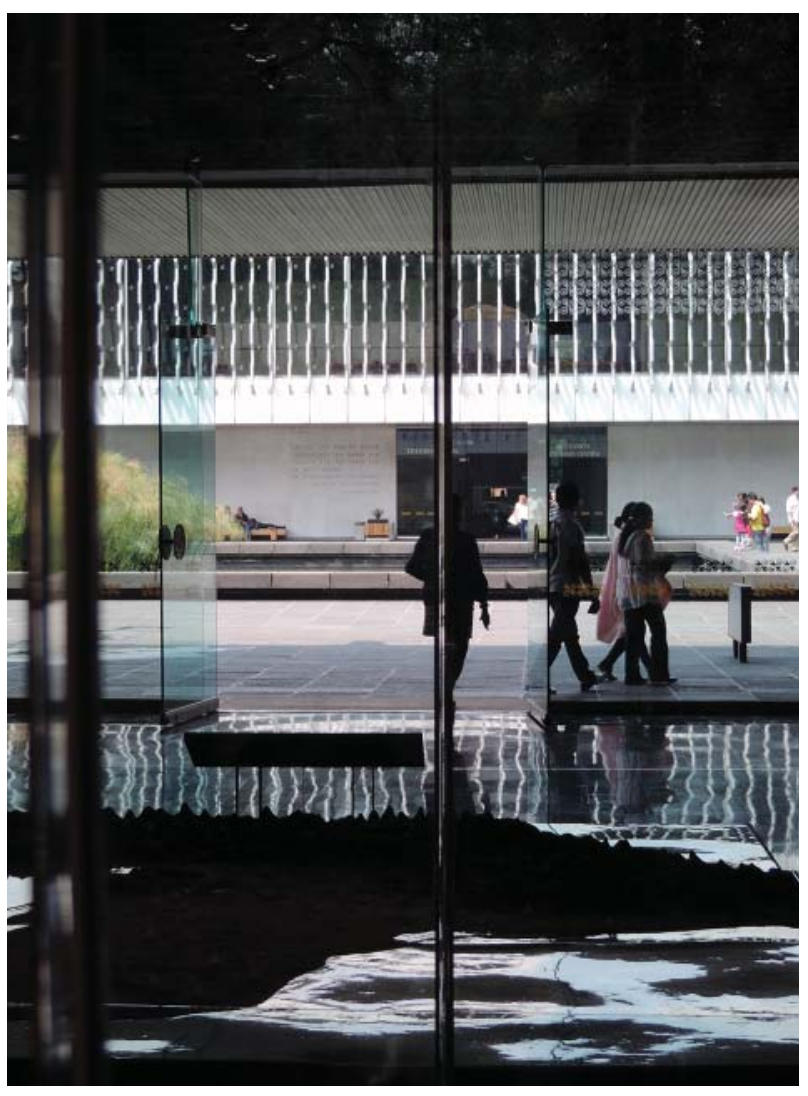

sobresalientes del inmueble, mismos que desde 1965 se venían repitiendo en las revistas especializadas. A diferencia de los artículos citados antes éste aportó los primeros datos duros sobre el pleno funcionamiento del museo - 125 mil visitantes al mes; en días festivos se alcanzaba la cifra de 20 mil- a dos años de abrir sus puertas al público nacional e internacional. Se hizo famosa la crítica de Philip Johnson quien — a pesar de no gustarle la arquitectura del vestíbulo de acceso- calificó al edificio como el mejor museo del mundo. El arquitecto enfatizó que el recurso de obligar al visitante a salir al patio central cada dos salas no sólo evitaba el cansancio y el aburrimiento, sino que este juego de interrelaciones interior-exterior, luz-sombra, pasado-presente se hacía el principal efecto positivo que se experimenta al visitar el museo, además de su amplitud y la claridad de su distribución.

Se prueba así que la difusión del MNAH entre 1965 y 1967 mantuvo constante el interés en México en las publicaciones periódicas europeas y estadounidenses. Hacia el final de la década de 1960 es manifiesto un receso en la construcción de magnas obras institucionales que, desde los diversos programas nacionales, solventaron parte de las cada vez más crecientes demandas sociales de un país que no dejó de construirse y -muy pronto- de autoconstruirse ${ }^{135}$. Así, el último
135. Se utiliza el término autoconstrucción en el sentido de lo construido sin la participación del arquitecto, el profesional o el técnico calificado, sino en la improvisación que, especialmente en el rubro de la vivienda, se volvería la solución para los estratos menos favorecidos de la sociedad. 
136. Como ya se ha comentado para otros temas, en esta sección se revisan los aspectos más generales de la difusión, pero un análisis en profundidad se puede consultar en el apartado 7.5 El último desafío. La Olimpiada de México 68.

137. Véase Arquitectura, no. 116 (agosto 1968). También se comentaron el Auditorio Nacional, el club de yates de Acapulco, la pista olímpica de remo y canotaje y la Villa Olímpica. El interés de $A r$ quitectura no terminó con este número, pues en febrero de 1969 detalló la solución estructural del Palacio de los Deportes y presentó los proyectos que concursaron para el citado palacio y para la piscina y el gimnasio.

138. El texto de presentación "México ante las Olimpiadas", de Pedro Ramírez Vázquez publicado en Arquitectura, fue cortesía de la revista mexicana Calli. Cabe recordar, hablando de los medios especializados mexicanos, que Arquitectura México no prestó atención al programa arquitectónico olímpico debido a que Mario Pani era el gran ausente de las obras olímpicas, marginalizado por Ramírez Vázquez. Información amablemente comunicada por Louise Noelle.

139. Véase Informes de la Construcción, no. 205 (noviembre 1968).

140. "Palacio de los Deportes," Arquitectura, no. 116 (agosto 1968): 10-13 y "Palacio de los Deportes," Informes de la Construcción, no. 205 (noviembre 1968): 6-12. La obra se debió a Félix Candela, Antonio Peyri y Enrique Castañeda Tamborrell. reto que enfrentó el país y que lo conservó en la mira de los medios, fue la arquitectura olímpica que - levantada ex profeso o adaptada al evento internacional - fue apareciendo gradualmente en las revistas de arquitectura $^{136}$.

El fuego olímpico, que en su viaje hacia México atravesó España - partiendo del puerto de Palos como cinco siglos antes lo había hecho Cristóbal Colón- puso en alerta a las revistas de arquitectura ibéricas. Éstas tuvieron especial interés en difundir las instalaciones deportivas del primer país de habla hispana que había ganado la sede de los Juegos para 1968. En agosto, dos meses antes del magno evento, Arquitectura publicó un número especial con el avance informativo sobre los proyectos de infraestructura competitiva, entre los que destacó el Estadio Olímpico de la Ciudad Universitaria, el Palacio de los Deportes, la Piscina y el Gimnasio, el Velódromo y el Estadio Azteca ${ }^{137}$. También, hay que considerar que la rapidez con que la información cruzó el Atlántico se debió no sólo al interés del país receptor sino al de los propios medios mexicanos que muy pronto pusieron en circulación el material gráfico ${ }^{138}$.

Pero Arquitectura no fue la única revista que editó un número especial con motivo de la arquitectura olímpica, también Informes de la Construcción, en noviembre del mismo año, comunicó al lector español las novedades técnicas de la arquitectura mexicana ${ }^{139}$. Sin duda, el Palacio de los Deportes - con su imponente retícula de armaduras de acero de directriz circular, cubierta por estructuras laminares de aluminio y madera, forrada con láminas de cobre- fue el edificio protagonista de ambas publicaciones. Las ediciones españolas fueron generosas en mostrar tanto parte del proceso constructivo como la estructura finalizada, así como plantas, cortes y alzados y una amplia descripción del edificio, la técnica utilizada y la capacidad de espectadores que podía albergar ${ }^{140}$.

Aunque resulta obvia la coincidencia en la mayoría de los edificios entre ambos números, hay que destacar que hubo lugar a ligeros cambios en la selección del material, lo que propoció que inmuebles de menor escala como el Polígono Olímpico de Tiro, el Gimnasio Revolución, la pista de hielo Insurgentes, la Sala de Armas, la torre de telecomunicaciones o la Villa Cultural, ganaran protagonismo y se les ubicara - en el caso de Informes de la Construcción - en la misma categoría informativa que a los colosos más conocidos. 


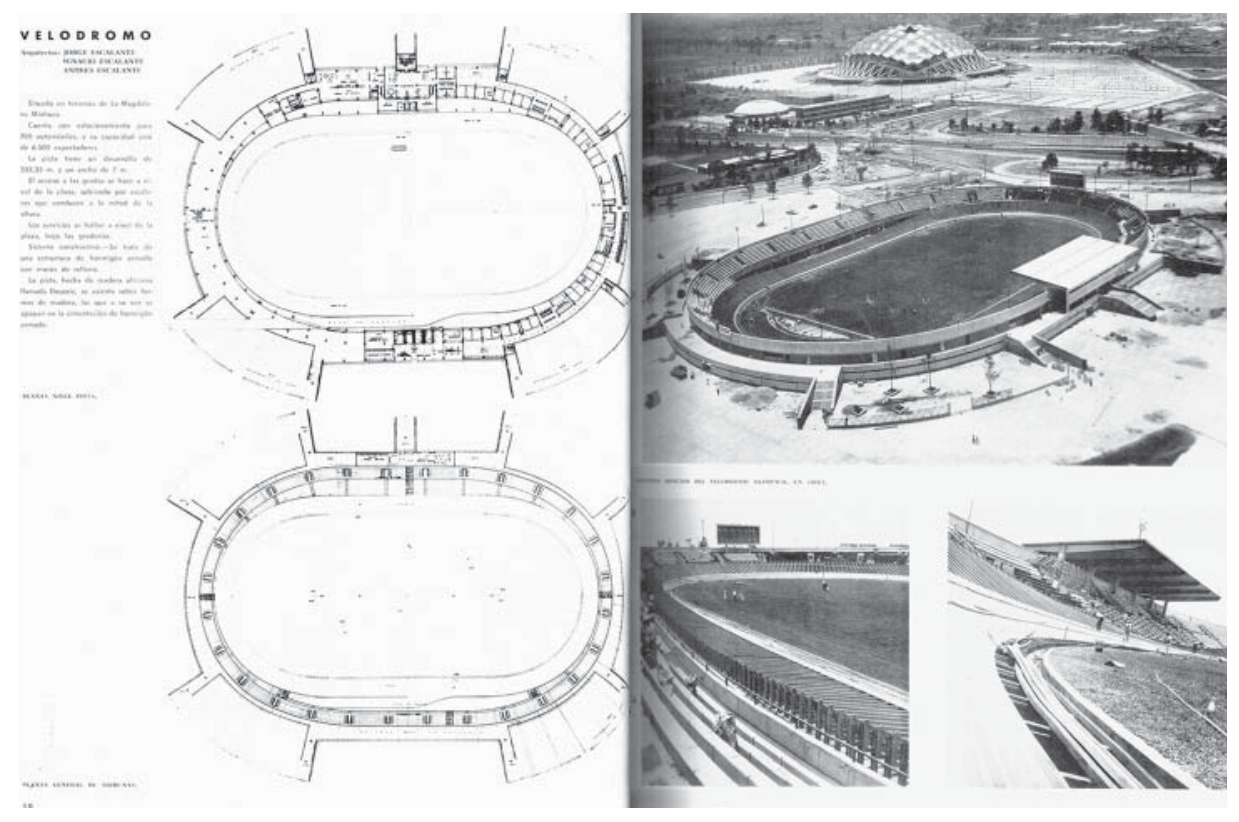

De especial interés para los arquitectos del mundo fue el simposio organizado como parte de la Olimpiada Cultural que materializó en el Primer Encuentro de Jóvenes Arquitectos, con reuniones en el Instituto Politécnico Nacional (IPN) los primeros días de octubre de 1968. Después de los lamentables sucesos ocurridos en Tlatelolco a pocos días del encuentro, que prefiguraron el fracaso de la reunión, se presentaron en Zacatenco, en la fecha indicada, los representantes de la UIA y del Comité Olímpico Internacional (COI), así como cerca de 200 participantes. Las reuniones se llevaron a cabo en el IPN en estado de control y ocupación por parte de los estudiantes, pero a pesar del clima desfavorable, se alcanzó a debatir la situación de la arquitectura del momento entre jóvenes arquitectos de al menos 20 países. Si bien el encuentro fue anunciado meses antes por varias revistas internacionales, fue Hogar y Arquitectura la que presentó una reseña precisa del encuentro en su número de noviembre de 1968, tan sólo un mes después de las reuniones en la capital mexicana ${ }^{141}$.

Además de España, también otros países dieron a conocer la arquitectura olímpica, pero antes hay que puntualizar que en cuanto a la calidad de la información y la cantidad de páginas publicadas, las revistas madrileñas fueron las que aumentaron exponencialmente el interés en México en 1968.

Entonces, otra revista que actualizó a sus lectores antes de iniciada la Olimpiada, fue la londinense The Architectural Review, cuando en septiembre de 1968 - en su sección de noticias de actualidad- mostró tres de los edificios representativos de México 68: el Palacio de los Deportes,

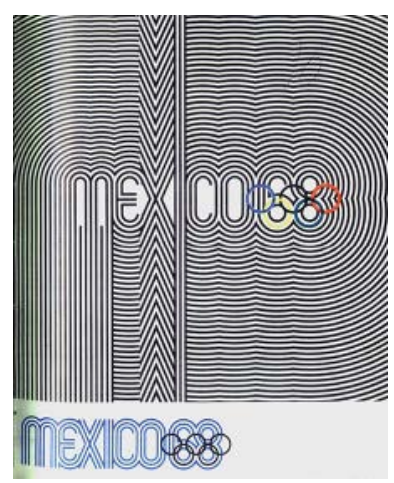

Número especial de Arquitectura dedicado a la arquitectura olímpica mexicana de 1968.
141. Manuel Trillo, "I Encuentro de Jóvenes Arquitectos," Hogar y Arquitectura, no. 79 (noviembre-diciembre 1968): 83-84. 


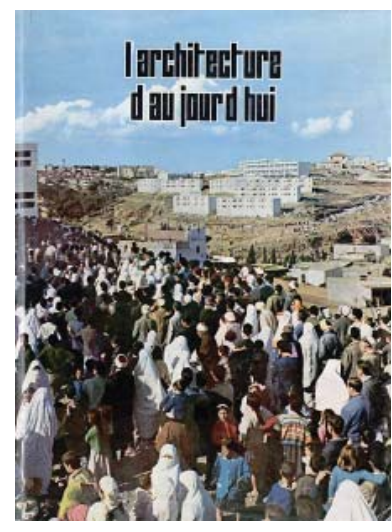

La Ruta de la Amistad de México 68 en L'Architecture d'Aujourd'hui (octubre 1968).

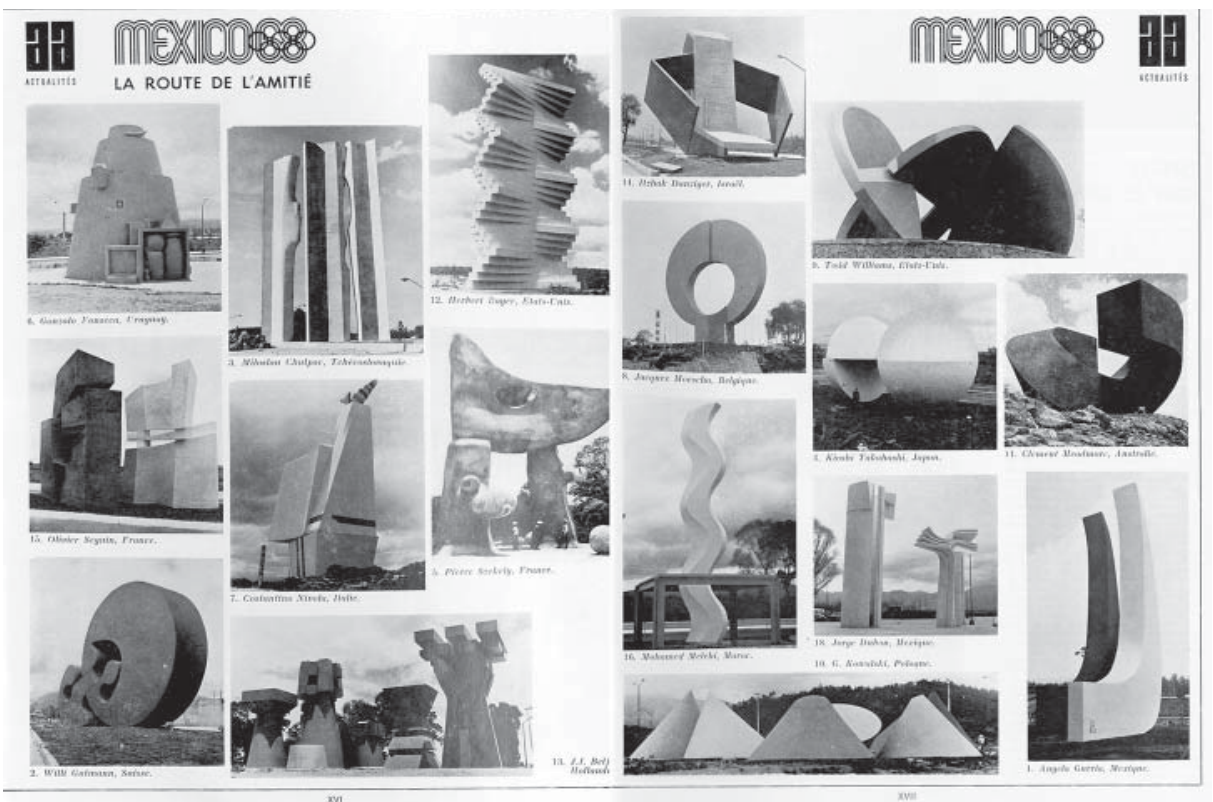

la Piscina y Gimnasio Olímpicos y el Estadio Azteca ${ }^{142}$. Del primero, se destacó la capacidad de 22 mil espectadores sentados, con lo que se convertía en el espacio olímpico cerrado más grande construido hasta ese momento. Lo más innovador había sido la combinación de materiales estructurales - arcos de acero entrecruzados que libran un claro de $132 \mathrm{~m}$ - con su cubierta de paraboloides hiperbólicos prefabricados de aluminio y madera revestidos con cobre. El soporte de las vigas maestras fueron pilares de concreto armado. Del segundo, se subrayó la estructura en catenaria de cables tensados y anclados en columnas de hormigón armado.

The Architectural Review también destacó el amplio programa cultural mexicano, que en el caso de las olimpiadas anteriores no había sido significativo. Como parte de éste fue notable el diseño gráfico que se pensó para facilitar la información al público internacional. Es curioso cómo $A R$ bautizó de Aztec Nouveau lo que a su juicio fue la combinación del arte azteca y el popular con el Art Nouveau y el Op Art.

El interés de la revista londinense no terminó aquí, pues en diciembre de 1968 - dos meses después de los Juegos- publicó la Ruta de la Amistad ${ }^{143}$. Sin duda, la Olimpiada Cultural fue una contribución única al concepto de las olimpiadas - se mencionó antes el Encuentro

142. "Mexico Olympics," The Architectural Review 144, no. 859 (septiembre 1968): 221-23.

143. John Adams, "Route of Friendship," The Architectural Review 144, no. 862 (diciembre 1968): 402-404. de Jóvenes Arquitectos - y uno de sus programas - bajo la dirección del artista Mathias Goeritz - fue la materialización de esculturas monumentales de escala urbana, obra de carácter internacional que contó con la participación de diecinueve escultores provenientes de dieciséis 


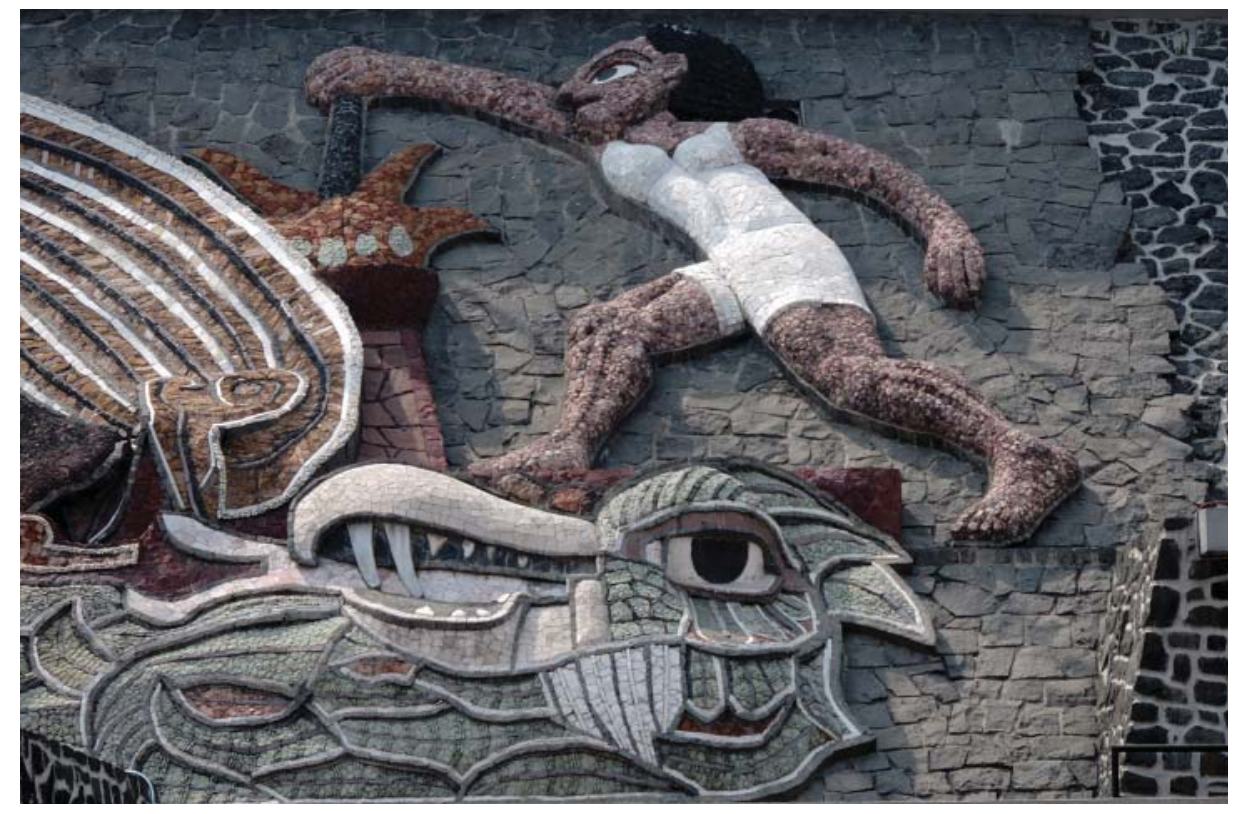

países. Su mayor alcance fue que el arte se dirigió por primera vez a reavivar las —entonces- desoladas vías suburbanas.

La Ruta de la Amistad también llegó a L’Architecture d’Aujourd'hui en el año olímpico. En palabras de Mathias Goeritz, se insistió en el concepto de arte integral dentro de la trama urbana, de importancia fundamental ya que liberaba la creación artística del dominio del «arte por el arte» y lo insertaba en un contexto que facilitaba el acercamiento del mismo al público en general. Las esculturas de escala urbana serían así un medio de cubrir las necesidades espirituales fundamentales de la sociedad contemporánea ${ }^{144}$. Pero no solo las enormes piezas de hormigón armado alcanzaron a la revista parisina, también algunos de los edificios olímpicos fueron publicados. Destacó en la selección francesa la Villa Olímpica, seguida por la Piscina y Gimnasio Olímpicos y el Palacio de los Deportes ${ }^{145}$. El texto enfatizó el papel del arquitecto frente al reto de la escala y la velocidad de ejecución, pero sobre todo, en la materialización de iconos urbanos significativos para la ciudad. Se buscó que las obras respondieran al ideal moderno del deporte: el de reunir a la juventud internacional bajo un clima de paz propicio para las relaciones humanas, que a su vez mostraran las virtudes de la capacidad física del ser humano.

A diferencia de $A A$, Techniques et Architecture se interesó en explicar las innovaciones tecnológicas que el Palacio de los Deportes aportó a la práctica arquitectónica mundial. Si bien la revista francesa esperó hasta junio de 1969 para publicar uno de los edificios olímpicos mexicanos, éste se contextualizó en un número especial dedicado a las
La antorcha olímpica en el alto relieve del estadio olímpico universitario, ciudad de México, 2016.
144. "Mexico 68: La Route de L'Amitié," L'Architecture d'Aujourd'hui, no. 140 (octubre 1968): XV-XVII.

145. Irving Nerubay, "Espaces pour le Sport: Village Olympique, Piscine et Gymnase Olympique et Palais des Sports," L'Architecture d'Aujourd'hui, no. 140 (octubre 1968): XVIII-XX. 
nuevas estructuras y la industrialización ${ }^{146}$. El artículo contó con una descripción precisa de la técnica constructiva, un croquis de interés especial que mostró un módulo estructural y las fotos de los avances de obra que se compararon con las de la estructura terminada.

En relación a México 68, queda por comentar sólo dos revistas estadounidenses que en meses consecutivos reseñaron también las aportaciones artísticas y arquitectónicas del evento olímpico. Si hubo algo que sobresalió en los medios internacionales -además de los edificios emblemáticos ya citados - fue la Ruta de la Amistad y el extenso programa de diseño gráfico que a todas las escalas - desde la urbana hasta los billetes de acceso a los eventos- ayudarían al visitante a situarse en la extensa ciudad. Para Architectural Forum, la xıx Olimpiada también sería recordada por su gráfica, tradición ancestral vinculada a la herencia cultural mexicana ${ }^{147}$.

Para Architectural Record fue importante mencionar la escala de la ciudad, que por entonces contaba con apenas siete millones de habitantes. En octubre de 1968, la capital mexicana recibió a cien mil visitantes, de los cuales el diez por ciento fueron atletas y sus entrenadores y - sorprendentemente - la magnitud de la ciudad no sería un inconveniente para el visitante, ya que se sistematizaron las rutas de circulación y se garantizó la puntualidad tanto de atletas como de espectadores. La señalización a escala urbana sería una aportación fundamental al entendimiento de la ciudad. Siguiendo al autor del artículo, Raymond Lifchez, la descentralización de las sedes ofreció al visitante la posibilidad de conocer un panorama más extenso de la capital y de vivirla realmente, lo que no sucede cuando los eventos internacionales concentran en grandes parques las exposiciones mundiales o los Juegos

146. "Mexico: Palais des Sports," Techniques et Architecture 30, no. 5 (junio 1969): 78-79.

147. "The Olympics: art, buildings, graphics," Architectural Forum 129, no. 3 (octubre 1968): 66-71. El diseño gráfico estuvo a cargo del arquitecto Eduardo Terrazas y los diseñadores gráficos Lance Wyman y Peter Murdock.

148. Raymond Lifchez, "Mexico's Olympic achievement was also architectural," Architectural Record 144, no. 5 (noviembre 1968): 42-43.
Olímpicos ${ }^{148}$.

Con la arquitectura olímpica se cerró el periodo en que los hitos arquitectónicos que se publicaron en las revistas extranjeras surgieron de planes nacionales. El final de la década de 1960 marcó la transición entre la arquitectura institucional y la de iniciativa privada como protagonista y modelo de la nueva arquitectura nacional. Si bien la arquitectura comercial siempre estuvo presente en los medios, hay que recordar que los edificios emblemáticos publicados hasta ese momento -1968surgieron de programas gubernamentales. Así, se cierra este capítulo con 


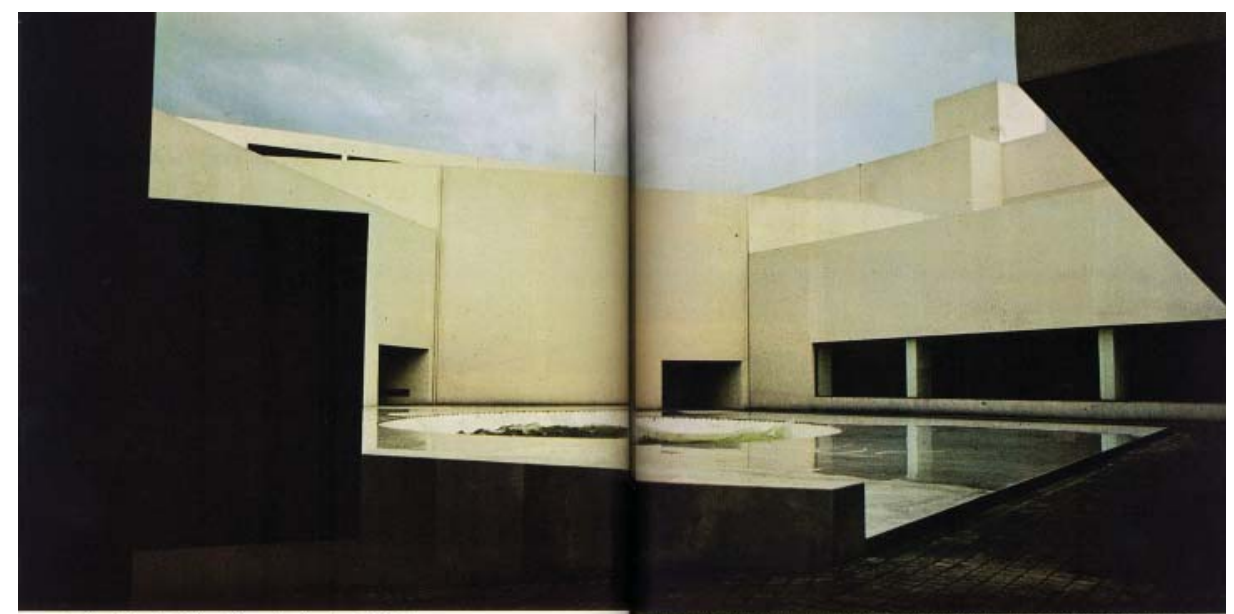

\section{EVERYMAN'S MEXICAN HOME}

A hotel in Mexico City by architect Ricardo Legorreta shows the fascinating ambivalence of such transient residences.

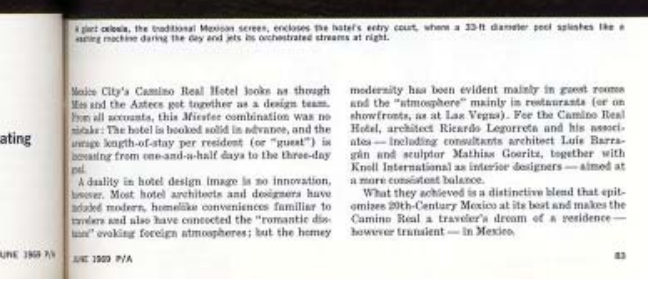

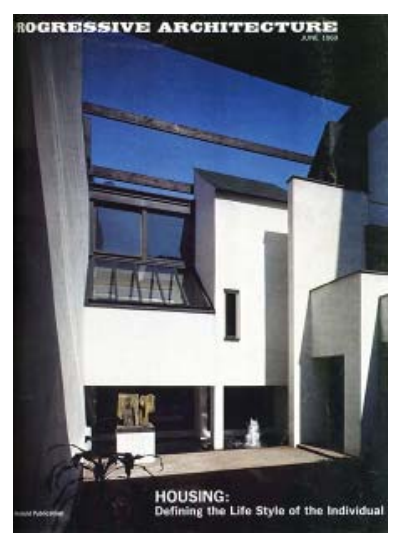

Hotel Camino Real en Progressive Architecture (junio 1969).

la breve mención a los edificios y arquitectos que marcaron el punto de inflexión que, a partir de entonces, siguió la difusión internacional de la arquitectura mexicana.

Así como el reto del Comité Olímpico Mexicano fue proveer de la infraestructura necesaria para la realización de los Juegos en octubre de 1968, los inversionistas privados tenían sus propios retos que vencer. Uno de ellos fue la construcción de hoteles que, bajo estándares internacionales de calidad, cubrieran la demanda de habitaciones de la ciudad de México a tiempo para el magno evento. Surgió así uno de los edificios que determinó definitivamente el cambio de rumbo de la arquitectura mexicana al final de la década de 1960: el Hotel Camino Real, de Ricardo Legorreta y asociados.

A diferencia del escaso interés que habían prestado las revistas norteamericanas a otros temas mexicanos como la vivienda social o la educación, la arquitectura comercial y de servicios facilitó que éstos tomaran la delantera en su difusión internacional ${ }^{149}$. De esta manera, Architectural Forum, en noviembre de 1968 - un mes después de que el hotel abriera al público- y Progressive Architecture, al año siguiente, publicaron extensos artículos sobre el Camino Real, inmueble que, por primera vez, había cambiado el concepto del hotel de lujo convencional.

La estrategia de Legorreta para superar lo impersonal de los hoteles urbanos construidos hasta ese momento debe mucho a Luis Barragán, de quien había aprendido que el valor de los espacios no estaba en el uso de

149. Tampoco debemos soslayar que los inversores del Camino Real eran los propietarios de Western Hotels of Mexico, una subsidiaria de la cadena Western Hotels de los Estados Unidos, y, también, que se esperaría mucho más turismo norteamericano, por su cercanía, que el proveniente de otras partes del mundo. 
Los muros de la cuadra Egerstrom de Luis Barragán en Domus (noviembre 1968).
150. Víctor R. Zeballos, "Camino Real," Architectural Forum 129, no. 4 (noviembre 1968): 86-91. El logotipo del hotel y el diseño gráfico se debió a Lance Wyman y Peter Murdock, los mismos que diseñaron toda la gráfica de México 68.

151. "Everyman's Mexican Home," Progressive Architecture 50, no. 6 (junio 1969): 82-91.

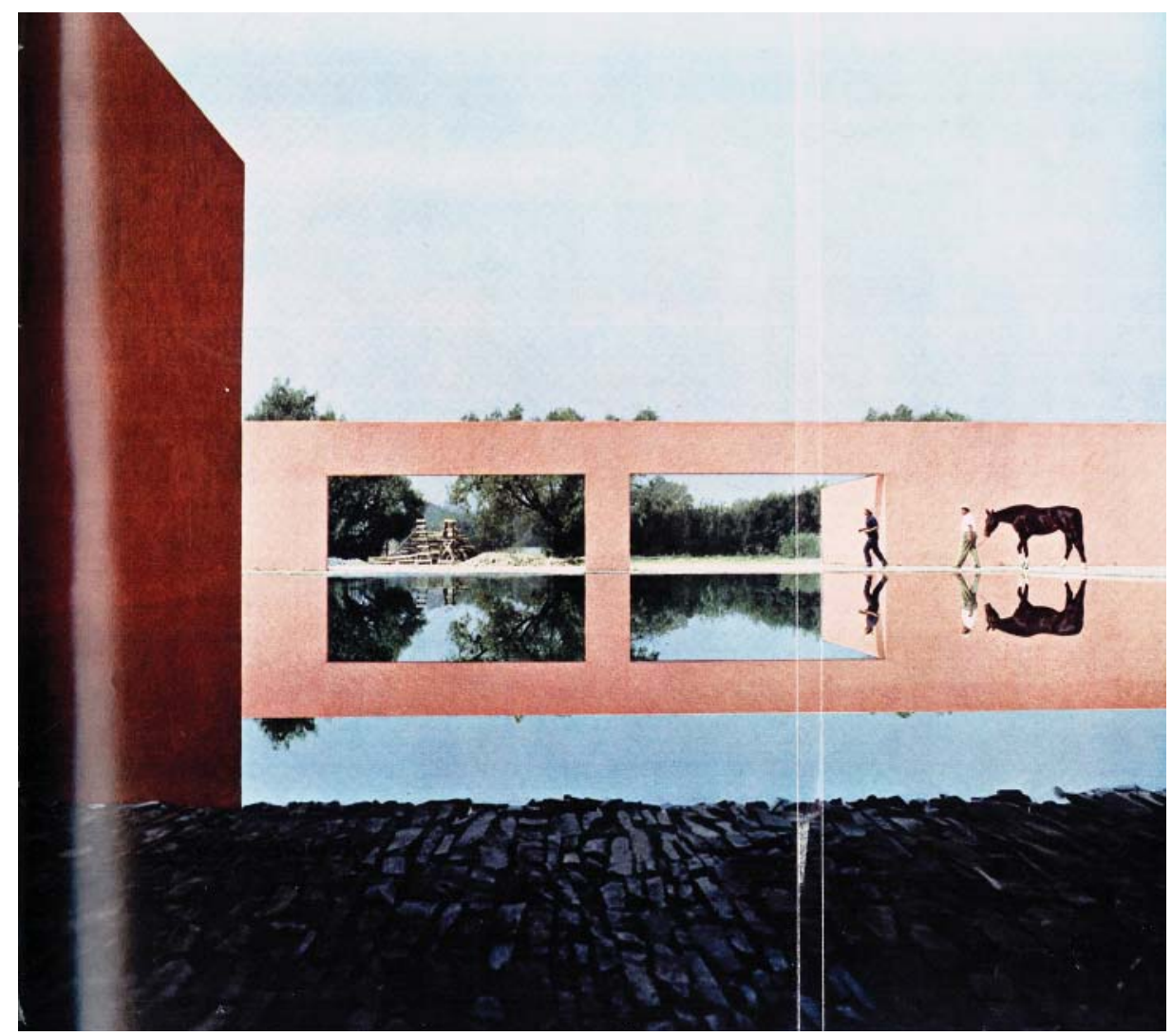

materiales costosos sino en la calidez de los ambientes. Legorreta llevó a escala pública la introspección que había aprendido de su maestro, superándolo. Las páginas de Architectural Forum -aunque en blanco y negro- detallaron fuentes, celosías, patios y corredores, pero también se mostró con especial interés el diseño gráfico que completó la concepción arquitectónica $^{150}$.

Por otro lado, en un número especial dedicado a la vivienda, Progressive Architecture transmitió vivamente el oasis de paz y tranquilidad que ofrecía el Camino Real al viajero fugaz que visitaba México: detalles minimalistas de corte miesiano combinados con elementos tradicionales mexicanos en un feliz resultado ${ }^{151}$. Si el éxito del hotel ya se había probado, la conquista de Progressive fueron las fotografías a color que realmente comunicaron el ambiente moderno y tradicional a la vez. Aunque el texto denotó las tradiciones ancestrales y rememoró las pirámides prehispánicas - por la inclinación de algunos muros- o evocó la intimidad del mundo virreinal - por el uso de celosías - lo cierto es que los colores brillantes — rojos, naranjas, rosas - de la mano de importantes obras de artistas abstractos, ofrecían al huésped mucho más que las añoranzas del pasado.

En Europa, L'Architecture d'Aujourd'hui y Arquitectura se sumaron a la difusión del Camino Real, si bien con comunicaciones más modestas. 
La parisina, con sólo dos páginas de su sección de actualidad, y en blanco y negro, repitió los textos descriptivos que ya se habían publicado en los otros medios ${ }^{152}$. Desde Madrid, en un número dedicado a los hoteles en España, Arquitectura incluyó el caso mexicano con un artículo también convencional, si bien extenso en páginas, que, a pesar de repetir el argumento narrativo, aportó una curiosa anécdota que acentuó la novedad arquitectónica de buscar el lujo en la calidad espacial y no en los materiales ${ }^{153}$.

Como conclusión, se hace necesario dejar atrás los muros de radiantes colores del Hotel Camino Real y regresar a la escala privada del muro - como el elemento más puro y significativo de la arquitecturay a su máximo exponente mexicano: Luis Barragán. Esta reducción de escala, esta vuelta a lo privado y a la exaltación del arquitecto como actor, como personaje mitológico al que rendir ilimitada devoción, fue parte de la transición que a partir de 1968 indicó el cambio de la arquitectura institucional a la de iniciativa privada como protagonista en la difusión internacional.

Desde Milán y Nueva York, los muros materializados como elementos aislados, como planos de color, alimentarían el cada vez más creciente interés extranjero en esta síntesis mexicana de modernidad y tradición. En Domus, en noviembre de 1968, los muros - en fotos a todo color- de la casa y cuadra Egerstrom, serían bautizados de muros mitológicos y a Barragán como su creador en el sol, entre las aguas y en el silencio ${ }^{154}$. En Progressive Architecture, en agosto de 1971, se dedicó un artículo que, al igual que la revista milanesa, potenció las fotos a color $^{155}$. Aspecto éste último fundamental, cuando se asevera que su autor compone con el color como un pintor trabaja en un lienzo. La portada de este número mostró los muros que iban de los tonos naranjas a los rosas, en un entendimiento permanente con el agua que los rodea.

Se han recorrido más de veinte años de difusión de la arquitectura moderna mexicana en las revistas europeas y norteamericanas. Con esto se hace evidente no solo la continuidad del flujo informativo y la existencia de hitos arquitectónicos fundamentales, sino también la diversidad de temas y nombres que ampliaron sustancialmente el panorama de la arquitectura mexicana, que, de otra forma, suele recaer en un puñado de arquitectos y obras. Es importante hacer notar que la difusión en
152. "Hotel Camino Real Mexico," L'Architecture d'Aujourd'hui, no. 144 (junio-julio 1969): XXXI-XXXII.

153. "Hotel Camino Real: México," Arquitectura, no. 131 (noviembre 1969): 31-37. La anécdota cuenta la experiencia de los editores españoles durante los Juegos Olímpicos de 1968 , al tomar un taxi y pedir al conductor que los llevara al mejor hotel de México, el Camino Real. El taxista no sólo no sabía de la existencia de dicho hotel ni su ubicación, sino que se sintió francamente decepcionado al encontrar un hotel falto de mármoles, muros cortina $\mathrm{y}$ bronce.

154. Gio Ponti, "I muri di Luis Barragán," Domus, no. 468 (noviembre 1968): 2.

155. Esther McCoy, "Designing for a dry climate," Progressive Architecture 52, no. 8 (agosto 1971): 50-57. Todas las fotos del artículo son autoría de Armando Salas Portugal, desde entonces el fotógrafo que gozó de la exclusividad de la obra de Barragán. 
estos años fue mucho más allá de los monográficos y los iconos urbanos - si bien fueron significativos- y superó los vínculos personales y las preferencias editoriales, que tampoco se deben obviar. Un gremio fuerte y bien dirigido, un mundo editorial competitivo y unas escuelas de arquitectura vivas y abiertas al diálogo y al debate, fortalecieron las redes dispuestas a proyectar fuera de las fronteras nacionales la mejor parte del México moderno, la de un país trabajando de forma constante en resolver sus demandas sociales. 


\section{Parte II}

A vista de página Las publicaciones periódicas de arquitectura 



\section{Edición impresa \\ La difusión internacional de México en las revistas especializadas}

Como quedó manifiesto en la primera parte de esta tesis, un flujo constante de noticias sobre la arquitectura moderna mexicana en las publicaciones periódicas de arquitectura dibujó un panorama heterogéneo compuesto de un cuantioso volumen de nombres y edificios que disminuyen el protagonismo a la historia contada sólo a través de un reducido número de arquitectos y obras. Se verificó, con esa primera aproximación, que la difusión en las revistas especializadas fue más allá de los monográficos y de los iconos urbanos y arquitectónicos más conocidos de la modernidad mexicana.

Por su parte, las publicaciones periódicas de arquitectura se perfilaron como uno de los medios de difusión más vigorosos y con características muy particulares. Se citan entre las más destacadas: su periodicidad, lo que las hace objetos sujetos a cambios y por lo mismo las mantiene "vivas"; su actualidad, ya que presentan la imagen del momento; el carácter mixto de sus contenidos, y el ser generalmente resultado de un trabajo de equipo que responde a determinados criterios ideológicos y comerciales. Hay que destacar que también fue fundamental en las revistas la participación directa de muchos de los arquitectos que estaban ejecutando las obras publicadas por esos años; además de los críticos y los historiadores, los propios arquitectos se convirtieron en los «rostros del periodismo arquitectónico» ${ }^{1}$.

El desarrollo de esta sección de la investigación se sustenta en la consulta rigurosa y en el análisis cuantitativo de una selección de títulos que, por su impacto en la época y por su accesibilidad actual en los fondos públicos de las bibliotecas madrileñas, se consolidaron como el corpus principal de esta investigación ${ }^{2}$. Por lo tanto, se revisaron algunos de los más importantes focos de transmisión de noticias de la arquitectura moderna de la segunda mitad del siglo xx: Estados Unidos, Francia,

1. Eva Hurtado Torán, "Desde otra voluntad de permanencia: Las publicaciones periódicas de arquitectura. España 1897-1937" (Tesis de Doctorado, Universidad Politécnica de Madrid, 2001), 14-15.

2. El periodo de investigación de campo de esta tesis se llevó a cabo en las bibliotecas de la Escuela Técnica Superior de Arquitectura de Madrid (ETSAM) y del Colegio Oficial de Arquitectos de Madrid (COAM) entre septiembre de 2012 y junio de 2014. 
Inglaterra e Italia. Además, se amplió la consulta a España, país que tuvo especial interés en México y su arquitectura, lo que sitúa a la nación ibérica con un destacado papel en la difusión de la misma, completando significativamente la propagación foránea de la información ${ }^{3}$.

Este análisis detectó los diferentes temas publicados en los distintos medios extranjeros, lo que sugirió los posteriores estudios cualitativos que forman la tercera parte de esta tesis. En éstos, se considera el impacto de la información en cada revista, la velocidad de difusión, las semejanzas y diferencias con respecto a un mismo tema en las publicaciones entre los países citados, así como la verificación de algunas obras que por su interés generalizado mantuvieron constante la publicación de noticias en los medios especializados extranjeros.

Esta investigación reconoció en principio dos hitos arquitectónicos que delimitaron el periodo de estudio, el primero - la construcción de la Ciudad Universitaria (CU) de México en 1952- por su función detonante del interés internacional hacia la arquitectura mexicana y el segundo - la Olimpiada de México 68- por su condición de cierre de un periodo constructivo altamente institucionalizado en el país. No obstante, muy pronto se hizo evidente que los límites tendrían que ampliarse unos años debido a las frecuentes comunicaciones en las revistas extranjeras desde el inicio de 1950, y, después del año olímpico, se hizo patente un declive en la frecuencia de noticias acompañado de un claro giro en la producción arquitectónica mexicana, como ya se enunció en los últimos párrafos de la sección anterior. Es por esto que la delimitación cronológica abarca por completo la sexta y la séptima décadas del siglo $\mathrm{xx}$.

Antes de 1950, si bien fueron puntuales las comunicaciones sobre la arquitectura moderna mexicana - si se piensa en el caso especial de Architectural Record (ARec) y de la Revista Nacional de Arquitectura

3. Vanessa Nagel, "Tan lejos, tan cerca. México y España: encuentros en las publicaciones periódicas de arquitectura entre 1946 y 1968" (ponencia presentada en el I Encuentro Internacional Rutas Ibero-americanas. Contactos e intercambios en la arquitectura del siglo $x x, \mathrm{Ma}-$ drid, 9 junio, 2015).

4. "Arquitectura Mexicana," Revista Nacional de Arquitectura, no. 98 (febrero 1950): 47-58. (RNA), ya citados como antecedentes en la primera parte de esta tesisfue justo al mediar el siglo cuando desde varios países inició un flujo constante de noticias que delimitaron esta cronología. Las importantes obras de Mario Pani de los finales de la década de 1940: el Conservatorio Nacional de Música (1946), la Escuela Nacional de Maestros (1947) y el Centro Urbano Presidente Alemán (1949) se publicaron en España ${ }^{4}$, mientras que Francia dio a conocer, también en 1950, el aludido primer gran conjunto habitacional de interés social del país en L’Architecture 
d'Aujourd'hui $(A A)^{5}$. El mismo año, la parisina publicó asimismo una vivienda unifamiliar de los arquitectos Jorge González Reyna y Rafael Arozarena ${ }^{6}$. Por otro lado, los temas técnicos de actualidad desarrollados en México también iniciaron un prolífico periodo de difusión, como se prueba al revisar las páginas de Architectural Forum $(A F)$ en relación al sistema constructivo "descimbrar-cimbrando" del ingeniero Manuel González Flores ${ }^{7}$ o, en la $R N A$, el estudio de las estructuras laminares prismáticas en diente de sierra de la temprana producción mexicana de Félix Candela ${ }^{8}$. En esta última revista, el diseño de interiores para la compañía aérea Iberia - que abría sus puertas en la céntrica calle Juárez de la capital mexicana en 1950- lucía la propuesta de Eduardo Robles Piquer y Vicente Martín Hernández (Ras-Martín) ${ }^{9}$ en las páginas impresas madrileñas ${ }^{10}$.

Hacia los últimos años de 1960 — más allá de la arquitectura olímpica de 1968 - ya se comentaron dos hitos que insinúan un cambio de la arquitectura institucional a la de iniciativa privada, sugiriendo el fin del predominio de las grandes obras gubernamentales de las décadas de 1950 y 1960. Por un lado, el Hotel Camino Real de la ciudad de México, de Ricardo Legorreta, y por otro, la explosión del color que las publicaciones periódicas dedicaban entonces a las recientes obras de Luis Barragán. Esto también indica un giro en la difusión de la arquitectura mexicana a partir de la década de 1970: el interés estará centrado en personajes, al contrario de la visión más plural e inclusiva que caracterizó el flujo informativo de las décadas anteriores y que es tema de este análisis.

El año de 1970 en las publicaciones periódicas está marcado por dos noticias fundamentales en relación a la arquitectura moderna mexicana y al urbanismo de la ciudad capital. La primera sería la destrucción de la casa de Juan O'Gorman en el Pedregal — pérdida irreparable para el patrimonio arquitectónico mexicano- que puntualmente anunciaron Progressive Architecture $(P A)^{11}$ en Nueva York y Architectural Design $(A D)^{12}$ en Londres. La segunda refiere a la ciudad de México, siempre en constante expansión, y a la apertura del Sistema de Transporte Colectivo (Metro) que desde 1969 se mantiene como una opción viable de transporte público.

Esta nueva manera de moverse en la ciudad fue una verdadera noticia de actualidad en Architectural Forum ${ }^{13}$, pues tan solo un
5. "Centre Urbain 'President Aleman' Mexico," L'Architecture d'Aujourd'hui, no. 31 (septiembre 1950): 2-7.

6. "Residence a Mexico City," L'Architecture d'Aujourd'hui, no. 28 (febrero 1950): 105.

7. "Pouring concrete slabs from the top down. Mexican system places seven floors in seventeen days," Architectural Forum 93, no. 5 (noviembre 1950): 149.

8. Félix Candela, "Cubierta prismática de hormigón armado en la ciudad de México," Revista Nacional de Arquitectura, no. 99 (marzo 1950): 126-32.

9. Ambos arquitectos fueron españoles exiliados en México.

10. "Local de 'Iberia' en la Ciudad de Méjico," Revista Nacional de Arquitectura, no. 108 (diciembre 1950): 532.

11. "O'Gorman Cave House Disappears," Progressive Architecture 51, no. 3 (marzo 1970): 40.

12. "O'Gorman house," $A r$ chitectural Design 40, no. 9 (septiembre 1970): 429.

13. "Mexican Metro," Architectural Forum 131, no. 3 (octubre 1969): 71. 
Interior de la estación del metro Insurgentes en Architectural Forum (octubre 1969). La integración plástica permanece al lado de la funcionalidad. A la derecha, publicidad en Architectural Record (abril 1970) de la Glorieta de Insurgentes.
14. "Mexico City Metro," The Architectural Review 148, no. 885 (noviembre 1970): 324. La línea 1 abrió en septiembre de 1969 con 12,6 km de recorrido y la finalización de las líneas 2 y 3 en 1970 aumentaría esta distancia hasta los $42,5 \mathrm{~km}$; actualmente la red cuenta con más de $225 \mathrm{~km}$ y un promedio diario de pasajeros de 7,6 millones, más del total de la población capitalina que lo vio nacer.

15. "Publicidad: Wide-Lite," Architectural Record 147, no. 4 (abril 1970): 180-81.

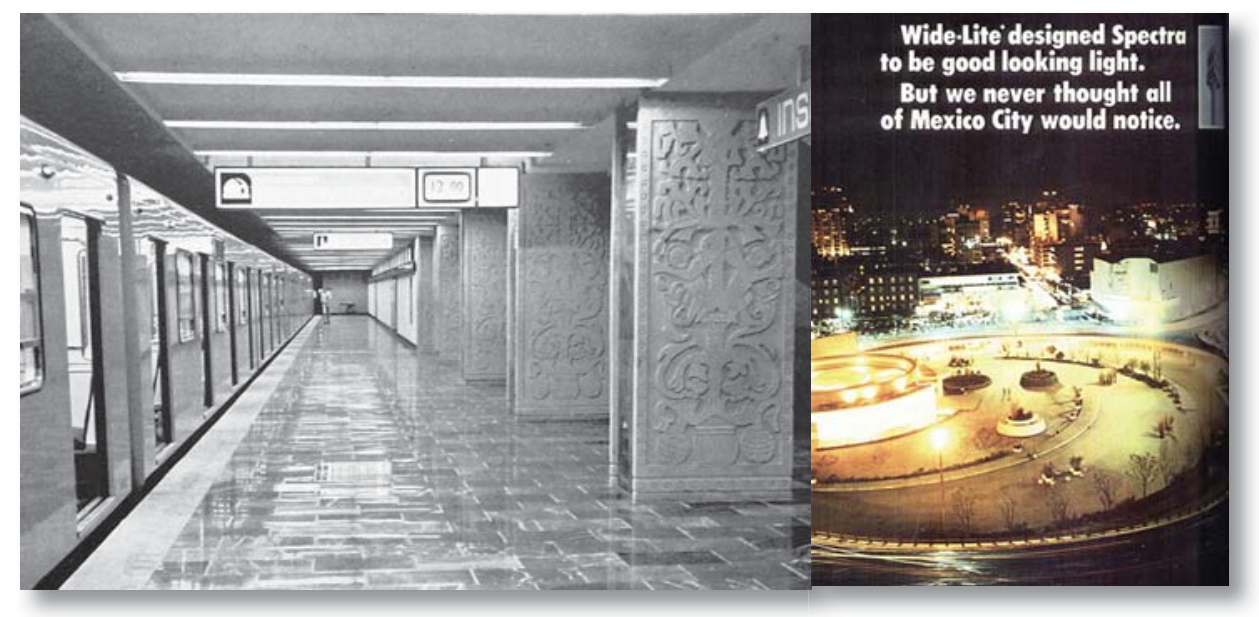

mes después de la apertura del Metro, ya se hablaba del milagro de la ingeniería - las instalaciones subterráneas se enfrentaron a un suelo arcilloso con altos niveles freáticos- y de la habilidad artística expresada en las estaciones, en especial la de Insurgentes. Forum subrayó el sistema computarizado electrónico para el control de los trenes y los billetes sencillos codificados reconocidos por los torniquetes de acceso, así como el llamativo color naranja de los trenes con sus silenciosas ruedas neumáticas. Para la neoyorquina, el viaje sencillo a 8 centavos era una oferta incuestionable.

Ya en 1970, The Architectural Review (AR), en noviembre ${ }^{14}$, subrayó los kilómetros lineales de recorrido - la distancia de una maratón para una ciudad que ya entonces contaba con casi siete millones de habitantes-, señaló las cubiertas de algunas estaciones que diseñó Félix Candela y sobre todo acentuó el diseño gráfico encabezado por Lance Wyman, personaje fundamental en relación a la gráfica de México 68. También en Architectural Record se encuentra una extensa reseña sobre el nuevo sistema de transporte público, sin embargo, sería a través de dos páginas de publicidad a todo color que se destacó en especial la Glorieta de Insurgentes iluminada artificialmente de noche ${ }^{15}$.

Estas noticias innegablemente sitúan una época de transición. En el caso de la casa O'Gorman, la inmediatez temporal de la obra impidió una valoración adecuada, lo que facilitó su destrucción. Por otro lado, las soluciones urbanas de transporte colectivo indicaron la escala de la ciudad que por entonces ya rebasaba sus límites funcionales, marcando un nuevo periodo de aproximación a la misma. El año 1970 registró un descenso en la cantidad de noticias en comparación con las que se reconocieron los años inmediatos anteriores —en especial el año 1968- aspecto sintomático 
del cambio de época y de la transformación en la difusión de la arquitectura mexicana fuera de sus fronteras a partir de entonces.

La primera aproximación a la totalidad de páginas recabadas en dieciséis títulos internacionales dibuja marcados picos y una que otra hondonada. Si bien la caída experimentada en el cambio de década es notoria, hay un mínimo de planas que dan asiento a la gráfica durante todos los años de estudio, alcanzando la cota mínima —entre el año 1960 y 1961 - un promedio de treinta y dos páginas por año, cantidad considerable de difusión aunque nada equiparable con las más de doscientas planas que acumuló el pico más alto de 1963.

Si a este volumen de papel impreso superponemos la suma total de comunicaciones, es decir, el número de noticias sin tomar en cuenta la extensión de las mismas, se nota de inmediato que algunos de los picos se diluyen manteniendo una distribución mucho más pareja, en donde sigue destacando sobre manera el pico de los monográficos de 1963, pero no ya el de $A A$ de 1955.
En la gráfica superior se muestra la totalidad de páginas publicadas en todas las revistas contempladas durante el periodo de estudio y abajo, en morado, se sobrepone la totalidad de comunicaciones a la gráfica inicial, indicada como fondo verde claro.
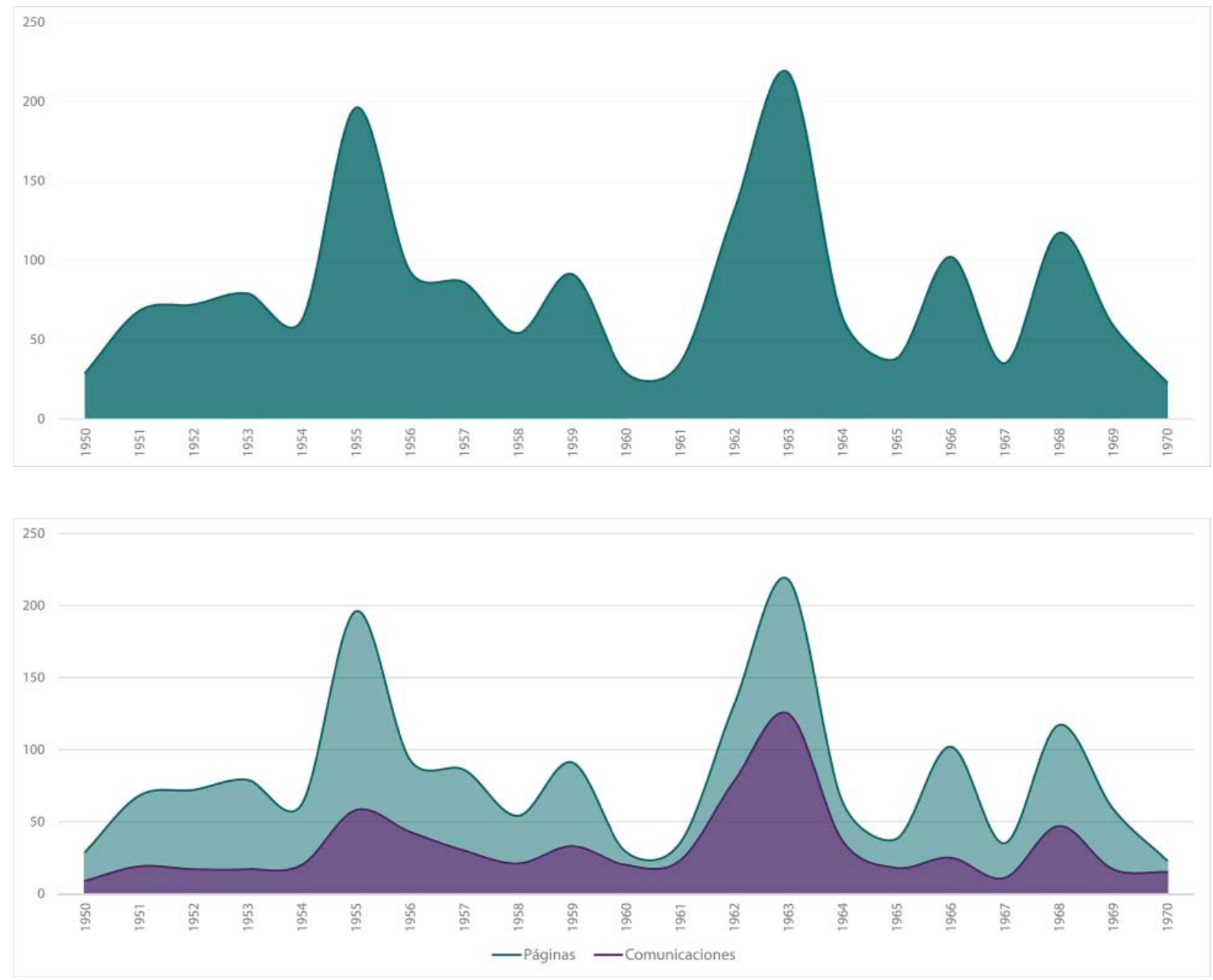
Si bien la totalidad de comunicaciones - artículos, noticias de actualidad, secciones, menciones, reseñas, cartas y publicidad- se catalogó y analizó cualitativamente de acuerdo a su impacto en cada revista, cabe destacar - como lo expresa la gráfica anterior - el contraste entre la cuantificación considerando un solo registro por categoría y su expansión al tomar en cuenta la cantidad de páginas. Se ha valorado este último como un aspecto fundamental para medir la difusión en cada revista. Así, el siguiente análisis por países, examina tanto la cantidad de comunicaciones como la totalidad de papel impreso.

Si por un lado contamos con casi setecientas noticias - repartidas entre las dieciséis publicaciones periódicas consultadas- al cuantificar el total de páginas la suma asciende a casi mil setecientas. Esas mil planas son las que respaldan en la gráfica al perfil de comunicaciones y que claramente indican el incremento en la cantidad de papel impreso destinado al tema mexicano.

Hasta este momento se ha insistido en los años de apertura y cierre del periodo de estudio obviando los años centrales, esto se debe a que el análisis por países que se ofrece a continuación profundiza en los temas y circunstancias que trazaron los contenidos principales. Entonces, interesa destacar ahora el papel de las diversas revistas extranjeras en relación a la modernidad y la aproximación de las mismas con México y en cómo dieron a conocer su arquitectura. En consecuencia, se considera la situación particular de las publicaciones de cinco países durante las décadas de 1950 y 1960, periodo de intensa actividad constructiva en México y, también, de importante difusión foránea. Es así que se subraya qué temas importaron en general y cómo éstos coincidieron con los lineamientos generales de cada revista. 


\subsection{Cinco miradas extranjeras Las publicaciones periódicas de Estados Unidos, España, Inglaterra, Francia e Italia}

\section{La información pragmática: Estados Unidos}

Estados Unidosiniciómuytempranola difusión dela arquitectura moderna mexicana. Se recuerda The New Architecture in Mexico, de Esther Born, publicado en Nueva York en 1937, volumen que tuvo como antecedente el número de abril del mismo año de Architectural Record. La aproximación norteamericana hacia la arquitectura mexicana fue pragmática, ésta enfatizó sobre todo los métodos constructivos artesanales y la facilidad que tuvieron los arquitectos para trabajar como sus propios contratistas, situación impensable en Estados Unidos. Esta praxis fue uno de los filtros a través del cual se dio a conocer la arquitectura de otras latitudes, siendo habitual encontrar en las páginas impresas datos duros sobre costos de obra por metros cúbicos, tiempos de ejecución o valor de las estructuras y del solar donde se levantaban los edificios. Se puede afirmar que las revistas norteamericanas consideraban especialmente a sus lectores — sus clientes a fin de cuentas - al brindar información comparativa útil, siempre en relación con su propio país. Tampoco se deben soslayar los constantes - y casi permanentes - intereses comerciales de Estados Unidos en México; es demostrativo no sólo que todos los anuncios lucrativos que se registraron durante las consultas ${ }^{1}$ corresponden exclusivamente a las revistas estadounidenses, sino que algunos edificios emblemáticos de la capital mexicana, como la Torre Latinoamericana, tuvieron más difusión en la sección de publicidad ${ }^{2}$ que en los artículos o apartados de actualidad de las publicaciones periódicas.

Otro aspecto a destacar aquí es la — relativa- cercanía geográfica entre la capital mexicana y las ciudades que más influyeron en la difusión de la arquitectura moderna a nivel internacional: Nueva York y, en menor medida, Los Ángeles ${ }^{3}$. Sin duda las distancias se acortaron virtualmente al establecerse vuelos comerciales entre estas ciudades norteamericanas,
1. Se hace referencia a toda aquella publicidad que directamente difundió edificios concretos de la arquitectura moderna mexicana.

2. Esto se debió principalmente al uso en la obra de materiales importados del país del norte. Véase Tuberías de cobre para drenaje marca NIBCO, "Publicidad: NIBCO," Architectural Record 119, no. 1 (enero 1956): 27; hormigón con aditivo marca Pozzolith en "Publicidad: The Master Builders Co.," Progressive Architecture 38, no. 12 (diciembre 1957): s/p. y Architectural Record 123, no. 1 (enero 1958): s/p.

3. En América las distancias parecen percibirse de manera muy distinta a como se viven en Europa; la distancia que separa el Distrito Federal de Nueva York es de 3,365 km; entre Los Ángeles y Acapulco hay cerca de 2,650 km. Como referencia, la distancia entre Madrid y Moscú es de 3,445 $\mathrm{km}$. Es curioso que un viaje entre la capital mexicana y Nueva York no se piensa como una distancia larga. 


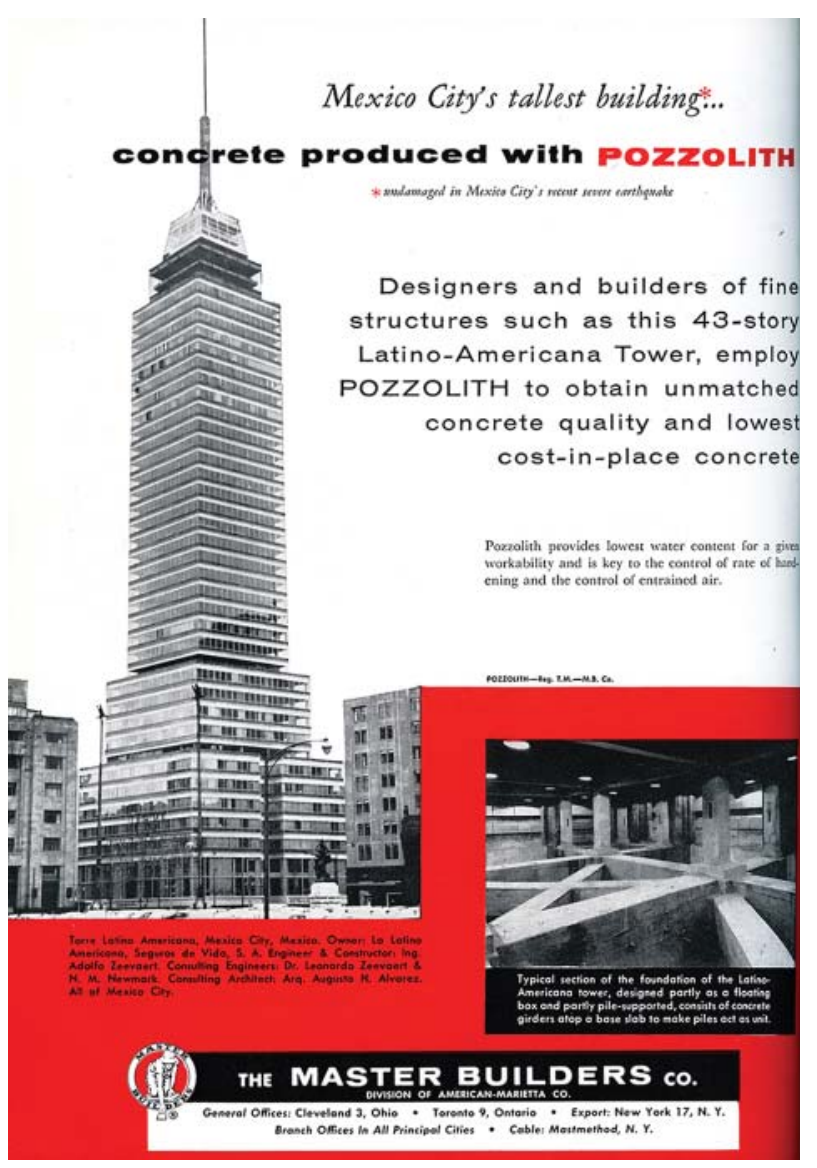

Torre Latinoamericana en la publicidad de Progressive Architecture (diciembre 1957).

la ciudad de México y Acapulco, fortaleciendo los vínculos económicos y turísticos gracias a las empresas de aviación ${ }^{4}$.

Desde la Costa Oeste, la revista que editaron John Entenza

4. Es significativo que desde 1957 la compañía Aeronaves de México obtuviera los permisos para explotar las rutas aéreas México-Nueva York y Acapulco-Los Ángeles.

5. La revista tuvo como antecedente directo a California Arts \& Architecture, fundada en 1929; en 1938 John Entenza la encuentra casi en bancarrota y la rescata. Fue entre 1943 y 1944 que se eliminó de su portada el nombre de California, quizá con la intención de brindar a la publicación un carácter nacional. En 1945 inició su famoso programa Case Study House y, a partir de 1962 y hasta su cierre en 1967 David Travers fue su editor. "Arts \& Architecture," David Travers, consultada 30 septiembre, 2013, http://www. artsandarchitecture.com/ about.html.

6. "Chairs by Clara Porset," Arts \& Architecture 68, no. 7 (julio 1951): 34-35. y David Travers: Arts \& Architecture (A\&A), fue bien conocida internacionalmente por su programa "Case Study House", que promovió nuevas ideas para el diseño arquitectónico de la vivienda unifamiliar durante más de veinte años ${ }^{5}$. La revista fue la plataforma desde la que se consolidó una importante generación de arquitectos californianos naturales o radicados definitivamente junto al Pacífico- entre los más conocidos Richard Neutra. Resulta innegable el interés de A\&A en los temas relacionados con la casa individual, por lo tanto no es sorprendente que tan temprano como 1951 se dedicara casi un número completo para dar a conocer la producción nacional. Lo que puede ser más significativo es la primera aproximación a la casa mexicana de la década de 1950 antes de ese número especial de agosto de 1951; el mes anterior se publicaba en la angelina el mobiliario diseñado por Clara Porset, extensamente utilizado en las casas modernas mexicanas ${ }^{6}$.

Con todo, la vivienda unifamiliar no fue lo único que interesó a la revista californiana - aunque sí el tema que acaparó la mayor cantidad 


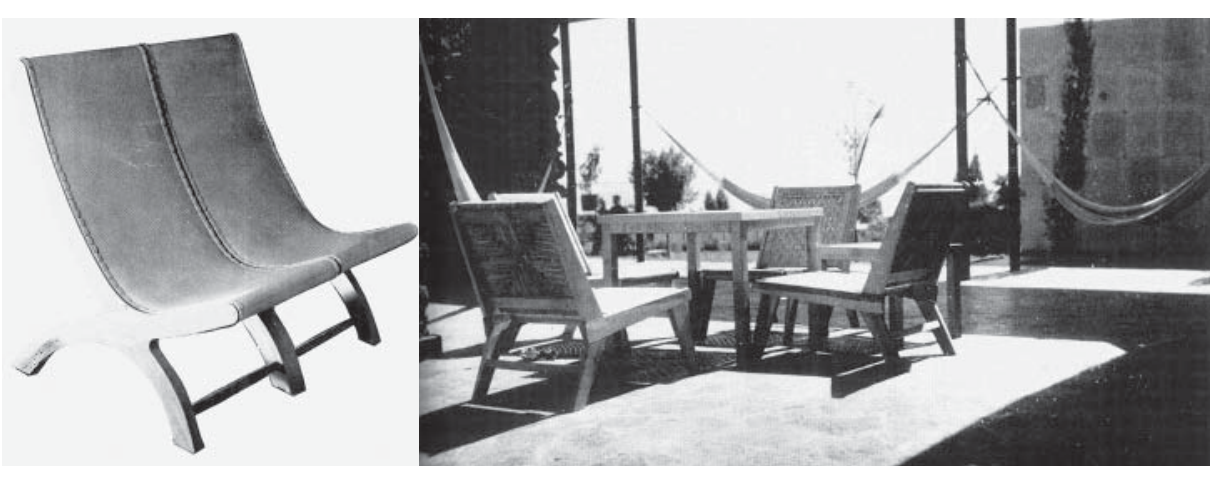

de artículos- pues también la Ciudad Universitaria gozó de difusión puntual y de la mayor cantidad de páginas dedicadas a un solo asunto. El ojo crítico de $A \& A$ - con el nombre de Esther McCoy- sería el vínculo permanente entre México y la publicación estadounidense, lo que facilitó que se dieran a conocer los ejemplos más emblemáticas de la modernidad mexicana en sus páginas. Así, las obras de Félix Candela, de Luis Barragán o el aeropuerto internacional de la Ciudad de México, de Augusto H. Álvarez, tuvieron un lugar destacado. En su momento se estudiará la estrecha relación de McCoy en cuanto a la difusión de la obra de Juan O'Gorman en $A \& A$ y, después de 1967, en otras revistas de impacto internacional.

En el otro extremo del país, en la Coste Este, Nueva York se situaba como el polo de difusión de la arquitectura moderna más importante de Estados Unidos ${ }^{7}$. Este trabajo contempló tres títulos neoyorquinos fundamentales: Architectural Record, Architectural Forum y Progressive Architecture, de los que se ofrece a continuación una semblanza sobre su difusión de la arquitectura moderna mexicana durante las décadas de 1950 y 1960.

Architectural Record, una de las revistas de arquitectura más longevas - se publica desde 1891- ha mantenido sus intereses centrados en la producción estadounidense $-\mathrm{o}$ de arquitectos norteamericanos en el extranjero- en la tecnología y en los análisis tipológicos (Building Types Study). En relación con México hay que destacar la temprana difusión de la arquitectura moderna mexicana -1937- y la continuidad de noticias durante la década de 1940. No obstante, al iniciar la década de 1950 la obra emblemática de la modernidad mexicana -la Ciudad Universitaria- pasó por completo desapercibida. El interés de la revista se dirigió hacia temas muy puntuales, como los proyectos de arquitectos estadounidenses en suelo mexicano ${ }^{8}$, la construcción de grandes hoteles
Mobiliario de Clara Porset adaptado a los materiales, el clima y la mano de obra mexicana. Imágenes de Arts \& Architecture (julio 1951).
7. Para el año que $A \& A$ cerraba sus puertas - 1967por falta de anunciantes, las neoyorquinas Progressive Architecture, Architectural Record y Architectural Forum contaban - cada una-con una media de 40 a 50 mil suscriptores registrados como arquitectos. La angelina cerró con 12,500 suscriptores, de los cuales alrededor de 3,000 estaban registrados como profesionales en el campo del diseño y la arquitectura. "Arts \& Architecture."

8. "Tropical House arcs to Ocean Panorama," Architectural Record 120, no. 3 (septiembre 1956): 202-204. 
de capital norteamericano o los temas técnicos ${ }^{10}$ y las noticias de actualidad en relación a la tecnología mexicana y su puesta a prueba por las fuerzas naturales ${ }^{11}$. También interesó especialmente la arquitectura comercial expresada en edificios privados de oficinas; un caso notable que ilustra muy bien esta tendencia seguida por Record es el edificio para la compañía Bacardí, de Mies van der Rohe, en Tultitlán ${ }^{12}$. Tampoco es desdeñable el volumen impreso de publicidad que en más de una ocasión refirió directamente algún edificio mexicano que utilizó materiales de construcción importados del norte.

Architectural Forum, también veterana al igual que Record, se esforzó en promover la industria de la construcción norteamericana al mismo tiempo que consolidar la arquitectura moderna ${ }^{13}$. Sin perder de vista sus intereses comerciales, la revista mensual eventualmente proveyó una mezcla única de teoría, arquitectura y diseño, sin olvidar los aspectos relativos a la industria y a la técnica. Esto dio paso a contenidos equilibrados, condición notoria al revisar su difusión con relación a la arquitectura mexicana.

Al iniciar el periodo de estudio, Forum evidenció el marcado interés comercial de la publicación con un artículo - citado antessobre el sistema constructivo del ingeniero mexicano Manuel González. En éste se recalcó el ahorro de tiempo y dinero y se resaltó el crecimiento de la empresa en un corto periodo de tiempo: había iniciado en 1946 con seis ingenieros y veinte trabajadores, contaba hacia finales de 1950 con veinticinco ingenieros y más de mil trabajadores. Para ese momento, varias compañías del suroeste de Estados Unidos ya habían obtenido la licencia para la aplicación de este método - cubierto con varias patentesempleándolo exitosamente tanto en estructuras metálicas como de

9. "Continental Hilton Mexico City," Architectural Record 121, no. 5 (mayo 1957): 232-35. El artículo formó parte de los Building Types Studies número 246 dedicado a hoteles.

10. Félix Candela, "Understanding the Hyperbolic Paraboloid," Architectural Record 124, no. 1 (julio 1958): 191-95 y "Understanding the Hyperbolic Paraboloid part 2," Architectural Record 124 no. 2 (agosto 1958): 205-207 y 215 .

11. Robert E. Fischer,
"Mexico City's Earthquake," Architectural Record 122, no. 4 (octubre 1957): 243-47 y Adolfo Zeevaert, "Tower Latino Americana: Mexico City's 'Quake-Proof Skyscraper," Architectural Record 122, no. 4 (octubre 1957): 249-52.

12. "Mexican Headquarters for Bacardi Rum," Architectural Record 127, no. 4 (abril 1960): 178-79.

13. Publicada desde 1917 - con el antecedente de Brickbuilder desde 1892- cerró en 1974. En 1932 la compró el magnate Henry L. Luce, quien apostó por la industria de la construcción con la idea de «influir en la vida a través de la arquitectura». Su circulación alcanzó los 60,000 ejemplares durante la década de 1960, aunque registrando pérdidas económicas. No obstante su influyente papel en la difusión arquitectónica del momento, Luce vendió la revista en 1964 a Urban America quien la publicó por otra década. "Codex 99," consultada 10 julio, 2015, http://www.codex99.com/design/130.html. 
madera. Esta primera visión de la arquitectura mexicana — una mirada desnuda a los edificios emblemáticos de la capital ${ }^{14}$ - es muy distinta de la que caracterizó después la difusión; aquí — todavía- predominan los datos técnicos.

Esta tendencia de Architectural Forum en sus análisis se comprueba al revisar algunas obras representativas de la modernidad, como el edificio de las Naciones Unidas en Nueva York, del que, además de diversas críticas, de una generosa descripción de su diseño y su influencia en edificios futuros, también se discutió su orientación y en cómo afectaba ésta al sistema de aire acondicionado y a otras instalaciones mecánicas ${ }^{15}$. Con todo, el interés de Forum en la arquitectura no se centraba exclusivamente en la producción norteamericana, pues para 1950 la mirada seguía puesta en Brasil ${ }^{16}$.

La siguiente noticia sobre México que se encuentra en Forum, la dedicada a la casa Silverstone en Taxco, encontró un lógico cauce de difusión debido a su autoría, la firma Anshen \& Allen. Para 1952, cuando se dio a conocer la Ciudad Universitaria, no obstante se enfatizó el uso de materiales tradicionales, primero se destacó el costo total de la obra y el hecho de haber sido ésta la primera obra mexicana con deadline, construida en tiempo record. Para el caso de Forum, CU actuó efectivamente como detonante del interés hacia la arquitectura moderna mexicana. Así, la difusión en $A F$ trazó un panorama equilibrado en temas a lo largo de todo el periodo de estudio, que incluyó los hitos emblemáticos de 1952 y 1968, las obras representativas de Candela y otros edificios de servicios como el Centro Comercial Jacaranda o el Hotel Camino Real, por citar solo algunos.

Progressive Architecture, la más joven de las tres —fundada en $1920^{17}$ - inició la difusión de noticias sobre México con un caso absolutamente comercial y anodino: el proyecto de un hotel de lujo en la ciudad de México, diseño del arquitecto Kemper Nomland, de Los Ángeles, California ${ }^{18}$. No se tendría nada que anotar acerca de otro diseño norteamericano en suelo mexicano si no fuese porque el texto subrayó como acabados finales la piedra local, que también sería empleada en su faceta decorativa en murales y esculturas de los espacios públicos. El auge de la integración plástica de los primeros años de la década de 1950 se hacía presente incluso en propuestas extranjeras para el territorio
14. En una de las imágenes vemos el edificio de la Secretaría de Recursos Hidráulicos de Mario Pani, construido entre 1946 y 1950.

15. "United Nations Secretariat," Architectural Forum 93, no. 5 (noviembre 1950): 93-112.

16. Véase "Farm Machinery Building," Architectural Forum 93, no. 5 (noviembre 1950): 136-137 y "Works of Oscar Niemeyer," Architectural Forum 93, no. 5 (noviembre 1950): 138-139.

17. Su último número se registró en diciembre de 1995 , contaba entonces con 52 mil suscriptores, la mayoría arquitectos. La vigencia de las revistas de arquitectura poco tiene que ver con las tendencias arquitectónicas; sus pulsaciones se miden por la relación entre suscriptores y anunciantes, y los beneficios económicos directos que las mantienen en circulación. "H-Net: Humanities and Social Sciences Online," consultada 10 julio, 2015, http://h-net.msu.edu/ cgi-bin/logbrowse.pl.

18. "Resort Hotel south of the border," Progressive Architecture 34, no. 6 (junio 1953): 15-16. 
nacional. La perspectiva - en la que este aspecto pasaba inadvertidodestacó especialmente el emplazamiento del hotel en el valle de México, que se veía todavía despoblado, limitado al oriente por las siluetas de los volcanes Iztaccíhuatl y Popocatépetl.

Pero el interés real en la arquitectura mexicana llegó a Progressive a través de dos fuentes, una, los estudios y críticas de Sibyl Moholy-Nagy y, también, por el desarrollo de los cascarones de hormigón armado de Félix Candela. La inclinación de Moholy-Nagy hacia la arquitectura latinoamericana moderna sin duda marcó una línea muy definida en la publicación, iniciando con su crítica a la Ciudad Universitaria de México en noviembre de $1953^{19}$. Por otro lado, a partir de 1954, con la publicación de "Stereo-Structures"20, Progressive volcaría su interés casi por completo en la vida y obra de Candela, dedicando más del $40 \%$ del total de artículos dirigidos a temas mexicanos al arquitecto español radicado en México. A pesar de esta clara tendencia, $P A$ también publicó obras fundamentales de Mathias Goeritz, Augusto H. Álvarez, Mario Pani, Ricardo Legorreta y Pedro Ramírez Vázquez.

La gráfica con la totalidad de páginas editadas sobre México en las publicaciones estadounidenses durante todo el periodo de estudio muestra un panorama bastante equilibrado y constante, con algunos picos que explican temas clave del momento. A diferencia de lo que se verá más adelante en otros países, la ausencia de monográficos manifiesta que la cota más alta no supere las veinticinco páginas al año por revista. En 1951 Arts \& Architecture sobresalió por su extenso número dedicado a la vivienda unifamiliar, mientras que en 1952, la misma angelina y Architectural Forum despuntaron por los extensos artículos dedicados a la Ciudad Universitaria. $A \& A$ acumuló importantes artículos durante todo el año 1955 - los cascarones de Candela y el aeropuerto de la ciudad de México de Álvarez entre los más destacados- y ya en 1964 otro pico indica el número especial sobre Juan O’Gorman y el arte y la arquitectura maya.

19. Sibyl Moholy-Nagy, "Mexican critique," Progressive Architecture 34, no. 11 (noviembre 1953): 109, 170, 172, 175-76.

20. Félix Candela, "StereoStructures," Progressive Architecture 35, no. 6 (junio 1954): 84-93.

Forum, después del extenso artículo sobre la CU en 1952, cerró el periodo de estudio con otro pico en el año 1968 debido tanto a la arquitectura olímpica como al Hotel Camino Real de Legorreta. Por su parte, Progressive registró un crecimiento constante a partir de 1952 y hasta 1957, resultado de la acumulación de noticias sobre distintos inmuebles. 


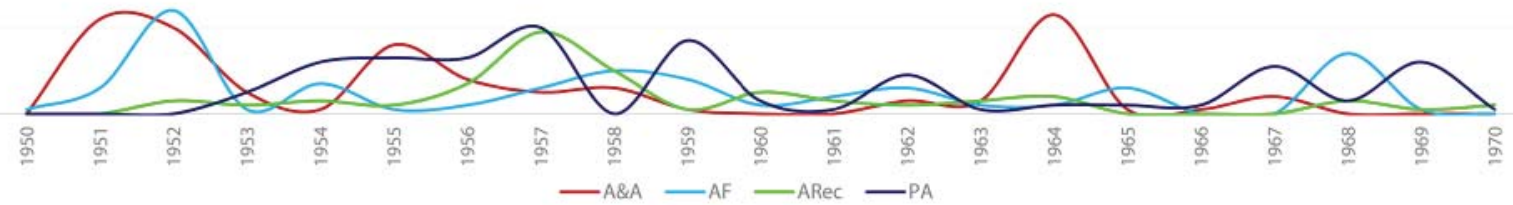

Gráfica que muestra la distribución de páginas por año en cuatro publicaciones estadounidenses. Arts \& Architecture en color vino, Architectural Forum en azul claro, Architectural Record en verde y Progressive Architecture en azul oscuro.

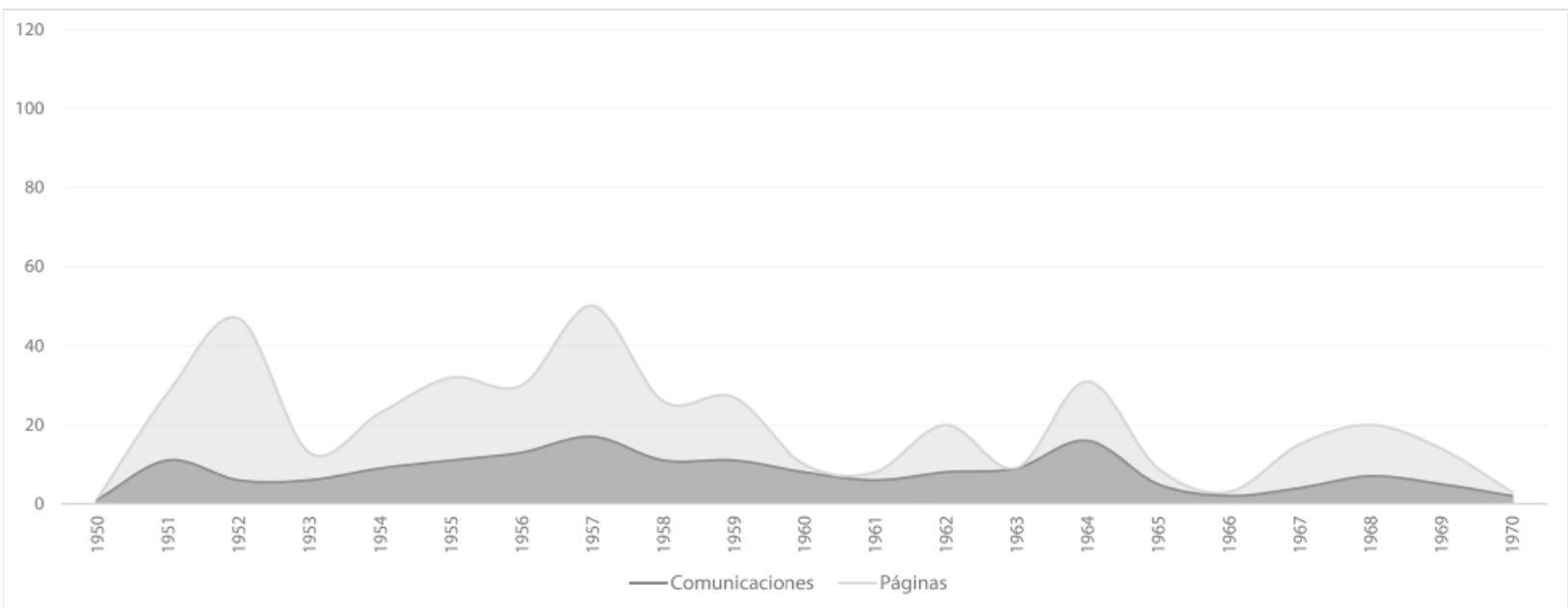

Gráfica con la distribución por año de comunicaciones —en gris oscuro—y páginas —en gris claro—en las cuatro revistas estadounidenses contempladas en este estudio.

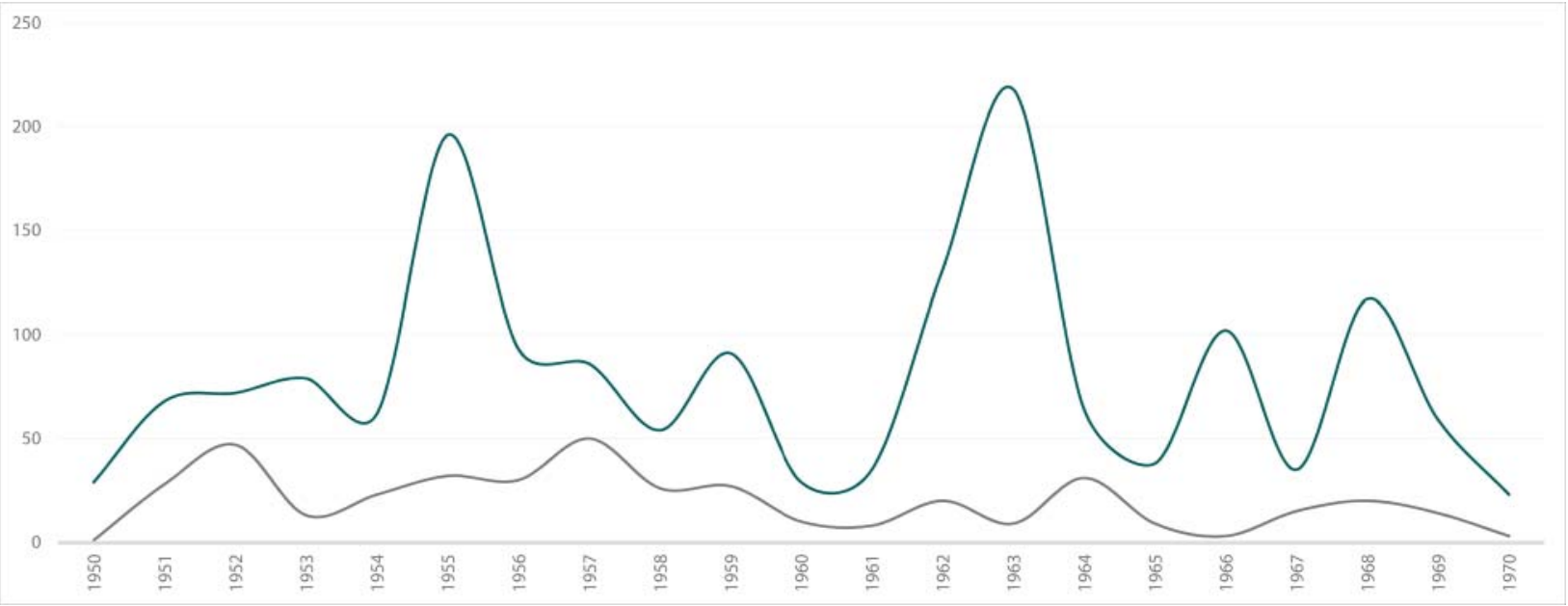

Gráfica que compara el total de páginas publicadas en todas revistas de los cinco países — perfil superior-contra la suma de papel impreso en las cuatro revistas de Estados Unidos. 
21. Si bien todas las publicaciones neoyorquinas $-A R e c$ $A F$ y $P A$ - estuvieron vigentes entre 1950 y 1970 , de $A \mho A$ se consideraron los años de 1950 a 1967 - momento de su cierre. Con todo, la angelina registró más páginas que $R e$ cord y Forum, quedando tan sólo ocho páginas por debajo de Progressive, que alcanzó las 127 planas.
Después de una caída repentina, el flujo informativo se recuperó en 1959, especialmente por la publicación de las obras recientes de Candela. Progressive no alcanzaría otro pico significativo, ni siquiera hacia finales de la década de 1960, cuando lo más sobresaliente que dio a conocer fue el Museo Nacional de Antropología e Historia (MNAH) de Ramírez Vázquez e, igual que Forum, el Camino Real.

No casualmente, Architectural Record reunió en 1957 sus principales temas de interés: la arquitectura de hoteles y oficinas, así como una extensa revisión técnica a ciertos edificios de la ciudad de México después del fuerte sismo de ese año. De las cuatro revistas norteamericanas, Record contó con el menor número de páginas totales destinadas a la difusión de la arquitectura mexicana. Si bien se registró un promedio de cien páginas por revista en las publicaciones de Nueva York y Los Ángeles durante las dos décadas de análisis ${ }^{21}$, Record alcanzó apenas setenta, lo que deja todavía más patente la pérdida de interés en el país vecino del sur después del empuje que significó la publicación de Born en 1937 y las constantes comunicaciones durante la década de 1940.

El panorama global estadounidense apunta un total de cuatrocientas veinte páginas y alrededor de ciento setenta noticias, mismas que vemos representadas en el perfil de la gráfica. Se observa que las intersecciones entre la curva de comunicaciones y de páginas - entre 1960 y 1961, en 1963 y en 1966- hacen evidente que la extensión de las noticias en esos años nunca superó una página, pues coinciden en número ambos registros. Esto indica la ausencia de artículos — de por lo menos dos páginas-y la presencia de comunicaciones concisas.

$\mathrm{Al}$ acumular las páginas de las cuatro revistas estadounidenses se hacen notables algunos temas de interés común que se integran a la tendencia internacional, como se verifica al equiparar la silueta total de información con la correspondiente al país norteamericano. En especial, al inicio de la difusión con la curva cuyo pico máximo alcanza el año 1952. También es coincidente la caída del año 1958 y la hondonada del cambio de década. 


\section{Tiempos de apertura al exterior: España}

Mientras la relación de Estados Unidos con México en las publicaciones periódicas estuvo marcada por intereses comerciales e información práctica, España trazó un panorama de difusión muy distinto debido a los vínculos que mantuvieron ambos países en los años posteriores a la Guerra Civil, tiempo en que España «vivió de puertas adentro» ${ }^{22}$ y sin relaciones oficiales con México, que siempre reconoció al gobierno Republicano en el exilio. Durante todo el periodo de estudio, los lazos entre ambos países se mantuvieron constantes a pesar del clima político desfavorable que tiñó los años del franquismo. De esta manera, la consolidación de los vínculos históricos, el intercambio editorial, los viajes transatlánticos en ambas direcciones, el interés especial de España en publicar lo de fuera para abrirse a la modernidad, el reconocimiento al notable trabajo de los arquitectos en el exilio y hasta una búsqueda de modelos arquitectónicos con fines muy específicos fomentaron el conocimiento de lo mexicano en los medios españoles de difusión de la arquitectura.

Cuatro publicaciones forman el corpus español de esta tesis, las cuatro madrileñas por dos motivos principales. El primero se debe al papel que jugó Madrid en la puesta al día de la arquitectura española durante las décadas de 1950 y 1960, resultado —en gran medida - de la publicación constante de ejemplos modernos de otras latitudes. Para Oriol Bohigas, las revistas madrileñas se lanzaron a «la aventura del reencuentro de la arquitectura moderna en España $»^{23}$ gracias a la polémica que generaron y al desarrollo de unos instrumentos críticos que hicieron posible la trasformación. El autor insiste en que «su influencia alcanzó a toda la arquitectura española [y] en Madrid su papel se radicalizó» ${ }^{24}$. Por otro lado, se consideró sustancial para esta investigación la consulta exhaustiva de los fondos de las décadas de 1950 y 1960, condición que se cubría en las bibliotecas de la Escuela Técnica Superior de Arquitectura de Madrid (ETSAm) y del Colegio Oficial de Arquitectos de Madrid (COAm).

Es así que los títulos que se analizan son la Revista Nacional de Arquitectura/Arquitectura (RNA/A), el Boletín de Información de la Dirección General de Arquitectura (BDGA), Hogar y Arquitectura (HyA) e Informes de la Construcción (IC), de los que a continuación se repasan sus lineamientos en relación a la arquitectura moderna mexicana durante el periodo de estudio.
22. Ana Esteban Maluenda, "Transmisión bipolar: la difusión de la arquitectura moderna latinoamericana en España (1949-1968)," Revista 18029 (2012): 24.

23. Oriol Bohigas, "Tres revistas," Arquitecturas Bis, no. 23-24 (julio-septiembre 1978): 60. El autor se refiere particularmente a Arquitectura, Hogar y Arquitectura y Nueva Forma, en sus periodos editados por Carlos de Miguel, Carlos Flores y Juan Daniel Fullaondo respectivamente. Aquí se agrega Informes de la Construcción, que, al igual que los títulos citados antes, también jugó un papel sustancial en cuanto a la difusión de la arquitectura foránea durante esos años.

24. Bohigas, "Tres revistas," 60. 
25. A partir de ese momento se convirtió de nueva cuenta en el órgano oficial del Colegio de Arquitectos de Madrid.

26. Véase Ana Esteban Maluenda, "La modernidad importada. Madrid 19491968: Cauces de difusión de la arquitectura extranjera" (Tesis de Doctorado, Universidad Politécnica de Madrid, 2007). En especial el capítulo titulado "RNA y Arquitectura: crónica de una época”, páginas 247-327.

27. "Seminario menor en el Km. 17,5 de la carretera México-Toluca," Revista $\mathrm{Na}$ cional de Arquitectura, no. 196 (abril 1958): 37-46.

28. Carlos de Miguel viajó a México para participar en el Congreso; a principios de 1953 publicaría su reseña sobre la experiencia en el $B D G A$, que también tenía a su cargo.
La Revista Nacional de Arquitectura tuvo como antecedente Arquitectura, publicada desde 1918 como órgano del Colegio Oficial de Arquitectos de Madrid. El inicio de la Guerra Civil interrumpió su edición hasta 1941, año en que fue retomada como RNA y publicada por la Dirección General de Arquitectura. La RNA mantuvo ese nombre hasta 1959, cuando recobró su título original: Arquitectura ${ }^{25}$. Desde 1948 y hasta 1973 estuvo al frente de la publicación madrileña el arquitecto Carlos de Miguel, lo que justifica considerarla la misma revista ${ }^{26}$.

No obstante lo anterior, el flujo informativo de la arquitectura moderna mexicana en esta publicación siguió un curso discontinuo y con diferencias muy marcadas entre el periodo de la RNA y de Arquitectura. Después del potente arranque noticioso de 1950, que dio a conocer la obra reciente de Mario Pani y los estudios técnicos de Candela, en los siguientes años se notó un vacío considerable, que sería revertido los últimos meses de la $R N A$ con la publicación de un proyecto de José Luis Benlliure ${ }^{27}$. En estos nueve años - de 1950 a 1958 - apenas registramos el 15\% del total de información publicada sobre México en esta revista. Llama la atención la ausencia de noticias sobre la Ciudad Universitaria, la obra mexicana más importante de esos primeros años de la década de 1950. Sorprende más la falta de información pues Carlos de Miguel recibió la invitación para asistir al viı Congreso Panamericano de Arquitectos de 1952 - que inauguró simbólicamente la CU-e incluso lo comunicó a sus lectores en el número de julio de 1952; sin embargo, no publicó ningún artículo sobre el tema en la $R N A^{28}$.

Entonces, el $85 \%$ de las páginas recaen en Arquitectura en el periodo de 1959 a 1970. Se debe considerar que, a diferencia de las revistas norteamericanas, las españolas sí dedicaron monográficos a México, por lo que el total de papel difundido aumentó considerablemente. También, cabe destacar el número de octubre de 1959, momento en que los lectores españoles por fin accedieron a un compendio significativo de la obra más reciente de Candela, que antes se había publicado sólo a cuentagotas en las revistas madrileñas. Para agosto de 1962, hay que mencionar el indispensable monográfico mexicano con más de setenta páginas de información y, tres años más tarde, el Museo Nacional de Antropología e Historia sería tema de una extensa revisión. Hacia el final del periodo de estudio, se cuentan entre los temas fundamentales que dio a conocer 
Arquitectura el número especial sobre la arquitectura olímpica de 1968 y, al año siguiente, el Hotel Camino Real.

Cabe recordar que este interés en lo de fuera no fue exclusivo hacia México, la apertura del mundo editorial madrileño, en un esfuerzo por ponerse al día, benefició la publicación de arquitectura extranjera en las revistas especializadas, las que hoy se consideran el «vehículo más eficaz de propagación de la producción foránea en España» ${ }^{29}$. El panorama edilicio que ocupó las páginas de las publicaciones periódicas españolas fue mucho más amplio y diverso del que ofrecía el limitado a la obra construida en las fronteras nacionales. En este sentido el papel de los directores de las revistas fue fundamental, y, en el caso que aquí se trata, Carlos de Miguel al frente de la RNA y Arquitectura «sin llegar a demostrar nunca una predilección especial por la arquitectura foránea ... entendió muy pronto que la evolución y puesta al día de nuestra producción pasaba por el conocimiento de lo que se hacía fuera ${ }^{30}$.

Ante esta afirmación, tampoco se puede obviar el tipo de publicación a la que nos referimos, esto es, el órgano de difusión de una agrupación colegiada, dispuesta a atender a todo el colectivo y por lo tanto, abierta a difundir los contenidos de la profesión a la que representan además de ser «vehículo de información y foro de debate de la actualidad más significativa» ${ }^{31}$.

Para la $R N A$ y $A$, mirar fuera de las fronteras nacionales no era ni mucho menos un ejercicio de xenofilia, casi se diría que al contrario, el fin principal fue «la mejora de la producción española y su equiparación con la internacional» ${ }^{32}$. Como se va viendo, lo que motivó la difusión de la arquitectura mexicana en los distintos países se definió por situaciones nacionales muy particulares, lo que, necesariamente, dibujó características especiales en la transmisión de noticias de los medios periódicos.

Una publicación emparentada en cierto modo con la RNA fue el Boletín de Información de la Dirección General de Arquitectura, ya que, como lo indica su nombre, provenía del mismo Ministerio de Vivienda que durante los primeros años de la dictadura editó la propia RNA. No sólo eso, su director, de forma paralela a la RNA, fue también Carlos de Miguel. El BDGA surgió en el momento en que la RNA dejó de ser editada por la Dirección General de Arquitectura para serlo por el Consejo Superior de Colegios de Arquitectos de España ${ }^{33}$, con el fin de ser el órgano oficial de
29. Esteban Maluenda, “Transmisión bipolar," 24. 30. Ana Esteban Maluenda, "Fuente y fundamento. Las publicaciones periódicas como soporte de la reincorporación de la arquitectura española a las corrientes internacionales en la segunda mitad del siglo xx", Revista de Arquitectura 23 (2011): 53-54.

31. Hurtado Torán, "Publicaciones periódicas de arquitectura," 163.

32. Esteban Maluenda, "La modernidad importada," 240.

33. Aunque editada por el Colegio de Arquitectos desde 1947 , se recuerda que no volvería a ser el órgano oficial del Colegio de Arquitectos de Madrid sino hasta 1959. 
información de dicha Dirección. Desde sus inicios, las comunicaciones sobre viajes y congresos internacionales fueron de especial interés, así como la apertura hacia los debates de la época, sustanciales porque sirvieron de plataforma para exponer no sólo el panorama español sino también el de otras latitudes. Es por tal motivo que interesa especialmente el Boletín a esta investigación, no obstante la información sobre México fue bastante limitada.

El BDGA, cuyo primer número se lanzó en diciembre de $1946^{34}$, expresó una premisa muy bien definida: establecer el debate sobre el futuro de la arquitectura española que, después de la Guerra Civil, experimentaba momentos de retroceso e historicismo debido al empeño del gobierno franquista en crear un "estilo nacional" cimentado en la tradición. De Miguel abría las páginas del Boletín para recibir «todas las sugerencias e ideas» de los arquitectos para que, en colaboración conjunta, se "perfeccionara" la arquitectura española ${ }^{35}$. Así, a partir de 1947 la publicación editó varios artículos dirigidos a constituir la discusión en torno a las tendencias estéticas que debían caracterizar la "genuina" arquitectura española. Lo que interesa destacar aquí no es el tema en sí sino la similitud del debate que, de forma paralela, se desarrollaba en México. Tradición versus modernidad fue una discusión constante desde la década de 1930 en México. Cuando esta disyuntiva se convirtió en la incógnita a resolver en España hacia finales de los años cuarenta, los propios arquitectos españoles notaron que «no eran los únicos que se hacían todas esas preguntas y decidieron mirar hacia fuera para comparar con su caso» ${ }^{36}$.

En este contexto, se recuerda el artículo firmado por Alberto T. Arai y publicado en el BDGA el último trimestre de $1951^{37}$, mismo que expuso no sólo la inquietud de un grupo de arquitectos mexicanos

34. La vida del Boletín fue bastante corta pues su último número se registró en 1957.

35. "Presentación," Boletín de Información de la Dirección General de Arquitectura, no. 1 (diciembre 1946): s/p.

36. Esteban Maluenda, "La modernidad importada," 375. 37. Alberto T. Arai, "La arquitectura mexicana contemporánea," Boletín de Información de la Dirección General de Arquitectura v, (cuarto trimestre 1951): 27-30. interesados en los programas de necesidades nacionales, sino también en cómo encontrar una expresión arquitectónica propia y diferenciada del resto del mundo.

$\mathrm{Y}$ en el tema de los congresos internacionales, el entusiasmo por visitar el mundo y así equiparar lo que se hacía fuera con la producción española se notó también desde muy temprano en el Boletín. En diciembre de 1947 De Miguel publicó una extensa crónica sobre el viaje de los arquitectos españoles al vi Congreso Panamericano de Lima, tema al que 
dio continuidad en el siguiente número, el de marzo de 1948, con otro artículo sobre el mismo evento y con la publicación de las láminas que presentó su país. El interés en lo foráneo, con el fin antes enunciado, sería una de las características principales de este órgano de difusión. Ya se ha comentado que el propio De Miguel viajó a México con motivo del viII Congreso Panamericano de Arquitectos de 1952, viaje del que quedaría constancia impresa en el Boletín en el primer trimestre de 1953, con una extensa reseña del editor y sus impresiones del evento internacional y su justa organización ${ }^{38}$.

Cabría puntualizar que esta publicación de la Dirección General de Arquitectura no tuvo como fin divulgar edificios particulares - nunca se valió del recurso de la fotografía de arquitectura- sino que se centró especialmente en difundir temas como los citados congresos o, también, bienales, viajes de estudio, planes gubernamentales de vivienda o construcción a nivel nacional, concursos, ensayos sobre discusiones actuales como el estilo, la tradición en la arquitectura o noticias sobre la arquitectura moderna. Si bien la cantidad de información que publicó el Boletín sobre México apenas sobresale en comparación con Arquitectura e Informes de la Construcción, el espacio editorial que dedicó a los temas de debate del momento y el intercambio de información entre países dejan constancia de un aspecto particular - y no menos importante- de la difusión de la arquitectura mexicana en los medios foráneos.

Otra revista madrileña, Hogar y Arquitectura, órgano de la Obra Sindical del Hogar, inició su vida en 1955 con una estricta difusión dirigida, en primer lugar, a la producción nacional del sindicato al que representaba y, en segundo término, mostró en sus primeros números una cierta apertura hacia el exterior - especialmente con ejemplos alemanes e ingleses-, pero sin desvincularse del tema de la habitación social. La participación directa del arquitecto Carlos Flores, como articulista desde 1958 y como editor a partir de 1963 y hasta 1974, transformaría la revista en una verdadera plataforma desde la cual conocer la arquitectura contemporánea más actual ${ }^{39}$.

La labor de Flores en Hogar y Arquitectura generó pliegos «repletos de un esfuerzo de divulgación y puesta al día», con la intención expresa de «hacer de ella una revista de arquitectura» ${ }^{40}$. Los contenidos, como lo recordaría el propio Flores pocos años después de finalizado su trabajo
38. "El viII Congreso Panamericano de Arquitectos," Boletín de Información de la Dirección General de Arquitectura vII (primer trimestre 1953): 28-32.

39. La salida de Carlos Flores como director de Hogar y Arquitectura supuso una reestructuración de contenidos de la misma que, en términos generales, la devolvió a los postulados que le dieron origen en 1955: la difusión exclusiva de la Obra Sindical del Hogar. La revista, después de varios meses en pausa durante 1975 y 1976, se publicaría tan sólo hasta 1978. Véase Candelaria Alarcón Reyero, "La arquitectura en España a través de las revistas especializadas 1950-1970. El caso de Hogar y Arquitectura" (Tesis de Doctorado, Universidad Politécnica de Madrid, 2000), 344-410.

40. Bohigas, "Tres revistas," 60. 
como editor, tuvieron la intención de «desarrollar en cada número un tema central tratado con cierta amplitud y completar este bloque monográfico con artículos, secciones diversas [y] colaboraciones» ${ }^{41}$. En este contexto se sitúa el número especial dedicado a la arquitectura religiosa, de marzoabril de 1965, en que la iglesia de la virgen de la Medalla Milagrosa y la capilla de San Vicente de Paul de Félix Candela fueron parte de la selección de Flores para su artículo "Un siglo de arquitectura religiosa"42.

Hay que destacar que, no obstante la tarea fundamental de Flores de dar a conocer la arquitectura foránea, el caso mexicano se redujo prácticamente a menciones puntuales de la obra de su connacional radicado en América, y en un periodo muy tardío, cuando el calculista ya gozaba de un sólido - y merecido- éxito internacional. En el citado número de 1965 también se transcribió una frase titulada «Hipertrofia técnica» ${ }^{43}$, firmada por el propio Candela, que advertía sobre los peligros de una excesiva tecnificación en un mundo gobernado por la Guerra Fría y la amenaza de un desastre nuclear todavía latente.

Pocos años antes —en 1962 - la primera mención a alguna obra mexicana en $H y A$ provino de la reseña del número once de Bauen \& Wohnen (noviembre 1961), que trató las estructuras laminares de hormigón, por lo que tanto Candela como Alejandro Zohn se hicieron eco en la publicación madrileña ${ }^{44}$. El hormigón —desde sus aspectos plásticos hasta los estructurales- no podía evitarse como tema central en las publicaciones periódicas de arquitectura durante los años de estudio. La revista que encabezó Flores no fue la excepción y en su número 64 - de 1966- dio a conocer un edificio que interesó especialmente a esta investigación: el santuario de Nuestra Señora de Guadalupe en Madrid, de diseño mexicano ${ }^{45}$. En el mismo número, una selección cuidadosa de

$$
61 .
$$

41. Bohigas, "Tres revistas,"

42. Carlos Flores, "Un siglo de arquitectura religiosa," Hogar y Arquitectura, no. 57 (marzo-abril 1965): 30.

43. Véase en la sección "Han dicho...": "Hipertrofia técnica," Hogar y Arquitectura, no. 57 (marzo-abril 1965): 78. «No es de extrañar la enorme, si bien injustificada soberbia, que caracteriza al hombre actual. Cree éste ser capaz de conseguirlo todo con rapidez y facilidad y le parece tener dominada a la Naturaleza, olvidando que antes necesita dominarse a sí mismo; que sin un desarrollo parejo de las otras ciencias -las morales, políticas y sociales- el germen de destrucción que lleva dentro de sí amenaza claramente con dar al traste con toda la civilización actual. La desequilibrada hipertrofia técnica sólo servirá, en definitiva, para darle más poderosas armas con las que pueda cómodamente completar su propia destrucción».

44. "Resumen de revistas,"

Hogar y Arquitectura, no. 38 (enero-febrero 1962): 65-66. Del primero se mencionó el restaurante Los Manantiales, en Xochimilco y la Iglesia de San José Obrero en Monterrey, y del segundo sus cubiertas en la capital de Jalisco.

45. "Santuario de Nuestra Señora de Guadalupe en Madrid," Hogar y Arquitectura, no. 64 (mayo-junio 1966): 2229. El proyecto fue de Enrique de la Mora y el español José Ramón Azpiazu Ordóñez y para el cálculo estructural se contó con Félix Candela y, de España, José Antonio Torroja. 
Iglesia de Nuestra Señora de Guadalupe en Madrid, 2014.

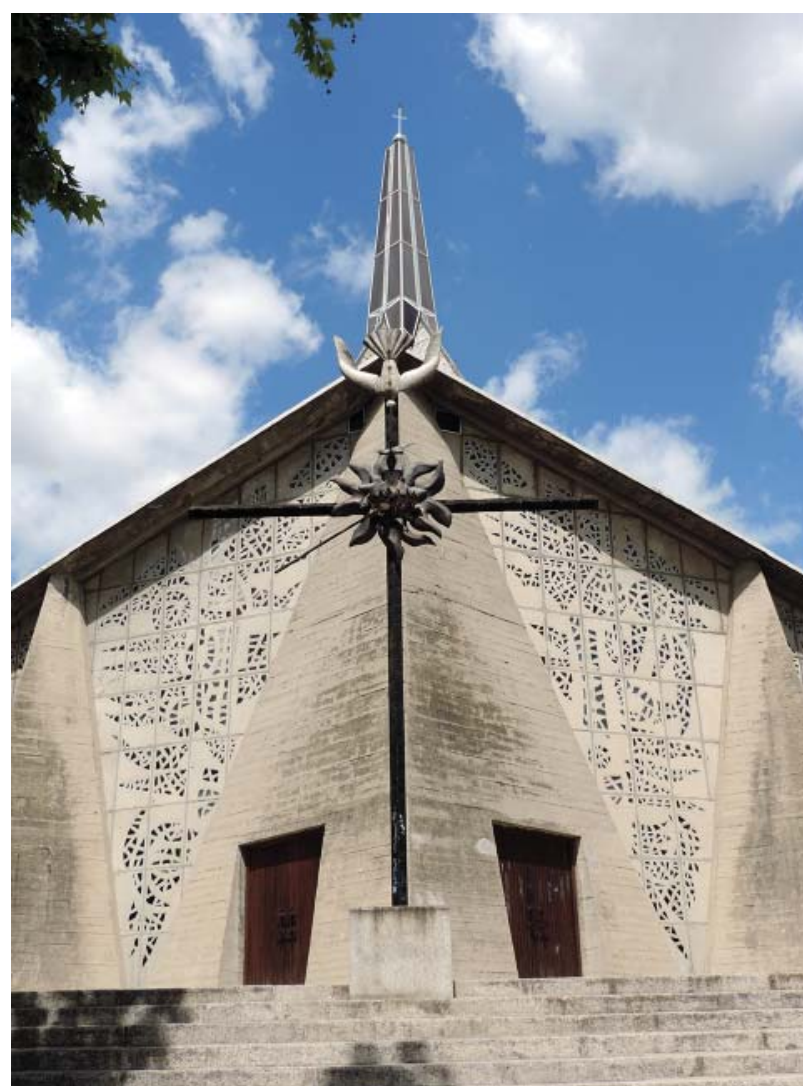

imágenes de todo el mundo que ilustró la "plástica del hormigón armado» ayudaba a consolidar a la iglesia de la virgen de la Medalla Milagrosa como la obra de Candela más repetida en los medios periódicos de la época ${ }^{46}$.

Es notorio que, en este caso, el papel de $H y A$ fue más bien el de robustecer el reconocimiento en los medios foráneos hacia la obra y el personaje de Candela. Los ejemplos que se publicaron en la década de 1960 en la revista de Flores tenían ya varios años circulando y aumentando la fama del arquitecto español radicado en México.

Más allá de las estructuras laminares de hormigón, otro tema en relación a México interesó en Hogar y Arquitectura: los congresos internacionales. En su número 54 - del año 1964- Flores publicó en su Suplemento el resumen del vir Congreso de la Unión Internacional de Arquitectos (UIA) que se había llevado a cabo en Cuba en septiembre de 1963 y las Jornadas Internacionales de Arquitectura —organizadas por la misma UIA - realizadas en México en octubre del mismo año ${ }^{47}$. También, el Primer Encuentro de Jóvenes Arquitectos, dispuesto dentro del marco de la Olimpiada Cultural de 1968, se hizo eco en HyA con un intenso debate sobre el papel actual del arquitecto $^{48}$. En esos años se hizo evidente la crisis que atravesaba el arquitecto de cara a su aislamiento $-\mathrm{y}$ hasta cierto punto desinterés- en resolver las necesidades de la sociedad.
46. "La plástica del hormigón armado." Hogar y Arquitectura, no. 64 (mayo-junio 1966): 58.

47. "VII Congreso de la Unión Internacional de Arquitectos," Hogar y Arquitectura, no. 54 (septiembre-octubre de 1964): 68-72. El texto fue cortesía de la revista mexicana de arquitectura Calli.

48. George Candilis, "En busca de un nuevo sentido para la palabra arquitecto," Hogar y Arquitectura, no. 79 (noviembre-diciembre 1968): 4-5 y Manuel Trillo, "I Encuentro de Jóvenes Arquitectos," Hogar y Arquitectura, no. 79 (noviembre-diciembre 1968): 83-84. 

61.

49. Bohigas, "Tres revistas,"

50. Además, Flores fue corresponsal de Architectural Design, lo que con seguridad estableció una red de intercambio de información entre Londres y Madrid.

51. La revista se originó en 1948 y se imprimió en papel hasta el año 2013, iniciando su vida $100 \%$ digital a partir de su número 533 del primer trimestre de 2014.

52. Es por demás significativo que de 3 mil referencias sobre arquitectura foránea en las revistas madrileñas entre 1949 y 1968 , casi el $50 \%$ recaen en IC. Ana Esteban Maluenda, "Informes de la Construcción: más que una revista técnica," Informes de la Construcción 60, no. 510 (abril-junio 2008): 88.

53. Ana Esteban Maluenda entrevistó a José Antonio Corrales y Rafael Moneo, quienes, al hablar de las publicaciones periódicas de la época, no recordaban especialmente la consulta de Informes de la Construcción, pero sí de los títulos encabezados por los arquitectos que formaban parte del gremio: Arquitectura y Hogar y Arquitectura especialmente.
Flores sancionaba que el arquitecto «constituye ... una de las figuras profesionales más confusas, contradictorias y anacrónicas ... su trabajo sigue desarrollándose ... de espaldas a la realidad, con una profunda desconexión ... respecto a problemas y exigencias que son fundamentales dentro de la sociedad actual» ${ }^{49}$.

No cabe duda que los años gloriosos de Hogar y Arquitectura corresponden al periodo de dirección de Carlos Flores, quien facilitó a los lectores españoles un panorama extenso del acontecer arquitectónico internacional ${ }^{50}$. Si bien México no tuvo un lugar prioritario en la difusión de lo foráneo, al igual que pasó con el Boletín de la Dirección General de Arquitectura, las comunicaciones puntuales de $H y A$ fortalecieron, por un lado, una parte de la arquitectura mexicana que ya se conocía en el extranjero - el caso de Candela-y por otro, al abrirse hacia las discusiones del momento, incluyó los temas de actualidad en el panorama mexicano general, lo que necesariamente da otra perspectiva de la difusión.

A través de los títulos expuestos queda en evidencia la estrecha relación de un organismo oficial o sindical como soporte de las publicaciones periódicas madrileñas. No será la excepción del último título que se revisa: Informes de la Construcción, revista de información técnica y comercial publicada por el Instituto Técnico de la Construcción y del Cemento de Madrid - a partir de 1962 Instituto Eduardo Torroja de la Construcción y del Cemento- en honor de su director fundador ${ }^{51}$.

El caso de Informes de la Construcción durante las décadas de estudio sorprende por dos aspectos, el primero, porque al igual que Hogar y Arquitectura -órgano de difusión de la Obra Sindical del Hogar - en principio, no prometería una apertura suficiente hacia los temas extranjeros y sin embargo resultó ser el título madrileño que publicó más extensamente los edificios construidos fuera de las fronteras españolas ${ }^{52}$. Por otro lado, su mayor contradicción radica en el desinterés que el gremio de arquitectos prestó a esta publicación que, a diferencia de las otras revistas analizadas, informó puntual y constantemente sobre el acaecer arquitectónico internacional. La ansiada información sobre el mundo exterior estaba ahí, y los arquitectos españoles la obviaron ${ }^{53}$. Si se considera la avidez visual de los arquitectos, tampoco sería justificado decir que la ausencia en Informes de textos que planteasen una crítica sobre el estado de la arquitectura fuese el motivo de su escasa consulta. 


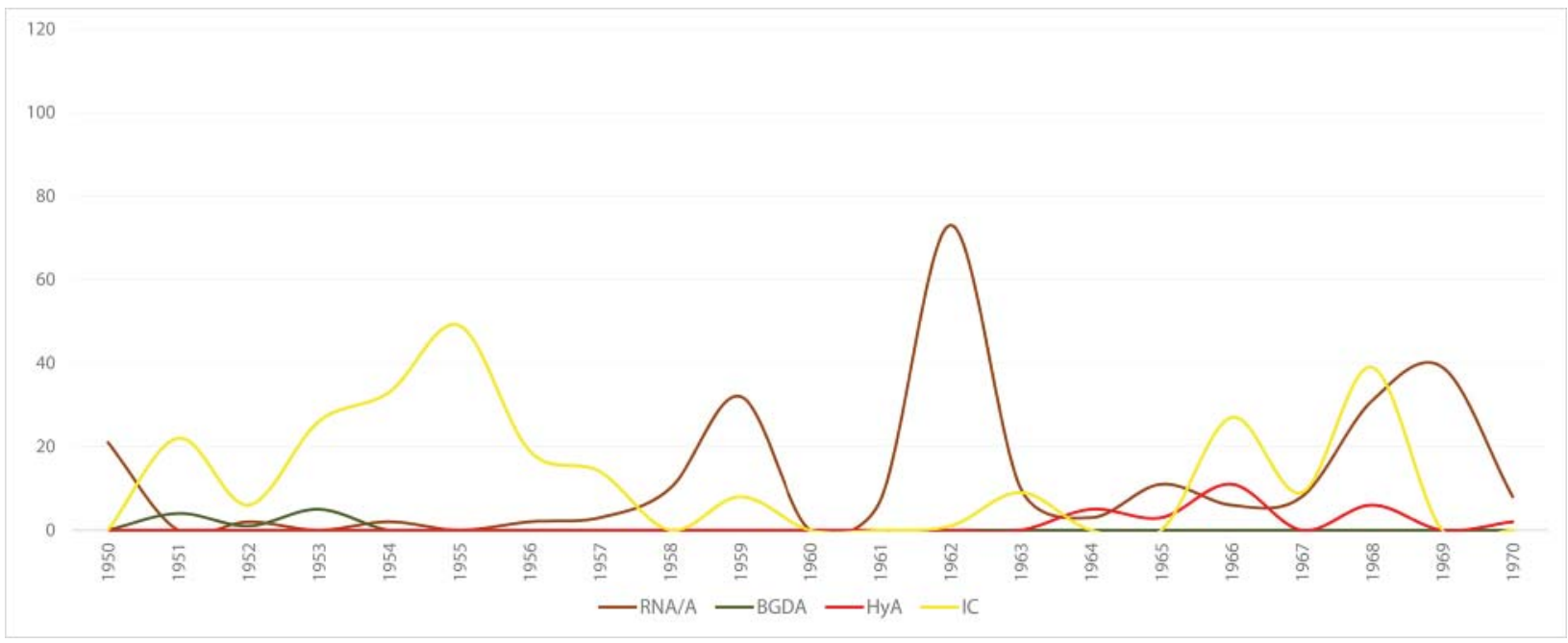

Gráfica que muestra la distribución de páginas por año en cuatro publicaciones españolas. RNA/Arquitectura en café, BDGA en verde oliva, Hogar y Arquitectura en naranja e Informes de la Construcción en amarillo.

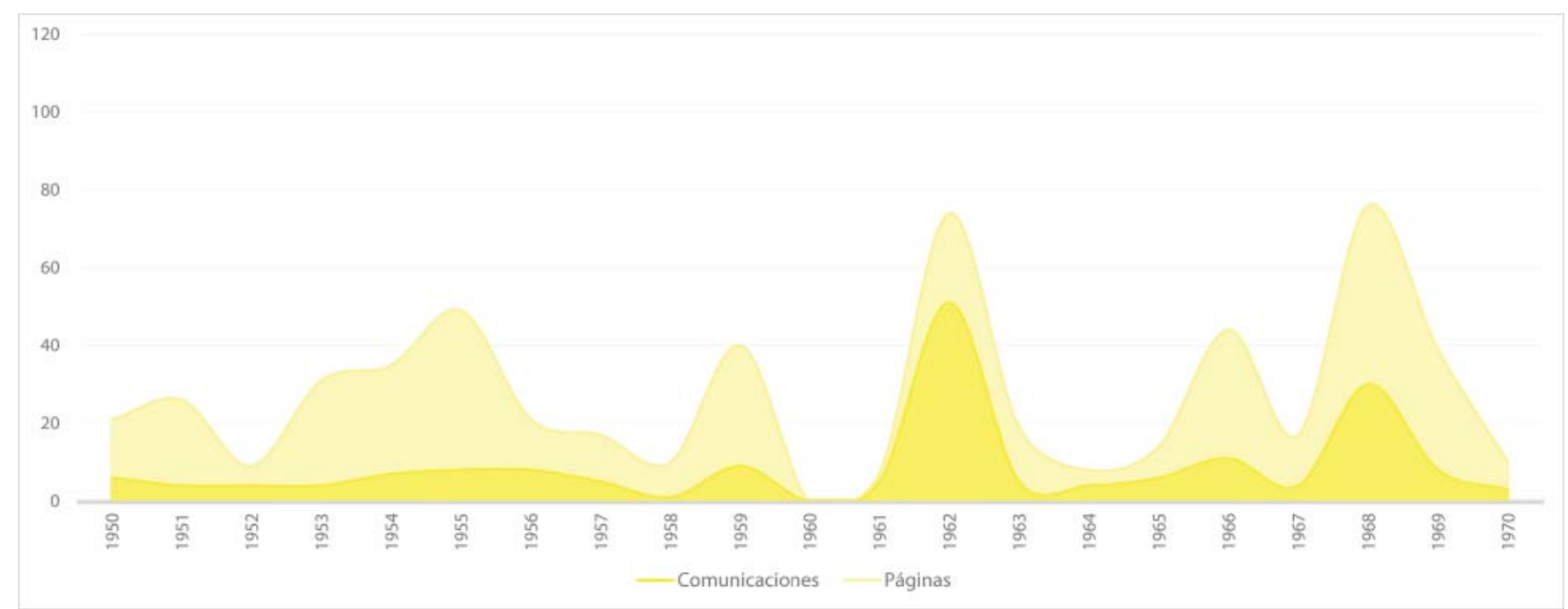

Gráfica con la distribución por año de comunicaciones —en amarillo—y páginas —en amarillo claro— en las cuatro revistas españolas contempladas en este estudio.

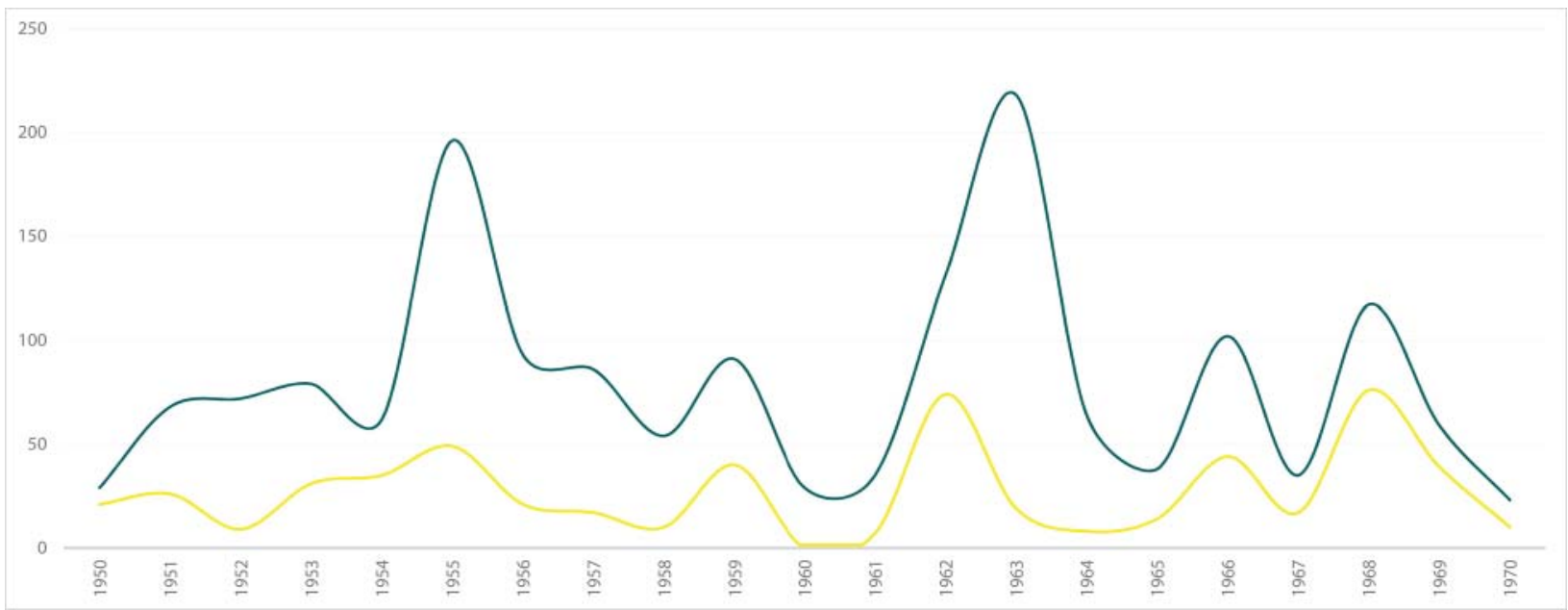

Gráfica que compara el total de páginas publicadas en los cinco países contemplados — perfil superior- contra el papel impreso de las cuatro revistas españolas. 
54. Esteban Maluenda, "Informes," 89.

55. "Descimbrar cimbrando," Informes de la Construcción, no. 29 (marzo 1951): s/p. Si bien Informes publicaba apenas cuatro meses después que $A F$ la misma noticia, en Arquitectura México el sistema de González Flores ya se había dado a conocer desde diciembre de 1947.

56. "Conservatorio nacional de música (México)," Informes de la Construcción, no. 45 (noviembre 1952): s/p. y "Centro urbano 'Presidente Juárez,' Informes de la Construcción, no. 56 (diciembre 1953): $\mathrm{s} / \mathrm{p}$.

57. "La Ciudad Universitaria de México," Informes de la Construcción, no. 58 (febrero 1954): s/p.
IC nació con un «criterio establecido en cuanto a la difusión de la producción foránea ${ }^{54}$, lo que se hizo patente con la ingente cantidad de artículos publicados de forma constante sobre edificios construidos fuera de España. Siempre en relación a los contenidos foráneos, la arquitectura de Estados Unidos fue lo que más publicó Informes, siguiendo en difusión Alemania, Italia, Suiza, Inglaterra, Francia, Brasil, Holanda, Dinamarca, Japón y México. La cota de México en el panorama global de la difusión en Informes se transforma, en los términos de esta investigación, en un dieciséis por ciento del total de páginas publicadas sobre México en todas las revistas consideradas en este estudio durante las décadas de 1950 y 1970. Tomando en cuenta que el porcentaje mayor recayó en L'Architecture d'Aujourd'hui - que alcanzó el veinte por ciento- y que RNA/Arquitectura se equipara a Informes en cantidad de noticias, nos da buena idea de la importancia de esta revista "técnica" en el tema de la difusión de la arquitectura moderna mexicana.

Lo que desde un principio ofreció Informes fueron comunicaciones muy extensas, reelaboradas por la editorial, es decir, en su mayor parte artículos que ya habían sido publicados en otras revistas, traducidos y editados. La línea general fue la de informar sobre edificios nuevos, facilitando documentación amplia sobre los mismos, aunque sin establecer una crítica. Otra característica propia de $I C$ en esos años fue la sección Noticias que, a partir de 1954, solía incluir un avance de algún edificio que sería publicado in extenso en un número posterior.

Ahora bien, la difusión del tema mexicano en Informes inició -tampoco es sorprendente- con un extenso artículo técnico. De nueva cuenta en una publicación extranjera, el sistema constructivo desarrollado por el ingeniero Manuel González se hacía eco en las páginas madrileñas ${ }^{55}$. Después, la obra monumental de Mario Pani del final de la década de 1940, que la RNA ya había adelantado desde 1950, también llegó a la revista de la Construcción y del Cemento entre 1952 y $1953^{56}$. Por otro lado, aunque con varios meses de atraso en relación a su publicación en otras revistas foráneas, el generoso artículo dedicado a la Ciudad Universitaria de México ${ }^{57}$ cubrió el vacío del panorama editorial madrileño con respecto a esta obra señera de la modernidad mexicana, lo que posicionó a Informes, durante los primeros años de la década de 1950, como la revista que efectivamente dio a conocer las obras más importantes que se construían en México. 
Monumento funerario para Jorge Negrete, del arquitecto Francisco Artigas. Publicado en Informes de la Construcción (diciembre 1959).

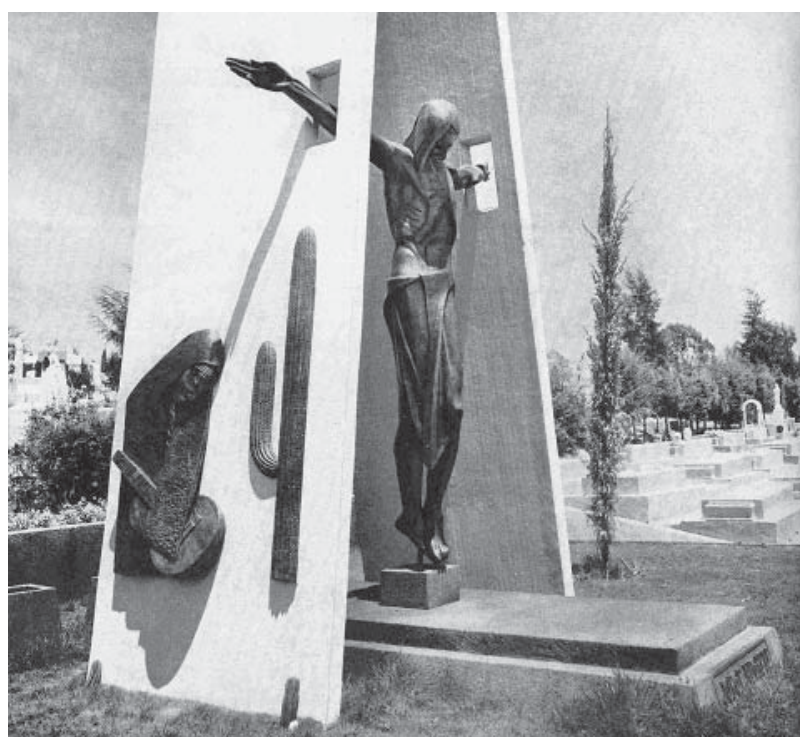

En diciembre de 1955, se recuerda el citado número que publicó las opiniones de arquitectos de distintas partes del mundo. Sin duda, Informes dirigía la mirada al gremio de arquitectos con este especial que se salía por completo de su línea editorial. Tampoco faltó en ese número información técnica de ultramar que superaría la censura del régimen franquista, ya que se publicó una extensa revisión a las estructuras laminares de Félix Candela ${ }^{58}$.

Por otro lado, un edificio que se "adelantó" en la sección de Noticias para ser publicado meses después en un amplio artículo fue el aeropuerto internacional de la ciudad de México de Augusto H. Álvarez. Así, primero aparecería brevemente en noviembre de 1956 y después, en mayo de 1957, en ocho páginas con planos y fotografías ${ }^{59}$. Y ya mediada la década de 1960, los programas nacionales de construcción de mercados y museos llegarían también a $I C$, donde los mercados de La Lagunilla y Coyoacán, y los museos de Antropología e Historia, de Arte Moderno, la Galería de Historia y el museo de Ciudad Juárez, todos —incluidos los mercadosencabezados por Pedro Ramírez Vázquez, darían cuenta de las soluciones a algunas de las demandas sociales y culturales del momento. En 1968, al igual que había hecho Arquitectura, Informes dedicó casi la totalidad de su número 205 a la arquitectura olímpica mexicana.

Por supuesto, no es el fin de esta sección enumerar la totalidad de comunicaciones que sobre México publicó Informes de la Construcción. Más bien, se busca indicar el tipo de difusión que cada revista privilegió, pues se prueba que ésta corresponde a criterios editoriales establecidos más que a una excepción hacia la arquitectura moderna mexicana. De
58. Félix Candela, "Estructuras laminares parabólico-hiperbólicas,” Informes de la Construcción, no. 76 (diciembre 1955): s/p.

59. "Aeropuerto central," Informes de la Construcción, no. 91 (mayo 1957): s/p. El análisis de este y otros artículos sobre el mismo tema se encuentra en la tercera parte de esta tesis en el apartado $6.3 \mathrm{La}$ construcción como noticia. El edificio y su autor. 
60. "Nuevo centro de comunicaciones en Méjico," Informes de la Construcción, no. 73 (agosto-septiembre 1955): s/p. y "Banco de Méjico, en Veracruz," Informes de la Construcción, no. 75 (noviembre 1955): s/p.

61. "Casa Ramis," Informes de la Construcción, no. 108 (febrero 1959): s/p.

62. "Monumento funerario," Informes de la Construcción, no. 116 (diciembre 1959): s/p.

63. "Vivienda residencial - México," Informes de la Construcción, no. 184 (octubre 1966): 27-31. esta manera, además de los informes técnicos mundiales que se esperaría encontrar en $I C$, la divulgación de cientos de edificios modernos -entre los cuales varias decenas de inmuebles mexicanos-ocuparon las constantes páginas de la revista madrileña.

Ante la totalidad de páginas publicadas durante todo el periodo de estudio en las revistas españolas, de inmediato sobresale el comportamiento dispar en comparación con el que se anotó antes frente al caso estadounidense. La cantidad de información del BDGA apenas despunta un poco los años 1951 y 1953 con las noticias ya revisadas y, ya entrada la década de 1960, HyA acumuló también suficiente información para sobresalir discretamente los años 1966 y 1968.

Es notable que las dos revistas que más difundieron la arquitectura mexicana en España - RNA/A e IC — prácticamente igualaran la cantidad de páginas publicadas; ambas alcanzaron un total de poco más de 260 . El comportamiento de la primera es mucho más puntual y fácilmente se reconocen los picos que muestra la gráfica: Candela en 1959, el monográfico de México en 1962 y la xix Olimpiada en 1968. Para el caso de Informes se nota una acumulación a partir de 1950 y hasta 1958, con una curiosa caída intermedia en 1952, año de la inauguración de la CU pero, como ya se citó, publicada hasta 1954. En 1955 se alcanzarían casi 50 páginas de difusión debido - además del número especial de diciembrea dos obras clásicas de Carlos Lazo: la Secretaría de Comunicaciones y Transportes en la capital y el Banco de México en Veracruz ${ }^{60}$.

El año 1959 en Informes fue el del arquitecto Francisco Artigas, de quien se dieron a conocer dos obras: la casa Ramis ${ }^{61}$ y el monumento funerario de Jorge Negrete $^{62}$, lo que explica la curva de pendiente positiva. Otra vivienda de Artigas publicada en $1966^{63}$ se sumó a la amplia divulgación sobre mercados y museos que ya citamos ese año, lo que indica el penúltimo pico de IC en la gráfica. Al igual que Arquitectura, el año olímpico mexicano también aumentó considerablemente la cantidad de información, aunque sin darle continuidad al año siguiente, algo que sí hizo la revista del Colegio de Arquitectos de Madrid.

Al observar las siluetas que indican la cantidad de páginas publicadas contra la totalidad de registros, sobresale de inmediato la extensión de los artículos, representados por el color de fondo claro de la gráfica. Así se explican las más de quinientas sesenta planas que 
difundieron las revistas madrileñas en poco más de ciento ochenta comunicaciones. Ciertamente, los artículos españoles se cuentan entre los más generosos que se dieron a conocer en esos años. Sólo en el caso del monográfico de 1962 vemos que el número de noticias genera un pico que alcanza la cota de los cincuenta registros, llegando el de número de páginas a las setenta y cinco, lo que significa que el desarrollo de los artículos en ese año fue limitado en comparación con los años previos.

Por otro lado, a la vista de los perfiles que equiparan la totalidad de páginas españolas con la suma global, se observa que el comportamiento de las revistas madrileñas se acopla casi perfectamente a la divulgación internacional, con excepción de los primeros años de difusión en que hay una notable caída en 1952, misma que se compensó en 1954, cuando se dio a conocer la Ciudad Universitaria en Informes de la Construcción.

A reserva de comparar los datos globales por país más adelante, es importante subrayar desde ahora el papel que jugó España en el panorama global de la difusión de la arquitectura mexicana durante las décadas de 1950 y 1960. Indudablemente, la cercanía histórica y cultural favoreció la publicación del tema mexicano en suelo español, manifiesto en la constancia de noticias en las revistas de arquitectura. Pero, hay que insistir que estas comunicaciones se dieron dentro de un marco de divulgación internacional que, de ninguna manera, benefició especialmente al ámbito mexicano sino que se insertó en una programa más amplio de difusión de la arquitectura foránea que promovieron las publicaciones periódicas madrileñas por esos años.

Los números hablan por sí solos. La doctora Esteban Maluenda ya analizó extensamente el caso de las publicaciones periódicas madrileñas y su apertura a lo foráneo, mismas que tuvieron como fin superar el periodo de la arquitectura franquista de los primeros años del régimen. Dentro del marco de la presente investigación España aportó casi seiscientas páginas sobre arquitectura moderna mexicana durante todo el periodo de estudio, situándose por encima de Estados Unidos y Francia. Lo anterior no significa que México fuese el país más publicado en el país ibérico. No es sorprendente que Estados Unidos encabece la lista, seguido de Alemania, Italia, Suiza, Inglaterra y Francia. Así, considerando este panorama global, nuestro país quedaría justo debajo del vecino del norte español y arriba —quizá inesperadamente- de países como Brasil, Holanda y Japón ${ }^{64}$.
64. Esteban Maluenda, "La modernidad importada," 504. La gráfica a la que se hace referencia considera el número de artículos que se publicaron en las revistas madrileñas sobre edificios construidos en países extranjeros entre 1949 y 1968. La cota más alta de Estados Unidos alcanzó más de 350 edificios, Alemania e Italia tienen más de 150 y Suiza poco menos de 150 . Inglaterra con alrededor de 120; Francia con poco menos de 100 y México en torno a los 90. Por debajo de 50 inmuebles quedarían Brasil, Holanda y Japón. 
Con todo, tampoco se debe soslayar que España no fue el principal foco de difusión de la arquitectura moderna. Ya se revisó el caso de Estados Unidos, cargado - como siempre- de fuertes intereses comerciales pero, también, de una de las más importantes redes de transmisión de noticias internacionales establecida en Nueva York a través de las publicaciones periódicas de arquitectura. Para el caso europeo, Inglaterra y Francia son los países que, sin duda, se posicionaron como fundamentales en la difusión arquitectónica después de la Segunda Guerra Mundial. Desde los títulos esenciales - Architectural Design, The Architectural Review o L'Architecture d'Aujourd'hui- el abanico arquitectónico mundial se reflejaría para ser ávidamente consumido en todo el orbe.

\section{La mirada objetiva: Inglaterra}

El corpus inglés de esta investigación se formó con tres títulos básicos: Architectural Design, RIBA Journal (RIBA) y The Architectural Review. De éstas, sólo una es el órgano oficial de una institución -el Royal Institute of British Architects- lo que le dará un carácter especial a la difusión. Las otras dos publicaciones son independientes - es decircomerciales. La selección londinense se publicó ininterrumpidamente durante las dos décadas de estudio, lo que favoreció el presente análisis comparativo.

A diferencia de España, los vínculos históricos de México con Inglaterra son mucho más sutiles y apenas detectables en las publicaciones periódicas de arquitectura. Así, la noticia que publicó Architectural Design en julio de 1952 pasaría por completo desapercibida si se pasa por alto la consolidada tradición de los exploradores ingleses en tierras americanas ${ }^{65}$. La pasión por la arqueología mesoamericana fue compartida entre franceses e ingleses desde el siglo XIX, lo que mantuvo vivo el gusto por los viajes transatlánticos a tierras exóticas durante el siguiente siglo. De esta manera, un detalle del Templo de Quetzalcóatl en Teotihuacán

65. Se recuerda al pionero inglés Frederick Catherwood -explorador, dibujante, arquitecto y fotógrafo- quien partiría en 1840 desde la entonces Honduras Británica - hoy Belice- a explorar las ruinas de la civilización maya.

66. "Temple of Teotihuacan," Architectural Design 22, no. 7 (julio 1952): 210. -fotografía de Tania Stanham - ilustraría la breve noticia que Design publicó sobre el altiplano mexicano en su sección Miscellania ${ }^{66}$.

Pero, abordando directamente el tema de la arquitectura moderna mexicana en el medio londinense se verifica que la circunstancia que propició la transmisión de noticias fue directamente el canje editorial. Por citar un ejemplo, el intercambio de información entre la revista 
Templo de Quetzalcóatl en Teotihuacán. Fotografía de Tania Stanham publicada en Architectural Design (julio 1952).

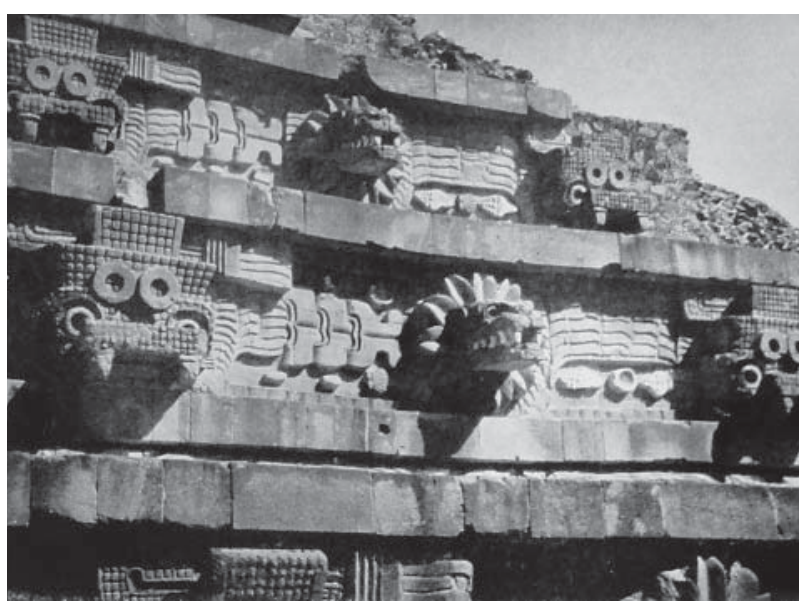

mexicana Espacios, dirigida por Lorenzo Carrasco y Guillermo Rossell ${ }^{67}$ y The Architectural Review, cuando en diciembre de 1952 aparecía en esta última un conjunto de cuatro viviendas unifamiliares, obra de los citados arquitectos mexicanos, cuya principal característica fue una serie de murales expuestos a la vía pública ${ }^{68}$. Esta intervención artística seguía por completo la línea editorial que Carrasco y Rossell propusieron para Espacios, ya que «buscaron que en sus páginas aparecieran las expresiones plásticas y arquitectónicas que se enlazaban con la corriente nacionalista del momento» ${ }^{69}$. Al tiempo que se inauguraba la magna obra universitaria en México, el contacto editorial con la capital anglosajona se hallaba bien establecido. Por otro lado, el detonante de la Ciudad Universitaria daría lugar, en los siguientes años, a un flujo constante, - si bien no tan caudaloso como el español- de noticias sobre el acontecer al otro lado del Atlántico.

Volviendo a Design, cabe comentar que en sus orígenes la revista se concentró en la información técnica y en promover la industria inglesa de la prefabricación — característica que ya se anotó para las neoyorquinas Record y Forum - manteniéndose activa incluso en años de guerra ${ }^{70}$. En los años de posguerra se convirtió en una verdadera revista de arquitectura, tanto por su conocida oposición al estilo nacional contemporáneo que impuso el LCC Housing Department y el RIBA, como por formarse una extensa red internacional de contactos gracias a la labor editorial de Monica Pidgeon ${ }^{71}$. Mediada la década de 1950, con Theo Crosby como editor técnico, se potenció en la revista la comunicación visual, por lo que también se hizo famosa. Al iniciar la siguiente década sucedió a Crosby como editor técnico Kenneth Frampton y, desde 1965 y hasta 1972 Robin Middleton tuvo dicho cargo ${ }^{72}$.
67. La revista se publicó entre 1948 y 1959, y tan temprano como junio de 1949 ya se reseñaba en la francesa L'Architecture d'Aujourd'hui, lo que comprueba la veloz instauración de redes noticiosas internacionales.

68. "Pictures in the street," The Architectural Review 112, no. 672 (diciembre 1952): 404.

69. Louise Noelle, "La arquitectura mexicana en las publicaciones periódicas del siglo xx," Bitácora, no. 19 (2009): 13.

70. $A D$ tuvo su origen en 1930 con Architect's Standard Catalogue y, a partir de 1932, se conoció como Architectural Design and Construction. Sería hasta 1946 cuando Monica Pidgeon la renombró como Architectural Design, nombre que mantiene en la actualidad. "Architectural Design," consultada 14 julio, 2015, http://www.architectural-design-magazine.com/ view/0/history.html.

71. Pidgeon fue la editora desde 1946 y hasta 1975.

72. "Architectural Design." 
73. David Aberdeen, "House in Mexico," Architectural Design 25, no. 10 (octubre 1955): 326.

74. "Félix Candela," Architectural Design 26, no. 7 (julio 1956): 235.

75. "Private Houses," Architectural Design 26, no. 7 (julio 1956): 236.

76. "Factory for manufacture of clothes, Mexico," Architectural Design 27, no. 1 (enero 1957): 32.

77. "L'Architecture d'Aujourd'hui," Architectural Design 27, no. 4 (enero 1957): 143.

78. "Arquitectura México," Architectural Design 28, no. 10 (octubre 1958): 415.

79. "Arquitectos de México," Architectural Design 29, no. 1 (enero 1959): 36.

80. "Mexican Architecture Exhibition at the R.I.B.A.," Architectural Design 25, no. 6 (junio 1955): 204.
Para constatar la importante red de contactos que se forjó Design se revisan los inicios de la difusión mexicana en esta revista pues, sobre todo en los primeros años, se nutrió de la consulta de otras publicaciones periódicas, recurso habitual en la época. En su sección Review of Periodicals poco a poco se fue advirtiendo la prolífica actividad constructiva de México. En octubre de 1955 se comentaba el extensísimo monográfico de $A A$ de abril de ese mismo año, reseña ilustrada con una casa de Carlos Lazo $^{73}$. En julio de 1956 se anotó el artículo de Giovanni Maria Cosco sobre Candela publicado en Arquitectura México (AM) en diciembre del año anterior ${ }^{74}$, así como una casa de Francisco Artigas, también dada a conocer en la revista de Pani pero exactamente un año atrás ${ }^{75}$. En enero de 1957 Design reseñaría — con un año de atraso- el número de enero de 1956 de Techniques et Architecture ( $T \mho A$ ) que se dedicó al hormigón reforzado. La imagen no sería otra que la famosa fotografía de Erwin Lang de las cubiertas perforadas con vitro-block de la fábrica de ropa High Life en Coyoacán, obra de Candela ${ }^{76}$.

No sólo obras puntuales se divulgaron de esta manera, en ocasiones, números completos como el que dedicó $A A$ en octubre de 1956 a la arquitectura en países cálidos recordó a los lectores británicos que varias de las obras tratadas eran mexicanas. La reseña en Design salió seis meses después de que la parisina saltara a la calle ${ }^{77}$. Y volviendo a los cascarones de hormigón armado, no sólo Candela se registró en las reseñas de Design, pues también Alejandro Zohn gozó de reconocimiento con su mercado Libertad en Guadalajara, así, el número 61 de Arquitectura México de marzo de 1958 se subrayaba en la londinense en octubre del mismo año ${ }^{78}$. Y tampoco fue $A M$ la única revista mexicana que se revisó, pues en enero de 1959 Design repetía la imagen de un edificio de vivienda colectiva de lujo de Ramón Torres y Héctor Velázquez que se había publicado en Arquitectos de México en el número de marzo de $1958^{79}$.

Estas citas no agotan las numerosas reseñas a las publicaciones periódicas que poblaron las páginas de Architectural Design; se evidencian así las frecuentes comunicaciones entre las diferentes revistas de arquitectura. Por otro lado, las exposiciones internacionales - otro recurso para dar a conocer la arquitectura mexicana fuera de sus fronterastambién llamaron la atención de la londinense; como la que organizó el RIBA en 1955 y que fue comentada en junio de ese año en Design ${ }^{80}$. 
Torres de vivienda y oficinas diseñado por Pani y Salvador Ortega. Se dio a conocer en Architectural Design el mes de septiembre de 1956.

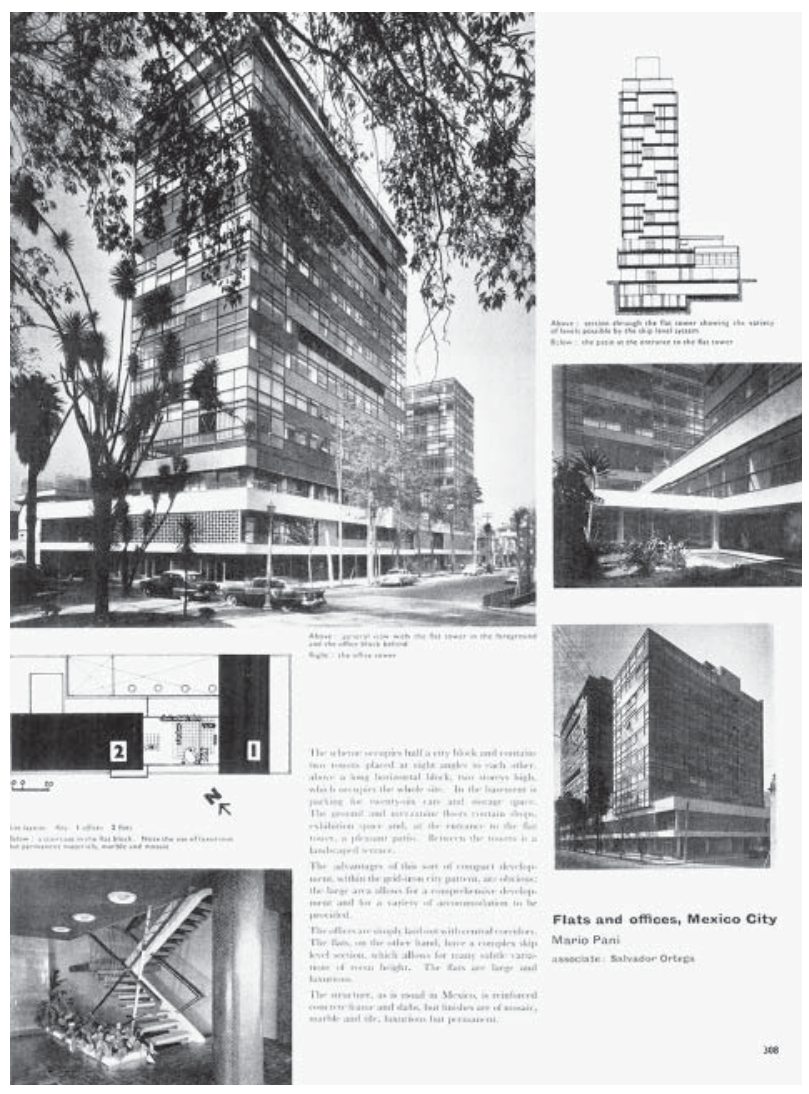

Más allá de las reseñas y las exposiciones, las noticias de actualidad —de una página- y los artículos de por lo menos dos páginas también comenzaron a aparecer regularmente en $A D$, sobre todo a partir de 1956. Por citar algunos casos, en septiembre de dicho año se dio a conocer un edificio de oficinas y vivienda de Mario Pani y Salvador Ortega ${ }^{81}$, y, en febrero de 1957 se publicó el aeropuerto de Acapulco, también de Pani ${ }^{82}$. Unos meses más tarde, en septiembre, el Museo Experimental El Eco de Mathias Goeritz, se cuenta entre los artículos más extensos que dedicó Design al tema mexicano ${ }^{83}$.

Este crecimiento constante de noticias, registrado a partir de 1955 y que continuó hasta 1962, dio paso en el año 63 al monográfico que salió a la luz en septiembre, al igual que el de L'Architecture d'Aujourd'hui. Este será el punto culminante de la difusión de $A D$, pues después de esta fecha no se mantuvo ni la constancia que había caracterizado los años previos ni fue suficiente el empuje de la arquitectura olímpica del año 68 como para reactivar sus comunicaciones en torno al tema mexicano.

Antes se insinuó que la divulgación de la arquitectura mexicana en la revista oficial del RIBA sería peculiar debido al propio carácter de esta publicación, más abocada a mantener al gremio de arquitectos británicos bien informados sobre cuestiones administrativas y económicas de la
81. "Flats and offices, Mexico City," Architectural Design 26, no. 9 (septiembre 1956): 308 .

82. "Acapulco Airport, Mexico," Architectural Design 27, no. 2 (febrero 1957): 5960 .

83. "Mathias Goeritz," $A r$ chitectural Design 27, no. 9 (septiembre 1957): 327 329. Aunque sólo contó con tres páginas, la mayoría de las noticias y artículos que publicó $A D$ sobre México nunca sobrepasaron las dos hojas - cuatro páginas- de difusión. 
profesión. Asimismo, se reconoce un interés mayor en la difusión de la propia arquitectura inglesa antes que en los casos más conocidos a nivel internacional.

El órgano oficial de difusión del Real Instituto de Arquitectos Británicos —institución activa desde 1834- se publica desde 1893 de forma constante. Sorprende su periodicidad incluso en tiempos de la Segunda Guerra Mundial, cuando se revisan las listas de sus miembros sirviendo a las fuerzas $\operatorname{armadas}^{84} \mathrm{o}$ las promociones que se hacían del RIBA a los soldados británicos prisioneros en campos alemanes ${ }^{85}$. En general, las publicaciones que se mantuvieron activas durante la guerra se ocuparon en esos años críticos de extensos artículos técnicos y teóricos $\mathrm{y}$, - se entiende- de muy pocos casos de arquitectura de reciente factura. El fin del conflicto bélico, como ya se comentó para otros títulos, se acompañó del impulso a la industria de la construcción, lo que reactivó a las revistas de arquitectura.

RIBA Journal, a diferencia de las otras londinenses, tuvo un carácter más bien dirigido a lo social y por supuesto sus intereses se centraron en lo que directamente podía relacionarse con la reconstrucción inglesa, en especial los temas de vivienda social, educación y salud. Pero, al igual que en otros títulos, se hizo común la revisión a otras publicaciones periódicas. En agosto de 1944 RIBA Journal reseñaría el número dedicado a Brasil en marzo del mismo año por The Architectural Review. De México se recibía Arquitectura y lo demás, cuyos contenidos encontraban lugar en las extensas listas que elaboraba RIBA sobre temas particulares ${ }^{86}$.

Mediada la década de 1950, una exposición temporal sobre arquitectura moderna mexicana que se presentó en la sede del RIBA en mayo de 1955, sin duda potenció el conocimiento del tema mexicano en Londres. El suceso se recogió en la publicación oficial del instituto británico ${ }^{87}$, así como en

84. Véase el número de noviembre de 1943 con una extensa lista de miembros bajo los encabezados: "Killed", "Missing", "Prisoners of War" y por último los miembros en servicio activo. La única noticia sobre arquitectura de actualidad es una serie de casas en Suiza. Llena el número un estudio teórico sobre la ventilación natural en las viviendas.

85. Véase el número de marzo de 1944 que publicó la lista sobre los arquitectos prisioneros aprobados por el RIBA en Alemania. Gracias al apoyo de diversas organizaciones, los prisioneros ingleses recibieron los libros que les ayudaron a preparar los exámenes de historia de la arquitectura, cálculo, diseño constructivo, teoría de estructuras, higiene y hasta especificaciones técnicas.

86. "Review of Periodicals," Journal of the RIBA
52, no. 12 (octubre 1945): 368-369. En la sección sobre Hospitales se mencionó el proyecto para una clínica regional en el Río Consulado de la ciudad de México y en el apartado sobre arquitectura religiosa se citaron los diseños del concurso para el Santuario Nacional del Sagrado Corazón de Jesús.

87. "Mexican architecture: exhibition at the RIBA," RIBA Journal 62, no. 5 (mayo 1955): 282-85. 


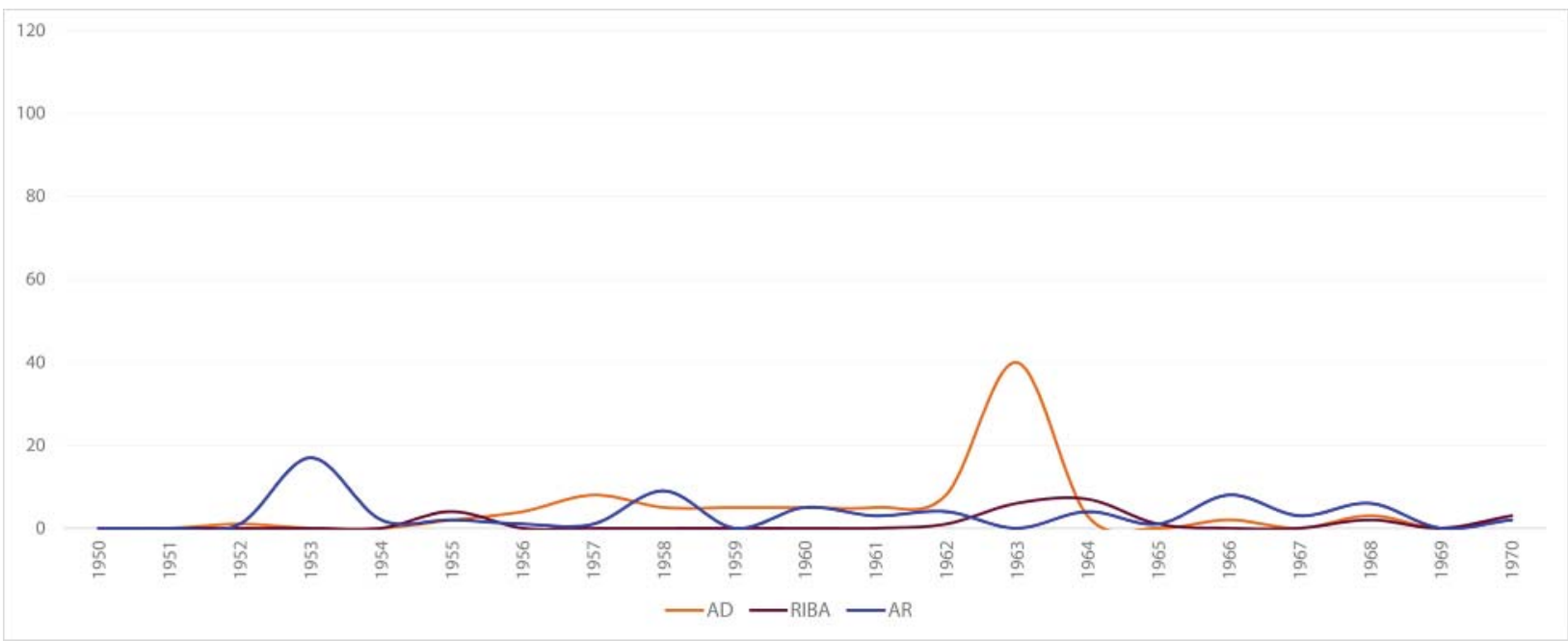

Gráfica que muestra la distribución de páginas por año en tres publicaciones inglesas. Architectural Design en ocre, RIBA Journal en morado y The Architectural Review en azul rey.

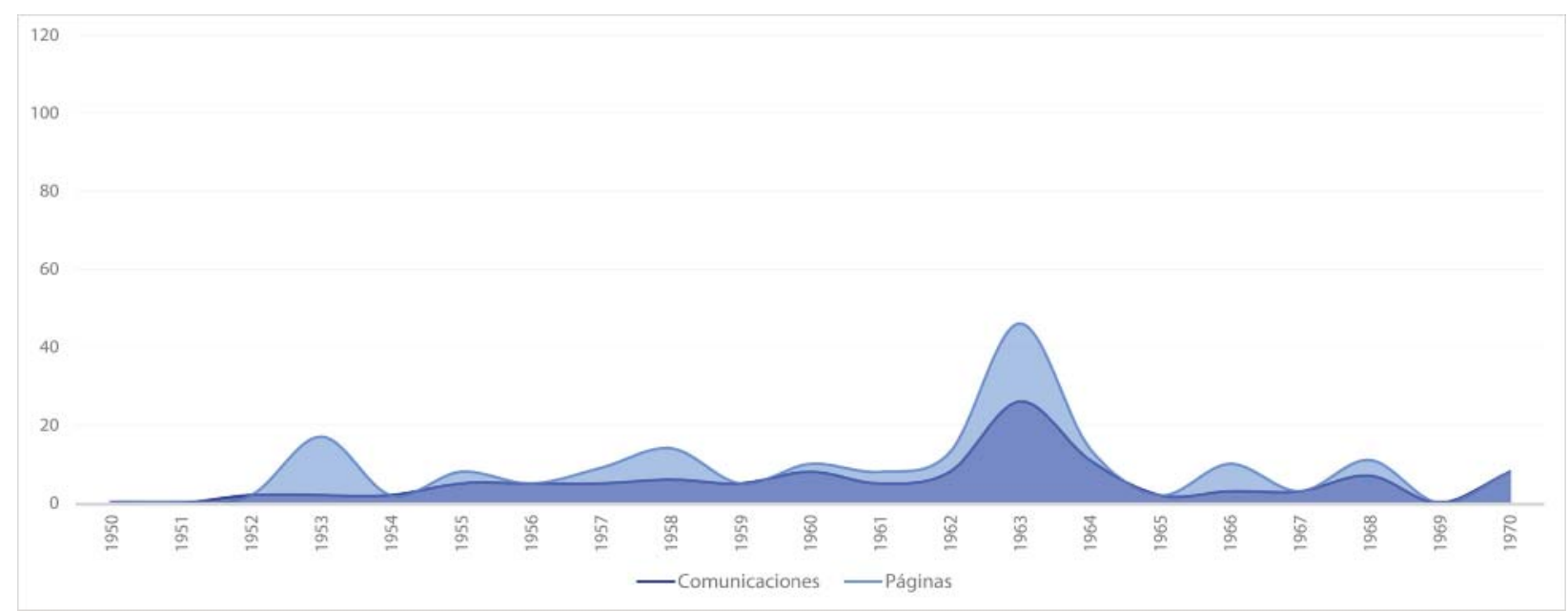

Gráfica con la distribución por año de comunicaciones —en azul—y páginas —en azul claro— en las tres revistas inglesas contempladas en este estudio.

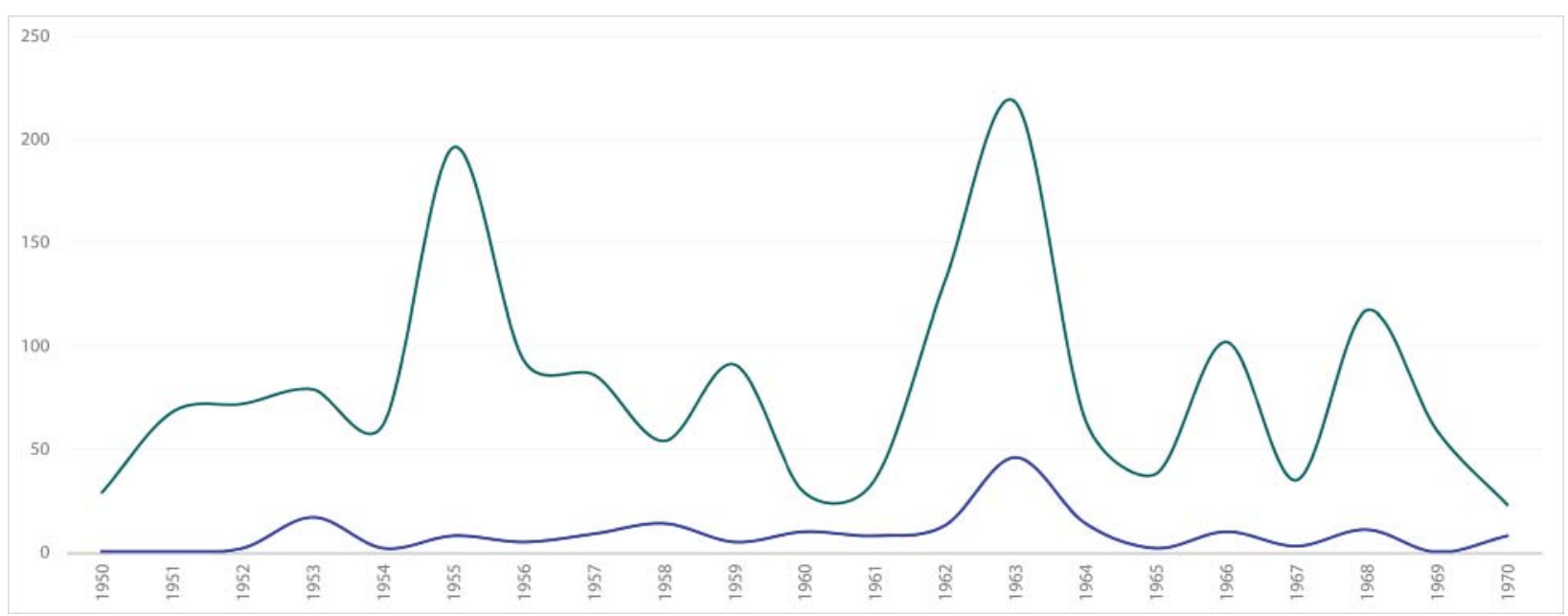

Gráfica que compara el total de páginas publicadas en los cinco países contemplados — perfil superior- contra el papel impreso de las tres revistas inglesas. 
la prensa local ${ }^{88}$. No cabe duda que la arquitectura mexicana se conocía en Londres, aunque su divulgación - especialmente en esta revista- quede acotada por circunstancias particulares.

Para el caso de RIBA Journal no sólo las exposiciones temporales, sino también los congresos internacionales fueron fuente de comunicaciones frecuentes sobre México y su labor edificatoria. En 1962, las reuniones de la Comisión de Construcción de Escuelas de la UIA se hacían eco en la londinense ${ }^{89} \mathrm{y}$, al siguiente año, el vir Congreso de la UIA en La Habana y la Asamblea y el Comité Ejecutivo de la UiA en la ciudad de México ${ }^{90}$ servirían de fondo para uno de los años fundamentales en la difusión de la arquitectura moderna mexicana en los medios foráneos.

El tercer título londinense que se revisa es The Architectural Review, otra revista muy longeva, fundada en 1896 y todavía en activo. Se caracteriza por un comportamiento opuesto a RIBA Journal y, desde luego, más emparentado a Architectural Design en el sentido de una divulgación basada en artículos y noticias de actualidad sobre edificios emblemáticos de la modernidad mexicana.

Si bien ya se anotó una primera noticia en $A R$ sobre las viviendas de Carrasco y Rossell, el inicio de la difusión de alto impacto se debió tanto al éxito internacional de la Ciudad Universitaria como a la tecnología del hormigón armado en superficies regladas. Así, en septiembre de 1953, la revisión a los primeros ensayos de Candela —en especial el pabellón de rayos cósmicos - con un texto crítico de Reyner Banham llegaba a las páginas de la reconocida londinense ${ }^{91} \mathrm{y}$, al siguiente mes, la crónica de Thomas Sharp sobre la Ciudad Universitaria ocuparía un lugar destacado con su extenso artículo de análisis dedicado a la magna obra mexicana ${ }^{92}$.

88. La opinión de The Times se consignó en Arquitectura México ese mismo año. Véase "Una exposición de arquitectura mexicana en Londres," Arquitectura México, no. 50 (junio 1955): 115, donde se afirma que "Ciertos edificios de la ciudad de México son tan elegantes y sofisticados como cualesquiera de Chicago y Milán», y con respecto a la Ciudad Universitaria, el mismo diario sentenció que "constituye la evidencia del desarrollo de un estilo específicamente mexicano, de alta calidad; uno de los cuales ... hace uso de la escultura ex- terior y de los mosaicos en un sentido que lo liga con la primitiva tradición barroca».

89. Kenneth Campbell, "Report of Meeting of the School Construction Commission of the IUA in Mexico," RIBA Journal 69, no. 10 (octubre 1962): 384. Este tema se analiza en la tercera parte de esta tesis en el apartado 7.3 Camino a la escuela. El aula-casa rural y la educación básica, media y superior.

90. Véase "1963 Congress and Assembly of the International Union of Architects," RIBA Journal 70, no. 3 (marzo 1963): 92; "VII' Congress
Havana Cuba," RIBA Journal 70, no. 11 (noviembre 1963): 433-34 y "The Seventh Congress of the IUA," RIBA Journal 70, no. 12 (diciembre 1963): 478-80.

91. Reyner Banham, "Concrete: Simplified vaulting practices," The Architectural Review 114, no. 681 (septiembre 1953): 199-202.

92. Thomas Sharp, "Mexico University," The Architectural Review 114, no. 683 (noviembre 1953): 306-18. Véase el apartado 7.1 Reto e innovación. La Ciudad Universitaria de México, para más detalles de este texto. 
$A R$ se caracterizó por amplios análisis críticos, pero también difundió edificios aislados de un contexto más amplio de discusión, con apenas unos breves párrafos de descripción de la obra y su emplazamiento; este último sería el caso del artículo dedicado al Teatro de los Insurgentes de Alejandro Prieto, publicado en febrero de $1958^{93}$. Si bien los análisis extensos y los artículos completos sobre edificios específicos podrían considerarse las noticias de mayor impacto en esta publicación, la sección World, con sus comunicaciones puntuales, sin duda fue uno de los medios más eficaces para enterarse del acontecer mundial y comparar en unas cuantas páginas los casos sobresalientes de todo el orbe. En esta sección se dieron a conocer también varios edificios mexicanos, como el condominio Los Cocos en Acapulco, de Mario Pani ${ }^{94}$, el Centro Cultural Puebla de Guillermo Rossell ${ }^{95}$ o el Palacio de Justicia de Juan Sordo Madaleno ${ }^{96}$.

No obstante Review nunca dedicó un monográfico al país, sí ofreció un excelente resumen global al tema de la arquitectura mexicana al iniciar la década de 1960; se recuerda el texto de Irene Nicholson, que brindó un apropiado panorama nacional de la modernidad mexicana ${ }^{97}$. Y, hacia el final de la década, dos noticias cierran el periodo de estudio. También de Nicholson, el artículo sobre el Museo Nacional de Antropología e Historia $^{98} \mathrm{y}$, respondiendo al patrón que ya se ha visto en otras revistas - AF, $A, I C$ - en $A R$ también hubo un repunte debido a la arquitectura olímpica de $1968^{99}$.

A la vista del total de páginas publicadas en Inglaterra en las tres revistas consultadas sobresalen los picos de 1952 y 1963. El primero, el citado artículo de Sharp sobre la obra universitaria en The Architectural Review y el segundo el monográfico de septiembre de Architectural Design con cuarenta páginas. Si bien esta revista — debido al número especial— acumuló más páginas sobre la arquitectura moderna mexicana entre 1950 y 1970, Review fue más constante, ya que publicó por lo menos una noticia breve prácticamente todos los años de estudio.

En el caso de RIBA Journal, si bien no sobresale nunca en comparación con las otras dos publicaciones, sí es notoria la acumulación de noticias en determinados años: 1955 con la exposición de arquitectura mexicana en Londres, 1963 y 1964 con el vir Congreso de la UIA y en 1968 con el Primer Encuentro de Jóvenes Arquitectos.
93. "Theatre in Mexico City," The Architectural Review 123, no. 733 (febrero 1958): 110-13. Este edificio, en el panorama global de la difusión de la arquitectura mexicana ya se comentó en la primera parte de esta tesis.

94. "Condominio in Acapulco," The Architectural Review 128, no. 762 (agosto 1960): 96.

95. "Puebla Cultural Centre," The Architectural Review 136, no. 812 (octubre 1964): 236.

96. "Public Palaces," The Architectural Review 142, no. 848 (octubre 1967): 249.

97. Irene Nicholson, “Mexican Newsletter," The Architectural Review 130, no. 774 (agosto 1961): 101-103.

98. Irene Nicholson, "Anthropological Museum, Mexico City," The Architectural Review 140, no. 834 (agosto 1966): 118-25.

99. "Mexico Olympics," The Architectural Review 144, no. 859 (septiembre 1968): 22123. 
Ahora bien, es notable que hacia el año 1970 hay un discreto repunte en la información de estas tres publicaciones. Esto no responde al mismo evento sino a comunicaciones breves de origen distinto, que sólo en algunos casos tuvieron eco en otros títulos internacionales. En Architectural Design el alza se debió a las noticias sobre la Casa O’Gorman, ya citada al inicio de este capítulo. En RIBA Journal, dos reseñas de libros que involucraron el contexto mexicano en estudios más amplios -latinoamericanos y mundiales ${ }^{100}$ - generó la subida y, por último, en The Architectural Review la apertura del Sistema de Transporte Colectivo en la ciudad de México, así como una breve mención al pabellón mexicano en Osaka 70 emparejaron el volumen de noticias en las revistas londinenses.

A diferencia de lo que se observó en España, la distribución por año del total de comunicaciones y páginas en las revistas londinenses indica una proporción mayor de noticias de actualidad que de artículos generosos. La única excepción es evidente en 1953 y, en cierto grado, en el monográfico de la década siguiente. Casi ciento noventa páginas contra más de ciento diez registros no llegan a promediar dos planas por noticia, lo que es indicativo del tipo de información que se recopiló de las hojas inglesas. También, cabe subrayar la disparidad entre el perfil noticioso global con el particular de Inglaterra. Las coincidencias se perfilan discretamente los años de 1953, 1966 y 1968, y, sólo en 1963, la relación es inminente debido al monográfico de $A D$.

\section{Equilibrio de contenidos: Francia}

Dos publicaciones parisinas comprenden el material de consulta francés: L'Architecture d'Aujourd'hui y Techniques et Architecture. Se ha tomado el riesgo de hablar de Francia aun considerando la avasalladora cantidad de páginas que acumuló la primera; más del 90\% de la información francesa de esta investigación proviene de $A A$, quedando Techniques con apenas algunas comunicaciones puntuales durante todo el periodo de estudio, contrastando enormemente con la constancia $-\mathrm{y}$ los impresionantes monográficos- de la revista fundada por André Bloc en 1930.

100. Se trató de los libros History of Latin American art and Architecture from pre-Columbian times to the present de Leopoldo Castedo y Matrix of man de Sibyl Moholy-Nagy, en junio y julio respectivamente.
Hasta antes de la Segunda Guerra Mundial París seguía siendo el principal polo artístico del mundo occidental, lo que mantenía a prácticamente todo el orbe con la mirada puesta en sus vanguardias arquitectónicas, hábilmente comunicadas a los cuatro vientos por Le 

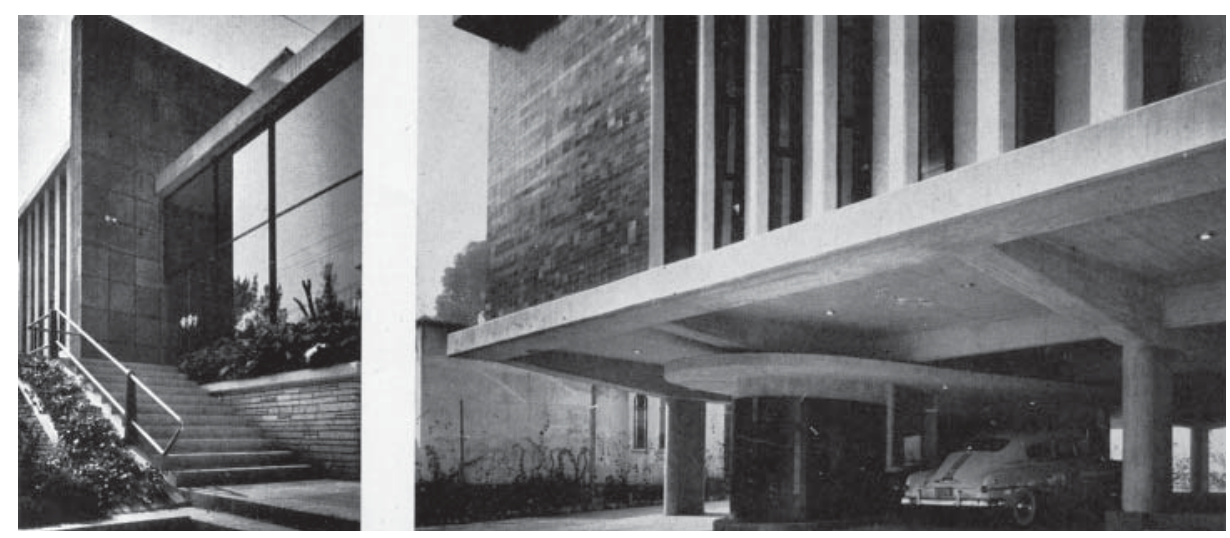

Corbusier. México no fue ninguna excepción en sentirse atraído hacia este imán y en establecer relaciones que permitiesen comunicaciones constantes. La atracción hacia Francia podría considerarse incluso natural en nuestro país, cuyo origen sería un primer rechazo hacia lo español después de la Independencia en el siglo XIX y hasta antes del giro inevitable - e irremediable - que supuso dirigir la mirada hacia el vecino del norte para encontrar el supuesto modelo de progreso de la nación. Con todo, Francia - y en especial su capital - se mantendría como el lugar idóneo para legitimar las propuestas de la modernidad arquitectónica mexicana.

Entonces, L'Architecture d'Aujourd'hui se erige como la publicación que más páginas dedicó a México; sin embargo, al igual que se puntualizó para el caso español, el interés no fue privativo hacia lo mexicano sino hacia todo el mundo, característica de esta revista desde sus inicios en la década de $1930^{101}$. Otra particularidad de $A A$ fueron sus monográficos, dedicados no sólo a países sino a géneros arquitectónicos o temas de debate e interés general del momento. Muchas de las noticias recabadas sobre México formaron parte de números especiales, por lo que los edificios quedaron contextualizados en un análisis determinado.

Por otro lado, al igual que se verificó en relación al caso inglés, el principal flujo informativo que nutrió a L'Architecture d'Aujourd'hui se dio a través del canje editorial entre revistas de arquitectura. Para este caso fue fundamental Mario Pani al frente de Arquitectura México, quien tuvo como constante colaborador a Vladimir Kaspé, quien fue el corresponsal mexicano en la revista parisina durante todo el periodo de estudio. En cualquier caso, la publicación del Centro Urbano Presidente Alemán (CUPA) de Pani en $A A$ en septiembre de 1950 no fue por mucho una noticia exclusiva, pues meses antes ya se vio publicada en Madrid. Lo cierto es que con el nombramiento de Kaspé como corresponsal a
Sucursal bancaria en las Lomas de Chapultepec, de Gustavo Struck. Techniques et Architecture (marzo 1955).
101. Desde el primer número ya se nota un marcado interés en lo internacional, incluso en lo latinoamericano, pues se publicó sobre Rio de Janeiro. "L'Architecture d'Aujourd'hui," consultada 14 julio, 2015, http://www.larchitecturedaujourdhui.fr/retro. 
102. Además del CUPA, ya citado, véase de Mario Pani: "Conservatoire National de Musique," L'Architecture d'Aujourd'hui, no. 38 (diciembre 1951): $49-52$ y de Vladimir Kaspé: "Lyceé Franco-Mexicain," L'Architecture d'Aujourd'hui, no. 34 (febrero-marzo 1951): 88-90 y "Poste d'essence, centre de commerce et ateliers de réparations, Mexico," L'Architecture d'Aujourd'hui, no. 40 (abril 1952): 60-62.

103. Es notable que en el primer monográfico se registraron cuarenta y dos arquitectos como autores principales de las obras y para el segundo monográfico la cantidad aumentó hasta los cuarenta y siete. Cabe destacar que no se tomaron en cuenta a los autores de ensayos teóricos o a los colaboradores de las obras arquitectónicas.

104. Nagel, "Tan lejos, tan cerca."

105. "Musée National d'Anthropologie à Mexico," L'Architecture d'Aujourd'hui, no. 129 (diciembre 1966): 12-15 y "Musée National à Ciudad Juárez," L'Architecture d'Aujourd'hui, no. 129 (diciembre 1966): 16-17.

106. "Mexico 68: La Route de L'Amitié," L'Architecture d'Aujourd'hui, no. 140 (octubre 1968): XV-XviI.

107. "Hotel Camino Real Mexico." L'Architecture d'Aujourd'hui, no. 144 (junio-julio 1969): XXXI-XXXII. partir de 1949 inició el periodo de difusión constante de la arquitectura mexicana en la revista francesa.

Si bien en los primeros años de divulgación quedó patente la preferencia en publicar las obras recientes de Pani y de Kaspé102, el preparativo del primer monográfico dedicado a México en 1955 rompió la supuesta exclusividad para dar lugar a un abanico muy amplio de nombres y obras, situación que se repetiría con el segundo monográfico de $1963^{103}$. Estos números especiales equilibraron por completo el panorama editorial dirigido a la difusión de la modernidad mexicana en $A A$.

La gran cantidad de información que proporcionó L'Architecture d'Aujourd'hui durante las dos décadas de estudio dirigen a cuestionarse ¿a quién no publicaron? La pregunta no es retórica pues se encuentra la respuesta en las revistas madrileñas de las que ya se afirmó su sólida apertura hacia lo foráneo. Allí, el contexto político entre España y México da por lo menos una respuesta. Algunos arquitectos emigrados a México después de la Guerra Civil española —más de uno formado en la Escuela Técnica Superior de Arquitectura de Madrid- se dieron a conocer únicamente en Arquitectura, en especial en su monográfico de $1962^{104}$. Esta excepción confirma que, a pesar de la impresionante cantidad de datos recabados de la parisina, ésta no publicó todos los nombres, aunque sí los más conocidos.

Superando la mitad de la década de 1960, el programa nacional de construcción de museos y la xix Olimpiada propiciaron un discreto aumento de noticias, nada comparable con el pico de casi ciento veinte páginas que representó el monográfico del 63. Así, el Museo Nacional de Antropología e Historia y el museo de Ciudad Juárez se integraron a un número dedicado a los edificios culturales en diciembre de $1966^{105}, \mathrm{y}$, dos años más tarde, la revisión a la arquitectura olímpica mexicana aparecía en la sección de actualidad de octubre de $1968^{106}$. El cierre del periodo de estudio en $A A$ lo dibuja una curva que desciende en 1970 después de sugerirse una única noticia el año anterior, la que responde a la difusión del Hotel Camino Real, presente entre 1968 y 1969 en varios de los títulos consultados ${ }^{107}$.

La segunda publicación francesa que se revisó para este estudio fue Techniques et Architecture, la revista fundada en 1941 - se diría que con demasiado optimismo por ser años de guerra- por Auguste Perret, A. 


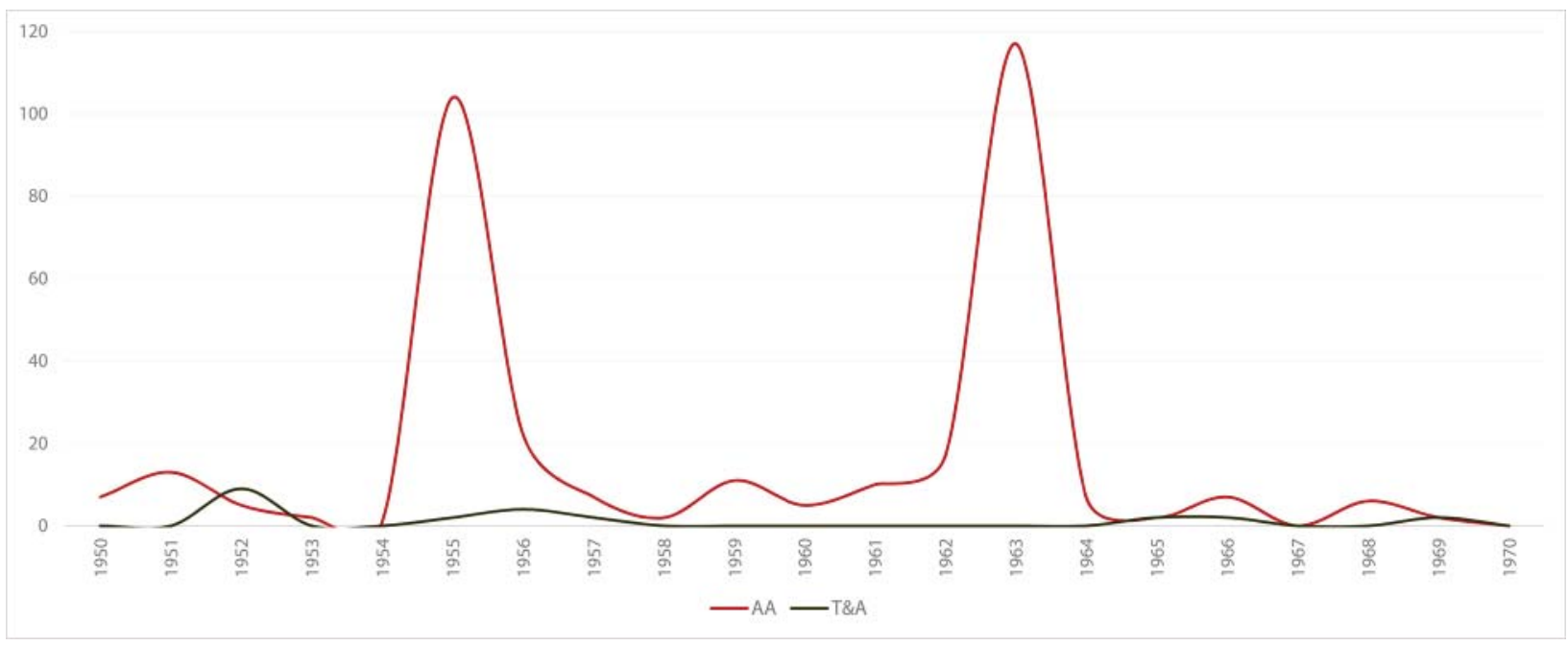

Gráfica que muestra la distribución de páginas por año en las dos publicaciones francesas. L'Architecture d'Aujourd'hui en rojo y Techniques et Architecture en verde oscuro.

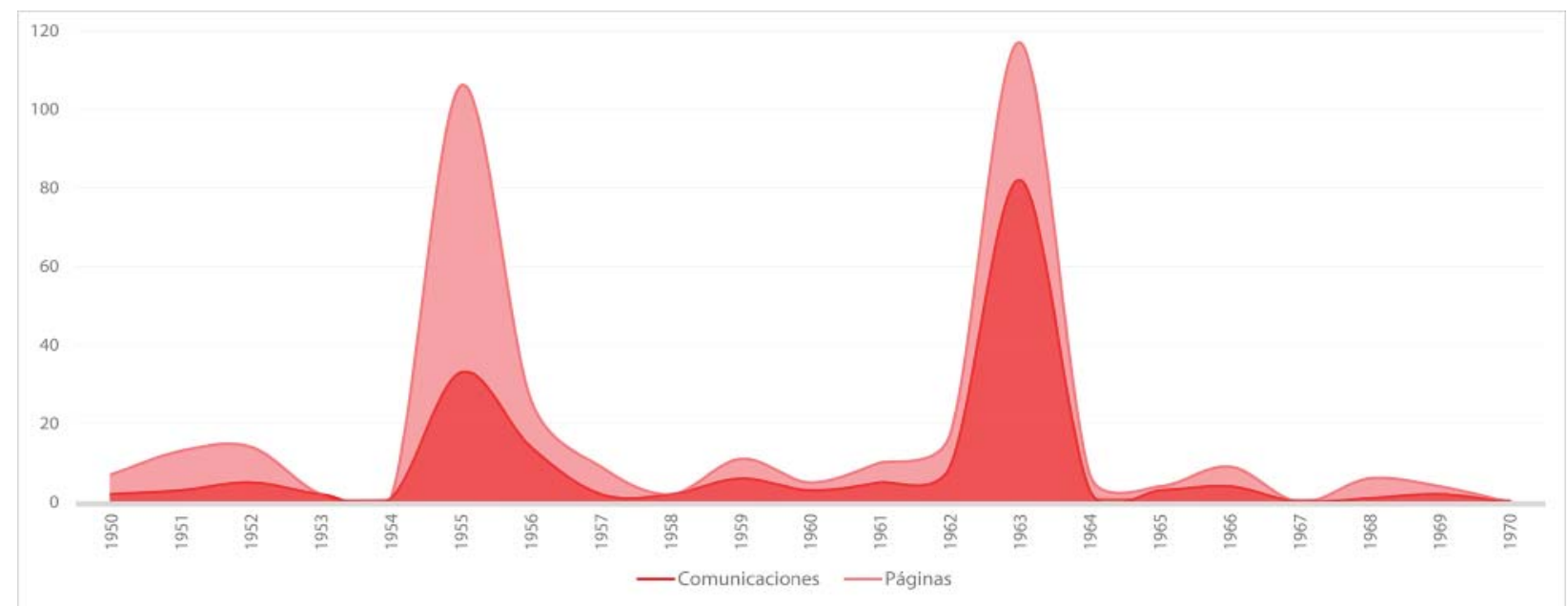

Gráfica con la distribución por año de comunicaciones —en rojo—y páginas —en rosa— en las dos revistas francesas contempladas en este estudio.

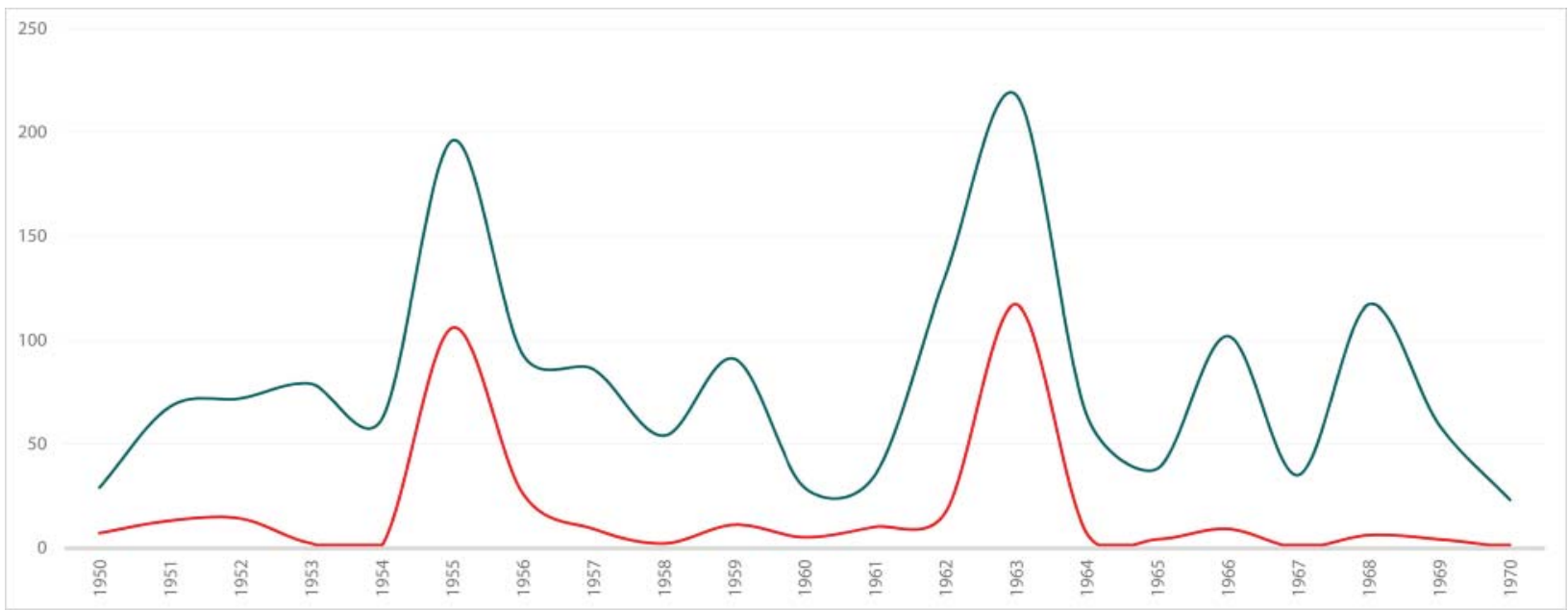

Gráfica que compara el total de páginas publicadas en los cinco países contemplados — perfil superior- contra el papel impreso de las dos revistas francesas. 
108. El primer número se publicó en septiembre/octubre de 1941 y se mantuvo activa durante todos los años de guerra. Su último ejemplar, el número 492 saldría en octubre/noviembre de 2007. "Bibliothèque Kandinsky. Centre de Documentation et de Recherche du Musée National d'Art Moderne." Consultada 22 julio, 2015. http:// bibliothequekandinsky.centrepompidou.fr.

109. "Bureaux de la sécurité sociale à Mexico," Techniques et Architecture 11, no. 5 (junio 1952): 16-18.

110. "Cité universitaire de Mexico," Techniques et Architecture 11, no. 6 (julio 1952): 13-18.

111. "Constructions en voiles minces, au Mexique," Techniques et Architecture 15, no. 4 (enero 1956): 117-19.

112. "Immeuble tour à Mexico," Techniques et Architecture 26, no. 6 (junio 1966): 144-145.

113. "Succursale de la Banque Nationale à Mexico," Techniques et Architecture 14, no. 9-10 (marzo 1955): 46-47.

114. "Museé d'Anthropologie et d'Histoire," Techniques et Architecture 25, no. 4 (mayo-junio 1965): 14-15.

115. "Mexico: Palais des Sports," Techniques et Architecture 30, no. 5 (junio 1969): 78-79.
Hermant, Le Corbusier, Robert Le Ricolais y Jean Prouvé108. T\&A tuvo un carácter mucho más técnico que $A A$, pero de igual forma siempre se abrió para mostrar el panorama mundial actual. Durante sus primeros años los números se consagraron a temas particulares, por lo que constituyeron importantes monográficos en los que se insertó algún ejemplo puntual de la arquitectura moderna mexicana.

En el caso de Techniques, la difusión sobre la modernidad que tenía lugar en México inició con un inmueble clásico y muy poco difundido en las publicaciones periódicas foráneas: el edificio del Instituto Mexicano del Seguro Social, diseñado por Carlos Obregón Santacilia y construido entre 1945 y 1950. Este símbolo de las instituciones sociales modernas, de perfil racionalista y toques de integración plástica se publicó en junio de $1952^{109}$. El siguiente mes, coincidiendo con un interés generalizado en la magna obra por parte de las revistas de arquitectura extranjera, la Ciudad Universitaria llegó también a las páginas de la revista de Perret ${ }^{110}$.

Otros ejemplos mexicanos se integraron a números especiales de T\&A, por ejemplo, en enero de 1956 un compendio de obras de Félix Candela formó parte de un monográfico dedicado al hormigón armado111 y en junio de 1966 el edificio de oficinas del Paseo de la Reforma de Augusto H. Álvarez se ajustó en un número centrado en los edificios altos $^{112}$. También se dieron a conocer algunos inmuebles en la sección de actualidad, como la sucursal bancaria de Gustavo Struck en las Lomas de Chapultepec, publicada en marzo de $1955^{113}$ o el Museo Nacional de Antropología e Historia, dado a conocer en T\& $A$ en mayo de $1965^{114}$. En los últimos años del presente análisis aparecería el Palacio de los Deportes, pero descontextualizado de la demás arquitectura olímpica de México 68 y situado en Techniques en un número dedicado a las nuevas estructuras y la industrialización ${ }^{115}$.

La gráfica que muestra el total de páginas publicadas en las dos revistas francesas es contundente en dos aspectos, el primero, la disparidad entre la cantidad de información acumulada por $A A$ sobre $T \mho A$, y, el segundo, cómo los datos de $A A$ se alzan airosos los años 1955 y 1963, correspondientes a los citados monográficos. Ante esta evidencia gráfica de la distribución anual de noticias, poco quedaría por comentarse, acaso lo que expresan los picos menores. Para el caso de L'Architecture d'Aujourd'hui en torno al año 1951 se acumuló el avance sobre la obra 
universitaria, el Conservatorio Nacional de Música y el Liceo francomexicano y en 1959 se dio a conocer la Unidad de habitación Santa Fe, de Mario Pani ${ }^{116}$. Por otro lado, aunque ya se anotaron los principales intereses de Techniques en relación a México, quedaría por decir que sus artículos casi siempre se publicaron en dos páginas, lo que hace todavía más imperceptible su apreciación en la gráfica. La única excepción fue el artículo dedicado a la Ciudad Universitaria, con seis páginas, por lo que constituye la única curva sobresaliente de la distribución.

Ahora bien, se observa que las trescientas setenta páginas que las dos revistas francesas destinaron al tema mexicano se distribuyen en una proporción de una comunicación por cada dos páginas, en casi la totalidad de la gráfica, exceptuando el monográfico de $A A$ de 1955 en que es notable la diferencia entre el pico más alto de registros y la totalidad de páginas de ese año, que superó las ciento cinco. Esto revela que los artículos de ese año fueron mucho más extensos que los del siguiente monográfico. Por lo demás, las comunicaciones, que sumaron más de ciento ochenta, se distribuyeron de manera bastante homogénea con relación a la cantidad de papel ya anotado.

No cabe duda que la información francesa -especialmente en el año 1955- perfiló significativamente la curva global. Ese año y 1963 son los que de forma rotunda se asemejan a la silueta que representa la totalidad de datos. En este caso, la concentración de noticias fue sustancial, lo que no significa la interrupción del flujo informativo, mismo que se mantuvo constante aunque en una cota muy baja.

\section{Entre la poesía y la técnica: Italia}

A diferencia de Francia, Inglaterra y España, cuyas capitales fueron sede de las publicaciones periódicas de más impacto a nivel internacional, en Italia, la cuna de la industria editorial se localizó en el norte, en Milán, en la llamada capital económica y productiva de dicho país. Los casi diez mil kilómetros que separan a la ciudad de México de Milán desdibujan unos vínculos de por sí tenues entre ambos países. Si bien en los inicios del siglo $\mathrm{xx}$ se reconoce un importante nexo entre la arquitectura italiana ${ }^{117} \mathrm{y}$ México, el viaje de vuelta hacia Lombardía no se haría patente sino hasta el "descubrimiento" de la arquitectura moderna mexicana por parte de los editores italianos, al iniciarse un periodo fructífero de difusión.

116. "Unité d'Habitation et de Services Sociaux No. 1 a Santa Fe, Mexico," L'Architecture d'Aujourd'hui, no. 87 (diciembre 1959): 62-67.

117. Durante el Porfiriato (1876-1910) se importaron numerosos arquitectos extranjeros para diseñar las obras públicas más importantes del país. Adamo Boari (1863-1928) fue el más notable de los italianos, quien realizó el diseño general del que ahora es Palacio de Bellas Artes. 
118. "Una abitazione messicana," Domus, no. 259 (junio 1951): 56.

119. Ponti fue editor de Domus desde su inicio en 1928 y hasta 1940. Durante los años de conflicto bélico se sucedieron varios editores $\mathrm{y}$, aunque todavía se imprimió durante 1944 se interrumpió en 1945. Volvió a aparecer en 1946, con Ernesto Nathan Rogers como editor. En 1948 Ponti volvió a ponerse al frente hasta 1979, el año de su muerte.

120. Ponti visitó México con motivo del viII Congreso Panamericano de Arquitectos en octubre de 1952, momento a partir del cual inició la verdadera difusión de la arquitectura mexicana en Domus.

121. Gio Ponti, "Il Pedregal di Città del Messico," Domus, no. 280 (marzo 1953): 15-22.

122. Gio Ponti, "Antologia della Città Universitaria di Città del Messico," Domus, no. 285 (agosto 1953): 1-6.

123. "Sedie messicane," Domus, no. 281 (abril 1953): 50-51.

124. El análisis sobre la difusión de Luis Barragán en Domus se contempla en el apartado 6.2 Entre la vida y la obra. El arquitecto como protagonista.

125. Véase "Una chiesa al Messico," Domus, no. 308 (julio 1955): 2; "Breve documentario di Felix Candela," Domus, no. 319 (junio 1956): 3-5 y Ove Arup, "Su Felix Candela," Domus, no. 410 (enero 1964): 9-10.

126. Véase el apartado 7.3 Camino a la escuela, citado antes.
Antes de la revelación que supuso el conocimiento de la Ciudad Universitaria y los Jardines del Pedregal, la presencia de México en una publicación italiana se realizó solo a través de las conocidas reseñas a las distintas revistas de arquitectura de todo el mundo. Este primer intercambio editorial, no obstante, proporcionó el conocimiento de ciertas características de la geografía y el clima de México, más que algún ejemplo señero de la arquitectura nacional. Se hace referencia a la casa Silverstone de Taxco, que Domus $(D)$ dio a conocer tan solo cinco meses después que Architectural Forum, lo que indica la velocidad de transmisión de noticias entre las publicaciones periódicas. Como sea, la casa firmada por Anshen \& Allen, si bien ofrecía un buen ejemplo de modernidad asociado a la tradición de los materiales locales, no significaba un conocimiento directo de la arquitectura moderna mexicana ${ }^{118}$.

Domus — fundada en 1928 por Gio Ponti ${ }^{119}$ — debe su interés en la modernidad mexicana a su propio editor, quien después del conocimiento in situ de las obras emblemáticas de los primeros años de la década de 1950 se mantendría al tanto del acontecer mexicano ${ }^{120}$, pero, a diferencia de otras publicaciones más abiertas a la diversidad de nombres —en especial aquellas que dedicaron monográficos al país como Arquitectura y L'Architecture d'Aujourd'hui-, Ponti centraría su atención en dos figuras emblemáticas de la mitad del siglo xx: Luis Barragán y Félix Candela.

En términos de difusión, es notable que Ponti publicase primero el extenso artículo sobre el Pedregal de San Ángel que la Ciudad Universitaria, aunque ambos artículos salieron a la luz en 1953, el primero en marzo ${ }^{121}$ y el segundo en agosto ${ }^{122}$. Domus, desde sus inicios, y por los propios intereses de su editor, fue un medio mucho más cercano al arte y al diseño - si se piensa en Milán como capital de la moda y del diseño industrial- y en este contexto tampoco sorprende el interés que se tuvo en el mobiliario diseñado desde México por Clara Porset, del que ya se anotó su temprana difusión en $A \& A$. La revista de Ponti lo dio a conocer en abril de $1953^{123}$.

Además de Barragán ${ }^{124}$ y Candela ${ }^{125}$, un tema que tuvo especial difusión en las revistas italianas fueron las trienales de arte y arquitectura de Milán. Para el caso mexicano, la de 1960 tuvo mayor interés debido al prototipo prefabricado de aula-casa rural que ganó el primer premio y considerable difusión a nivel internacional ${ }^{126}$. Un nombre más apareció en 


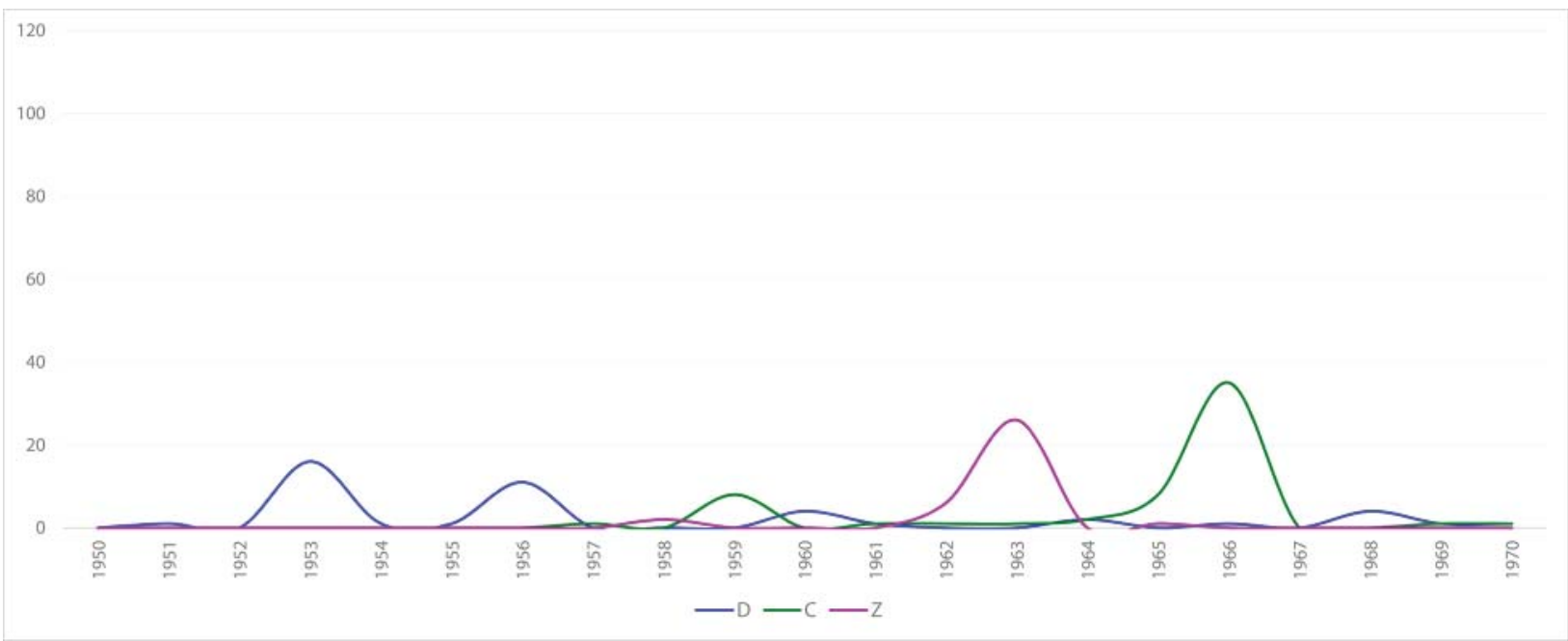

Gráfica que muestra la distribución de páginas por año en tres publicaciones italianas. Domus en azul, Casabella en verde bandera y Zodiac en magenta.

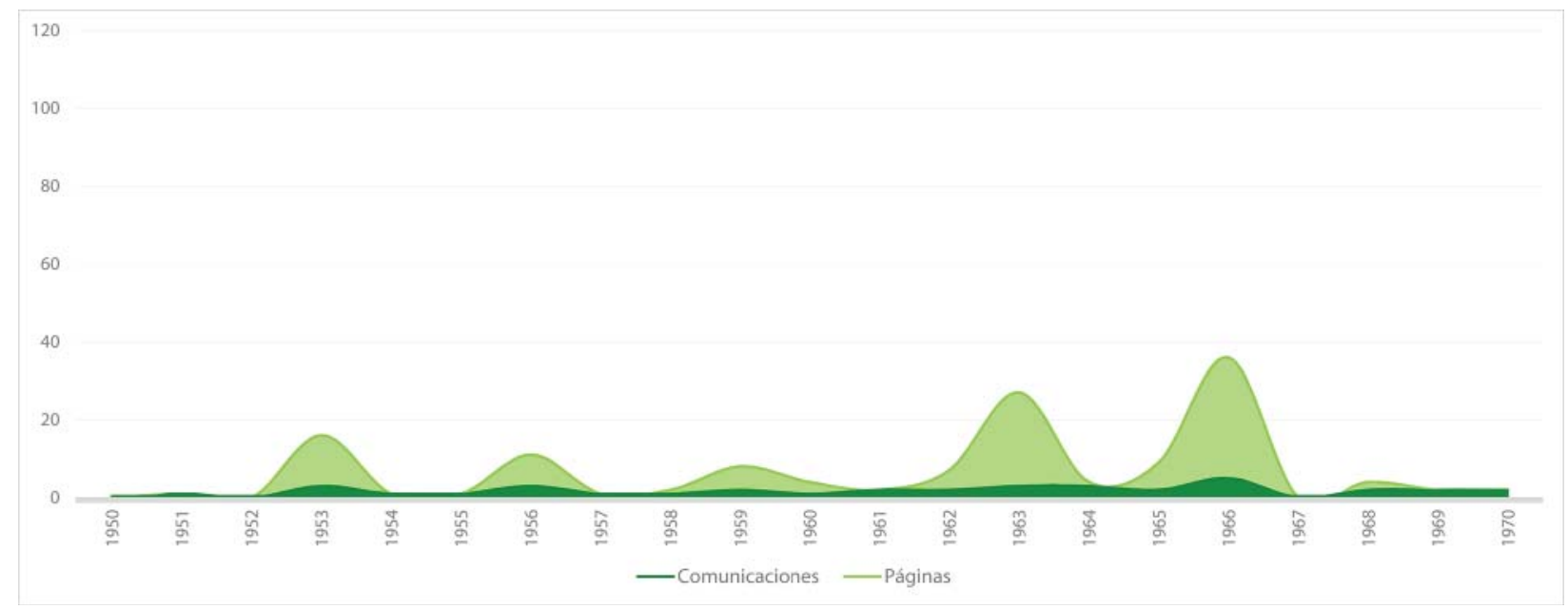

Gráfica con la distribución por año de comunicaciones —en verde_y páginas —en verde claro— en las tres revistas italianas contempladas en este estudio.

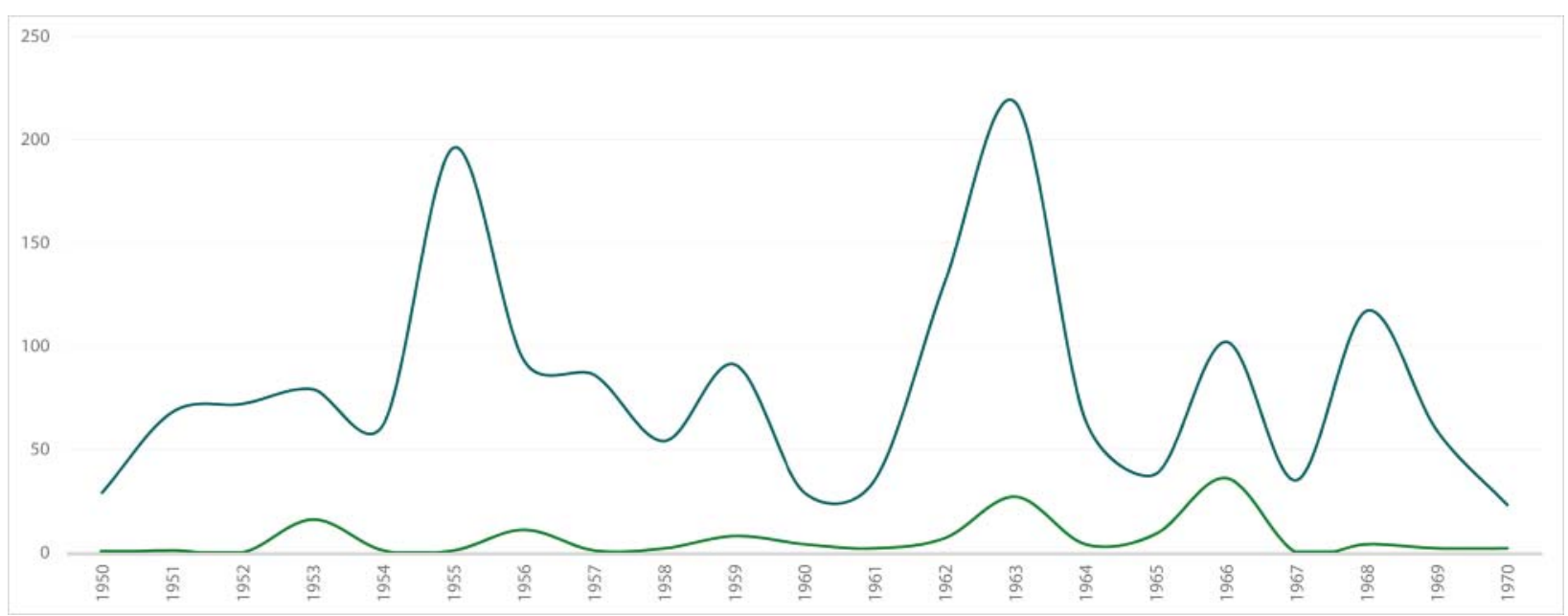

Gráfica que compara el total de páginas publicadas en los cinco países contemplados — perfil superior- contra el papel impreso de las tres revistas italianas. 
127. "Aeroporto in Messico," Domus, no. 320 (julio 1956): 6.

128. Bajo la dirección de Rogers - entre 1953 y $1964-$ se llamará Casabella Continuitá, para recobrar su nombre original a partir de 1965, mismo que mantiene en la actualidad. "Casabella," consultada 22 julio, 2015, http:// casabellaweb.eu/the-magazine/short-magazine-history.

129. A. T. Anselmi, "Dai giornali e dalle riviste," Casabella Continuitá, no. 214 (febrero-marzo 1957): 82-85.

130. "Una mostra dell'architettura messicana a Milano," Casabella Continuitá, no. 255 (septiembre 1961): 60. Ya se comentó que la misma exposición estaba circulando en Europa desde 1955. En esta segunda ronda expositiva la muestra se había inaugurado en Bremen "con gran éxito». Véase "Exposición mejicana en Europa." Arquitectura, no. 31 (julio 1961): 2.

131. "Strutture e Strutturalismo: Una lettera di Felix Candela." Casabella Continuitá, no. 232 (octubre 1959): 48-53.

132. Félix Candela, "Comprendere il paraboloide iperbolico," Casabella, no. 298 (octubre 1965): 56-63 y "Architettura e strutturalismo," Casabella, no. 306 (junio 1966): 24-29.
Domus durante todo el periodo de estudio, el de Pani ligado al aeropuerto de Acapulco, con una noticia de actualidad ${ }^{127}$.

Otra revista milanesa emparentada de cierta manera con Domus es Casabella (C). Fundada en 1928 por Guido Marangoni fue comprada por la editorial de Domus en 1946. Tras algunos años inciertos volvió a salir a la luz hasta finales de 1953 con Ernesto Nathan Rogers como su editor $^{128}$. Si Domus se rindió ante la poética de Barragán, Casabella lo hizo ante Candela, quien, sin duda, fue el arquitecto mexicano más publicado en esta revista italiana. Con todo, sin obviar el impacto menor de su difusión, la arquitectura mexicana se conocía y reconocía en la publicación de Rogers. A principios de 1957 se reseñó en la sección Dai giornali e dalle riviste - a cargo de A. T. Anselmi- el número 55 de Arquitectura México dedicado a la obra de José Villagrán García, pionero de la arquitectura moderna mexicana ${ }^{129}$. Una pequeña fotografía del edificio Palma en la ciudad de México ilustró la noticia.

También cabe destacar que al inicio de la década de 1960 el interés en el tema mexicano debió ser suficiente como para promover, desde la Sociedad de Arquitectos Mexicanos y el Collegio Imprese Edili ed Affini di Milano, la exposición "4000 años de arquitectura mexicana", que, con algunos años de retraso con respecto a otras ciudades europeas, hacía escala en Lombardía ${ }^{130}$.

Por otro lado, a diferencia de Domus — más interesada en el diseño y en el arte-Casabella se inclinó más en los aspectos estructurales - si se piensa en el contacto con Pier Luigi Nervi y sus audaces construcciones de hormigón armado- lo que dirigiría la mirada a las cubiertas laminares de ultramar. Para el momento en que Rogers encabezó Casabella Candela ya estaba siendo publicado en todo el mundo, así, el artículo de octubre de 1959 se insertó en un flujo continuo de comunicaciones sobre el tema del momento: los excesos a que llegaban las estructuras y los peligros del exhibicionismo ${ }^{131}$. Si bien las aportaciones de Candela a Casabella continuaron aun después de la partida de Rogers ${ }^{132}$, sería bajo la dirección de Gian Antonio Bernasconi que se publicó un resumen significativo de la arquitectura moderna mexicana más reciente. Así, en octubre de 1966, el conjunto habitacional Nonoalco-Tlatelolco, el Museo de Arte Moderno, la Galería de Historia, el Museo Nacional de Antropología e Historia y el Palacio de Justicia fueron motivo de un análisis completo 
debido a M. Brunatti y G. Carnevale Cantoni ${ }^{133}$. Este artículo amplió significativamente la cantidad de nombres que se conocían en Milán a través de las publicaciones periódicas, pues, como se va viendo, la diversidad de contenidos en relación a la arquitectura mexicana no fue la meta de las revistas italianas.

Por último, Zodiac (Z), la publicación fundada por Adriano Olivetti y con Bruno Alfieri como editor principal, lanzó su primer número en noviembre de $1957^{134}$. Desde sus inicios se dirigió al público internacional, ya que contó con un comité de colaboradores reconocidos en otros medios, y también gracias a una amplia red de distribución en una veintena de países. Zodiac mantuvo siempre los textos de sus artículos en el idioma original de sus autores, traduciendo resúmenes, según el caso, al inglés, francés o italiano.

En un principio de aparición semestral, con los años se fue convirtiendo en un compendio, mitad revista, mitad libro, que por su periodicidad anual se caracterizó no ya por sus noticias de actualidad sino por su papel legitimador de la arquitectura que uno o dos años antes ya había circulado ampliamente en las publicaciones periódicas. A pesar de estas particularidades, se decidió mantener a Zodiac como parte del corpus italiano por sus puntuales aportaciones sobre el tema mexicano, lo que permite una comparativa con los otros dos títulos milaneses.

Se recuerda el año 1963 como sustancial de la difusión mexicana en el extranjero; año del que se ha insistido suficiente en relación a los monográficos de $A A$ y $A D$. Pero también Zodiac, sin llegar a ser monográfico, se sumó al flujo informativo que sirvió de fondo a las Jornadas Internacionales de Arquitectura que organizó la UIA en la ciudad de México en ese año. La extensión de los artículos publicados en Milán —veintiséis páginas - hacen equiparar esta aportación casi al nivel de los citados números especiales.

El artículo que preparó Esther McCoy para Zodiac, no obstante su acertado carácter crítico sobre algunos aspectos de la modernidad mexicana, sigue siendo una visión parcial del país, demasiado centrada en el encanto de la arquitectura prehispánica de la zona maya y en el atractivo - todavía en ese momento inagotable- de los cascarones de hormigón armado de Candela ${ }^{135}$.
133. M. Brunatti y G. Carnevale Cantoni, "Nuova architettura in Messico," Casabella, no. 310 (octubre 1966): 32-55.

134. La primera serie se publicó hasta 1973 y quince años después aparecería la segunda serie, publicada entre 1988 y 1999. Zodiac fue una revista más de las publicadas por la industria editorial Olivetti.

135. Esther McCoy, "Mexico Revisited (I)," y "Mexico Revisited (II): The Presence of Candela," Zodiac, no. 12 (octubre 1963): 106-17 y 118-131 respectivamente. El contenido de estos artículos ya se anotó en la primera parte de esta tesis, por lo que no se insiste aquí en su análisis. 
Lo más interesante de la gráfica que expone el total de páginas publicadas en las tres revistas italianas entre 1950 y 1970 es que, a diferencia del comportamiento evidente en los demás países, aquí las publicaciones se complementan para cubrir prácticamente todos los años de estudio. Al acercarse a la serie de datos por revista, es notable que los picos están o en uno o en otro extremo de la línea de años. Entre 1959 y 1960 parecería que las revistas se pasan la estafeta de la difusión, cediendo Domus el monopolio de noticias a Casabella y a Zodiac, títulos que, en la década de 1960, acumularon la mayor cantidad de información sobre el tema que aquí se atiende.

Cierto que sólo Domus se publicó ininterrumpidamente durante todo el periodo de estudio, mientras que Casabella retomó su andadura hacia finales de 1953 - aunque la primera noticia sobre México se registró en 1957-y Zodiac, cuyo inicio se consignó en 1957, no daría información consistente sino hasta 1963.

La línea que se dibujará por país será explícita en presentar un periodo constante de divulgación con sus curvas ajustándose al patrón general de los otros países, aunque con menor cantidad de páginas publicadas. No obstante, regresando al análisis por revista, es importante insistir en que, si bien en la mayoría de los casos las comunicaciones coincidieron en el tema de interés general internacional -la Ciudad Universitaria en 1952-53 y los monográficos en 1963- las publicaciones italianas siguieron sus gustos particulares.

Domus, por ejemplo, dio un protagonismo casi absoluto a Barragán, lo que explica no sólo las más de quince páginas de 1953, pues fue el año que, además de la obra universitaria se publicó extensamente los Jardines del Pedregal y, en 1956, mientras en todo el mundo se publicaba a Candela, Gio Ponti acrecentó la curva significativamente con un amplio artículo sobre la casa Prieto. Lo mismo sucedió en el año olímpico, pues Domus se centró en la cuadra San Cristóbal de Barragán y dejó de lado la arquitectura deportiva mexicana. En 1966, el pico que dibujó Casabella con las treinta y cinco páginas de su artículo a la nueva arquitectura mexicana, no sólo dio a conocer el MNAH - tema generalizado ese año en varias revistassino también otras obras que, curiosamente, no recibieron la difusión esperada a nivel internacional - Tlatelolco- o con escasa presencia en las publicaciones periódicas foráneas, como el Palacio de Justicia. 
De todos los países expuestos, Italia es el que, en promedio, dedicó más páginas por cada noticia. Esto se hace patente en la gráfica que muestra claramente una sólida línea que no se levanta más de cinco puntos por año contra unas prominentes curvas que, como ya quedó anotado, respondieron a noticias muy puntuales de las tres publicaciones en estudio. En resumen, las revistas milanesas acumularon casi ciento cuarenta páginas en no más de cuarenta comunicaciones durante todo el periodo de estudio. Comparando el perfil global con el italiano, de nueva cuenta comprobamos su integración en los intereses generales de divulgación en los años 1953, 1963 y 1966, pero quedando notablemente bajas o nulas las cotas en los años de inicio y término de las décadas analizadas.

\section{Una visión global de la difusión}

Después del análisis de cada revista y en su conjunto por naciones, todavía cabe puntualizar algunos detalles ante la gráfica que expone la totalidad de páginas que cada país consagró a la difusión de la arquitectura moderna mexicana.

Los primeros cinco años del periodo de estudio iniciaron con la divulgación en España y Francia de las obras emblemáticas de Mario Pani, no obstante, el punto más alto, con casi cincuenta páginas, lo alcanzó Estados Unidos gracias a los generosos artículos sobre la Ciudad Universitaria que publicó Arts \& Architecture y Architectural Forum. El mismo tema levantó la curva de Inglaterra - The Architectural Reviewe Italia -Domus - en 1953, para ser repetido en España los primeros meses de 1954 en Informes de la Construcción.

Entre 1955 y 1959 se suceden tres puntos máximos, el primero francés, que corresponde al monográfico de $A A$ y el último español, debido principalmente al extenso artículo que Arquitectura destinó a su connacional Candela. El punto intermedio - año 1957- acumuló en Estados Unidos más páginas que en 1952, sin embargo, no se trató un tema o edificio en particular sino que fue el resultado de una acumulación heterogénea de noticias. Entre éstas destacó el reportaje gráfico sobre el terremoto de 1957 y el análisis estructural de la Torre Latinoamericana, que salió indemne del fenómeno natural. También se publicó la arquitectura industrial de los Laboratorios Lederle, el Hotel Hilton, el nuevo aeropuerto 


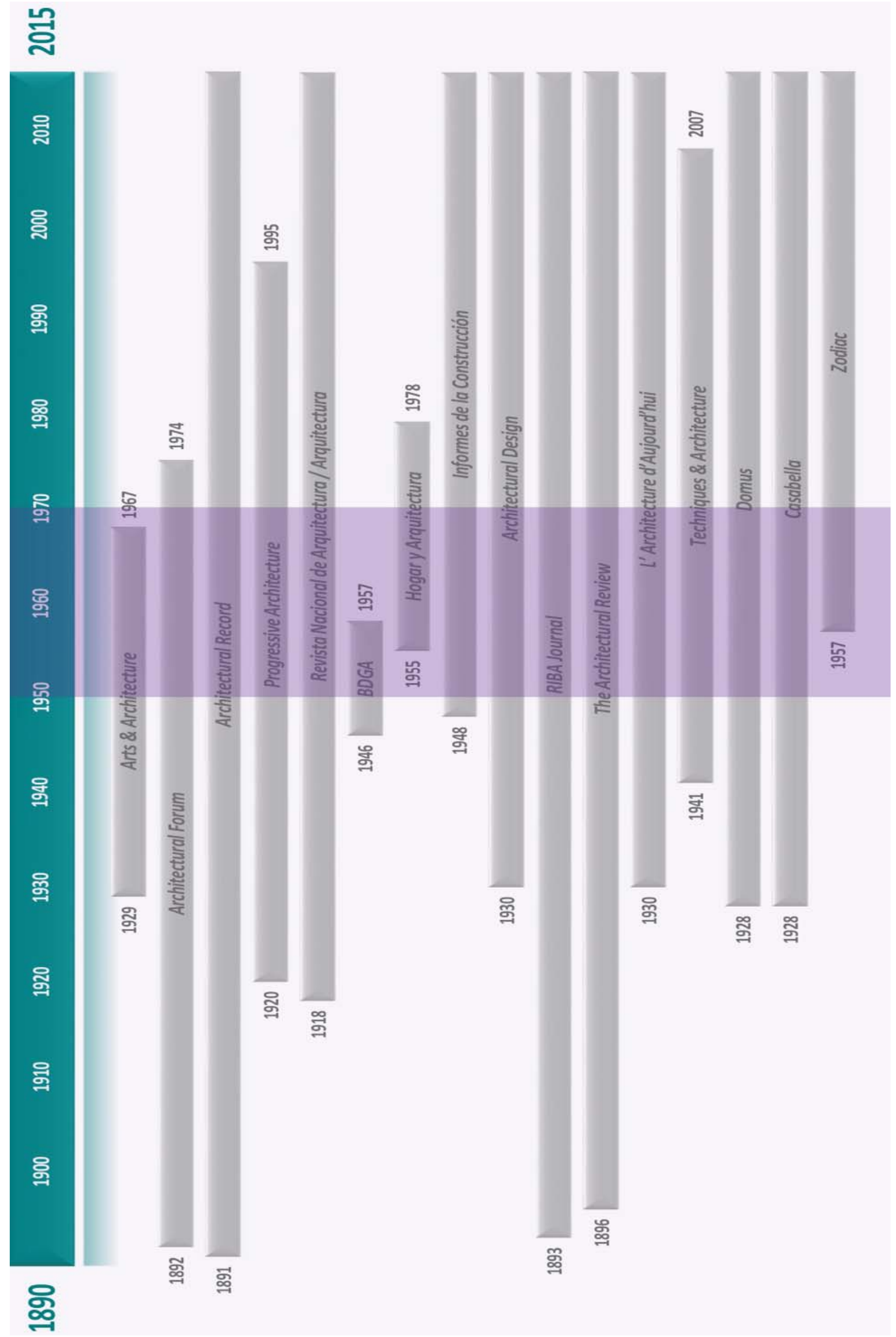


internacional — todos estos ejemplos en la ciudad de México—y, asimismo, el costeño aeropuerto de Acapulco. Tampoco podrían faltar algunas noticias de rigor, como las destinadas a la iglesia de la virgen de la Medalla Milagrosa en $A \& A$ y a otras obras recientes de Candela en $A F$.

De 1960 a 1964 sobra insistir en los monográficos, así que quizá sea más indicativo anotar en este caso las cotas bajas que fueron, a fin de cuentas, las que mantuvieron este periodo de la difusión de la arquitectura mexicana constante en las publicaciones periódicas foráneas. Así, el prototipo prefabricado de aula-casa rural que viajó a Milán en 1960 fue un tema que tuvo eco en varias revistas. $\mathrm{Al}$ año siguiente, el análisis de Irene Nicholson en $A R$ cubrió el panorama general de la modernidad mexicana y en 1964 haría el equivalente el texto de Irving Nerubay en $A A$.

Los últimos años de estudio dibujan dos curvas muy pronunciadas en torno a 1966 y 1968. En estos casos sí se reconocen dos temas generales: primero, los programas nacionales de construcción de mercados y museos y, segundo, la Olimpiada de México 68. Para este último tema es muy significativo que, en menor o mayor escala, todos los países lucen un claro incremento en la cantidad de noticias. Ahora bien, si se sigue el perfil estadounidense desde el año 1965 vemos que hay una caída abrupta en 1966, que se recupera en 1967 y sube todavía un poco más al año siguiente. Este declive no indica desinterés en los temas del momento, pues también desde Nueva York se publicó el MNAH, pero sería en los primeros meses de 1967. Con esto se justifica el interés común en todos los países hacia el final de la presente investigación.

Con este análisis quedan patentes los temas más representativos de la modernidad mexicana que se difundieron en las revistas internacionales. Cabe aclarar que los contenidos enunciados no son todos, sino quizá los más emblemáticos. En la tercera parte de esta tesis se abordan diversos análisis cualitativos que profundizan tanto en los temas como en los intercambios de información que aquí quedaron apuntados.

Se buscó, también, exponer las tendencias generales de distribución de noticias por años para acercar al lector — con datos objetivos- al extenso panorama de la divulgación y a sus puntos más distintivos. Asimismo, en este análisis cuantitativo se asumió el riesgo de señalar obras que pueden no ser familiares al lector -incluso después de la lectura de la primera parte de este documento- o de citarlas sin un
En la página anterior, línea de tiempo de las revistas contempladas en esta investigación. 


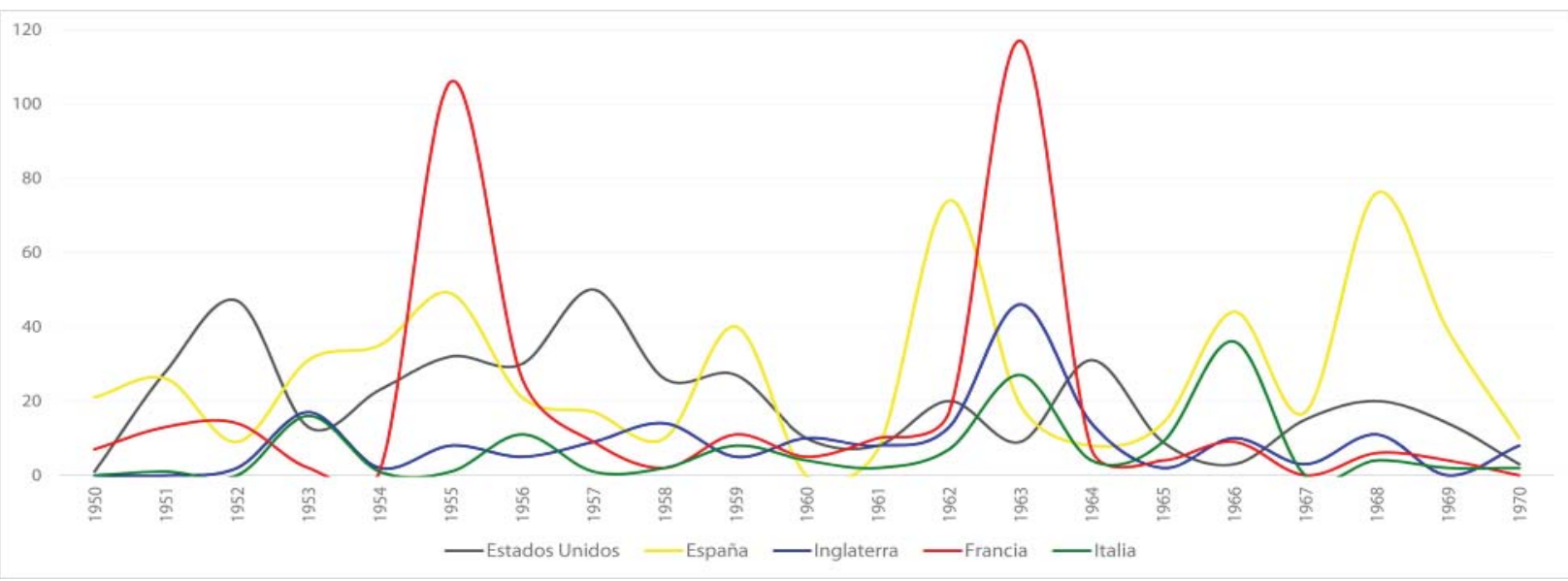

Gráfica que muestra la distribución de páginas publicadas por año en los cinco países contemplados en este estudio. Estados Unidos en gris, España en amarillo, Inglaterra en azul, Francia en rojo e Italia en verde. estricto rigor académico. Esto se debe a dos motivos: muchas de las obras y los artículos que las difundieron ya se citaron antes o, como se asentó en diversas referencias a pie de página, no se ha querido profundizar en un análisis que compete a la tercera parte de esta tesis. Los contenidos que aquí apenas se formulan encuentran su espacio en los grandes temas en el extranjero que tratan tanto la presencia de arquitectos mexicanos en las revistas extranjeras como los edificios en su papel de protagonistas de las páginas impresas.

Una vez que se ha revisado la difusión por revista y su distribución anual, es conveniente considerar el impacto por nación haciendo una comparativa entre los cinco países, al sumar el total de páginas publicadas durante todos los años de análisis. El esquema indica de forma contundente el predominio de las revistas madrileñas al acumular un 34\% del total de información, quedando arriba de Estados Unidos y Francia, con un 25\% y un $22 \%$ respectivamente. Inglaterra quedaría con un $11 \%$ mientras que Italia alcanzó apenas el 8\% de la suma final. Con todo y que los datos son objetivos, no se puede obviar que para el caso español, RNA/Arquitectura e Informes de la Construcción unieron sus fuerzas frente al gigante francés L'Architecture d'Aujourd'hui. Considerando el total de páginas por revista - y si de un concurso se tratara, que no es el caso- la parisina se alzaría victoriosa con casi ochenta páginas más que su competidor más cercano.

Y ya que se menciona el número de planas, tampoco sobra recordar que el $34 \%$ al que nos referimos antes equivale a más de quinientas sesenta páginas que - repartidas casi equitativamente entre $R N A / A$ e $I C$ y con un porcentaje mínimo en $H y A$ y el $B D G A$ - las publicaciones madrileñas destinaron al tema mexicano. Entonces, las revistas con sede en Los Ángeles y Nueva York sumaron cerca de cuatrocientas veinte 


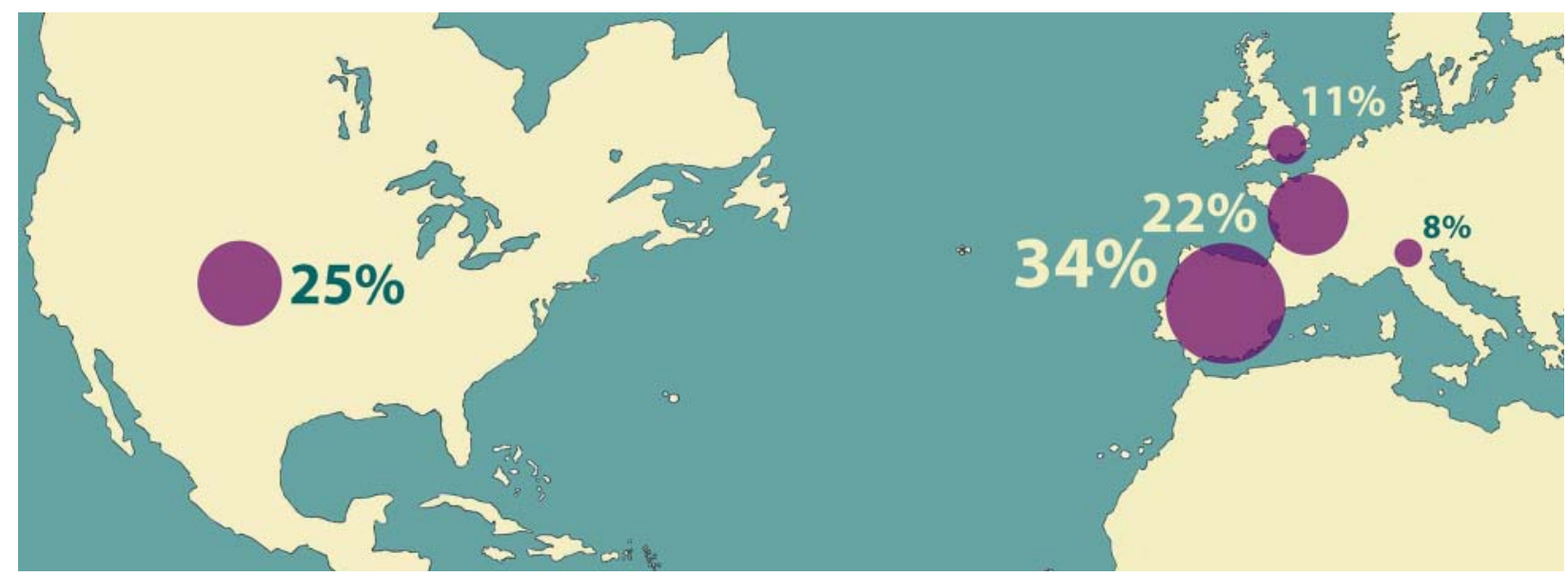

planas mientras que, desde París, se acumularon trescientas setenta. Inglaterra e Italia, no casualmente los países cuyos vínculos con México son más difusos, reunieron ciento noventa y ciento cuarenta páginas de la totalidad de páginas publicadas entre 1950 y 1970 en los países estudiados.

respectivamente. De esta manera, alrededor de mil seiscientas ochenta páginas filtradas de entre las miles que conforman las revistas estudiadas, se convirtieron en el material principal de análisis de esta tesis.

Esta discriminación, vista en conjunto y desde una perspectiva global, pareciera ser mucho más homogénea, en especial cuando se habla de temas de interés general. Sin embargo, la aproximación por países perfiló los intereses particulares de cada territorio que, a veces respondiendo a cuestiones económicas o a gustos personales de los editores, expuso un mismo tema siguiendo patrones muy marcados para el caso de cada publicación. Estas diferencias serán todavía más evidentes cuando se particularice en los temas de análisis cualitativo más adelante. La revisión a las distintas aproximaciones por país trazó un panorama mucho más heterogéneo y valioso que la consulta limitada a un solo país. No cabe duda que la diversidad de perspectivas enriqueció la difusión cuando se la considera, como se ha hecho en esta revisión, desde un punto de vista plural.

\section{Monográficos versus números regulares}

Para terminar esta sección, cabe concretar el análisis cuantitativo sobre la información publicada tanto fuera como dentro de números monográficos. A lo largo de este estudio se ha ido enunciando, en diversas oportunidades, tanto la importancia de los monográficos, cuya publicación siempre respondió a un acontecimiento determinado, como el flujo constante de noticias en los números regulares. 
136. La Escuela Normal Regional de Ciudad Guzmán, de Salvador de Alba, el edificio para Seguros Monterrey, de Enrique de la Mora, el Instituto Politécnico Nacional de Reynaldo Pérez Rayón, la Unidad Independencia de Alejandro Prieto o el Instituto Nacional de Protección a la Infancia, de Pedro Ramírez Vázquez, por citar sólo unos ejemplos.

137. El Centro Urbano Presidente Alemán de Mario Pani, la casa Prieto de Luis Barragán, el restaurante Los Manantiales y la capilla abierta de Cuernavaca, de Félix Candela, el Museo Experimental El Eco y las Torres de Satélite, de Mathias Goeritz, el Hotel Camino Real, de Ricardo Legorreta o el Museo Nacional de Antropología e Historia, de Pedro Ramírez Vázquez, entre muchos otros casos.

138. La Ciudad Universitaria, de varios autores, los Jardines del Pedregal de San Ángel, de Barragán, la iglesia de la Virgen Milagrosa, de Candela, el Centro Comercial Jacaranda, de Ramón Torres Martínez y Héctor Velázquez, el mercado Libertad de Alejandro Zohn, el aula-casa rural, de Pedro Ramírez Vázquez o la unidad habitacional Nonoalco-Tlatelolco de Mario Pani, por citar sólo algunos casos.
Ya se sabe que los monográficos potenciaron, en momentos muy puntuales, la difusión internacional de la arquitectura moderna mexicana, pero aún cabe preguntarse qué porcentaje de la información tuvo lugar en estos números especiales dedicados a México.

De los cinco países considerados, sólo tres publicaron monográficos: España, Inglaterra y Francia. En el primer caso, apenas un 13 por ciento de las páginas españolas corresponden al ejemplar de Arquitectura de agosto de 1962. Por otro lado, del total de información que dieron a conocer las revistas inglesas, un 19 por ciento pertenece al número de septiembre de 1963 de Architectural Design. Por último, el 57 por ciento de la divulgación francesa se concentró entre los números de abril de 1955 y septiembre de 1963 de L'Architecture d'Aujourd'hui. Es significativo que sólo para el caso francés, la información contenida en monográficos superó la mitad del total de páginas.

Después de un estricto análisis numérico, se confirma que apenas un 20 por ciento de la totalidad del papel impreso en los cinco países pertenece a monográficos. Así, la cantidad de información accesible sólo en números regulares verifica la continuidad en la difusión de la arquitectura mexicana durante las décadas de 1950 y 1960.

Pero, más allá de la cuantificación, un aspecto sustancial de este análisis se pregunta sobre las particularidades de la información vertida tanto en monográficos como en números regulares. Si bien es cierto que algunos edificios de la modernidad mexicana sólo se conocieron en el extranjero a través de los monográficos ${ }^{136}$, lo mismo aplica al contrario, ya que numerosos inmuebles se dieron a conocer en exclusiva fuera de los citados números especiales ${ }^{137}$. Y, también, se contó con obras que se conocieron tanto fuera como dentro de los números regulares ${ }^{138}$.

Entonces, es indiscutible que el panorama de la modernidad arquitectónica mexicana no estaría completo si se omite tanto una como otra vertiente de las publicaciones periódicas de arquitectura. Si en su momento los monográficos dibujaron los picos de la difusión, es innegable que complementaron el caudal noticioso de la divulgación foránea entre 1950 y 1970. 


\subsection{Recuento de contenidos De la reseña al artículo}

Una vez reconocidas las distintas publicaciones que entre 1950 y 1970 dieron a conocer la producción arquitectónica moderna en el extranjero, se hace indispensable definir la distribución, por tipo de noticia, de las más de mil seiscientas ochenta páginas que forman el corpus principal de esta investigación.

A lo largo de este documento se ha mencionado la presencia de artículos y noticias de actualidad, sin que se haya precisado la sutil diferencia entre una y otra expresión. Pero más allá de estos dos términos, la captura de información se delimitó por ocho campos que graduaron las comunicaciones para medir su impacto dentro de cada ejemplar. Por consiguiente, este apartado puntualiza las definiciones aquí empleados a la vez que ofrece otro punto de vista al análisis cuantitativo: la distribución de datos por tipo.

Las expresiones "artículo" y "noticia de actualidad" se definieron con base en dos características principales, su extensión y su título -reflejado o no- en los contenidos generales de cada ejemplar. Entonces, un artículo es aquel cuya extensión mínima es de dos páginas, mientras que una noticia de actualidad no suele abarcar más de una página. En el primer caso, el encabezado siempre se refleja en el índice, mientras que en el segundo caso, puede formar parte de secciones independientes dirigidas a actualizar el panorama arquitectónico mundial y, por lo tanto, no siempre estar expresado en el contenido. En ambos casos, el tema está directamente relacionado con alguna obra reciente o, en contadas ocasiones, con proyectos. Si bien es cierto que las noticias sobre la vida de los arquitectos mexicanos fueron prácticamente inexistentes, los análisis técnicos sí llegaron a formar un corpus generoso, es decir, sí se manifestaron en artículos. Hay que señalar que ambos tipos de noticia reflejaron en su totalidad y de forma directa la situación arquitectónica mexicana. 


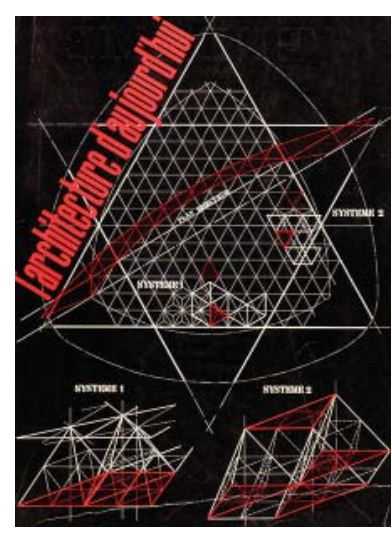

Artículo: proyecto de Félix Candela para un estadio de fútbol, en L'Architecture d'Aujourd'hui (diciembre 1961).
1. Se hace referencia a importantes recursos digitales como el RIBA British Architectural Library Catalogue online o el Avery Index to Architectural Periodicals (Columbia University).

2. Con esta aseveración tampoco se niega el valor intrínseco de dichas bases de datos, sólo se subraya su papel complementario para esta y futuras investigaciones. Se tiene la certeza de que ninguna consulta virtual puede sustituir - aún - la consulta física del material de trabajo.

3. "Avant projet pour un stade de foot ball," L'Architecture d'Aujourd'hui, no. 99 (diciembre 1961): 22-23.
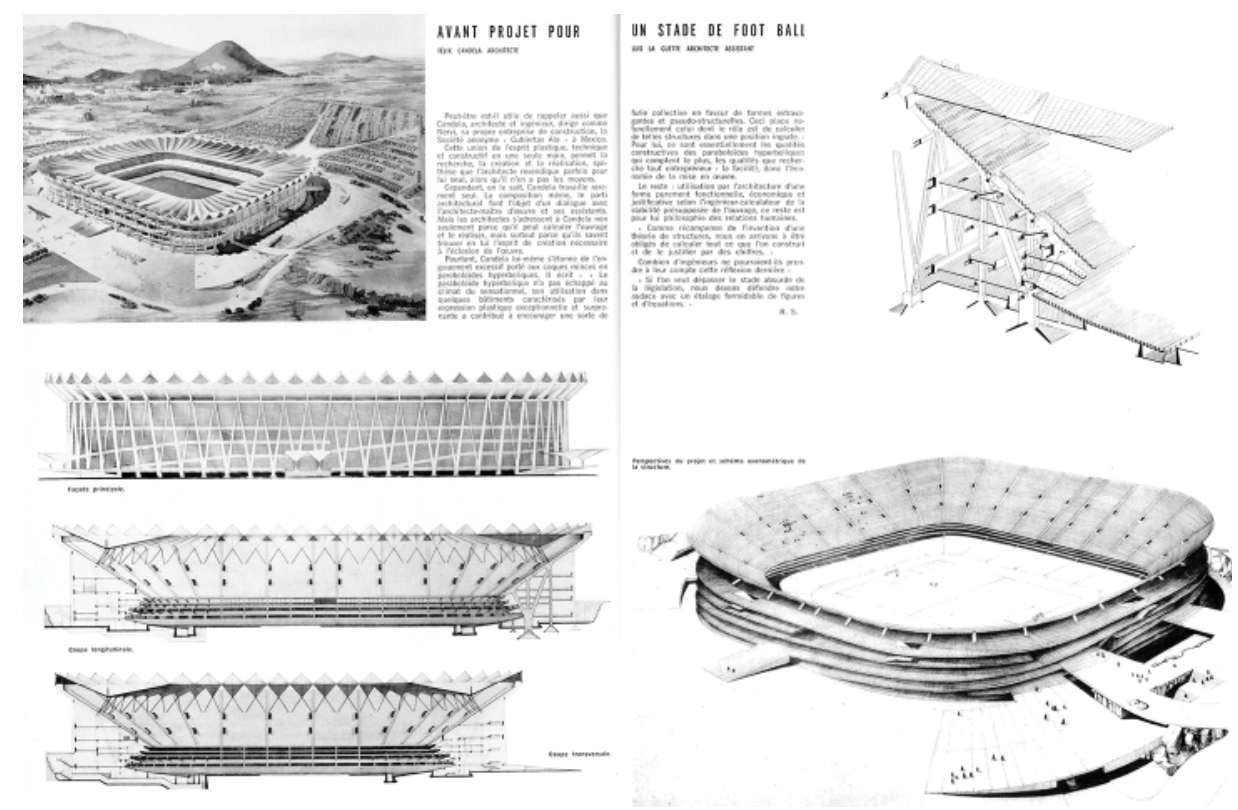

En este punto es importante subrayar algunos aspectos metodológicos de la investigación. Si bien la búsqueda de artículos se ha facilitado en los últimos años gracias a las potentes bases de datos que ofrecen en red los títulos de los mismos ${ }^{1}$, no pasa igual con las noticias de actualidad, ya que en muchos casos éstas formaron parte de secciones definidas bajo un nombre particular, que es el que aparece en el índice general de cada revista. Así, la consulta física de los ejemplares arrojó una considerable cantidad de valiosa información que no hubiera sido accesible solo a través de una consulta virtual ${ }^{2}$.

Por citar dos casos que ejemplifican estas definiciones, el proyecto para un estadio de fútbol que publicó $A A$ en diciembre de 1961 sería un modelo de artículo por componerse de dos páginas y estar su título expresado en el contenido general del número que la parisina dedicó a los arquitectos e ingenieros ${ }^{3}$. En este contexto, no es extraña la presencia de Félix Candela ni tampoco del proyecto con el que concursó para la realización del Estadio Azteca de la ciudad de México. Cabe aclarar que la definición no considera los contenidos del artículo - si incluye fotografías, plantas, alzados, perspectivas, texto descriptivo o análisis arquitectónico- pues fue distintivo de cada editorial cómo dio a conocer un edificio o proyecto. En otros casos se cuenta con artículos teóricos o históricos - los menos- que carecen de información gráfica, por lo que se vuelve inapropiada para este estudio una clasificación que se vuelque en las particularidades de los artículos cuando éstas son revisadas y comparadas en los análisis cualitativos. 
Un ejemplo de noticia de actualidad sería la casa que diseñó Víctor de la Lama en Cuernavaca y que se publicó en Architectural Forum en diciembre de 1957 en la sección Abroad ${ }^{4}$. En este caso el título que aparece en el índice es el del apartado que revisa la arquitectura más reciente construida fuera de las fronteras norteamericanas. Aquí, cabe decir que por una cuestión metodológica se decidió dejar como título en todas las referencias a pie de página y en la bibliografía al final del documento el encabezado de la noticia mexicana y no el de la sección, pues resulta mucho más indicativo de los contenidos que estudiamos.

Además de los artículos y noticias de actualidad, que directamente comunicaron la situación de la arquitectura moderna mexicana en el extranjero, también se localizaron constantes referencias al tema de estudio como parte de otros artículos no concernientes estrictamente con el argumento. Al encontrar esta información durante las consultas se definieron dos campos más de captura de datos: la "sección" y la "mención". La primera se apunta como un segmento de la totalidad de un artículo no vinculado estrictamente con la arquitectura moderna mexicana. La segunda se refiere, dentro de un artículo, a las menciones -tanto textuales como fotográficas- de ejemplos mexicanos que ilustren o formen parte del artículo, aunque el mismo, ni por título ni por tema general se dedique al país. La cantidad de páginas en este apartado se vuelve irrelevante pues una sección podrá alcanzar varias páginas mientras que una mención suele ser una imagen ocupando no más de una plana.

$\mathrm{Al}$ igual que se anotó para las noticias de actualidad, se hace evidente que sólo la consulta exhaustiva de las fuentes hizo posible el conocimiento y posterior análisis de estas numerosas menciones. Ha sido también a través de estas constantes apariciones que se ha podido medir el impacto que la arquitectura mexicana —en especial a través de ciertos edificios emblemáticos - tuvo en las publicaciones periódicas foráneas durante las décadas de 1950 y 1960.

El edificio de oficinas de Juan Sordo Madaleno en una esquina del Paseo de la Reforma compartió un artículo en Architectural Record en junio de 1957, en el que también se conoció un inmueble de Atlanta, Georgia ${ }^{5}$. Este sería el típico caso de una sección, pues no la totalidad sino solamente una parte del artículo se destinó al tema mexicano, pero en un contexto bien definido, el de la arquitectura comercial de oficinas.

4. "Mexican looking glass," Architectural Forum 107, no. 6 (diciembre 1957): 210.

5. "Two Office Buildings," Architectural Record 121, no. 6 (junio 1957): 207-14. 


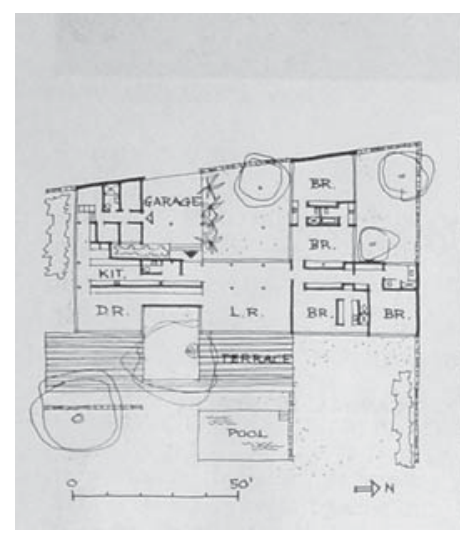

Noticia de actualidad: casa en Cuernavaca de Víctor de la Lama, publicada en la sección Abroad de Architectural Forum (diciembre 1957).
6. Carlos Flores, "El espacio interior-exterior en la arquitectura," Hogar y Arquitectura, no. 90 (septiembre-octubre 1970): 9-76.

7. Sandra Kocher, "Mexico," Architectural Record 143, no. 4 (abril 1968): 274, 282 y 290.

8. "Arquitectura. Agosto 1968," Hogar y Arquitectura, no. 78 (septiembre-octubre 1968): 146.

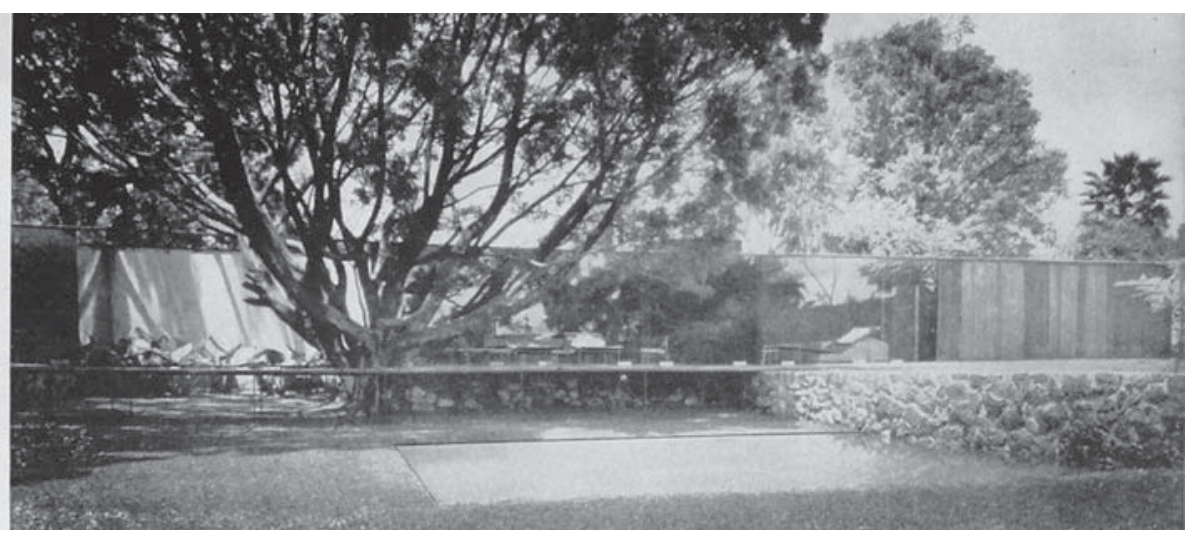

Por otro lado, del extenso artículo que Carlos Flores preparó para el número 90 de Hogar y Arquitectura en 1970, se rescata una página que mostró las rampas de la Facultad de Medicina de la Ciudad Universitaria de México. Este fue uno de varios ejemplos que ilustraron el tema del espacio interior-exterior en la arquitectura ${ }^{6}$. La mención a este aspecto muy particular de la obra universitaria fuera del contexto de una primera divulgación consolidó el conocimiento previo de la arquitectura mexicana en el ámbito foráneo. Más adelante se comprobará el peso de estas aportaciones - casi todas gráficas- que también resultaron muy significativas para este análisis.

Todavía quedan por comentarse cuatro términos más que formaron la base de la captura de datos derivados de las consultas a las publicaciones periódicas. Una "reseña", ya sea sobre un libro o sobre otra revista, representa las noticias sobre otras obras publicadas. Se alude a las revisiones sobre volúmenes y publicaciones periódicas sobre México. Para este caso tampoco se toma en cuenta la extensión, pues una reseña puede ser lo más sucinta posible o extenderse varias páginas.

La utilidad de las reseñas como herramienta de análisis ya quedó expuesta en el segundo capítulo de esta tesis, cuya primera parte trató la arquitectura mexicana en los libros entre 1937 y 1969. Por citar un caso, se recuerda aquella crónica que redactó Sandra Kocher sobre Builders in the sun: Five Mexican Architects, el libro de Clive B. Smith publicado en 1967 y comentado en Architectural Record en abril de $1968^{7}$. El papel de las reseñas sobre revistas ha sido especialmente destacado en el subcapítulo anterior, sobre todo por hacer evidentes los intercambios de información entre editoriales. Antes se enunciaron varios ejemplos, uno más sería la que anotó Hogar y Arquitectura sobre el monográfico que Arquitectura publicó sobre las obras olímpicas en $1968^{8}$. 
Ahora bien, bajo el rubro "noticias" se encuentra la información afín a eventos próximos, invitaciones a congresos, conferencias, viajes, cursos o las crónicas derivadas de los mismos. De igual forma, lo concerniente a exposiciones de arte y arquitectura mexicana en el extranjero y las críticas emanadas de dichos eventos. Los escasos informes que aparecieron en las publicaciones periódicas foráneas sobre la vida —o muerte - de contados arquitectos mexicanos también se consignaron bajo este título de noticias. Ya en la primera parte de la tesis se ha citado en puntuales ocasiones la importancia de los congresos internacionales y sus vínculos con la difusión en las publicaciones periódicas, así como la circulación de exposiciones temporales de arquitectura y su anuncio en las revistas. Hay que insistir en que las citas que aquí se ofrecen descontextualizadas son sólo ilustrativas de cada rubro o tipo de noticia, pues según el desarrollo de cada tema de análisis se ha contextualizado la información que se catalogó en el campo de "noticias".

Así, las referencias sobre México como organizador de las Jornadas de Arquitectura posteriores al viI Congreso de la Unión Internacional de Arquitectos en La Habana, Cuba, en $1963^{9}$, se encontrarán en este apartado de noticias. Otros ejemplos que caben en este apartado serían el resumen de una serie de conferencias en París que trataron el tema de la arquitectura en México y Sudamérica ${ }^{10}$ o la invitación a la exposición itinerante que organizó la Sociedad de Arquitectos Mexicanos que tuvo lugar, también en la Ciudad Luz, en diciembre de $1955^{11}$.

A reserva de profundizar más adelante en el tema de los arquitectos mexicanos que tuvieron presencia en las revistas foráneas con un trato protagónico, quedan aquí registradas como muestra, el doctorado honorífico que la Universidad de Nuevo México otorgó a Félix Candela en $1964^{12}$ o, hacia la vertiente trágica de lo noticioso, la prematura muerte de Carlos Lazo en 1955 en un accidente aéreo ${ }^{13}$.

El penúltimo campo de registro se compuso por las "cartas", tanto las firmadas por los editores como las que los lectores enviaron a las revistas y que fueron publicadas como seguimiento a determinados artículos. En este rubro también se integraron algunos textos informales que, sin llegar a ser ensayos críticos ni reseñas extensas, acompañaron en varias ocasiones las presentaciones de los monográficos. Se recogen aquí los escritos que dieron una visión personal de la arquitectura moderna mexicana.
9. "Mexico City Scene of UIA Meeting and Pacific RIM Architectural Conference," Architectural Record 134, no. 4 (octubre 1963): 10.

10. "Conferences sur L'Amerique du Sud et le Mexique," L'Architecture d'Aujourd'hui, no. 93 (diciembre 1960): v.

11. "Exposition d'Architecture Mexicain," L'Architecture d'Aujourd'hui, no. 63 (diciembre 1955): VII.

12. "Candela receives Hon. Ph. D." Architectural Forum 120, no. 4 (abril 1964): 13.

13. "Carlos Lazo," L’Architecture d'Aujourd'hui, no. 63 (diciembre 1955): VII. 
Distribución porcentual de la totalidad de información según tipo de noticia, sin considerar la cantidad de páginas.
14. "Genius: miraculous," Progressive Architecture 36, no. 9 (septiembre 1955): 13.

15. Thomas H. Creighton, "Progressive Architecture P.S." Progressive Architecture 36, no. 9 (septiembre 1955): 250. Se trató de la casa del señor Eduardo Suárez, en Tepotzotlán, de 1943, de diseño por completo tradicional-vernáculo.

16. "Mexican Man Hole," Progressive Architecture 50, no. 10 (octubre 1969): 6 .

17. E. Beaudouin, "Impressions d'un voyage au Mexique," L'Architecture d'Aujourd'hui, no. 59 (abril 1955): 3.

18. "Publicidad: Republic Steel Corporation," Architectural Record 127, no. 6 (junio 1960): 326-327.

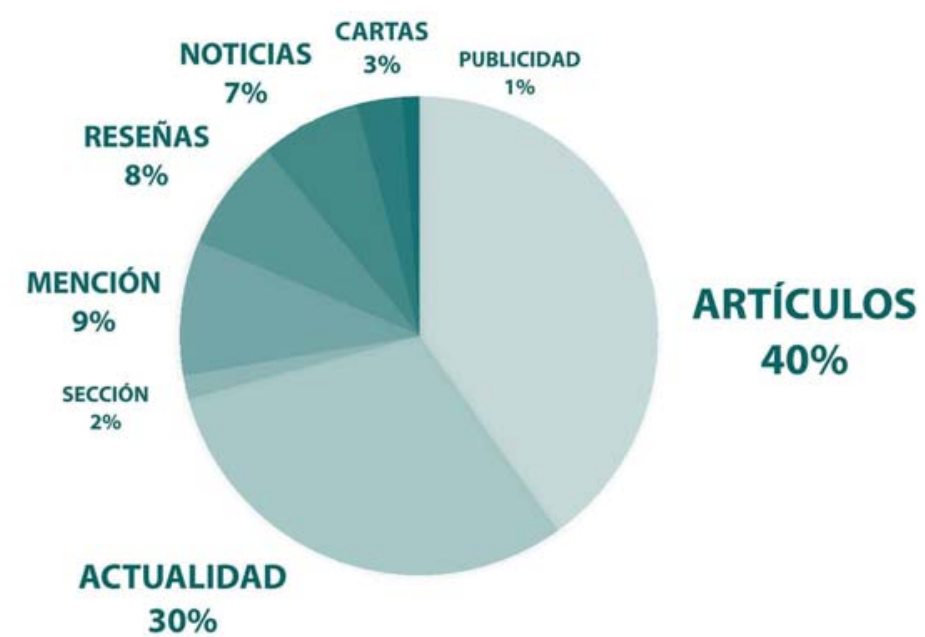

En septiembre de 1955, por ejemplo, Thomas H. Creighton, editor de Progressive Architecture, ante la respuesta favorable que recibió su artículo sobre Candela del mes de junio anterior - a quien ya se calificaba de genio y a sus obras de milagrosas ${ }^{14}$ - publicó la fotografía enviada por el propio arquitecto para verificar sus inicios convencionales en el diseño arquitectónico ${ }^{15}$. Años más tarde, ya con Forrest Wilson como editor, Progressive abriría la sección Your Point of View, en la que, en octubre de 1969, publicaría una carta en la que se comentaba el Hotel Camino Real, que se había dado a conocer en dicha revista en junio del mismo año ${ }^{16}$. Por otro lado, la visión personal recogida en esta sección quedaría bien tipificada con el texto que escribió E. Beaudouin sobre sus impresiones del viaje a México en 1952, carta que formó parte del monográfico de 1955 de L'Architecture d'Aujourd'hui ${ }^{17}$.

Por último, sin pretender un análisis en profundidad del tema, se registró también la publicidad que de forma directa difundió la arquitectura moderna mexicana en las revistas consignadas. En este caso, las citas a un inmueble específico - siempre en relación a algún material o producto importado de Estados Unidos utilizado en una obra mexicanareforzó el conocimiento de la modernidad del sur de la frontera. Además del caso ya comentado de la Torre Latinoamericana, otro ejemplo sería el edificio del Banco Popular en Monterrey, obra de Mario Pani, Salvador Ortega y Ramón Lamadrid, que utilizó acero inoxidable de la compañía Republic Steel de Cleveland, Ohio ${ }^{18}$. La publicidad que se reconoció en esta sección se caracteriza por la imagen del edificio y una breve descripción del mismo que - evidentemente siguiendo fines comerciales - lo califica como paradigma de la arquitectura más actual. 
De esta manera se capturó la información extractada de las publicaciones periódicas contempladas durante el periodo de estudio. La aproximación por países que se presentó en el apartado anterior comparó el total de páginas editadas contra el número de comunicaciones, lo que hizo patente la extensión de los artículos por país, pero ahora interesa puntualizar otro aspecto. ¿Cómo se distribuyó la totalidad de la información de acuerdo a los ocho campos definidos?

Es importante precisar que las casi mil setecientas páginas que conforman la base de datos principal se inscribieron en alrededor de setecientos registros, mismos que se clasificaron en las ocho categorías definidas arriba. La distribución porcentual que se explica a continuación hace referencia a los registros sin considerar la cantidad total de páginas. Esta decisión metodológica se sustenta en la accesibilidad de medir el impacto de las comunicaciones en cada ejemplar — según su catalogación - tomando en cuenta un encabezado o título por cada registro.

Los artículos representan el $40 \%$ del total de comunicaciones recopiladas. Esto significa que se cuenta con poco más de doscientos setenta artículos, publicados entre 1950 y 1970, repartidos entre las dieciséis revistas de arquitectura de cinco países. La extensión de los mismos va de un mínimo de dos páginas hasta el más generoso que contó treinta y dos páginas ${ }^{19}$ — un caso excepcional—seguido por un puñado de comunicaciones que van de las veinte a las veintiséis páginas ${ }^{20}$. Pero lo común fueron los artículos breves de dos páginas, ya que suman más de ciento diez y representan el 40\% del total de artículos. Las comunicaciones de cuatro páginas alcanzan un $16 \%$ del total mientras que los de tres o seis planas suman, cada categoría, un $10 \%$. Con esto queda todavía un $21 \%$ que se reparte entre los artículos que cuentan con cinco o entre siete y diecinueve páginas. Estos datos manifiestan el tipo de comunicación más frecuente del análisis cualitativo.

Hay que decir que los artículos representan las noticias de más impacto en las publicaciones periódicas, no sólo por su extensión sino por su expresión en los contenidos generales de cada ejemplar, ya que en muchos casos se integraron con monográficos que discutieron temas de actualidad ${ }^{21}$. Con todo, no es posible hacer una valoración objetiva de la difusión arquitectónica considerando únicamente este tipo de registro,
19. "Láminas de hormigón armado," Arquitectura, no. 10 (octubre 1959): 2-33.

20. Véase "La Cité Universitaire de Mexico," L'Architecture d'Aujourd'hui, no. 59 (abril 1955): 14-39; M. Brunatti y G. Carnevale Cantoni, "Nuova architettura in Messico," Casabella, no. 310 (octubre 1966): 32-55; "La Ciudad Universitaria de México," Informes de la Construcción, no. 58 (febrero 1954): s/p.; "Centro urbano 'Presidente Juárez,"' Informes de la Construcción, no. 56 (diciembre 1953): s/p.; "Mexico's University City," Architectural Forum 97, no. 3 (septiembre 1952): 99-119 y "The new University City of Mexico," Arts \& Architecture 69, no. 8 (agosto 1952): 20-37 y $41-42$.

21. Véase por ejemplo el número especial 67-68 que $A A$ dedicó a la arquitectura en países cálidos en octubre de 1956, el ejemplar de junio de 1957 de Record, que estudió la tipología de los edificios de oficinas, el de $A D$ en octubre de 1963 destinado a la vivienda unifamiliar o aquél de junio de 1969 en que $T \ll A$ analizó las nuevas estructuras y la industrialización. En todos ellos algún caso mexicano se integró al discurso general propuesto por los editores de las respectivas publicaciones. 
pues, como ya se adelantó, todavía queda un 60\% de información que complementa sustancialmente estas comunicaciones principales.

Entonces, las noticias de actualidad -las comunicaciones concisas de una página - sumaron la nada desdeñable cifra del 30\% del total de la información, esto es, poco más de doscientas páginas. Cabe insistir en que la gran mayoría de estas referencias siempre estuvieron en relación con algún edificio de reciente factura ${ }^{22}$, lo que potenció que una diversidad importante de inmuebles se diera a conocer y, en muchos casos, las construcciones se repitieran en distintas publicaciones periódicas, incrementando así su difusión internacional.

Con todo y que las noticias de actualidad no tienen el impacto de los artículos, fueron piezas fundamentales de la divulgación de la arquitectura mexicana fuera de sus fronteras pues sin duda su inclusión en las secciones de información internacional de las revistas promovió su conocimiento. Estos aparatos de difusión, si bien se caracterizaron por textos breves e imágenes llamativas dirigidas a una comprensión básica de las obras, no ofrecían información superficial; en estas secciones también se encuentran acertadas críticas ${ }^{23}$. Así, secciones como World, en The Architectural Review, Miscellania y News en Architectural Design, News Report en Progressive Architecture, Abroad en Architectural Forum, The Record Reports en Architectural Record o Notes in Passing en Arts \& Architecture, nutrieron considerablemente este 30\% de información que se catalogó como noticias de actualidad.

Otro aspecto sustancial de estas páginas no recae solamente en la

22. En las noticias de actualidad también se registraron desarrollos urbanos a gran escala, hitos citadinos y obras de infraestructura como puentes peatonales y vehiculares, circuitos viales, estaciones fronterizas o el Sistema de Transporte Colectivo "Metro".

23. Véase por ejemplo "Glass walls patent glazing tradition in Mexico," The Architectural Review 135, no. 808 (junio 1964): 391.

24. Véase por ejemplo "Mexican Stadium: two competition projects," The Architectural Review 132, no. 789 (noviembre 1962): 305-306, en relación al concurso para el Estadio Azteca, los proyectos de Pedro Ramírez Vázquez y Félix Candela. posibilidad de comparación de las obras mexicanas con otras que al mismo tiempo poblaban el mundo, sino en la inmediatez de las comunicaciones. Estas secciones, al ser concisas, solían brindar la información de forma eficiente, adelantando noticias sobre proyectos o avances de obras antes de finalizarse los edificios ${ }^{24}$.

Antes se anotó que la característica principal de la sección -a diferencia de la mención - fue el compartir una parte sustancial de un artículo pero sin que el ejemplo de arquitectura mexicana fuese el argumento principal. Se recuerda el caso de los edificios de oficinas en Atlanta y el Distrito Federal citado antes. Este tipo de registro —considerado muy efectivo en términos de difusión- sumó el $2 \%$ del total de la información registrada, esto es, un promedio de 30 páginas. De estas 
comunicaciones el arquitecto más referido fue Félix Candela, debido a que sus cascarones de hormigón armado fueron continuamente comparados con otras obras similares en esos años. Diversos artículos que estudiaron el comportamiento estructural del material del siglo $\mathrm{xx}$ incluyeron una sección con las obras mexicanas ${ }^{25}$. Pero también, la Ciudad Universitaria fue objeto de análisis comparativos en diversas ocasiones ${ }^{26}$, o la vivienda unifamiliar, otro de los temas clásicos de análisis durante la modernidad ${ }^{27}$.

Por su parte, las menciones alcanzaron el 9\% del total de la información vertida en la base de datos, lo que equivale a poco más de sesenta registros que, a diferencia de las secciones, abarcaron un panorama edificatorio más amplio y singular. Aquí, por ejemplo, en vez de estudiarse la Ciudad Universitaria en su conjunto, se puso el acento en dos o tres edificios emblemáticos ${ }^{28}$. También, las obras de Candela tomaron protagonismo como inmuebles aislados y no ya como un grupo de cubiertas similares ${ }^{29}$. Además, casos de hoteles, museos, pabellones, unidades habitacionales y hasta domos geodésicos se cuentan entre las diversas construcciones que alimentaron este apartado noticioso ${ }^{30}$.

Lo que más interesa destacar de estas cuatro primeras categorías -artículos, actualidad, sección y mención - fue el mayor impacto que se registró en comparación con el señalado para las clasificaciones restantes. Esto se debe a que las comunicaciones se relacionaron directamente con obras de reciente factura, mismas que, a partir de una primera divulgación, comenzaron a repetirse para ilustrar diferentes

25. Véase por ejemplo "Shell concrete today," Architectural Forum 101, no. 2 (agosto 1954): 156-67; Ervin Galantay, "Les voiles minces et la couverture autoportante," L'Architecture d'Aujourd'hui, no. 64 (marzo 1956): 28-43 o Robin Boyd, "Engineering of excitement," The Architectural Review 124, no. 742 (noviembre 1958): 294-308.

26. Véase Richard Neutra, "The Shapes on a Campus are not extracurricular," Architectural Record 122, no. 2 (Agosto 1957): 174-77 o Richard P. Dober, "Form and Style in Campus Design," Progressive Architecture 41, no. 9 (septiembre 1960): 122-33.

27. "Four foreign houses," The Architectural Review 128, no. 765 (noviembre 1960): 329-40.

28. En especial en la Biblio- teca Central, el Estadio Olímpico o el pabellón de rayos cósmicos. Véase "Stone in today's building," Architectural Forum 101, no. 1 (julio 1954): 156-157; "Bulldozer architecture," Architectural Forum 113, no. 2 (agosto 1960): 8491 o "Struttura e colore," Domus, no. 299 (octubre 1954): 47-48, respectivamente para cada edificio citado.

29. Por ejemplo, la iglesia de la virgen de la Medalla Milagrosa en “¿Qué orientación debe darse al arte sacro actual?" Revista Nacional de Arquitectura, no. 189 (septiembre 1957): 21-31 o la iglesia de San José Obrero en Antonio F. Alba, "La arquitectura después de los grandes maestros," Arquitectura, no. 53 (mayo 1963): 30-40.

30. Véase el Hotel Hilton de Acapulco en "Hilton Plus
Statler. A big client gets bigger," Architectural Record 116, no. 4 (octubre 1954): 154-55; el Museo Experimental El Eco en Thomas Creighton, "The New Sensualism," Progressive Architecture 40, no. 9 (septiembre 1959): 141-47; el pabellón de México en la Exposición Internacional de Bruselas 1958 en "The Foreign Section," The Architectural Review 124, no. 739 (agosto 1958): 86-99; la unidad habitacional Nonoalco-Tlatelolco en J. P. Vouga, "Analyse critique des termes propres aux urbanistes britanniques," L'Architecture d'Aujourd'hui, no. 118 (diciembre 1964): 50-55 o el domo geodésico que construyó Alcomex en el balneario de Oaxtepec en Z. S. Makowski, "A survey of recent three-dimensional structures," Architectural Design 36, no. 1 (enero 1966): 10-41. 
argumentos, lo que necesariamente reforzó la difusión de la arquitectura moderna mexicana.

Por otro lado, las reseñas y las noticias sumaron el 8\% y el 7\% del total de información respectivamente, es decir, un promedio de cincuenta registros. Estas comunicaciones, si bien de impacto menor que las anteriores, tienen el valor de consolidar el contexto en el que se desarrolló la trama principal de la historia. Las constantes alusiones a otras revistas y libros que trataron el tema de estudio, así como las numerosas noticias sobre congresos internacionales y exposiciones apoyaron sustancialmente esta investigación. Esta aseveración se prueba en los análisis cualitativos de la tercera parte de esta tesis, en los que son constantes las referencias a cuantiosas reseñas e innumerables noticias.

Hasta ahora se ha cuantificado ya un $96 \%$ de los datos volcados en la base de datos. El último 4\% se reparte entre las cartas y la publicidad cuyo impacto es todavía más limitado que en las clasificaciones previas. Con todo, las poco más de veinte cartas y los menos de diez registros publicitarios encontrarían sitio adecuado en los ensayos finales de esta investigación, ya que, al igual que las reseñas y noticias, complementan el análisis global que se ofrece sobre la difusión de la arquitectura mexicana durante las décadas de 1950 y 1960 en los medios periódicos foráneos. 


\subsection{Diversidad edificada Desde vivienda hasta infraestructura urbana}

Una vez analizadas las distintas categorías en que se vertió la información recopilada de las publicaciones periódicas, es sustancial profundizar en los géneros edificatorios a través de los cuales se dio a conocer la arquitectura moderna mexicana entre 1950 y 1970. Interesa sobre manera subrayar la diversidad de inmuebles ya que se habla de revistas de arquitectura, y, si bien siempre caben en ellas los debates teóricos, los ensayos históricos o las noticias sobre la trayectoria profesional de determinados arquitectos, el mayor porcentaje informativo recae en los propios edificios. En este caso, el $80 \%$ del material que forma el corpus de la investigación se dedicó a un edificio o conjunto arquitectónico específico, lo que justifica sobradamente la siguiente aproximación que discrimina la información según los usos particulares de los inmuebles.

Así, se decidió catalogar los contenidos de las comunicaciones en doce diferentes campos, todos ellos con un título descriptivo que diera cuenta eficazmente del tipo de inmueble que en cada ocasión se daba a conocer. Si bien en casi todos los registros la relación es directa entre el nombre del campo y el edificio publicado - por ejemplo la vivienda unifamiliar-, se cuenta con dos campos que merecerán un análisis más amplio debido a que se consideraron subniveles de información que especifican en mayor profundidad los contenidos de los artículos. Se trató de los "servicios" y de otro campo que se denominó "varios" pues en una misma comunicación se divulgaron diversas tipologías edificatorias.

Entonces, las primeras tres categorías cubrieron la habitación en sus diferentes expresiones edilicias. Se inicia con la "vivienda unifamiliar", tema siempre presente en las revistas por ser uno de los géneros que más se ha prestado a la experimentación arquitectónica en tiempos modernos. También, hay que considerar que, en general, es más accesible construir una sola vivienda que un conjunto urbano que rebasa la escala unifamiliar. 
1. En el apartado 7.2 se analiza el tema de la vivienda unifamiliar durante todo el periodo de estudio.

2. La única excepción es la Casa Silverstone en Taxco, de Anshen \& Allen, publicada en junio de 1951 en la revista de Gio Ponti.

3. Véase Ana Esteban Maluenda y Vanessa Nagel, “"Habitar en los medios. La difusión de la vivienda social mexicana en las revistas europeas y norteamericanas (1950-1968)," Arquitecturas del Sur 32, no. 45 (2014): 3447.
Esto ha propiciado, no sólo para el caso mexicano, la presencia constante de este género edificatorio en las publicaciones periódicas; como ya se vio, algunos títulos - Arts \& Architecture- incluso se especializaron en el tema. De esta manera, no sorprende que del total de páginas publicadas durante todo el periodo de estudio, la vivienda unifamiliar cuente con el $10 \%$ del material impreso.

Lo anterior tampoco significa que el interés en publicar la vivienda unifamiliar fue generalizado en todas las revistas. Por cantidad de páginas, L'Architecture d'Aujourd'hui sobresale entre todos los títulos, pero esto se debe a que la publicación francesa fue la que dedicó más planas al tema mexicano, entonces, la habitación familiar fue uno más de los asuntos que publicó, pero no al que reservó más páginas. Incluso revisando el caso de $A \& A$ sorprende que, si se considera la marcada inclinación de la angelina al tema de la casa familiar, tampoco sea este el género al que destinó más papel impreso. Con todo, estas dos publicaciones y Domus son las que, proporcionalmente siguiendo el análisis de sus contenidos sobre el tema mexicano, se revelan como las más interesadas en el asunto.

En el caso de $A A$ los ejemplos de vivienda individual se concentraron en los monográficos de 1955 y 1963, especialmente en el primero, lo que respondió a los años de mayor divulgación de casas individuales mexicanas, si se piensa en el boom del Pedregal, pero también aportó algunos ejemplos aislados desde 1950 y durante toda la década. Es notorio que después del monográfico del 63 este tema desapareció de las páginas de la publicación francesa ${ }^{1}$. Por su parte $A \mho A$ reunió la mayoría de los casos en su número especial de 1951, aunque mantuvo algunas menciones más también durante la década de 1950. En ambos títulos la diversidad de nombres es característica. Lo contrario pasó en Domus, donde la totalidad de ejemplos corresponden a casas diseñadas por Luis Barragán y publicadas en un rango más extenso de años².

Los casos opuestos - que se citan por contraste-serían Progressive Architecture, The Architectural Review, Techniques et Architecture, Casabella y Zodiac, títulos en que el porcentaje de comunicaciones sobre la vivienda unifamiliar quedó muy por debajo del interés que mostraron hacia otros asuntos.

Propósito contrario a la habitación aislada es la "vivienda colectiva de interés social", tema capital hacia la mitad del siglo $\mathrm{xx}^{3}$. Es 
notable que sólo las revistas españolas — RNA/Arquitectura e Informes de la Construcción - destinaron más páginas a este tema que al de la vivienda unifamiliar. Por supuesto, se sabe del empuje para solventar el déficit habitacional que se imprimió en los años posteriores a la Guerra Civil y, también, es sobresaliente que nacieran revistas de arquitectura especializadas - Hogar y Arquitectura - en exponer los logros alcanzados en el tema de la vivienda social. Este panorama explica el predominio de este tipo de habitación en las revistas madrileñas sobre la casa sola, de escaso desarrollo en las ciudades ibéricas ${ }^{4}$.

Además de las publicaciones españolas, sólo $A A$ — de nuevose cuenta entre los títulos con una considerable cantidad de páginas impresas sobre el tema. En menor grado, Architectural Design, A\&A o Casabella, también se interesaron en los grandes conjuntos habitacionales mexicanos que - de alguna manera- libraban una batalla que se sabía perdida ante la explosión demográfica y la autoconstrucción.

Cabe comentar que el desinterés en el tema de la vivienda social se generalizó en las publicaciones neoyorquinas, pues ninguno de los tres títulos consultados - Architectural Forum, Architectural Record y Progressive Architecture- dedicó espacio editorial a este género edificatorio. Al contrario de la vivienda unifamiliar, que favoreció el conocimiento de un gran número de arquitectos mexicanos, la vivienda social, debido a la escala de sus desarrollos, fue monopolizada por unos pocos nombres, el más conocido, por supuesto, el de Mario Pani. La extensión de los conjuntos, en muchos casos, propició amplios artículos, lo que se ve reflejado en la cantidad de páginas dedicadas al tema. Es así que un $7 \%$ del total de información corresponde a esta categoría, asunto que se desarrolla in extenso en la tercera parte de este documento.

Un tercer apartado se destinó a otro tipo de vivienda, ciertamente de menor impacto que los anteriores pero presente en las publicaciones periódicas de arquitectura: los edificios de apartamentos de lujo. No sorprende lo limitado de sus muestras, pues apenas un $2 \%$ de páginas divulgaron esta tipología. Esto se explica por la inclinación de los mexicanos hacia la casa sola en vez de los edificios en altura, lo que ha dibujado un perfil básicamente horizontal en nuestras ciudades. Con todo, algunos ejemplos señeros de habitación vertical —aquí se están obviando aquellos edificios altos que formaron parte de los conjuntos urbanos de
4. Se hace referencia a la cantidad proporcional de edificios colectivos sobre la casa unifamiliar, no a los notables ejemplos aislados que, efectivamente, poblaron las revistas de arquitectura, tanto nacionales como internacionales. 
5. En este número se conoció el trabajo de Ricardo de Robina y Jaime Ortiz Monasterio, Augusto H. Álvarez y Juan Sordo Madaleno, Abraham Zabludovsky o Ramón Marcos Noriega.

6. Con ejemplos de Augusto H. Álvarez, Héctor Velázquez y Ramón Torres Martínez.

7. En la londinense sepublicó a Augusto H. Álvarez mientras que en la parisina surgieron nombres como Eric Coufal, Pascual Broid, Jorge Creel de la Barra, Héctor Velázquez o Abraham Zabludovsky.

8. Fuera de la ciudad de México, el ejemplo más sobresaliente refiere al inmueble "Los Cocos", en Acapulco, obra de Mario Pani. Véase "Condominio in Acapulco," The Architectural Review 128, no. 762 (agosto 1960): 96 e "Immeuble 'Los Cocos', Acapulco, Mexique," L'Architecture d'Aujourd'hui, no. 104 (octubre-noviembre 1962): 110-11.

9. Véase "Less in Mexico," Architectural Forum 108, no. 1 (enero 1958): 184 y "Apartments, Mexico City, Mexico," Architectural Record 129, no. 3 (marzo 1961): 212.

10. Véase en la tercera parte de esta tesis los apartados 7.1 Reto e innovación. La Ciudad Universitaria de México y 7.3 Camino a la escuela. El aula-casa rural y la educación básica, media y superior.

11. "Frontones," Arquitectura, no. 44 (agosto 1962): 56-57.

12. "Arquitectura Mexicana," Revista Nacional de Arquitectura, no. 98 (febrero 1950): 47-58. interés social- llegaron a las páginas internacionales. Curiosamente, su presencia en las publicaciones periódicas tiene un margen cronológico bien definido. Una primera concentración de inmuebles se dio a conocer en el monográfico de $A A$ de $1955^{5}$ y, en 1962, en el especial de Arquitectura $^{6}$ y, en 1963, en los correspondientes de $A D$ y $A A$, se congregó una considerable cantidad de ejemplos ${ }^{7}$. Antes y después de estos años no se registró ni un solo caso, pero en los años intermedios sí se cuenta con algunos registros aislados, en especial en $A D$ y $A A^{8}$.

Si la vivienda unifamiliar interesó poco en España, los edificios de apartamentos de lujo importaron todavía menos, pues los únicos registros son los que antes se consignaron en el monográfico de Arquitectura de 1962. Asombra bastante que de entre las más de doscientas sesenta páginas extractadas de Informes de la Construcción, ni una sola se ofreció a esta materia. El mismo caso se encuentra en las revistas milanesas, pues ninguno de los títulos publicó ejemplos mexicanos de vivienda en altura. En Estados Unidos, las excepciones fueron Architectural Forum y Record, quienes en puntuales ocasiones divulgaron el tema9.

Más allá de la vivienda, se registró un panorama edificatorio bastante extenso que tomó como característica para su clasificación el uso particular de cada inmueble. La cuarta categoría se denominó "educación", en la que se incluyeron los edificios destinados a la educación básica, media y superior. Cabe aclarar desde ahora que, debido al impacto de la Ciudad Universitaria en las revistas de arquitectura de la época, se redactó un ensayo aparte para este tema y otro destinado a todos los demás ejemplos de arquitectura educacional ${ }^{10}$. Si la categoría "educación" alcanzó un 17\% del total de páginas publicadas entre 1950 y 1970, en gran medida se debió a la magna obra universitaria, ya que de esta última cifra, el $60 \%$ trató sobre este hito fundamental de la arquitectura moderna.

Ahora bien, ¿qué títulos se interesaron tanto en la obra universitaria como en otros ejemplos de educación? Empezando por las publicaciones españolas, destaca que a $R N A / A$ concernieron mucho más otros temas que la Ciudad Universitaria, de la que veremos apenas la reproducción de la planta de conjunto en un artículo que difundió los frontones diez años después de su realización ${ }^{11}$. Pero en la revista encabezada por Carlos de Miguel sí se registró desde la Escuela Nacional de Maestros y el Conservatorio Nacional de Música ${ }^{12}$ hasta el Instituto Politécnico 


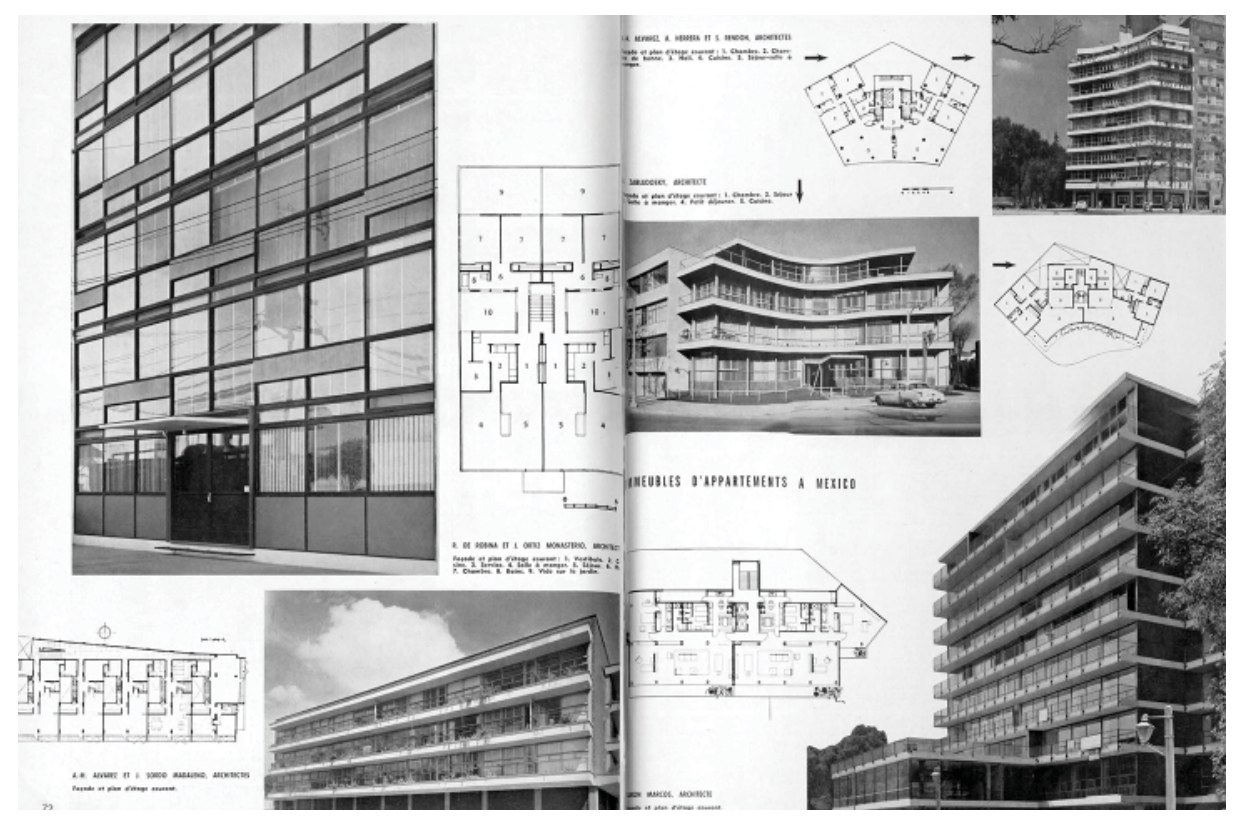

Nacional, El Colegio de México y un Centro Pedagógico en la ciudad de México, pasando por la notable Escuela Normal Regional de Ciudad Guzmán, una escuela agropecuaria en Dolores Hidalgo o una escuela rural en Pachuca, ejemplo del programa nacional de construcción de escuelas con elementos prefabricados ${ }^{13}$. Por su parte, Informes de la Construcción apenas diversificó la información sobre arquitectura educativa, pues además del muy extenso artículo dedicado a la Ciudad Universitaria ${ }^{14}$, solamente ofreció el Conservatorio de Música de Pani ${ }^{15}$.

De las revistas londinenses la única que varió sus contenidos educativos fue Architectural Design. Curiosamente la CU sólo aparece en menciones ${ }^{16}$, mientras que la escuela rural ganó protagonismo, así como otras muestras del mismo programa nacional de principios de la década de $1960^{17}$. Y de las italianas, sólo Domus se centró en la escuela rural ${ }^{18}$ además de en la obra universitaria. De hecho, ni Casabella ni Zodiac publicaron en algún momento ninguna obra relacionada con la educación.

Además de $R N A / A$, la única otra revista que diversificó especialmente sus contenidos en este rubro fue L'Architecture d'Aujourd'hui. Aparte de la Ciudad Universitaria, la parisina publicó el Liceo Francomexicano, el Conservatorio Nacional de Música, el Centro Universitario México, la escuela rural, el Colegio de México, el Instituto Politécnico Nacional, la escuela agropecuaria de Dolores Hidalgo, la Escuela Normal Regional de Ciudad Guzmán, el Internado Cervantes, el Centro Pedagógico de la ciudad de México y la Universidad Anáhuac ${ }^{19}$. Si bien la mayoría de estos inmuebles se agruparon en los monográficos, no sólo en
Muestra de vivienda en apartamentos de lujo en la ciudad de México. Páginas de L'Architecture d'Aujourd'hui (abril 1955).

13. Para todos los ejemplos citados véase el monográfico de Arquitectura de agosto de 1962.

14. "La Ciudad Universitaria de México," Informes de la Construcción, no. 58 (febrero 1954): s/p.

15. "Conservatorio nacional de música (México)," Informes de la Construcción, no. 45 (noviembre 1952): s/p.

16. El pabellón de rayos cósmicos en "A discussion about future developments in Building Techniques." Architectural Design 27, no. 11 (noviembre 1957): 399-415 y la Biblioteca Central en Alison \& Peter Smithson, "The function of architecture in cultures-in-change," Architectural Design 30, no. 4 (abril 1960): 149-150.

17. Véase el monográfico de septiembre de 1963.

18. "Alla XII Triennale: la scuola rurale messicana." Domus, no. 373 (diciembre 1960): 13-16 y "Scuola messicana in Sicilia." Domus, no. 378 (mayo 1961): 37.

19. "Lyceé Franco-Mexicain," L'Architecture d'Aujourd'hui, no. 34 (febrero-marzo 1951): 88-90; "Conservatoire National de Musique," L'Architecture d'Aujourd'hui, no. 38 (diciembre 1951): 49-52 y “Cité Universitaire 'Anahuac' Mexico," L'Architecture d'Aujourd'hui, no. 123 (diciembre 1965): xxI. Para todos los otros casos véase los monográficos de abril de 1955 y de septiembre de 1963. 
20. Véase el análisis sobre la Ciudad Universitaria en la tercera parte de esta tesis para más referencias.

21. "Bureaux de la sécurité sociale à Mexico," Techniques et Architecture 11, no. 5 (junio 1952): 16-18.

22. "Institut Mexicain de la Sécurité Sociale a Mexico," L'Architecture d'Aujourd'hui, no. 59 (abril 1955): 43. el caso de $A A$ sino también en $A$ y en $A D$, fuera de estos números especiales el despliegue informativo fue suficiente como para mantener el tema de la arquitectura educativa presente durante todo el periodo de estudio.

Por otro lado, todos los registros estadounidenses en relación a la arquitectura escolar aludieron a la Ciudad Universitaria. Tanto Arts \& Architecture como Architectural Forum consignaron un promedio de treinta y dos páginas al asunto y, aunque en cantidad muy escasa de papel, Progressive y Record también aportarían algo sobre el tema universitario ${ }^{20}$.

Las siguientes dos categorías corresponden a inmuebles destinados al mismo uso, pero, al tratarse de oficinas, y según se fueron recopilando numerosos ejemplos, se decidió separar los registros en un apartado para los edificios gubernamentales y otro para las oficinas comerciales o de la iniciativa privada. En total sumaron el $9 \%$ de la información, aunque los primeros sólo representen el $2 \%$.

Para el caso de las oficinas de gobierno es notorio el desinterés absoluto de Estados Unidos, ya que ninguna revista en todo momento se comprometió en publicar la cuestión. De los otros países sí se tienen comunicaciones puntuales, aunque, al igual que se comentó sobre la arquitectura educativa, los ejemplos se aglutinan en los monográficos. Esta situación es indicativa de una difusión especializada, ya que los edificios gubernamentales - con pocas excepciones- encontraron cabida sólo en los números que dedicaron la totalidad de su información a la arquitectura mexicana más actual.

Lo más interesante de este tema, a pesar de que la información disponible se agota demasiado pronto para abordar un análisis extenso, es la repetición, en las publicaciones periódicas, de la mayoría de los inmuebles, lo que confirma una divulgación consistente y no casual. Se revisan enseguida algunos casos. Ahora que en México se están viniendo abajo las instituciones sociales modernas, el edificio sede del Instituto Mexicano del Seguro Social (IMss), de Carlos Obregón Santacilia, se muestra con la nostalgia propia de quien ve privatizarse en su país lo que se ganó después de una década de lucha armada revolucionaria. Pero en el momento de su difusión en la década de 1950, las oficinas centrales del IMSs todavía enarbolaban el espíritu de la igualdad social y de la necesaria prestación de servicios médicos al grueso de la población. Así, dos revistas francesas, Techniques et Architecture ${ }^{21}$ y L'Architecture d'Aujourd'hui22 
divulgaron el imponente y —en cierta medida— clásico edificio del Paseo de la Reforma.

Otra sede administrativa que gozó de considerable difusión en la mitad de la década de 1950 fue la Secretaría de Comunicaciones y Obras Públicas, proyecto arquitectónico de Carlos Lazo y diseño de murales pétreos de Juan O’Gorman. El mismo año de 1955, primero en abril, después en junio y finalmente en agosto, la extraña combinación de volúmenes cuadrangulares recubiertos por una extensísima obra mural figurativa de seis mil metros cuadrados llegó a las páginas de L’Architecture d'Aujourd'hui ${ }^{23}$, Architectural Review ${ }^{24}$ e Informes de la Construcción ${ }^{25}$ en artículos - en la parisina y la madrileña- y también como parte de una noticia sobre la exposición de arquitectura mexicana en la sede del RIBA londinense ${ }^{26}$.

Ya iniciada la década de 1960 una figura clave de la amplia producción gubernamental fue el arquitecto Pedro Ramírez Vázquez, de quien se publicaron varios inmuebles administrativos en las revistas extranjeras ${ }^{27}$. Se cita aquí como muestra el Instituto Nacional de Protección a la Infancia (INPI), que entre 1962 y 1963 —en los monográficos de Arquitectura, Design y $A A$ - hacía patente el interés del gobierno central en mejorar las condiciones de los niños en edad escolar ${ }^{28}$. El edificio multifuncional -además de alojar la sede administrativa y un auditorio con capacidad para 400 asistentes tenía como característica principal una nave industrial donde se preparaban desayunos que se repartían gratuitamente en las escuelas públicas ${ }^{29}$ - hacía gala de un funcionalismo duro sin concesiones plásticas, tan frecuentes en los edificios gubernamentales de la década anterior.

Toca revisar ahora del 7\% correspondiente a las oficinas de iniciativa privada. Si antes el desinterés de Estados Unidos hacia las

23. "Sécretariat d'Etat aux Communications et aux Travaux Publics," L'Architecture d'Aujourd'hui, no. 59 (abril 1955): 40-41.

24. "Mexican architecture," The Architectural Review 117 no. 702 (junio 1955): 361.

25. "Nuevo centro de comunicaciones en Méjico," Informes de la Construcción, no. 73 (agosto-septiembre 1955): $\mathrm{s} / \mathrm{p}$.

26. Esta obra se analiza en el apartado 6.3 La construc- ción como noticia. El edificio y su autor, en relación a Carlos Lazo.

27. Para más referencias véase el apartado 6.3, la sección dedicada a Pedro Ramírez Vázquez.

28. "Instituto Nacional de Protección a la infancia," Arquitectura, no. 44 (agosto 1962): 35; "National Institute of Infant Welfare, Mexico City," Architectural Design 33, no. 9 (septiembre 1963): 425-427 y "Usine de L'Insti- tut National de Protection de L'Enfance a Mexico," LArchitecture d'Aujourd'hui, no. 109 (septiembre 1963): 54-55.

29. El InPI se fundó en enero de 1961, y en sus primeros años ya repartía 161 mil desayunos diarios, alimentos que eran preparados siguiendo estrictos estudios nutricionales. Este Instituto es el antecedente del Sistema Nacional para el Desarrollo Integral de la Familia (DIF) todavía vigente. 
Instituto Nacional de Protección a la Infancia (INPI), de Pedro Ramírez Vázquez. Publicado en L'Architecture d'Aujourd'hui (septiembre 1963).

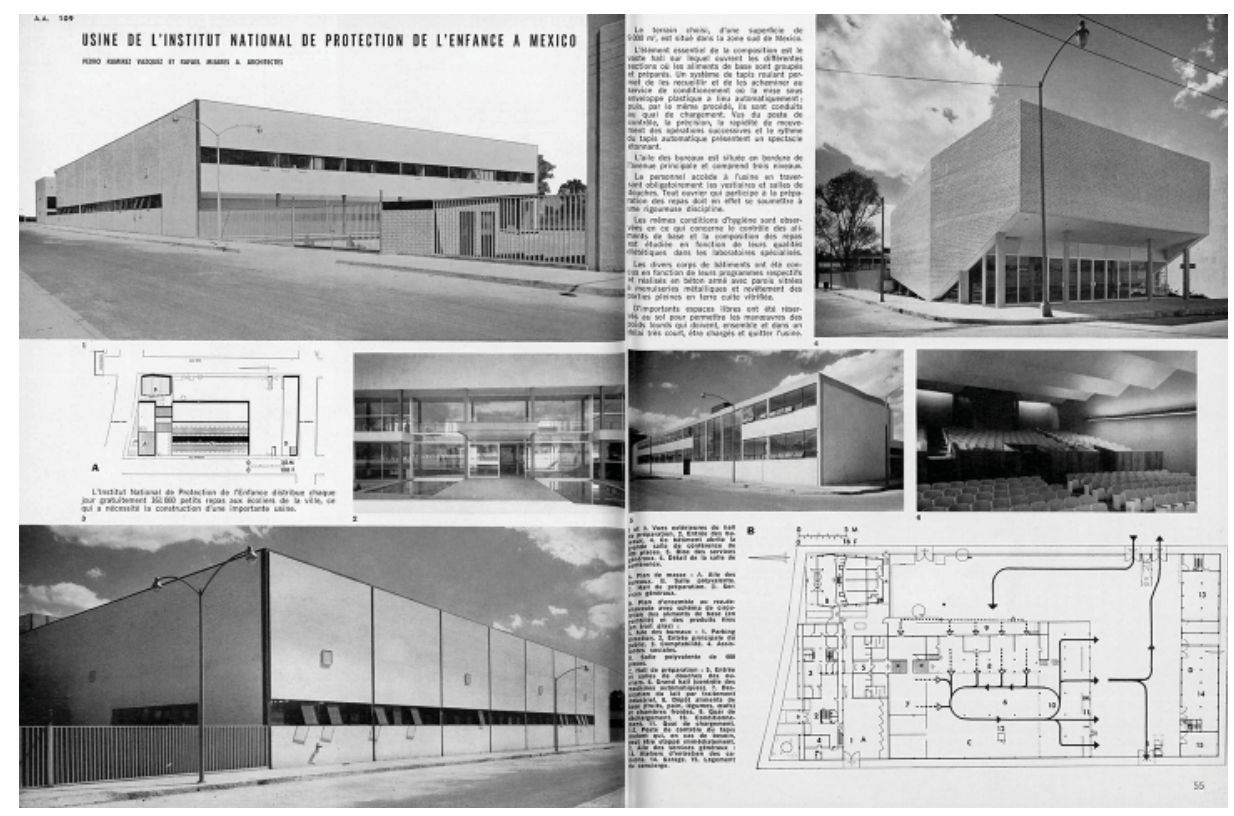

oficinas gubernamentales fue patente, para el caso de los edificios privados sucedió lo contrario. Todas las revistas norteamericanas registraron por lo menos en una ocasión algún ejemplo de esta categoría. Por su parte, las publicaciones madrileñas - salvando una excepción ${ }^{30}$ - concentraron todas sus muestras en el monográfico de Arquitectura de 1962. En Londres, Design fue la única publicación que se mostró interesada en el tema más allá del número especial que dedicó al país en 1963, pues entre 1960 y 1962 divulgó regularmente el tema ${ }^{31}$. En París, la distribución noticiosa siguió más o menos el mismo patrón comentado antes tanto para los edificios de gobierno como para la vivienda de lujo en altura, esto es, casi todos los ejemplos se encuentran en los monográficos de 1955 y 1963, aunque sí hay ejemplos aislados, tanto en la misma $A A^{32}$ como en Techniques et Architecture en $1966^{33}$.

Además de los ejemplos 100\% mexicanos, se registró también una excepción notable, pero que merece ser comentada aquí de forma sucinta: el edificio que Mies van der Rohe diseñó para la compañía Bacardí y que se construyó en Tultitlán, Estado de México. En la primera parte

30. "El nuevo edificio de oficinas auto-mex," Informes de la Construcción, no. 76 (diciembre 1955): s/p. El diseño fue de Lorenzo Carrasco y Guillermo Rossell.

31. Véase "Mexico. Office block," Architectural Design 30, no. 12 (diciembre 1960): $487 \mathrm{y}$ "Offices in Mexico, D.F.", Architectural Design 32, no. 2 (febrero 1962): 85-86. Se hace referencia al edificio de seguros La Comercial, de Héctor Mestre y Manuel de la Colina y al edificio de Manuel Rosen para la Asociación Cinematográfica de Productores de Cine, respectivamente.

32. "Immeuble a Mexico," L'Architecture d'Aujourd'hui, no. 66 (julio 1956): 92-93. De Mario Pani y Salvador Ortega. Se trata del conjunto ubicado sobre el Paseo de la Reforma, donde una de las dos torres se destinó a despachos privados.

33. "Immeuble tour à Mexico," Techniques et Architecture 26, no. 6 (junio 1966): 144-45. Se trata de una torre de oficinas en el Paseo de la Reforma de Augusto H. Álvarez. Otros edificios comerciales de Álvarez se analizan en el capítulo sobre arquitectos mexicanos. 


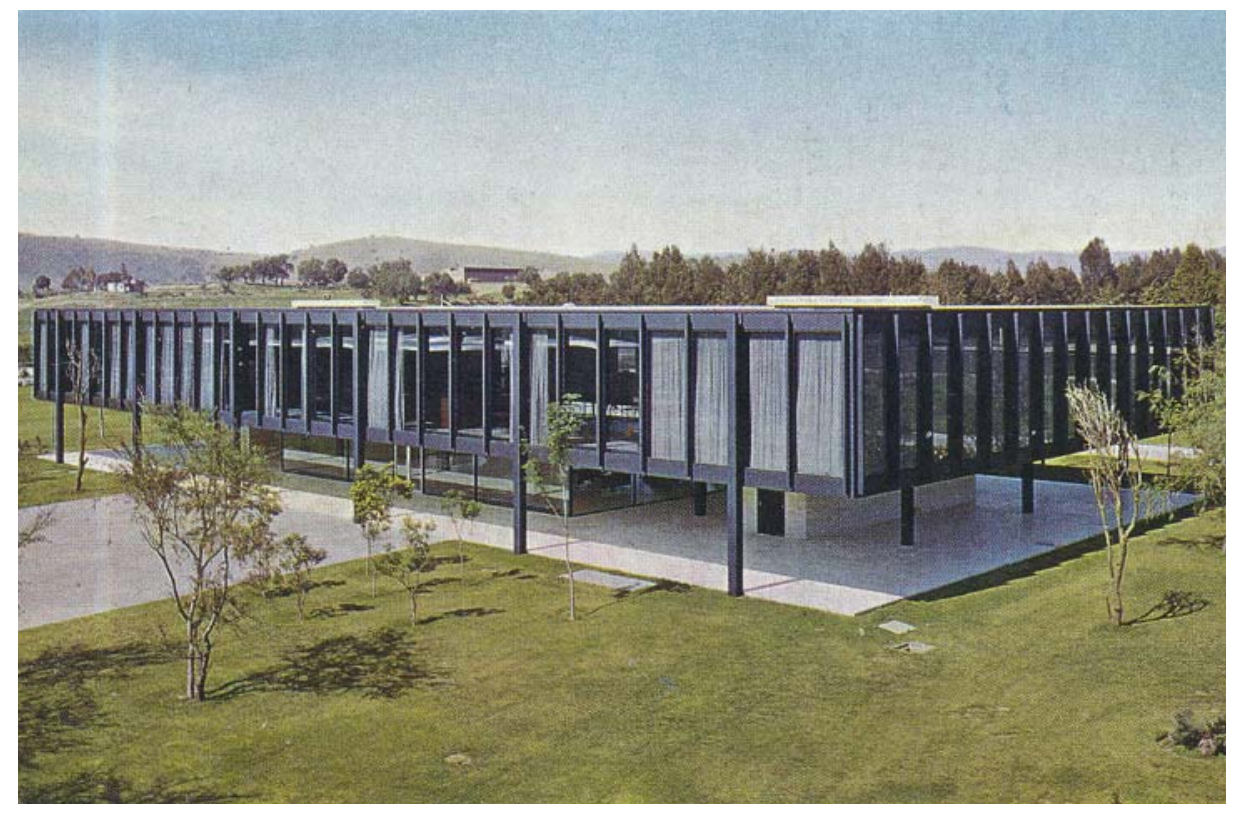

La excepción en los edificios de oficinas privadas. La sede para la compañía Bacardí, de Mies van der Rohe. Imagen de Zodiac (junio 1962).

de esta tesis ya se comentaron algunas noticias en relación con este inmueble, pero quedaron contextualizadas dentro de la narrativa cronológica, por ejemplo, el número especial Panorama 1960 que $A A$ preparó ese año. Aquí cabe agregar que, además de la parisina ${ }^{34}$, Los Ángeles ${ }^{35}$, Nueva York ${ }^{36}$, Londres ${ }^{37}$ y Milán ${ }^{38}$ se sumarían a la difusión internacional de este edificio que - circunstancialmente- nació en suelo mexicano.

Las oficinas centrales de Ron Bacardí en Tultitlán no cierran estos apuntes sobre casos singulares de arquitectura administrativa. No se puede perder la oportunidad de citar aquí un edificio que, aunque oficialmente arquitectura de Estado, se incluyó — sin ser irónicos- como parte de la iniciativa privada. Se asume que la excepción va más de acuerdo en dicha categoría que en la de sedes gubernamentales mexicanas; se trata del nuevo edificio para la Embajada de Estados Unidos en México. Si bien el proyecto arquitectónico nació en un despacho tejano encabezado por Max Brooks ${ }^{39}$, los mexicanos Carlos Contreras y Leonardo Zeevaert dirigieron las obras de construcción en la capital del país.

34. El edificio de Bacardí de Mies van der Rohe también se publicó en $A A$ en diciembre de 1963 en un número especial dedicado a las oficinas y la industria. Véase "Batiment administratif de la compagnie Bacardi a Mexico," L'Architecture d'Aujourd'hui, no. 111 (diciembre 1963): 26-27.

35. "Administration Building," Arts \& Architecture 79, no. 5 (mayo 1962): 18-19 y 32 .
36. "Mexican Headquarters for Bacardi Rum," Architectural Record 127, no. 4 (abril 1960): 178-79 y "Mies van der Rohe's Bacardi building in Mexico," Architectural Forum 116, no. 1 (enero 1962): 92-95. 37. "Administration building for Compania Ron Bacardi, S.A. Mexico D.F., Mexico," Architectural Design 31, no. 3 (marzo 1961): 116-17 y "Bacardi building, Mexico
City," Architectural Design 32, no. 10 (octubre 1962): 470-73. 38. "Uffici per lo stabilimento della Bacardi Rum Co. a Città del Messico," Casabella Continuitá, no. 228 (junio 1959): 13-14 y "An administrative building in Mexico," Zodiac, no. 10 (junio 1962): 182-87.

39. Southwestern Architects \& Engineers of Austin, Texas. 
Con este inmueble se insiste en la importancia de las secciones de actualidad de las revistas, pues Architectural Forum, en su apartado Projects, adelantó la foto del modelo a escala y - por supuesto- el imprescindible dato duro del costo previsto en tres millones de dólares. Acompañó a la comunicación un enlistado con los materiales a utilizar y la nota pintoresca sobre la distribución de las oficinas alrededor de un típico patio mexicano ${ }^{40}$. Con todo y que Forum no recalcó en el diseño, no pasó desapercibido para otras publicaciones, pues quien sílo cuestionó fue Review. Para la londinense, se vivía una fase de la arquitectura diplomática estadounidense que, si bien moderna en sus volúmenes generales, tendía demasiado al ornato en los detalles. La embajada del país vecino del sur no escapaba a esa tentación. La esperanza — fallida - de Review apuntaba a que el Departamento de Estado Norteamericano sabría lo que estaba haciendo al promover este tipo de arquitectura ecléctica ${ }^{41}$.

Se deja atrás a las oficinas y se continúa con una categoría que, con todo y ser de enorme utilidad a la sociedad, reunió apenas el 1\% de las páginas publicadas en las revistas foráneas: la arquitectura nosocomial. Si en varios de los casos anteriores se generalizó su aparición en los monográficos, para el campo que titulamos "salud" habría que hacer una mínima excepción ${ }^{42}$ antes de afirmar que la totalidad de clínicas y hospitales que se dieron a conocer en el extranjero fue solo a través de los multicitados especiales de L'Architecture d'Aujourd'hui, Arquitectura y Architectural Design. Esta distribución redujo prácticamente a tres revistas el interés en los ejemplos que, a través del programa nacional de construcción de hospitales, se llevó a cabo en México durante las décadas

40. "U.S. Embassy building for Mexico City," Architectural Forum 110, no. 1 (enero 1959): 27.

41. "Mexican Embassy," The Architectural Review 132, no. 788 (octubre 1962): 233 y "Caribbean embassies. Mexico and Havana," The Architectural Review 135, no. 804 (febrero 1964): 84.

42. "New Medical Buildings in other countries," Architectural Record 113, no. 2 (febrero 1953): 20. Se trata de la reseña al número 127-128 de L'Architecture Française, dedicado por completo a los edificios médicos. De México se ilustró una clínica diseñada por G. Quintanar y A. Serrato. de estudio.

Cabe comentar que, a diferencia de otros géneros arquitectónicos, las obras destinadas al cuidado de la salud tuvieron la peculiaridad de diversificar el panorama geográfico de los casos de estudio, que hasta ahora se habían centrado en la ciudad de México y, con algunos ejemplos aislados, en Guadalajara o Monterrey. Este tema se desarrolla in extenso un poco más adelante, pero aquí era conveniente adelantar esta particularidad para subrayar la importancia de esta clasificación en relación al mapa general del país. A reserva del análisis que comprende la geografía nacional y las clínicas y hospitales de la seguridad social, todavía hay que señalar algunos edificios clave de la modernidad mexicana inscritos en 
Comunicaciones puntuales sobre la arquitectura nosocomial en las publicaciones periódicas foráneas. Centro Médico Nacional de Enrique Yáñez en Architectural Design (septiembre 1963).

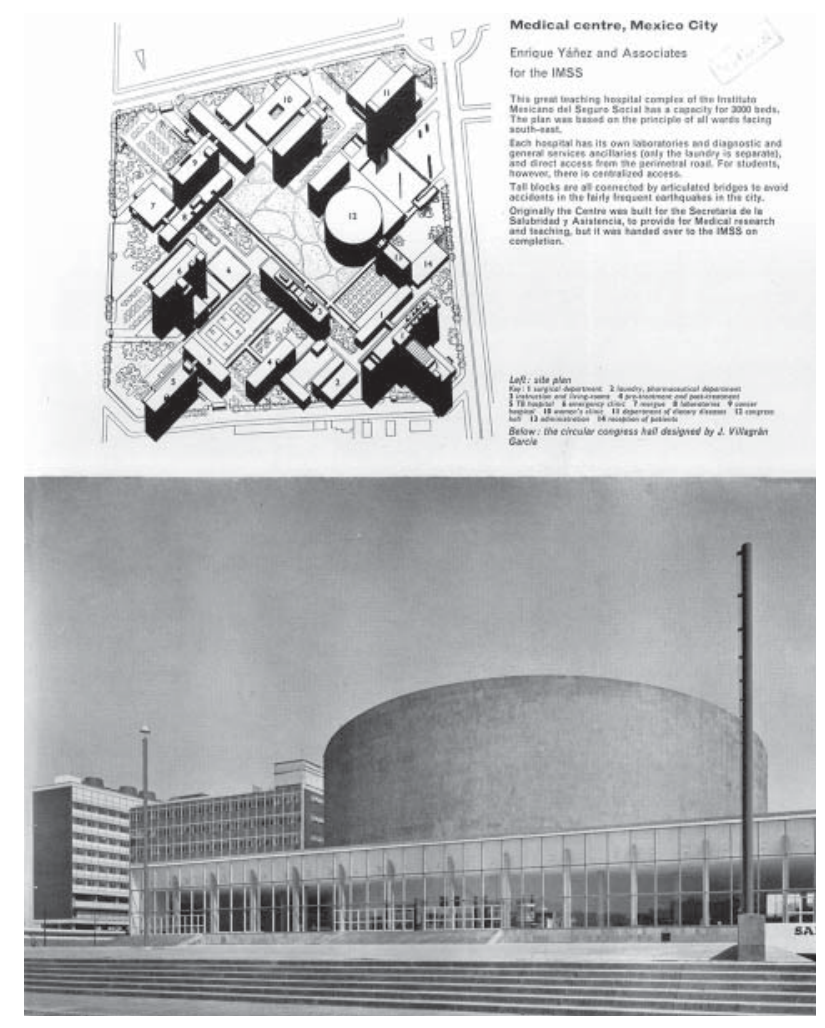

el territorio de la capital, como el Hospital de la Raza y el Centro Médico Nacional, de Enrique Yáñez. Ambos se divulgaron puntualmente en las publicaciones periódicas internacionales ${ }^{43}$.

A diferencia de la arquitectura reservada al mantenimiento de la salud, caracterizada por programas arquitectónicos complejos $y$ un funcionamiento preciso, el siguiente campo de registro se particulariza por su diversidad. Bajo el concepto de "servicios" se catalogaron los inmuebles cuya principal función estuviera basada en algún tipo de actividad comercial. Esta generalidad provocó una sub catalogación con el fin de precisar todavía más el uso particular de cada edificio consignado aquí. No es extraño que debido a lo cuantioso de estas comunicaciones - que suman un 34\% del total de páginas publicadas - se encuentren ejemplos de servicios en todas las revistas consultadas.

Así, sucursales bancarias, centros comerciales y culturales, construcciones deportivas y para espectáculos, hoteles, iglesias, mercados, monumentos, museos, restaurantes y hasta un taller mecánico se cuentan entre los inmuebles catalogados bajo el rubro de servicios. Pero, para no perder el hilo de lo general, se deja hacia el final de esta parte el análisis particular de estas categorías secundarias. Se continúa, entonces, con el análisis cuantitativo de los registros principales.
43. "Hospital de la Securité Sociale a Mexico," L'Architecture d'Aujourd'hui, no. 59 (abril 1955): 54-55 y "Medical centre, Mexico City," Architectural Design 33, no. 9 (septiembre 1963): 445 . 
44. Félix Candela, "StereoStructures," Progressive Architecture 35, no. 6 (junio 1954): 84-93.

45. En el apartado 6.2 Entre la vida y la obra. El arquitecto como protagonista, se verifican los edificios más difundidos de Candela y se contextualizan en una narrativa que toma como centro al arquitecto.

46. "Hall d'une usine a Cuautitlan prés de Mexico," L’Architecture d'Aujourd'hui, no. 95 (abril 1961): 48-49.

47. En ese número también se dieron a conocer dos ejemplos mexicanos más, uno de ellos también de Candela y el otro de Rodrigo Zorrilla Martínez. Véase "Deux solutions pour des halls industriels," L'Architecture d'Aujourd'hui, no. 95 (abril 1961): 50-51.

48. "Four great pours," Architectural Forum 115, no. 3 (septiembre 1961): 104-115.

49. "Edificio Industrial 'Bacardí, S. A., en Cuautitlán," Arquitectura, no. 44 (agosto 1962): 69.
Hasta ahora, considerando los diferentes tipos de vivienda $y$ oficinas, la arquitectura educacional y la nosocomial, así como la dirigida a los servicios, se reúne ya el $80 \%$ del total de páginas publicadas en todas las revistas consideradas durante todo el periodo de estudio. El restante $20 \%$ se divide en cuatro categorías más: arquitectura industrial, infraestructura, urbanismo y, por último, en la clasificación que bajo el título de "varios" reúne los casos en que en una misma comunicación se divulgaron diversas tipologías.

Entonces, la arquitectura industrial recogió el $4 \%$ de la información, esto es, poco más de cincuenta páginas. Así como antes se habló del monopolio que en el tema de la educación significó la Ciudad Universitaria, para el tema que ahora se ocupa y haciendo una analogía, se dirá que la cuantiosa producción industrial de Cubiertas Ala sería el equivalente a la obra universitaria, pero con mayor ventaja, ya que aquí los cascarones de hormigón armado de Félix Candela acapararon el 77\% de todas las comunicaciones de este campo.

Progressive Architecture inició la difusión de la arquitectura industrial con el primer artículo del calculista publicado en la neoyorquina en junio de $1954^{44}$. En éste, una fábrica de electrónicos en San Bartolo Naucalpan, los Laboratorios Farmacéuticos CIBA o la planta textil "Parisina" se cuentan entre varios ejemplos. No es el fin de este apartado enlistar todos los inmuebles de cierta categoría o de determinado arquitecto, sino exponer los resultados cuantitativos que encauzaron los posteriores análisis cualitativos que conforman la tercera parte de esta tesis $^{45}$. Es por esto que, a modo indicativo, se mencionan aquí $-\mathrm{y}$ como complemento al edificio de oficinas proyectado por Mies van der Rohelas tres naves para la planta embotelladora de Bacardí, quizá el ejemplo de arquitectura industrial más espectacular de Candela.

De esta manera, entre 1961 y 1962, tres publicaciones revelaron puntualmente la monumental nave industrial sita en Tultitlán. Primero L'Architecture d'Aujourd'hui en abril de $1961^{46}$, en un número especial destinado a la industria ${ }^{47}$. Después Architectural Forum en septiembre del mismo año, en un artículo que también divulgó importantes obras de Riccardo Morandi, Eero Saarinen y Pier Luigi Nervi ${ }^{48}$ y, por último, Arquitectura, en su monográfico de $1962^{49}$, con lo que actualizaba la obra de su compatriota publicada en Madrid en octubre de 1959. 
La arquitectura industrial ventiladores de José Legorreta. Página de L'Architecture d'Aujourd'hui (septiembre 1963). mexicana: fábrica de Villagrán García y Ricardo

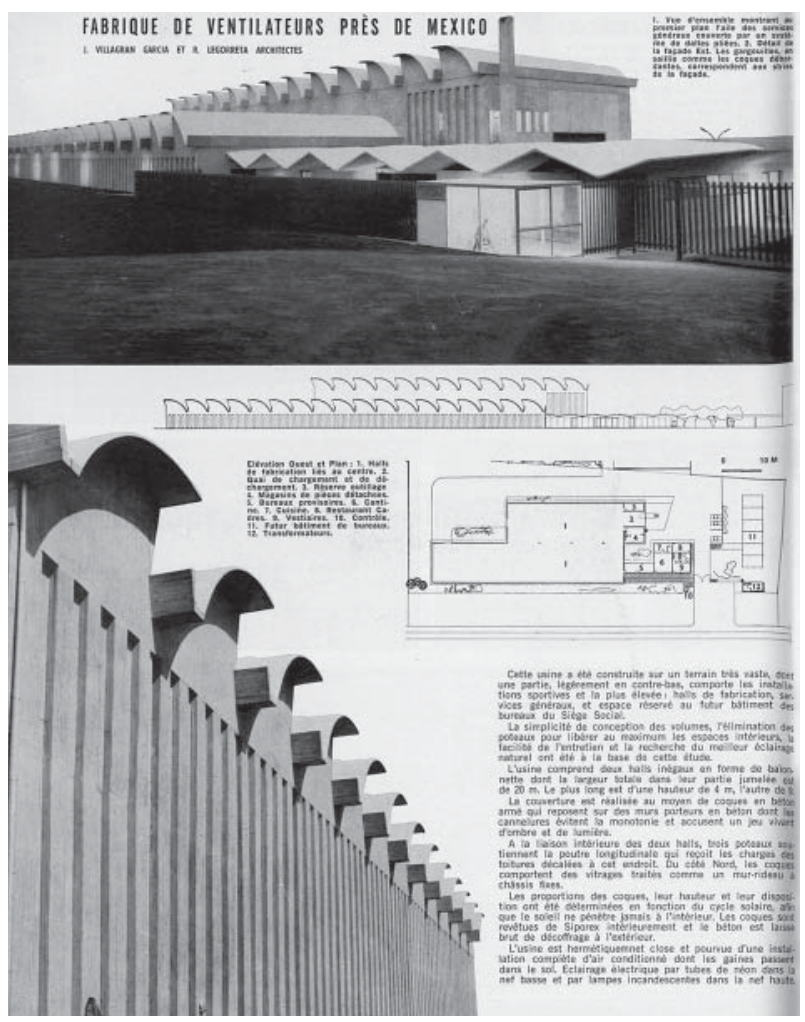

Más allá de Candela, se cuenta con algunos nombres más entre los ejemplos de arquitectura industrial que cabe comentar. Vladimir Kaspé mereció la difusión de un taller de reparaciones de motores de avión y de los Laboratorios Roussel en $A A$ en 1959 y 1963, respectivamente ${ }^{50}$. En Arquitectura, Sergio Torres y Eduardo Vázquez dieron a conocer los Laboratorios Morín ${ }^{51}$, mientras que, de nuevo en la parisina, de Franco D’Ayala Valva, Juan Sordo Madaleno, José Villagrán García y Ricardo Legorreta se difundieron los Laboratorios Martini Rossi ${ }^{52}$, el Laboratorio farmacéutico Merck, Sharp \& Dohme $e^{53}$ y una fábrica de ventiladores ${ }^{54}$. Fuera de los monográficos, la planta de motores de Auto-Mex, en Toluca, con su característica Plaza de los Conos, sería la introducción al despliegue internacional de Ricardo Legorreta ${ }^{55}$. Con este artículo de Progressive Architecture se cierran las comunicaciones sobre arquitectura industrial que - si bien discretamente en comparación con otros rubrosmantuvieron presente el tema en las publicaciones periódicas foráneas.

No obstante las comunicaciones sobre temas urbanos no alcanzaron las 50 páginas de difusión, lo que corresponde al 3\% del total de información, se decidió distinguir con una categoría propia a este asunto. Es cierto que este rubro también fue acaparado - por decirlo de alguna manera- por dos obras fundamentales de la modernidad mexicana: los Jardines del Pedregal de San Ángel y las Torres de Satélite. Uno y otro
50. "Atelier de reparation de moteurs d'avion, Mexico, Mexique," L'Architecture d'Aujourd'hui, no. 83 (abril 1959): XXv y "Laboratoires Roussel a Mexico," L'Architecture d'Aujourd'hui, no. 109 (septiembre 1963): 58.

51. "Laboratorios Morín," Arquitectura, no. 44 (agosto 1962): 65.

52. "Laboratoires de la Société Martini Rossi a Mexico," L'Architecture d'Aujourd'hui, no. 109 (septiembre 1963): 57.

53. "Laboratoire Pharmaceutique a Mexico," L'Architecture d'Aujourd'hui, no. 111 (diciembre 1963): 70-71.

54. "Fabrique de Ventilateurs prés de Mexico," L'Architecture d'Aujourd'hui, no. 109 (septiembre 1963): 56.

55. "La Plaza de los Conos," Progressive Architecture 47, no. 6 (junio 1966): 203-04. 


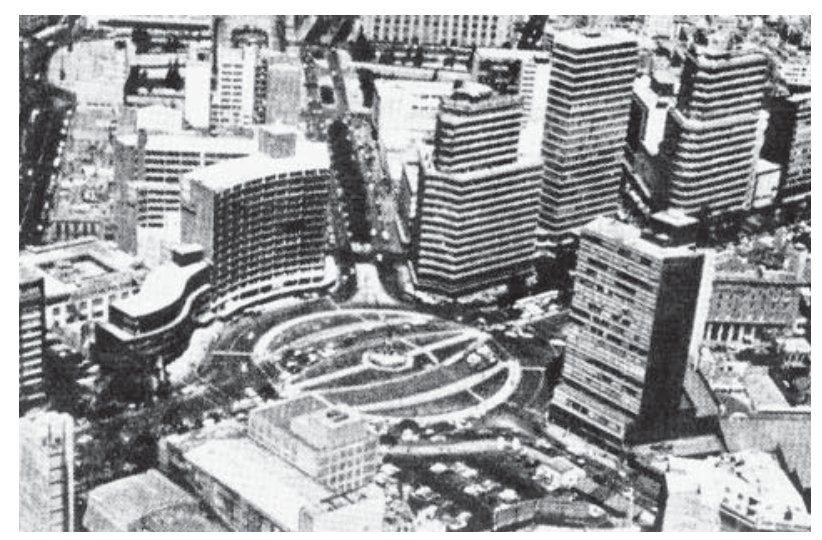

Crecimiento en altura en torno de la Glorieta Colón de la ciudad de México. Architectural Design (septiembre 1964).

tema son desarrollados en los análisis de la tercera parte, el primero en el capítulo sobre la vivienda y el segundo en la sección de arquitectos. No se abusa aquí de la repetición de citas, por lo que también se reservan los comentarios sobre diversos planes urbanos a nivel nacional para su análisis en esta segunda parte del documento, pero en el capítulo que trata los casos más allá de la capital.

Se insiste entonces en la ciudad de México, con el caso del desarrollo urbano de San Juan de Aragón, al noreste del centro histórico. Si bien su presencia en las publicaciones periódicas no se compara con la obra patrocinada por Barragán citada arriba, o con las numerosas aportaciones que en el terreno urbano dirigió Pani, este caso aislado de Aragón es importante pues indicó la otra vertiente del diseño urbano que se desarrollaba en el país y que se benefició de suficiente apoyo gubernamental como para provocar - en gran medida - la urbe horizontal que conocemos ahora. Así, en el año 1962, el entonces regente capitalino Ernesto Uruchurtu encomendó al destacado arquitecto y urbanista Enrique Cervantes la transformación de la zona noreste que por entonces todavía estaba prácticamente despoblada, con el fin de reubicar a la población que había ocupado irregularmente el Cerro de la Villa. Es de destacarse la contemporaneidad de este desarrollo urbano horizontal - algo que Uruchurtu siempre favoreció- contra la propuesta más radical de tabula rasa de Pani para Tlatelolco.

La noticia en L'Architecture d'Aujourd'hui para San Juan de Aragón subrayó la extensión del área $-1,100$ ha- y una población estimada de 200 mil habitantes ${ }^{56}$. No obstante en esta comunicación

56. "Urbanisme et Planification Régionale au Mexique," L'Architecture d'Aujourd'hui, no. 109 (septiembre 1963): XIII. también se dieron a conocer otras planificaciones urbanas, con lo que la escala de las reproducciones ayudó poco a la valoración de los planos, la parisina recordó la exposición sobre el tema urbano que se 
mostró en el Museo de Arte Moderno de París, con una considerable participación mexicana.

Ya casi mediada la década de 1960, una imagen del improvisado desarrollo urbano vertical de la zona inmediata al centro histórico de la ciudad de México, fue motivo de una mención en las revistas de arquitectura. En septiembre de 1964 Walter Bor escribió para Design un extenso análisis comparativo de los edificios altos alrededor del mundo ${ }^{57}$. La capital mexicana se contó entre los casos de estudio, y se ilustró con una vista aérea de la Glorieta Colón en el Paseo de la Reforma. Lo que se ve es un crecimiento en altura que sigue la curva de la rotonda, pero sin un diseño homogéneo ni en los edificios circundantes ni en la elevación de los inmuebles. Si algo sorprendía al autor era la insistencia generalizada en todo el orbe en la construcción de rascacielos, incluso con las condiciones de suelo aparentemente más inadecuadas, entre ellas, por supuesto, el barro de la ciudad de México.

Apenas dos meses después de publicado este artículo, Mariano Bayón -en su sección 30 Días de arquitectura - ofreció lo que sería su muy personal interpretación del tema, aunque sin relación con el texto de Bor y sin entrar en debates con la cuestión ${ }^{58}$. Lo que interesa destacar aquí es que dentro de la selección de Bayón para ilustrar su texto, repitió la Glorieta Colón de la capital mexicana. Este ejemplo urbano es indicativo de la realidad nacional, pues, si por un lado es cierto que se desarrollan incontables proyectos integrales, por otro lado la ciudad está —desde hace décadas - en manos de la especulación inmobiliaria coadyuvada por gobiernos deshonestos que han propiciado un crecimiento irresponsable.

Ante este panorama, las noticias urbanas con que se cuenta o son circunstanciales - Glorieta Colón — o son de impacto muy reducido - San Juan de Aragón - o surgieron de iniciativas privadas, como se verá en su momento con el caso del Pedregal y las Torres de Satélite. Una última intervención urbana merecería citarse sólo por quitar el toque amargo a este apartado: la Ruta de la Amistad, un verdadero intento de integrar el arte contemporáneo a la ciudad ${ }^{59}$. Este análisis —como se puede suponer- espera en el capítulo sobre México 68.

Aparte del urbanismo, queda por revisar la categoría de “infraestructura”, que reunió el 3\% del papel impreso que se discriminó de las consultas. Bajo este título se recopiló todos aquellos elementos o
57. Walter Bor, "High buildings: a blessing or a curse?" Architectural Design 34, no. 9 (septiembre 1964): 426-34.

58. Mariano Bayón Álvarez, "Edificios altos," Arquitectura, no. 71 (noviembre 1964): s/p. 59. John Adams, "Route of Friendship," The Architectural Review 144, no. 862 (diciembre 1968): 402-404. 
servicios que se consideran necesarios para la creación y funcionamiento de la ciudad, tales como aeropuertos, estaciones fronterizas, circuitos viales, puentes vehiculares y peatonales, estaciones de tren o de transporte público como el metro o parques urbanos. De todos estos casos, sin duda los conjuntos de mayor impacto para la ciudad - por su escala y su programa arquitectónico- son los aeropuertos. Así, el de la ciudad de México de Augusto H. Álvarez y el de Acapulco de Mario Pani circularon profusamente en las revistas extranjeras. El primero se analiza como parte de la obra de Álvarez, en el capítulo sobre arquitectos, y el segundo tiene lugar un poco más adelante en el estudio de la geografía nacional. Sin embargo, todavía quedan otros casos — ciertamente de menor impactoque explican esta sección.

En junio de 1955, Informes de la Construcción, en su sección de Noticias, publicó una imagen casi a plana completa de la capital mexicana que hoy es imposible de repetir: el Viaducto Piedad, a plena luz del día, con apenas un vehículo casual en primer plano ${ }^{60}$. La obra, en su momento, mejoró sustancialmente los problemas de tránsito de circulación rodada; los créditos del diseño se concedieron al arquitecto Lazo, quien en ese momento estaba al frente de la Secretaría de Comunicaciones y Obras Públicas.

Si la fotografía del Viaducto mediada la década de 1950 parece ahora idílica, cinco años más tarde la desmesurada escala de la ciudad capital era un hecho incuestionable. Una consistente mancha gris en la que se destaca el crecimiento vertical en avenidas como la Juárez, el Eje Central o el Paseo de la Reforma fue el marco idóneo para la publicidad de los ascensores Otis, anunciados en Progressive en 196061. La compañía neoyorquina se jactaba de haber instalado el 50\% de los ascensores que, en ese momento, daban vida a los edificios en altura mexicanos. Esta imagen bien sirve de contexto para situar el siguiente ejemplo de infraestructura que también se acometió en la capital del país.

En 1962, Arquitectura dio a conocer la estación de trenes de Buenavista,

60. "Méjico," Informes de la Construcción, no. 72 (junio-julio 1955): s/p.

61. "Publicidad: Mexico City. Otis Elevator Company," Progressive Architecture 41, no. 8 (agosto 1960): 185.

62. "Estación Central," Arquitectura, no. 44 (agosto 1962): 73. cuyo proyecto se debió a Jorge Medellín ${ }^{62}$. El amplio vestíbulo que se expone desierto de gente no da idea de una urbe que por entonces ya superaba los cinco millones de habitantes. También, como parte de este campo de registro se cuenta con las noticias sobre el Sistema de Transporte Colectivo Metro que, hacia el final de la década, da término no solamente a este apartado sino en general a todas las comunicaciones de nuestro periodo de estudio. 
El Viaducto Piedad recién inaugurado en 1955, en Informes de la Construcción (junio 1955) y a la derecha Otis en la ciudad de México, en Progressive Architecture (agosto 1960). publicidad de ascensores

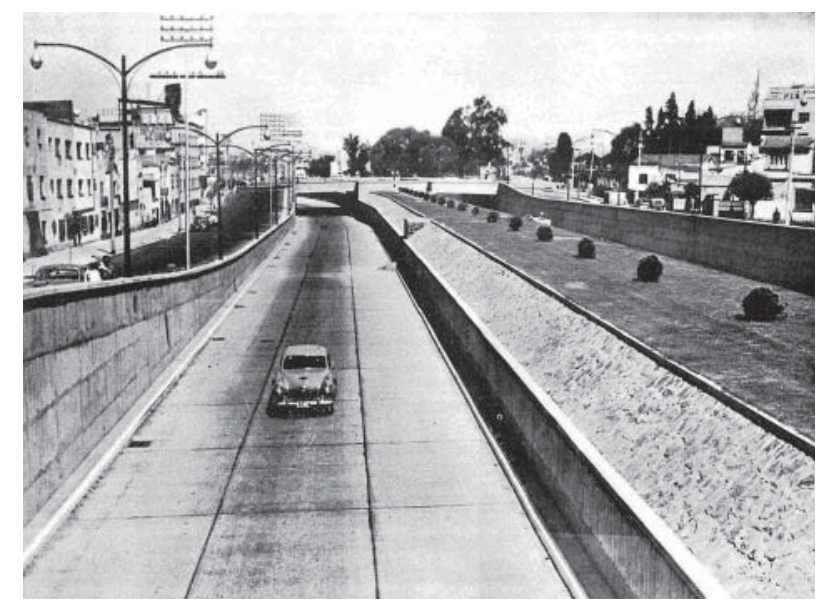

Hasta aquí se ha puntualizado en todas las categorías que, dependiendo del uso de cada inmueble, coinciden con las obras que se dieron a conocer en las revistas foráneas entre 1950 y 1970. Sin embargo, todavía queda pendiente el análisis de un 10\% de páginas que se clasificaron con la denominación de "varios" debido a que las comunicaciones reunieron diferentes tipologías. Esta decisión metodológica, lejos de complicar el estudio, favorece la discriminación de artículos que agruparon importantes actualizaciones sobre el estado de la arquitectura moderna mexicana en determinados años.

La revisión de casos específicos precisará el valor de estas comunicaciones, en especial, porque sin tener la extensión de un monográfico $-\mathrm{y}$, se entiende, tampoco su impacto- la síntesis que ofrecieron sobre algunos ejemplos señeros de la arquitectura nacional fue, sin duda, una de sus mayores aportaciones. Al finalizar 1959, el editor de noticias de Progressive Architecture, James T. Burns Jr., después de un viaje a México, publicó sus impresiones sobre la actualidad y el devenir arquitectónico del país ${ }^{63}$. Lo más notable de su análisis no recayó en los modelos que por entonces ya tenían varios meses circulando en diversas revistas del mundo - las Torres de Satélite, la capilla abierta de Cuernavaca o la de San Vicente de Paul— sino en hacer notar que, más allá de los paradigmas reconocidos internacionalmente, la ciudad se colmaba con una arquitectura anodina que, sin orden ni concierto, saturaba las calles de la ciudad. Era el caso del Paseo de la Reforma, donde incontables edificios imitando el sistema de muro-cortina, en vez de resolver un problema de diseño, lo complicaban. No cabe duda que — siguiendo a Burns - los viajes a México siguen provocando a la vez experiencias tan alentadoras como aflictivas.
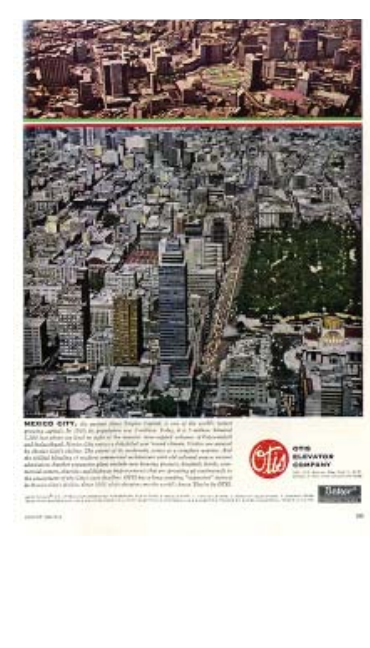

(n)

\section{(1)}




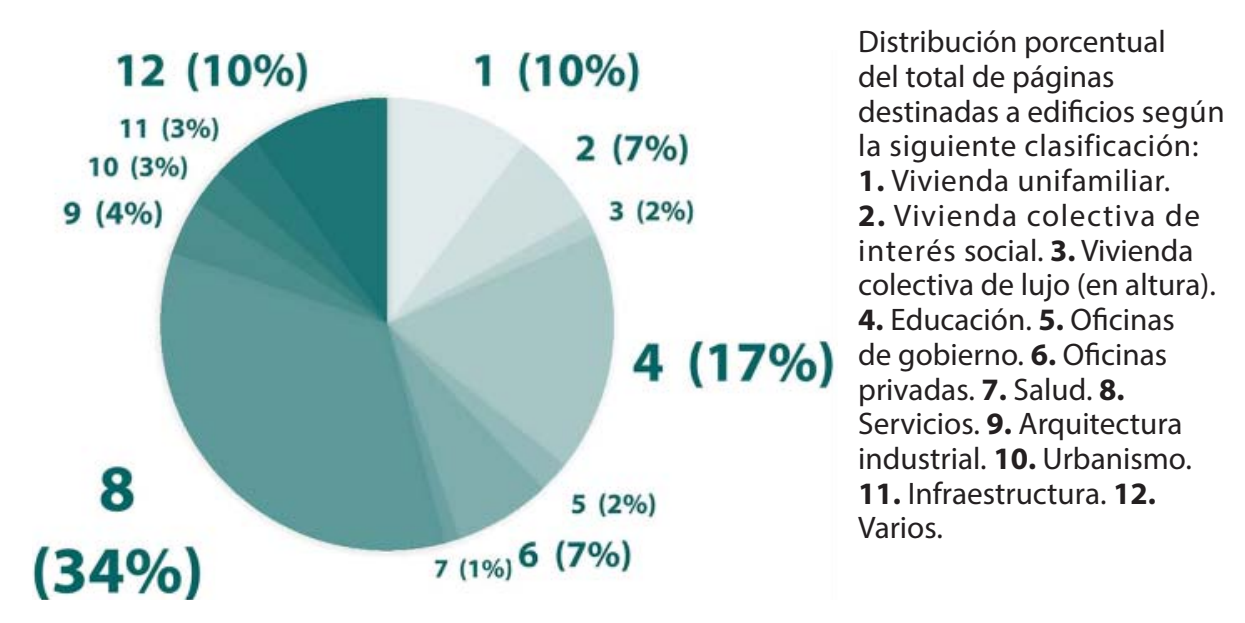

También se anota la actualización que Irene Nicholson publicó en 1961 en The Architectural Review ${ }^{64}$. La selección de obras incluyó vivienda unifamiliar de lujo, de interés social, edificios de gobierno, oficinas privadas, bodegas y varios servicios como cines, iglesias, mercados y hasta la casa de bolsa. Ante el abanico de la diversidad construida, la autora acometió el esfuerzo de proponer algunas tendencias que, según lo expresado en los numerosos ejemplos, podrían guiar la arquitectura mexicana en el futuro cercano.

Otra visitante notable aportaría en Zodiac su visión particular del país. Se trató de Esther McCoy y sus artículos publicados en $1963^{65}$, en los que habló de la vivienda unifamiliar de lujo, de las nuevas urbanizaciones como la Ciudad Satélite o de la Ciudad Universitaria después de casi una década en uso. Por supuesto, los textos de Burns, Nicholson y McCoy no son todos los que se registraron en esta sección, pero sí son lo suficientemente indicativos como para esclarecer la utilidad de esta catalogación.

Fuera de la línea de las comunicaciones de actualidad arquitectónica, pero también con el recurso de acompañar el texto de análisis con inmuebles de diversos géneros, se puede citar el reportaje gráfico que Robert Fischer preparó para Architectural Record después

64. Irene Nicholson, "Mexican Newsletter," The Architectural Review 130, no. 774 (agosto 1961): 101-103.

65. Esther McCoy, "Mexico Revisited (I), y "Mexico Revisited (II): The Presence of Candela," Zodiac, no. 12 (octubre 1963): 106-17 y 118-131 respectivamente.

66. Fischer, Robert E. "Mexico City's Earthquake," Architectural Record 122, no. 4 (octubre 1957): 243-47. del sismo de julio de $1957^{66}$. El interés de Estados Unidos no se centró solamente en los daños causados al antiguo edificio de su embajada o a los hoteles de capital norteamericano - como el Continental Hilton- sino que revisó suficientes ejemplos que dibujaron un panorama en el que, si bien varias estructuras colapsaron y otras más serían derribadas por los irreparables daños estructurales, importantes iconos citadinos - como la Torre Latinoamericana o el Palacio de Bellas Artes- salían ilesos del movimiento de tierra. 
Para completar esta sección, todavía queda por señalar que también se anotaron aquí numerosos artículos que trataron de forma general la obra de Félix Candela, o, lo que es decir lo mismo, que estudiaron las estructuras delgadas de hormigón armado, por lo que se ilustraron con edificios de diversos usos ${ }^{67}$.

Una vez que se abordó las categorías en que se clasificaron los edificios dependiendo de su uso, conviene retomar el rubro de servicios que, como se dijo antes, merece una explicación más detallada. Para definir la siguiente catalogación se consideró que la totalidad de inmuebles respondían a una determinada actividad comercial o a la oferta de servicios culturales y de entretenimiento. Con el fin de facilitar los análisis posteriores se nombraron catorce secciones - todas dentro del rubro general de servicios- que son las que se detallan a continuación. Así, un primer grupo comprendió los [1] centros comerciales, los [2] mercados, las [3] sucursales bancarias y los [4] talleres mecánicos. Después, como parte de los servicios básicos turísticos, se cuenta con [5] hoteles y [6] restaurantes. Los [7] monumentos y la arquitectura dedicada al culto religioso a través de las [8] iglesias y capillas vendrían enseguida y, ya de lleno en las actividades formativas se tiene a los [9] centros culturales, los [10] museos y los [11] pabellones de México en el extranjero. Por último, dedicados al esparcimiento y al entretenimiento masivo, las [12] construcciones deportivas — sin contar la arquitectura olímpica-, los edificios para [13] espectáculos y como una categoría aparte todo lo relacionado con [14] México 68.

Hay que insistir en que este capítulo ofrece algunos resultados cuantitativos y ejemplifica los casos con citas desvinculadas de un análisis en profundidad. Esto no se debe a un error metodológico o de contenido, sino a la intención expresa de enumerar la información con la que se cuenta, señalar cómo fue capturada para su posterior análisis y advertir en qué proporción se distribuyó dependiendo de cada publicación, del tipo de noticia o del uso de los inmuebles. Lo más importante de este análisis es que pone en evidencia los grandes temas de la modernidad mexicana que se difundieron en las revistas foráneas.

De esta manera, lo que queda como colofón a este capítulo es un repaso a las catorce secciones en que se dividió el apartado de servicios, que, como se comprueba en la gráfica de distribución porcentual, acumuló
67. Véase por ejemplo, Reyner Banham, "Concrete: Simplified vaulting practices," The Architectural Review 114, no. 681 (septiembre 1953): 199-202; "A new approach to Structure," Architectural Forum 106, no. 1 (enero 1957): 124-143 y Gunhard-Aestius Oravas, "Thin Shells: Engineering fitness and Architectural Form," Architectural Record 127, no. 3 (marzo 1960): 216-21. 


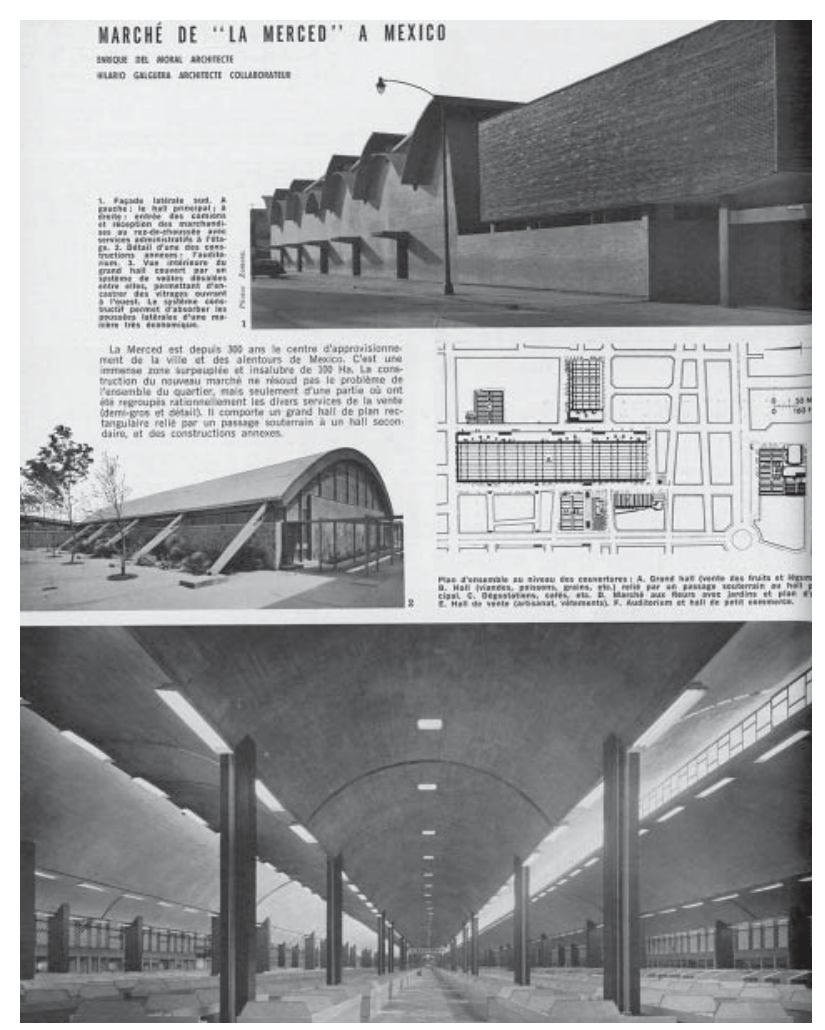

Los mercados públicos como un servicio imprescindible para la ciudad moderna. El mercado de La Merced de Enrique del Moral en L'Architecture d'Aujourd'hui (septiembre 1963).

el 34\% del total de páginas impresas en las que se registró algún inmueble en particular.

Bajo el título de centros comerciales se agruparon desde los locales individuales hasta los conjuntos que destacaron por su actividad lucrativa. Si bien en muchos edificios de oficinas privadas u hoteles fue característico destinar la planta baja al uso comercial, se clasificaron estos inmuebles en las dos categorías previas por ser ese - despachos y hospedaje- el uso predominante. Entonces, en este apartado hay un protagonista indiscutible, el Centro Comercial Jacaranda, publicado en

68. El análisis de este centro comercial puede revisarse en el capítulo sobre arquitectos en la sección destinada a sus autores: Ramón Torres Martínez y Héctor Velázquez.

69. También de Torres Martínez y Velázquez se conoció otro inmueble, formalmente emparentado con el Centro Comercial Jacaranda. Véase "Edificio Comercial," Arquitectura, no. 44 (agosto 1962): 67.

70. "Méjico," Informes de la Construcción, no. 59 (marzo 1954): s/p. La fuente no da información sobre el autor, sin embargo es muy precisa la descripción estructural que se acompaña de dos fotografías que muestran la obra durante su construcción. varias revistas entre 1962 y $1963^{68}$, pero también otros ejemplos de menor impacto y escala reducida ${ }^{69}$. Es el caso del local de Iberia, en la ciudad de México, que ya se ha comentado, o un edificio, también capitalino, que dio a conocer Informes de la Construcción en 1954 por su notable estructura de arcos de hormigón armado que suspenden la cubierta ${ }^{70}$.

Los mercados modernos mexicanos pueden jactarse no sólo de haber resuelto la provisión básica de mercancías a escala local —de barrio- sino de haber formado parte de un programa nacional que, por primera vez, estudió el problema del abastecimiento de la ciudad y propuso una red planificada de mercados urbanos. Así, no sólo se sustituyeron o ampliaron los antiguos mercados sino que se desarrollaron programas arquitectónicos especializados en acceso de mercancías, almacenamiento 
y venta. Una de las características principales de los mercados modernos es la amplitud del área central de exposición y venta, ya que los puestos individuales son de baja altura, lo que beneficia la continuidad espacial.

Varios mercados populares se conocieron en el extranjero debido a la calidad de su diseño arquitectónico y a la audacia de sus propuestas estructurales. El mercado Libertad, de Alejandro Zohn y el Alcalde, de Horst Hartung, ambos en Guadalajara, se cuentan entre los casos muy notables $^{71}$. En la capital, los encabezados por Pedro Ramírez Vázquez y Rafael Mijares - mercado de La Lagunilla y Coyoacán - o el diseñado por Enrique del Moral e Hilario Galguera -mercado de La Mercedtuvieron también su momento de gloria en las publicaciones periódicas nacionales $^{72}$ y extranjeras ${ }^{73}$.

Un reducido porcentaje de páginas recayó en aquellas que dieron a conocer edificios o sucursales bancarias, no obstante, por tratarse de un uso muy específico - aunque podrían catalogarse como edificios de oficinas, la zona de atención al público genera un programa arquitectónico concreto- se decidió mantener el campo de registro para estos casos muy particulares. Sin duda el Banco de México en Veracruz, de Carlos Lazo ${ }^{74}$, destacó notablemente sobre el edificio del Banco Popular en Monterrey, de Pani y asociados, antes comentado.

Todavía, con menor cantidad de páginas que las sucursales bancarias, el campo denominado arriba talleres mecánicos en realidad podría consignarse más apropiadamente en singular. El programa múltiple del edificio que, si bien prioriza en área a las reparaciones automotrices, también contó con gasolinera, zona de exhibición y venta de automóviles, comercios, oficinas - en menor escala en estos dos últimos casos-centro nocturno con terraza y, en una segunda etapa, hasta apartamentos para algunos empleados. Ante la multifuncionalidad y singularidad, y sobre todo ante la repetición en los medios del mismo inmueble, se decidió crear un registro individual para esta obra de Vladimir Kaspé, misma que se estudia con detalle al analizar también otras obras del arquitecto.

Los cuatro campos anteriores - centros comerciales, mercados, sucursales bancarias y taller mecánico- suman apenas el 11\% del total de páginas en que se dieron a conocer inmuebles inscritos en servicios. Los destinados principalmente a la industria turística reunieron la nada desdeñable cifra del $17 \%$ entre hoteles y restaurantes. Los primeros,
71. Se pueden revisar las referencias completas a estos diseños tanto en el siguiente capítulo que trata los casos de fuera del DF como en la sección de arquitectos: Alejandro Zohn.

72. No es el fin de esta investigación comparar lo publicado en México con lo que se dio a conocer fuera de sus fronteras, pero el caso de los mercados es sintomático del periodo de estudio por el marcado interés de la época en mejorar los servicios básicos de la mayoría de la población: salud, educación, vivienda $y$, como vemos, el abastecimiento popular de víveres y artículos de primera necesidad. Véase el número 84 de Arquitectura México, que se destinó al tema en diciembre de 1963.

73. El estudio de los mercados capitalinos es parte del análisis a la obra de Pedro Ramírez Vázquez, en el capítulo dedicado a los arquitectos mexicanos con presencia en el extranjero.

74. El análisis del imponente inmueble veracruzano puede revisarse en la sección dedicada a Carlos Lazo en el multicitado capítulo sobre arquitectos. 
con mayor impacto en las publicaciones, alcanzaron el 14\% del total de páginas que comprende esta sección.

Si bien al final de la década de 1960 el protagonista indiscutible de este género fue el Hotel Camino Real de Ricardo Legorreta ${ }^{75}$, otros ejemplos, tanto en la capital como en los consabidos destinos turísticos de la época, diversificaron el panorama de la difusión hostelera. Se recuerda, en la ciudad de México el polémico Hotel del Prado ${ }^{76}$, de Carlos Obregón Santacilia, el Hotel Alameda ${ }^{77}$, de José Villagrán García o el Hotel María Isabel $^{78}$, de Juan Sordo Madaleno o incluso el Continental Hilton ${ }^{79}$, de Fernando Parra. Fuera de la capital, el destino turístico principal fue sin duda Acapulco, pero también, en la costa del Pacífico, Mazatlán o, en el centro del país, Tequesquitengo, Valle de Bravo y Oaxtepec pusieron una nota puntual a la arquitectura vacacional ${ }^{80}$.

Los restaurantes, salas de fiestas y centros nocturnos tuvieron presencia en las publicaciones periódicas sólo gracias a los intrépidos cascarones de hormigón armado de Félix Candela. Casi se podría hacer una excepción, pues la primera noticia que clasificamos en este campo tuvo como autor principal al arquitecto cubano Max Borges, responsable del proyecto arquitectónico de la sala de fiestas “Jacaranda" de la ciudad de México. No obstante, Eduardo Robles Piquer - a quien se recuerda como autor del local de Iberia- se encargó de la decoración y la jardinería y, por supuesto, la cubierta laminada fue diseño de Candela ${ }^{81}$.

De nombre casi homónimo y de uso también equivalente, el cabaret "La Jacaranda" en el Hotel Presidente de Acapulco, se sumó a los ejemplos que dibujaron la imagen festiva del turismo de playa en las revistas de arquitectura foráneas ${ }^{82}$. Y, de vuelta en la capital, uno de los cascarones más difundidos de Candela cobijó justamente un restaurante: "Los Manantiales".

75. La arquitectura de Legorreta publicada durante el periodo de estudio puede revisarse en el capítulo dedicado a arquitectos. Es sorprendente que el Camino Real, en cantidad de páginas publicadas, sólo quedó por debajo del MNAH, la iglesia de la virgen de la Medalla Milagrosa y el CUPJ, compartiendo la cuarta posición con la capilla de Nuestra Señora de la Soledad.

76. "Hotel del Prado," Informes de la Construcción, no. 33 (agosto-septiembre 1951): s/p.

77. "Hotel Alameda a
Mexico," L'Architecture d'Aujourd'hui, no. 109 (septiembre 1963): 49.

78. Los artículos publicados sobre el Hotel María Isabel se analizan junto con otras obras de Juan Sordo Madaleno en el capítulo correspondiente.

79. Ya se contextualizó este hotel en el análisis sobre $A r$ chitectural Record y sus Building Types Studies al iniciar el capítulo 3.1.

80. Todos los ejemplos del interior de la República son analizados en el capítulo siguiente, agrupados en zonas geográficas diferenciadas.

81. "Sala de fiestas Jacaranda," Informes de la Construcción, no. 80 (abril 1956): s/p. Aunque discretamente, pero sirva este ejemplo para corroborar que, con todo $y$ la censura del régimen franquista, los compatriotas republicanos se publicaron en Madrid; tanto Robles Piquer como Candela fueron arquitectos españoles exiliados en México.

82. "Láminas de hormigón armado," Arquitectura, no. 10 (octubre 1959): 7. 


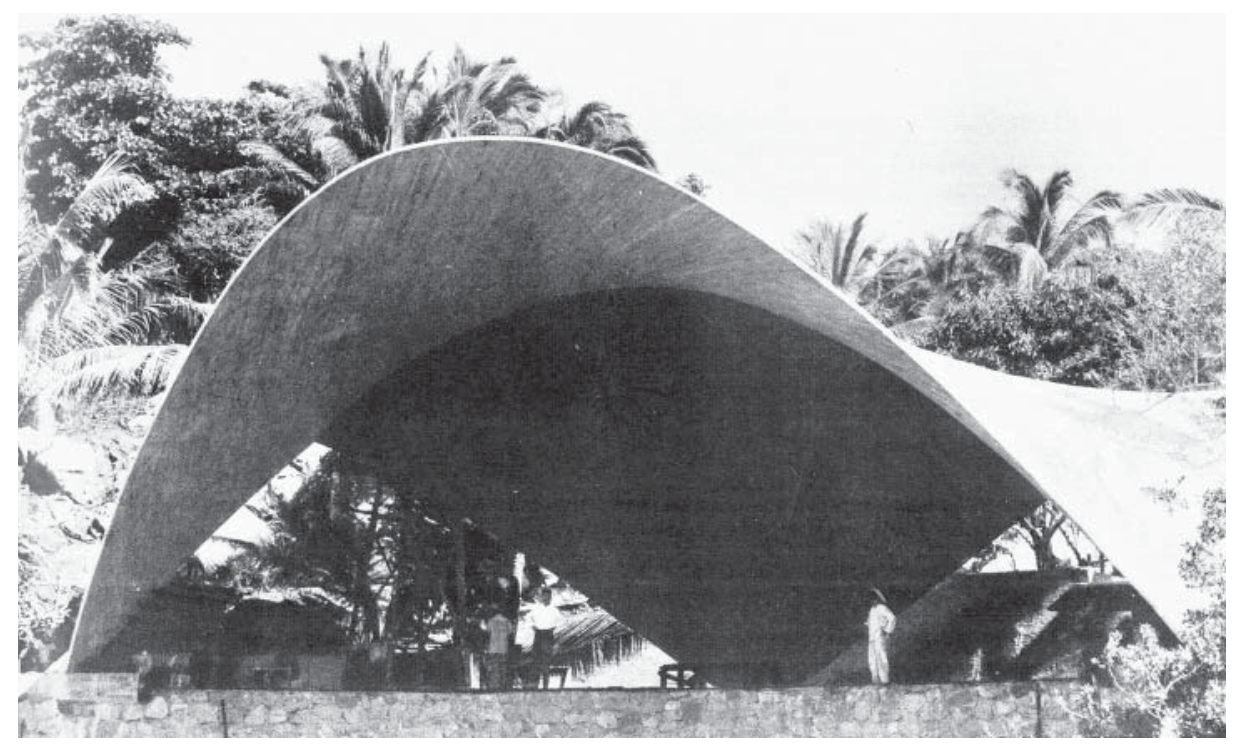

Ahora bien, se pasa de lo festivo a lo conmemorativo y lo fúnebre para situarse en una categoría que, aunque con pocas menciones, demandó su propia clasificación debido a lo específico de su programa arquitectónico. Así, el monumento de la Libertad en Puebla, de Jorge Bravo y Fernando Peña, se erigió para conmemorar los cien años de la famosa batalla del 5 de mayo de 1862, ganada a Francia. Y fue precisamente L'Architecture d'Aujourd'hui la revista que publicaría el helicoide pétreo conmemorativo $^{83}$. Los otros ejemplos que se registraron en este campo son obras particulares de menor escala. Por un lado, la tumba de Jorge Negrete, proyecto de Francisco Artigas y publicado en Informes de la Construcción en $1959^{84,}$ y por otro, un monumento funerario para un joven artista, diseño de Manuel González Rul, dado a conocer en $A A$ en $1963^{85}$.

La arquitectura religiosa, con ser la sección más amplia del campo de servicios, no aportó mayor complejidad para su análisis pues apenas un puñado de ejemplos conforma esta parte. Sobraría decir que la mayoría de los casos se divulgaron - al igual que vimos antes con los restaurantespor sus audaces cubiertas de doble curvatura. Si bien solo un caso - la iglesia de la virgen de la Medalla Milagrosa - fue proyecto integral de Candela —-tanto arquitectónico como del cálculo estructural— la mayoría fueron diseños en colaboración con Enrique de la Mora. De esta manera, obras muy conocidas como las capillas de Nuestra Señora de la Soledad y San Vicente de Paul o las iglesias de San Antonio de las Huertas y San José Obrero, sin olvidar la capilla abierta de Cuernavaca o el proyecto para la catedral de Villahermosa, se cuentan entre los inmuebles más difundidos.
Cabaret "La Jacaranda" en el Hotel Presidente de Acapulco. Diseño de Juan Sordo Madaleno y cálculo estructural de Félix Candela. En Arquitectura (octubre 1959).

83. "Monument de la Liberté a Puebla," L'Architecture d'Aujourd'hui, no. 109 (septiembre 1963): 42.

84. "Monumento funerario," Informes de la Construcción, no. 116 (diciembre 1959): s/p. 85. "Monument Funéraire a Mexico," L'Architecture d'Aujourd'hui, no. 109 (septiembre 1963): 43. 
86. "Iglesia en el Asilo de Zoquiapán," Arquitectura, no. 44 (agosto 1962): 47.

87. "Église pour un nouveau quartier de Guadalajara," L'Architecture d'Aujourd'hui, no. 109 (septiembre 1963): XVII.

88. Ambos casos se contextualizan debidamente en el siguiente capítulo: Territorio descubierto. La geografía nacional en el papel impreso.

89. La obra de Goeritz se trata en la tercera parte de esta tesis.

90. "Musée du Folklore, Mexico," L'Architecture d'Aujourd'hui, no. 100 (febrero-marzo 1962): XxxI.

91. Véase el capítulo $7.4 \mathrm{La}$ presencia discreta. Los pabellones de México en las ferias internacionales.
Para romper la inercia que provocan las curvaturas, se citan dos excepciones en este campo. La primera, la iglesia en el asilo de Zoquiapán, de Israel Katzman, publicada en el monográfico de Arquitectura ${ }^{86}$, y la segunda, la iglesia de San Javier de Julio de la Peña, en Guadalajara, y dada a conocer en el especial de $A A$ de $1963^{87}$.

Al observar la gráfica de distribución de los edificios catalogados como servicios, es perceptible que entre la arquitectura religiosa y los museos hay una franja apenas notable denominada "centros culturales". Las comunicaciones de este campo son muy escasas, pero se destacan por beneficiarse de un programa arquitectónico que no cabría en otra clasificación. Entonces, la Biblioteca del Estado y Casa de la Cultura de Guadalajara, de Julio de la Peña y el Centro Cultural Centenario, en Puebla, de Guillermo Rossell y Abraham Zabludovsky se sumaron a la diversidad edificada que narra esta historia ${ }^{88}$.

El panorama editorial del rubro de museos se podría cubrir con dos nombres: Mathias Goeritz y Pedro Ramírez Vázquez. Situados en las antípodas, el museo experimental El Eco, de Goeritz, no fue sólo una obra de iniciativa privada, sino un verdadero ensayo formal que propuso una envolvente a la manera de una escultura habitable capaz de producir emociones humanas ${ }^{89}$. Nada semejante se hallará en los programas arquitectónicos de los museos institucionales.

Además del Museo Nacional de Antropología e Historia, el Museo de Arte Moderno, la Galería de Historia o el museo de Ciudad Juárez, cabría anotar una curiosa excepción, el proyecto para un museo del folklor, de Héctor García Olvera, que sería construido en el Bosque de Chapultepec, pero que no llegó a realizarse $\mathrm{e}^{\mathbf{9 0}}$.

Como parte de la difusión cultural se anotó otro campo de registro que consignó los pabellones de México que se construyeron en ferias y exposiciones internacionales. Aquellos erigidos en Bruselas y Nueva York son los que forman el grueso de estas comunicaciones. El carácter experimental que suponen los pabellones, aunado siempre a una ideología nacional determinada, potenció el desarrollo de un capítulo específico que profundiza en el caso mexicano y en los edificios temporales que se erigieron en suelo extranjero con un mensaje muy claro: exponer lo que, desde las instituciones oficiales, sería la arquitectura y el arte moderno mexicanos ${ }^{91}$. 


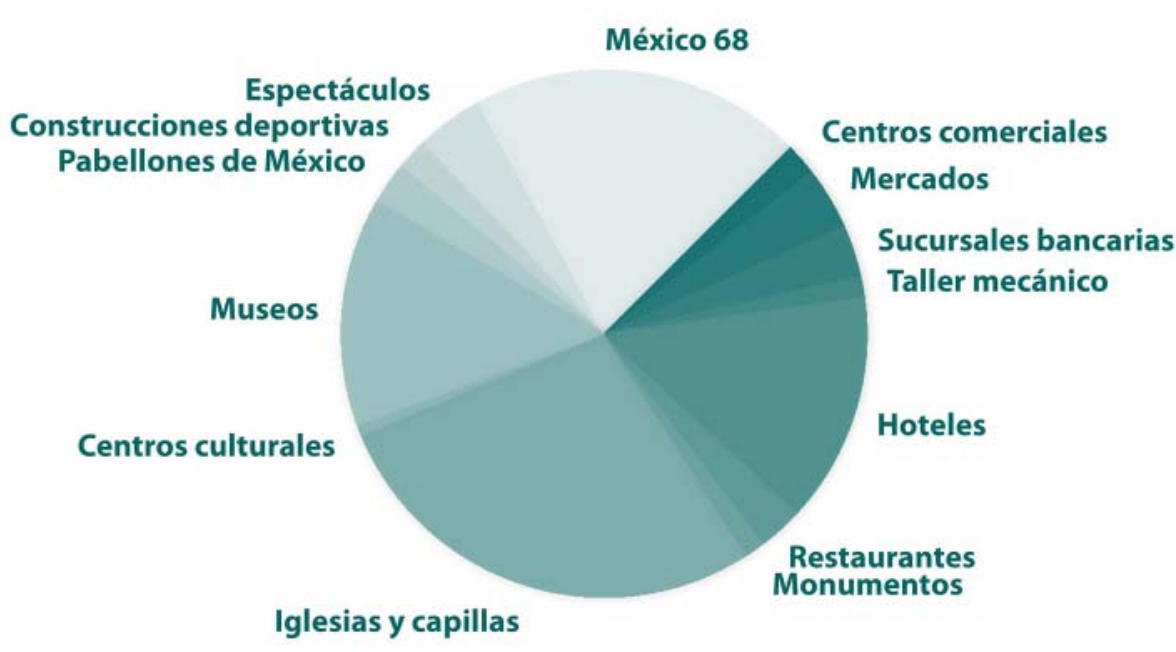

Por otro lado, desde el inicio de esta investigación interesó agrupar las construcciones de la XIX Olimpiada, pero pronto se detectó también la presencia de otras obras destinadas al ejercicio físico, pero sin relación con la arquitectura olímpica y casi todas ellas derivadas del sector privado. Entonces, se dividió el campo de la arquitectura deportiva en dos. Así, lo que quedó fuera de México 68 se nombró simplemente como construcciones deportivas, y aquí se tienen los casos de campos de golf, piscinas o centros deportivos. Por ejemplo, de Enrique del Moral, Mario Pani y Salvador Ortega un campo de golf que se publicó junto con un centro deportivo y social de Vladimir Kaspé en L'Architecture d'Aujourd'hui en $1955^{92}$. Y, de nuevo en la francesa, una piscina y la Unidad Deportiva Presidente López Mateos, en Guadalajara, de Alejandro Zohn, fueron los casos de arquitectura deportiva que cubrió el monográfico de $A A$ de $1963^{93}$.

Entre 1955 y 1968, diversos inmuebles que se destinaron al entretenimiento poblaron las páginas de las revistas foráneas. La arquitectura del espectáculo se conformó con cines, teatros, auditorios, cubiertas ligeras para su uso en espacios abiertos e incluso una plaza de toros. La mayoría de los casos se benefició sólo de una cita puntual, mientras otros se repitieron en dos o hasta tres publicaciones, lo que incrementó notablemente su difusión. Entre los primeros se cuenta el cine Ermita, de Juan Sordo Madaleno ${ }^{94}$, el proyecto para el teatro Hidalgo, de Alejandro Prieto ${ }^{95}$, el diseño de un pabellón para una feria anual de flores, de Félix Candela ${ }^{96}$, la Plaza Monumental de Tijuana de Jaime A. Sandoval ${ }^{97}$ o el teatro al aire libre en el parque Agua Azul de Guadalajara de Alejandro Zohn ${ }^{98}$.
Distribución de los edificios catalogados como servicios. La figura desglosa el $34 \%$ del total de páginas destinadas a inmuebles con un uso característico.
92. "Constructions Sportives," L'Architecture d'Aujourd'hui, no. 59 (abril 1955): 48-49.

93. "Piscine Olympique a Mexico," L'Architecture d'Aujourd'hui, no. 109 (septiembre 1963): 48 y "Centre Sportif a Guadalajara," L'Architecture d'Aujourd'hui, no. 109 (septiembre 1963): 44-45.

94. 'Cinéma 'Ermita' a Tacubaya," L'Architecture d'Aujourd'hui, no. 59 (abril 1955): 50.

95. "Théatre 'Hidalgo' a Mexico," L'Architecture d'Aujourd'hui, no. 59 (abril 1955): 50.

96. "Shell-vaulting in Mexico," The Architectural Review 118, no. 708 (diciembre 1955): 351-352.

97. "Paso Doble on the Double," Progressive Architecture 42, no. 1 (enero 1961): 60 . 98. "Théatre en plein air a Guadalajara," L'Architecture d'Aujourd'hui, no. 109 (septiembre 1963): 111. 
Otras obras dirigidas al espectáculo tuvieron mayor fortuna en las revistas internacionales, como el Teatro de los Insurgentes, de Prieto, cuya primera difusión abarcó aspectos meramente tecnológicos y arquitectónicos, como en el artículo de The Architectural Review ${ }^{99}$, o intereses artísticos, como en la noticia de actualidad de Architectural Forum $^{100}$ que acentuó la intervención de Diego Rivera y su extenso mural. Ya en el año olímpico, la adaptación que se hizo al mismo para los eventos de levantamiento de pesas, que dio a conocer en detalle Informes de la Construcción ${ }^{101}$, concluyen la divulgación de este inmueble durante el periodo de estudio.

Por último, uno de los campos de registro más significativos dentro del rubro de servicios fue el denominado México 68, en el que, por razones metodológicas, se agrupó no solamente la arquitectura de nueva factura para la Olimpiada sino que también se integraron aquellos ejemplos fundamentales para el evento deportivo internacional, como el estadio olímpico universitario o el Estadio Azteca ${ }^{102}$. La riqueza de la información y la cualidad de clausura de un periodo sustancial de la arquitectura mexicana, hicieron posible el desarrollo de un análisis particular que involucra tanto las edificaciones y la ciudad, como el complejo ambiente político de la época que se sitúa como telón de fondo de la narrativa.

Como conclusión a esta parte se insiste en la diversidad de construcciones que se conocieron a través de las publicaciones periódicas foráneas. Aunque no se debe soslayar el impacto de ciertos nombres y edificios, este análisis abrió las puertas a variados ensayos, ya que facilitó la información, primero desde el punto de vista cuantitativo y por su confrontación según revistas y años de difusión. Con esto se expone un

99. "Theatre in Mexico City," The Architectural Review 123, no. 733 (febrero 1958): 110-13.

100. "Scale in the city," Architectural Forum 108, no. 5 (mayo 1958): 223.

101. "Levantamiento de pesas y Teatro Insurgentes," Informes de la Construcción, no. 205 (noviembre 1968): 34-35. 102. En el capítulo 7.5 El último desafío. La Olimpiada de México 68, se revisa la historia de estos inmuebles y sus vínculos con los Juegos incluso antes de ganarse la sede. amplio panorama de la arquitectura moderna mexicana que se divulgó fuera de las fronteras nacionales. No cabe duda que esta aproximación era no solo necesaria sino fundamental para abordar la tercera parte de la tesis, por tal motivo se ha tratado aquí de la manera más precisa posible, considerando lo que permite todo análisis historiográfico. 


\section{Territorio descubierto La geografía nacional en el papel impreso}

En el capítulo anterior se analizaron las publicaciones periódicas que forman el corpus principal de esta investigación, se definieron los tipos de comunicaciones en los que se capturó la información - con el fin expreso de medir su impacto en cada ejemplar-y, también, se presentó una descripción detallada de la diversidad arquitectónica que se dio a conocer fuera de las fronteras nacionales. Pero, más allá de algunas menciones casuales a varias ciudades y poblaciones, lo que faltaría para completar esta aproximación cuantitativa es determinar $-\mathrm{y}$ valorar- en dónde se edificó aquello que se publicó en el extranjero entre 1950 y 1970.

Es así que este cuarto capítulo estudia, en un primer apartado, la distribución de las obras según el territorio nacional, y finaliza con una segunda aproximación geográfica que reduce la escala solamente al valle de México. Lo que interesa destacar en este capítulo, ya que se sabe quién publicó y qué tipo de edificio, es ahondar en dónde exactamente tuvo lugar lo que se ha dado en llamar "modernidad mexicana".

Cabe decir que, a diferencia de los análisis cuantitativos previos, que se caracterizaron por la descripción puntual de términos y la enumeración concisa de géneros arquitectónicos - algo quizá tan poco apasionante como necesario- el acercamiento a un territorio vasto y las circunstancias particulares de clima y desarrollo de cada población, prometen una narración mucho más rica, pero — así se espera- igual de objetiva. 



\subsection{Más allá de la capital Otra visión a la modernidad mexicana}

Al contrario de lo que se suele pensar, la arquitectura construida fuera de la capital tuvo una presencia importante en las revistas de arquitectura foráneas durante las décadas de 1950 y 1960. Así, las referencias a más de treinta ciudades, localizadas desde la frontera norte y hasta el sur, trazaron, de forma paralela a las comunicaciones sobre la ciudad de México y su zona metropolitana, la visión moderna de un territorio de casi dos millones de kilómetros cuadrados.

Mientras de algunas localidades se dieron a conocer edificios de diversos usos, en muchos casos predominó un solo tipo de inmueble por ciudad, por lo que se ha estructurado la primera parte de este análisis de acuerdo a las definiciones del capítulo previo: vivienda, educación, salud, etc. Después, el estudio de algunas ciudades concretas, en las que la pluralidad de lo construido fue indicativo $-\mathrm{y}$ no circunstancial- cierra el análisis a la visión moderna que se dibujó más allá de la capital.

Se observa, en la primera silueta del país, la distribución de ciudades mencionadas en las publicaciones extranjeras. Hacia el norte, desde el extremo occidental - Tijuana - y hasta el límite fronterizo nororiental -Matamoros-, están señaladas varias poblaciones que demarcan claramente la división política del país con Estados Unidos. Hacia el sur, siguiendo el contorno del Pacífico, se nota actividad constructiva desde la Península de Baja California - Mulegé- y hasta el istmo de Tehuantepec -Salina Cruz. Hacia el golfo de México, apenas dos capitales estatales -Veracruz y Campeche- delimitan ese vasto territorio costero. Y, a diferencia de lo que se señaló en la frontera norte, la frontera sur se desdibuja por completo ante la ausencia de puntos de referencia.

Se hace evidente que la mayor concentración de inmuebles se localizó en la zona sur del país, en un territorio concentrado en torno al valle de México. Al norponiente de este conglomerado, la escuadra 


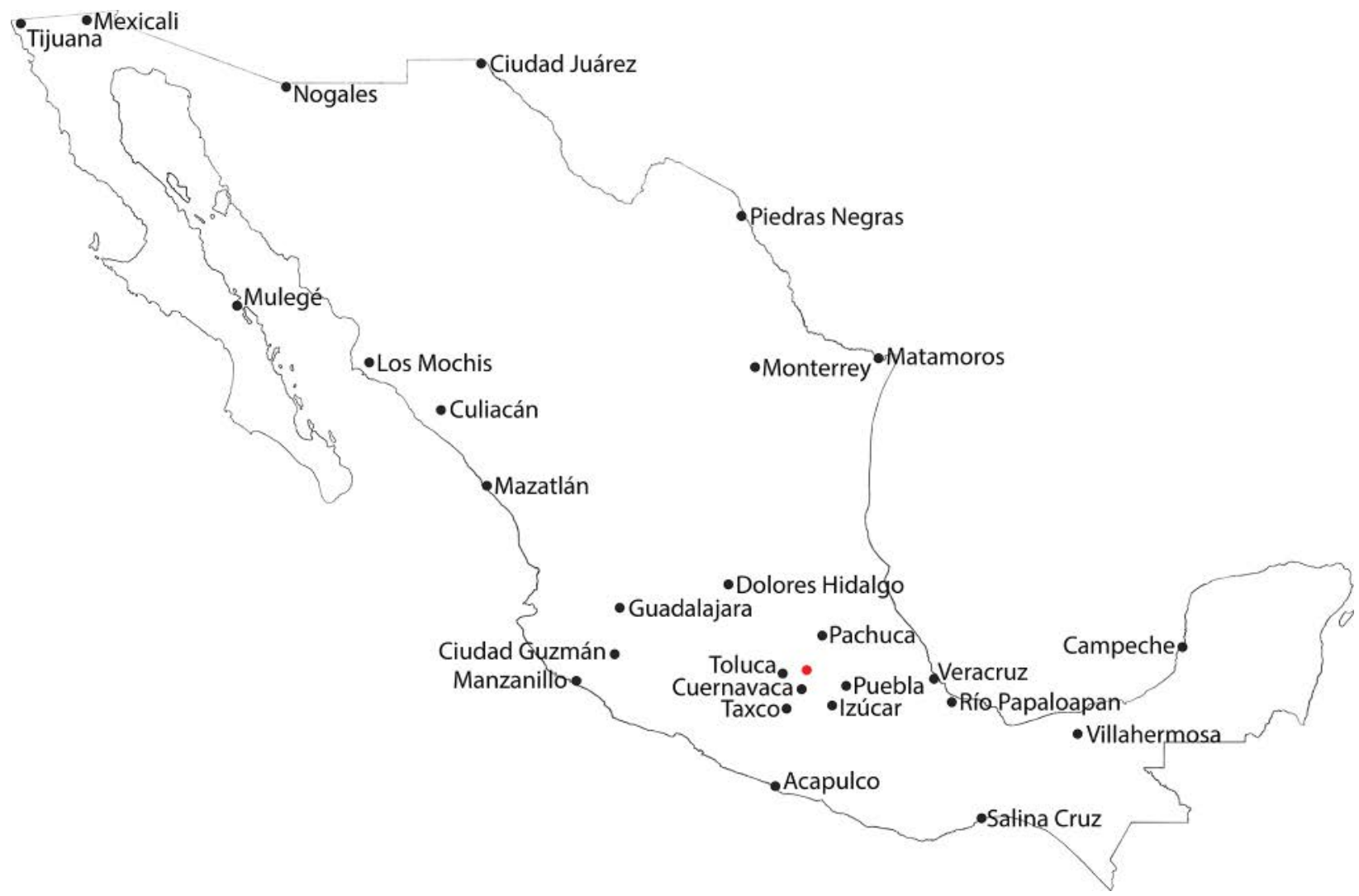

Ciudades mexicanas de las que se dio a conocer por lo menos un inmueble o infraestructura en las revistas foráneas contempladas en esta investigación. que forma Ciudad Guzmán, Guadalajara y Dolores Hidalgo es también notable y, de forma aislada, Monterrey se alza como la única ciudad del norte que, sin estar en la frontera o en la línea costera, tuvo alguna mención en las revistas internacionales.

Para profundizar en el análisis territorial, se estudiará la distribución de poblaciones en relación al tipo de edificio publicado. Las zonas geográficas antes dichas se diluyen en una serie de impactos coloridos que revelan la clave para el siguiente análisis.

\section{La propuesta exótica: los casos de vivienda unifamiliar}

Cuatro poblaciones se distinguen en el mapa por contar únicamente con noticias relacionadas a la vivienda unifamiliar: Taxco, Guerrero; Tepotzotlán, Estado de México; Río Papaloapan, Veracruz y Mulegé, Baja California Sur. La primera de ellas se distingue por el círculo verde de mayor tamaño, lo que indica que un considerable número de páginas se publicaron sobre un inmueble sito en esa localidad. Esta distinción — círculo más grande igual a más noticias- será una referencia visual constante para estos análisis del territorio nacional.

Así, de la primera localidad, Taxco, destacó la casa Silverstone, de Anshen \& Allen, construida en 1951 y publicada a lo largo de varios 


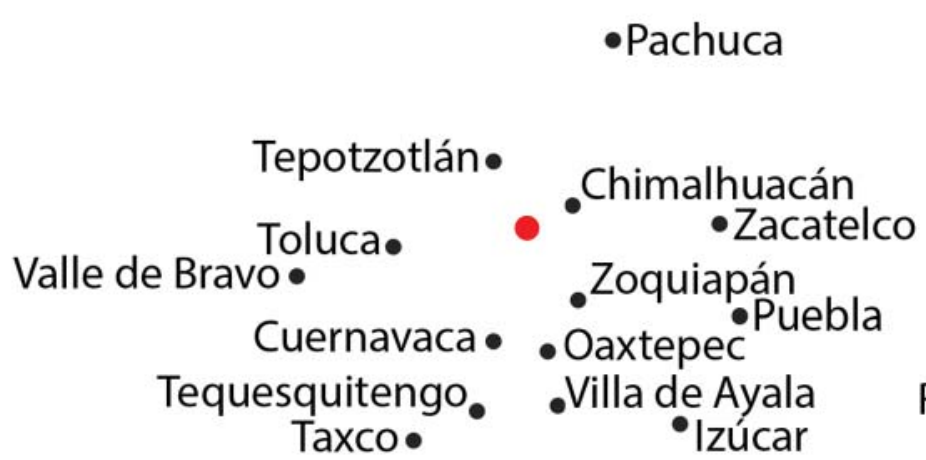

años en las revistas foráneas. Como ya se comentó en la primera parte de esta tesis, sobre esta vivienda se enfatizó el uso del hormigón armado acompañado de materiales regionales, lo que dio al inmueble levantado en clima tropical un pretendido toque exótico. Pero, sin duda, la propia autoría de la residencia fue lo que motivó su publicación en el extranjero, pues el equipo de arquitectos norteamericanos ya era reconocido internacionalmente por sus construcciones del suroeste de los Estados Unidos, en especial por la capilla de la Santa Cruz en Sedona, Arizona.

Taxco, una pequeña población del estado mexicano de Guerrero, de origen prehispánico y ciudad minera muy importante durante el virreinato, hoy se considera una de las ciudades turísticas más destacadas de esa entidad, debido a su emplazamiento, su arquitectura vernácula y colonial y a los recuerdos de su industria platera. En 1950 - cuando estaba en construcción la casa Silverstone- Taxco contaba con apenas diez mil habitantes, lo que la hizo destino principal de fin de semana, por su tranquilidad y relativa cercanía con la capital del país: poco más de 160 $\mathrm{km}$ distan entre la población guerrerense y el Distrito Federal.

Architectural Forum, en enero de $1951^{1}$, publicó un primer artículo sobre la casa Silverstone, comunicación que se hizo eco pocos meses después en $D_{0 m u s}{ }^{2}$ con una noticia de actualidad, en la que la revista italiana utilizó el mismo material fotográfico que la neoyorquina. Pasarían más de cinco años - un lapso de tiempo demasiado largoantes de que se retome este inmueble en las publicaciones periódicas. En diciembre de 1956 Informes de la Construcción, en su sección de Noticias ${ }^{3}$, la anunció sucintamente para, pocos meses después, dedicarle un artículo completo ${ }^{4}$. Llama la atención la distancia temporal entre las primeras noticias y las últimas publicadas varios años después. Hay que hacer notar que aunque la planta arquitectónica se repitió, el material
Detalle de la imagen anterior en la que se muestra la zona centro-sur del país. 
Casa Silverstone en Taxco, Guerrero, publicada en Informes de la Construcción (abril 1957).
5. Esto advierte sobre la repetición de esta casa en otros medios pues, como se sabe, IC no solía preparar artículos originales para la mayoría de los inmuebles que dio a conocer, sino que ajustaba -o en su caso traducíalo recibido por otras editoriales. También se anota que esta investigación, con todo y ser rigurosa, no excedió los límites presupuestos desde un principio en cuanto a los títulos de consulta.

6. "Progressive Architecture P.S.," Progressive Architecture 36, no. 9 (septiembre 1955): 250.

7. "Habitation Tropicale," L'Architecture d'Aujourd'hui, no. 67-68 (octubre 1956): XXXI.

8. "Tropical House arcs to Ocean Panorama," Architectural Record 120, no. 3 (septiembre 1956): 202-204.
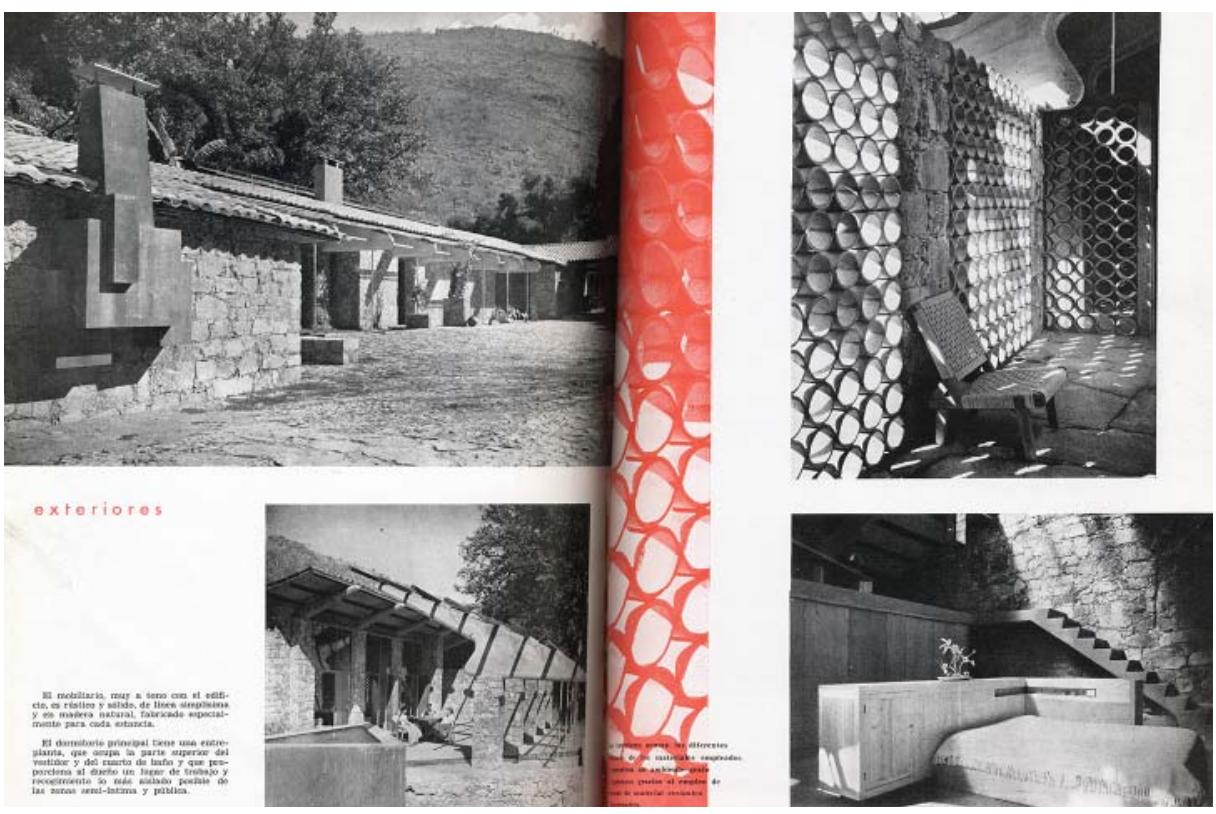

fotográfico en IC no es el mismo con respecto a sus predecesoras norteamericana e italiana ${ }^{5}$.

Otras localidades cuyas comunicaciones trataron únicamente el tema de la vivienda unifamiliar fueron Tepotzotlán y las inmediaciones del Río Papaloapan. De la primera, se recuerda la breve noticia de Progressive Architecture de septiembre de 1955: la casa del Sr. Eduardo Suárez que fue expuesta por el editor para que sus lectores comprobasen los inicios tradicionales de la obra arquitectónica de Félix Candela ${ }^{6}$. Por otro lado, el territorio veracruzano fue campo de experimentación para el arquitecto Alberto T. Arai - ya muy conocido desde principios de la década de 1950 gracias al diseño de los frontones de la Ciudad Universitaria de Méxicocon un prototipo de vivienda que utilizó materiales autóctonos. En palabras de su autor, el resultado formal fue consecuencia del estilo de vida de la región, que se desarrolla principalmente al aire libre, y del clima propio de la zona: humedad y lluvia abundante. La noticia fue publicada por L'Architecture d'Aujourd'hui en octubre de 1956, en el número especial que dedicó a la construcción en países cálidos ${ }^{7}$.

Si se dirige la mirada del centro del país hacia la península de Baja California Sur, se localizará la pequeña población costera de Mulegé, donde se sitúa una última noticia relacionada con un proyecto de vivienda unifamiliar. Architectural Record publicó en septiembre de $1956^{8}$ el diseño del arquitecto norteamericano F. J. Dennis Beatty -afincado en San Francisco- para sus clientes Mr. and Mrs. Guy R. Daniel. A diferencia de las noticias antes mencionadas, es interesante que en este caso se tratara 


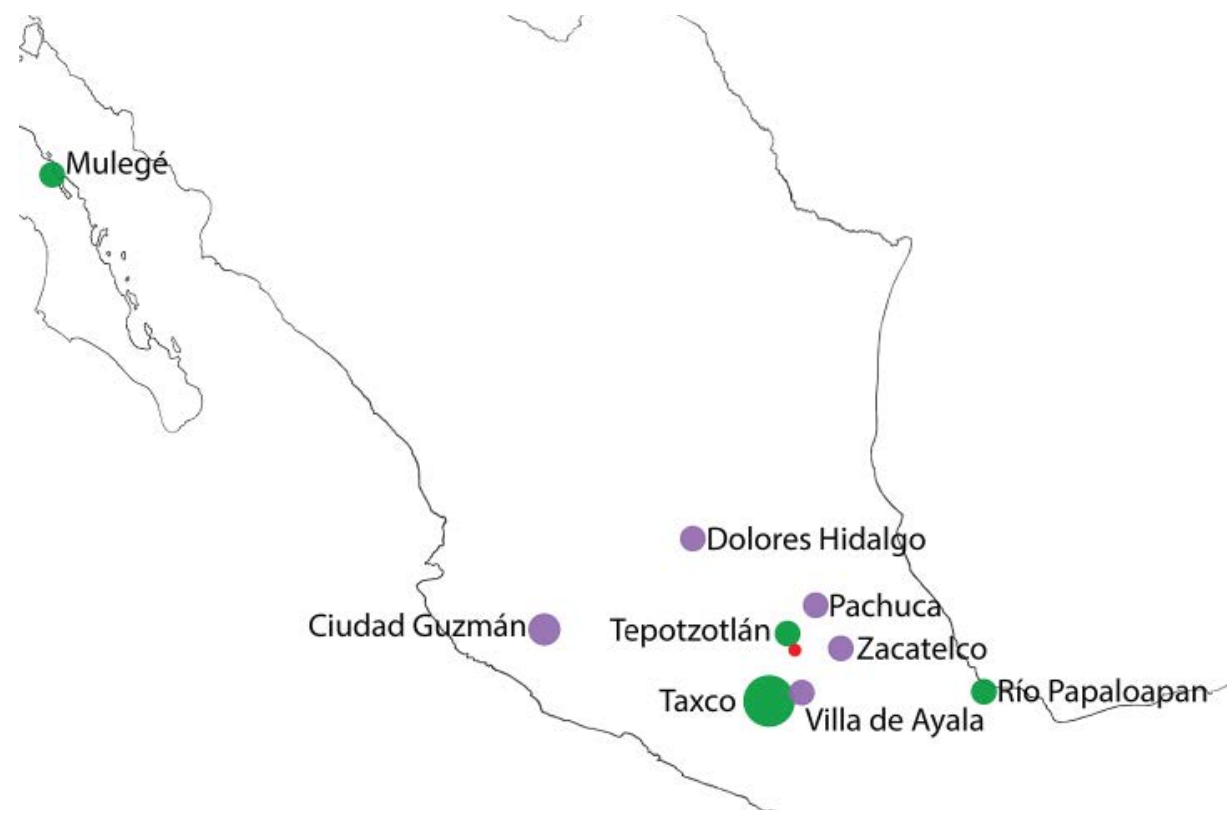

de un proyecto que consideró el clima seco y que potenció los espacios abiertos, pero también, como en Taxco y Veracruz, promovía el uso de materiales locales.

Como conclusión a este primer grupo de noticias, es notable que en la mitad de los ejemplos los arquitectos sean norteamericanos afincados en San Francisco, que ambos proyectos - casa Silverstone y Mulegé- destaquen por el uso de materiales locales y por su adaptación al clima, así como por su diseño racional moderno en cuanto a la distribución de espacios. De esta manera, la mención a un proyecto $100 \%$ mexicano quedaría en la aportación de Alberto T. Arai y su aproximación a la vivienda vernácula veracruzana.

\section{La conquista del medio rural: la arquitectura educacional}

La arquitectura educacional que se construyó fuera de la capital estuvo presente en las revistas foráneas principalmente gracias al tema del aulacasa rural -que en principio resolvería el déficit de escuelas de enseñanza básica- pero cuyo programa nacional se extendió al nivel medio y superior, cubriendo desde la primaria hasta la normal de maestros, pasando por los centros técnicos agropecuarios. Esto contrasta con los ejemplos publicados de la capital en los que la educación normal y superior universitaria fue preponderante. En los casos publicados para el interior del país, se destacó el papel del Estado mexicano que incursionaba en los ámbitos rurales aplicando los beneficios de las técnicas de prefabricación modernas, algo que se expresó en las nuevas edificaciones escolares.
Ciudades mexicanas de las que se dio a conocer solamente un tipo de inmueble por localidad: en verde los casos de vivienda unifamiliar y en lila los ejemplos de educación. Nótese que el tamaño de los círculos no sólo indican la localización geográfica sino también el impacto de la difusión en las revistas foráneas contempladas en este estudio. 
Cinco poblaciones del centro y sur del país se mencionaron en las revistas internacionales con noticias sobre arquitectura educativa: Ciudad Guzmán, Jalisco; Dolores Hidalgo, Guanajuato; Pachuca, Hidalgo; Zacatelco, Tlaxcala y Villa de Ayala, Morelos.

De la primera de ellas, destacaron los artículos dedicados a la Escuela Normal Regional del arquitecto Salvador de Alba Martín9. El primero de ellos - y el más completo- publicado por Arquitectura en agosto de $1962^{10}$, expuso a la normal regional como un ejemplo sobresaliente del programa que, a nivel nacional, construía escuelas para alfabetizar el país a través de la formación de nuevos maestros. Un año más tarde, en septiembre de 1963, tanto L'Architecture d'Aujourd'hui ${ }^{11}$ como Architectural Design ${ }^{12}$, en sus respectivos monográficos, también dedicarían páginas a este notable inmueble.

Otro caso ejemplar de un edificio para la enseñanza técnica especializada en la vida rural fue la escuela agropecuaria del arquitecto Jorge Campuzano en Dolores Hidalgo. De nuevo Arquitectura ${ }^{13}, A A^{14} \mathrm{y}$ $A D^{15}$ mantuvieron el interés en el tema con sus comunicaciones puntuales. Pero aun antes de que los citados monográficos prestaran atención al tema de la escuela rural, en Italia se venía comentando el asunto desde el inicio de la década de 1960, ya que con motivo de la XII Trienal de Milán, Domus publicó el prototipo de escuelas rurales que se diseñó para todo el país desde la capital ${ }^{16}$. Escasos meses después, la misma revista anunciaría que el prototipo que se construyó para la Trienal sería reconstruida en Sicilia como un regalo del gobierno mexicano a Italia ${ }^{17}$.

Si bien el tema de las escuelas rurales se desarrolla in extenso en la tercera parte de esta tesis, no se puede dejar de mencionar aquí la

9. Salvador de Alba Martín
(1926-1998), nació en Lagos
de Moreno, Jalisco, estudió
en la Escuela Nacional de
Arquitectura de la Universi-
dad Nacional Autónoma de
México y fue un personaje
clave en la creación de la
primera escuela de arquitec-
tura de Guadalajara, con-
solidando lo que después
sería conocido como la "Es-
cuela Tapatía". Véase Laura
Zohn, La nostalgia amotina-
da. Diez arquitectos opinan
sobre identidad y conser-
vación (Guadalajara: Institu-
to Tecnológico y de Estudios
Superiores de Occidente,

1996), 37 y ss. y Héctor Mendoza Ramírez, "Aportación de la Escuela Tapatía. Edificios de carácter colectivo de 1957 a 1968 en el estado de Jalisco" (Tesis de Doctorado, Universidad Politécnica de Cataluña, 2004).

10. "La Escuela Normal Regional en Ciudad Guzmán, Jalisco," Arquitectura, no. 44 (agosto 1962): 3841.

11. "École Normale Régionale a Guzmán," L’Architecture d'Aujourd'hui, no. 109 (septiembre 1963): 79.

12. "Three multi-storey schools," Architectural Design
33, no. 9 (septiembre 1963): 422-23.

13. "Escuela Agropecuaria," Arquitectura, no. 44 (agosto 1962): 45.

14. "École d'Agriculture a Dolores," L'Architecture d'Aujourd'hui, no. 109 (septiembre 1963): 78.

15. "Rural schools," Architectural Design 33, no. 9 (septiembre 1963): 419-21.

16. "Alla XII Triennale: la scuola rurale messicana," Domus, no. 373 (diciembre 1960): 13-16.

17. "Scuola messicana in Sicilia," Domus, no. 378 (mayo 1961): 37. 


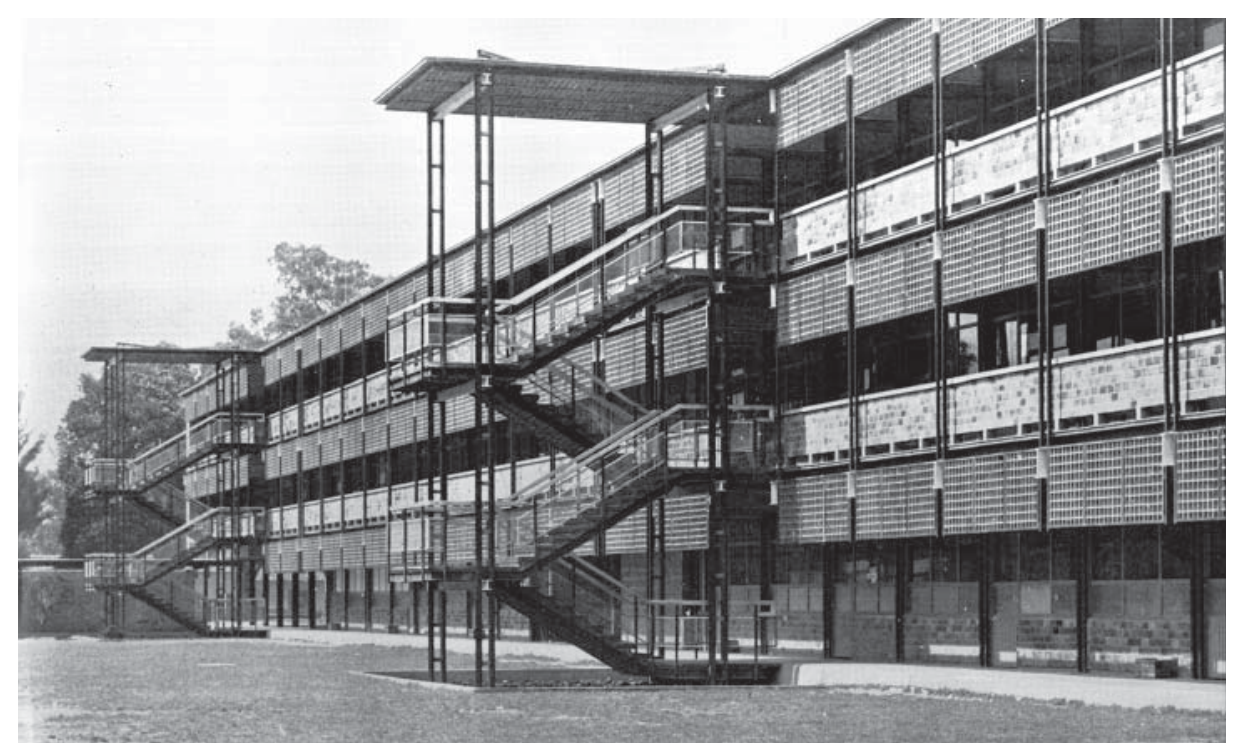

diversidad de locaciones en que se pusieron a prueba los prototipos de escuela surgidos del ambicioso programa nacional. Es dentro de este marco que se sitúa Pachuca ${ }^{18}$ — ciudad a poco más de cien $\mathrm{km}$ del Distrito Federal hacia el norte- Zacatelco ${ }^{19}$ y Villa de Ayala ${ }^{20}$-al sur y este de la ciudad de México, respectivamente. Las publicaciones destacaron de todos los ejemplos el uso de elementos prefabricados y los diseños funcionales y modernos. También, cabe puntualizar que la arquitectura educacional erigida fuera de la capital fue difundida principalmente en los números monográficos y, para el caso de Italia, hay que pensar en su estrecha relación con las noticias de las trienales milanesas.

\section{El triunfo de la seguridad social: la arquitectura nosocomial}

Así como los casos de arquitectura educativa se concentraron en el centro del país, con todo y que fueron resultado de un programa nacional, para el caso de la salud los ejemplos se sitúan en una extensa línea que sube por la costa del Pacífico desde Culiacán, pasando por Los Mochis —ambas ciudades en Sinaloa - hasta alcanzar la frontera norte en Mexicali - Baja California - ya tierra adentro. Estas tres ciudades son las que se muestran en el mapa con la edificación de centros médicos, clínicas y hospitales.

La arquitectura resultante del amplio programa nacional de construcción de hospitales y centros sociales, dirigido por el arquitecto Alejandro Prieto y formalizado a través del Instituto Mexicano del Seguro Social (IMSs), se señaló por L'Architecture d'Aujourd'hui como el modelo a edificar en las principales ciudades mexicanas. Por ejemplo, la obra de Culiacán —cuyos créditos compartió Prieto con Joaquín Sánchez
Escuela Normal Regional en Ciudad Guzmán, Jalisco. Obra de Salvador de Alba, publicada en Architectural Design (septiembre 1963).
18. "La escuela rural en México," Arquitectura, no. 44 (agosto 1962): 36-37.

19. "École Primaire et Secondaire a Zacatelco," L'Architecture d'Aujourd'hui, no. 109 (septiembre 1963): 74.

20. "École de Village a Villa de Ayala," L'Architecture d'Aujourd'hui, no. 109 (septiembre 1963): 76. 
Centro médico y social en Culiacán, Sinaloa. Proyecto de Joaquín Sánchez Hidalgo, en L'Architecture d'Aujourd'hui (septiembre 1963).
21. "Centre Social et Médical a Culiacan," L'Architecture d'Aujourd'hui, no. 109 (septiembre 1963): 68-69.

22. "Centre de Sécurité Sociale a Los Mochis," L'Architecture d'Aujourd'hui, no. 109 (septiembre 1963): XXI. Los créditos del proyecto se deben a Alejandro Prieto y Aaron Bolaños.

23. "Centre Social et Hospitalier de L'I.M.S.S. a Mexicali," L'Architecture d'Aujourd'hui, no. 109 (septiembre 1963): 66-67.

24. "Hospital General de Mexicali," Arquitectura, no. 44 (agosto 1962): 50.

25. "Hotel de Cima (Mazatlán),” Arquitectura, no. 44 (agosto 1962): 54. Un estudio completo de la arquitectura moderna sinaloense, incluyendo el caso citado, se puede revisar en el libro de Alejandro Ochoa Vega, Modernidad arquitectónica en Sinaloa (México: Ayuntamiento de Culiacán / UAS y UAM-X, 2004).

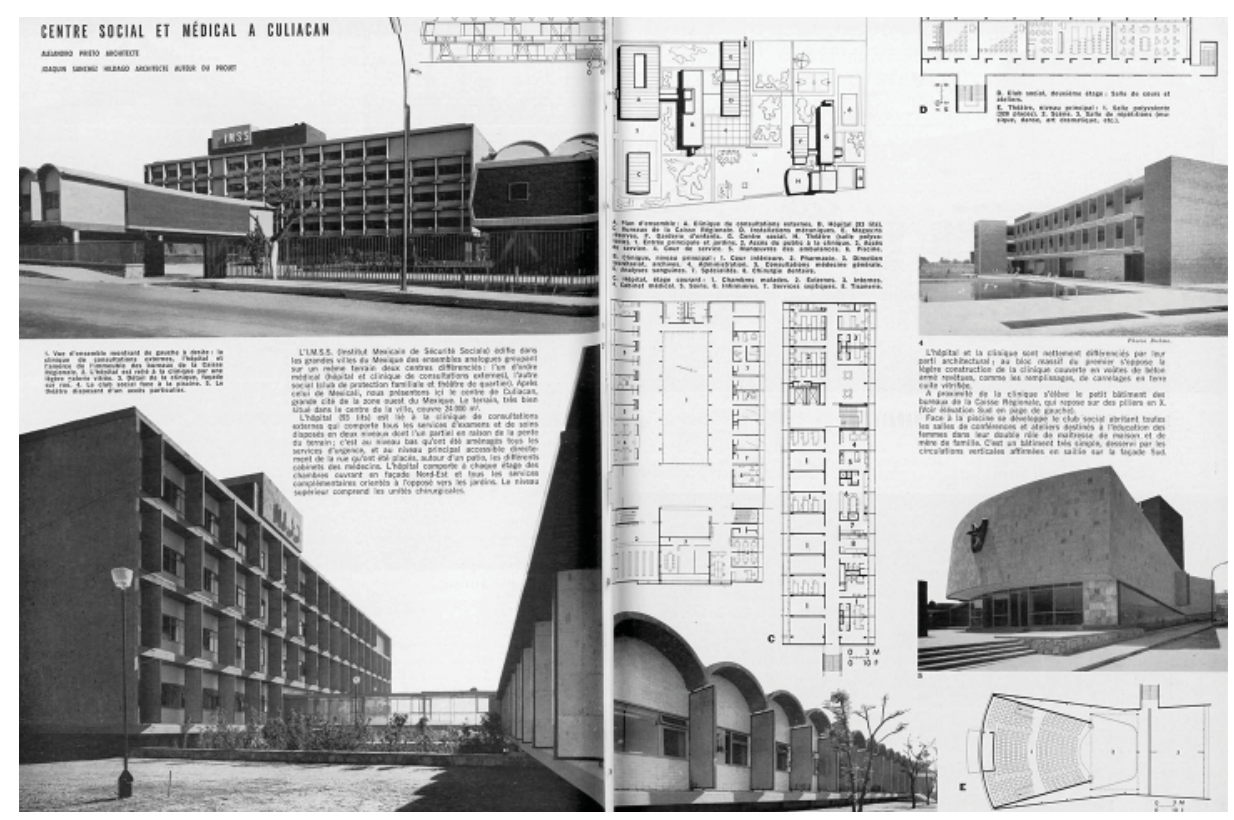

Hidalgo- expuso dos áreas bien diferenciadas, por un lado el hospital y clínica de consultas externas y por el otro, el centro social que incluyó sala de teatro y piscina. Se destacaron en el programa arquitectónico los salones destinados a la educación femenina, que consideraba el doble papel de la mujer mexicana moderna: ama de casa y madre de familia ${ }^{21}$. Para el caso de Los Mochis, también en Sinaloa, se siguió el mismo modelo que en Culiacán: hospital, clínica y centro social que incluyó teatro ${ }^{22}$. En el norte, en Mexicali, el proyecto del centro médico y social del IMss, de Alejandro Prieto, Imanol y Jokin Ordorika, fue publicado no sólo por $A A^{23}$, como en los casos anteriores, sino también por Arquitectura, en agosto de $1962^{24}$.

\section{Entre la recreación y el recogimiento: los servicios públicos y privados}

Hoteles y clubes náuticos, centros sociales y teatros o mercados e iglesias fueron algunos de los ejemplos de arquitectura moderna mexicana que, abarcando la extensa geografía nacional, desde la costa centro del Pacífico hasta el istmo de Tehuantepec, en el sur, se publicaron en diversas revistas extranjeras. Seis son las ciudades que contaron sólo con construcciones dedicadas a los servicios: Mazatlán, Sinaloa; Manzanillo, Colima; Valle de Bravo, Chimalhuacán y Zoquiapán, en el Estado de México y Villahermosa, Tabasco.

Dentro del espectro turístico, Mazatlán y Valle de Bravo cubrieron el panorama con un hotel y un club de yates. En la ciudad costera, el Hotel de Cima, del arquitecto Jorge Tarriba se publicó en Arquitectura en agosto de $1962^{25}$. Al siguiente año, en septiembre de 1963, L'Architecture 


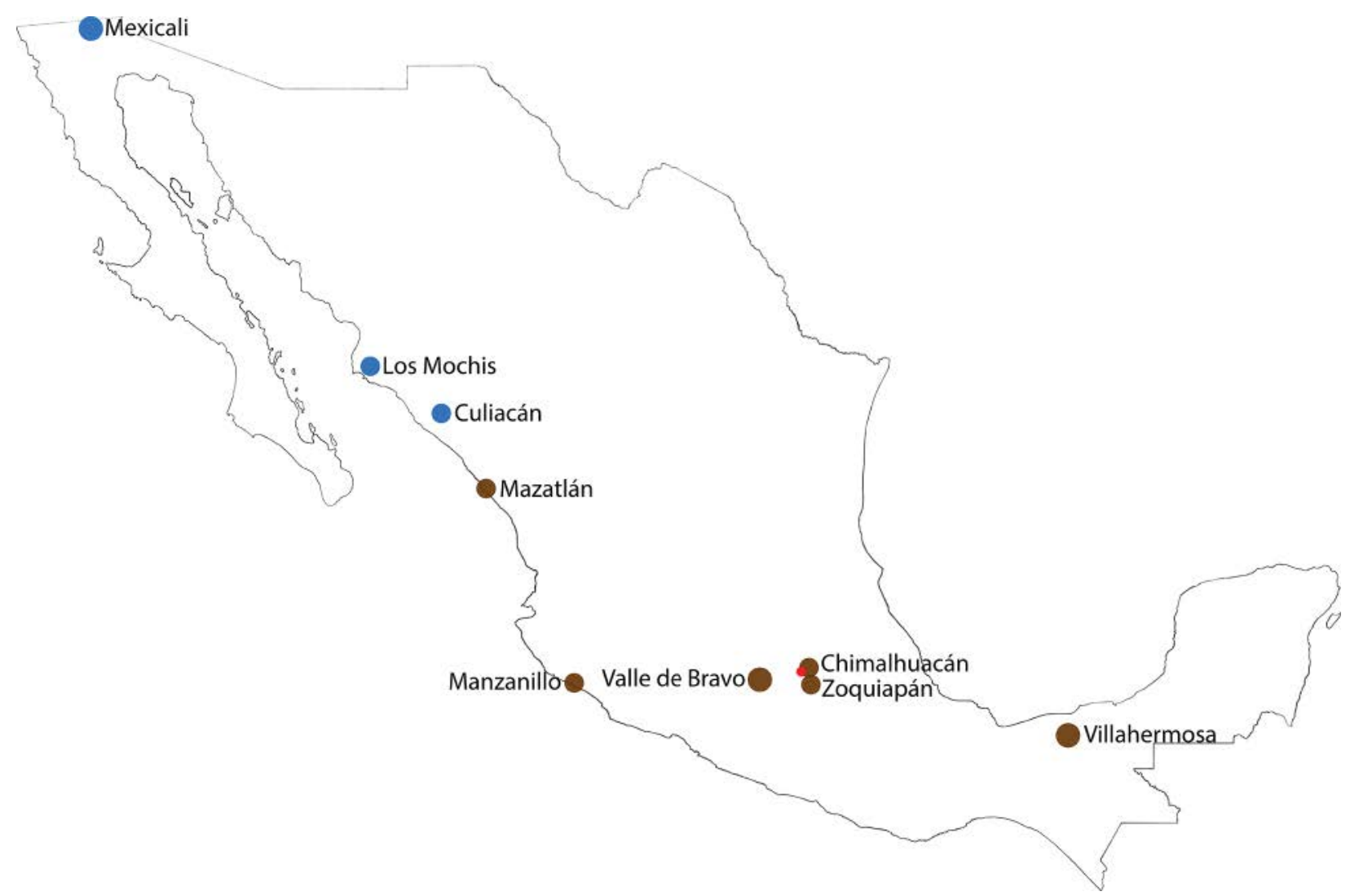

d'Aujourd'hui dio a conocer un club náutico en Valle de Bravo, del arquitecto Víctor de la Lama ${ }^{26}$. La misma construcción se repitió en enero de 1964 en Arts \& Architecture ${ }^{27}$. No es casual que ambas poblaciones responden a un crecimiento poblacional y económico derivado en gran Ciudades mexicanas de las que se dio a conocer solamente un tipo de inmueble por localidad: en azul la arquitectura nosocomial y en marrón los servicios. parte de la industria turística.

En Manzanillo, el proyecto de Alejandro Prieto para un centro social y teatro se dio a conocer en L'Architecture d'Aujourd'hui ${ }^{28}$. Por otro lado, el programa nacional de construcción de mercados tuvo entre sus aportaciones no sólo mejorar las condiciones de higiene sino mantener el concepto de la tradicional venta al aire libre o tianguis, muy arraigado en la población. Un ejemplo de estos mercados fuera de la capital se construyó en Chimalhuacán, en el Estado de México. La construcción siguió un proyecto de Ricardo Legorreta, mismo que fue publicado de forma sucinta, de nuevo, por $A A^{29}$.

Para terminar con el apartado de servicios, se mencionan dos iglesias. La primera de ellas en el Estado de México, en Zoquiapán, de Israel Katzman, publicada en Arquitectura ${ }^{30}$ en una comunicación que mostró fotos del exterior y una descripción que destacó el espacio abierto del atrio, por ser área útil para el centro, ya que se pensaba incluso para representaciones teatrales. La segunda, el proyecto para la catedral de

26. "Club Nautique dans la Vallée de Bravo," L'Architecture d'Aujourd'hui, no. 109 (septiembre 1963): 46-47.

27. "Yacht Club in Mexico," Arts \& Architecture 81, no. 1 (enero 1964): 27.

28. "Centre Civique et Social a Manzanillo," L'Architecture d'Aujourd'hui, no. 109 (septiembre 1963): XLI. Este conjunto, que además del centro social y del teatro cuenta con una clínica y un pequeño hospital, se incluye en este apartado de servicios debido a que la noticia dio más importancia a los servicios sociales que presta el conjunto que a la salud.

29. "Marché de Chimalhuacan a Mexico," L'Architecture d'Aujourd'hui, no. 109 (septiembre 1963): XLIII.

30. "Iglesia en el Asilo de Zoquiapán," Arquitectura, no. 44 (agosto 1962): 47. 
Hotel de Cima, en Mazatlán, Sinaloa. Proyecto de Jorge Tarriba publicado en Arquitectura (agosto 1962).

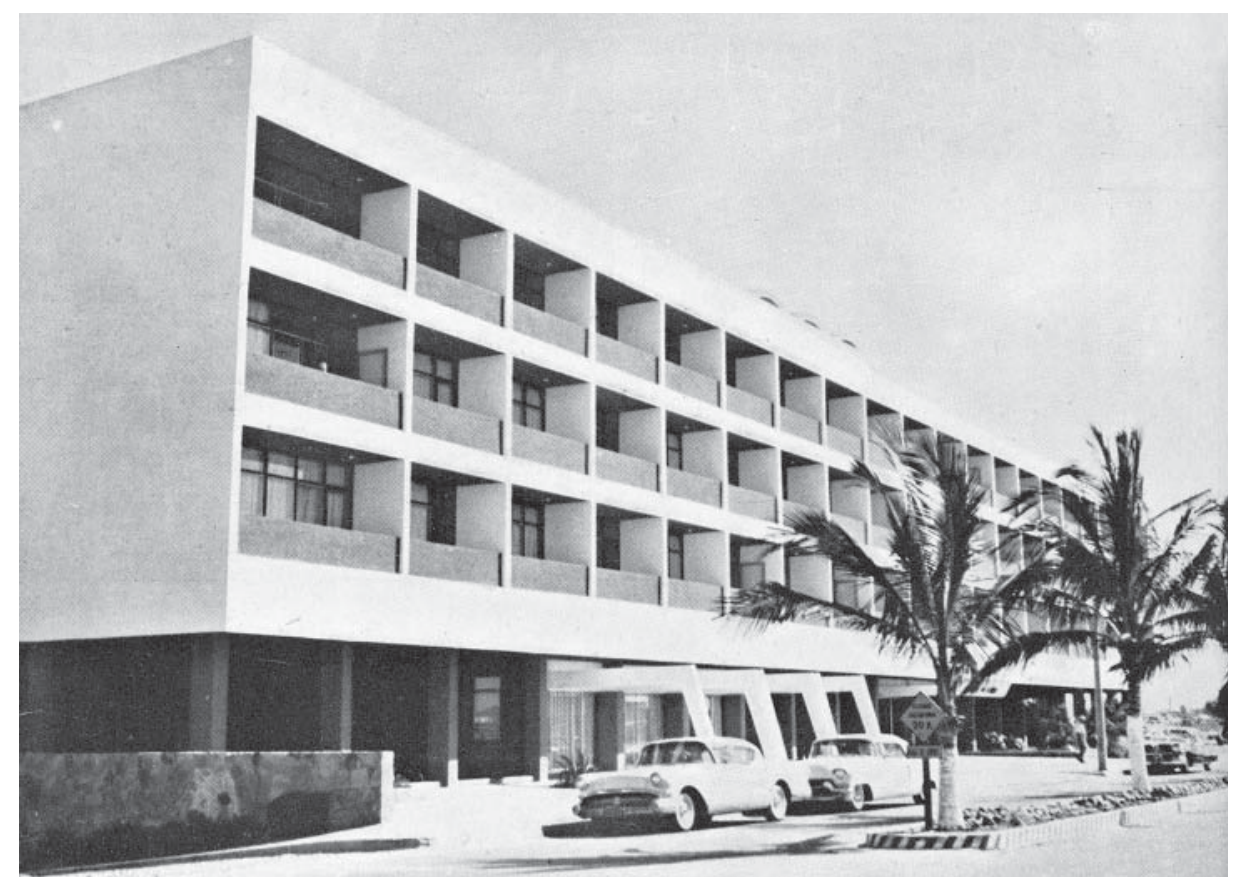

Villahermosa, en Tabasco, que se publicó primero en Architectural Forum ${ }^{31}$, con una noticia de actualidad, y después en L'Architecture d'Aujourd'hui ${ }^{32}$. Si bien el proyecto arquitectónico se debió a Jorge Creel de la Barra y Juan José Díaz Infante, sólo la revista francesa dio los créditos correspondientes, manteniendo a Félix Candela como el asesor de la estructura. No así la revista neoyorquina, que brindó todo el protagonismo al calculista, situación frecuente en las publicaciones periódicas.

\section{Si bebe, no conduzca: la arquitectura industrial}

Es por demás curioso que los únicos dos ejemplos de industria que se registraron fuera de la zona metropolitana de la ciudad de México representen el lugar común de una mala combinación. Conducir después de beber puede resultar catastrófico, pero en este análisis, tan solo enfatiza las dos plantas de producción industrial que conquistaron las páginas internacionales. Primero, la destilería de ron Bacardí, en Izúcar de Matamoros, Puebla, y después, la planta Auto-Mex de Chrysler, en Toluca, estado de México.

31. "Candela churches," Architectural Forum 118, no. 6 (junio 1963): 50.

32. "Projet pour la cathédrale de Tabasco a Villahermosa," L'Architecture d'Aujourd'hui, no. 109 (septiembre 1963): 40.

33. Diseño arquitectónico de Héctor Mestre y Manuel de la Colina y diseño estructural de Félix Candela. Galarza, se instaló la destilería de la conocida marca de ron $^{33}$. Su situación fue estratégica, pues la zona es fecunda en ingenios azucareros, con lo que la materia prima para la producción estaba asegurada. La planta abrió sus puertas en 1956, pero fue sólo dos años después que Progressive Architecture la dio a conocer profusamente, primero con una vista general 
del conjunto, en la que destacó el antiguo casco de la hacienda — adaptado como almacén- y la iglesia ${ }^{34}$. Pero sobre todo se conoció a través de generosas vistas interiores y exteriores de la planta de producción, en las que no faltó una sorprendente fotografía a color del complejo industrial infiltrado entre la vegetación exuberante.

En Toluca, la capital del estado de México, se construyó la planta Auto-Mex de Chrysler en 1964. De todo el conjunto, lo que llamó la atención de las revistas foráneas fue la Plaza de los Conos, una explanada coronada con gigantescos conos truncados, mismos que se convertirían en el emblema de la nueva fábrica automotriz. El proyecto de Ricardo Legorreta y socios ${ }^{35}$ contó con el asesoramiento escultórico de Mathias Goeritz. Los conos, utilizados uno como tanque de agua elevado y el otro como cisterna y auditorio con capacidad para 400 personas, fueron publicados en Progressive Architecture, en junio de $1966^{36}$. El artículo citó las Torres de Satélite como referente del diseño de la Plaza de los Conos; esta asociación no fue casual, pues el mismo año, en la revista francesa Urbanisme $^{37}$ apareció un artículo sobre el escultor Mathias Goeritz que mostró ambos iconos urbanos.

No obstante los años de estudio fueron prolíficos en crecimiento industrial, contados ejemplos llegarían a las publicaciones periódicas foráneas. Como se prueba, en todos los casos se debió a la participación de reconocidos arquitectos que se involucraron puntualmente en algunos diseños. En el siguiente subcapítulo se reconocerá que el mismo modus operandi aplicó también para la ciudad de México y el área conurbada.

\section{Buenas intenciones: los proyectos urbanos nacionales}

Con todo y que los casos de desarrollo urbano - casi todos ellos proyectos- de fuera de la capital se reducen sustancialmente a las menciones en el monográfico de 1963 de L’Architecture d'Aujourd'hui, se destaca aquí la ciudad de Campeche, que fija en el mapa el extremo más suroriental del territorio nacional de lo que se dio a conocer fuera de México. Así, la ciudad costera de la Península de Yucatán se mostró con un proyecto del urbanista Domingo García Ramos ${ }^{38}$. En el mismo artículo también hay menciones a Ciudad Juárez y Acapulco, pero éstas serán tratadas un poco más adelante cuando se analicen las poblaciones catalogadas como mixtas en cuanto a las noticias publicadas sobre ellas.
34. "Recent work of Mexico's Felix Candela," Progressive Architecture 40, no. 2 (febrero 1959): 132-36.

35. Ramiro Alatorre, Noé Castro y Carlos Hernández.

36. "La Plaza de los Conos," Progressive Architecture 47, no. 6 (junio 1966): 203-04.

37. "Mathias Goeritz: des phares pour la cité future," Urbanisme, no. 92 (1966): 60-61.

38. "Urbanisme et Planification Régionale au Mexique," L'Architecture d'Aujourd'hui, no. 109 (septiembre 1963): XIII. 
Arquitectura industrial fuera del valle de México. Destilería Bacardí en Izúcar de Matamoros, Puebla. Diseño de cubiertas de Félix Candela, publicado en Progressive Architecture (febrero 1959).
39. Si bien, como ya se anotó antes para el caso de Sinaloa, las modernidades de otras regiones del país son tema de estudios actuales. Los límites de esta investigación obligan a mostrar únicamente los ejemplos que se publicaron en las revistas contempladas y dentro de un rango cronológico específico.

40. "Méjico," Informes de la Construcción, no. 35 (noviembre 1951): s/p.
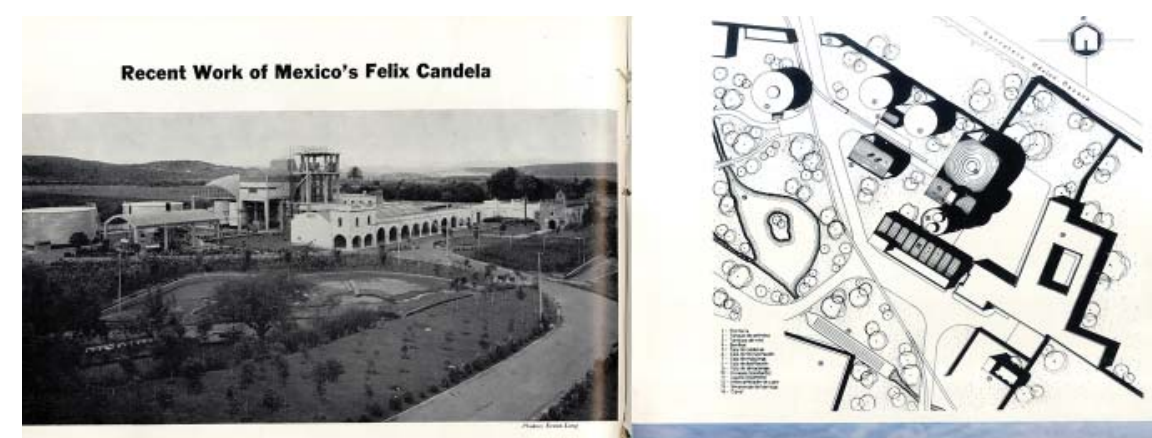

Distillery, State of Puebla

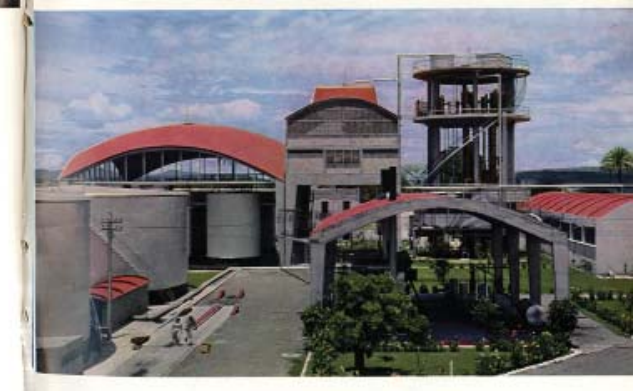

Hay que destacar, hasta este momento, no sólo que la concentración de noticias de fuera de la capital surgió de prácticamente los mismos números monográficos, sino que las propias propuestas para el interior del país provinieron de la capital. Se verificará más adelante la presencia de solamente dos focos de diseño bien diferenciados para toda la geografía nacional: la ciudad de México y Guadalajara. Esto no quiere decir que las distintas condiciones geográficas del país no aportaran condicionantes que fueron tomadas en cuenta por los proyectistas, sino que son prácticamente inexistentes las aportaciones de diseño local en las páginas internacionales ${ }^{39}$.

\section{Cerrando fronteras y otros temas: la infraestructura en el territorio nacional}

Puertos, puentes y estaciones de frontera fueron los ejemplos dados a conocer por las revistas internacionales como parte de la infraestructura. Al sur del país, en la costa del Pacífico, justo en el istmo de Tehuantepec, el puerto de Salina Cruz en Oaxaca consiguió una mención somera gracias a una batería de dragas de succión que remueven la arena que las corrientes arrastran al interior del puerto. La noticia en Informes de la Construcción ${ }^{40}$ destacó la manufactura holandesa de estas máquinas, cuyo buen funcionamiento impediría que se cerrase el puerto por acumulación de sílice.

También en el sur de México, pero del lado del Golfo, un puente en Río Blanco, Veracruz, fue registrado en 1954 por dos publicaciones periódicas: primero en Estados Unidos y pocos meses después en España. 


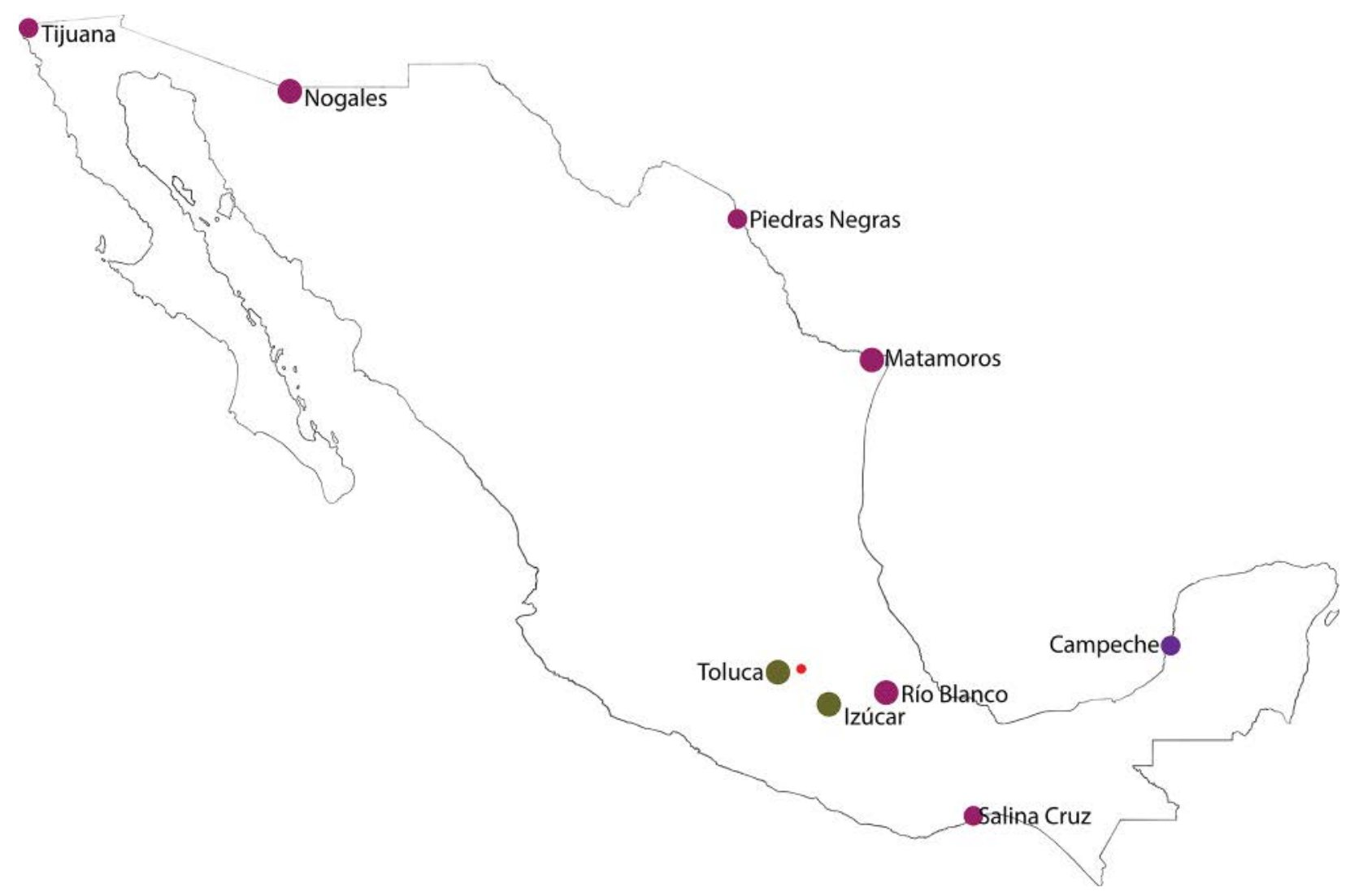

Así, la estructura de Thomas C. Kavanaugh, con un claro de 76 m, se publicó en Architectural Record en abril ${ }^{41}$ y en octubre, en la sección de Noticias, Informes de la Construcción repitió el puente de Río Blanco con dos vistas - una de frente y una lateral- pero sin la mención a su autor ${ }^{42}$.

Ciudades mexicanas de las que se dio a conocer solamente un tipo de inmueble por localidad: en verde olivo la industria, en morado el urbanismo y en magenta las infraestructuras.

Por último, el programa nacional de ciudades fronterizas, dirigido por Mario Pani, tuvo presencia en dos revistas extranjeras: Architectural Forum y L'Architecture d'Aujourd'hui. Las ciudades de Tijuana, Baja California; Nogales, Sonora; Piedras Negras, Coahuila y Matamoros, Tamaulipas, todas en la frontera norte, fueron tema de estudio de los urbanistas de la capital mexicana. Con un programa complejo, se pretendía no sólo la planeación urbana, sino potenciar la actividad y crecimiento económico, el comercio y la recreación. Las ciudades de la frontera mantenían desde entonces una población en tránsito, debido a la inmigración del sur hacia el norte, lo que originó diversos problemas sociales. Ante los retos que suponían su solución, los urbanistas y arquitectos se enfrentaron con un programa a nivel nacional que contempló no sólo las estaciones de frontera sino también complejos culturales y centros sociales.

En 1963, el número monográfico de L’Architecture d'Aujourd'hui concentró gran parte de la información publicada sobre las ciudades

41. " $57^{\text {th }}$ Architectural League Annual Honors," Architectural Record 115, no. 4 (abril 1954): 10. El puente construido en México ganó la medalla de oro en la categoría de ingeniería de la premiación promovida por la revista neoyorquina.

42. "Méjico," Informes de la Construcción, no. 64 (octubre 1954): s/p. 
Un caso de infraestructura al interior del país. Puente sobre el río Blanco, en Veracruz. Informes de la Construcción (octubre 1954).
43. "Programme National des Villes Frontières," LAArchitecture d'Aujourd'hui, no. 109 (septiembre 1963): 18-23.

44. "Archway on the border," Architectural Forum 123, no. 2 (septiembre 1965): 20 y 48.

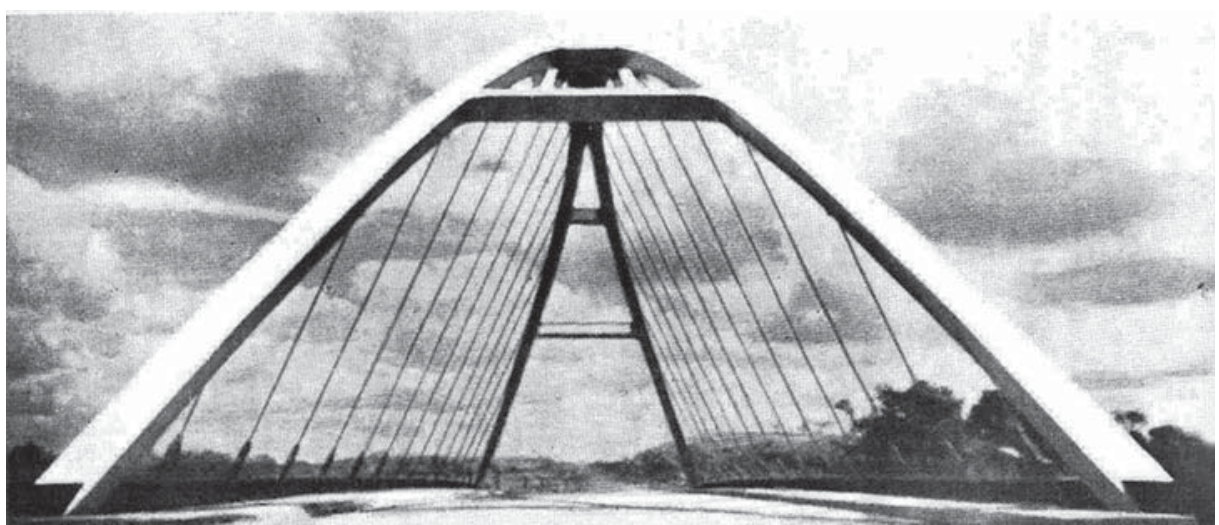

del norte del país. Un importante artículo describió la problemática urbana y social de la franja fronteriza y mostró posibles soluciones para las ciudades de Matamoros, Piedras Negras, Tijuana y Nogales ${ }^{43}$. Dos años después, algunas de las propuestas que publicó $A A$, se verían ya materializadas en Architectural Forum, en una noticia de actualidad, que se ilustró con las estaciones fronterizas de Matamoros y Nogales ya en pleno funcionamiento ${ }^{44}$.

\section{Una pausa antes de continuar}

Excluyendo de este primer análisis a las ciudades catalogadas como mixtas, es decir, aquellas de las que se publicó más de un género edificatorio, se anotan aquí unas primeras conclusiones sobre las casi treinta ciudades que se conocieron en las páginas foráneas con un solo tipo de inmueble.

Sin duda, los números monográficos monopolizaron la información. Sólo los casos de vivienda unifamiliar y de industria sitos al interior del país no ocuparon las páginas de los especiales de Arquitectura en 1962, L'Architecture d'Aujourd'hui y Architectural Design en 1963.

Para publicaciones como Architectural Forum, Architectural Record, Progressive Architecture o Arts \& Architecture, el tema de la vivienda unifamiliar, la infraestructura o los servicios, estuvo ligado a la difusión de arquitectos norteamericanos, con amplias carreras profesionales en los Estados Unidos y con pequeñas incursiones en el país vecino del sur. Aunque también es cierto que las revistas estadounidenses no sólo publicaron a sus nacionales, sino también a algunos de los muy conocidos arquitectos mexicanos que a lo largo de su trayectoria fueron ampliamente divulgados en sus páginas.

Dos publicaciones más, la española Informes de la Construcción y la italiana Domus, brindaron a este análisis algunos puntos más en el 
mapa, debido, en el primer caso, a noticias técnicas y, en el segundo, a la difusión de ferias internacionales, como la citada Trienal de Milán. Fue sustancial, para este último caso, la importancia de la técnica constructiva de la prefabricación y los materiales industriales, combinados con la manera local de construir, lo que resultó en la mezcla perfecta para llevar a las comunidades rurales mexicanas la vida moderna.

Con todo y que la gráfica que muestra la distribución de poblaciones de las que se dio a conocer solamente un tipo de inmueble o infraestructura es profusa en círculos coloridos, hay que reconocer que en la mayoría de los casos se trató de ejemplos aislados que no ofrecieron un mayor panorama sobre las ciudades en las que se construyeron los ejemplos publicados en las revistas foráneas.

Acaso se cuenta con algunas excepciones, en particular porque se publicó varias veces la misma obra — como la casa Silverstone de Taxcoo porque la difusión de un tema se concentró en un mismo artículo, como los planes de desarrollo para la frontera norte, lo que dio cohesión a una amplia zona geográfica. Esta apreciación aislada se rectifica a continuación, ya que se dirige ahora la mirada a las poblaciones que destacaron por la variedad de inmuebles que se conocieron en las páginas internacionales.

\section{Pluralidad edificada más allá de la capital}

Punto y aparte merecen ser expuestas las ciudades que, por su importancia durante el periodo de estudio, se conocieron en las publicaciones periódicas con más de un tipo de edificación, como se puede esperar de las grandes ciudades. Al observar el mapa que muestra las poblaciones que gozaron de difusión internacional, se nota que el cambio de escala de los puntos corresponde a una mayor cantidad de páginas publicadas en las revistas que comprende esta investigación.

Una primera impresión a la vista de esta figura centra la atención en la intensa actividad constructiva en el centro y sur del país, y la casi nula presencia de comunicaciones en el norte, omisión apenas salvada por la ciudad fronteriza de Ciudad Juárez, Chihuahua y la ciudad industrial de Monterrey, capital de Nuevo León. La ciudad de Acapulco, Guerrero, en el litoral del océano Pacífico - la más sureña de las mostradas aquí- es la que contó con mayor cantidad de información, seguida de cerca por la capital del estado de Jalisco: Guadalajara. Además de las anteriores, Cuernavaca, 
Tequesquitengo y Oaxtepec, en Morelos, así como Puebla y Veracruz, en el golfo de México, son las ciudades que se revisarán a continuación.

\section{El paraíso perdido: Acapulco}

Fundada en 1550, Acapulco no registró un crecimiento poblacional ni económico importante sino hasta mediado el siglo xx. Su relativa cercanía con el Distrito Federal — cerca de $400 \mathrm{~km}$ separan la capital del puerto-y una bahía espectacular, la hicieron propicia para desarrollar una industria turística que fue impulsada por los primeros vuelos comerciales regulares de la ciudad de México a la costa del Pacífico a partir de $1934^{45}$. Sin el establecimiento formal de la que llegaría a ser la compañía aérea más importante del país, Acapulco no hubiera pasado de ser un pequeño poblado de pescadores y de comercio marítimo al principal destino turístico internacional de la nación durante las décadas de 1950 a 1970.

Así, durante la década de 1940 y con la construcción de los primeros hoteles de lujo en playa Caleta, se estableció la industria turística al mismo tiempo que se consolidó la ruta comercial aérea desde el Distrito Federal. Si los primeros vuelos tenían tan reducida capacidad que sólo aceptaban 5 o 6 pasajeros más el piloto, al final de la década de 1940 los aviones que aterrizaban en la pista de la playa de los Hornos, ya llegaban con hasta 50 pasajeros. Para 1955, se publicó la noticia de la inauguración del aeropuerto "Plan de los Amates" junto a la laguna de Tres Palos, diseñado por el equipo del arquitecto Mario Pani. A este nuevo emplazamiento llegarían los primeros vuelos directos internacionales procedentes de Los Ángeles y Nueva York ${ }^{46}$.

Con estos antecedentes resulta evidente por qué Acapulco mereció diversas menciones en las revistas internacionales de arquitectura. Se revisan ahora las más importantes de ellas, que trataron desde el citado aeropuerto, viviendas unifamiliares o en condominio de lujo, varios hoteles, clubes de yates o hasta salas de fiestas, todas relativas a la actividad

45. "Academia de Historia Aeronáutica de México / Colegio de pilotos aviadores de México," Manuel Ruiz Romero y Hugo Gutiérrez González, consultada 9 enero, 2014, http://colegiodepilotos. org.mx/cabina/bolet37/04. pdf.

46. "Academia de Historia Aeronáutica de México." turística, al ocio o al esparcimiento.

\section{Aeropuerto de Acapulco}

La superficie curva que hace las veces de cubierta, soportada por dos enormes arcos de hormigón armado y extensos vanos laterales cerrados con tabicones huecos que forman celosías, fueron las principales imágenes 


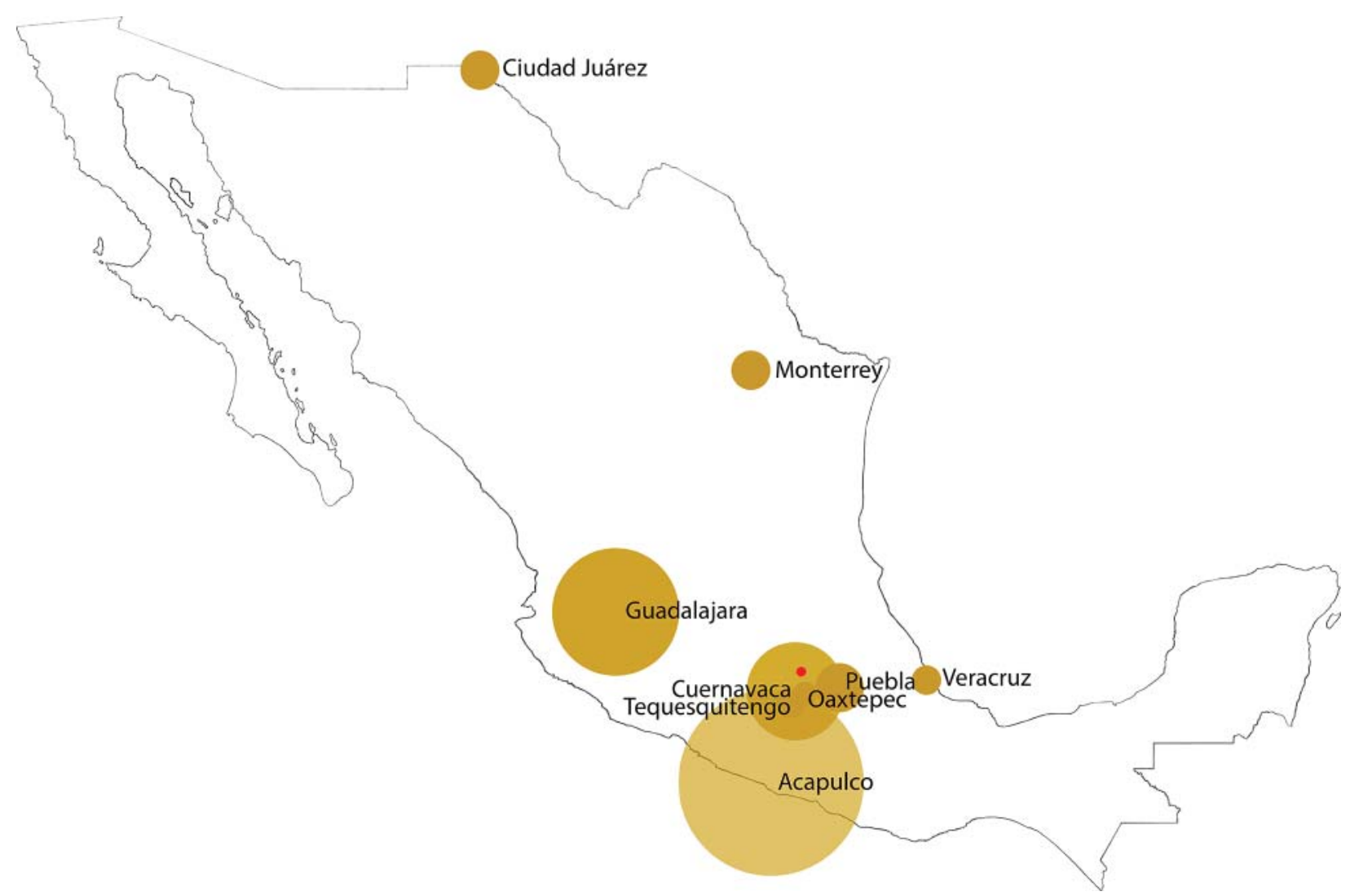

que circularon en las publicaciones para dar a conocer el aeropuerto de Acapulco, diseñado por Mario Pani y Enrique del Moral. Inaugurado en 1955, la nueva terminal aérea se divulgó en las revistas extranjeras desde ese año y hasta 1964. L'Architecture d'Aujourd'hui, en su monográfico de 1955, fue la primera publicación que dio cuenta de la obra con tres Ciudades mexicanas de las que se publicó más de un tipo de edificación en las revistas foráneas contempladas en este estudio. Los círculos más grandes corresponden a una mayor cantidad de páginas en las revistas foráneas. fotografías y una planta general; el texto descriptivo enfatizó, además de la notable cubierta, la ventilación cruzada y la singular entrada de luz debida a las celosías que cubren ambos lados del vestíbulo principal ${ }^{47}$. Las fotos de Guillermo Zamora - siempre despobladas_ remiten al material publicado en México en la revista dirigida por el propio Pani.

Un año más tarde, en junio de 1956, Architectural Forum dedicó un extenso artículo a los nuevos aeropuertos, tanto estadounidenses como los de fuera de sus fronteras. En éste se incluyó el aeropuerto de Acapulco ${ }^{48}$, destacando su techo de perfil aerodinámico y la ventilación de la sala principal refrescada con la brisa del mar. También se anotó el efecto salpicado de luces y sombras causado por la celosía de pequeñas piezas prefabricadas, mismas que se utilizaron en la torre de control.

Desde Italia, Domus dedicó una página a la difusión del nuevo aeropuerto mexicano ${ }^{49}$. Con apenas tres imágenes la noticia transmitió lo sustancial del emplazamiento en clima tropical y cómo éste potenció

47. "Aéroport d'Acapulco," L'Architecture d'Aujourd'hui, no. 59 (abril 1955): 46-47.

48. "The airport scramble," Architectural Forum 104, no. 6 (junio 1956): 127.

49. "Aeroporto in Messico," Domus, no. 320 (julio 1956): 6. Las fotografías son de Marilyn Silverstone. 
Litoral del Pacífico mexicano. A1: Aeropuerto internacional de Acapulco junto a la laguna de Tres Palos. Al noroeste la bahía turística.
50. "Aéroport d'Acapulco," L'Architecture d'Aujourd'hui, no. 67-68 (octubre 1956): 14041. Los créditos fotográficos, al igual que en Domus, pertenecen a Silverstone.

51. "Acapulco Airport, Mexico," Architectural Design 27 , no. 2 (febrero 1957): 5960 .

52. "One-Level frontal system: Acapulco, Mexico," Progressive Architecture 38, no. 12 (diciembre 1957): 100-101.

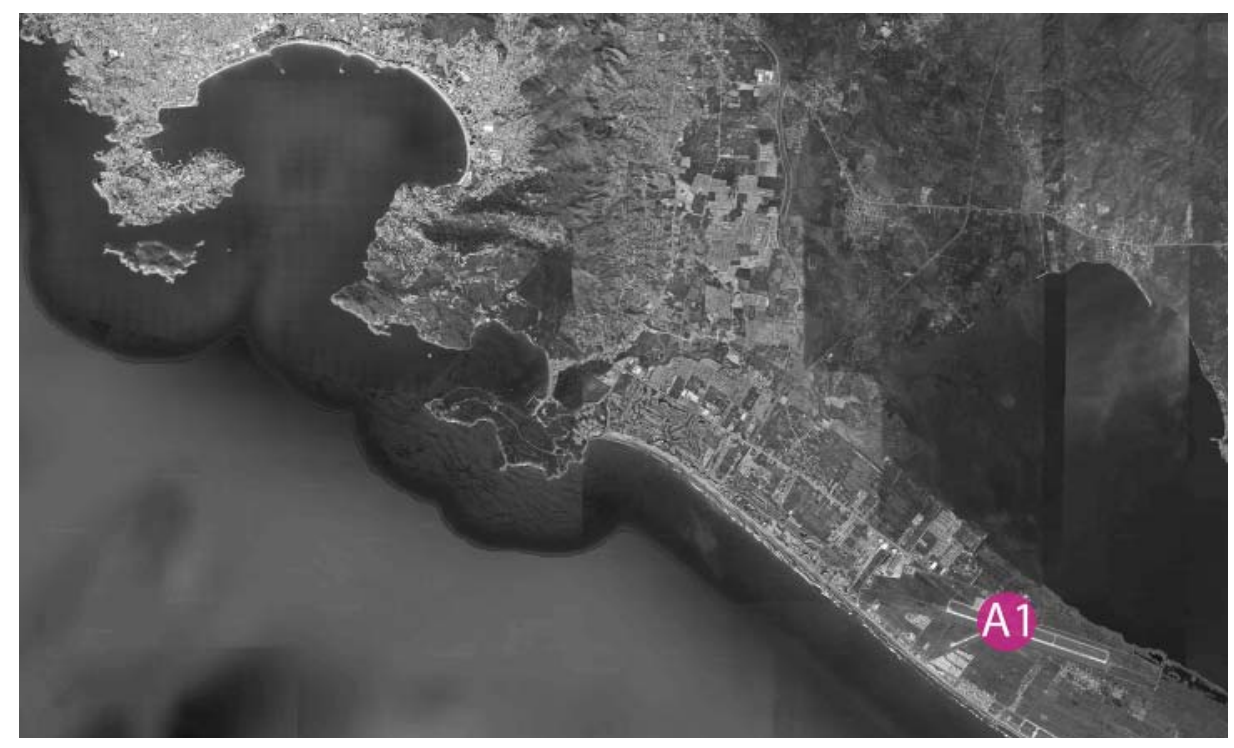

nuevas formas y texturas. La vista del exterior mostró el volumen general, la del interior sorprende por el tino no sólo en destacar las luces y sombras ganadas por el uso de las celosías, sino también porque se capta la escala real del edificio, ya que se halla la imagen poblada de usuarios. Para cerrar, un detalle de la doble fila de tabicones que forman la celosía de los muros laterales acerca a la textura del material prefabricado.

El mismo año de 1956, con motivo del número especial dedicado a la construcción en países cálidos, L'Architecture d'Aujourd'hui insistió en el aeropuerto de Acapulco. La novedad, con respecto al monográfico del año anterior, fue que las fotografías no se repitieron, pues, al igual que en Domus, se prefirió mostrar el edificio en plena actividad ${ }^{50}$. La noticia sobre el nuevo aeropuerto - y sobre todo las espléndidas fotografías de Marilyn Silverstone- no se detuvo aquí, pues también Architectural Design aportó un artículo al tema ${ }^{51}$. Para la londinense no pasó desapercibido que la pista en Plan de los Amates era suficiente para recibir vuelos intercontinentales. El paraíso tropical - ahora perdido - animaba la llegada de viajeros con todas las comodidades del mundo moderno.

En Estados Unidos el interés en los análisis comparativos sobre aeropuertos de todo el orbe se hizo patente de nuevo en diciembre de 1957, cuando Progressive Architecture publicó un número especial que incluyó al aeropuerto mexicano en cuestión ${ }^{52}$. Es interesante que el material fue distinto a lo que ya se había publicado en las revistas citadas antes - aquí el fotógrafo fue Erwin Lang - con lo que se apreciaron distintos aspectos del ya conocido aeropuerto, como la distancia de apenas unos metros que separa los dos grandes muros laterales que cierran la sala principal, 
Aeropuerto de Acapulco a través de la lente de Marilyn Silverstone en la italiana Domus (julio 1956).

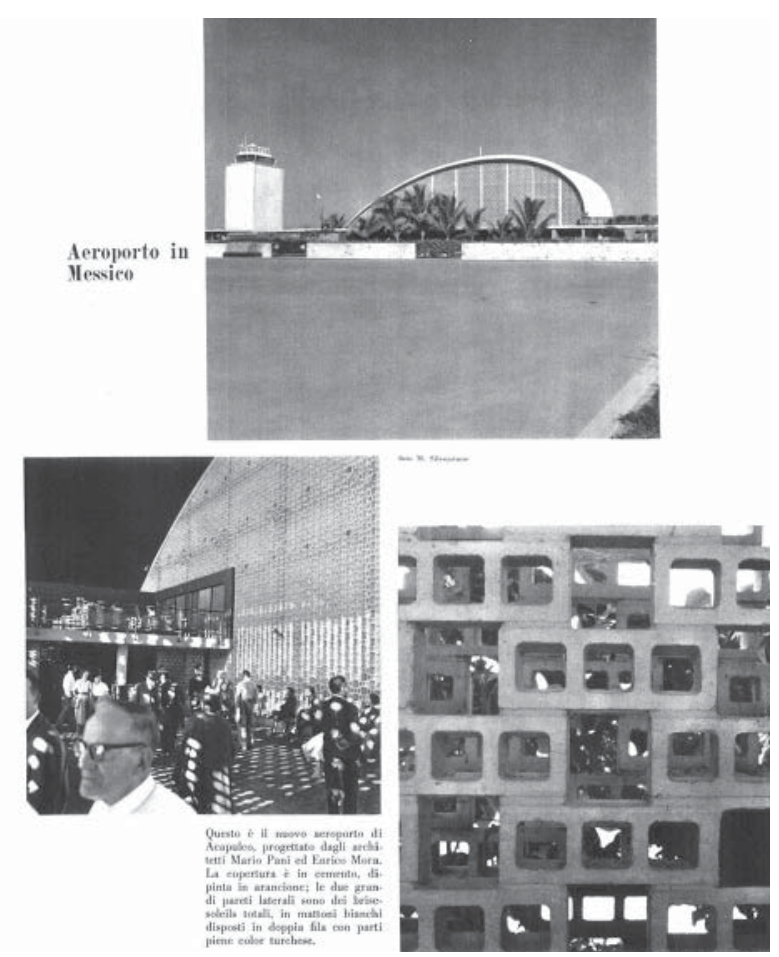

o el volumen de la torre de control, cubierta también con la celosía de tabicones. No deja de sorprender a los ojos del siglo xxi la pequeñísima escala del aeropuerto, en la que entonces era la ciudad turística más importante de México.

Otro artículo de análisis comparativo, no ya sólo de aeropuertos, sino de todo tipo de edificaciones, centrado en las estructuras no ortogonales, se publicó en noviembre de 1958 en The Architectural Review. Ahí tuvo cabida el aeropuerto de Acapulco gracias a su cubierta curva de hormigón $\operatorname{armado}^{53}$. El estudio reparó en los edificios contemporáneos de superficies alabeadas, onduladas, plegadas o inclinadas que se estaban convirtiendo más y más en la orden del día. Es interesante comprobar cómo a finales de la década de 1950 ya se cuestionaba ampliamente en las publicaciones periódicas la idea de que la arquitectura moderna, geométricamente contenida dentro de formas simples y regulares, parecía haber pasado de largo, y estaba siendo ampliada, si no es que sustituida, por un repertorio de estructuras cuyas siluetas intrigantes eran más bien producto de la ingeniería. Por supuesto, el autor de dicho análisis, Robin Boyd, dejó claro que la intención original de esta ruptura provendría necesariamente de los arquitectos.

Casi mediada la década de 1960, de nuevo desde Francia, se encuentra la última noticia relativa al aeropuerto de Acapulco. No sería la única vez que L'Architecture d'Aujourd'hui dedique un recuento sobre

53. Robin Boyd, "Engineering of excitement," The Architectural Review 124, no. 742 (noviembre 1958): 302. 
el acontecer a nivel mundial, esta vez gracias a su número especial "Un siglo de arquitectura”. El artículo sobre la arquitectura mexicana se debió a Irving Nerubay, y en éste se incluyó, entre otros importantes ejemplos, la terminal aérea de la costa del Pacífico ${ }^{54}$. Si bien el texto ofreció una excelente síntesis sobre las obras más representativas de la arquitectura propia, no se utilizó material fotográfico nuevo sino que se repitieron las mismas fotos de Guillermo Zamora que habían sido publicadas en la misma revista desde abril de 1955. Así, con la misma imagen abre y cierra el tema de la difusión del aeropuerto de la ciudad que fuera el destino de ocio más visitado a nivel nacional por varias décadas.

\section{Vivienda}

Ahora bien, el tema de la vivienda en Acapulco estuvo presente en las revistas foráneas tanto con ejemplos de casas aisladas como de edificios en condominio o apartamentos de lujo. En este caso sólo dos publicaciones se interesaron en el asunto. Así, en L'Architecture d'Aujourd'hui se divulgó una residencia de veraneo cuyos autores - no casualmente los mismos que para el aeropuerto- Mario Pani y Enrique del Moral, consolidaban sus vínculos con el puerto turístico a través - de nuevo también- de las fotografías puntuales de Guillermo Zamora ${ }^{55}$.

Por otro lado, cabe comentar que el régimen de propiedad horizontal o condominio fue introducido en México gracias a la labor de Mario Pani, cuyos primeros ejemplos en el Distrito Federal están ampliamente documentados ${ }^{56}$. En Acapulco también se construyó y vendió siguiendo estas pautas administrativas y de diseño. El mejor ejemplo dado a conocer en las revistas extranjeras fue el condominio Los Cocos, de Pani y Salvador Ortega, publicado en agosto de 1960 por The

54. Irving Nerubay, "Mexique," L'Architecture d'Aujourd'hui, no. 113-114 (abril-mayo 1964): 174-77.

55. "Habitation a Acapulco," L'Architecture d'Aujourd'hui, no. 67-68 (octubre 1956): 144 .

56. Véase en especial el número 67 de Arquitectura México (septiembre 1959), dedicado a la obra de Mario Pani.

57. "Condominio in Acapulco," The Architectural Review 128, no. 762 (agosto 1960): 96.
Architectural Review ${ }^{57}$. Es notable que la londinense eligiera esta obra de entre la vasta producción de Pani para recordar, en su sección World, el extenso abanico de la arquitectura moderna mexicana. El inmueble Los Cocos destacaría especialmente por el desarrollo en sección de medios niveles que resolvieron las circulaciones interiores de los ascensores y, también, por el uso de celosías que propiciaron la adecuada ventilación del inmueble. Se va viendo que las referencias al clima tropical y la adaptación de los edificios al mismo, sin grandes malabares tecnológicas, se convirtieron en una constante en estas comunicaciones internacionales. 


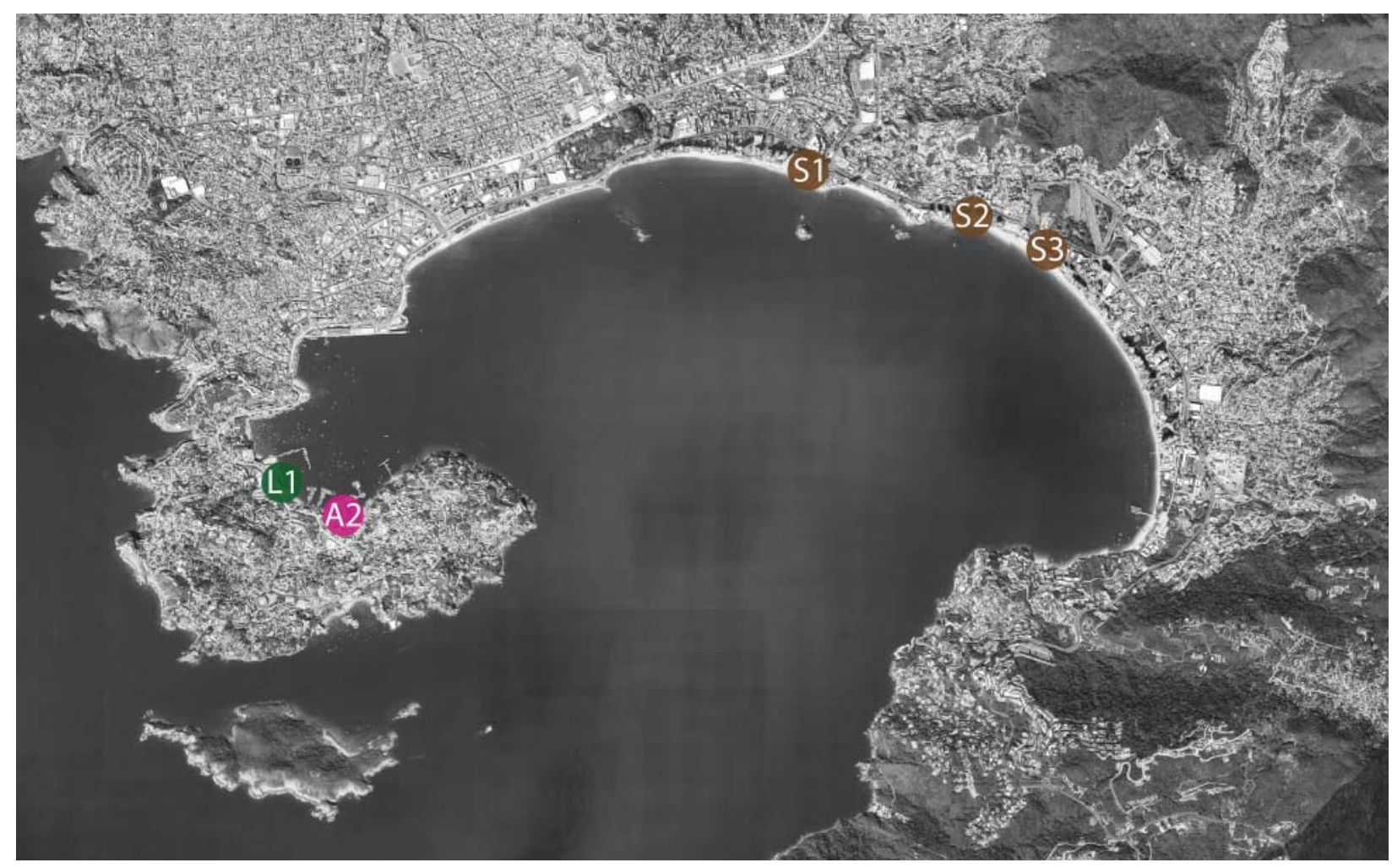

Dos años más tarde, en 1962, L'Architecture d'Aujourd'hui publicaría el mismo edificio Los Cocos aumentando considerablemente la información gráfica, pues lo que habían sido sólo dos pequeñas de yates, L1: Condominio Los Cocos, S1: Hotel Hilton, S2: Hotel Presidente y S3: Hotel Elcano. fotografías en la revista inglesa, en la francesa se convertiría en fotos exteriores, interiores, de detalles, plantas tipo e incluso una pequeña sección esquemática revelando los medios niveles y la distribución de los apartamentos $^{58}$. Este último aspecto - el corte transversal del edificiofue algo que extrañó la publicación londinense por no encontrarlo en la fuente original - Arquitectura México- pues consideró que sólo con la vista del volumen no era posible apreciar cómo se habían resuelto los medios niveles. Como si de una respuesta se tratase, en el artículo francés quedaba clara esta innovadora propuesta de diseño.

Hoteles y club de yates

Dos sedes se repartieron las noticias sobre la arquitectura hotelera del puerto, pero con intenciones bien diferenciadas entre ellas. Las publicaciones de Nueva York, por un lado, y Madrid, por el otro, se interesaron en dar a conocer algunos casos de lo que la industria turística desarrollaba en la bahía de Acapulco.

Por ejemplo, la cadena de hoteles Hilton gozó de difusión en dos de las más importantes revistas neoyorquinas: Architectural Forum

58. "Immeuble 'Los Cocos', Acapulco, Mexique," L'Architecture d'Aujourd'hui, no. 104 (octubre-noviembre 1962): 110-11. 
Club de yates de Acapulco en L'Architecture d'Aujourd'hui (octubre 1956).
59. "Hilton hotels in Mexico," Architectural Forum 100, no. 5 (mayo 1954): 49.

60. "Hilton Plus Statler. A big client gets bigger," Architectural Record 116, no. 4 (octubre 1954): 154-55.

61. "Láminas de hormigón armado," Arquitectura, no. 10 (octubre 1959): 7.

62. "Hotel Presidente (Acapulco)," Arquitectura, no. 44 (agosto 1962): 53.
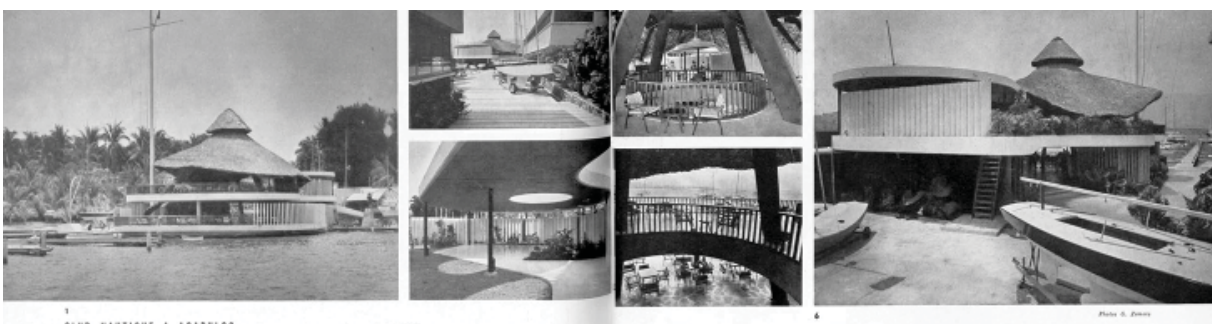

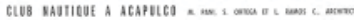
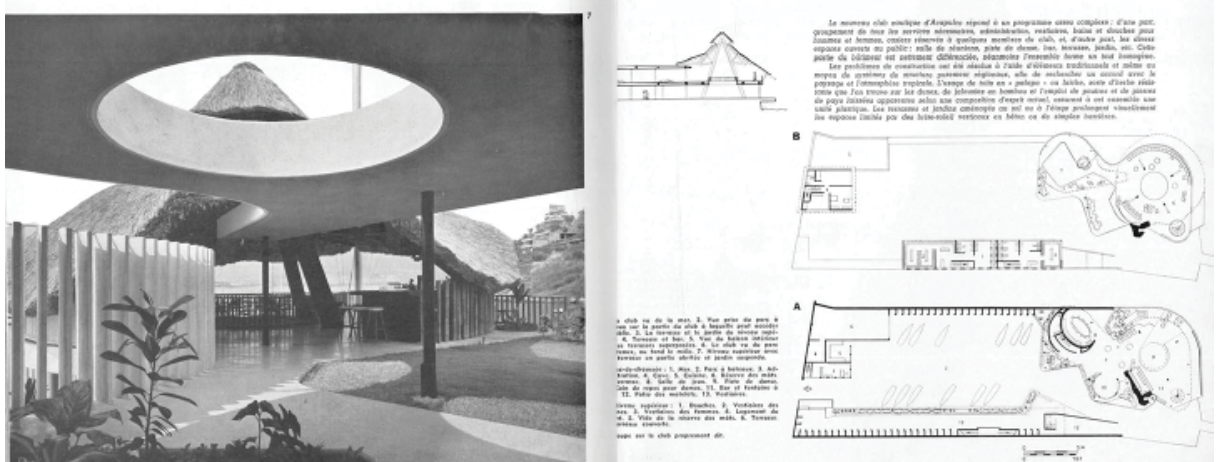

y Architectural Record. La primera mostró, en su sección de noticias, tanto el proyecto para el puerto como para la ciudad de México, ambos del arquitecto mexicano Fernando Parra. La noticia de actualidad destacó especialmente el uso del aire acondicionado y la construcción en hormigón armado a prueba de sismos ${ }^{59}$. Por su parte, Record incluyó los proyectos de Parra en una comunicación que también dio cuenta de otros hoteles del magnate de la industria hotelera ${ }^{60}$. Lo que más interesó en este artículo fue citar la cantidad de habitaciones - para el caso de Acapulco 250- y, por supuesto, el costo neto de la obra que ascendía a los tres millones de dólares. Ambas noticias de 1954 dieron cuenta de la construcción en curso del edificio y de la próxima apertura del centro vacacional durante 1955, no casualmente el mismo año que se inauguraría el nuevo aeropuerto y que se abrieran las rutas comerciales directas desde Los Ángeles y Nueva York.

En Madrid, el interés en el puerto turístico comenzó tangencialmente, pues fue en el extenso artículo que Arquitectura dedicó a Félix Candela en 1959 donde primero se publicó la sorprendente cubierta, abierta hacia el mar, del cabaret "La Jacaranda" en el Hotel Presidente ${ }^{61}$. El verdadero interés en el destino turístico se tendría que fijar hasta 1962, ya que en el monográfico de la revista madrileña se expusieron dos ejemplos de arquitectura hotelera en Acapulco. El primero, el Hotel Presidente de Juan Sordo Madaleno ${ }^{62}$, casa de la cubierta de Candela recién citada y cuya forma ovalada se distinguía en la planta de conjunto que publicó la revista de Carlos de Miguel. Lo que puede sorprender es la 
falta de actualidad, pues el hotel se había finalizado desde 1954, aunque, ciertamente, este monográfico fue un recuento justo de arquitectura mexicana. No obstante Arquitectura no ofreció ningún texto descriptivo de la obra, la información visual - dos fotografías, la planta baja, una planta tipo y la de conjunto- fue suficiente para transmitir el ambiente vacacional, apropiado a la imagen internacional del puerto mexicano.

El hotel Presidente no fue el único que publicó Arquitectura, pues también descubrió el Hotel Elcano, de Imanol Ordorika ${ }^{63}$. En este caso, sí se proporcionó una descripción textual del proyecto arquitectónico, una planta tipo y dos fotografías. Aquí, no sólo las imágenes sino también el texto insistieron en el emplazamiento privilegiado y la belleza del lugar, consolidando en el exterior el conocimiento de la infraestructura turística de Acapulco.

Así, los espacios abiertos, la vegetación tropical y los materiales locales — comolas hojas de palma cubriendo una palapa - fueron algunas de las características que se solían destacar para revelar la arquitectura costeña. En octubre de 1956, las fotografías que publicó L'Architecture d'Aujourd'hui del Club de yates de Acapulco hizo gala de este probado recurso visual ${ }^{64}$. Pero también se notaron cubiertas horizontales de hormigón armado, de perfiles sinuosos, a veces perforadas con huecos circulares, situando el material característico de la modernidad entre el exuberante follaje local. Este ejemplo sería de lo más atrevido - formalmente- de entre toda la obra de Pani. El artículo describió textual y gráficamente, a través de plantas, cortes e imágenes, el recién inaugurado centro de esparcimiento para los amantes de los deportes de vela marítimos.

El mismo club sería retomado una década más tarde con motivo de su adaptación para las competiciones olímpicas en mar abierto. Tanto Arquitectura como Informes de la Construcción citaron esta obra en sus números especiales dedicados a la arquitectura deportiva de México 68. Ambas revistas enfatizaron su adaptación para el evento internacional, llegando a mencionar, incluso, la cantidad de hormigón en metros cúbicos destinada a las mejoras del conjunto ${ }^{65}$.

\section{Urbanismo}

Como se esperaría de una población que pasó de apenas seis mil habitantes a principios del siglo xx a casi cincuenta mil al iniciar la
63. "Hotel Elcano (Acapulco)," Arquitectura, no. 44 (agosto 1962): 55. El arquitecto Imanol Ordorika (19311988), vizcaíno de nacimiento, llegó a México con su familia, exiliado por la Guerra Civil española. Aunque su formación profesional se desarrolló en el país de adopción, no son casuales los vínculos entre su producción arquitectónica y su publicación sólo en la revista madrileña.

64. "Club Nautique a Acapulco," L'Architecture d'Aujourd'hui, no. 67-68 (octubre 1956): 142-43. Proyecto de Mario Pani, Salvador Ortega y L. Ramos.

65. "Club de Yates," Arquitectura, no. 116 (agosto 1968): 22 y "Características de las instalaciones adaptadas," Informes de la Construcción, no. 205 (noviembre 1968): 39: «En el Club de Yates de Acapulco se realizaron las obras de ampliación del malecón, del muelle y la iluminación y abastecimiento de agua en el muelle para las pruebas específicas de los Juegos de la XIX Olimpiada. En dichas obras fueron empleados $4.205,59 \mathrm{~m}^{3}$ de hormigón». 
década de $1960^{66}$, la ciudad fue sujeto de estudios y planes de desarrollo urbano, con el fin de dirigir el crecimiento de las enormes áreas de vivienda de una localidad volcada a la actividad económica terciaria o de prestación de servicios. Así, en su número monográfico de septiembre de 1963, L'Architecture d'Aujourd'hui, divulgó el proyecto de los arquitectos Leduc y Cervantes para Acapulco ${ }^{67}$. En el plano esquemático se aprecia la propuesta de crecimiento urbano para la zona noreste de la bahía.

Así, la infraestructura más característica de la industria turística de Acapulco fueron temas destacados en las revistas extranjeras de arquitectura. La mayor cantidad de noticias, y también el interés principal de las publicaciones, se volcó en la nueva terminal aérea del puerto. Sin embargo, los alojamientos temporales - hoteles, condominios o casas de veraneo- también ocuparon importantes páginas en las publicaciones periódicas. Asimismo, durante los años de estudio, ante el crecimiento exponencial de la población, las propuestas de desarrollo urbano - aunque discretamente - también traspasaron fronteras en el papel impreso.

\section{Las ciudades del norte}

Ciudad Juárez, Chihuahua y Monterrey, Nuevo León, son las únicas poblaciones del norte del país en este análisis de ciudades con más de un tipo de inmueble publicado en las revistas foráneas. De carácter opuesto a Acapulco, las ciudades del norte se caracterizaron por su actividad industrial y comercial. Se comentó antes la actuación de un plan de desarrollo urbano a nivel nacional en otras ciudades de frontera; Ciudad Juárez también formó parte de este programa, y como tal se presentó en el artículo ya citado de L'Architecture d'Aujourd'hui que incluyó varias ciudades mexicanas ${ }^{68}$.

Sin embargo, la noticia que más llamó la atención sobre Ciudad

66. "Instituto Nacional de Estadística y Geografía," Estadísticas históricas de México 2009, consultada 3 febrero, 2014, http://www.inegi.org. $\mathrm{mx} /$ prod_serv/contenidos/ espanol/bvinegi/productos/ integracion/pais/historicas10/ Tema1_Poblacion.pdf. 67. "Urbanisme et Planification," XIII. 18.

68. "Programme National,"
Juárez fue la creación del Museo Nacional en dicha localidad. El fin principal del mismo fue integrar el centro y sur del país con el norte, ese vastísimo territorio desértico que siempre ha parecido a los del centro como un país distinto y distante. De esta manera, la obra de un museo didáctico, con la intención de acercar las culturas mesoamericanas - a través de reproducciones de sus piezas más representativas- al norte del territorio nacional, fue parte del esfuerzo que el gobierno llevaba a cabo en esos años de consolidación de la nación moderna. El proyecto de 
Pedro Ramírez Vázquez y Rafael Mijares apareció como noticia breve en Informes de la Construcción en abril de $1966^{69}$, para ser publicado como artículo extenso casi un año después en su número de marzo de $1967^{70}$.

Entre estas dos comunicaciones de Informes, L'Architecture d'Aujourd'hui publicó este museo del norte en diciembre de $1966^{71}$. Ahora bien, lo interesante, al comparar IC con $A A$ es que la española no menciona de qué tipo de museo se trataba, ya que sólo ofreció la descripción general de los espacios y los materiales, pero sin tocar nunca el tema de lo ahí expuesto. Por el contrario, la revista francesa sí informó sobre las intenciones de un museo didáctico dedicado a las culturas prehispánicas del centro del país en el territorio del norte.

La otra ciudad de este apartado es Monterrey, centro de negocios, industrial y económico, cuyo crecimiento se potenció desde principios del siglo xx con la fundación, en 1900, de la compañía Fundidora de Fierro y Acero de Monterrey. A pesar de su importancia como ciudad industrial durante todo un siglo, y en continuo crecimiento hasta el día de hoy, la presencia de Monterrey durante el periodo de estudio en las revistas extranjeras, es más bien modesta, aunque sí característica del tipo de ciudad referida. Así, las oficinas bancarias, los edificios comerciales y también un ejemplo de servicios, fueron los inmuebles que acapararon las escasas noticias sobre esta ciudad del norte del país.

Por ejemplo, en julio de 1960 aparecía en Architectural Forum la breve noticia - apenas un párrafo y una foto pequeña - de unas oficinas diseñadas por Gustavo Struck, construidas por el Banco Nacional de México (Banamex) en Monterrey ${ }^{72}$. Mucho más interesante fue la publicidad de los aceros Republic Steel en Architectural Record en junio de 1960 y enero de 1961, que divulgaron las oficinas del Banco Popular, diseñadas por Mario Pani, Salvador Ortega y Ramón Lamadrid ${ }^{73}$. No deja de ser irónico que la ejecución de esta torre se realizase precisamente con acero estadounidense proveniente de Ohio, en vez de con el producido en la propia ciudad por la Fundidora de Monterrey. Hay que considerar que el proyecto nació en la capital del país, y, con toda seguridad, los contratistas mantuvieron sus contactos comerciales de fuera del territorio nacional para surtir la materia prima de la edificación.

Sobre Monterrey se cuenta con otra noticia, ahora relacionada con la arquitectura religiosa. La iglesia de San José Obrero, de Candela-
69. "México," Informes de la Construcción, no. 179 (abril 1966): 137. Después de varios años de comunicaciones, notamos que por fin $I C$ aceptó la ortografía mexicana y cambió la desconcertante “ $j$ ” por la correcta " $x$ " en el nombre del país.

70. "Dos museos en México," Informes de la Construcción, no. 188 (marzo 1967): 15-23. Este artículo también dio a conocer el Museo Nacional de Arte Moderno de la ciudad de México.

71. "Musée National à Ciudad Juárez," L'Architecture d'Aujourd'hui, no. 129 (diciembre 1966): 16-17. En el mismo número se publicaría también el monumental Museo Nacional de Antropología e Historia.

72. "Co-op office building in Mexico," Architectural Forum 113, no. 1 (julio 1960): 7.

73. "Publicidad: Republic Steel Corporation," Architectural Record 127, no. 6 (junio 1960): 326-327 y "Publicidad: Republic Steel Corporation," Architectural Record 129, no. 1 (enero 1910): 241. 
74. "Deux Églises au Mexique," L'Architecture d'Aujourd'hui, no. 91-92 (septiembre-noviembre 1960): 166-67.

75. "Panorama de la arquitectura en el 1960," Arquitectura, no. 30 (junio 1961): 14 .

76. Antonio F. Alba, "La arquitectura después de los grandes maestros," Arquitectura, no. 53 (mayo 1963): 36.

77. "Universidad Autónoma de Nuevo León," consultada 30 enero, 2014, http:// www.arquitectura.uanl.mx/ historia.html.
De la Mora, fue uno de los ejemplos a los que L'Architecture d'Aujourd'hui recurrió para ilustrar la arquitectura mexicana en torno a $1960^{74}$. Es evidente que la selección de los casos mexicanos por parte de $A A$ se debió a los arquitectos - muy reconocidos por esos años-y no especialmente al emplazamiento regiomontano. Como sea, San José Obrero se hizo eco - modestamente - en dos ocasiones más. La primera, en la selección de imágenes que realizó Luis Moya para el artículo Panorama 1960 -que tomó como base el número que publicó $A A$ con ese título- y que Arquitectura transmitió a mitad del año $1961^{75}$. La segunda mención se encuentra en un artículo que preparó Antonio F. Alba, también para Arquitectura, publicado en mayo de $1963^{76}$. En ambos casos, la imagen es una más entre una amplia selección de obras contemporáneas y se está obviando la ubicación geográfica para dar protagonismo a la que entonces era una de las realizaciones más recientes de Candela.

También, hay que decir que si bien desde 1946 se creó la carrera de Arquitectura en la Universidad de Nuevo León ${ }^{77}$, no hubo presencia en las publicaciones periódicas foráneas de una "escuela de arquitectura regiomontana", como sí lo hubo de Guadalajara - la segunda ciudad en importancia después del Distrito Federal- cuya "escuela tapatía” se revisará un poco más adelante.

Este análisis hace patente que la presencia del norte del país en las revistas internacionales se debió a la participación de arquitectos de la capital ya muy conocidos y difundidos en el extranjero. También, es interesante comprobar el cambio en el tipo de inmuebles que se publicaron de Monterrey, esto es, arquitectura básicamente financiera y comercial, respondiendo al carácter regiomontano. Sobre Ciudad Juárez, una de las urbes fronterizas más alejadas de la capital, es sintomático comprobar la intención centralista que, desde el gobierno federal, buscó integrar en el norte del territorio los aspectos más característicos de la cultura nacional que por esos años se consolidaba brindando importancia capital a los vestigios del mundo mesoamericano.

\section{La ruta del Golfo de México}

El establecimiento y consolidación de las rutas aéreas comerciales entre la ciudad de México y Europa, a partir de 1948, marcó el fin de la era de los viajes transatlánticos, que por más de cuatro siglos significaron el 


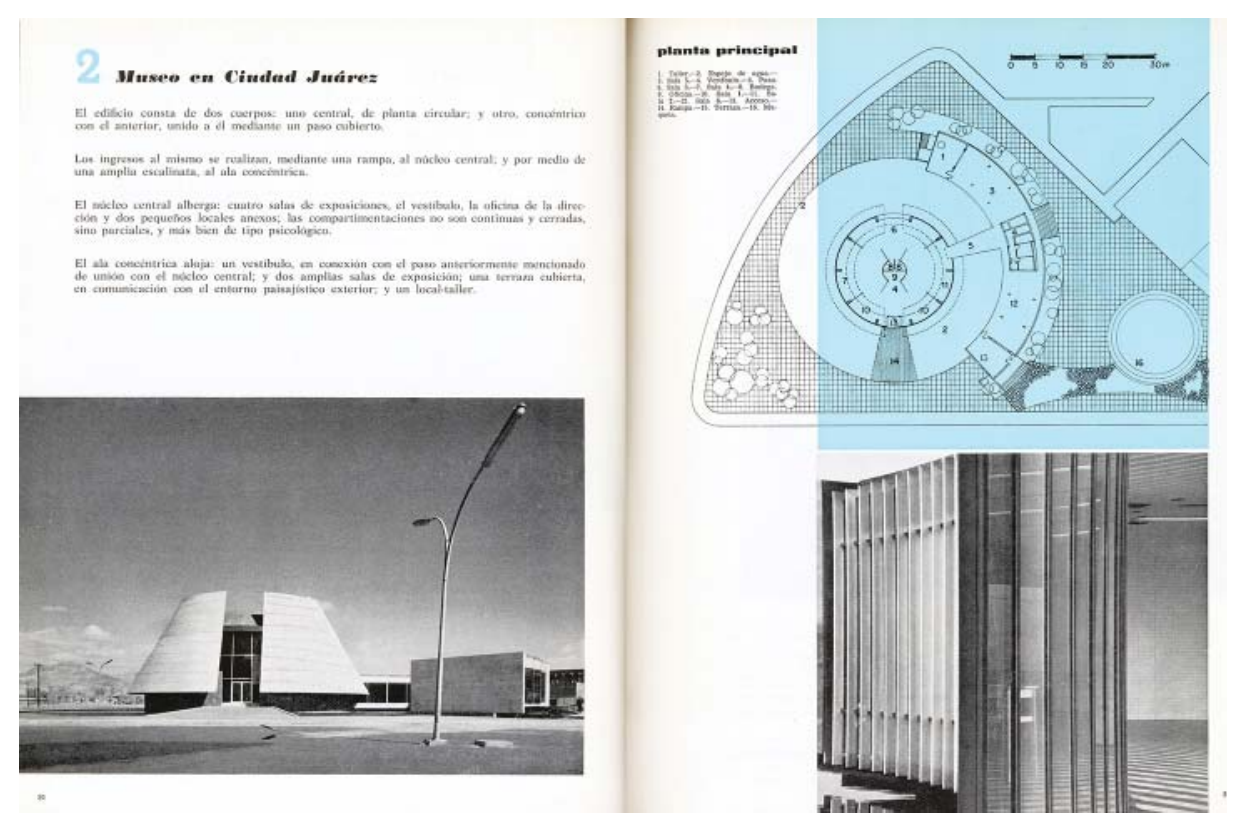

único medio de transporte, tanto de pasajeros como de mercancías, entre el Viejo y el Nuevo Mundo. El puerto de Veracruz, en el golfo de México, fue desde tiempos virreinales la entrada natural al centro del país y a la capital nacional, y la ciudad de Puebla, a medio camino entre el mar y el altiplano central, debió mucho de su crecimiento a su estratégica situación geográfica. La revolución en los medios de transporte intercontinentales - de un promedio de dos semanas de viaje en alta mar se pasó a un vuelo con escalas de apenas 30 horas- dejó al margen del crecimiento económico a ciudades como Veracruz y Puebla, si se comparan con los casos de Acapulco y Monterrey. Sin embargo, es interesante comprobar que, con todo, estas ciudades de la ruta del Golfo, tuvieron presencia en las revistas extranjeras con importantes ejemplos de arquitectura moderna mexicana.

Así, de la ciudad de Veracruz se conoció la sucursal del Banco de México, de Carlos Lazo, que se publicó primero en abril de 1955 en L'Architecture d'Aujourd'hui ${ }^{78}$, con una foto concisa entre otros edificios gubernamentales, y, pocos meses después, Informes de la Construcción dedicaría un extenso artículo a esta obra ${ }^{79}$. Ahora bien, entre los escasos ejemplos de vivienda colectiva de interés social construidos fuera de la capital y publicados en los medios internacionales, se encuentra un conjunto habitacional en las inmediaciones de Veracruz, proyecto de Felipe Salido Torres. En su número dedicado a la construcción en países cálidos L'Architecture d'Aujourd'hui destacó de este grupo de casas el buen uso de materiales económicos para dar texturas, romper la monotonía
El Museo Nacional en Ciudad Juárez, un intento moderno de llevar las culturas del centro y sur del país a la frontera norte. Informes de la Construcción (marzo 1967).
78. "Banque du Mexique a Veracruz," L'Architecture d'Aujourd'hui, no. 59 (abril 1955): 43.

79. "Banco de Méjico, en Veracruz," Informes de la Construcción, no. 75 (noviembre 1955): $\mathrm{s} / \mathrm{p}$. Esta obra y los contenidos de estas comunicaciones se analizan en la sección dedicada a Carlos Lazo en el apartado 6.3 La construcción como noticia. El edificio y su autor. 
del conjunto y ventilar de forma natural con celosías a base de elementos prefabricados ${ }^{80}$.

Se comprueba, al igual que en los casos anteriores, la presencia de los arquitectos formados en la Universidad Nacional de México o en universidades extranjeras, pero cuya carrera profesional se desarrolló tomando como base la capital del país.

La mirada se posa ahora en la ciudad de Puebla, fundamental durante el periodo virreinal y con un papel destacado en la historia nacional durante las primeras décadas de vida independiente del país. La posición geográfica de Puebla, entre la capital y el puerto de Veracruz, ha sido determinante en su historia. Sin embargo, las noticias relacionadas con su arquitectura moderna publicadas en las revistas internacionales, no aparecerían sino hasta los primeros años de la década de 1960. Año importante para la ciudad fue 1962, pues se cumplió el centenario de la legendaria batalla ganada por el Ejército Mexicano a las tropas del Segundo Imperio Francés. Si bien el 5 de mayo se ganó una batalla, no se impidió la Segunda Intervención Francesa en México, pero sí quedó registrada esta lucha como símbolo de unidad entre los mexicanos, muy divididos en facciones e intereses. Lo cierto es que, después de la fiesta nacional por la independencia, el aniversario por la batalla del 5 de mayo sigue siendo una fecha cívica importante para el país.

De esta manera, en mayo de 1962, el presidente Adolfo López Mateos inauguró obras de infraestructura y servicios en el estado de Puebla para conmemorar el importante centenario. Así, se abrió la autopista México-Puebla y el Centro Cívico Centenario 5 de Mayo, cuyas noticias se revisan un poco más adelante. Primero, hay que subrayar que - de nueva cuenta - la principal fuente de consulta en el extranjero para las construcciones de fuera de la capital se concentraron en los números monográficos y, para el caso de Puebla, el de 1963 de L'Architecture d'Aujourd'hui fue sustancial, ya que dio a conocer un hospital, un monumento conmemorativo y, por supuesto, el citado centro cívico.

La ciudad virreinal de Puebla se transformó, durante el siglo xx, en una urbe básicamente industrial - automotriz y textil- y comercial.

80. "Cité d'Habitation a Veracruz," L'Architecture d'Aujourd'hui, no. 67-68 (octubre 1956): 146-47.
El desmedido crecimiento poblacional —denominador común a todo el país - demandó servicios básicos, y, entre ellos, la seguridad social se materializó con un hospital diseñado por el arquitecto Alejandro Prieto 


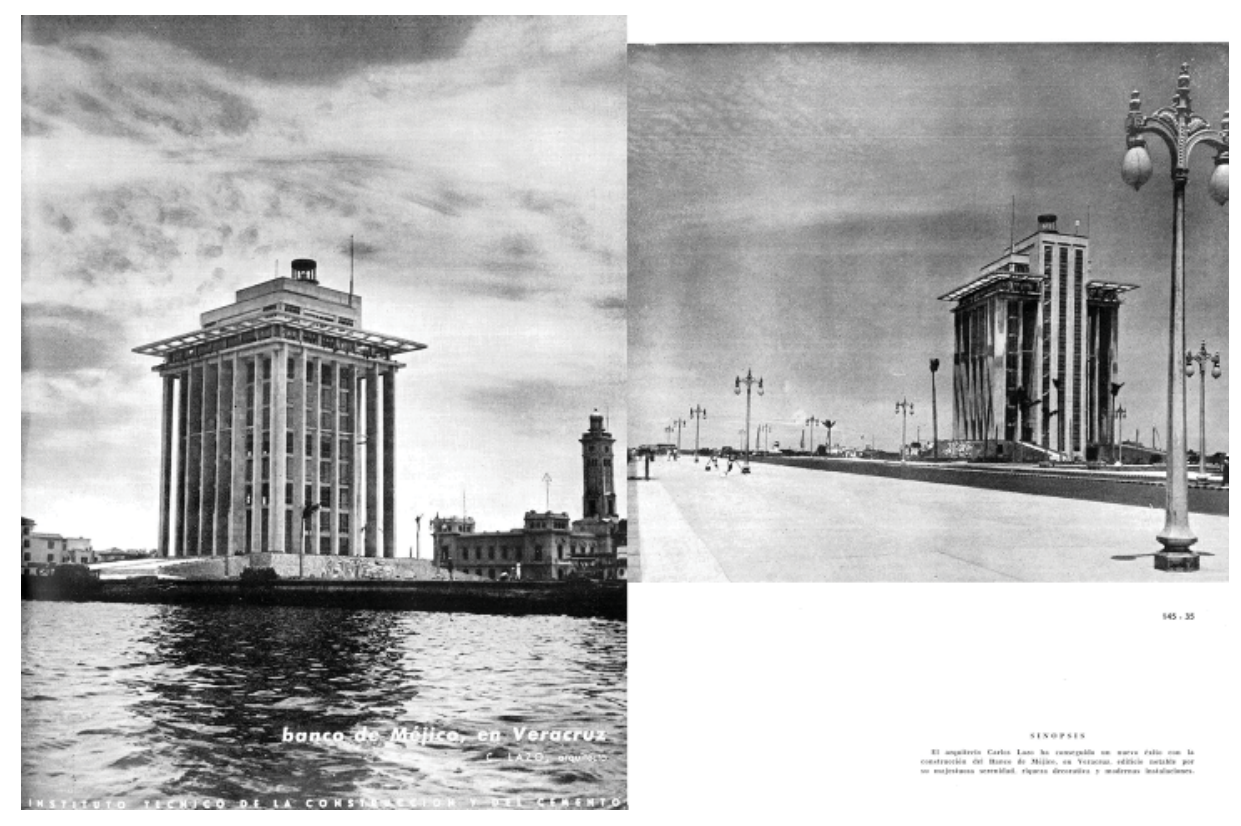

como parte del programa nacional de construcción de hospitales. La edificación - considerando su programa arquitectónico - se anotó como bien adaptada al centro histórico de la ciudad. La acuciosa descripción de $A A$ dio cuenta del emplazamiento, sus desniveles y su forma rectangular en dos fotos y tres plantas. A diferencia de otros casos comentados antes para otras ciudades del país, en Puebla no se integró un centro social, únicamente se construyó la clínica de consultas externas y una pequeña sección para atender urgencias ${ }^{81}$.

Por otro lado, uno de los hitos urbanos que conmemoró el centenario de la batalla de 1862 fue el Monumento a la Libertad, de Jorge Bravo y Fernando Peña, en colaboración con el escultor Rodrigo Arenas Betancourt. En la publicación francesa se vieron los dos tramos de cono truncado que se abren para permitir un espacio interior abierto hacia el cielo, en el que se encuentra el fuego conmemorativo ${ }^{82}$. La factura en piedra volcánica consiguió juegos favorables de texturas y variación de colores y las esculturas alusivas a los protagonistas del hecho histórico se integran con el volumen masivo del monumento. Una de las fotografías publicada muestra algunas personas visitando el monumento, con lo que se comprueba la escala de la construcción. Como nota curiosa, la revista parisina mencionó el objeto de la conmemoración, esto es, la batalla de liberación del pueblo mexicano contra la invasión francesa.

La última noticia que se publicó en el monográfico en relación a Puebla fue el Centro Cívico Centenario $5 \mathrm{de} \mathrm{Mayo}^{83}$. De Guillermo Rossell y Abraham Zabludovsky, el papel impreso devuelve fotos del volumen del
Banco de México en

Veracruz, de Carlos Lazo, en Informes de la Construcción (noviembre 1955.)
81. "Clinique de la Sécurité Sociale a Puebla," L'Architecture d'Aujourd'hui, no. 109 (septiembre 1963): XxI.

82. "Monument de la Liberté a Puebla"' L'Architecture d'Aujourd'hui, no. 109 (septiembre 1963): 42.

83. "Centre Civique et Culturel Memorial de la Bataille au 5 Mai a Puebla," L'Architecture d'Aujourd'hui, no. 109 (septiembre 1963): 36-37. 

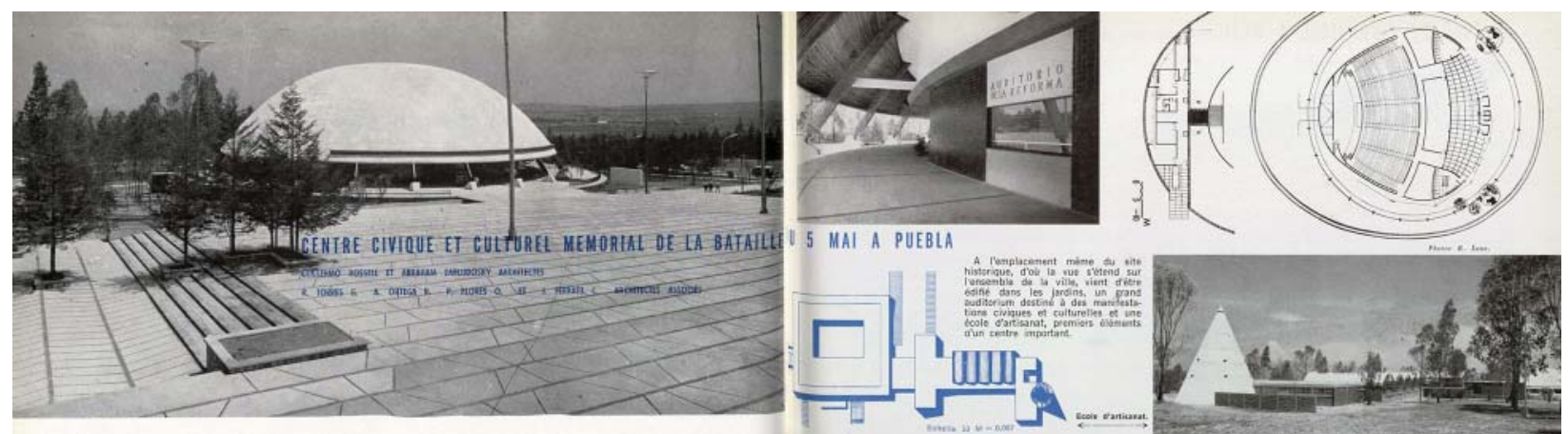

Centro Cívico Centenario 5 de Mayo en Puebla. L'Architecture d'Aujourd'hui (septiembre 1963).
84. El auditorio, con capacidad para dos mil espectadores y butacas de madera, cerró en 2008 por problemas de mantenimiento, para ser reabierto el pasado 15 de enero de 2014 con motivo de la lectura del Tercer Informe de Gobierno del Estado de Puebla, por parte del gobernador Rafael Moreno Valle Rosas. "Milenio," consultada 31 enero, 2014, http:// www.milenio.com/region/ Reabren-Auditorio-Reforma-despues-anos_14_22511. html.

85. "Puebla Cultural Centre," The Architectural Review 136, no. 812 (octubre 1964): 236.

86. Dejo en el texto "Sudamérica" por ser la palabra utilizada por The Architectural Review; sin embargo, hay que puntualizar que México, geográficamente, forma parte de América del Norte. En términos culturales, sería más precisa la palabra "Latinoamérica” para calificarlo.
Auditorio de la Reforma ${ }^{84}$, del pasillo que circunda el volumen esférico y del conjunto de la escuela de artesanías. Una planta de conjunto completó la información gráfica. A pesar de la reducida calidad de impresión, inherente a este tipo de publicaciones en esos años, se distingue la madera laminada de la cubierta e incluso de los apoyos transversales en la pequeña fotografía del detalle del acceso al auditorio que muestra también el pasaje que lo rodea.

Un año después, en octubre de 1964, The Architectural Review publicó también el conjunto cultural ${ }^{85}$, situado a escasos dos kilómetros del centro histórico de la ciudad, en lo que entonces eran las afueras de la población y que hoy en día se descubre completamente rodeado por la mancha urbana. La breve noticia, en la sección de actualidad alrededor del mundo, mostró dos fotos pequeñas — del auditorio, con su cubierta cupular de madera laminada y estructura de acero, y del museo, de estilo miesiano- y un párrafo descriptivo, en el que se hacía notar el contraste de la arquitectura contemporánea con la colonial del casco antiguo. Es interesante la apreciación de la revista londinense, pues asevera que cualquier persona del norte de Europa desearía en sus propios países estos ejemplos arquitectónicos, pero preferiría no verlos en Sudamérica ${ }^{86}$.

Con esta última noticia finaliza el análisis de lo publicado sobre el área geográfica de la ruta del golfo de México. La difusión provino únicamente de Madrid, París y Londres. Se verifica aquí la divulgación no sólo de arquitectura conmemorativa o administrativa, como los casos del Centro Cultural Centenario, en Puebla, o el Banco de México en Veracruz, sino también la infraestructura propia del crecimiento poblacional y sus demandas, como los conjuntos de vivienda de interés social o los hospitales. 


\section{La región de la eterna primavera: Morelos}

Las poblaciones de Cuernavaca, Tequesquitengo y Oaxtepec, en el estado de Morelos, al sur de la ciudad de México, han sido explotadas con fines curativos y de descanso - desde tiempos prehispánicos- y turísticos, ya en pleno siglo xx. Las bondades de su clima - en Cuernavaca la temperatura media anual es de $21,5^{\circ} \mathrm{C}$ y en Tequesquitengo hay 360 días de sol promedio en el año- aunado a manantiales de aguas termales en Oaxtepec, y su cercanía con la capital, han hecho de Morelos un importante destino de ocio a nivel nacional.

La totalidad de las obras localizadas en este triángulo geográfico y publicadas en las revistas internacionales, están directamente relacionadas con actividades recreativas, de descanso o de servicios destinados a las nuevas urbanizaciones de casas de fin de semana o veraneo.

Cuernavaca, una ciudad separada por apenas $85 \mathrm{~km}$ del Distrito Federal, contaba en 1950 con alrededor de 30 mil habitantes. Su población escasamente creció en esa década, pues el censo de 1960 contó 37 mil ciudadanos. La explosión demográfica tuvo lugar durante la década de 1960, ya que la localidad alcanzó los 134 mil habitantes en el conteo de 1970, esto es, la población se triplicó en diez años ${ }^{87}$. Esto se debió a la apertura, en 1966, de la Ciudad Industrial del Valle de Cuernavaca (CIVAC), el polo de desarrollo industrial más importante del estado de Morelos. Este complejo, originalmente en las afueras de la ciudad, está ahora completamente integrado en la desbordada trama urbana de la zona metropolitana de Cuernavaca.

Pero cuando las revistas internacionales publicaron noticias sobre la arquitectura moderna de Cuernavaca, la ciudad todavía se perfilaba como lugar de descanso, destinado únicamente a satisfacer la demanda de nuevas urbanizaciones para casas de fin de semana y los servicios requeridos por las mismas. De esta manera, la primera imagen que reveló la población morelense se encuentra en L'Architecture d'Aujourd'hui en 1955, gracias a un proyecto de Mario Pani ${ }^{88}$. La fotografía más potente mostró una piscina en primer plano y una vivienda de formas sencillas. La vida al exterior se hacía inminente como lo demostraban las hamacas colgadas en la terraza.

En junio de 1956, la publicación angelina Arts \& Architecture, refirió en una página la casa diseñada por el arquitecto Arnold Wasson
87. "Instituto Nacional de Estadística y Geografía." 88. "Habitations individuelles," L'Architecture d'Aujourd'hui, no. 59 (abril 1955): 83. 
89. "House in Cuernavaca," Arts \& Architecture 73, no. 6 (junio 1956): 28.

90. Pocos años después Faber sería ampliamente reseñado en las revistas de arquitectura por la publicación que dedicó a Félix Candela: The shell builder, de 1963.

91. "Four foreign houses," The Architectural Review 128, no. 765 (noviembre 1960): 329-40.

92. "Habitation a Cuernavaca," L'Architecture d'Aujourd'hui, no. 67-68 (octubre 1956): 145.

93. "Mexico. House at Cuernavaca," Architectural Design 29, no. 12 (diciembre 1959): 506.

94. "Résidence a Cuernavaca," L'Architecture d'Aujourd'hui, no. 109 (septiembre 1963): 87.

95. "Strutture e Strutturalismo: Una lettera di Felix Candela," Casabella Continuitá, no. 232 (octubre 1959): 50 y "Láminas de hormigón," 1213.
Tucker, de origen canadiense, afincado en los Estados Unidos ${ }^{89}$. Los créditos del diseño también caen en Colin Faber, como asistente ${ }^{90}$. Cuatro años más tarde, en noviembre de 1960, The Architectural Review expondría la misma casa junto con otras en Melbourne, Australia; Near Porvoo, Finlandia y Sao Paulo, Brasil ${ }^{11}$. Este artículo, mucho más extenso que su precedente, describió a detalle la disposición de espacios y los materiales usados, enfatizando el empleo de materiales locales y el clima tropical. Si bien es cierto, este texto también subrayó la disolución de la casa-caja del primer periodo del Movimiento Moderno, en este caso la apreciación fue corroborada con los cuatro ejemplos publicados por la revista londinense.

De dimensiones mucho más modestas que el ejemplo anterior, la casa construida por Vladimir Kaspé en Cuernavaca y publicada por L'Architecture d'Aujourd'hui en octubre de 1956, puso el acento en el clima cálido y en la adecuada ventilación ${ }^{92}$. Por su parte, Architectural Design, en diciembre de 1959, prefirió el estilo miesiano de Víctor de la Lama para hablar de las bondades del clima mexicano y la fusión — hasta donde lo permitía el sueño moderno- de los espacios interiores y exteriores ${ }^{93}$. Se cuenta con un último ejemplo de vivienda unifamiliar para los fines de semana en la "ciudad de la eterna primavera", publicado de nuevo en $A A$, pero en su número de septiembre de 1963. Así, la casa diseñada por el arquitecto Carlos Reyes Navarro se destacó por la configuración de la planta en el terreno y la interpenetración de espacios ${ }^{94}$.

Ahora bien, las nuevas urbanizaciones promovieron tanto los hitos urbanos como los servicios para los futuros habitantes. Fue el caso de Lomas de Cuernavaca, desarrollo iniciado en 1958 en las colinas de Palmira, que se trazó según el proyecto de los arquitectos Guillermo Rossell y Manuel Larrosa.

Así, de la mano de Félix Candela como calculista y constructor, se erigieron dos estructuras que dieron la vuelta al mundo a través de las páginas de las revistas de arquitectura. La Plaza de los Abanicos, que indicaba el acceso al conjunto, se publicó simultáneamente en Milán y Madrid, en octubre de $1959^{95}$. La llamada plaza es una fuente de planta triangular de $23 \mathrm{~m}$ por lado que divide, a manera de camellón, el acceso vehicular del sitio. Ambos artículos en que se publicó este caso mostraron otros ejemplos de la obra reciente de Candela. 

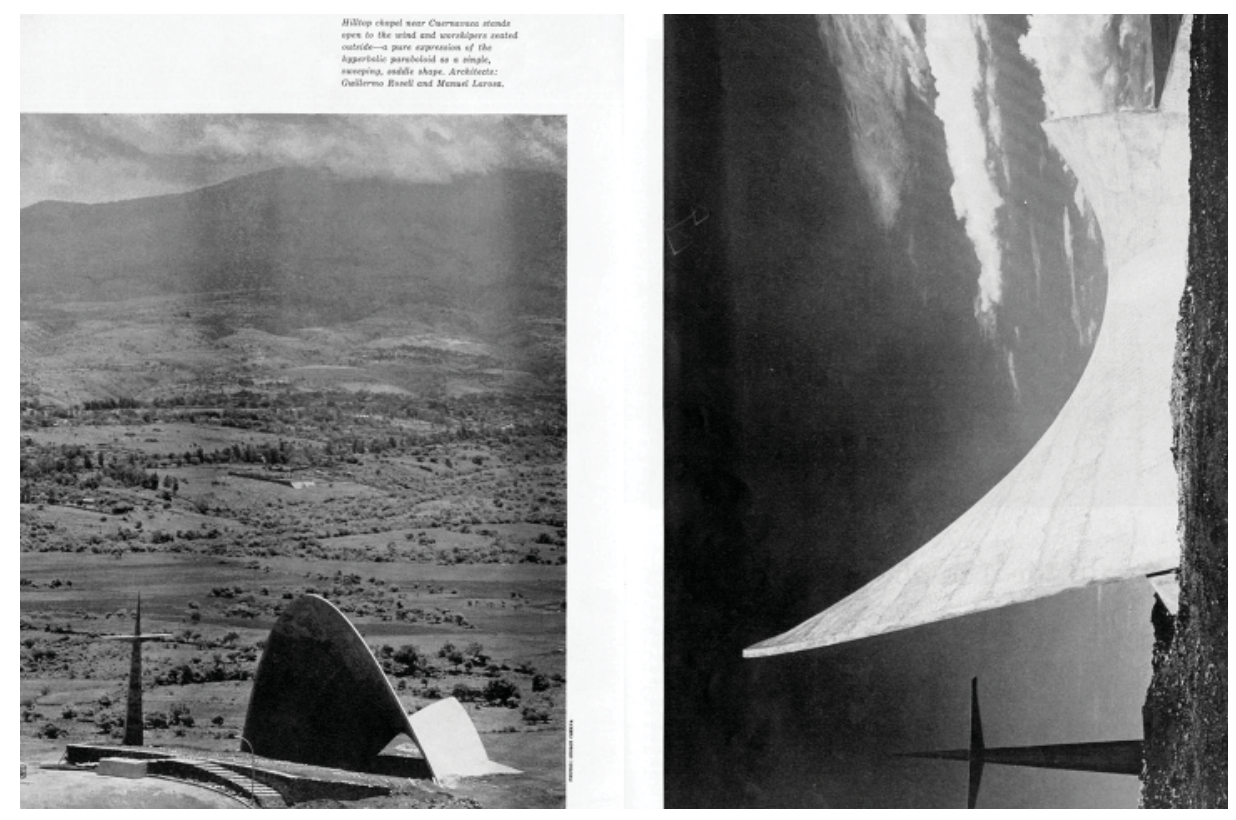

Como parte de los servicios propios del nuevo fraccionamiento, se construyó una capilla en la parte más elevada de las colinas, en un emplazamiento inmejorable. Con diseño del mismo equipo de arquitectos, la parroquia de san Felipe de Jesús sería mundialmente conocida como la "capilla abierta de Cuernavaca”. Arquitectura sería la primera en publicarla, en el mismo artículo que ilustró la Plaza de los Abanicos. Sin duda, lo más espectacular es su cubierta formada por un paraboloide hiperbólico de hormigón armado de $4 \mathrm{~cm}$ de espesor que se corta por un plano inclinado en la boca grande $-30 \mathrm{~m}$ de claro por $21 \mathrm{~m}$ de altura - y por dos planos verticales en la boca de atrás ${ }^{96}$. Un mes más tarde, Architectural Forum dio a conocer las estructuras más recientes del calculista, una de ellas la capilla abierta $^{97}$. La imagen que se observa en la página impresa, que ofrece un paisaje todavía campestre y despoblado, enaltece la singularidad de esta capilla abierta moderna, sobre todo si se compara con el horizonte urbano actual, que luce por completo deforestado.

Dosañosdespués, en diciembre de 1961,L'Architectured'Aujourd'hui publicó también un artículo sobre las últimas realizaciones de Candela. Aunque mucho más tarde que sus predecesoras de habla castellana e inglesa, la francesa aportó material fotográfico original, debido a Leni Iselin $^{98}$. La noticia llamó la atención en las construcciones de hormigón armado de México y sus casi infinitas posibilidades formales, que podían ser más económicas que las tradicionales y también relativamente fáciles de ejecutar. La misma página se ocupó en divulgar, además, la Plaza de los Abanicos.
Capilla abierta de

Cuernavaca, de Félix Candela en Architectural

Forum (noviembre 1959).
96. "Láminas de hormigón," 14-16.

97. "Wizard of the shells," Architectural Forum 111, no. 5 (noviembre 1959): 158-59.

98. "Trois réalisations récentes au Mexique," L'Architecture d'Aujourd'hui, no. 99 (diciembre 1961): 20-21. 
99. "Mexican cliff-hanger," Architectural Forum 108, no. 6 (junio 1958): 196. Las fotografías se deben a Warren Reynolds.

100. "Láminas de hormigón," 8-9 y "Strutture e Strutturalismo," 48-53.

101. J. D. Bennet, "Posibilidades estructurales de las superficies parabólico-hiperbólicas," Informes de la Construcción, no. 148 (marzo 1963): 82.

102. Ove Arup, "Su Felix Candela," Domus, no. 410 (enero 1964): 9-10.
De la capital de Morelos, un poco hacia el sur siguiendo la línea de la autopista México-Acapulco, en lo que todavía es el extenso valle, se encuentra la pequeña población de Tequesquitengo, rodeando el lago del mismo nombre. Con un $98 \%$ de su población económicamente activa dedicada al turismo y una temperatura media anual de $25^{\circ} \mathrm{C}$, esta localidad se ha convertido en la capital nacional del esquí acuático, la actividad deportiva más destacada del lugar.

Casi al finalizar la década de 1950, un ejemplo de la industria turística de Tequesquitengo llegó a la neoyorquina Architectural Forum. Una fotografía tomada desde el lago muestra cómo diversos volúmenes ocultan prácticamente la geografía propia del sitio y construyen un paisaje artificial de terrazas y ventanales abiertos hacia varios puntos del cuerpo de agua. El lector intenta imaginar, a través de estas reproducciones en blanco y negro, la metáfora — citada por la revista — de una buganvilia colorida creciendo tenazmente en lo escarpado de un acantilado. Paralelepípedos con usos distintos se comunican por medio de pasillos descubiertos, como se comprueba al ver una segunda imagen tomada desde la carretera de acceso al hotel y, en una tercera, que muestra uno de los pasajes, que contrasta la vegetación exterior y el sol radiante con las líneas rectas del pasillo abierto. Se hace referencia al hotel que Mario Pani construyó en Tequesquitengo y que publicó Architectural Forum en junio de $1958^{99}$.

Las siguientes noticias pertenecen todas al mismo hito urbano: la entrada a un fraccionamiento residencial en el lago de Tequesquitengo. Su diseño y construcción se debió, al igual que en Lomas de Cuernavaca, a los arquitectos Guillermo Rossell y Manuel Larrosa, así como a Félix Candela. De esta manera, el doble voladizo formado por paraboloides hiperbólicos en abanico, de hormigón armado de $4 \mathrm{~cm}$ de espesor y $32 \mathrm{~m}$ de longitud, se publicó - al igual que la Plaza de los Abanicos- en octubre de 1959 en Arquitectura y en Casabella ${ }^{100}$. Pasarían más de tres años antes de que esta obra reapareciera en los medios internacionales. Desde España, Informes de la Construcción, en marzo de 1963, la aprovechó para ilustrar un artículo sobre las posibilidades estructurales de las superficies parabólico-hiperbólicas ${ }^{101}$. La última mención encontrada sobre esta atrevida estructura está en Domus, en enero de 1964, en un artículo firmado por Ove Arup sobre la obra de Félix Candela ${ }^{102}$. A diferencia, por 

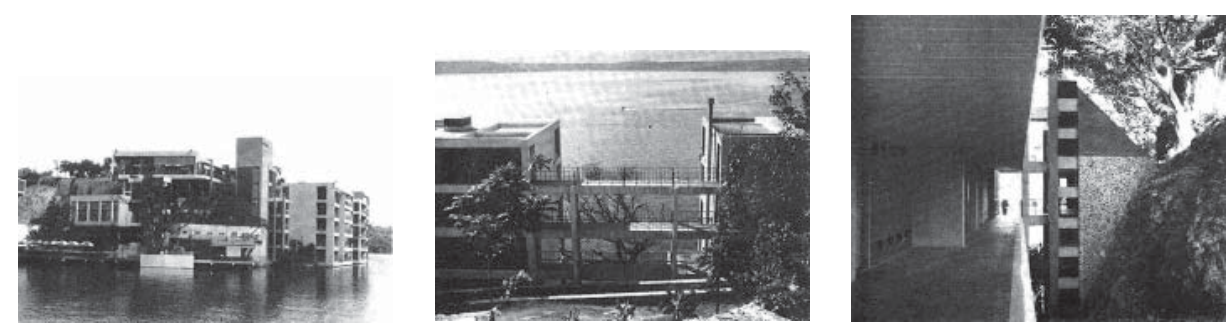

ejemplo, de Architectural Forum, en que hay un claro predominio de las imágenes sobre el texto, este análisis prefirió la narración al extensivo uso de las fotografías.

Para continuar, se sigue la línea virtual trazada desde Cuernavaca hasta Tequesquitengo, y que ahora toma dirección hacia el nororiente para sugerir un triángulo que tendría su tercer vértice en Oaxtepec, y que cierra así la geografía analizada de Morelos a través de las publicaciones periódicas internacionales. Oaxtepec, $80 \mathrm{~km}$ al sur de la capital del país, es un poblado de origen prehispánico, que fue lugar de descanso de los emperadores mexicas debido a sus aguas termales minerales de propiedades curativas. Dedicado desde siempre a la agricultura y al turismo local, se masificaron sus servicios turísticos a partir de 1964, con la apertura del balneario "Centro vacacional Adolfo López Mateos", perteneciente al Instituto Mexicano del Seguro Social y con una extensión de 120 hectáreas.

La construcción de un domo geodésico de 28 toneladas y casi 61 $\mathrm{m}$ de diámetro, levantado por Alcomex, una subsidiaria de la compañía Alcoa, pionera en industrializar el aluminio, fue el motivo por el que se sitúa Oaxtepec en este análisis. El manantial de aguas termales sulfurosas, principal destino turístico de esta población, se cubrió con esta gigantesca estructura cuando el sitio se abrió como balneario popular en 1964. La sorprendente estructura tuvo una primera aparición en L'Architecture d’Aujourd'hui en septiembre de $1965^{103}$. La revista señaló no sólo el domo tubular de aluminio sino también los servicios complementarios que ofrecía el nuevo centro recreativo, como hospedaje, restaurante o diversas instalaciones deportivas. A los pocos meses se repitió la imagen que, como en la mayoría de los casos que aquí se comentan, revelan paisajes todavía idílicos.

Así, Architectural Design, en enero de $1966^{104}$ e Informes de la Construcción en mayo del mismo año ${ }^{105}$, publicaron breves noticias sobre esta obra. La primera, como parte de un artículo que mostró ejemplos
Hotel a orillas del lago de Tequesquitengo, Morelos. Obra de Mario Pani publicada en Architectural Forum (junio 1958).
103. "Dome géodésique au Mexique," L'Architecture d'Aujourd'hui, no. 122 (septiembre 1965): LXV.

104. Z. S. Makowski, "A survey of recent three-dimensional structures," Architectural Design 36, no. 1 (enero 1966): 31.

105. "México," Informes de la Construcción, no. 180 (mayo 1966): 99. 
Domo geodésico en el balneario de Oaxtepec, Morelos. Architectural Design (enero 1966).
106. Mariano Bayón, "Hacia una tecnología integral," Arquitectura, no. 102 (junio 1967): 45.

107. "Instituto Nacional de Estadística y Geografía.”

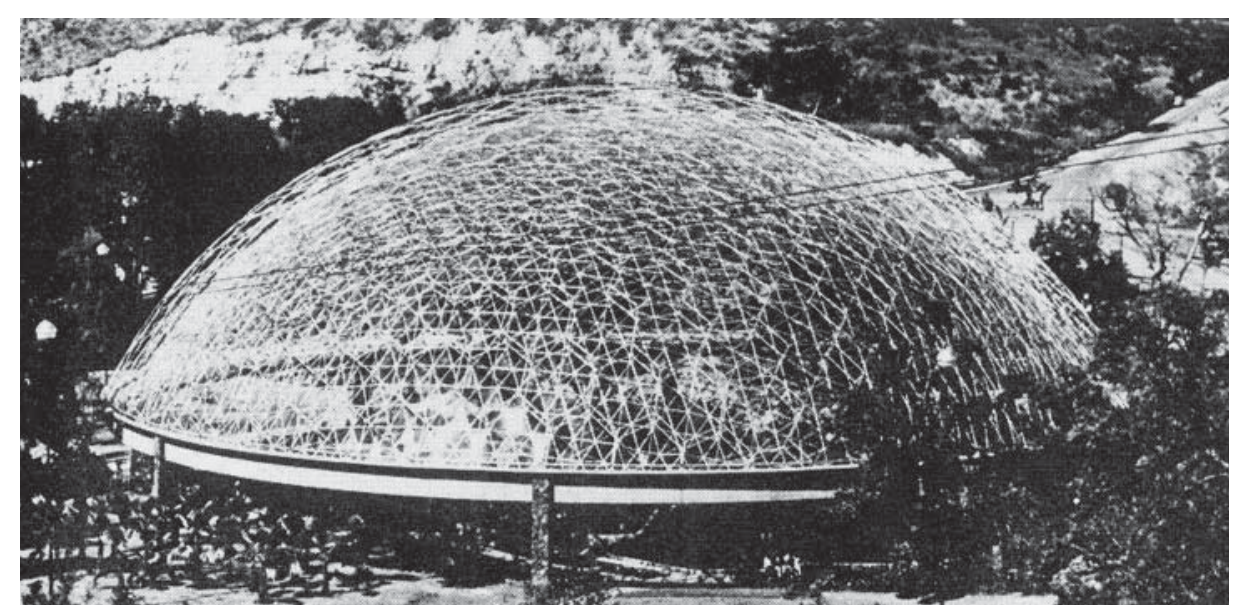

alrededor del mundo de estructuras tubulares y la segunda en su sección de Noticias. Ambas revistas proporcionaron el nombre de la compañía productora del material, no obstante, para ninguna de las dos fue importante mencionar el lugar exacto de su edificación. El domo de Oaxtepec llegaría también a Arquitectura, en junio de $1967^{106}$, gracias a la traducción de Mariano Bayón al artículo originalmente publicado en Design.

Este análisis pone de manifiesto el interés de las publicaciones en mantener la imagen del estado de Morelos como destino turístico, no obstante el incipiente desarrollo industrial de la década de 1960, potenciado por la creación de la Ciudad Industrial del Valle de Cuernavaca. Con el paso de las décadas, y hasta el momento actual, se confirma que ambas industrias, la turística y la industrial, se mantienen en esta zona geográfica, lo que ha generado un crecimiento desmesurado, no sólo en Cuernavaca sino en casi todas las poblaciones aledañas, formando una de las zonas metropolitanas más extensas cercanas a la ciudad de México.

\section{La Escuela Tapatía: Guadalajara}

Fundada definitivamente en 1542 en un valle del occidente de México, Guadalajara, con una economía basada en la industria - especialmente en la tecnología de la información - aunque también del calzado, los textiles y el procesamiento de alimentos, se ha convertido en la segunda ciudad más extensa del país. Su población, al finalizar la primera década del siglo XXI, fue de 4 millones 500 mil habitantes, y continúa en aumento. En relación al periodo de estudio, hay que mencionar que la población en 1950 era de apenas unos 380 mil habitantes, en 1960 casi se duplicó, al alcanzar los 740 mil ciudadanos y diez años más tarde, en el censo de 1970 se contaron alrededor de 1 millón 200 mil personas ${ }^{107}$. 
Ahora bien, para la creación de la única "escuela de arquitectura" con presencia en los medios impresos extranjeros fue fundamental que durante la década de 1940, Guadalajara vivió tranquilidad social y política, así como crecimiento constante en la demografía, el comercio y la industria. El remonte económico que propició el fin de la Segunda Guerra Mundial coincidió con la época de estabilidad política del país, y también fomentó los planes de mejoras urbanas y equipamiento. Además, se constata que «la época de mayor auge económico coincidió con una época de gran calidad arquitectónica» ${ }^{\mathbf{1 0 8}}$ en la ciudad de Guadalajara.

Hasta 1948 no existió una escuela de arquitectura en la capital de Jalisco y las construcciones se realizaban por ingenieros locales o arquitectos egresados de la única escuela de arquitectura del país, la de la ciudad de México. Pero más allá de este dato anecdótico, algo que resultó esencial en la conformación de la nueva escuela tapatía, fue el reclutamiento o importación de profesores europeos ${ }^{109}$. La situación de posguerra en Europa facilitó que muchos profesionales de la arquitectura y la construcción estuviesen dispuestos a cruzar el Atlántico en busca de mejores oportunidades de desarrollo. También, dado el nivel de especialización que se buscaba para los nuevos cursos de arquitectura, fue más eficaz llevar a México, desde varios países europeos como Austria, Alemania, Italia o España, a los nuevos profesores que contratarlos de la propia Escuela de Arquitectura de San Carlos de la ciudad de México, pues los honorarios excedían los presupuestos iniciales del estado de Jalisco ${ }^{110}$.

De esta manera, la pluralidad académica que se ganó gracias a los profesores extranjeros, que confrontaban diferentes maneras de pensar y hacer, «abrió paso a una nueva manera de entender y hacer la arquitectura, local y globalmente» ${ }^{111}$. Así, en 1955 recibieron su título de arquitecto los primeros egresados de la Escuela de Arquitectura de la Universidad de Guadalajara. Los pilares de esta nueva escuela, fundamentales en el quehacer arquitectónico tapatío, se resumían en el entendimiento del objeto arquitectónico en relación con la ciudad, la incorporación de nuevas tecnologías constructivas y la experimentación geométrica ${ }^{112}$. Esto se hizo evidente sobre todo en edificios de escala mayor, casi siempre públicos o de carácter colectivo y en la transición que sufrió la población, que pasó de ser una ciudad provincial a una metrópoli.
108. Héctor Mendoza Ramírez, "Aportación de la Escuela Tapatía. Edificios de carácter colectivo de 1957 a 1968 en el estado de Jalisco" (Tesis de Doctorado, Universidad Politécnica de Cataluña, 2004), 107.

109. Mendoza, "Aportación de la Escuela Tapatía," 10.

110. Mendoza, "Aportación de la Escuela Tapatía," 21-23.

111. Mendoza, "Aportación de la Escuela Tapatía," 60.

112. Mendoza, "Aportación de la Escuela Tapatía," 11. 
113. "Eglise a Guadalajara, Mexique," L'Architecture d'Aujourd'hui, no. 52 (febrero 1954): XXIII.

114. "Iglesia de san Luis Gonzaga en Guadalajara," Informes de la Construcción, no. 66 (diciembre 1954): s/p. Número especial dedicado a la arquitectura religiosa moderna. El único ejemplo de México es éste de Guadalajara, entre otros de España, Estados Unidos, Francia, Alemania, Inglaterra, Italia y Suiza.

115. "Arquitectura México," Architectural Design 28, no. 10 (octubre 1958): 415 y "Nuevo Mercado Libertad, Guadalajara, Jal., México," Architectural Design 30, no. 10 (octubre 1960): 427.

116. "Mexico. Footbridge," Architectural Design 30, no. 7 (julio 1960): 257.

117. Alejandro Zohn (19302000) fue de los primeros egresados con título de arquitecto de la Escuela de Arquitectura de Guadalajara en 1955. Su obra publicada en las revistas extranjeras se puede consultar en el apartado 6.3 de esta tesis.
Antes de la Escuela Tapatía, incursiones de la capital en occidente

El caso de las noticias internacionales sobre la arquitectura moderna de Guadalajara es muy distinto a las otras ciudades y zonas antes estudiadas. Si se considera el inicio de los primeros cursos de arquitectura y la fecha de los primeros egresados con título de arquitecto - esto es, entre 1948 y 1955- se entiende que la presencia de esta nueva escuela en las publicaciones periódicas no se daría sino hasta varios años después, cuando la producción local pudiera equiparase con la nacional, en especial con la capitalina. Resulta también sorprendente que el empuje inicial de esta escuela consiguiera logros tan asombrosos como para conquistar las revistas especializadas durante el periodo de estudio.

Sin embargo, pocos años antes de este suceso, Guadalajara tuvo una primera incursión en los medios, con la publicación, en 1954, del diseño de Enrique de la Mora para la iglesia de San Luis Gonzaga, sita en una nueva urbanización al sur del centro histórico. En febrero, la perspectiva del proyecto tuvo cabida en una página de L'Architecture d'Aujourd'hui ${ }^{113}$; ese mismo año, en diciembre, Informes de la Construcción proporcionó un artículo completo sobre el tema ${ }^{114}$. Sorprende el diseño de una nave única en forma de cúpula elipsoidal que se levanta desde el suelo; la misma cubierta define el espacio centrado del interior, integrando presbiterio y nave de feligreses. El volumen, por el exterior, de aplanado uniforme, sólo se interrumpe por una franja de vidrieras ocupando el sentido de meridianos y paralelos.

\section{La Escuela Tapatía en AD y AA}

Con todo y que no se puede negar la delantera que siempre caracterizó a L'Architecture d'Aujourd'hui en dar a conocer información internacional, para el caso de la escuela tapatía la revista francesa quedó bastantes años detrás de la inglesa Architectural Design, publicación que descubrió la temprana obra de Alejandro Zohn y la difundió puntualmente entre 1958 y 1960. Así, el mercado Libertad ${ }^{115}$ y un puente peatonal en el parque Agua Azull16 fueron los primeros ejemplos que se conocieron fuera de México de la significativa producción local jalisciense. Sin embargo, estas referencias no dejan de ser un caso aislado, centrado en la figura de un solo arquitecto ${ }^{117}$, insuficiente para dar una idea completa de la riqueza de lo que se estaba produciendo en Guadalajara por esos años. 


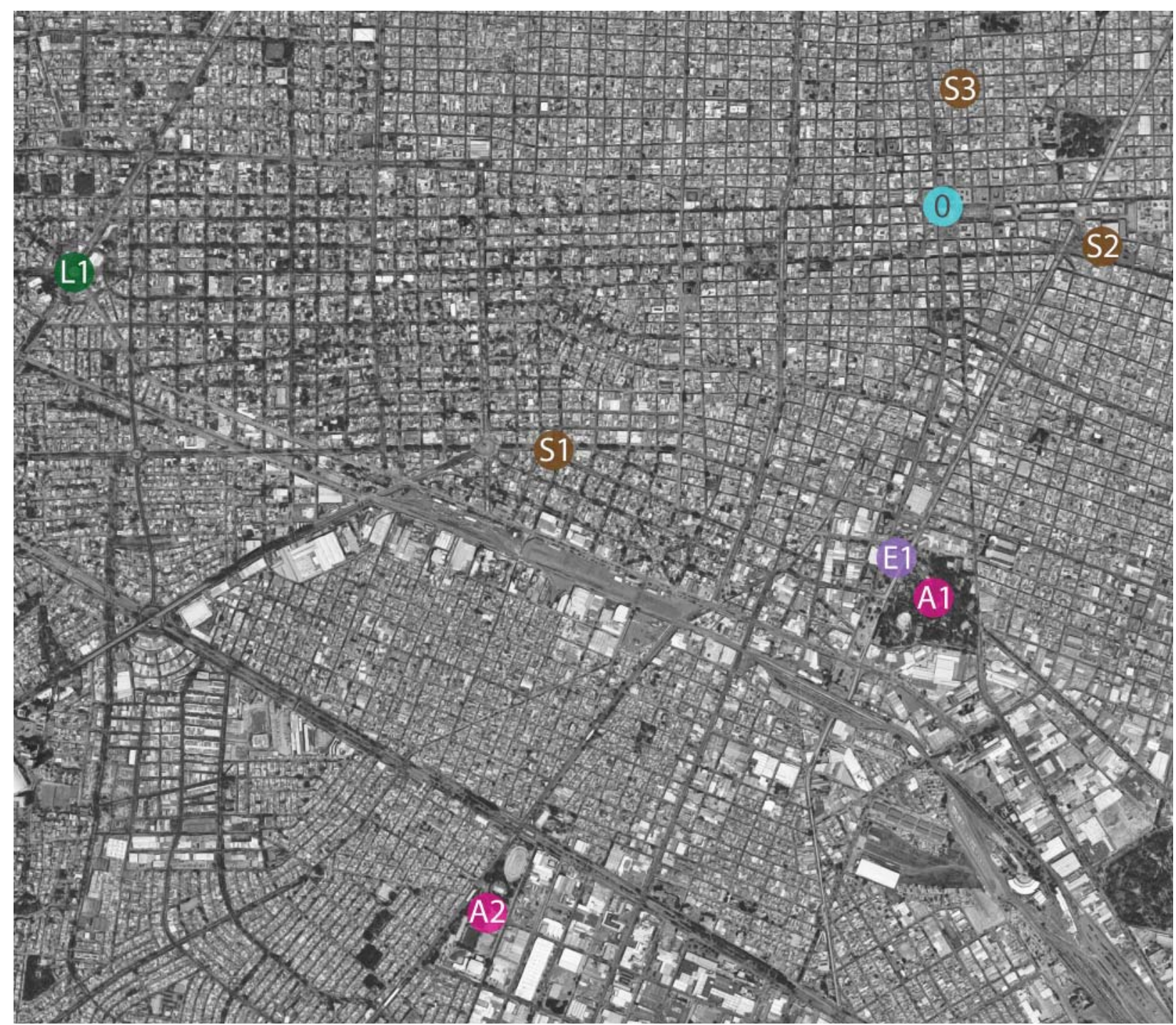

Pero ahora hay que volver a L'Architecture d'Aujourd'hui y brindar una perspectiva más amplia del acontecer arquitectónico que refrescaba al occidente mexicano. Como se ha insistido para otras secciones de este apartado, el ejemplar que concentró la mayor cantidad de obras de fuera de la capital fue el monográfico de 1963. Para valorar la información sobre la nueva escuela tapatía, es conveniente recordar el anterior monográfico de $A A$ - el número 59- y comparar a grandes rasgos algunos aspectos de su edición. En 1955, la mayor parte de la información giró en torno a grandes obras nacionales, como la Ciudad Universitaria, el Centro Urbano Presidente Juárez, el Pedregal de San Ángel, la Secretaría de Comunicaciones y Transportes o el aeropuerto de Acapulco. Hay que notar que, con excepción de este último caso, y del Banco de México en Veracruz, todos los edificios publicados en ese número se ubican en la ciudad de México.

Para 1963 los usos se diversificaron y el número especial aportó ejemplos comerciales, oficinas, centros médicos, bibliotecas, el Instituto

Guadalajara, Jalisco. 0: Centro Histórico

A1: Parque Agua Azul

A2: Unidad Deportiva

Adolfo López Mateos

E1: Biblioteca y Casa de Cultura

L1: Torre Minerva

S1: Iglesia de San Luis Gonzaga

S2: Mercado Libertad

S3: Mercado Alcalde 
118. Julio de la Peña (19172000) fue cofundador de la Escuela de Arquitectura de Guadalajara y uno de sus primeros profesores locales.

119. "Église pour un nouveau quartier de Guadalajara," L'Architecture d'Aujourd'hui, no. 109 (septiembre 1963): XVII.

120. "Bibliothèque maison de la culture a Guadalajara," L'Architecture d'Aujourd'hui, no. 109 (septiembre 1963): 36-37.
Politécnico Nacional, iglesias, hoteles, penitenciarias, centros deportivos, fábricas, laboratorios, mercados, residencias, unidades habitacionales y edificios de apartamentos. En general, se trató de edificios aislados de su contexto urbano, y de escala mucho menor que los publicados en la década previa. Pero lo más sorprendente de este número no serían los edificios en sí, sino la gran cantidad de ellos, que proporcionaron material más que suficiente para la publicación. Para este ejemplar fue sustancial que no sólo se diversificaron los usos, sino que se amplió considerablemente la geografía, ya que se salió de la capital y se alcanzaron puntos que nunca antes se habían citado en los medios internacionales.

Así, se agrupó en este número especial lo relativo a la ciudad de Guadalajara y lo que hoy se conoce como Escuela Tapatía. Ahora bien, y volviendo a uno de los pilares que la propia escuela promovió -la experimentación geométrica- resulta un buen ejemplo la iglesia de San Javier, de Julio de la Peña ${ }^{118}$, muy distinta en su forma a la que se comentó antes de Enrique de la Mora.

A unos nueve $\mathrm{km}$ del centro histórico de la ciudad, en las colinas de San Javier, un gigantesco techo a dos aguas, levantado desde el suelo, envuelve la nave principal de la iglesia. La construcción fue parte de los servicios comunitarios de una nueva urbanización que contó con centros comerciales, sucursales bancarias, estación de policía, zona de recreo con parque y jardín de niños. Una pequeña foto del exterior del volumen, una planta y una foto del presbiterio - que muestra un Cristo crucificado como único ornamento del retablo- dan una idea bastante cercana de esta propuesta formal ${ }^{119}$.

Del mismo autor, Julio de la Peña, en otra zona de desarrollo urbano de la ciudad - Agua Azul - al sur del centro histórico y a tan sólo unos dos km de distancia, la Biblioteca del Estado y Casa de la Cultura asombra por sus paralelepípedos limpios, sin ornatos, con ventanas diminutas. Los volúmenes recuerdan a algunas imágenes de archivo de la Biblioteca Central de la UnAM antes de ser recubierta por sus murales. Este conjunto se completaría con la creación de un pequeño museo arqueológico ${ }^{120}$.

Ahora bien, con la intención de dotar de servicios y extensas áreas verdes públicas, se trabajó en la zona de Agua Azul —nombre debido a un manantial que tuvo ahí su fuente- cuya principal realización consistió en la apertura de un parque público. Parte de la infraestructura fue un 
teatro al aire libre y un puente peatonal — que ya se había visto publicado también en $A D$ - además de la recién citada Biblioteca del Estado y Casa de la Cultura.

Entonces, el teatro al aire libre se formó con un cascarón de hormigón armado, de ángulos agudos y planta trapezoidal, que cubre el escenario hacia el frente y los camerinos en la parte posterior. Esta innovadora propuesta de la arquitectura moderna se integró con la idea clásica del anfiteatro dispuesto en semicírculo. El proyecto se debió a Alejandro Zohn, quien utilizó magistralmente no sólo los nuevos materiales sino que explotó la relación estructura-espacio, derivada de las enseñanzas indirectas de Pier Luigi Nervi ${ }^{\mathbf{1 2 1}}$. Así, una imagen del paraboloide hiperbólico que envuelve el escenario, lanzando sus formas apuntadas y rígidas a las alturas, llegó a los lectores franceses en septiembre de $1963^{122}$. Una planta del conjunto, señalando la disposición de las gradas a cielo abierto, y dos más de la estructura de hormigón armado - una de la cubierta y otra del interior- completaron la información visual de esta noticia de actualidad. A poca distancia del teatro al aire libre, en el mismo parque Agua Azul, un arco parabólico de hormigón que hace las veces de puente peatonal, llegó también al monográfico de L’Architecture d'Aujourd'hui' ${ }^{123}$.

Al sur poniente del parque Agua Azul, la Unidad Deportiva Presidente López Mateos — también de Zohn - se construyó en quince hectáreas. Rodeada de cuatro vías de circulación, la más importante dirige directamente al centro de la ciudad, a unos cinco $\mathrm{km}$ de distancia. El artículo que divulgó la unidad deportiva describió el conjunto, que cuenta con piscina, velódromo, gimnasio, varias canchas de fútbol, basquetbol, volibol, frontones, juegos infantiles, pista de patinaje $y$ gradas a cielo abierto ${ }^{124}$. El texto notó que, a pesar que las instalaciones son independientes, se leía unidad arquitectónica en el lugar, lograda por la utilización de los mismos materiales. Aquí, también encontramos el uso de paraboloides hiperbólicos de hormigón armado en varias de las estructuras, como la caseta de acceso, el tanque de agua elevado, o la cubierta de las gradas.

Otro tema fundamental de los programas de regeneración urbana que se llevaron a cabo en Guadalajara, entre 1954 y 1961, fue el de los mercados públicos. En los dos ejemplos que siguen, los terrenos donde se
121. El curso de "Edificación” en los primeros años de la Escuela de Arquitectura de Guadalajara lo llevó Silvio Alberti, quien fue reclutado en Milán por Ignacio Díaz Morales, el fundador de la escuela. Alberti fue recomendado directamente por Pier Luigi Nervi, de quien había sido colaborador.

122. "Théatre en plein air a Guadalajara," L'Architecture d'Aujourd'hui, no. 109 (septiembre 1963): 111.

123. "Passarelle dans le Parc Agua Azul aménagé dans la nouvelle zone urbaine de Guadalajara," L'Architecture d'Aujourd'hui, no. 109 (septiembre 1963): 42-43.

124. "Centre Sportif a Guadalajara," L'Architecture d'Aujourd'hui, no. 109 (septiembre 1963): 44-45. 
Biblioteca del Estado y Casa de la Cultura en Guadalajara, de Julio de la Peña.

L'Architecture d'Aujourd'hui (septiembre 1963).
125. "Marché 'Libertad' a Guadalajara," L'Architecture d'Aujourd'hui, no. 109 (septiembre 1963): 62-63.

126. El análisis de este singular inmueble se encuentra en la sección dedicada al arquitecto Alejandro Zohn.

127. Horst Hartung fue de los primeros maestros llegados de Europa, proveniente de Stuttgart. Impartió clases de Historia de la arquitectura y el urbanismo en la recién fundada Escuela de Arquitectura de Guadalajara.

128. "Marché 'Alcalde' a Guadalajara," L'Architecture d'Aujourd'hui, no. 109 (septiembre 1963): 61.

129. "Internat Cervantes a Guadalajara," L'Architecture d'Aujourd'hui, no. 109 (septiembre 1963): 109. También de Zohn.
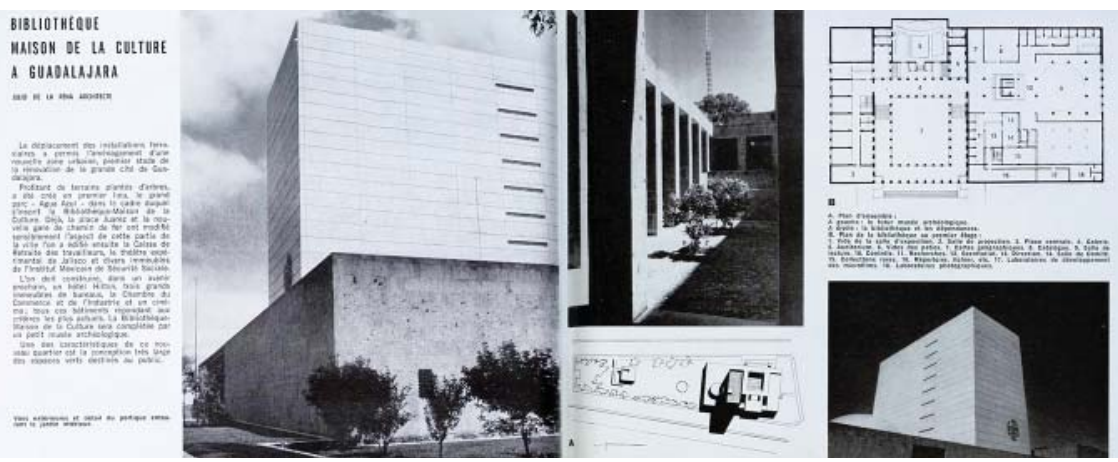

ubicaban los tradicionales mercados al aire libre de un barrio habitacional, fueron expropiados y demolidos para construirse en su lugar instalaciones modernas e higiénicas. El primero de ellos, el citado mercado Libertad, de Zohn, diseñado y edificado entre 1954 y 1959, rehabilitó un área extensa del centro histórico de la ciudad, entre la catedral y el hospicio Cabañas ${ }^{\mathbf{1 2 5}}$. El enorme conjunto integró otros servicios públicos, como restaurantes, sucursales bancarias, escuela o guardería, además del mercado. El techo alto de la nave principal - la de venta de productos frescos- se cubrió con paraguas de hormigón armado, unidos entre sí por tragaluces, que se pensaron para dar la sensación de un mercado al aire libre, aunque con todas las ventajas de disposición e higiene de los mercados modernos ${ }^{\mathbf{1 2 6}}$.

El otro ejemplo es el mercado Alcalde, de 1961, de Horst Hartung ${ }^{127}$, localizado seis calles al norte de la catedral, en pleno centro histórico ${ }^{128}$. Este proyecto, de escala menor que el mercado Libertad, buscó diferenciar los distintos usos con volúmenes característicos; el resultado fue una composición equilibrada y espacios interiores bien iluminados y ventilados. Las cubiertas de la nave principal son secciones trapezoidales de hormigón armado. Entre los servicios adicionales que proporcionó, se contó con una guardería para los hijos de los comerciantes. La fotografía del interior, todavía deshabitada, cobra vida en la vista del exterior, con la actividad cotidiana de las calles tapatías.

En lo que respecta a otros inmuebles, el único ejemplo que se dedicó a la educación en Guadalajara, se ubica en la página dedicada al Internado Cervantes ${ }^{129}$. Un complejo programa de habitaciones, salones de clase y espacios administrativos y recreativos fue resuelto a través de volúmenes sobrios y espacios porticados, todos en lenguaje contemporáneo, destacando la horizontalidad del conjunto y la composición estrictamente ortogonal.

La vivienda, por su parte, estuvo representada por dos ejemplos opuestos. El primero, un grupo de casas de interés social para trabajadores 
de los ferrocarriles, y el segundo, una torre de apartamentos de lujo. El primer caso mostró un prototipo de vivienda en bloques hexagonales, pensados para reducir la cantidad de muros divisorios y así economizar la producción de unidades de habitación ${ }^{130}$. Los jardines comunes buscaron la similitud del diseño con el de las viviendas unifamiliares tradicionales. El artículo puntualizó que la economía no se basó en el detrimento de los materiales ni en la reducción de los espacios, sino que se logró por la buena composición del conjunto.

El segundo caso descubrió la Torre Minerva, con diez niveles de apartamentos, cuyo conjunto incluyó un supermercado, una sucursal bancaria, pequeños locales comerciales y estacionamiento ${ }^{131}$. El texto subrayó el crecimiento urbano de Guadalajara y cómo la ciudad promovía los nuevos barrios con generosos espacios verdes. Este proyecto se debió al arquitecto Éric Coufal ${ }^{132}$. La vista desde la fuente de Minerva, en la rotonda, da la impresión de una torre casi aislada de la trama urbana. Sin embargo, la planta de conjunto, también publicada, expuso los trazos colindantes zigzagueantes de la parte posterior, que dan cuenta de un solar insertado en la urbanización existente.

Por último, para terminar este análisis sobre las edificaciones de Guadalajara, se revisa el tema de la salud y las prestaciones sociales. Si bien este ejemplo no pertenece a la Escuela Tapatía, ya que su diseño y construcción provino de un programa nacional, se incluye aquí como parte de la información que dio a conocer L'Architecture d'Aujourd'hui en su monográfico de $1963^{133}$. Así, el Centro de Seguridad Social del IMss, de Alejandro Prieto, siguió los prototipos que ya se señalaron de centros similares en otras ciudades mexicanas. Sin embargo, los parasoles construidos con láminas prefabricadas de hormigón aportaron un acento distintivo al diseño. El conjunto incluyó un hospital y una clínica de consultas externas, así como un teatro y varias aulas de clase. Se planteó un programa, dirigido especialmente a mujeres y niños, para mejorar su calidad de vida a través de medicina preventiva y actividades sociales; estas acciones tendrían lugar en los nuevos centros sociales del Instituto Mexicano del Seguro Social, construidos en su gran mayoría durante las décadas de 1950 y 1960 en todo el país.

Es importante destacar la presencia de esta ciudad en las publicaciones periódicas foráneas con una cantidad significativa de
130. "Habitation du Personnel des Chemins de Fer a Guadalajara," L’Architecture d'Aujourd'hui, no. 109 (septiembre 1963): xxxvi. Proyecto de Pascual Broid con B. Méndez, C. Ortega y O. Urrutia.

131. "Immeuble d'Habitation a Guadalajara," L'Architecture d'Aujourd'hui, no. 109 (septiembre 1963): 105.

132. Éric Coufal (1926) llegó de Viena para impartir clases de dibujo y modelado en la recién abierta Escuela de Arquitectura de Guadalajara. 133. "Centre de Sécurité Sociale a Guadalajara," L'Architecture d'Aujourd'hui, no. 109 (diciembre 1963): 70-71. 


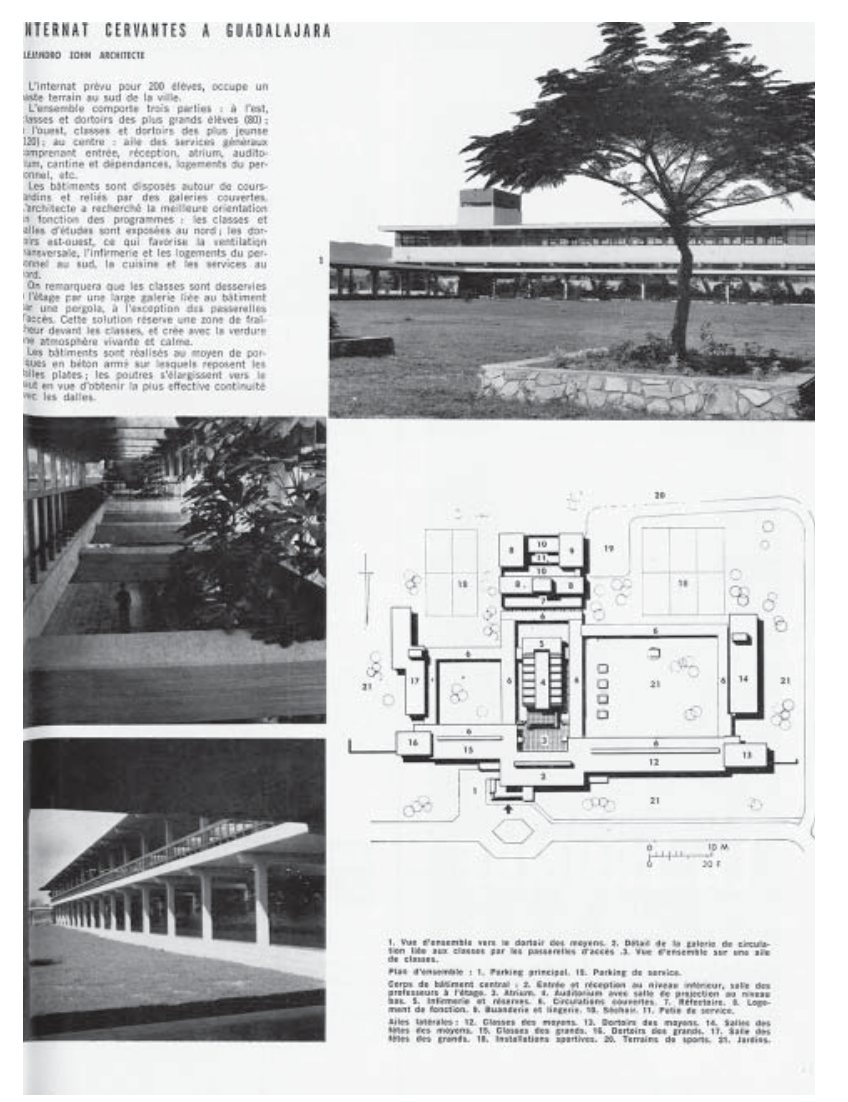

Internado Cervantes de Alejandro Zohn en Guadalajara. L'Architecture d'Aujourd'hui (septiembre 1963).

edificios de usos distintos, pero también, hay que enfatizar la energía con que la nueva escuela irrumpió en el ámbito de la arquitectura nacional ${ }^{134}$. La Escuela Tapatía se ganó un lugar propio en las revistas extranjeras debido a los excelentes ejemplos de su arquitectura moderna; su actividad se desarrolló de forma paralela al principal foco de producción arquitectónica durante el periodo de estudio: la ciudad de México.

A diferencia de Acapulco - la segunda ciudad con más artículos publicados en las revistas extranjeras después del Distrito Federal y su zona metropolitana- en Guadalajara los ejemplos estuvieron intrínsecamente relacionados con arquitectos locales ${ }^{135}$. La ciudad no se

134. Si bien tan pronto como 1955 Arquitectura México comenzó a publicar algunas obras aisladas construidas en Guadalajara, la ciudad mereció tres monográficos en la revista de Pani durante el periodo de estudio: el no. 61 en marzo de 1958, el no. 80 en diciembre de 1962 y, por último, el no. 101 de octubre de 1969.

135. Al decir locales nos referimos a los profesionales establecidos de forma permanente en la ciudad - extranjeros o nacionales- egresados de la Escuela de Arquitectura o docentes en la misma. caracterizó por estar volcada al turismo, sino que se conoció como una localidad que estaba al tanto de su crecimiento urbano y ocupada en brindar infraestructura, servicios básicos y vivienda a sus ciudadanos.

Como conclusión a esta parte, hay que insistir en el origen bien definido de los proyectos arquitectónicos que se localizaron en las diversas poblaciones y que se publicaron en las páginas internacionales. La mayor cantidad de diseños surgió de los mismos arquitectos que construían en la ciudad de México, formados, casi todos, en la Escuela Nacional de Arquitectura. Después, tenemos el caso singular de Guadalajara y, por último, se cuenta con varios casos aislados, casi todos en relación a la 
Torre Minerva de Éric Coufal en Guadalajara. Imagen de L'Architecture d'Aujourd'hui (septiembre 1963).

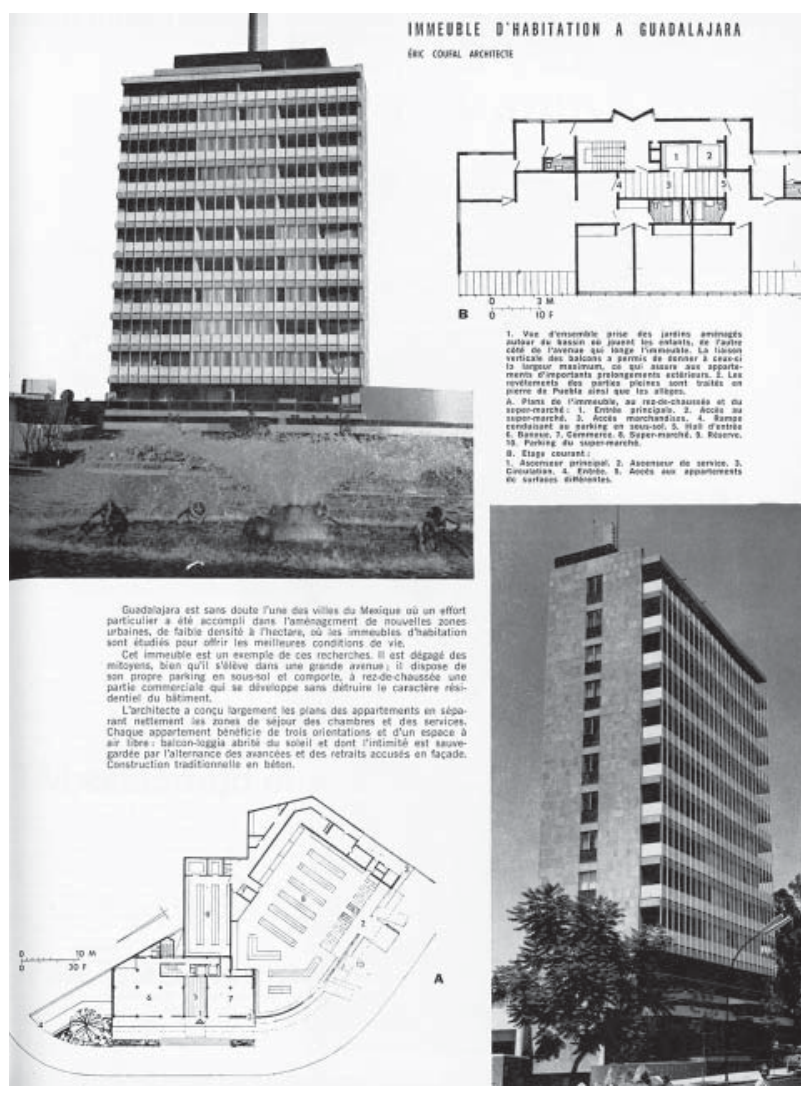

vivienda unifamiliar, de proyectos importados a México desde Estados Unidos, aunque - hay que decirlo- bien adaptados a las condiciones climáticas de cada región.

Otro aspecto que destacó en las comunicaciones sobre las obras construidas fuera de la capital, en especial aquellas ubicadas en clima tropical, fue la insistencia en el uso de celosías, parasoles, ventilación natural cruzada - la excepción, por supuesto, sería el Hotel Hilton de Acapulco que anunció el uso del aire acondicionado en todo el edificioy materiales locales como piedra, madera y hoja de palma, siempre en convivencia con los materiales modernos más tradicionales.

Por otro lado, se reconoce una gran concentración de noticias en los números monográficos de Arquitectura en 1962, y, especialmente, en L'Architecture d'Aujourd'hui en 1963. Con todo, estas comunicaciones suman apenas el 35\% del total de artículos que se publicaron sobre inmuebles localizados más allá de la ciudad de México. De esta manera, un $65 \%$ de la información se encuentra repartida entre otros títulos y números, diluyendo la imagen de una difusión centrada exclusivamente en los monográficos ${ }^{136}$.

También, hay que decir que uno de los fines de este estudio geográfico fue cuestionar la idea generalizada de que todo lo que se
136. Los porcentajes se refieren únicamente a las comunicaciones publicadas sobre lo construido fuera de la capital mexicana. 
construía y publicaba en el extranjero en esos años, tenía lugar en la ciudad de México. No obstante las comunicaciones sobre inmuebles erigidos fuera de la capital y su zona metropolitana fueron la minoría, no son menos importantes para puntualizar, no tanto en la vastedad del territorio nacional sino en quién construía y qué publicaciones divulgaron casos específicos. No está de más señalar que, del total de noticias que difundieron algún edificio en particular, cerca del 20\% fueron ejemplos levantados en el interior de la República. Es cierto que todavía queda un $80 \%$ de información que - es verdad — se erigió en el territorio del valle de México, aun así, este otro 20\% de comunicaciones resultó un material nada desdeñable de análisis.

Finalmente, se tiene la certeza que este análisis puede entenderse de dos maneras, una, como la extensión de la obra de los arquitectos ya conocidos en la capital, pero en otra geografía o, más bien, como una fisura que se abrió en distintos puntos y que dio paso a otra diversidad. Esto es, ya fuese gracias a la nueva escuela de arquitectura de Guadalajara, o también, debido al enfrentamiento con un clima distinto, la geografía se impuso y transformó a la arquitectura moderna mexicana que tuvo como origen la ciudad de México. Con esto se diversificó todavía más, enriqueciéndola, a la ya de por sí heterogénea arquitectura moderna mexicana. 


\subsection{De norte a sur en la región más transparente La zonificación urbana del valle de México}

Custodiado por los volcanes Popocatépetl e Iztaccíhuatl, el valle de México, con una extensión de 9 mil $600 \mathrm{~km}^{2}$ y una altitud media de 2,240 metros sobre el nivel del mar, mantuvo un clima templado estable -y privilegiado- por siglos ${ }^{1}$. Su situación estratégica entre el golfo de México y el Océano Pacífico lo hicieron punto clave de asentamientos prehispánicos - de todas las poblaciones, sin duda la principal fue Tenochtitlan, capital del imperio mexica, fundada en 1325- y centro político y social del virreinato de la Nueva España por tres centurias a partir de 1521. La pureza del viento del valle —otro de nuestros paraísos perdidos- hizo exclamar al viajero Alexander von Humboldt, en 1804, que se encontraba en la "región más transparente del aire". La misma frase sería repetida por Alfonso Reyes en el epígrafe a su obra Visión de Anáhuac, de 1917. Pero, sin duda, la referencia más conocida debe ser la de aquella novela fundacional de Carlos Fuentes, publicada en 1958, en la que la ciudad moderna de la mitad del siglo xx se volvía la protagonista principal del texto.

Esa región más transparente se disipó hace varias décadas, dando lugar a una metrópoli que, en los primeros setenta años del siglo $\mathrm{xx}$ aumentó su superficie urbana veinticuatro veces ${ }^{2}$ y pasó de tener $345 \mathrm{mil}$ habitantes en 1900 a casi 7 millones en 1970. Esa urbe de finales de la década de 1960, totalmente desbordada incluso de sus propios límites políticos y ya emparentada con el vecino Estado de México, es la que cobijó la mayor parte de la arquitectura moderna que se publicó en las revistas foráneas entre 1950 y $1970^{3}$.

El crecimiento de la ciudad fuera de sus límites virreinales tuvo un decidido empuje desde el final del siglo XIx, momento en que la capital «ofreció alternativas a las clases privilegiadas para salir de un centro histórico cada vez más proletarizado» ${ }^{4}$, pero también se abrió a los
1. El área central del valle se define como templada $-25^{\circ}$ $\mathrm{C}$ en verano y mínimas de $0^{\circ} \mathrm{C}$ en invierno- con una temperatura media anual entre los 13 y los $17^{\circ} \mathrm{C}$. Sin embargo, la desecación de los lagos, la pérdida de humedad y el proceso de urbanización del último siglo, aunado a la contaminación atmosférica y de los mantos acuíferos, no sólo destruyó la fértil región sino que ha ido transformando -desfavorablemente- el clima.

2. Carlos González Lobo, "Crecimiento y desarrollo urbano arquitectónico de la ciudad de México entre 1920 y 1970," en Ciudad de México. Arquitectura: 1921-1970, coord. Enrique X. de Anda Alanís, (Ciudad de México: Gobierno del Distrito Federal, 2001), 58.

3. Durante los veinte años de estudio la ciudad se duplicó, ya que de contar tres millones de habitantes en 1950 alcanzó más de seis en 1970.

4. Rodolfo Santa María, "La arquitectura anónima en la Ciudad de México," en Ciudad de México. Arquitectura: 1921-1970, coord. Enrique X. de Anda Alanís, (Ciudad de México: Gobierno del Distrito Federal, 2001), 128. 
5. González Lobo, “Crecimiento y desarrollo urbano", 77.

6. Por cuestiones prácticas, en este capítulo se hace referencia a la ciudad de México o a la capital, como nombre genérico, pero siempre se considera a la zona metropolitana que la rodea, que incluye a varios municipios del vecino Estado de México.

7. Cabe aclarar que al decir "las obras más representativas" no se sigue un criterio propio, sino el que las publicaciones periódicas de la época brindaron como parámetro de valoración. sectores sociales emergentes que demandaron vivienda y servicios fuera del núcleo urbano central, lo que propició - desde un principio- un crecimiento diferenciado y clasista. Fue durante la década de 1940 cuando el país inició un precipitado proceso de industrialización que triplicó su producción, lo que motivó la inmigración masiva del campo a la ciudad que, de la mano de un crecimiento demográfico favorecido por unos estándares mínimos de calidad de vida, generó los sucesivos «cinturones de población marginal que fueron progresivamente incorporados a la urbe, que se extendió a un ritmo cada vez más intenso» ${ }^{5}$.

A partir de los años cincuenta, la mancha urbana se extendió hacia todas direcciones y a ritmos inconcebibles. El casco antiguo perdió su cualidad de centro comercial y económico y la urbe se expandió sobre antiguas y nuevas vialidades generando diversos polos de atracción que rápidamente fueron rodeados por un entramado de tendencia horizontal.

Dentro de este complejo tejido urbano se levantarían algunos de los edificios más característicos de la modernidad, tanto obras de interés social de iniciativa gubernamental como también las concernientes a la mercantilización y especulación del espacio comercial, industrial y habitacional del valle de México ${ }^{6}$.

Así, este capítulo explora el asentamiento en la ciudad de los inmuebles emblemáticos que se dieron a conocer en las páginas extranjeras durante el periodo de estudio. Con el fin de puntualizar en los rasgos generales de su situación, se revisará si ésta respondió - o no- a una zonificación urbana predeterminada, en los casos en que los inmuebles se insertaron en un tejido consolidado, o, en caso contrario, si el ejemplo en turno inició una tendencia de desarrollo según determinado uso.

Lo que se pretende aquí no es ubicar la totalidad de la información registrada - un asunto que por su amplitud sería tema de otra investigación - sino de medir el impacto en la metrópoli de las obras más representativas de la modernidad mexicana ${ }^{7}$. También, hay que decir que por cuestiones metodológicas este discurso sigue la clasificación presentada en el apartado que trató la diversidad edificada. Se adelanta que de dos géneros - vivienda colectiva de lujo y salud- no obstante se dieron a conocer casos puntuales en las revistas de arquitectura, se consideró que no hay un inmueble emblemático de la ciudad de México, como sí se verá para todos los otros casos que a continuación se presentan. 


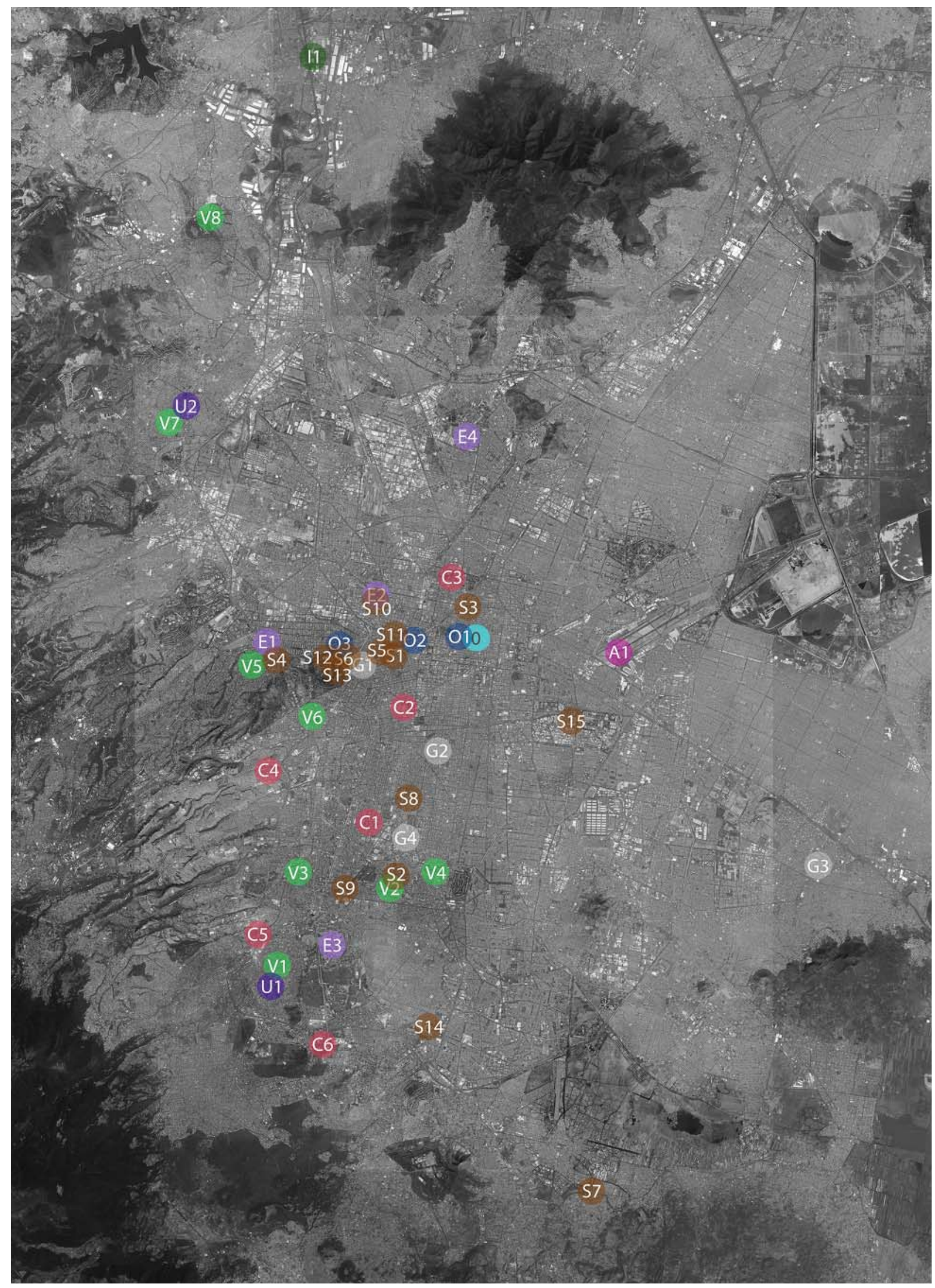

Ciudad de México y zona metropolitana. Distribución geográfica de los principales inmuebles que se dieron a conocer en las publicaciones periódicas foráneas durante el periodo de estudio. 0:Centro Histórico, V:vivienda unifamiliar, C:vivienda colectiva de interés social, E:educación, G:oficinas gobierno, O:oficinas privadas, S:servicios, I:industrial, U:urbanismo, A:infraestructura. 
De esta manera, al igual que se señaló antes frente al mapa general del país, los círculos dispersos en el valle de México indican no sólo la localización de las obras, sino también, según su escala, la difusión que en mayor o menor medida se registró en las publicaciones periódicas. Así, la visión de la capital invita a reflexionar sobre la ubicación precisa de aquellas obras que, a través del papel impreso, dieron la vuelta al mundo durante los llamados años heroicos de la modernidad mexicana.

\section{Sobre la lava del Pedregal: la vivienda moderna mexicana en la capital}

En esta segunda parte de la tesis, cuando se tocó el tema de la diversidad edificada, ya se anotó qué publicaciones se interesaron más en la vivienda unifamiliar y, también, en el apartado anterior, se situaron las casas construidas fuera de la capital. Entre las poblaciones de las que sólo se conoció este género arquitectónico y aquellas localidades clasificadas como mixtas, se recabó un total de diez casas distribuidas en diversos puntos geográficos. Entonces, resulta por demás sobresaliente que, del total de viviendas registradas en esta investigación - que alcanzó la suma de noventa - tan solo diez se levantaran en el interior de la República, contando así la ciudad de México con ochenta ejemplos. No cabe duda que la urbanización de los Jardines del Pedregal de San Ángel está estrechamente relacionada con este auge edificatorio de vivienda unifamiliar moderna. Sin embargo, para este análisis cuantitativo hay que puntualizar varios aspectos metodológicos.

En resumen, dentro del territorio del Distrito Federal y su zona metropolitana se reconocieron alrededor de ochenta viviendas que se dieron a conocer puntualmente en las revistas foráneas ${ }^{8}$. No obstante, aunque se sabe que el boom constructivo moderno en esos años se llevó a cabo principalmente en la urbanización del Pedregal, el registro en la base de datos sólo anotó como cierta dicha locación cuando se tenía la certeza de su ubicación, ya fuese porque la propia noticia lo informaba o porque son casos muy conocidos de la historia de la arquitectura moderna mexicana. Aunque se asume que la mayoría de los casos se

8. Los arquitectos como autores principales sumaron cuarenta y seis, debido a que, en muchos casos, un mismo nombre se dio a conocer con más de un ejemplo. construyeron en el Pedregal de San Ángel, aquí sólo se pueden brindar los datos objetivos con los que se cuenta.

Entonces, se sabe que de las ochenta viviendas que se publicaron durante el periodo de estudio, sitas en el territorio del valle de México, al 


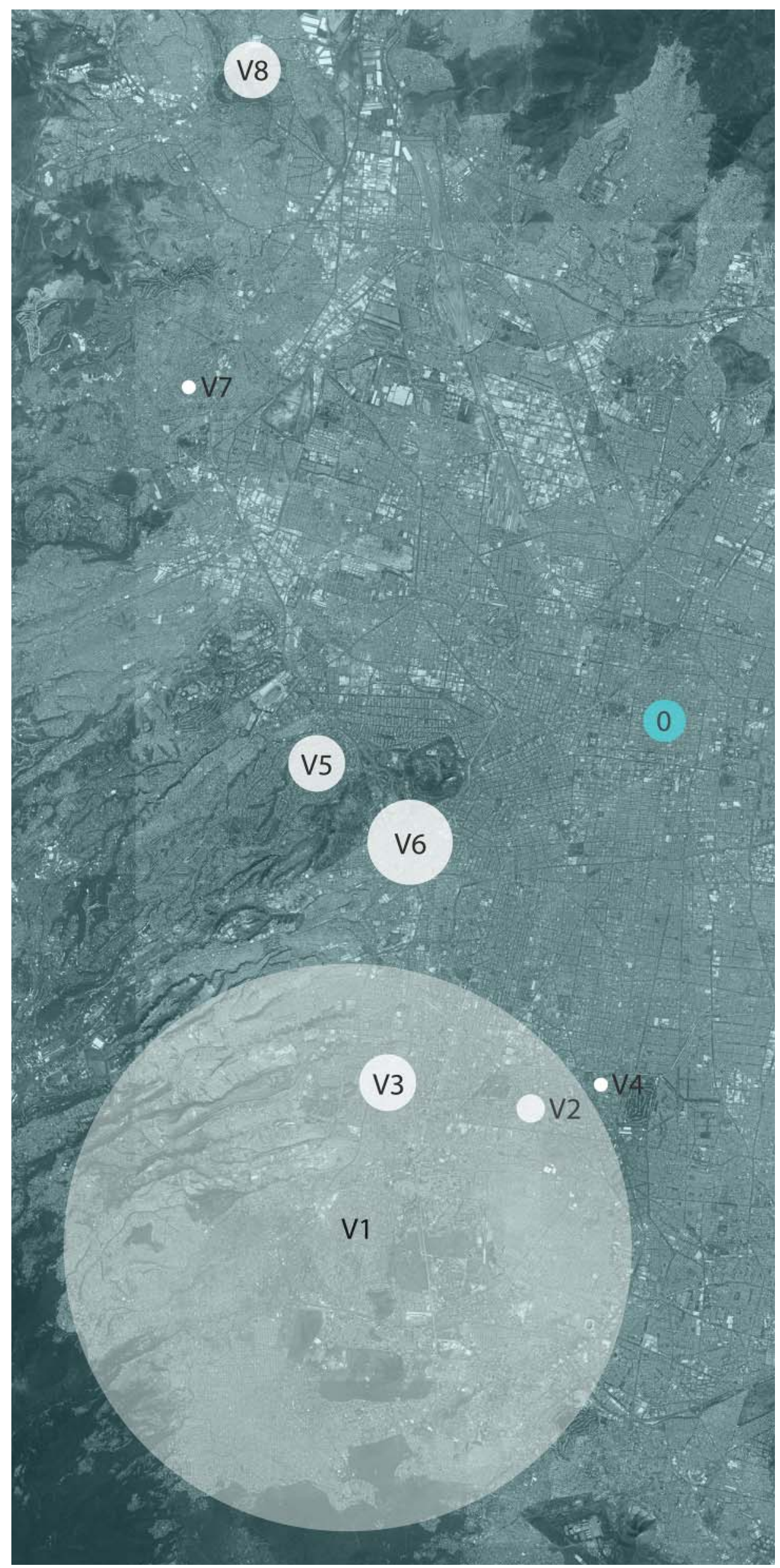

Vivienda unifamiliar en la ciudad de México y zona conurbada. 0:Centro Histórico, V1:Jardines del Pedregal de San Ángel, V2:Coyoacán, V3:Tlacopac, V4:Churubusco, V5:Lomas de Chapultepec,

V6:Tacubaya, V7:Ciudad Satélite, V8:Atizapán. El centro del círculo indica la ubicación geográfica precisa mientras que su radio sugiere la extensión de las comunicaciones en las revistas foráneas. 
9. "Barragán a Città del Messico," Domus, no. 321 (agosto 1956): 1-7.

10. "Gueugnier residence, Jardines del Pedregal, Mexico City," Architectural Design 33, no. 9 (septiembre 1963): 433; "Habitation d'un ingénieur a Pedregal, Mexico," L'Architecture d'Aujourd'hui, no. 109 (septiembre 1963): XxVII y "Vivienda residencial - México," Informes de la Construcción, no. 184 (octubre 1966): 27-31.

11. "Habitation a Coyoacan, Mexico," L'Architecture d'Aujourd'hui, no. 109 (septiembre 1963): Xxv.

12. "Residencia Rodríguez Alday (Tlacopac, D.F.)," Arquitectura, no. 44 (agosto 1962): 24 y "House in Calzada de las Flores, Mexico City," Architectural Design 33, no. 9 (septiembre 1963): 431-432.

13. "Habitation a Churubusco, Mexico," L'Architecture d'Aujourd'hui, no. 109 (septiembre 1963): Xxvi.

14. "Habitations individuelles," L'Architecture d'Aujourd'hui, no. 59 (abril 1955): 90 y "House in Mexico," Architectural Design 25, no. 10 (octubre 1955): 326.

15. "Habitations individuelles," L'Architecture d'Aujourd'hui, no. 59 (abril 1955): 92.

16. "Habitation a Lomas de Chapultepec, Mexique," L'Architecture d'Aujourd'hui, no. 62 (noviembre 1955): 38 y "Habitation a Chapultepec," L'Architecture d'Aujourd'hui, no. 109 (septiembre 1963): 86. menos dieciséis se localizaron en la nueva urbanización que se integró a la lava petrificada del volcán Xitle. Entre los casos más divulgados, sin duda, se encuentra la que fuera casa del arquitecto Juan O’Gorman - tema tratado in extenso más adelante-, la casa Eduardo Prieto López, de Luis Barragán, que generó el artículo más extenso destinado a una habitación unifamiliar, o la casa Gueugnier, de Francisco Artigas, también con importantes artículos en tres revistas foráneas ${ }^{10}$.

Con todo y que se acepta una gran concentración de viviendas en los Jardines del Pedregal -mucho más generosa de lo que se puede mostrar en la gráfica- también es importante situar otras áreas de la ciudad. En el sur, tres poblaciones de origen prehispánico y que muy pronto en el siglo xx se integraron a la trama urbana, se nombraron en las páginas foráneas con algunos ejemplos aislados. Así, Coyoacán, Tlacopac y Churubusco se conocieron por proyectos de Manuel Larrosa ${ }^{11}$, Jaime Ortiz Monasterio ${ }^{12}$ y E. García Formenti ${ }^{13}$, respectivamente. En estos barrios - que durante los años coloniales se mantuvieron como pueblos cercanos a la capital - se levantaron importantes edificios religiosos que, desde el siglo XVI, mantuvieron a la población nativa cohesionada en torno a los centros misioneros. La tranquilidad de su ambiente campestre propició la construcción de haciendas y, posteriormente, casas de fin de semana. Durante los procesos de urbanización del siglo xx, estas zonas mantuvieron un aire señorial que se fue mezclando con el tejido urbano que generó la clase media. Con el tiempo, Coyoacán, Churubusco y Tlacopac - por citar los casos que aquí se tratan - se conservaron como un oasis de tradición en el que - siempre en menor medida que para el caso del Pedregal - buscaron sitio de acomodo las clases altas de la sociedad mexicana. Fueron principalmente las viviendas de esta clase social las que se publicaron en las revistas internacionales.

Hacia el poniente, la que fuera desde la década de 1930 la mejor urbanización —las Lomas de Chapultepec - destinada a los más privilegiados, apenas si se mencionó durante el periodo de estudio con alguna casa de Carlos Lazo $^{14}$, Lorenzo Carrasco y Guillermo Rossell ${ }^{15} \mathrm{o}$ Carlos Reyes Navarro ${ }^{16}$. La ausencia de noticias en esta zona exclusiva tampoco es una sorpresa, pues para la década de 1950 el barrio residencial ya estaba bastante consolidado y era el asiento de los mejores ejemplos de lo que se conoció entonces como estilo colonial californiano. Con todo, 
Casa Rodríguez Alday en Tlacopac. Proyecto de Jaime Ortiz Monasterio publicado en el monográfico de Arquitectura (agosto 1962).

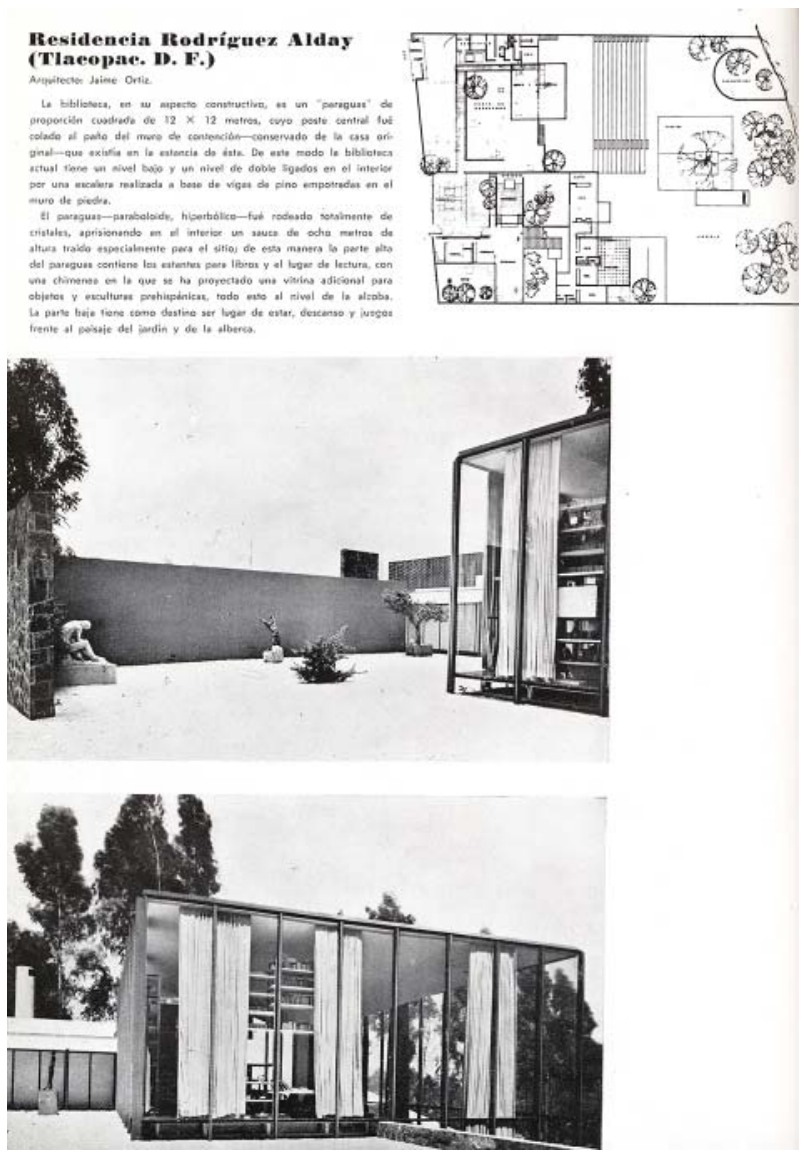

los clientes más atrevidos propiciaron la construcción de casas modernas que no se diferenciaban de aquellas que se levantaban sobre el manto de lava del sur de la ciudad.

También en el poniente, pero hacia el barrio popular de Tacubaya, se levantaría la que, con el tiempo, se convertiría en la casa moderna mexicana más reconocida a nivel internacional: la vivienda del arquitecto Luis Barragán, en la calle de Francisco Ramírez. Su difusión, durante los años revisados en esta investigación, tuvo lugar en Arts \& Architecture ${ }^{\mathbf{1 7}}$, L'Architecture d'Aujourd'hui ${ }^{18}$ y Domus ${ }^{19}$, entre 1951 y 1955. Tacubaya, asimismo una población de origen prehispánico, vio cómo se consolidaba en sus alrededores un entramado clase mediero y popular, carente del ambiente provincial y apacible que identificó a otros barrios. La ubicación de la casa Barragán en Francisco Ramírez sigue sorprendiendo a quien la visita por primera vez, por su fachada gris entre medianeras en una calle anodina y característica de la capital.

$\mathrm{Y}$ hacia el norponiente, en los que ahora son municipios conurbados al Distrito Federal - Naucalpan y Atizapán — se sitúan otros dos casos aislados de vivienda unifamiliar. El primero en Ciudad Satélite, con una noticia de lo más sucinta, una casa en hormigón armado del
17. "House by Luis Barragán, Architect," Arts \& Architecture 68 , no. 8 (agosto 1951): 24-25.

18. "Habitations individuelles," L'Architecture d'Aujourd'hui, no. 59 (abril 1955): 78.

19. Gio Ponti, "Il Pedregal di Città del Messico," Domus, no. 280 (marzo 1953): 20-22. 
20. "Mexico. Architect's House," Architectural Design 31, no. 4 (abril 1961): 142.

21. Gio Ponti, "I muri di Luis Barragán," Domus, no. 468 (noviembre 1968): 2.

22. La casa Barragán, la que diseñó Carlos Lazo en las Lomas de Chapultepec y la casa Rodríguez Alday de Ortiz Monasterio, todas con eco en las revistas foráneas, serían las viviendas con mayor impacto en las publicaciones periódicas más allá de los Jardines del Pedregal, y sin considerar lo ya expuesto de fuera de la capital.

23. La localización de las cincuenta viviendas restantes, a través de fuentes documentales, archivos y visitas de campo, es un asunto que queda por completo al margen de los fines de esta tesis.

24. El tema de los Jardines del Pedregal de San Ángel es contextualizado en el apartado 7.2 de esta tesis, dedicado a la vivienda. En dicho capítulo también se analiza el programa arquitectónico de la vivienda, se anotan algunos ejemplos sobresalientes y se ofrece una narrativa cronológica guiada por las publicaciones periódicas. arquitecto Enrique Reinking ${ }^{20}$, y, en el fraccionamiento Los Clubes, la casa y cuadra Egerstrom, de Luis Barragán ${ }^{21}$, limita hacia el norte el vasto territorio del valle de México, en lo que se refiere a la vivienda unifamiliar.

Hay que insistir que todos los casos citados fuera del Pedregal, quizá con pocas excepciones ${ }^{22}$, son ejemplos aislados que no dan cuenta de la intensa actividad constructiva que caracterizó al desarrollo urbano vecino de la Ciudad Universitaria, en especial durante la década de 1950. En síntesis, de las ochenta viviendas unifamiliares que se registraron dentro del territorio del valle de México, se cuenta con la ubicación cierta para tan solo treinta de ellas, esta información es la que se ve reflejada en la gráfica correspondiente ${ }^{23}$. Con todo, interesa subrayar como zona predominante de construcción de la casa moderna mexicana el fraccionamiento que desarrolló Barragán a partir de $1945^{24}$.

\section{Entre tabula rasa y despoblado: la vivienda colectiva de interés social}

Los grandes conjuntos habitacionales de la ciudad de México, según cada caso, se enfrentaron a diversos condicionantes topográficos y urbanos. Ya fuese adaptándose a una retícula establecida, sorteando pendientes naturales o, en los ejemplos radicales, limpiando el terreno de antiguas construcciones para establecer una trama moderna, los centros urbanos de interés social - a diferencia de los casos aislados de vivienda unifamiliar-, por su escala, tuvieron un mayor impacto en la urbe.

El primer ejemplo de vivienda colectiva que se realizó en México, el Centro Urbano Presidente Alemán (CUPA), tuvo como ubicación el predio de $40 \mathrm{mil} \mathrm{m}^{2}$ que la Dirección de Pensiones Civiles compró en la colonia Del Valle con el fin de desarrollar la vivienda que sería ofrecida a los trabajadores del Estado. Así, entre las calles de Félix Cuevas, Mayorazgo, Parroquia y Avenida Coyoacán, materializó en 1949 un conjunto que, si bien se adaptó en su disposición general a la retícula urbana existente, rompía por primera vez la imagen de una ciudad horizontal constituida básicamente por viviendas de dos niveles. Las fotografías aéreas de la época son prolijas en mostrar el contraste que aquí se enuncia.

El CuPA se consideró en varios sentidos un experimento, pero pasó la prueba y dio lugar a un segundo gran conjunto habitacional en un predio seis veces mayor —de alrededor de $250 \mathrm{mil} \mathrm{m}^{2}$ - ubicado en una zona cercana al casco histórico - la colonia Roma- y, por lo tanto, 


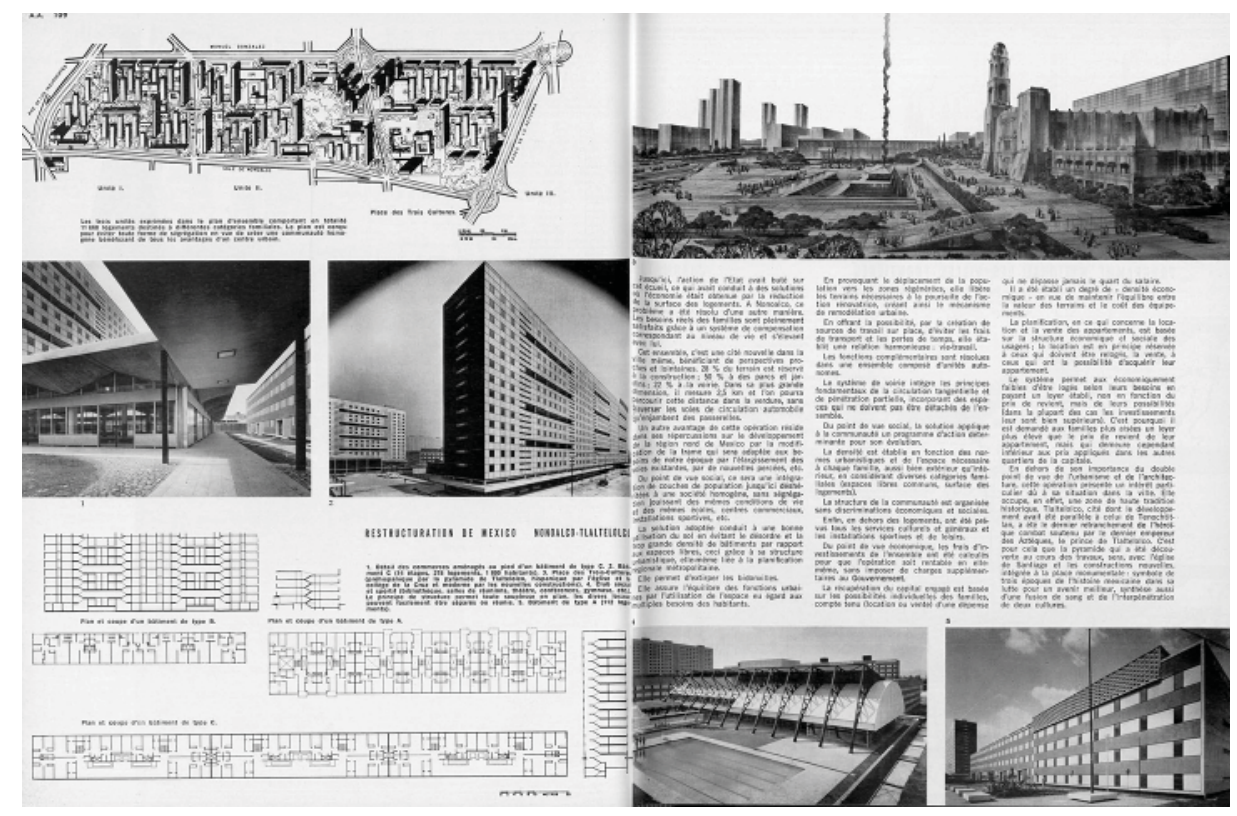

mucho más consolidada. Así, el Centro Urbano Presidente Juárez (CUPJ), dividido por la avenida Orizaba y entre las calles de Jalapa, Antonio M. Anza, Huatabampo y la avenida Cuauhtémoc, ofreció una innovadora propuesta urbana que consistió en la construcción de cuatro de sus edificios sobre la avenida Orizaba, emplazados de forma perpendicular a la vía rodada ${ }^{25}$. Mientras en el cupa se notaba una imagen urbana todavía un tanto despoblada - aunque con la retícula ya trazada - el cupj destacó sobre todo por su irrupción en una trama sólida y por los generosos espacios abiertos y verdes que contrastaron con la ciudad erigida hasta ese momento.

Siguiendo una diagonal que se traza de sur a norte, desde el CUPA, pasando por el CUPJ y salvando el centro histórico, se llega a Tlatelolco - lugar de la última batalla entre mexicas y españoles aquel 13 de agosto de 1521 - para verificar el impacto del último gran conjunto dirigido por Mario Pani y que tuvo como escenario la ciudad ya consolidada. En oposición a los casos anteriores, aquí se intentó una regeneración total del área siguiendo los postulados modernos del tabula rasa que sugerían empezar de cero obviando cualquier disposición urbana preexistente ${ }^{26}$.

De esta manera, el conjunto habitacional Nonoalco-Tlatelolco, ubicado entre Insurgentes Norte, Manuel González, calzada de Nonoalco y Paseo de la Reforma Norte, con su superficie casi veintiocho veces mayor que la apropiada por el CUPA, sobrepasó todo lo realizado hasta ese momento dirigido a solventar la demanda de vivienda de interés social. Desde el punto de vista urbano, su construcción fue una imposición
Conjunto habitacional Nonoalco-Tlatelolco. Dentro de la radical intervención urbana quedó espacio para integrar algunos vestigios prehispánicos así como importantes obras virreinales en la Plaza de las Tres Culturas. Páginas de $A A$ (septiembre 1963).
25. El terremoto de septiembre de 1985 dañó la estructura de la mayoría de los edificios de este conjunto, por lo que se procedió a la demolición de los mismos.

26. Puede sorprender todavía que, a pesar de todo, se resguardaron algunos vestigios prehispánicos y la iglesia virreinal de Santiago, integrados a la llamada Plaza de las Tres Culturas. 
al arraigado entramado popular. Esta intervención mayor, asimismo, propició la apertura hacia el norte del Paseo de la Reforma y la ampliación de vialidades que comunicaron el centro de la ciudad con la Villa de Guadalupe.

Por otro lado, hacia el sur-poniente y poniente del valle, nuevos centros habitacionales de interés social se levantaron sobre terrenos casi despoblados, lo que activó esos polos de crecimiento de la metrópoli. En 1957, la Unidad de Servicios Sociales y de Habitación No. 1 Santa Fe, promovida por el Instituto Mexicano del Seguro Social (IMSs), ofreció los servicios indispensables para la vida comunitaria en un área desvinculada de los nodos económicos y comerciales más importantes de la capital. Si bien ya en el cupj se había dotado de algunos servicios básicos como comercios y guardería, en Santa Fe se integró un verdadero centro de desarrollo social que incluyó aulas para la enseñanza y aprendizaje de oficios y artesanías, biblioteca, cine, auditorio, teatro, gimnasio y canchas deportivas; además de clínica médica de especialidades y amplias zonas comerciales. Se pretendió así la total independencia de sus nuevos habitantes con respecto de la ciudad consolidada, facilitando —especialmente - la vida cotidiana de mujeres e infantes.

En el sur-poniente, la Unidad Independencia, finalizada en 1960, siguió el mismo patrón que Santa Fe en cuanto a los servicios sociales brindados, pero sin duda valoró mucho más el entorno boscoso preexistente y potenció la vida al exterior gracias a sus senderos peatonales diferenciados de las circulaciones vehiculares. Su cercanía con importantes arterias viales - Periférico Sur- y su vecindad con los Jardines del Pedregal, no sólo favorecieron su rápida integración con la urbe sino que aumentaron considerablemente su plusvalía.

De los principales conjuntos de vivienda colectiva que se dieron a conocer en las publicaciones periódicas foráneas entre 1950 y 1970, quedaría por destacarse uno más que determina la cronología hacia el final del periodo de estudio y que, geográficamente, limita hacia el sur del valle los ejemplos hasta ahora expuestos. La Villa Olímpica, de 1968, no sólo ofreció alojamiento temporal a los atletas internacionales sino que, una vez finalizado el evento deportivo, el centro urbano se sumó a la oferta de vivienda destinada a la clase media de la capital. Su asentamiento, colindante con la Avenida Insurgentes Sur y muy cercano 


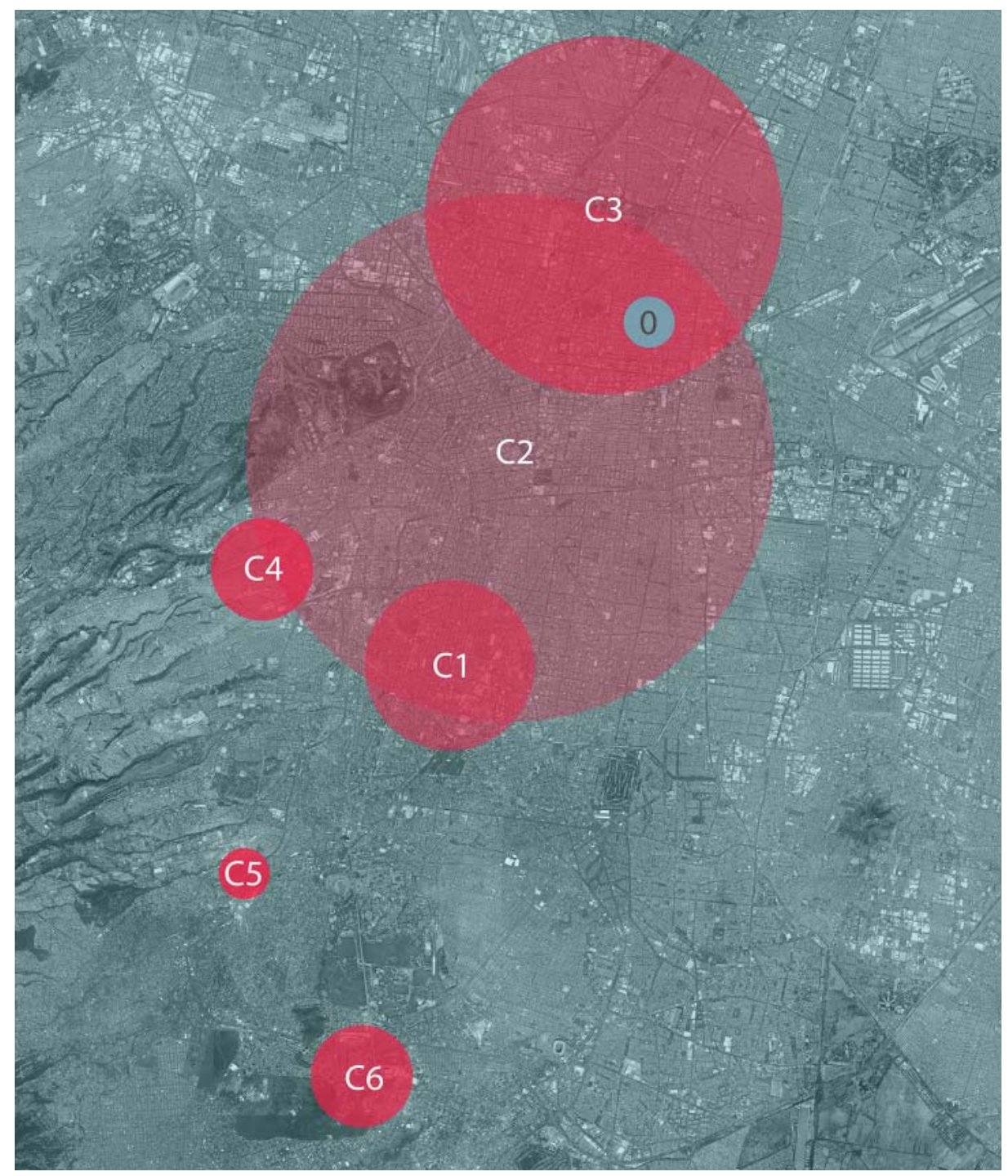

Vivienda colectiva de interés social en la ciudad de México. 0:Centro Histórico, C1:Centro Urbano Presidente Alemán, C2:Centro Urbano Presidente Juárez, C3:Unidad habitacional Nonoalco-Tlatelolco, C4:Unidad de habitación Santa Fe, C5:Unidad Independencia, C6:Villa Olímpica. Nótese el impacto en cantidad de páginas del Presidente Juárez, que claramente dominó el panorama de las publicaciones contempladas en este estudio.

al anillo Periférico, comunicó de forma eficaz y directa a los deportistas hacia las principales sedes de la XIx Olimpiada, en especial al Estadio Olímpico sito a escasos kilómetros de los edificios de apartamentos.

En todos los casos, ya fuese que los conjuntos se integraran a una trama establecida o generaran una disposición urbana nueva, siempre resultaron insuficientes para frenar $-\mathrm{y}$ ordenar- el crecimiento urbano desorbitado que terminó por ocupar prácticamente toda la superficie del valle de México y sus áreas colindantes.

\section{Norte, sur, centro y poniente: los emplazamientos para la}

\section{arquitectura educativa}

Uno de los primeros edificios del Programa Federal de Construcción de Escuelas, cuya difusión cruzó muy pronto las fronteras nacionales, fue el Conservatorio Nacional de Música, de Mario Pani, terminado en 1946. Éste se ubicó en la avenida Presidente Mazaryk, al poniente del centro 


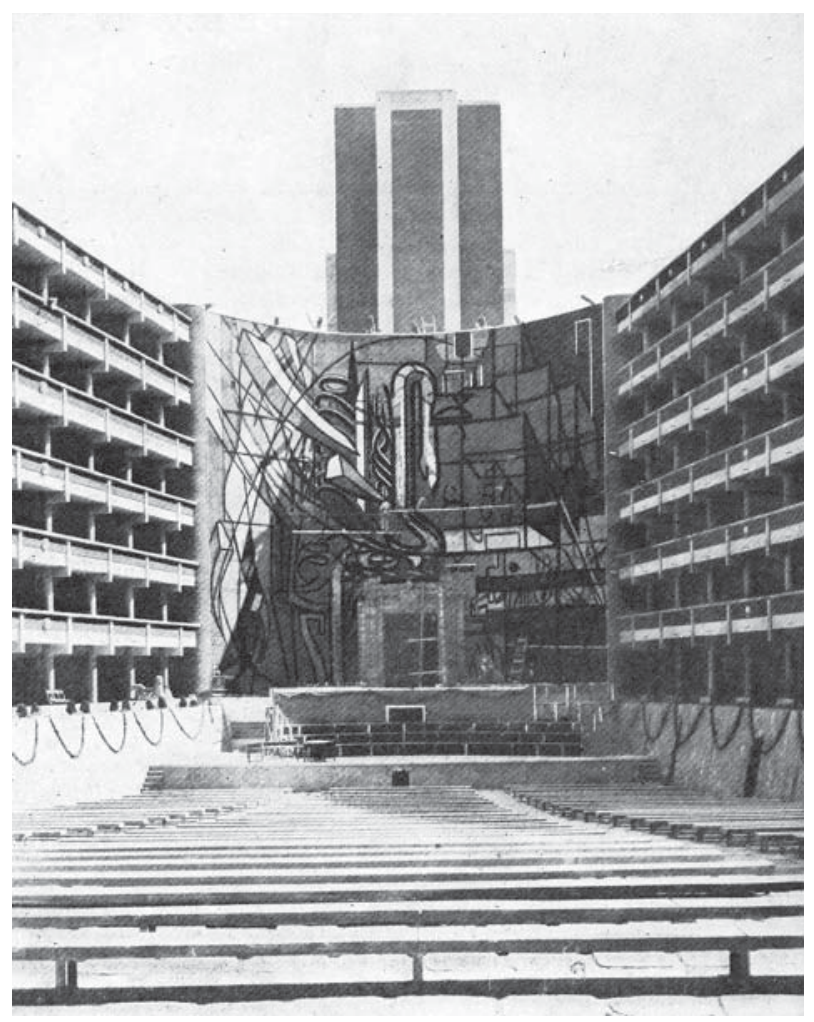

histórico en la zona residencial y comercial de Polanco. A diferencia de otras escuelas nacionales, el Conservatorio no contó con instalaciones propias hasta este momento, siendo el edificio de Polanco su primera $-\mathrm{y}$ todavía activa - sede de enseñanza. El extenso predio trapezoidal entre Presidente Masaryk y Campos Elíseos perteneció al Club Hípico Alemán, mismo que fue expropiado para cederlo a la institución educativa ${ }^{27}$. Su disposición axial de dos alas que se abren generando un espacio central destinado al teatro al aire libre, respondió al lote urbano ya definido por las calles existentes.

También de Pani, la Escuela Nacional de Maestros, finalizada en 1947, se erigió a escasos kilómetros del casco antiguo, sobre una de las calzadas más antiguas de la ciudad, la México-Tacuba. El enorme conjunto ocupó el mismo sitio de la antigua Escuela Normal, que fue casi por completo demolida. De ésta se conservaron dos alas secundarias que albergarían escuelas primarias - a las que se cubrió con nuevas fachadas para homogeneizar el conjunto- así como la portada del antiguo edificio, que se recicló en la pared posterior del auditorio abierto, justo al centro del mural de José Clemente Orozco que cubrió el muro curvo del auditorio.

27. "Conservatorio Nacional de Música," consultada 24 agosto, 2015, http://www.conservatorio.bellasartes.gob.mx.
Tanto en el Conservatorio como en la Nacional de Maestros, las plantas de conjunto se adaptaron a esquinas oblicuas determinadas por la trama urbana precedente que delimitó el contorno general del terreno. 


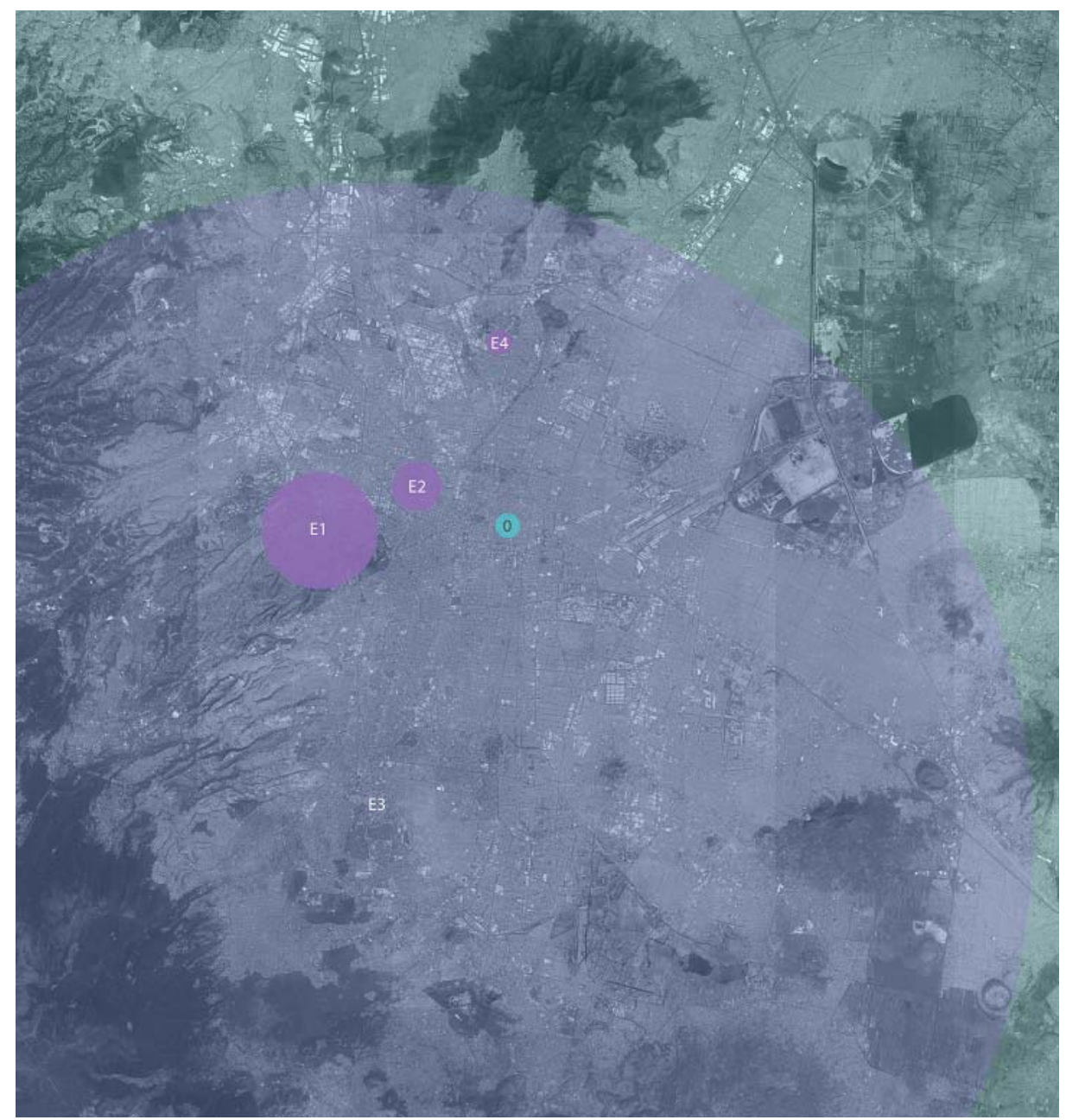

Al tiempo que se inauguraba la Escuela Nacional de Maestros en la calzada México-Tacuba, los anteproyectos para el nuevo campus de la Ciudad Universitaria eran ya una realidad después de varios años de gestiones. El plan de reubicar las escuelas profesionales, que tradicionalmente se encontraban en el centro histórico en edificios aislados, tuvo desde un principio opiniones a favor y en contra, pero, sin duda, la compra de los terrenos en el Pedregal de San Ángel, - proceso que inició en 1943 y que finalizó tres años más tarde- acrecentó los ánimos por ver materializada la universidad moderna en el sur de la metrópoli.

La extensa zona del valle cubierta por lava petrificada, había sido hasta 1945 un área inhóspita que, como mucho, invitaba a los más aventureros a una larga caminata dominical. La mancha urbana durante la década de 1940 ya había alcanzado San Ángel, siendo este antiguo poblado su límite más meridional. La adquisición de los predios para la Universidad se realizó casi de forma simultánea a la arriesgada inversión que Luis Barragán emprendía entonces en el área adyacente. No obstante el desarrollo urbano de los Jardines del Pedregal inició desde 1945,
La arquitectura para la educación en la ciudad de México. 0:Centro Histórico. E1:Conservatorio Nacional de Música, E2:Escuela Nacional de Maestros, E3:Ciudad Universitaria, E4:Instituto Politécnico Nacional. La sombra que proyecta la difusión de la Ciudad Universitaria -ocupando prácticamente toda la extensión del valle- es suficientemente indicativa del impacto de dicho conjunto en los medios internacionales. 
ambos proyectos alcanzarían fama internacional los primeros años de la década de 1950. Gracias a estos importantes conjuntos, que salvaron las irregularidades pedregosas, inició la expansión de la capital todavía más hacia el sur, hacia el poblado de Tlalpan y siguiendo la línea de la antigua carretera a Cuernavaca.

Y hacia el norte, en una extensa superficie plana de 250 hectáreas, próxima a la avenida Insurgentes Norte y colindante con calzada Vallejo, el Instituto Politécnico Nacional llevaría a cabo la Unidad Profesional Zacatenco entre 1958 y 1964 . Esta importante obra educativa activó el flujo estudiantil hacia una zona urbana que se había caracterizado mucho más por su desarrollo industrial, equilibrando la distribución de estudiantes universitarios de la ciudad de México.

\section{La arquitectura de la administración pública}

Como puede suponerse, si hasta finales del siglo xix la ciudad se concentró dentro de sus límites históricos, los edificios de gobierno, siendo los más representativos de la urbe - al menos a nivel político- se situaron siempre en un sitio privilegiado del casco antiguo. El proceso de modernización del país y la consecuente aparición de nuevas secretarías e instituciones, promovió emplazamientos diferentes para los edificios gubernamentales. Así, la sede del Instituto Mexicano del Seguro Social se ubicó sobre el Paseo de la Reforma, muy próximo al acceso del bosque de Chapultepec. La tradicional avenida neoclásica, — que por muy poco tiempo fue paseo imperial - se convertiría, en la primera mitad del siglo xx, en la imagen del México moderno.

La importante vialidad, que por varias décadas comunicó la residencia oficial presidencial con el Palacio Nacional, muy pronto se transformó en la avenida comercial más valorada de la capital, por lo que no es extraño que incluso las nuevas oficinas gubernamentales buscaran espacio en zonas menos caras de la metrópoli. Para 1954, cuando se abrieron las puertas del nuevo edificio de la Secretaría de Comunicaciones y Obras Públicas (scop), el éxodo del centro histórico continuaba. Para esta sede oficial se planeó la comunicación directa con el centro, pero en un entorno lo suficientemente amplio como para alojar oficinas con capacidad para cinco mil empleados. De esta manera, el terreno de $54 \mathrm{mil} \mathrm{m}^{2}$ en el Eje Central Lázaro Cárdenas esquina Xola, 


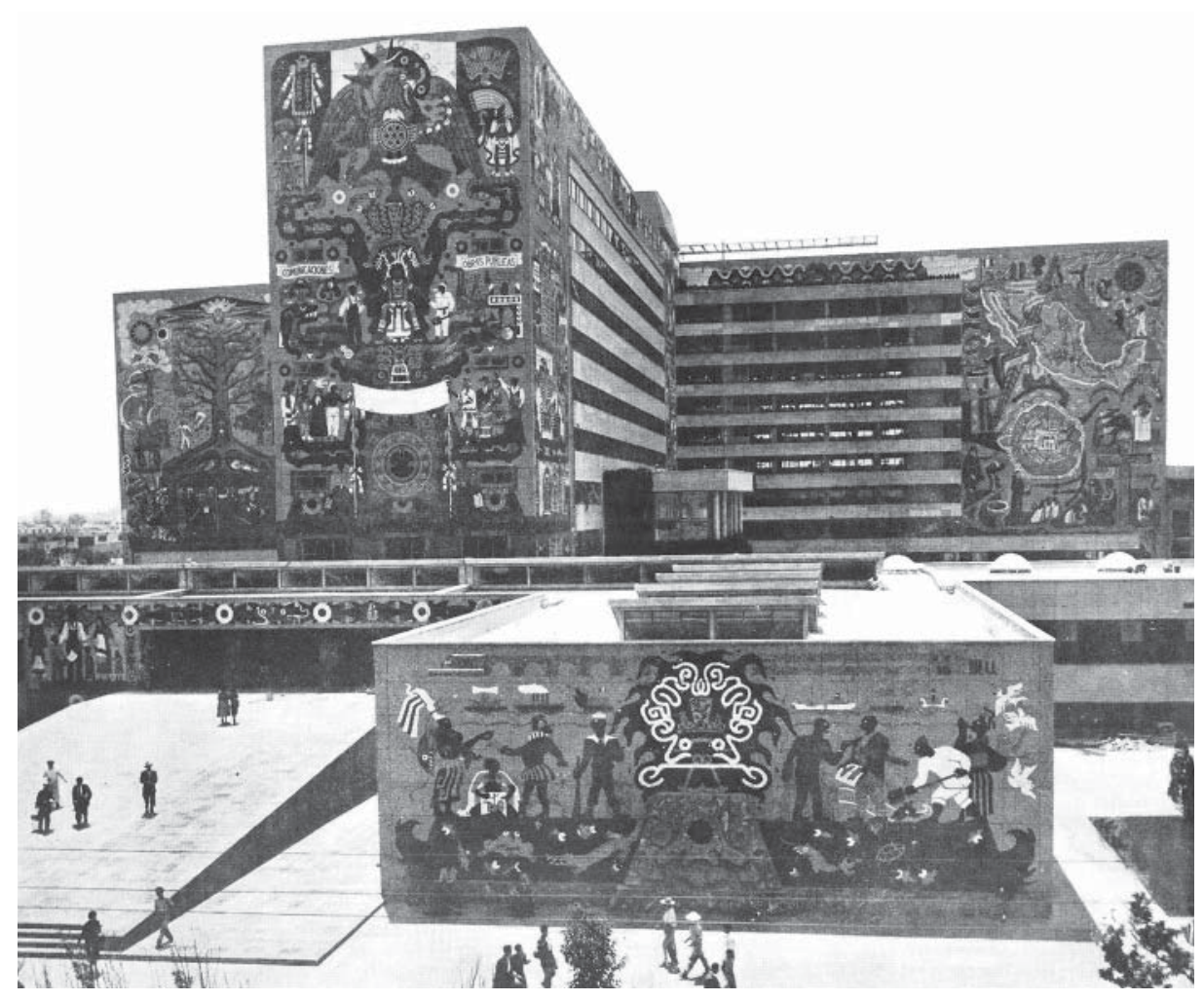

en la colonia Narvarte, alojó al importante conjunto dirigido por el arquitecto Carlos Lazo.

Por razones obvias, el siguiente ejemplo se situó al suroriente del valle, en el antiguo pueblo de Santa Marta Acatitla, en Iztapalapa, uno de los barrios populares más pobres - y marginales - de la capital. La nueva penitenciaría del Distrito Federal, erigida entre 1956 y 1957 por Ramón Marcos Noriega, sustituyó a la antigua prisión de finales del siglo xix que se había vuelto obsoleta a mediados del siglo xx. Para este momento, el programa moderno, cargado de considerable responsabilidad social, proporcionó al recluso algo más que el simple espacio habitacional, pues el conjunto se enriqueció con talleres, escuela, huertas, campos deportivos y auditorio ${ }^{28}$. Los nuevos métodos de reeducación y la terapia ocupacional remunerada tomaban forma en los edificios modernos que, -todavía entonces- se mostraban en un paraje desolado ${ }^{29}$.

De vuelta en la urbe, al sur del casco histórico, en un terreno de 9 mil $\mathrm{m}^{2}$ frente a la avenida Emiliano Zapata - hoy el Eje 7 A Sur- en la colonia Santa Cruz Atoyac, se edificó el Instituto Nacional de Protección a la Infancia. Su función principal, la elaboración de desayunos escolares que se repartían gratuitamente en las escuelas públicas, no sólo demandó una amplia nave industrial y una extensa zona de maniobras para los vehículos de distribución, sino que su emplazamiento en una vía principal
La integración plástica en los edificios de gobierno mediada la década de 1950. Secretaría de Comunicaciones y Obras Públicas en Informes de la Construcción (agosto 1955).
28. "Penitenciaría del Distrito Federal," Arquitectura, no. 44 (agosto 1962): 33.

29. "Pénitencier du District Fédéral a Ixtapalapa, Mexico," L'Architecture d'Aujourd'hui, no. 109 (septiembre 1963): 50-51. 
y próxima a las más importantes arterias de la capital, garantizó la entrega eficaz y puntual de sus productos.

Estos ejemplos aislados no dan cuenta de la totalidad de inmuebles destinados a la administración pública que se levantaron durante las décadas de estudio. Sin embargo, como ya se anotó en el capítulo anterior, las oficinas gubernamentales tuvieron una difusión muy puntual y apenas un reducido número de obras se dio a conocer en las páginas foráneas. También, es cierto que este somero acercamiento a su situación en la metrópoli da cuenta de una distribución aleatoria, pues no revela ningún plan general de ordenamiento político. Hay que reconocer que esta disposición urbana azarosa ha sido el modus operandi incluso en proyectos de enorme magnitud, como se constatará en el capítulo dedicado a la arquitectura olímpica.

\section{Un futuro asegurado: las oficinas privadas}

La arquitectura comercial se caracterizó por un edificio emblemático: la torre de oficinas. Del auge inmobiliario que llenó la urbe de prismas anodinos y muros-cortina, algunos ejemplos destacados se publicaron en las revistas extranjeras. Su distribución en la capital siguió patrones de desarrollo bastante claros, guiados por la plusvalía del área urbana y por las posibilidades económicas de las empresas privadas que los comisionaron. Se citan aquí tres casos emblemáticos, todos ellos oficinas centrales de importantes compañías aseguradoras.

La torre para los Seguros Latinoamericana —levantada entre 1948 y 1956- se emplazó en el perímetro interior del centro histórico, en la esquina de San Juan de Letrán - hoy Eje Central Lázaro Cárdenas- y

30. Los dueños habían comprado el lote desde 1930; en esa década la avenida San Juan de Letrán registraba el mayor crecimiento en altura de la urbe, con inmuebles de hasta 12 niveles. Sin embargo, la construcción, entre 1932 y 1942, del edificio de 22 niveles para la Lotería Nacional sobre el Paseo de la Reforma, cambiaría el rumbo del desarrollo de los edificios altos de la capital. Véase Fabiola Hernández Flores, "Torre Latinoamericana: 50 años. Restauración de un testigo", Anales del Instituto de Investigaciones Estéticas, no. 98 (2011): 202. Madero. Su construcción no fue solo una proeza técnica sino también la afirmación del valor implícito de la empresa, pues la estructura se conoció como la más alta de la capital por muchos años. En su momento, la irrupción del inmueble en el casco antiguo fue mucho más violenta, pues el crecimiento en altura se desarrollaba ya sobre el Paseo de la Reforma y no sobre el Eje Central ${ }^{30}$. A pesar de todo, la torre de 42 niveles ha llegado a formar parte de un paisaje urbano familiar. También, hay que destacar el papel simbólico de su erección justo en el centro histórico, el lugar sede del poder político y, por tradición, también del poder económico y comercial. Su asentamiento respondió a un valor emblemático agregado, 

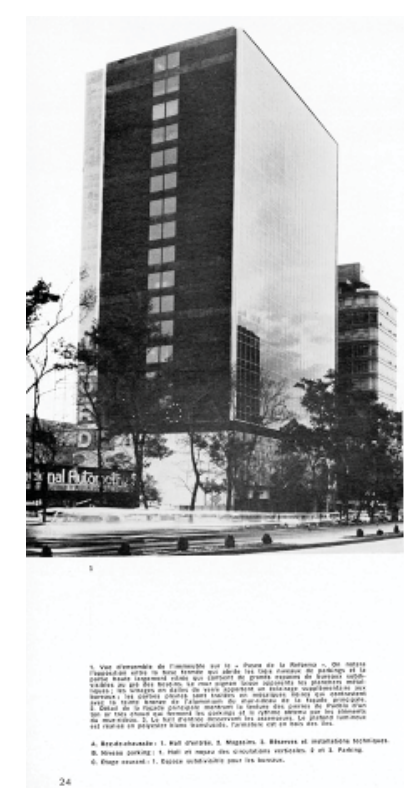
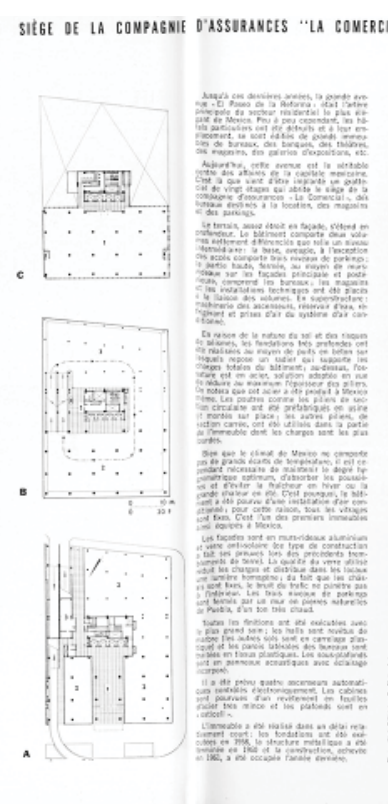

Las oficinas privadas en la ciudad moderna. Seguros La Comercial de Héctor Mestre y Manuel de la Colina en $A A$ (septiembre 1963).

aunque un poco a destiempo, pues el icono urbano permaneció aislado mientras el crecimiento en altura de la metrópoli se llevaba a cabo por derroteros cercanos.

Así, la fisonomía del Paseo de la Reforma estaba en plena transformación para convertirse en el nuevo centro de negocios de la capital. Las imágenes de la época son características en revelar los edificios altos que poco a poco iban sustituyendo las antiguas casonas neoclásicas del siglo xIx y también los edificios de tres o cuatro niveles que ya quedaban fuera de escala ante la nueva modernidad de mayor altura. En este contexto, el edificio de Seguros La Comercial, que se asentó en el Paseo haciendo esquina con la calle Milán, es representativo del auge inmobiliario del momento y de un emplazamiento definido por la plusvalía urbana.

De esta manera, en 1961 abría sus puertas la torre de veinte niveles diseñada por Héctor Mestre y Manuel de la Colina, ofreciendo al Paseo de la Reforma un basamento recubierto de placas pétreas, sobre el que se desplantó la torre de oficinas. La fachada principal recurrió al consabido muro-cortina, pero los tratamientos en las otras caras, en especial en la que mira hacia el poniente, se combinaron los vanos de las ventanas con placas de aluminio estriado, un recurso pensado para minimizar los gastos del aire acondicionado con que se dotó al inmueble ${ }^{31}$.

Si bien Reforma se mantiene como un importante centro de negocios - y su fisonomía no deja de transformarse- al poniente del centro histórico se consolidaba otra importante arteria corporativa:

31. Véase la noticia sobre el proyecto en "Mexico. Office block," Architectural Design 30, no. 12 (diciembre 1960): 487, y la obra finalizada en "Seguros 'La Comercial", Arquitectura, no. 44 (agosto 1962): 64 y "Siège de la Compagnie d'assurances ' $\mathrm{La}$ Comercial' a Mexico," L'Architecture d'Aujourd'hui, no. 109 (septiembre 1963): 24-25. 
Las oficinas de gobierno y privadas en la ciudad de México. 0:Centro Histórico. G1:Sede del Instituto Mexicano del Seguro Social, G2:Secretaría de Comunicaciones y Obras Públicas, G3:Penitenciaría de Santa Marta Acatitla, G4:Instituto Nacional de Protección a la Infancia; 01:Torre Latinoamericana, 02:Seguros La Comercial, 03:Seguros Monterrey.

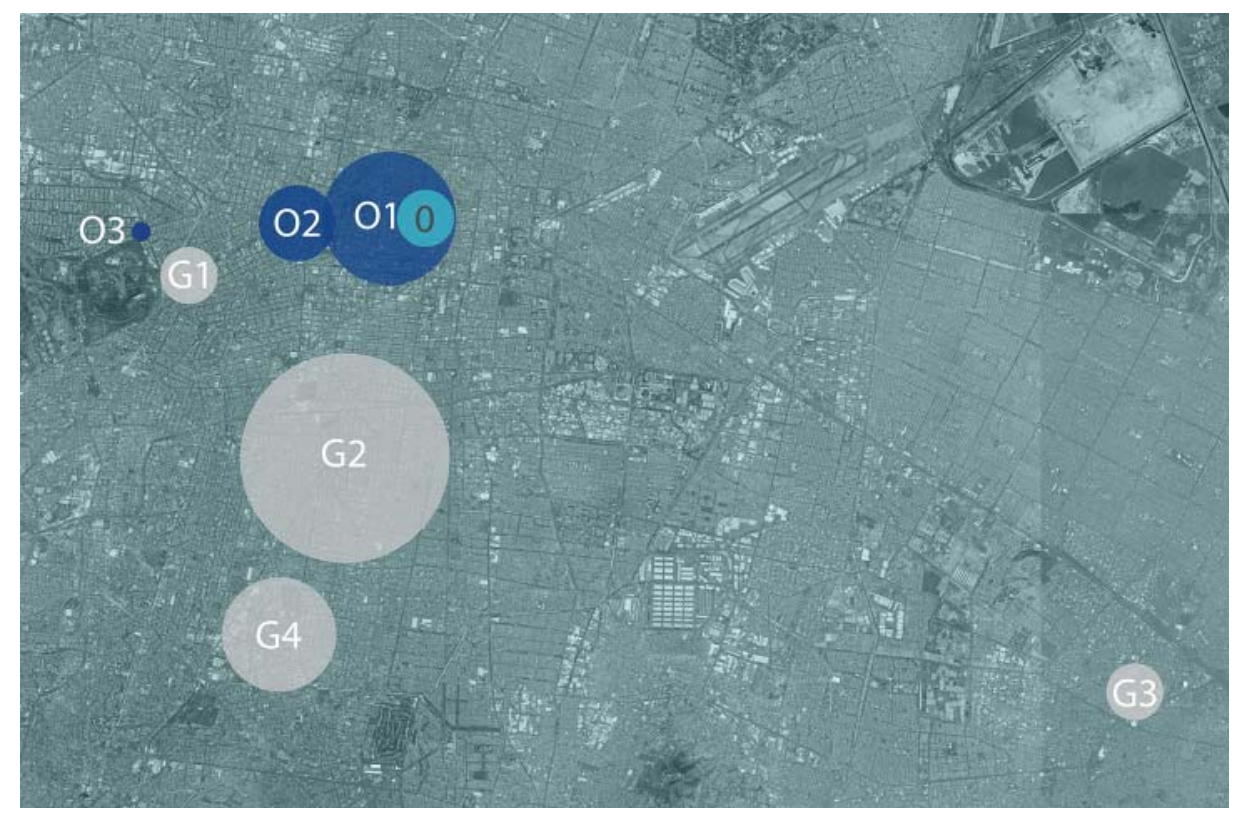

Presidente Masaryk, en Polanco. Sobre esta avenida, en esquina con Mariano Escobedo, el edificio de Seguros Monterrey de 1963 —de Enrique de la Mora- innovó con una estructura colgante que por primera vez cuestionó la funcionalidad de los entrepisos soportados por un bosque de columnas, liberando el área central de oficinas gracias a sus dos núcleos de hormigón armado que soportan la importante estructura de seis niveles.

Lo más notable de este recorrido ha sido verificar no sólo el cambio de emplazamiento de los edificios de oficinas sino que con cada ejemplo la altura de los inmuebles fue decreciendo de forma considerable. Aun cuando la apuesta por construir el edificio más alto de la ciudad no terminó con la Torre Latinoamericana, los años en estudio son precisos en indicar el distanciamiento de las construcciones modernas del casco antiguo, en donde la torre quedaría como una excepción y un caso aislado en el entorno urbano. También, es evidente el afianzamiento del Paseo de la Reforma como polo de crecimiento en altura, y, de manera simultánea, el impulso de vías secundarias de negocios - Presidente Masaryk- de gran impacto en el poniente del valle.

\section{Entre La Lagunilla y Xochimilco: la dispersión de los servicios}

Para el caso de la arquitectura destinada a las actividades comerciales - la denominada de servicios- y dada la amplitud de ejemplos que a continuación se presentan -incluso reduciendo la selección a las obras más emblemáticas - se haría necesario un estudio específico para cada género arquitectónico con el fin de establecer los diversos patrones de 
localización de los inmuebles a lo largo y ancho de la ciudad. Entonces, se propone aquí una visión particular para los casos más difundidos, mismos que se comentan puntualmente en torno a su situación geográfica en el valle de México.

La narrativa de esta parte sigue el orden usado antes para explicar la diversidad edificada de lo que se dio a conocer en las publicaciones periódicas foráneas durante las décadas de 1950 y 1960.

Así, el recorrido tiene como punto de partida el área comercial situada entre la Glorieta de Insurgentes y el Paseo de la Reforma, en la colonia Juárez. La Zona Rosa ${ }^{32}$, que durante el auge económico de la década de 1950 reflejó el bienestar de la clase dominante, se pobló de tiendas exclusivas y de una animada vida nocturna. Allí, entre las calles de Londres, Génova y Liverpool se construyó el Centro Comercial Jacaranda en 1959. La emblemática obra de Ramón Torres Martínez y Héctor Velázquez debió su éxito comercial al atinado emplazamiento urbano, además, - por supuesto- a su atractiva y novedosa propuesta de abrir calles peatonales hacia el interior de cuatro predios colindantes ${ }^{33}$.

Pero no sólo se edificó para dar cabida a los establecimientos de lujo, pues para abastecer los productos de primera necesidad los mercados de barrio cumplieron una labor sustancial. Ya quedó anotado en el capítulo anterior que su obra se debió a un extenso programa nacional, y, para el caso de la ciudad de México, los mercados populares materializaron gracias al Programa de Construcción de Mercados Públicos que se llevó a cabo entre 1955 y 1957 por el Departamento del Distrito Federal. Este plan, además del minucioso análisis del programa arquitectónico, estudió la distribución de los mismos en la población. Aquí se insiste en dos de ellos por su impacto en las revistas de arquitectura.

El primero resolvió una situación mucho más compleja, pues ocupó varios predios en una zona central altamente densificada y popular. Así, el mercado de La Lagunilla se adaptó a un entramado existente, sustituyendo antiguos inmuebles y aprovechando el espacio saneado, lo que dio como resultado un grupo aislado de cuatro unidades distintas repartidas entre calles cercanas ${ }^{34}$. El volumen principal, la gran sala de ventas de $8,400 \mathrm{~m}^{2}$, destinada a la comercialización de ropa y telas, se asentó en la avenida Héroes de Granaditas - hoy Eje 1 Norte- esquina Comonfort, en la colonia Centro. Sus gigantescas bóvedas esféricas de
32. La colonia Juárez, área en la que se encuentra inscrita la Zona Rosa, alojó a la aristocracia porfirista a partir de 1898; para la década de 1940 comenzó la transformación de sus antiguas casonas en comercios de todo tipo. Su curioso nombre no tiene un origen cierto, pudo ser el escritor Vicente Leñero, quien calificó esta zona «demasiado tímida para ser roja y demasiado atrevida para ser blanca», aunque también Carlos Fuentes, en La región más transparente, mencionó algunas fachadas pintadas de ese color. Véase "México desconocido," consultada 24 agosto, 2015, http://www.mexicodesconocido.com.mx/zona-rosa.html.

33. "Centro Comercial 'Plaza Jacaranda"” Arquitectura México, no. 65 (marzo 1959): 4. El análisis arquitectónico de este edificio así como el impacto de su difusión en las revistas internacionales puede revisarse en el apartado 6.3 de esta tesis.

34. "4 Mercados," Arquitectura México, no. 84 (diciembre 1963): 381-82. La venta se dividió en ropa y telas, alimentos, muebles y artículos para el hogar y comida preparada. 
Parte fundamental de los servicios modernos de la ciudad: los mercados populares. En la imagen "La Lagunilla" y "Coyoacán", L'Architecture d'Aujourd'hui (septiembre 1963).
35. La fecha indica el año de su demolición. La extensión de la zona corporativa del Paseo de la Reforma cruzando el anillo Periférico ha transformado en los últimos años lo que fue el acceso al fraccionamiento de Las Lomas de Chapultepec. En el predio que ocupó el Servicio Lomas se construyó la Torre Virreyes, de Teodoro González de León. La nueva obra reconstruyó parcialmente el edificio de Kaspé, en hormigón blanco aparente, integrándolo como acceso y vestíbulo de la torre de oficinas.

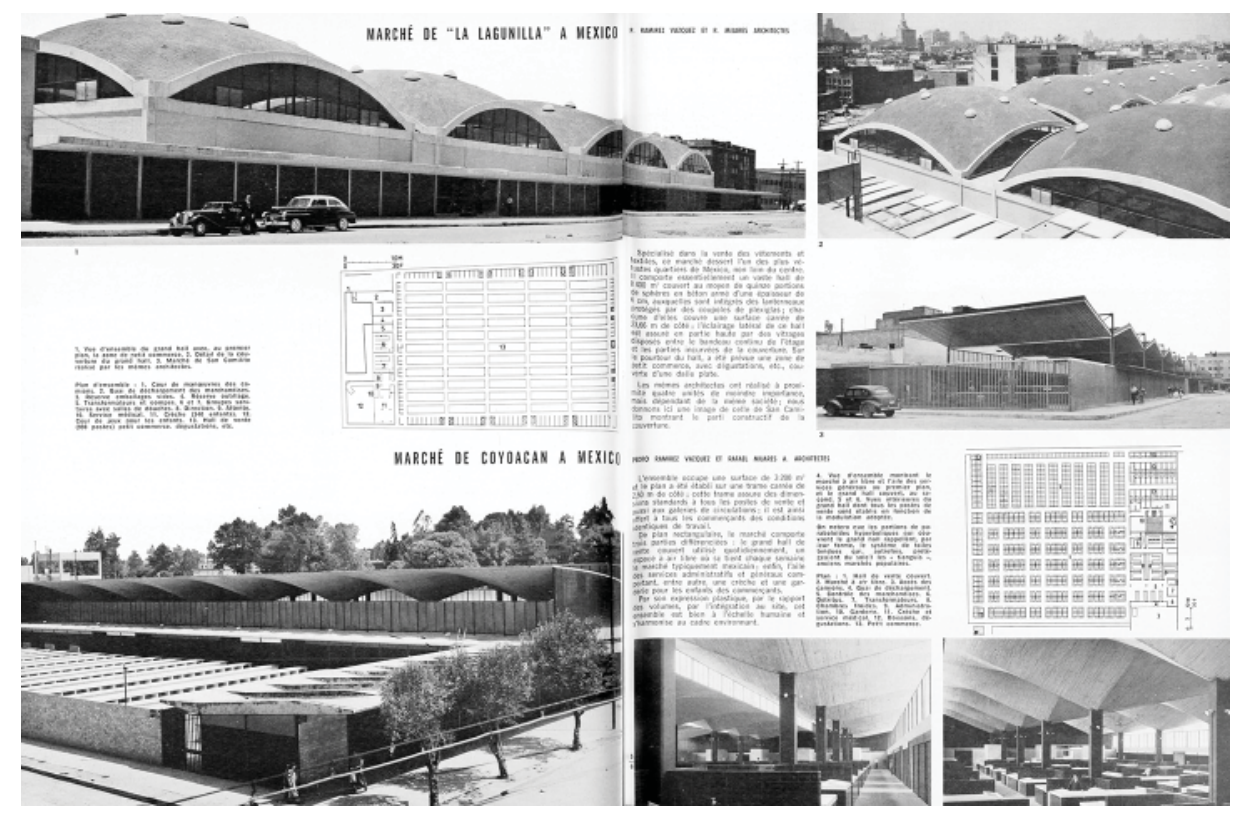

concreto armado - cada una cubre una superficie de $560 \mathrm{~m}^{2}$ - se han vuelto la imagen característica de este mercado popular del centro-norte de la capital.

Y hacia el sur, en la antigua población de Coyoacán, — que para la década de 1940 ya había sido alcanzada por la mancha urbana - el abasto básico se localizó entre las calles de Xicoténcatl, Allende y Malitzin, a poca distancia del jardín principal y del templo de San Juan Bautista, del siglo XVI. Este mercado, además de la sala de venta a cubierto, ofreció a sus habitantes un espacio a descubierto para la instalación semanal del tianguis, fortaleciendo así la tradición del comercio al aire libre que se mantiene desde tiempos prehispánicos en México. Aunque en su momento este mercado se dirigió a resolver el abasto de la clase media y baja de los alrededores, el nivel de vida de la zona, en constante aumento, fue encareciendo considerablemente los precios hasta hacerlos prácticamente inaccesibles a los vecinos, transformándose el mercado de Coyoacán en un punto turístico local más de entre los diversos sitios de interés con que cuenta el conocido barrio del sur de la capital.

Interesa situarse ahora en el norponiente, justo en la entrada al fraccionamiento de Las Lomas de Chapultepec. Ahí, en la calle del Pedregal esquina Ferrocarril de Cuernavaca, se localizó desde 1948 y hasta $2011^{35}$ el Servicio Lomas, de Vladimir Kaspé. Su innovador programa arquitectónico y su extensa difusión en las publicaciones periódicas se tratan con detalle en la tercera parte de esta tesis, por lo que aquí se destacan sólo algunos aspectos de su asentamiento. El principal 


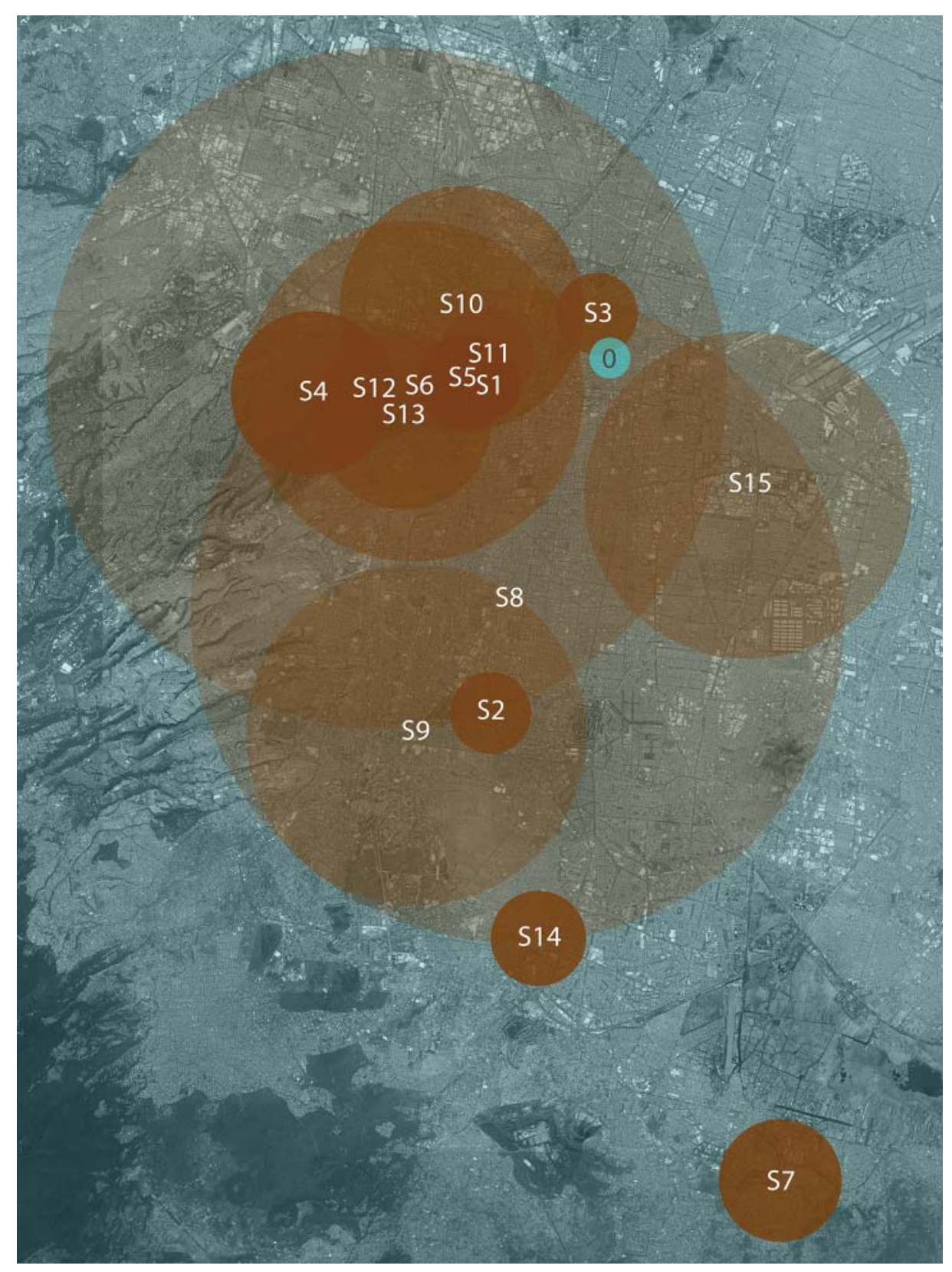

La distribución e impacto de los servicios en la ciudad de México. 0:Centro Histórico.

S1:Centro Comercial Jacaranda, S2:Mercado de Coyoacán, S3:Mercado de la Lagunilla, S4:Súper Servicio

Lomas, S5:Hotel María Isabel, S6:Hotel Camino Real, S7:Restaurante Los Manantiales, S8:Iglesia de la virgen de la Medalla Milagrosa, S9:Capilla de Nuestra Señora de la Soledad, S10:Iglesia de San Antonio de las Huertas, S11:Museo Experimental El Eco, S12:Museo Nacional de Antropología e Historia, S13:Museo de Arte Moderno, S14:Estadio Azteca,

S15:Palacio de los Deportes.

-y quizá más obvio- fue lo atinado de su emplazamiento en el acceso del que por esos años se había afianzado como la urbanización más lujosa de la capital. Los servicios que ofrecía - los principales fueron gasolinera, taller mecánico y venta de vehículos - estaban dirigidos a una clientela automovilista, es decir, a la clase alta del país ${ }^{36}$. No se insinúa que solamente en Las Lomas hubiera coches particulares, pero sí, que era un área en que los más favorecidos - los potenciales clientes- ya estaban bien establecidos. Caso contrario sería la urbanización de los Jardines del Pedregal de San Ángel, ya que en el momento en que abría sus puertas el Servicio Lomas, apenas se iniciaba su poblamiento.

El recorrido continúa en la misma zona poniente de la capital, de nueva cuenta en el Paseo de la Reforma, justo en la glorieta del Ángel de

36. Para 1950, en México, el automóvil particular era un bien material que distaba mucho - todavía- de ser accesible a las clases medias. 
37. La autoría se debió a Juan Sordo Madaleno y José Villagrán García, los artículos y noticias publicados sobre este inmueble se analizan junto con la obra del primero, en la tercera parte de esta tesis.

38. "Glass walls in Mexico City," Architectural Design 32, no. 7 (julio 1962): 313. la Independencia. En este punto privilegiado se levantó el Hotel María Isabel en $1962^{37}$. El inmueble se ubicó en el centro de negocios de la ciudad y frente a la llamada Zona Rosa, con su amplia oferta de comercios de lujo y entretenimiento, y a unos pasos del bosque de Chapultepec, en donde ya se planeaban los grandes museos nacionales. Esta obra, que en su momento se calificó como el hotel más lujoso de Latinoamérica ${ }^{38}$, respondió al patrón de éxodo que experimentaba el centro histórico, que se vaciaba de arquitectura comercial y de servicios, y se quedaba sin infraestructura hostelera moderna para cubrir la creciente demanda de habitaciones según estándares internacionales de calidad. Por varios años, el Hotel María Isabel se mantuvo como el paradigma del hotel de lujo, acelerando la transformación del propio Paseo de la Reforma.

A diferencia del Hotel María Isabel, cuya inversión económica no podría considerarse riesgosa, el cercano Hotel Camino Real, por su emplazamiento, pero sobre todo por su partido arquitectónico, fue, sin duda, una apuesta importante. Su ubicación, en la avenida Mariano Escobedo, en la colonia Anzures, en un solar próximo a Reforma pero sin comunicación visual directa hacia la importante avenida, pudo ser considerada un tanto marginal por los inversionistas. Con todo, a su favor jugó su colindancia con Chapultepec, pues para el momento de su construcción - entró en funciones en 1968- los museos nacionales ya estaban en funciones.

Lo más destacado de esta obra, en términos urbanos y de interacción con la ciudad, fue el cambio de modelo entre los hoteles de lujo como el María Isabel, abierto a la calle gracias a sus generosos muroscortina, y el partido arquitectónico del Camino Real que, por primera vez en un edificio público y a gran escala, aplicó la enseñanza introspectiva de Barragán. La vida hacia el interior — evitando una calle anodina, al igual que había hecho Barragán en su casa de Francisco Ramírez - se volvería un verdadero punto de inflexión, no sólo de la arquitectura de su autor -Ricardo Legorreta—, sino de la arquitectura mexicana del final de la década de 1960.

El siguiente inmueble se situó en un territorio que sólo muy tarde en el siglo xx fue alcanzado por la mancha urbana:Xochimilco. Población fundamental desde tiempos mesoamericanos por el desarrollo de la técnica agrícola de las chinampas - terrenos de cultivo o huertos en zonas 
lacustres de baja profundidad-, abasteció de víveres a la ciudad virreinal e independiente gracias a la eficaz comunicación fluvial que, a través de canales, conectaba la población ribereña con el casco antiguo. Su impulso turístico se favoreció - paradójicamente - por la desecación de los lagos, ya que este proceso destruyó el paisaje natural del tradicional canal de la Viga, haciéndolo intransitable e insalubre, por lo que se rellenó en la década de 1940 y para 1957 se pavimentó para dar lugar a la calzada de la Viga. El que había sido destino de esparcimiento para los capitalinos, por su agradable ambiente campestre, fue sustituido por Xochimilco debido a sus características naturales semejantes.

Justo cuando Xochimilco se encontraba al alza como destino turístico se construyó el restaurante Los Manantiales —entre 1957 y 1958 - famoso por su delicada cubierta laminada de hormigón armado ${ }^{39}$. A diferencia de la introversión que destacamos para el Hotel Camino Real, Los Manantiales se reconoció sobre todo por su apertura hacia un paisaje que - todavía entonces- resultaba paradisiaco ${ }^{40}$. Esta obra fue de las pocas que claramente interactuó con un entorno natural para potenciar sus atrevidas formas modernas, aspecto beneficiado - precisamentepor la ausencia de un entorno urbano predeterminado.

El restaurante Los Manantiales delimita al sur las obras aquí consideradas para su análisis en la extensa geografía del valle de México. Para continuar, es preciso situarse en una urbanización que, desde la década de 1930 y hacia el sur del centro histórico, trazó su retícula sobre la superficie llana del valle. Así, en la colonia Vértiz Narvarte, en la calle de Matías Romero esquina con Ixcateopan, se erigió uno de los edificios más difundidos durante el periodo de estudio: la iglesia de la virgen de la Medalla Milagrosa, de Félix Candela. Su construcción entre 1954 y 1955 se emprendió en una zona residencial caracterizada — como casi toda la capital - por viviendas de poca altura. No obstante su indudable fama internacional, la obra mantuvo la escala apropiada de una parroquia de barrio, de poco impacto a nivel urbano, adaptada al entorno como un servicio más de los ofrecidos a sus habitantes.

De condición semejante es la iglesia de San Antonio de las Huertas - terminada en 1956- y situada en la calzada México-Tacuba, entre las calles de Cacamatzin y Tonatzin, frente a la Escuela Nacional de Maestros. Aunque se localizó en los que fueron terrenos del antiguo
39. El proyecto arquitectónico se debió a Joaquín y Fernando Álvarez Ordoñez, el diseño y cálculo estructural a Félix Candela y la construcción - por supuesto- a Cubiertas Ala.

40. Si bien el área lacustre y de chinampas de Xochimilco está catalogada como Patrimonio de la Humanidad desde 1987, su título se mantiene en alto riesgo debido a la ocupación irregular de predios en la zona ecológica protegida y por la intensiva contaminación de sus canales. 
Escala adecuada de los servicios en un barrio habitacional. Iglesia de la virgen de la Medalla Milagrosa en la colonia Narvarte, 2016.
41. La primera de tres bóvedas por arista con paraboloides hiperbólicos de hormigón armado, alineadas y separadas entre sí; el espacio abierto entre éstas se cubrió con vitrales de tonalidad ámbar. Véase Juan Ignacio del Cueto RuizFunes, "Las bóvedas por arista de Félix Candela: variaciones sobre un mismo tema," Bitáco$r a$, no. 23 (2011): 41 .

42. Estas imágenes se utilizaron para ilustrar artículos técnicos firmados por el propio Candela; la difusión posterior del inmueble como obra arquitectónica solamente se benefició de vistas interiores. Véase Félix Candela, "Understanding the Hyperbolic Paraboloid," Architectural Record 124, no. 1 (julio 1958): 191 y "Understanding the Hyperbolic Paraboloid part 2," Architectural Record 124, no. 2 (agosto 1958): 205.

43. Enrique de la Mora y Fernando López Carmona para el proyecto arquitectónico y Félix Candela para el diseño estructural y construcción.

44. La congregación religiosa recibió los terrenos como donación particular en 1951; eran parte de la antigua Hacienda de San José del Altillo.

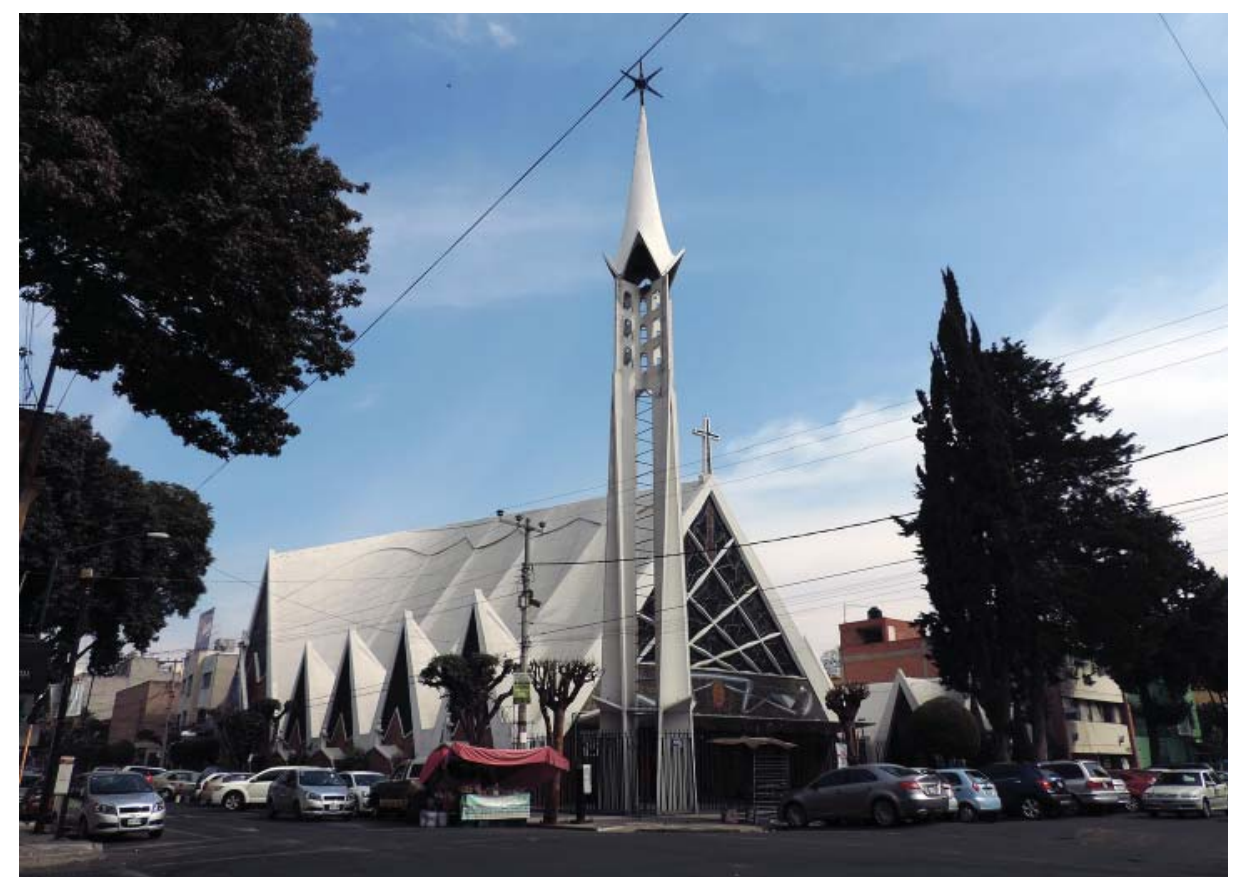

convento franciscano de San Antonio de las Huertas, - abandonado desde el siglo XIX - su erección como parroquia de barrio en el siglo xx en una zona previamente urbanizada, cercana al casco histórico y con una densidad edificatoria mucho mayor, propició que su emplazamiento se restringiera a un solar entre medianeras. Esta situación nunca favoreció su divulgación con la vista del volumen desde el exterior, caso contrario al que ya comentamos de Xochimilco, en que la integración con el paisaje fue determinante en su difusión. De esta manera, la disposición urbana de San Antonio de las Huertas provocó que las únicas fotos de exteriores se realizaran durante el proceso constructivo, en especial de la primera bóveda ${ }^{41}$, que se mira contenida entre un paisaje urbano por completo saturado $0^{42}$.

Del mismo equipo que proyectó San Antonio de las Huertas ${ }^{43}$, la capilla de Nuestra Señora de la Soledad -El Altillo- en Coyoacán, se asentó en el amplio predio que los Misioneros del Espíritu Santo poseen en la esquina de avenida Universidad y Francisco Sosa ${ }^{44}$. La construcción en 1955 se debió a un encargo particular de los religiosos que ya se habían establecido ahí con un seminario. Aunque abierta al público para determinadas ceremonias, el uso privado de esta capilla, que se integró a un conjunto mayor, hace que pierda cualquier interacción directa con su entorno urbano. Como sea, la amplia difusión que el inmueble gozó durante los años de estudio justifica sobradamente su inclusión en este análisis territorial. 


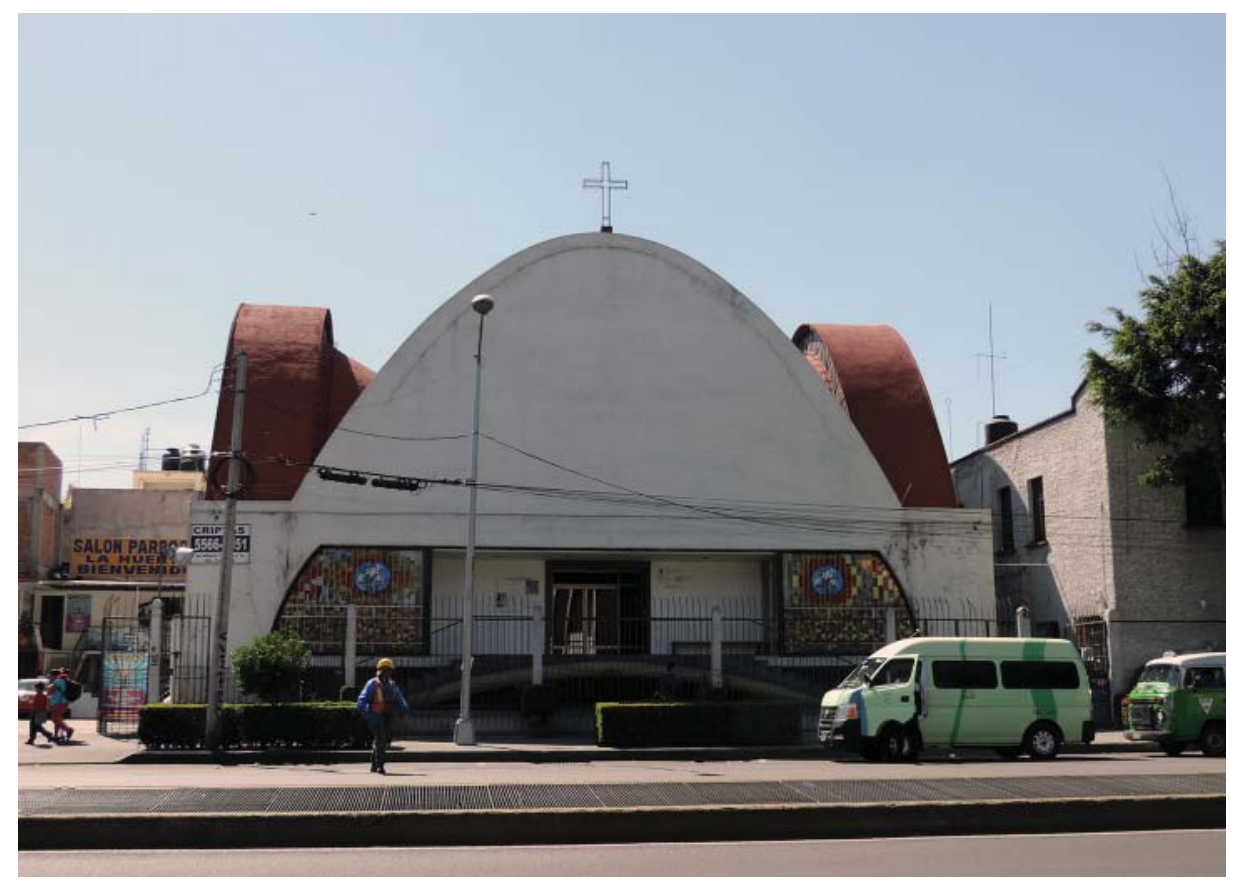

Construcción adaptada a una trama urbana altamente densificada. Iglesia de San Antonio de las Huertas, 2016.

Hasta este punto se han situado en la trama urbana de la ciudad de México un centro comercial, dos mercados, una estación de servicio automotriz, dos hoteles, un restaurante y tres iglesias, dentro del rubro de la arquitectura dirigida a la actividad comercial. Las obras que todavía quedan por comentar dentro de esta misma categoría de servicios, por su escala monumental, se convirtieron, casi desde el momento de su erección, en importantes iconos urbanos. Se hace referencia a los museos y a la arquitectura reservada a la exhibición deportiva.

Pero, todavía dentro de la escala del pequeño comercio, en un predio de unos $500 \mathrm{~m}^{2}$ en la calle de Sullivan, colonia San Rafael, se levantaría el ensayo arquitectónico realizado por Mathias Goeritz en 1953. El Museo Experimental El Eco concertó desde sus inicios una oferta cultural de vanguardia con el concepto más banal -y práctico, a decir de cualquier inversionista - de la oferta comercial. Este último aspecto se tradujo en la apertura de un restaurante-bar que, muy pronto, se convirtió en concurrido centro nocturno. Sin duda, la corta vida del experimento artístico se vio determinada no sólo por la temprana pérdida de su patrocinador sino por la situación estratégica del inmueble — próximo al cruce de Reforma e Insurgentes- que favoreció la transformación del edificio al rubro comercial puro y duro.

Por otro lado, de escala nacional y determinados para alcanzar una afluencia masiva, los museos erigidos en el bosque de Chapultepec en 1964 encontraron asiento en un lugar que ya era tradicionalmente frecuentado 


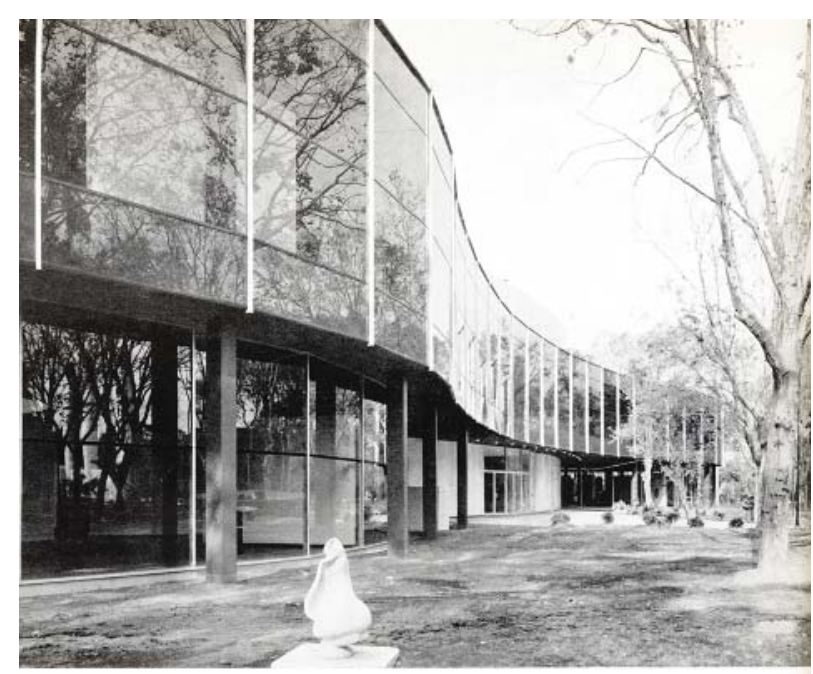

El resultado de los grandes programas nacionales culturales: Museo de Arte Moderno en la ciudad de México. Informes de la Construcción (marzo 1967).

45. El arquitecto Pedro Ramírez Vázquez, en el discurso inaugural del MNAH el 17 de septiembre de 1964 señaló que «El propósito de convertir a los museos en una necesaria lección permanente para el pueblo ... hizo aconsejable situar al museo aquí donde se cuenta con una numerosa y tradicional asistencia popular al bosque de Chapultepec». "Museo Nacional de Antropología," Arquitectura México, no. 88 (diciembre 1964): 195.

46. Sorprende lo temprano de su designación, pues tan solo nueve años antes caía Tenochtitlan frente a los españoles y la ciudad empezaría a ser reconstruida a partir de 1524.

47. Iniciado en 1785 como Palacio Virreinal, el inmueble conocido como "Castillo de Chapultepec" pasó por diversos usos antes de ser abierto al público como museo en 1939, durante la presidencia de Lázaro Cárdenas. "Bosque de Chapultepec," consultada 26 agosto, 2015, http://www. sedema.df.gob.mx/bosquedechapultepec/index.php?option $=$ com_content\&view $=$ article\&id $=46 \&$ Itemid $=29$.

48. "What makes 'the best museum in the world"?" Progressive Architecture 48, no. 2 (febrero 1967): 98.

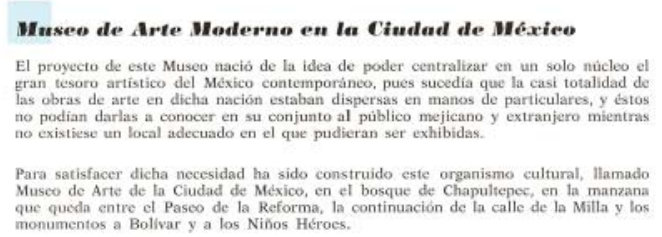

como zona de esparcimiento dominical ${ }^{45}$. El parque urbano más antiguo de América, ya que por cédula real de 1530 se otorgó Chapultepec a la ciudad de México como lugar de recreo para los habitantes de la nueva población ${ }^{46}$, era ya un lugar privilegiado en tiempos prehispánicos por sus abundantes mantos acuíferos que surtían a la ciudad mesoamericana y por su jardín botánico, solaz de los emperadores mexicas. El bosque ha pasado por momentos de gloria y abandono con los siglos. Durante el siglo xx, la cesión del antiguo Palacio Virreinal —erigido en el Cerro del Chapulín - como museo nacional de historia, sin duda impulsó de nuevo el sitio histórico como destino de entretenimiento familiar ${ }^{47}$. Entonces, el Museo Nacional de Antropología e Historia (MNAH) y el Museo de Arte Moderno son ejemplo de un cuidadoso emplazamiento, resuelto no sólo a base de espacio disponible sino pensado para facilitar el acceso a los museos públicos a la mayor parte de los habitantes de la urbe.

A dos años de su apertura, el MNAH ya recibía en días festivos hasta veinte mil visitantes, lo que da cuenta de su escala monumental ${ }^{48}$. Con todo, un verdadero evento masivo se tiene en la reunión de cien mil espectadores en torno a un partido de fútbol. El Estadio Azteca, sobre una superficie de $290 \mathrm{mil} \mathrm{m}^{2}$ en el Pedregal de Santa Úrsula —en la calzada de Tlalpan y Acoxpa - al sur del valle, materializó en 1966 la que quizá sea la estructura más significativa de la capital, en términos de escala. Su 


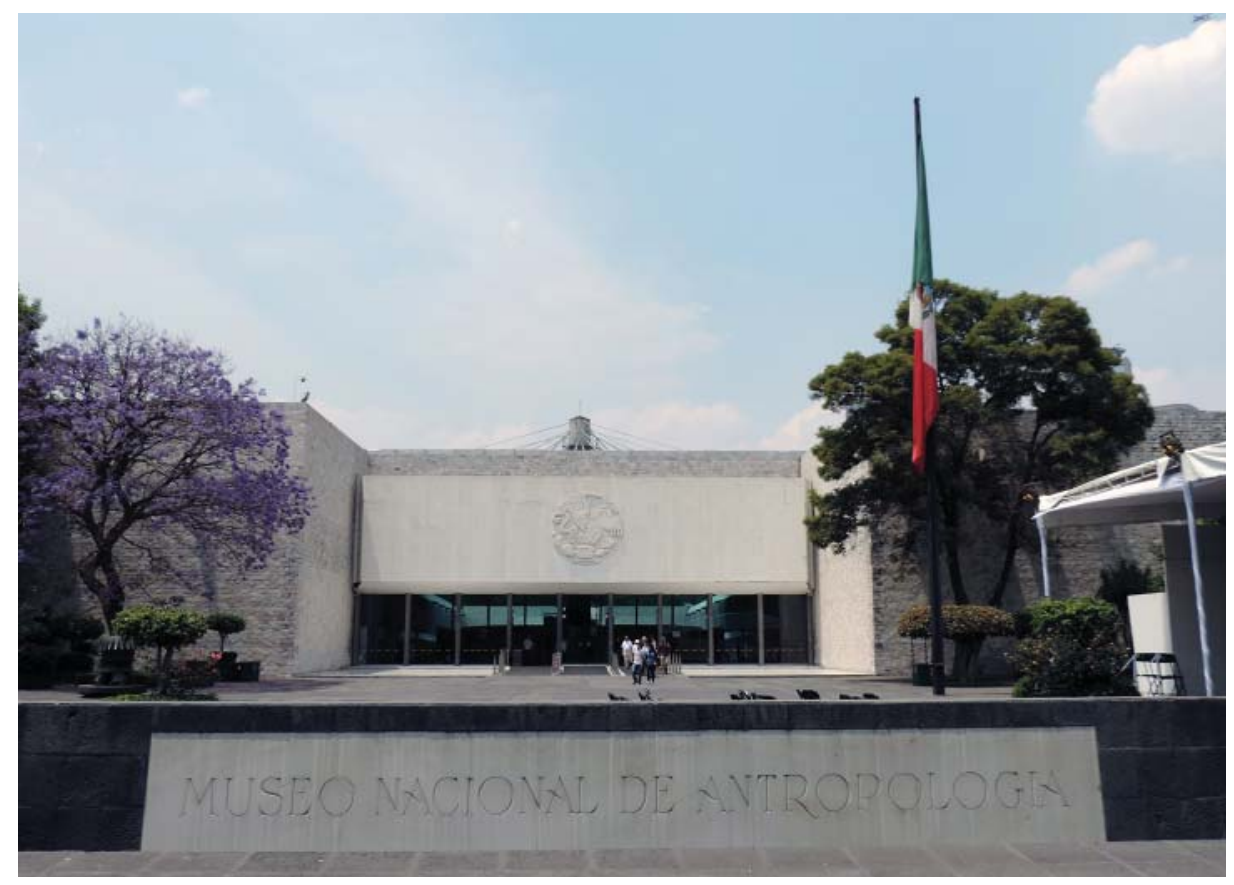

ubicación se debió no sólo al espacio libre disponible en esa zona, sino a las vías de comunicación directa con el centro de la ciudad y al transporte público accesible. El tamaño monumental del conjunto integró un amplio estacionamiento general para 5,500 autos - sin contar otras 1,200 plazas pertenecientes a los palcos privados- con accesos y salidas a vías rápidas como el anillo Periférico y la calzada de Tlalpan, sin cruces a nivel. A un año de su inauguración y una vez puesta a prueba su funcionalidad, se afirmó que «en virtud de la amplitud y disposición de las vías de acceso y circulación del estadio, éste puede vaciarse, después de un lleno completo, en sólo 18 minutos» ${ }^{49}$, tiempo récord imposible de superar hoy en día, dado el congestionamiento permanente de las arterias viales capitalinas. Como sea, la situación del inmueble se pensó para facilitar el movimiento masivo tanto vehicular como peatonal, un acierto indudable de su proyecto de conjunto en relación con su entorno inmediato.

Menor de tamaño, pero con mayor difusión en las publicaciones periódicas, el Palacio de los Deportes, finalizado en 1968 y ubicado casi en la esquina del viaducto Miguel Alemán con Río Churubusco, en la colonia Magdalena Mixhuca, se integró a un conjunto mayor, la Ciudad Deportiva. Más adelante, cuando se trate la arquitectura de los Juegos Olímpicos mexicanos, se puntualizará en la distribución azarosa de los inmuebles a lo largo y ancho de la ciudad. Aquí, se adelanta que, a diferencia del Estadio Azteca, el proyecto del Palacio de los Deportes fue más bien una obra introvertida, en cuanto a su interacción con el entorno
Obra de impacto mayor para la ciudad. Museo Nacional de Antropología e Historia, 2014.
49. "Estadio Azteca," Arquitectura México, no. 98 (septiembre 1967): 136. 
urbano. También, es cierto que la estructura de recubrimiento cúprico se ha convertido en una huella indeleble del oriente del valle de México.

Al final de este recorrido se hace evidente que la propia especificidad de la arquitectura de carácter comercial propició que su distribución territorial fuese dispersa. En algunos casos, se puede hablar de núcleos comerciales o de negocios en los que se confirma la presencia de más ejemplos, pero, aun así, lo reducido de la muestra no permite concluir positivamente una zonificación para cada uno de los géneros arquitectónicos comentados. Es verdad que se distinguió una importante zona comercial en torno al Paseo de la Reforma, y que se localizaron ahílos hoteles, el centro comercial o el museo experimental, y, en Chapultepec, por supuesto, se situaron los museos nacionales. Con todo, hay que insistir en que la selección de obras aquí expuesta respondió estrictamente a la mayor difusión que los inmuebles gozaron durante el periodo de estudio y en las revistas contempladas. Se buscó, más que nada, ubicar al lector en el escenario preciso de cada uno de los ejemplos y en brindar algunos datos útiles para entender su irradiación en la ciudad.

\section{En el límite norte del valle: la arquitectura industrial}

A diferencia delo que se analizó para la arquitectura comercialy de servicios, dispersa en el extenso territorio del valle, la arquitectura industrial se situó básicamente hacia el noroeste, siguiendo una zonificación intuitiva determinada, más que por alguna ley de ordenamiento urbano, por la comunicación directa de la zona con las vías de comunicación hacia el norte del país.

Durante la década de 1950 la expansión de la mancha urbana alcanzó límites insospechados todavía en la década anterior. En esos años,

50. Rodolfo Santa María, "La arquitectura de los Cincuenta," en Ciudad de México. Arquitectura: 1921-1970, coord. Enrique X. de Anda Alanís, (Ciudad de México: Gobierno del Distrito Federal, 2001), 268.

51. En el apartado $3.3 \mathrm{Di}$ versidad edificada ya se dio cuenta de las comunicaciones internacionales publicadas sobre las naves industriales de Bacardí, proyecto estructural y construcción de Félix Candela. la ciudad invadió los terrenos no urbanizados que la rodeaban superando sus límites políticos e introduciéndose con ímpetu en el Estado de México. En las revistas de arquitectura, las fábricas -y una consecuente formalidad distintiva - simbolizaron el progreso moderno. Nunca antes los arquitectos y artistas plásticos se habían involucrado activamente en la conformación de esta imagen de la modernidad mexicana ${ }^{50}$.

De esta manera, la disposición de la planta embotelladora para la compañía Bacardí, en Tultitlán, Estado de México, levantada entre 1959 y $1960^{51}$, respondió a un área caracterizada por el impacto de la industria 


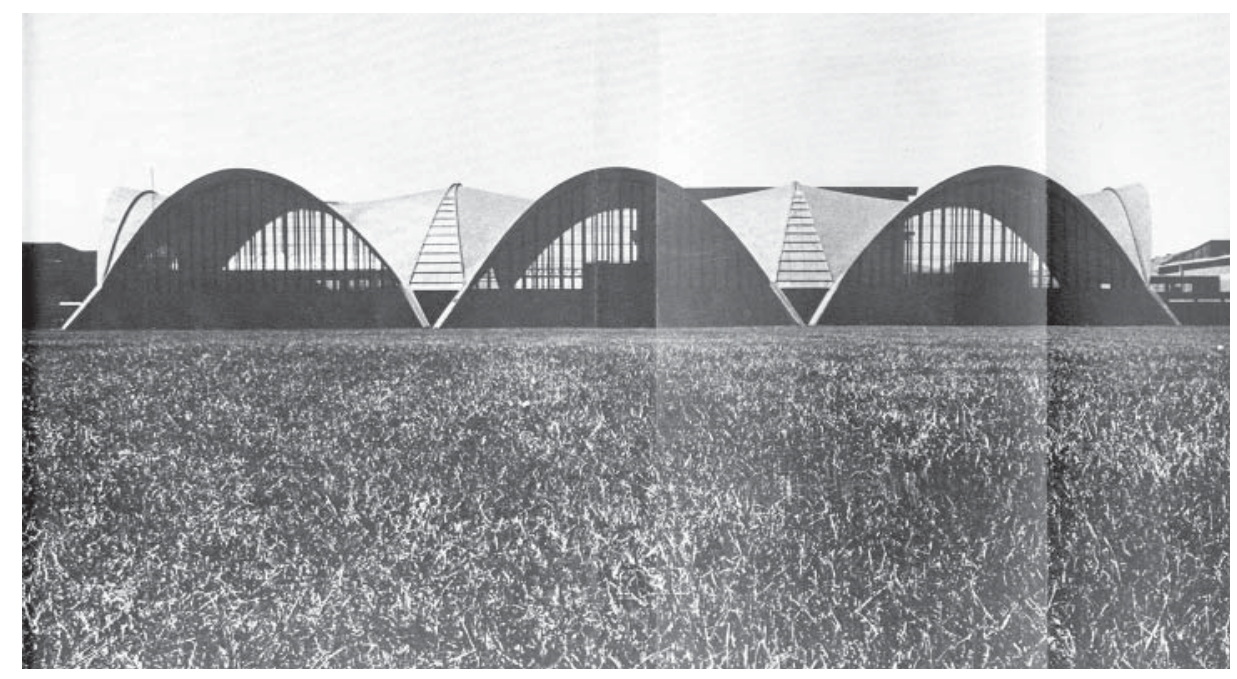

pesada colindante con la autopista México-Querétaro. Sin obviar el hecho de que la localidad ya no pertenece, en términos geográficos estrictos, al valle de México, su cercanía con el Distrito Federal y la integración actual de esta zona con la capital, argumenta positivamente su introducción en este capítulo ${ }^{52}$.

\section{Entre visionarios y artistas: las urbanizaciones modelo}

No obstante la mayor parte de la superficie urbanizada del valle - en el mejor de los casos- siguió modelos reticulares convencionales, los ejemplos de mayor impacto en las publicaciones periódicas foráneas fueron precisamente aquellas excepciones que se enfrentaron o a un paisaje natural abrupto, o, quizá todavía a una situación más desfavorable: la de un entorno anodino, sin carácter y sin elementos distintivos. Así, las páginas internacionales difundieron las dos singularidades que, al menos en el papel impreso, caracterizaron a la ciudad moderna mexicana. Primero, el fraccionamiento de los Jardines del Pedregal de San Ángel y, después, las Torres de Satélite en Naucalpan.

El proceso de desarrollo urbano del Pedregal partió de cuatro millones de metros cuadrados, adquiridos para su fraccionamiento al Rancho del Contongo. Para 1952, en apenas siete años desde que se comenzó el complejo, se había fraccionado ya el sesenta por ciento del área. En ese momento, el éxito comercial y la fama internacional de la urbanización ya eran un hecho consumado. No se había dejado nada al azar, su asentamiento se había valorado tanto desde la factibilidad económica de la inversión como desde sus posibilidades estéticas. Los emprendedores localizaron el sitio preferente «por su facilidad de
Uno de los iconos de la arquitectura industrial: la planta embotelladora de Bacardí de Félix Candela. Architectural Forum (septiembre 1961).
52. Geográficamente la población de Tultitlán se localiza en el valle de Cuautitlán, al norte del valle de México. 
53. "Los Jardines del Pedregal," Arquitectura México, no. 39 (septiembre 1952): 345.

54. "Los Jardines del Pedregal," 341.

55. En la entrevista Botello afirmó que «Todavía no se siente la influencia y el beneficio de la Ciudad Universitaria, esa realización arquitectónica que en un momento dado hará valer el acierto de quienes planearon el fraccionamiento más inquietante $[\mathrm{y}]$ asombroso de la capital». "Los Jardines del Pedregal,” 345. comunicaciones y por su continuidad con la vieja urbe, no obstante pretender la construcción de algo muy diferente a ella» ${ }^{53}$.

Esta visionaria empresa materializó gracias a más de un nombre, si bien el más famoso es, sin duda, el de Luis Barragán. Entrevistado por Arquitectura México, Noé Carlos Botello, gerente de la compañía urbanizadora del Pedregal, definiría con acierto a los dos personajes principales involucrados en el proyecto urbano. El primero, Barragán, aportaría su «afinado sentido estético, su especial comprensión de la jardinería y su concepción arquitectónica», mientras que el segundo, José Alberto Bustamante - experimentado fraccionador- participaría con su no menos importante conocimiento en cuestiones de urbanismo técnico y con «su espíritu impulsor y su dinámica infatigable que resuelve todos los obstáculos que se presentan y los problemas de orden práctico que se plantean $»^{54}$.

Ambos protagonistas podrían calificarse de visionarios ante una empresa tan arriesgada en términos de inversión económica. Por supuesto, se asumía la expansión de la urbe también hacia el sur, superando San Ángel, límite meridional de la mancha urbana a principios de la década de 1940. Con todo y que la compra de los terrenos, tanto para el fraccionamiento como para la Universidad, se realizó casi de forma simultánea, los empresarios del Pedregal confiaban en incrementar la plusvalía de sus predios una vez que los edificios universitarios entraran en funciones ${ }^{55}$.

Como se constatará en su momento, los Jardines del Pedregal de San Ángel fueron campo fértil para el desarrollo de la casa moderna mexicana en su versión más internacional. Hacia el sur, la capital se expandía en una burbuja de bienestar y con el beneplácito de la prensa internacional, mientras la mancha urbana seguía devorando con cinturones de miseria la otrora tierra fecunda del valle de México.

Por otro lado, la promoción de la Ciudad Satélite en el norponiente delvalle, en los términos municipales de Naucalpan, en el Estado de México, tuvo impacto en las páginas extranjeras sólo gracias a su monumental hito urbano que señaló el acceso al fraccionamiento: las Torres de Satélite, levantadas en 1957. La ciudad planeada para el automóvil, que ocupó ocho millones de metros cuadrados — el doble de superficie que El Pedregal—y su cuidadoso estudio de supermanzanas pasó por completo desapercibida 


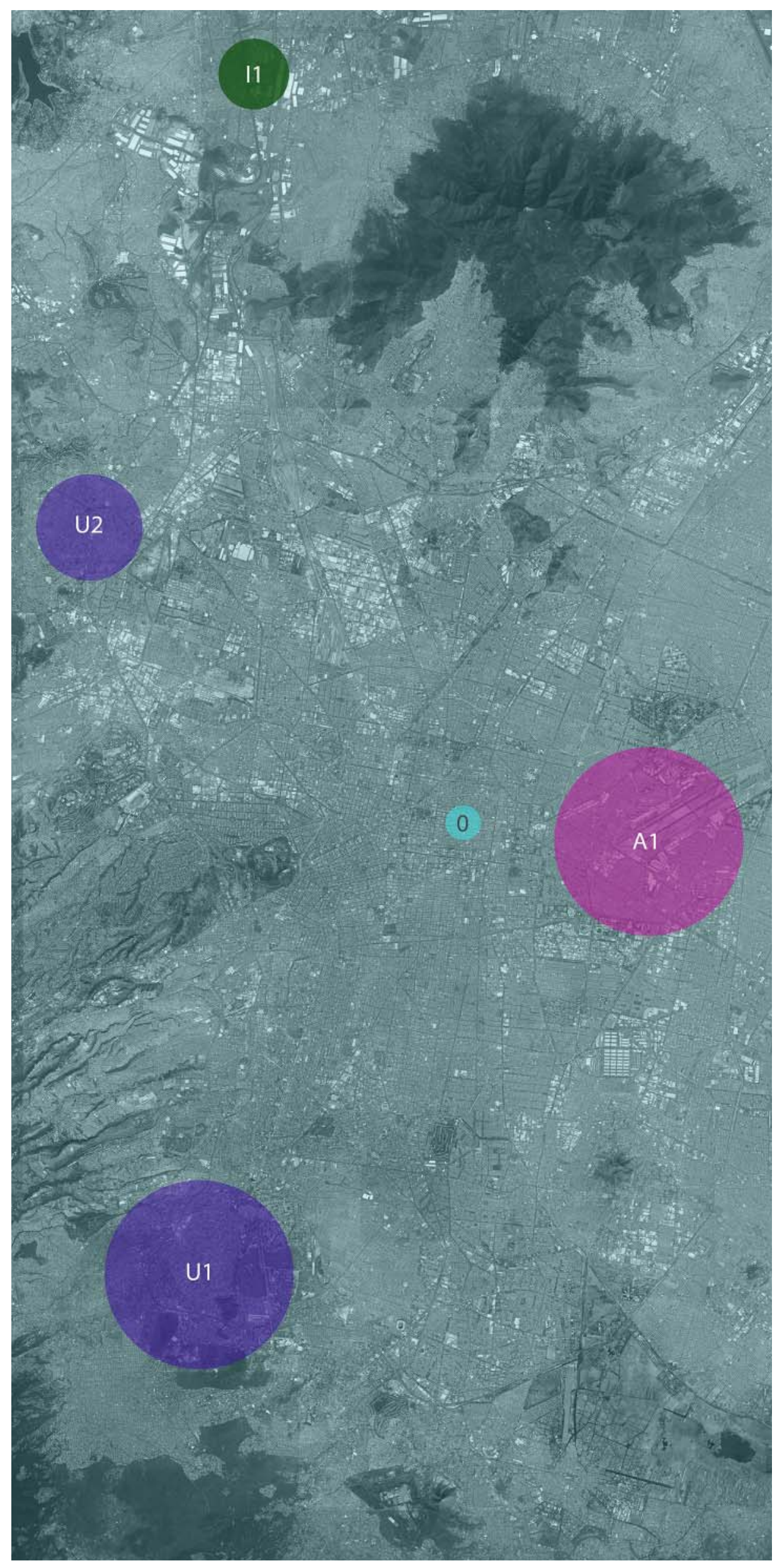

La arquitectura industrial, el urbanismo y la infraestructura en la ciudad de México.

0:Centro Histórico. I1:Planta embotelladora de Bacardí;

U1:Pedregal de San Ángel,

U2:Torres de Satélite;

A1:Aeropuerto Internacional de la Ciudad de México. 
56. En el apartado 6.2, en la sección dedicada a Mathias Goeritz, se estudia el impacto de las Torres de Satélite en su entorno originario. Ahí se comenta el contraste entre la difusión nacional e internacional; la primera abocada al conjunto urbano y la segunda más interesada en el hito urbano.

57. Mario Pani confirmó que se había «concebido y proyectado Ciudad Satélite como una entidad urbana verdaderamente autónoma [y que] todo el proyecto se basa en una previsión de elementos de servicio en los lugares adecuados». "México: un problema, una solución," Arquitectura México, no. 60 (diciembre 1957): 217.

58. "Aeropuerto central de México," Arquitectura México, no. 49 (marzo 1955): 13. en las publicaciones periódicas foráneas ${ }^{56}$. Pero el emplazamiento de las Torres, en el circuito vehicular que hoy se conoce como Periférico Norte, no fue circunstancial. La situación de la nueva urbanización se decidió siguiendo la importante vía que ya comunicaba al norte del país con la capital, y, también, se consideró dotarla de todos los servicios para hacerla independiente al Distrito Federal ${ }^{57}$.

Aunque de origen la ciudad se pensó para desahogar el crecimiento de la metrópoli, ya que ofrecía un satélite con todos los servicios, el resultado no deseado fue que este nuevo asentamiento favoreció que la mancha urbana de la capital se expandiera hacia la zona norponiente, alcanzando Ciudad Satélite desde la década de 1970. El paisaje despoblado con que se dio a conocer el hito urbano, haciendo efectiva su función de señalización en medio de la nada, se mantuvo por un corto periodo de tiempo; el necesario para trascender en la historia de la arquitectura mexicana.

\section{A campo abierto: la infraestructura}

En todo el valle de México, la infraestructura de mayor impacto - tanto a nivel urbano como en las publicaciones periódicas- fue sin duda el aeropuerto central. Localizado en el barrio de Peñón de los Baños, en la delegación Venustiano Carranza, se ubicó muy cerca de los Llanos de Balbuena, sitio emblemático por haber sido testigo del primer vuelo de avión sobre la ciudad de México en 1910 y asiento del aeródromo inaugurado en 1911. Pero la primera terminal de pasajeros de la urbe se construyó ya en el área del actual campo aéreo, iniciando su servicio regular desde 1929. En la década de 1950, la Secretaría de Transportes y Obras Públicas decidió ampliar la terminal aérea para recibir un promedio de 17 mil pasajeros diarios, provenientes tanto del interior del país como del resto del mundo ${ }^{58}$. Así, en 1955 entraba en funciones el flamante aeropuerto, que duplicó sus pistas de despegue y aterrizaje para cubrir la demanda del servicio. La nueva terminal de pasajeros, de Augusto H. Álvarez, fue la obra que dio la vuelta al mundo en las revistas de arquitectura foráneas.

La localización del aeropuerto al oriente de la ciudad se determinó por las extensas llanuras que había entre el lago de Texcoco, al este, y la sierra de Guadalupe, al norte. En la década de 1930, si bien relativamente 

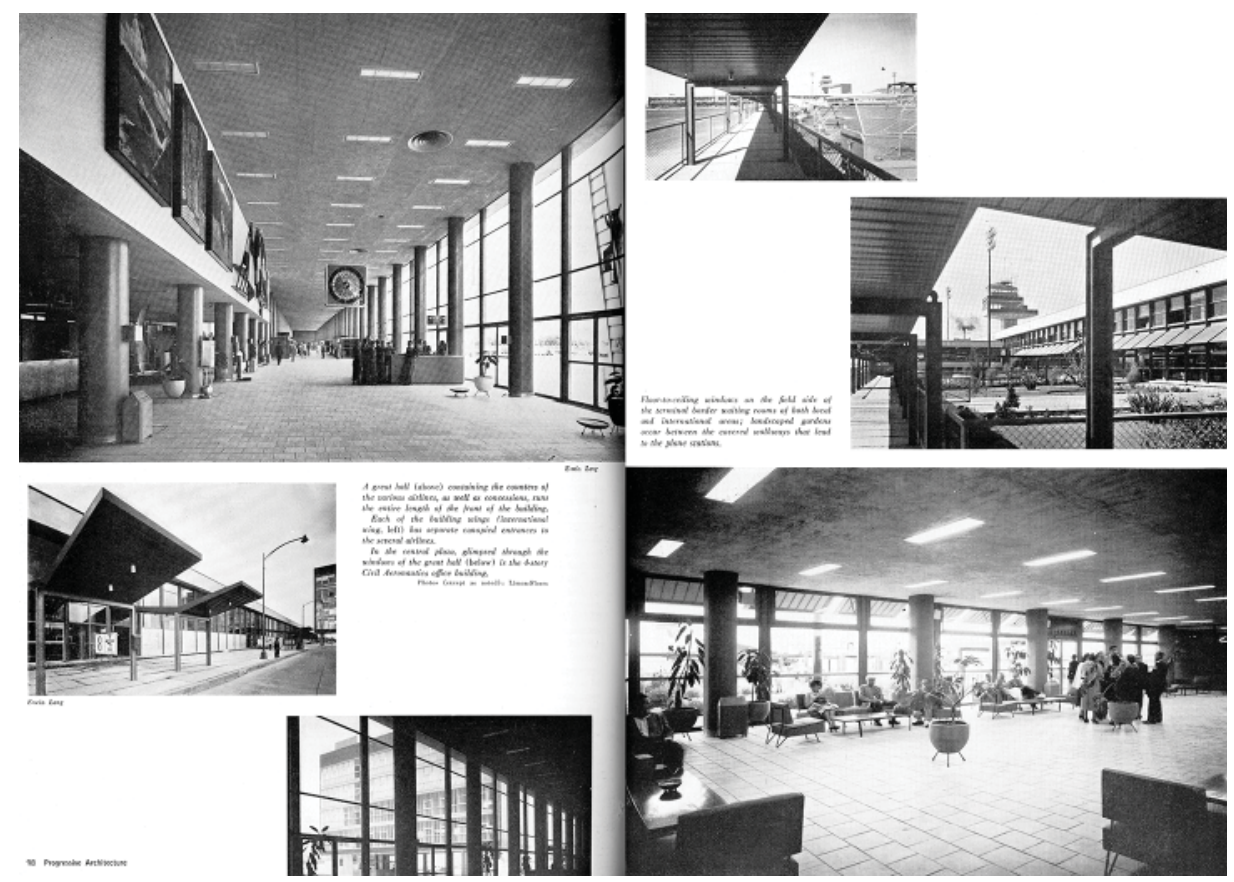

cerca del centro histórico - distante unos $5 \mathrm{~km}$ - la zona todavía parecía bastante alejada de la mancha urbana.

La panorámica actual de la metrópoli, una mancha gris que ocupa una extensión de $8 \mathrm{mil} \mathrm{km}^{2}$ y que aloja a más de veinte millones de personas, con apenas los picos más altos de las sierras que limitan el valle sin urbanizar, mínimas regiones lacustres y una que otra franja natural protegida pero en alto riesgo de perderse debido a la contaminación y a la demanda incansable de habitación y servicios, dista mucho de ser la región más transparente que durante el periodo de estudio fue asiento de algunos edificios emblemáticos de la modernidad mexicana. Se ha querido hacer explícito, en muchos casos, que los emplazamientos no se encontraban todavía conurbados a la capital, siendo esta característica intencional desde su origen. Sería el caso que acabamos de comentar del aeropuerto, pero también dela industria, la Ciudad Satélite, la penitenciaría del Distrito Federal e incluso el paraje turístico de Xochimilco, que se consideraron en ese entonces lo bastante alejados de la urbe como para beneficiar sus funciones primordiales.

Desde luego, muchas obras buscaron sitio en las colonias ya consolidadas porque sus programas así lo requirieron. Algo que hay que hacer notar, con relación al capítulo anterior en que se revisaron las poblaciones más allá de la capital, es que para el Distrito Federal y su zona metropolitana apenas se hizo énfasis en el clima de la región, con todo y ser muy distinto de aquel de origen de las revistas de arquitectura
La obra más importante de infraestructura para la capital: Aeropuerto Internacional de la ciudad de México (Progressive Architecture (diciembre 1957). 
que difundieron cada ejemplo. Como se verificará en la tercera parte de esta tesis, la vivienda unifamiliar fue quizá el único género en el que se destacaron especialmente las condiciones climáticas de la ciudad de México y su correspondencia con las soluciones arquitectónicas propias de esta geografía.

Ante la vista de las láminas generales, la selección de los inmuebles que ocuparon el extenso territorio del valle de México deja un paisaje de puntos dispersos, muchos de ellos aparentemente aislados y sin comunicación con el centro. Esta imagen virtual se diluye en cuanto profundizamos un poco en su ubicación precisa y se reconocen algunos de los determinantes que situaron en el mapa la modernidad arquitectónica mexicana de la que se viene hablando. 


\section{Parte III}

\section{Cruzando fronteras \\ Los grandes temas en el extranjero}





\section{Teorías y prácticas \\ La discusión académica y la especificación técnica}

El análisis de una selección de artículos, publicados entre 1950 y 1970 en las revistas internacionales de arquitectura, se divide aquí en dos grandes apartados, el primero, los debates en torno a conceptos y problemáticas de interés generalizado entre los profesionales de la arquitectura, y, el segundo, los estudios de materiales, su aplicación y técnica. La inclusión de ejemplos mexicanos en dichos artículos ha sido el principal filtro para su elección ${ }^{1}$.

Se verá que el impacto de este capítulo, en cuanto a extensión y al peso propio de los inmuebles mexicanos en los diferentes ensayos que se analizan, es mucho menor que el que se constatará en los capítulos en que se revisa la producción arquitectónica de determinados arquitectos y en los propios que toman los edificios como protagonistas de las páginas impresas. Se buscó con esto brindar una introducción al ambiente general del momento, tomado directamente de las revistas el material que, al ser una fuente de primera mano, refrescará la mirada actual hacia la arquitectura moderna. Asimismo, se confirmará, tanto en los debates académicos como en los análisis de materiales, la presencia de la arquitectura moderna mexicana y cómo ésta se involucró vivamente en las discusiones, más allá de verificar su difusión con los casos más conocidos o a través de comunicaciones puntuales sobre algún arquitecto o inmueble.

Así, el primer apartado que se desarrolla aborda los debates teóricos modernos que fueron parte indisoluble de las publicaciones periódicas. Su presencia constante y sus acaloradas argumentaciones se tradujeron, la mayoría de las veces, en historias interminables que no modificaron en lo absoluto el acontecer arquitectónico mundial que, en general, se desenvuelve a su propio ritmo y sin tomar en cuenta los intereses particulares de un contado número de arquitectos y críticos.

1. Si bien se puede debatir el criterio de discriminación aplicado, la metodología de investigación justifica la selección del tema mexicano entre un infinito número de posibles análisis que ofrecen las publicaciones periódicas modernas. 
Entre 1954 y $1970^{2}$, los arquitectos -en especial- pero también los críticos y los historiadores, ejercieron una importante labor argumentativa que fue divulgada puntualmente en las publicaciones periódicas. En muchos casos, los temas de fondo se implicaban con la propia obra arquitectónica de sus autores. Fue frecuente que estas discusiones académicas se ilustrasen con una serie de imágenes variopintas recabadas de los archivos de las editoriales o proporcionadas por los acervos personales de los propios autores. Si bien no se puede hablar de la arquitectura mexicana en general como parte de un único debate en esos años, sí se detectaron cuatro temas arquitectónicos que se integraron con menciones concretas en un amplio abanico de argumentos modernos.

De esta manera, los ejemplos de arquitectura moderna mexicana que se incluyeron en los diversos debates de la época a través de menciones o fotografías fueron la Ciudad Universitaria, casos concretos de vivienda unifamiliar, Tlatelolco, que representó a la vivienda colectiva de interés social y también las citas a la ciudad en general.

Los contenidos abarcaron un extenso espectro de discusiones académicas. Así, en la primera sección se revisa el papel del individuo desde sus necesidades orgánicas, como llamó Richard Neutra en Architectural Record a los determinantes fisiológicos y psicológicos de la forma arquitectónica. También, el problema de la escala y el usuario fue un asunto que interesó especialmente a uno de los editores de The Architectural Review, James M. Richards, mientras que el tema inagotable de la identidad vinculada a la geografía, es decir, a los condicionantes de clima, territorio, entorno original y materiales oriundos fue explorado por Joyce E. Lyndon en Arts \& Architecture. El contexto urbano a mayor escala, esto es, las relaciones de los inmuebles entre sí y de éstos con la ciudad, fue discutido ampliamente por Paul Rudolph en Architectural Record, al igual que la cuestión de cómo la uniformidad de la arquitectura en todo el orbe estaba obviando la importancia del sitio. Por otro lado,

2. El rango cronológico corresponde solamente al capítulo 5.1 La historia interminable. Los debates teóricos modernos. Es notable lo temprano de su fecha pues indica la presencia de obras mexicanas integradas a las discusiones académicas muy pronto en el periodo de estudio.
Alison y Peter Smithson en Architectural Design o Mariano Bayón en Arquitectura, insistieron en el papel social del arquitecto -o precisamente en la ausencia de éste- en el mundo contemporáneo.

El espacio arquitectónico - por supuesto- se mantuvo en la mesa de debate a través de análisis puntuales como aquel de Carlos Flores en Hogar y Arquitectura, sobre el espacio interior-exterior, 
pero también, desde los estudios tipológicos se trató el espacio para la vivienda unifamiliar en la ciudad consolidada, que se beneficiaría con patios o espacios abiertos privados, como lo subrayó Ian L. McHarg en Architectural Record. Otro asunto que interesó especialmente en esos años fue el del impacto de los rascacielos en las urbes modernas, cuestión que trató Walter Bor en The Architectural Review. Hacia el final del periodo de estudio, la ciudad se mantenía como la gran protagonista de las discusiones académicas, pero en vez de tratar el tema de las alturas, el historiador Eric Hobsbawm reparó en la estructura de la ciudad y las implicaciones que el diseño urbano — desde tiempos históricos hasta la ciudad moderna del siglo $\mathrm{xx}$ - ejercía en las protestas ciudadanas, asunto de tal relevancia social que incluso conquistó las páginas de la londinense Architectural Design.

Estas discusiones, si bien se entiende que no son todas las que interesaron durante los años de estudio ${ }^{3}$, son tan características de la época que dibujan perfectamente un panorama teórico desde el que se cuestionaba la producción arquitectónica y urbana contemporánea. La arquitectura moderna mexicana, con los casos particulares citados antes, se vio involucrada en esta actividad crítica, lo que indica, por un lado, la consolidación de su divulgación en las publicaciones periódicas extranjeras y, asimismo, su participación indirecta en los debates del momento.

Por otro lado, en numerosas comunicaciones que destacaron las propiedades mecánicas y estructurales de los materiales, así como sus posibilidades formales, determinados ejemplos mexicanos acompañaron a las descripciones técnicas en las páginas foráneas. De esta manera, en la segunda sección de este capítulo se propone un recorrido guiado por los distintos materiales que, desde su modernidad o tradición, completan este panorama introductorio a las obras que cruzaron la frontera gracias a las publicaciones periódicas de arquitectura.

La narración de este apartado se divide en seis materiales que, utilizados con mayor o menor extensión en la arquitectura mexicana, fueron tema de estudio generalizado en las revistas consultadas. El primero, y también el de mayor impacto en relación a esta investigación, fue el hormigón armado, pues desde 1950 se registraron artículos que puntualizaron en técnicas constructivas y propuestas formales. Los
3. Es evidente que otro tema muy jugoso de investigación - pero que no tiene cabida en esta tesis- es precisamente el de los debates teóricos que ocuparon las publicaciones periódicas como signo invariable de cada época. Por ejemplo, el uso de drogas - en especial el LSD - debió ser tan generalizado en la década de 1960 que incluso se debatió en las revistas de arquitectura si el uso de éstas por los arquitectos durante el proceso creativo beneficiaría o no a las propuestas arquitectónicas. Véase "LSD: A design tool?," Progressive Architecture 47, no. 8 (agosto 1966): $147-53$ y J. Thomas Ungerleider y Duke D. Fisher, "LSD: Fact and Fantasy," Arts \& Architecture 83, no. 11 (diciembre 1966): 1819. 
primeros años, el hormigón armado fue privativo del sistema bautizado por el ingeniero Manuel González como "descimbrar-cimbrando", mientras que, a partir de la mitad de la década de 1950 y por más de diez años, el hormigón armado en las publicaciones periódicas estará indisolublemente vinculado a las estructuras laminares de Félix Candela.

Otro material característico de la modernidad - el vidrio- fue sujeto de un extenso análisis por parte de Francisco Javier Sáenz de Oíza, publicado en la Revista Nacional de Arquitectura en 1952. Y como contraparte a los tiempos modernos, tanto la piedra como el tabique fueron asimismo tema central de comunicaciones en Architectural Forum y Progressive Architecture, en 1954 y 1957, respectivamente. El color, esto es, la aplicación de pintura como acabado final y distintivo para determinados inmuebles, fue sobre todo asunto que interesó a la italiana Domus, pero también a la neoyorquina Architectural Forum. Y por último, los metales -el acero estructural y el cobre como recubrimientotuvieron especial implicación en las estructuras tridimensionales como los domos geodésicos. En los artículos que investigaron estos elementos se incluyó siempre algún ejemplo preciso de arquitectura moderna mexicana; no está de más insistir que este fue el filtro que determinó la presente selección de artículos. 


\subsection{La historia interminable Los debates teóricos modernos}

No cabe duda que de los temas mexicanos que se vieron involucrados en las discusiones académicas de la época, la Ciudad Universitaria fue el conjunto que más impacto causó, por lo que su resonancia en diversos artículos da cuenta de la importancia de la obra, más allá de las comunicaciones consagradas a su difusión general, asunto que se desarrolla un poco más adelante en esta tesis.

La década de 1950, muy lejana ya de los años en que los pioneros del Movimiento Moderno parecían avanzar sólo a base de certezas, abrió innumerables debates que cuestionaron los postulados que ya no se aceptaban como verdades universales. Un asunto de especial significación para Richard Neutra - que trató no sólo en teoría sino que aplicó a su arquitectura - fue el papel del usuario desde sus necesidades orgánicas, algo que Neutra llamó los determinantes fisiológicos y psicológicos de la forma. Estas consideraciones se implicaban directamente en el diseño arquitectónico y en la tecnología propia de la modernidad, que no era «necesaria o automáticamente favorable a las sutiles relaciones humanas» ${ }^{1}$, mismas que había que buscar en orígenes menos mecánicos.

En un artículo que publicó Architectural Record en agosto de 1957, Neutra reflexionó sobre la forma y aseguró que ésta no sólo seguía a la función, pues «la forma no es estática y sin vida, es en sí misma funcionamiento, y más, es la causa de la función» ${ }^{2}$. Para el autor, las formas hechas por el hombre no eran todas mecánicas en origen y motivación, por lo tanto, no se podía explicar la realidad humana solamente en términos de uso, técnica, y materiales.

Como parte de su experiencia en el diseño de nuevas instalaciones universitarias en Estados Unidos, Neutra promovió un acercamiento a los diversos enfoques de la enseñanza haciendo propicia la arquitectura para dicho uso ${ }^{3}$. En relación a la arquitectura universitaria estadounidense,

1. Richard J. Neutra, "The Shapes on a Campus are not extracurricular," Architectural Record 122, no. 2 (agosto 1957): 174.

2. Neutra, "The Shapes," 176.

3. Específicamente en el St. John's College, en Annapolis, Maryland, Estados Unidos. Para Neutra, la arquitectura debía propiciar el aprendizaje y promover las relaciones humanas entre maestros y alumnos, a través de la conciencia de la forma, una necesidad orgánica de contacto con el aspecto exterior de las cosas que nos relaciona con nuestro entorno y le da sentido. 
Generosos espacios abiertos y pureza de volúmenes: Ciudad Universitaria de México, 2016.
4. Neutra, "The Shapes," 177.

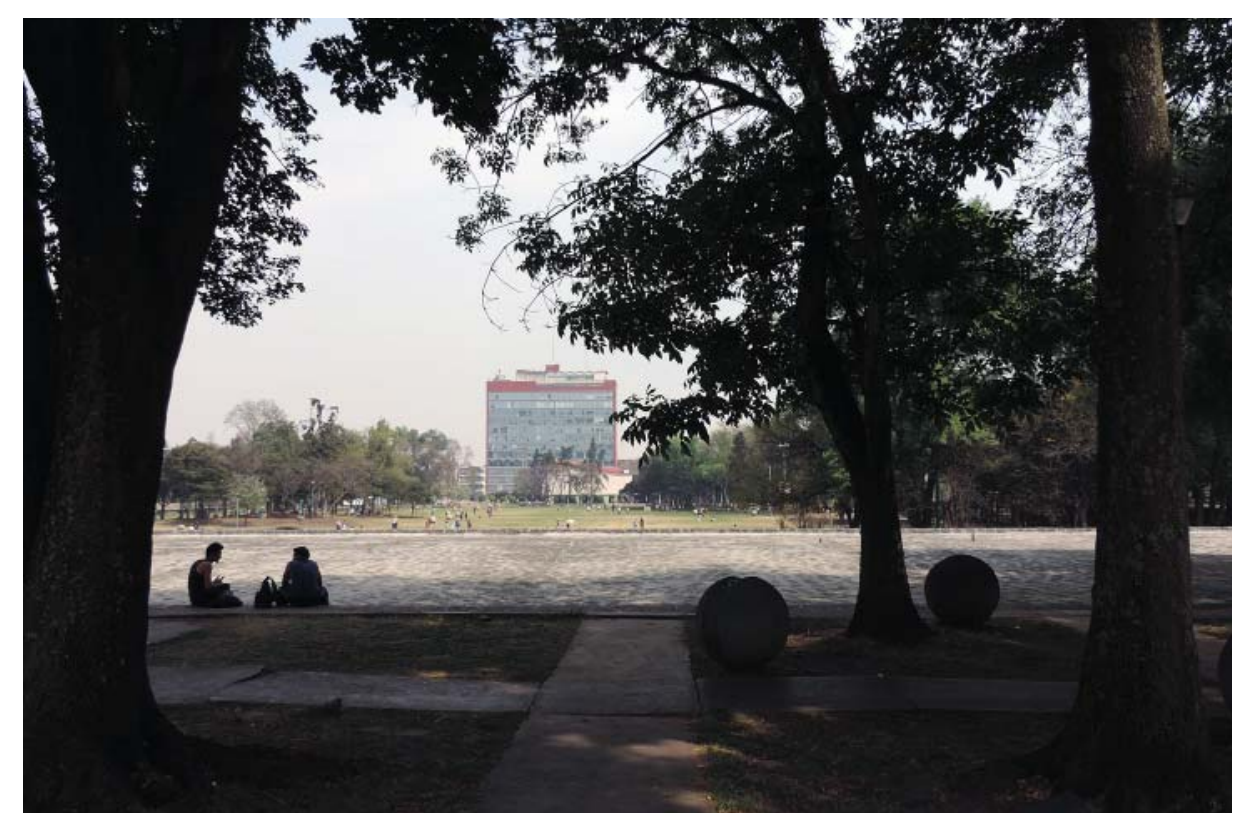

reconoció la propensión a «crear un cierto renacimiento sospechoso» ${ }^{4} \mathrm{y}$, como contraejemplo, comentó su experiencia como consultor honorario en la nueva universidad de México, a la que vio hacerse moderna en sus edificios, sin importar que algunos de sus inmuebles comenzaran a construirse durante el siglo XVI. El autor destacó cómo en países con una tradición cultural mucho más profunda, se hacían universidades modernas sin hacer uso de historicismos.

Es sustancial que la única imagen de un edificio moderno que acompañó el texto de Neutra fue la vista del fotógrafo Erwin Galloway del campus mexicano, tomada desde la Facultad de Medicina hacia la torre de Ciencias - hoy Torre II de Humanidades- prolija en mostrar los generosos espacios abiertos y la pureza de los volúmenes del conjunto. Mucho más interesante resulta la imagen de la Ciudad Universitaria en Record si se considera que la revista neoyorquina nunca dedicó un artículo al tema; la mención al campus mexicano se inscribe así en un momento en que la obra ya era conocida internacionalmente y su cita no tenía como fin divulgarla sino confirmar sus cualidades modernas.

También es cierto que, aunque Neutra fuese enfático en subrayar la tradición de la cultura mexicana y la antigüedad de sus construcciones universitarias y en cómo el nuevo campus nació moderno sin el recurso de los historicismos, el arquitecto obvia decir que las nuevas instalaciones se erigieron en un entorno natural sin tramas urbanas preexistentes y sin el conflicto implícito de insertar un complejo moderno entre edificios históricos. Esta visión general de la obra en mitad de un discurso teórico 


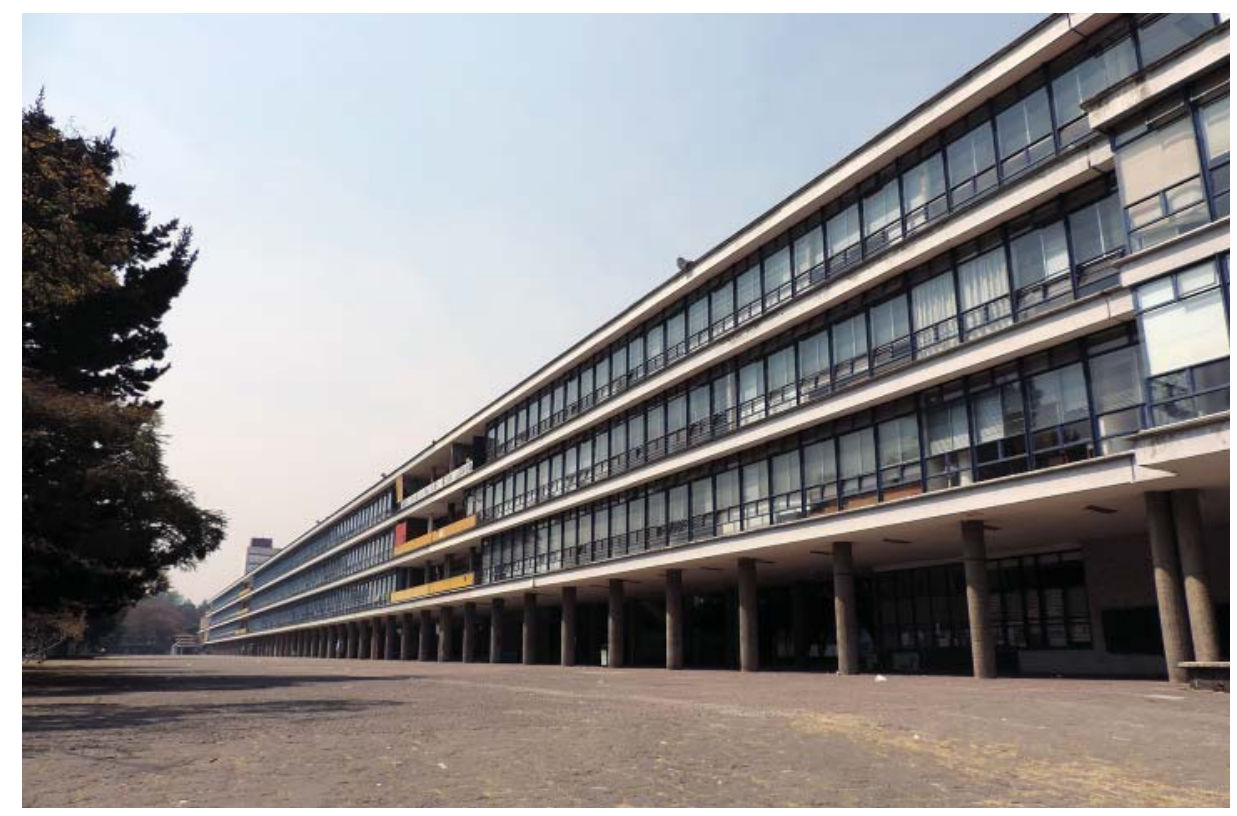

más amplio es sintomática de las comunicaciones que se abordarán en este apartado dirigido a revisar algunos de los argumentos modernos que, en muchos casos, se convirtieron en historias interminables.

No obstante Neutra centró su debate en el individuo y en sus necesidades fisiológicas y psicológicas, al puntualizar en la Ciudad Universitaria no reparó en otra cuestión que ya era tema frecuente en las publicaciones periódicas, y que afectaría directamente al entendimiento de la obra mexicana: el problema de la dimensión y el usuario. Hacia la mitad del siglo xx, los arquitectos hacían consciente que las dimensiones alcanzadas por los grandes edificios tenían como consecuencia, necesariamente, la falta de escala humana en los mismos. Esta situación dificultaba no sólo las relaciones de los inmuebles con sus ocupantes sino también la de las propias construcciones entre sí en el contexto más amplio de la ciudad.

Para 1954, James M. Richards identificó los que, a su juicio, eran los problemas significativos a que se enfrentaban los arquitectos de su tiempo: la escala y la técnica ${ }^{5}$. Así, con base en el análisis de proyectos recientes, Richards detectó tres posibles soluciones para el problema de la falta de escala humana en las construcciones muy grandes ${ }^{6}$. Para el autor, los problemas derivados del tamaño no eran sólo estéticos sino de la relación humana individual con sus propias creaciones. El conflicto entre la dimensión del edificio y sus ocupantes se convertía en el más inquietante de todos ${ }^{7}$. Entre otros ejemplos, Richards comparó el tratamiento urbano de dos grandes universidades. Primero, el nuevo plan para Cambridge,
Fachada del edificio de Humanidades de $300 \mathrm{~m}$ de largo, 2016.

5. J. M. Richards, "Preview," The Architectural Review 115, no. 685 (enero 1954): 7-13. En ese momento Richards era el editor de la revista junto con Nikolaus Pevsner y H. de C. Hastings.

6. Una solución era tratar estas construcciones como parte del paisaje y encontrar la escala humana en el primer plano - en los edificios más próximos- o en los intersticios de las estructuras; otra era imponer a la fachada un patrón abstracto que, aunque sonaría arbitrario, haría al inmueble visualmente comprensible. La tercera solución era aceptar el edificio grande en los términos del arquitecto-urbanista, esto es, como parte de una composición todavía más grande.

7. Richards, "Preview," 7. 
Adecuada adaptación al entorno: la extensa galería sombreada del edificio de Humanidades, 2016.
8. La misma publicación había dedicado un artículo a la Ciudad Universitaria en noviembre de 1953; con esto se constata que el tema mexicano seguía en el tablero y se integraba al debate teórico del momento.

9. "Mexico's mammoth campus. Does its size go beyond the bounds of human scale?" Architectural Forum 108, no. 3 (marzo 1958): 10813. No obstante el marcado interés de este artículo en el debate de la época - la escala y el usuario- por tratarse de un artículo destinado exclusivamente a la Ciudad Universitaria, el análisis de sus contenidos se integró al capítulo sobre la magna obra universitaria, un poco más adelante.

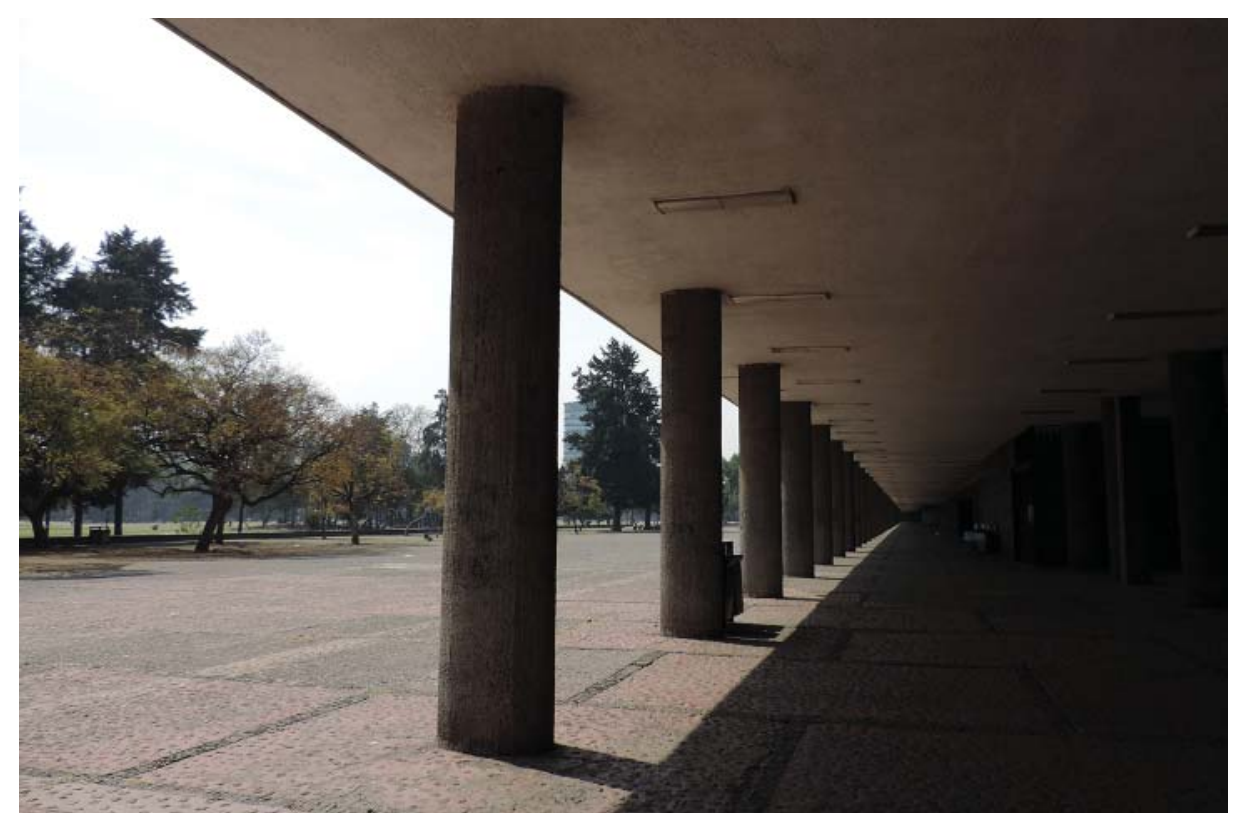

donde el diseño se había concebido para mantener la escala humana en concordancia con el uso de los inmuebles para la enseñanza; esto es, gracias a secuencias de patios parcialmente cerrados, la percepción general del conjunto se daba secuencialmente. Y como contraparte a este esquema, el autor citó la Ciudad Universitaria de México $^{8}$, de la que destacó que en secciones de esta vasta obra, la tendencia de utilizar métodos modernos de planeación y construcción para producir inmuebles de gran tamaño, propiciaba la pérdida de escala para el habitante. Esta aseveración podía comprobarse ante la fotografía del edificio de Humanidades, con su fachada ininterrumpida de 300 metros de largo. El vasto frente, con apenas un grupo de personas en primer plano, ciertamente daba la idea, todavía, de un espacio inabarcable. La apropiación de los inmuebles por los miles de universitarios en los próximos años rompería esa imagen desproporcionada de vacío que fue en su momento cuestión de debate.

El tema de la escala y el individuo fue una discusión académica generalizada dentro de la cual la obra universitaria fue cuestionada e integrada al debate del momento. La dimensión de la Ciudad Universitaria y sus implicaciones, como puntualizó Richards en 1954, era un asunto que estaba lejos de darse por terminado. Como muestra se podría citar el artículo que Architectural Forum publicó en marzo de 1958 para verificar la apropiación, por parte de los usuarios, de la vastedad del campus?.

Con poco más de una década en funciones, la magna obra mexicana había probado su efectividad y las implicaciones hacia el problema de la escala parecían diluirse. En el tablero de los académicos figuraban ahora 


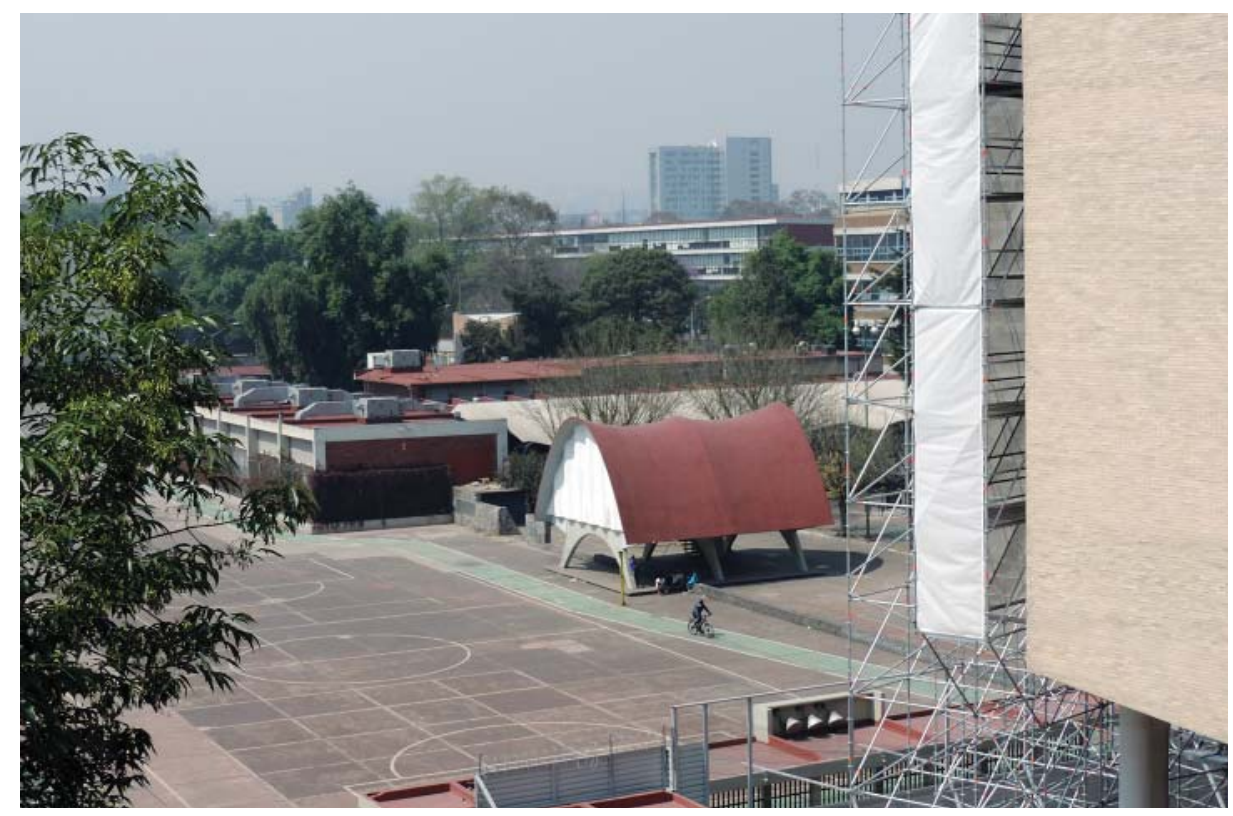

otras cuestiones, de las que la Ciudad Universitaria se mantenía partícipe dentro del debate teórico. Así, en las publicaciones periódicas se habló también -y mucho- sobre la geografía y la identidad, esto es, sobre los alcances que un clima específico ejercía en la selección de materiales tradicionales o industrializados en un territorio determinado y en cómo estas condiciones definían sustancialmente la arquitectura. La identidad, al igual que la tradición, la historia y los diversos estilos de vida, fueron conceptos que engrosaron las discusiones de la época; se buscaba entonces brindar un carácter más humano a la arquitectura moderna.

Hacia el final de la década de 1960, Joyce E. Lyndon, en Arts \& Architecture insistía en que el desarrollo del paisaje considerando el clima local y los recursos naturales del sitio eran elementos prioritarios para ser tomados en cuenta en diseños urbanos recientes ${ }^{10}$.

Una nueva población necesita una identidad, para que la gente se pueda referir al sitio, entenderlo, tener una imagen particular de él cuando escucha su nombre. Esta identidad puede hacer más que sólo distinguir un sitio de otro. Se puede convertir en un símbolo y en un modo de vida de orgullo para la comunidad ${ }^{11}$.

Entonces, se consideraba que el clima no solo influía sino que, en muchos casos, determinaba el carácter del paisaje y, como consecuencia lógica, la identidad del lugar. La identidad no era concebida como algo que surgiese de forma espontánea, sino, más bien, como el producto
El edificio aislado de su entorno inmediato: pabellón de rayos cósmicos, 2016.
10. Joyce Earley Lyndon, "New Town Landscaping," Arts \& Architecture 83, no. 11 (diciembre 1966): 24-25. Con recursos naturales el autor se refiere a las pendientes naturales, los cursos de agua, las colinas, los barrancos y montículos o la vegetación autóctona.

11. Lyndon, "New Town," 24. 
13. Paul Rudolph, "The six determinants of architectural form," Architectural Record 120, no. 4 (octubre 1956): 183-90. Para el autor, los seis determinantes eran: el entorno particular, la función, la geografía, los materiales, las demandas psicológicas y el espíritu del tiempo.

14. Rudolph, "The six determinants," 183.

15. Rudolph, "The six determinants," 188. de reconocer, proteger y destacar el entorno natural y su carácter. Al aprovechar el paisaje originario e integrarlo al diseño urbano, se creaban a la vez símbolos de identidad permanentes. No por casualidad una de las imágenes que ilustró este texto corresponde a la gran terraza cubierta del edificio de Humanidades de la Ciudad Universitaria de México. El mismo inmueble de 300 metros de largo que citaría Richards en 1954 encontraba eco una década después, pero ahora, el cambio en el discurso teórico transformó el cuestionable problema de la escala en una destacada zona sombreada y de dimensiones adecuadas para un edificio moderno ${ }^{12}$.

Con todo, el tamaño no era un asunto que se debatía de forma aislada, pues éste también implicaba las relaciones que los inmuebles mantenían entre sí y entre ellos como conjunto en la ciudad. En 1956, Architectural Record publicó un extenso análisis de Paul Rudolph que trató los determinantes de la forma arquitectónica ${ }^{13}$. Para el autor, el entorno de la obra, es decir, su relación con otros edificios y con el sitio se convertiría en el primer determinante de la forma arquitectónica. «La arquitectura moderna ha sido particularmente débil al respecto y a veces incluso negativa, ignorando especialmente la relación del edificio con el cielo» ${ }^{14}$. Para él, una obra en verdad exitosa debía relacionarse con sus vecinos en términos de escala, proporciones y con el espacio creado entre los mismos. Lo más importante de todo era que debía definir y representar su papel de forma elocuente en el esquema integral del emplazamiento urbano.

Es significativo que una de las imágenes que acompañó su amplia disertación fue la vista del pabellón de rayos cósmicos, en el conjunto general de la Ciudad Universitaria, cuyo pie de foto hacía notar que la obra dominaba especialmente el paisaje en vez de integrarse a la tendencia general de ángulos rectos de los inmuebles circundantes. Se entiende que lo extenso del debate y el uso de imágenes meramente ilustrativas de conceptos generales, no se prestaron a la puntualización de que aquel «edificio seductivo que sólo aloja una máquina» ${ }^{15}$ alcanzó esa forma por el requerimiento de una cubierta de espesor mínimo - la lámina de hormigón en su punto más delgado tiene apenas un centímetro y medio de grosor- que permitiera el funcionamiento adecuado de los aparatos científicos.

Más allá de la escala y el entorno, en esos años también se comentó vivamente que la uniformidad de la arquitectura no permitía distinguir un 


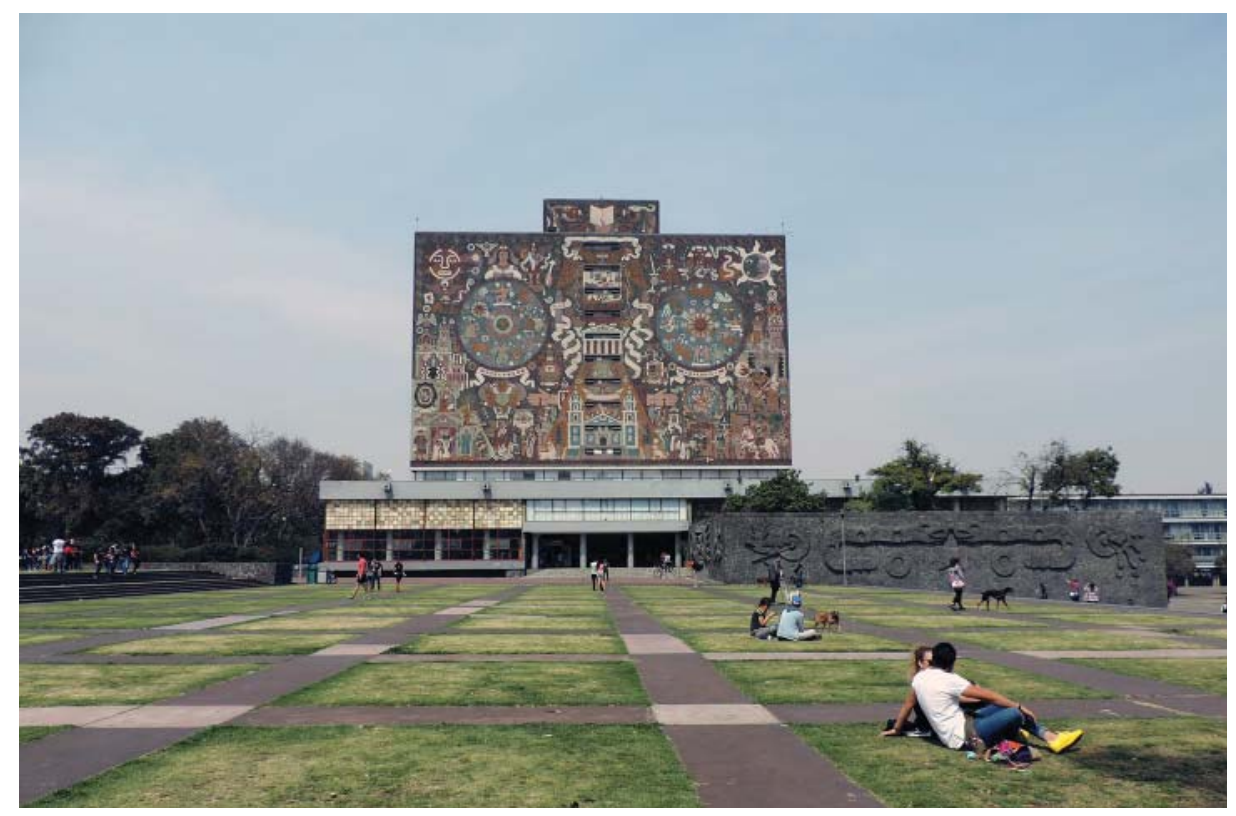

continente o un hemisferio de otro. «Seguimos ignorando lo particular» ${ }^{16}$ insistía Rudolph, al reconocer que los principios básicos de la arquitectura del siglo xx estaban lejos de haberse adaptado, agrandado y enriquecido fuera de sus primeros núcleos de desarrollo.

Es importante destacar que la crítica no mantuvo una postura unitaria en cuanto a considerar el paisaje y las condiciones climáticas particulares como determinantes de la arquitectura. Resulta curioso que esta postura se declarase desde las filas de los arquitectos más jóvenes, ya que, a diferencia de Rudolph, los arquitectos ingleses Alison y Peter Smithson, no confiaban en el ambiente físico para determinar la forma del edificio. El argumento a favor se centraba en la correcta utilización de la técnica, porque, desde su punto de vista, «una caja de vidrio o un volumen masivo de concreto, pueden producir las mismas condiciones de confort, si uno se puede permitir el correcto equipamiento mecánico» ${ }^{17}$. Los miembros del Team 10 tenían otras prioridades en relación a la forma arquitectónica.

En un artículo publicado en 1960 en Architectural Design, los Smithson apuntaron sus intereses hacia los aspectos sociales de la arquitectura $^{18}$. Allí discutieron sobre el sentido de una comunidad, de cómo el trabajo del arquitecto sería el hacer visible la identidad de un grupo a través de un conjunto de edificios que pudieran comprenderse globalmente como algo unitario y propio. En este contexto, el papel del arquitecto se volvería fundamental. Los autores comentaron la participación activa del profesional como conformador de una nueva
La tentación del edificio aislado como construcción emblemática: Biblioteca Central Universitaria, 2016.
16. Rudolph, "The six determinants," 184. Para el autor, las condicionantes que limitaban la expresión regional eran la industrialización, la facilidad de viajes y comunicaciones, el costo elevado de materiales tradicionales y de mano de obra calificada, la influencia de la prensa internacional y, por último, las cualidades abstractas inherentes al nuevo concepto del espacio.

17. Alison \& Peter Smithson, "The function of architecture in cultures-in-change," Architectural Design 30, no. 4 (abril 1960): 150.

18. Smithson, "The function," 150 . 


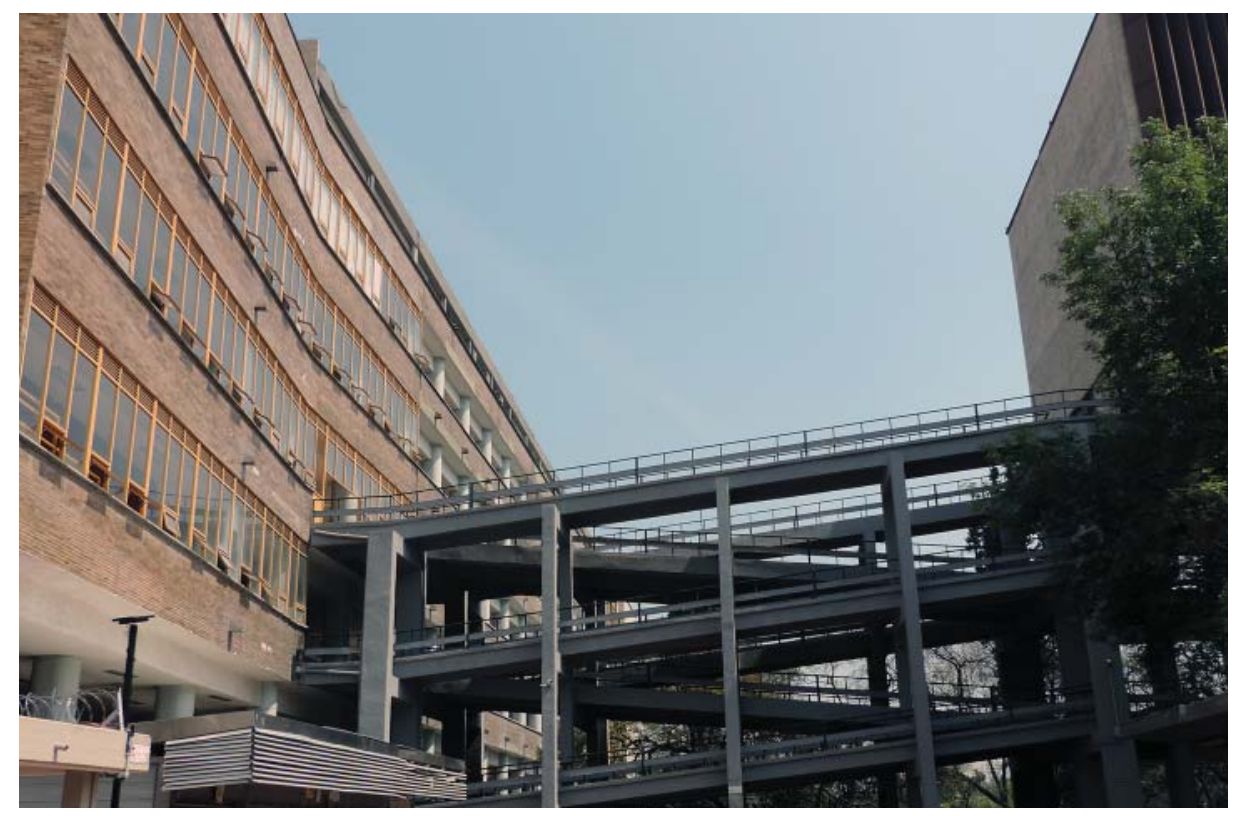

identidad, en lugares donde hay cambios agudos en el modo de vida y en los que no se cuenta con antecedentes culturales de peso para consolidar nuevos valores espaciales que fundamentarían la nueva identidad del sitio.

Este aspecto de cambio social es sobresaliente en el caso de México. Si bien los autores analizaron un ejemplo de vivienda social en Casablanca, la misma situación de una población rural que emigró a la ciudad y que de camino perdió cualquier arraigo y, con eso, la posibilidad de construir otra identidad en los nuevos asentamientos de las periferias urbanas, se podría comentar sobre cualquier ciudad latinoamericana en expansión descontrolada durante el siglo xx.

Los autores ingleses criticaron la postura de algunos países latinoamericanos - países que se reconocían con la misma problemática social que ellos analizaban de Marruecos- como Brasil, México y Venezuela, citando algunas de sus construcciones emblemáticas. Brasilia, la Biblioteca Central de la nueva ciudad universitaria mexicana o el Centro Simón Bolívar venezolano, surgían - a su juicio - de una cultura barroca vital y atractiva que todavía concebía a los edificios como monumentos aislados. En países pobres con conciencia social había que evitar tales tentaciones ${ }^{19}$. Lo importante aquí es destacar cómo los autores, desde la postura cómoda de la crítica, ponían el acento en los problemas sociales - la migración masiva del campo a la ciudad-y cómo sugerían que el arquitecto moderno se hiciera partícipe activo de esta problemática.

Hay que destacar que para este momento, la Biblioteca Central ya 9. Smithson, "The function," 150 . 


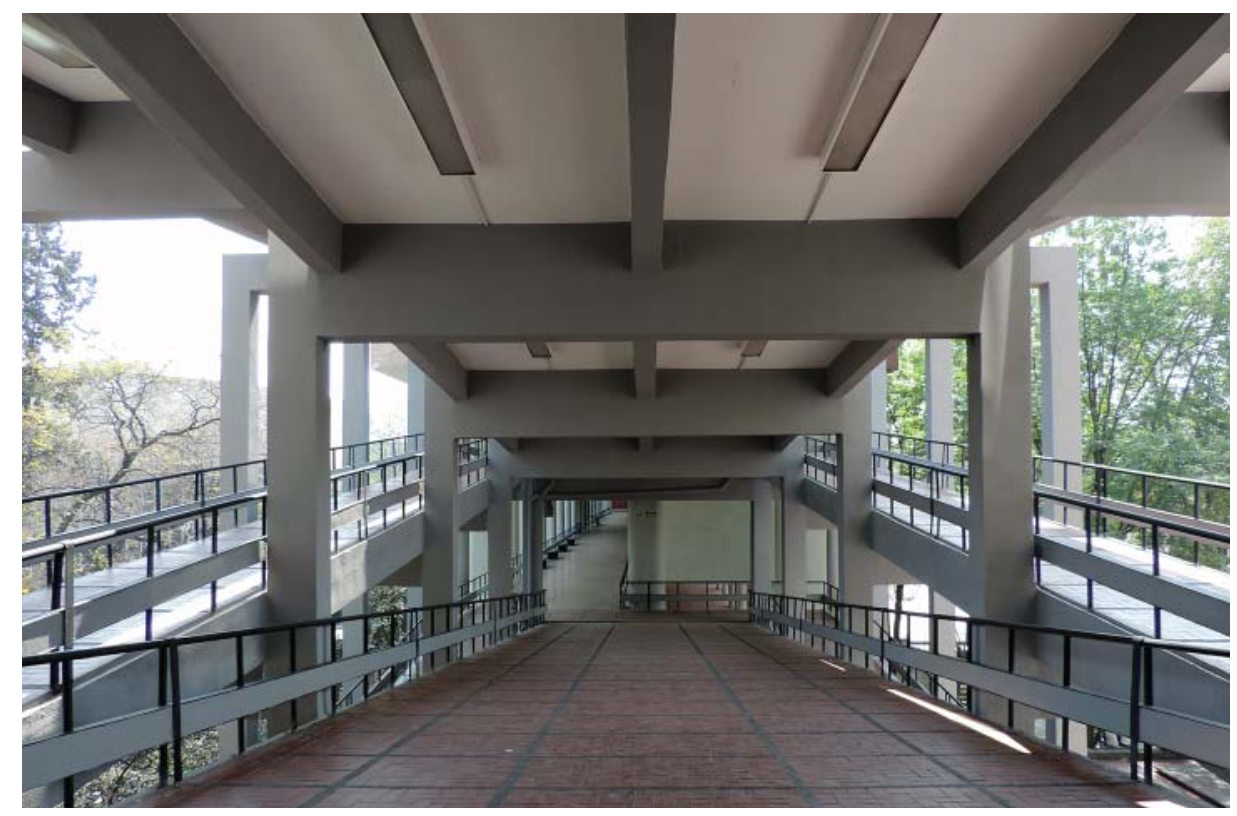

y su inclusión en este tipo de discusiones teóricas - por mucho que se lea cierta connotación negativa en su mención- no hacía sino reforzar su difusión fuera de las fronteras nacionales.

Al final del periodo de investigación todavía interesa comentar un análisis más que involucró directamente un edificio universitario. Antes se anotó que tanto los debates teóricos como los estudios tipológicos servían de marco de referencia e introducción para los grandes temas en el extranjero. Así, el argumento que desarrolló Carlos Flores en 1970 para Hogar y Arquitectura en torno al concepto del "espacio interior-exterior", abordó esa zona de transición entre los espacios interiores, esencialmente arquitectónicos, y los exteriores, de carácter urbano o paisajístico.

Entonces, Flores reconoció un espacio de «carácter ambiguo a pesar de ser diseñado y formar parte del edificio» ${ }^{20}$. Para el autor, sólo un mínimo porcentaje de los espacios interiores contemporáneos habían sido concebidos en términos arquitectónicos, quizá debido a la búsqueda de máxima economía y a la modulación totalmente regular. Por lo tanto, Flores apuntó la importancia cualitativa y cuantitativa que habían alcanzado estos espacios en la arquitectura moderna.

De tal forma, a través de patios, galerías, terrazas, azoteas, pasos cubiertos, plantas de acceso, comunicaciones elevadas de unos edificios con los inmediatos, o escaleras, el arquitecto tenía la libertad de expresarse y aportar ambientes de calidad. En su artículo, el arquitecto destacó cómo el empleo adecuado de estos elementos «permitirán una expresión arquitectónica eminentemente espacial, seguramente inasequible en
Debate sobre el espacio interior-exterior en la arquitectura.
20. Carlos Flores, "El espacio interior-exterior en la arquitectura," Hogar y Arquitectura, no. 90 (septiembre-octubre 1970): 9-76. 


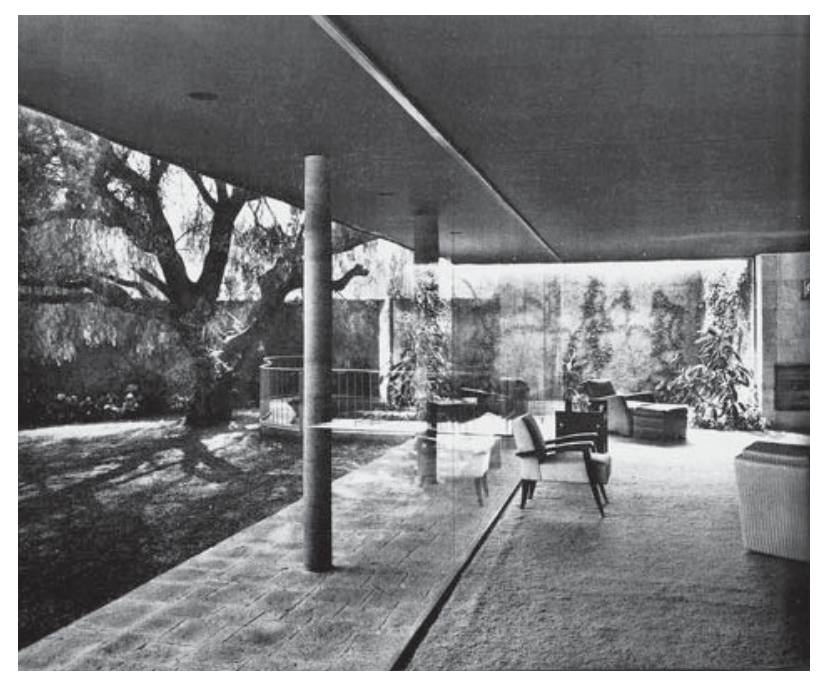

Vivienda unifamiliar para la clase alta mexicana. Diseño de Víctor de la Lama, citado por lan L. McHarg en Architectural Record (septiembre 1957).

cualquier otra parte de la obra $»^{21}$. Más que un debate en cuanto a las formas arquitectónicas, por lo demás en muchos casos esculturales, lo que reseñó el autor fueron variados ejemplos en que se destacó un patio, una escalinata o la disposición de juegos de terrazas.

En este contexto se encuentra una fotografía de las rampas de enlace entre dos edificios de la Facultad de Medicina, que ilustra cómo este tipo de elementos de vínculo sobre el espacio inmediato convierte a éste en protagonista ocasional de la obra ${ }^{22}$. Faltaría en este discurso una manera de comprobar lo que el autor daba por hecho: que los espacios interiores de los ejemplos por él seleccionados carecían de calidad arquitectónica suficiente.

Se verifica, con este último caso, la mención puntual de la obra universitaria en los debates teóricos y los estudios de la época sobre el espacio arquitectónico. Se ha visto que la escala, la identidad, el entorno, el clima o el espacio fueron el soporte de las argumentaciones que ponían a prueba la efectividad de la arquitectura moderna. A lo largo de casi dos décadas, la Ciudad Universitaria se mantuvo involucrada en las discusiones académicas, lo que, indudablemente, prueba su impacto constante en las publicaciones periódicas foráneas.

Otros temas de la arquitectura mexicana también se implicaron en estos debates, sin embargo, su inclusión puntual - a diferencia de lo que se ha visto para la Ciudad Universitaria - da cuenta de casos aislados de difusión. Esto responde al menor impacto que cuestiones como la vivienda unifamiliar o la colectiva de interés social, o aspectos generales

21. Flores, "El espacio," 11. 22. Flores, "El espacio," 52. de la ciudad como su conformación urbana o la inserción de edificios altos en la misma, estuvieron presentes en las revistas extranjeras pero en 